\title{
OESTUDO DO CONSÓRCIO ENTRE MUNICÍPIOS DE PEQUENO PORTE PARA DISPOSIÇÃO FINAL DE RESÍDUOS SÓLIDOS URBANOS UTILIZANDO SISTEMADE INFORMAÇÕES GEOGRÁFICAS
}

Mauro Kenji Naruo

Dissertação apresentada à Escola de Engenharia de São Carlos da Universidade de São Paulo, como parte dos requisitos para obtenção do título de Mestre em Engenharia Civil com ênfase em Transportes

ORIENTADOR: Prof. Dr. Edson Martins de Aguiar 
Ficha catalográfica preparada pela Seção de Tratamento da Informação do Serviço de Biblioteca - EESC/USP

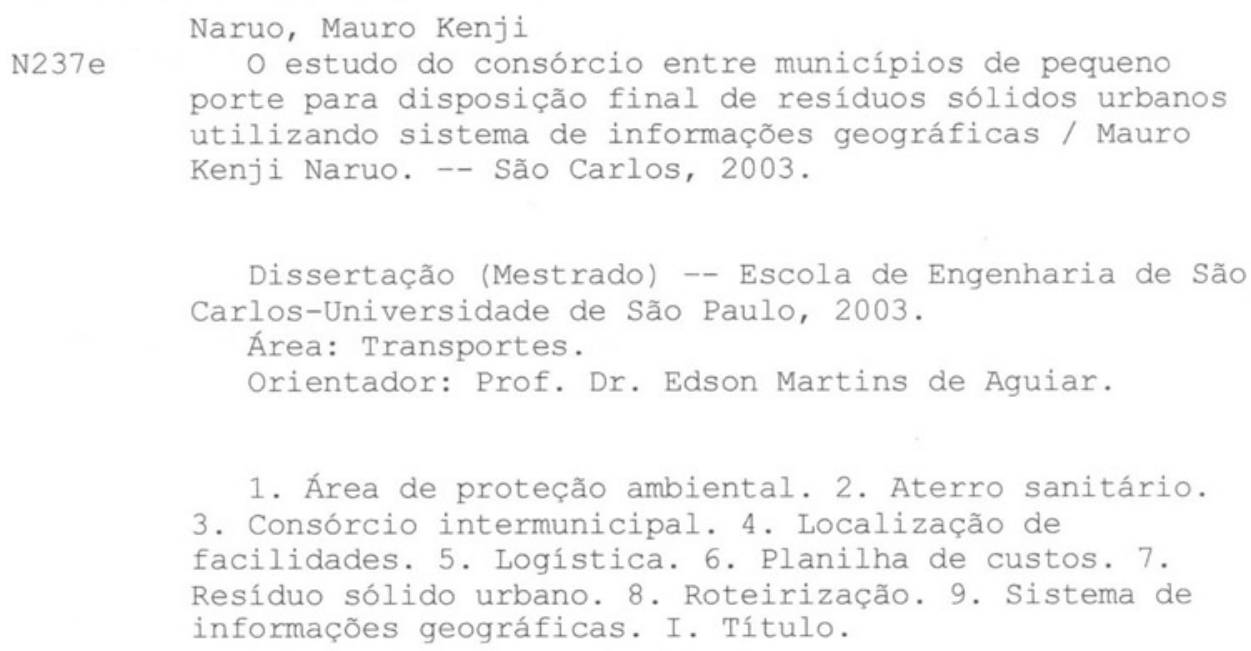




\section{FOLHA DE JULGAMENTO}

Candidato: Engenheiro MAURO KENJI NARUO

Dissertação defendida e julgada em 07-07-2003 perante a Comissão Julgadora:

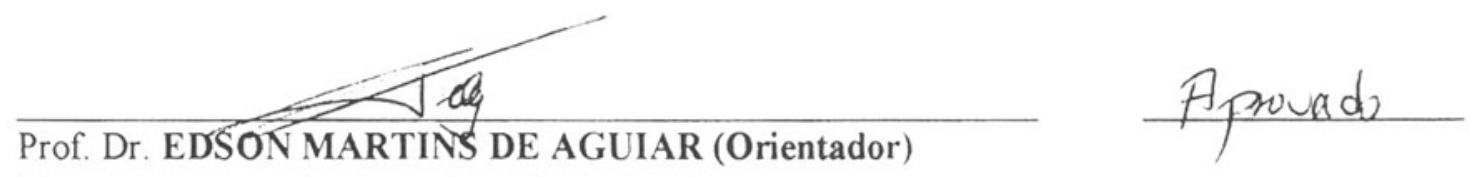

(Escola de Engenharia de São Carlos/USP)

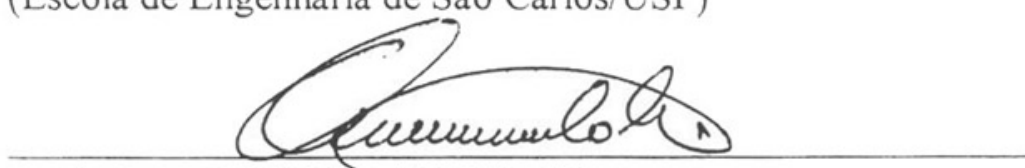

APROV $A$ DO

Prof. Assoc. VALDIR SCHALCH

(Escola de Engenharia de São Carlos/USP)

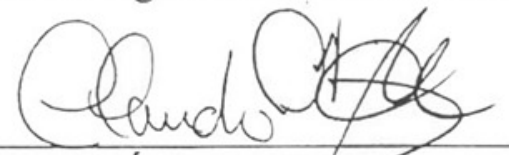

Prof. Dr. CLÁUDIO BARBIERI DA CUNHA

(Escola PolitécnieatUSP)

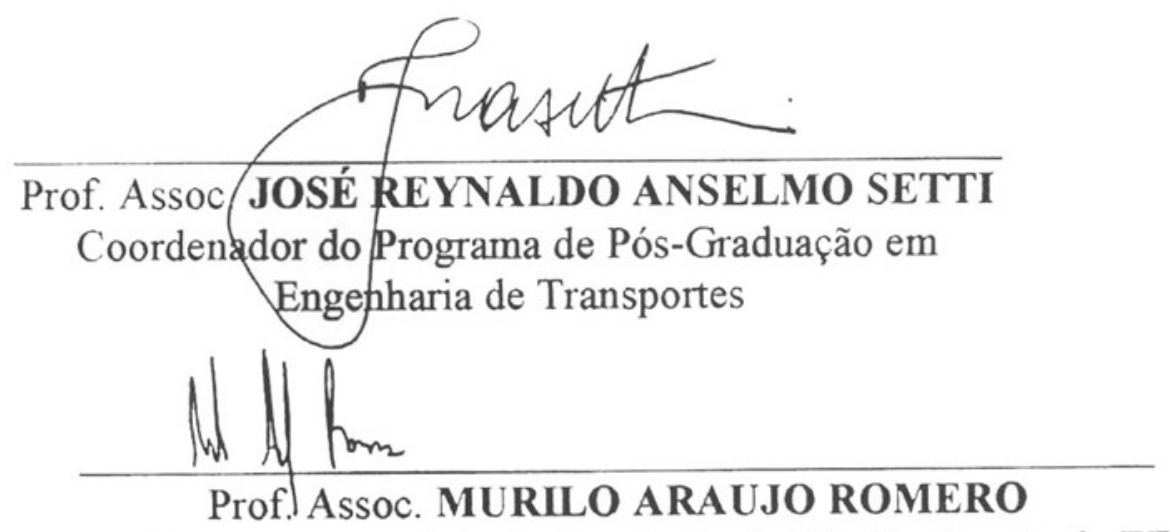

Vice-Presidente em exercício da Comissão de Pós-Graduação da EESC 
CAos meus pais OKiypshie Ofochico, de inabalável indole e inigualavel dedicação, ao meu irmão OTeniti, de invejavel paciência e perseverança, pessoas em quem sempre me espetharei, e também, a minha sempre Cintia, sempre. 


\section{AGRADECIMENTOS}

Primeiramente, só tenho que agradecer aos meus pais, que sob sacrifício tiraram do suor e da terra a oportunidade que eles não tiveram, mas fizeram questão de dar aos seus filhos. Ao meu irmão, por ser o espelho de toda a minha vida na luta por oportunidades que outrora, sob sol escaldante, nem nos atrevíamos a sonhar.

Ao Prof. Edson, pela orientação e pelo desafio que foi proposto neste trabalho.

Agradeço de forma generalizada, a todas as Prefeituras e empresas privadas e públicas, pela disposição em fornecer as informações necessárias para o desenvolvimento desta pesquisa de mestrado.

À Fundação de Amparo à Pesquisa e Ensino do Estado de São Paulo, FAPESP, pela oportunidade concedida através da bolsa de mestrado.

Aos professores e funcionários do Departamento de Transportes da Escola de Engenharia de São Carlos - USP, pelo suporte para as atividades de pesquisa e também pela amizade.

A todos os amigos e colegas da pós-graduação. Em especial, aos amigos que iniciaram o mestrado naquele mesmo ano em que o Departamento de Transporte não seria mais o mesmo, e também aos companheiros de república.

A Cintia, por me dar à oportunidade de compartilhar este momento especial de realização e todos os outros que estão por vir. 


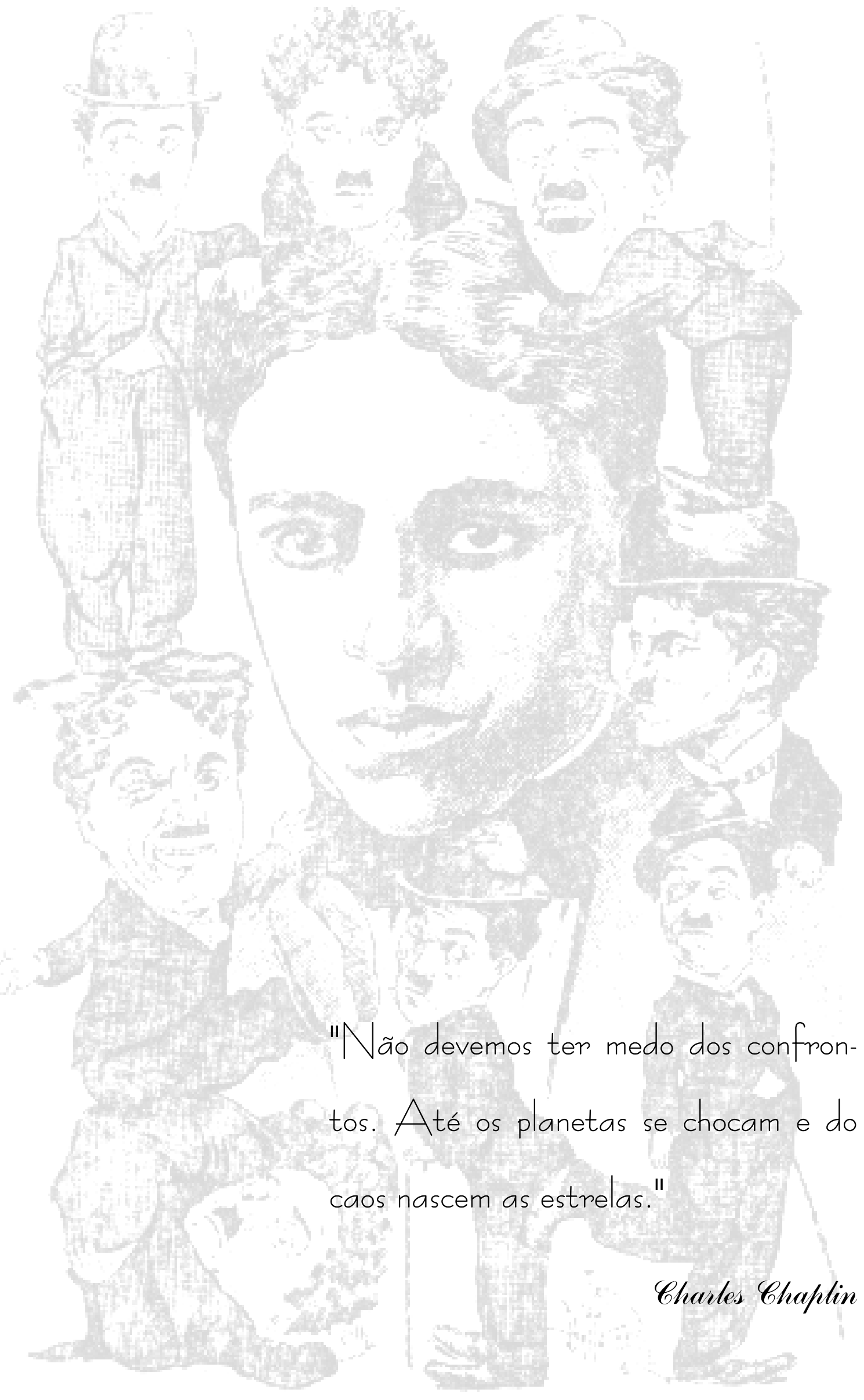




\section{SUMÁRIO}

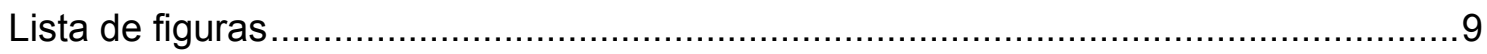

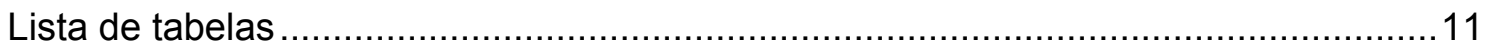

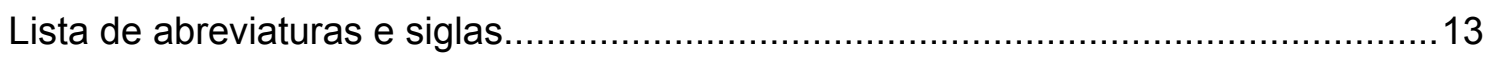

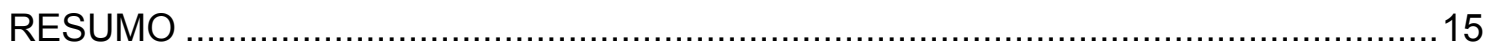

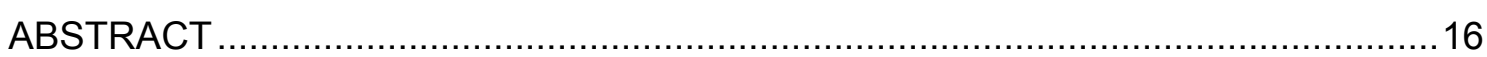

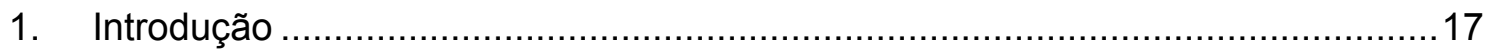

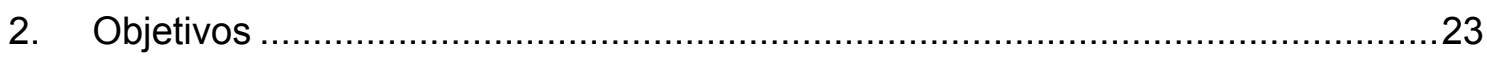

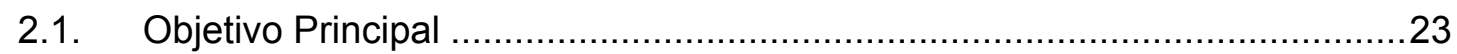

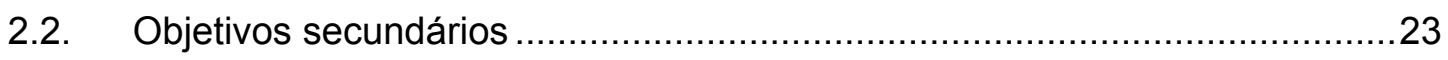

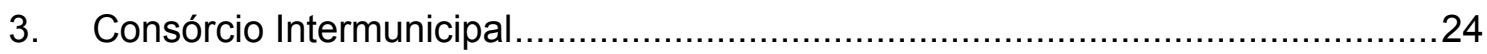

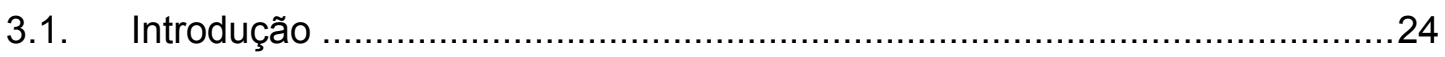

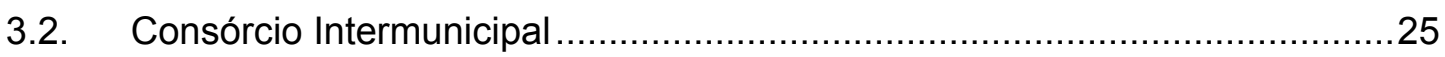

3.3. Atuação do Consórcio Intermunicipal.....................................................28

3.3.1. Consórcio Intermunicipal para Resíduos Sólidos................................30

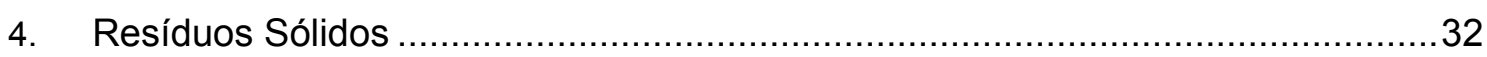

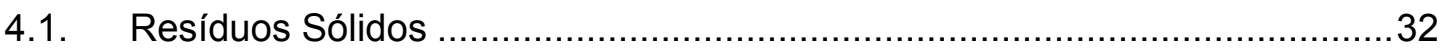

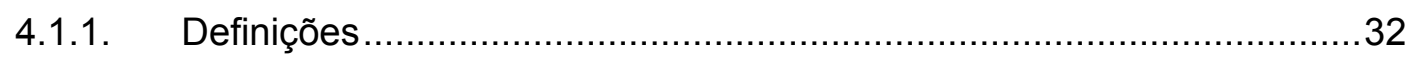

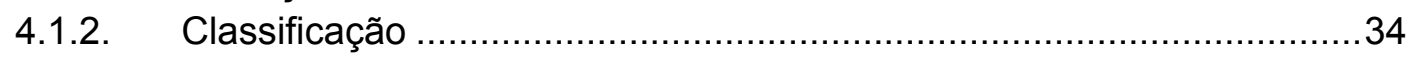

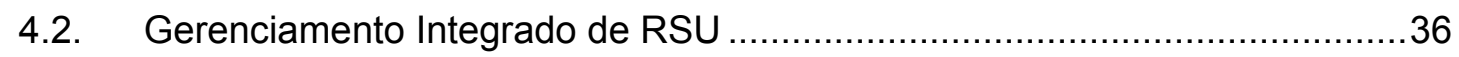

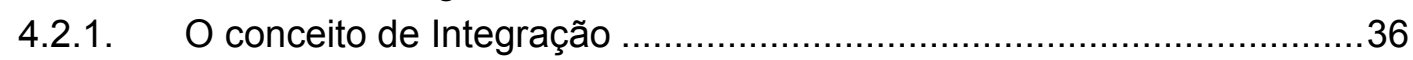

4.2.2. Modelo de Gerenciamento Integrado de RSU .................................. 38

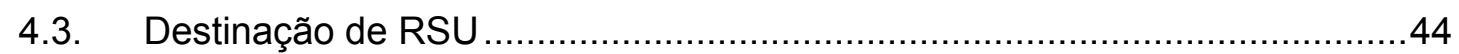

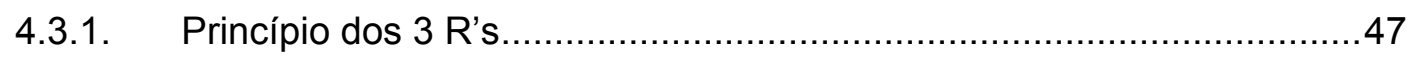

4.3.2. Processos intermediários para segregação ..................................... 49

4.3.3. Processo intermediário para tratamento térmico .................................50

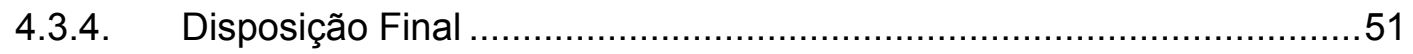

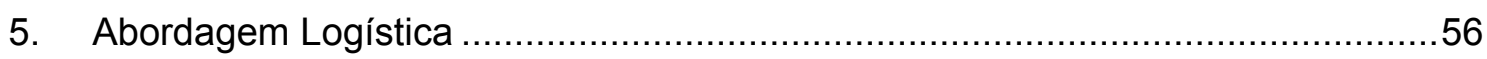

5.1. O trabalho no contexto da logística ......................................................56

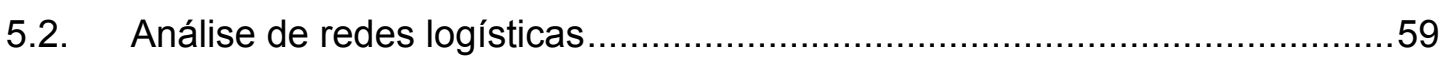

5.2.1. Localização de instalações.......................................................60

5.2.2. Roteirização e programação .............................................................64

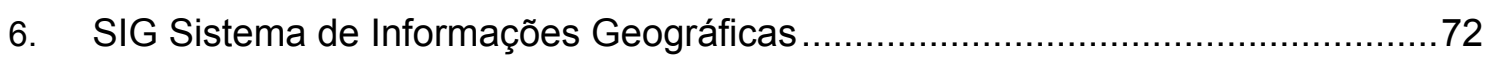

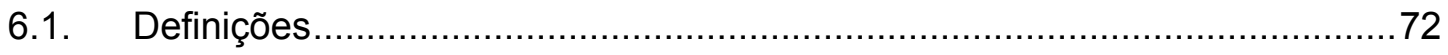

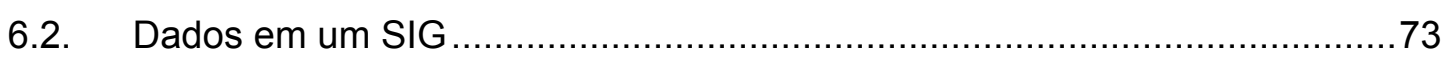

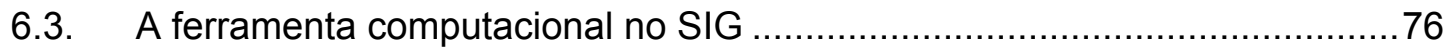

6.3.1. Características........................................................................ 76 


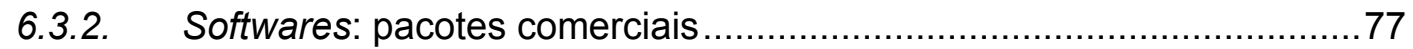

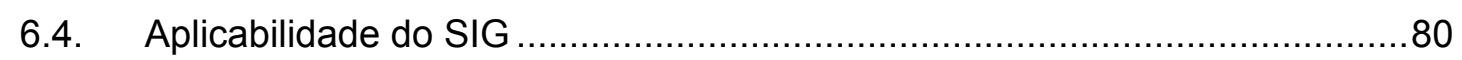

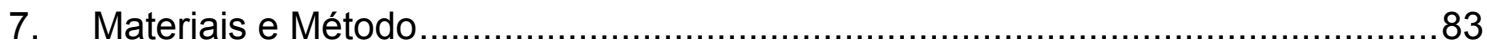

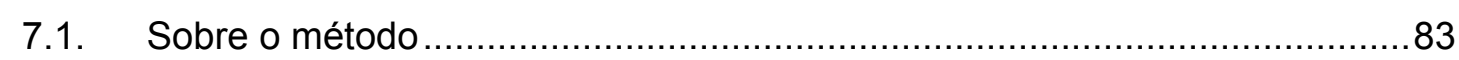

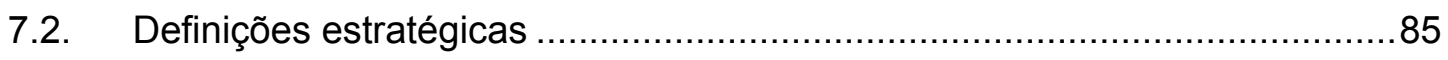

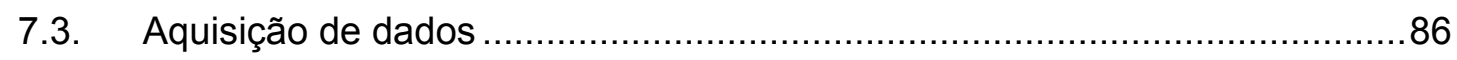

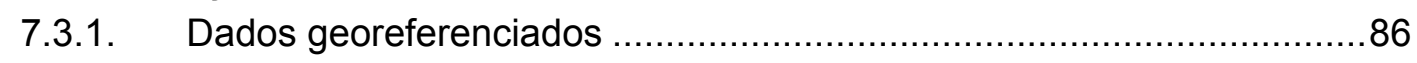

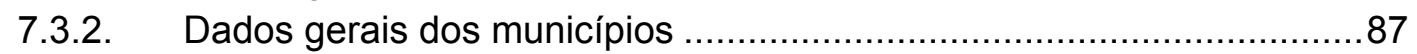

7.4. Dimensionamento da coleta de RSU nas cidades .....................................93

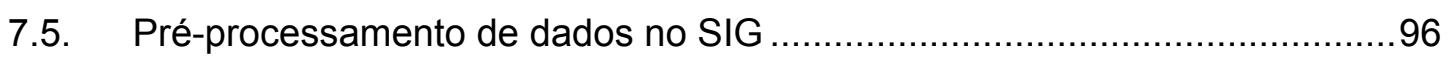

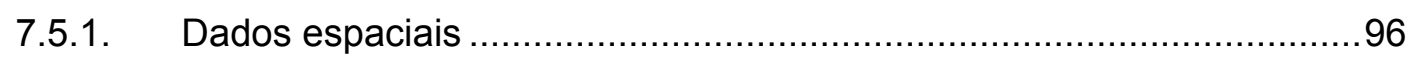

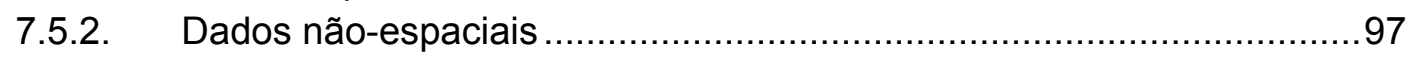

7.6. Gerenciamento de dados: importação para o TransCAD .............................98

7.7. Seleções de locais sem restrições .......................................................... 100

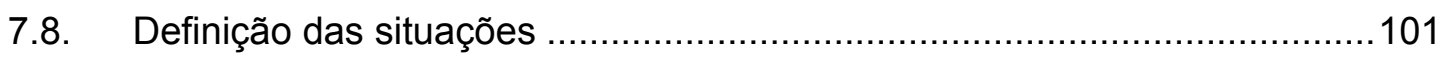

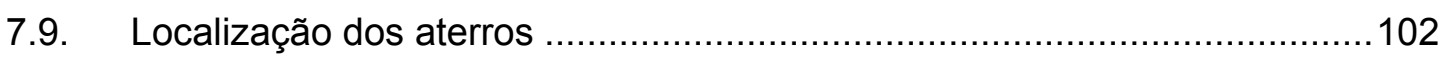

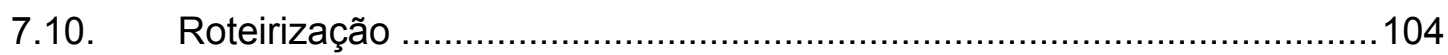

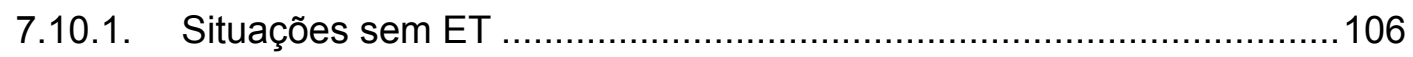

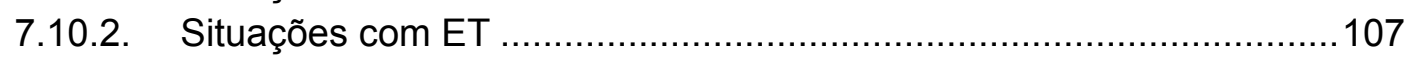

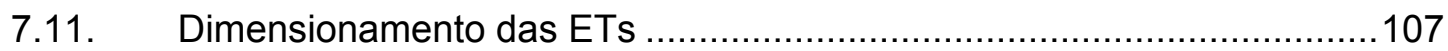

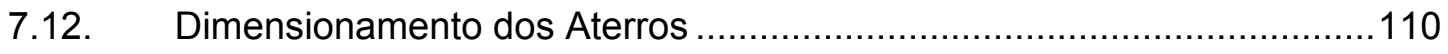

7.12.1. Aterro Sanitário em Valas............................................................... 111

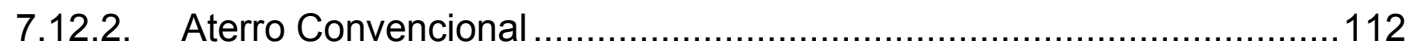

7.12.3. Componentes dos Dimensionamentos............................................ 112

7.13. Cálculo dos Custos para cada Situação Definida ...................................114

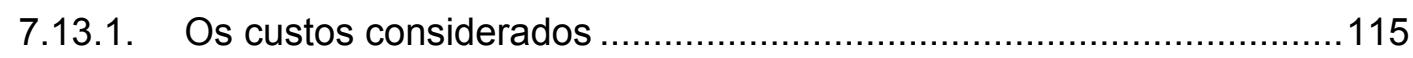

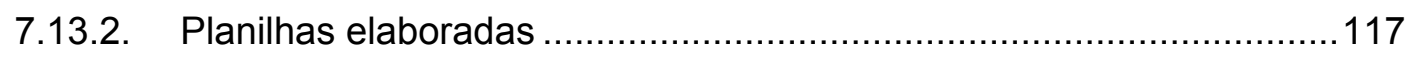

7.14. Avaliação das situações definidas....................................................... 121

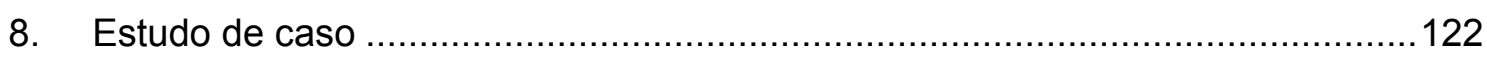

8.1. A Área Escolhida como Estudo de Caso ...............................................122

8.2. Considerações na aplicação do método ................................................124

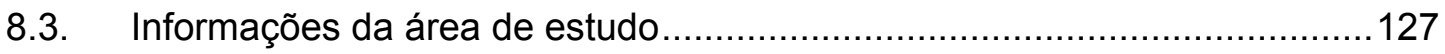

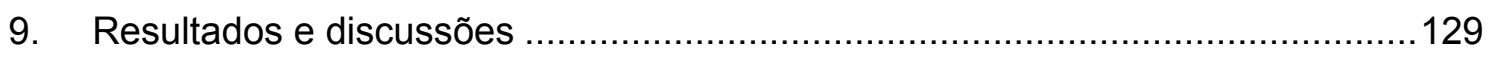

9.1. Resultados Intermediários.......................................................... 129

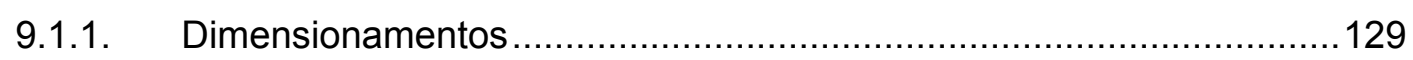

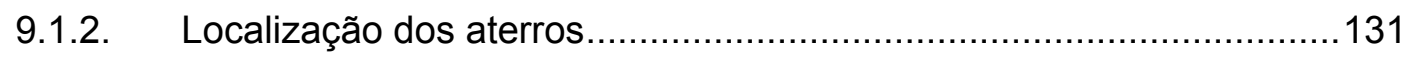

9.1.3. Roteirização dos veículos...........................................................140

9.2. Resultado Final ................................................................................ 145

9.2.1. Resultados Obtidos de Outras Etapas ......................................... 147

9.2.2. Resumo dos Resultados com os Custos........................................148

9.2.3. Análise dos resultados ................................................................... 151 


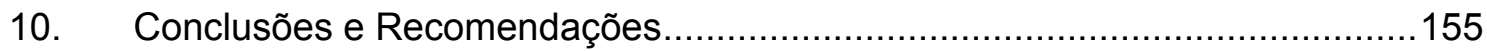

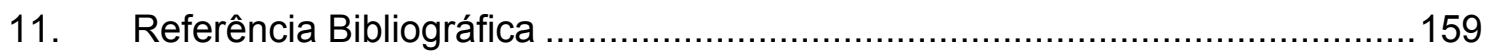

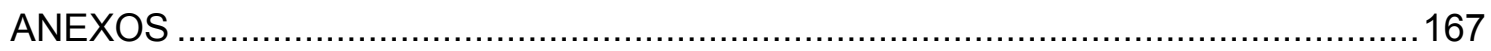

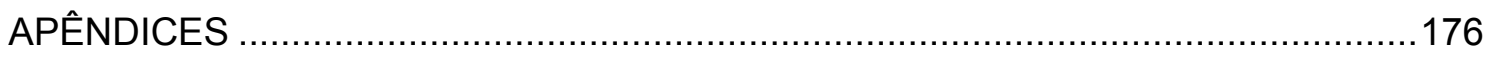




\section{Lista de figuras}

FIGURA 1.1 - Evolução da qualidade dos aterros de resíduos em todos os municípios do Estado de São Paulo

FIGURA 1.2 - Evolução da qualidade dos aterros de resíduos nos municípios de até 25.000hab do Estado de São Paulo ............................................................... 19

FIGURA 1.3 - Distribuição dos municípios por extrato populacional ..........................20

FIGURA 3.1 - Aspectos atrativos do consórcio intermunicipal ....................................26

FIGURA 4.1 - Roteiro para elaboração de Plano de Gerenciamento Integrado de Resíduos Sólidos....

FIGURA 4.2 - O Gerenciamento Integrado de Resíduos Sólidos

FIGURA 4.3 - Alcance dos serviços de limpeza urbana e/ou coleta de lixo prestados nos municípios do Brasil....

FIGURA 4.4 - A abrangência das formas de destinação de lixo coletado nos distritos

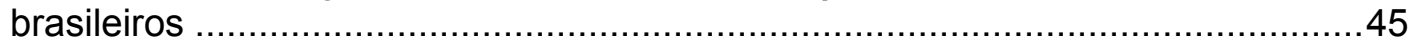

FIGURA 4.5 - O trajeto dos RSU e os processos envolvidos em seu manejo..............46

FIGURA 4.6 - Símbolo representativo do Princípio dos 3 R's ..................................4 47

FIGURA 4.7 - Padrões de cores para os diferentes resíduos ......................................50

FIGURA 4.8 - As fases do aterro sanitário e os sistemas de proteção ambiental .......53

FIGURA 4.9 - Tipos de aterros sanitários segundo o método de execução das células de lixo (executado em uma jornada de trabalho)................................................54

FIGURA 5.1 - Fluxo de produtos na cadeia de suprimento e retorno ..........................57

FIGURA 5.2 - O triângulo da tomada de decisões no planejamento logístico ...............59

FIGURA 5.3 - Representação do espaço real na forma de rede ...............................60

FIGURA 6.1 - Objetos espaciais em representação vetorial e matricial .......................74

FIGURA 6.2 - Representação topológica básica: nós, arcos e polígonos ....................75

FIGURA 6.3 - Dados armazenados em layers (camadas) no SIG ..............................76

FIGURA 6.4 - SIG no processo de decisão no planejamento estratégico ....................81

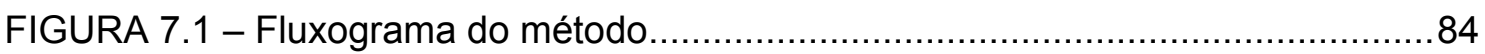

FIGURA 7.2 - Gráfico da Projeção da Taxa de Crescimento Populacional do Estado

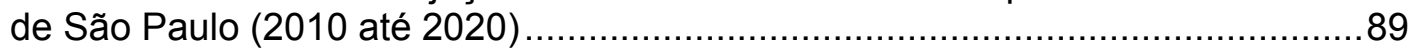

FIGURA 7.3 - Os pontos de controle escolhidos para importação dos dados espaciais para o TransCAD.

FIGURA 7.4 - Triangulação formada pelos pontos de controle escolhidos para importação do mapa rodoviário do DER-SP.

FIGURA 7.5 - Escolha de nós fora das restrições de zona urbana e águas superficiais. 
FIGURA 7.6 - Janela de entrada de dados para a rotina de localização do TransCAD.

FIGURA 7.7 - Codificação utilizada para cada situação definida...............................102

FIGURA 7.8 - Janela de entrada de dados para a rotina de roteirização do TransCAD.

FIGURA 7.9 - Tabela com a frota de veículos por aterro e capacidade de carga de cada modelo.

FIGURA 7.10 - Modelo criado para as ETs.................................................. 108

FIGURA 7.11 -Silo adotado no trabalho com sistema de pesagem acoplada...........108

FIGURA 8.1 - Localização da APA de Corumbataí.....................................................122

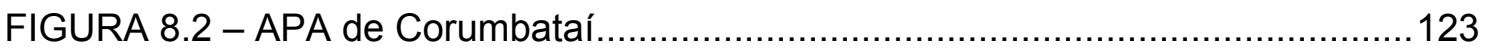

FIGURA 9.1 - Custo de Implantação de Aterro Sanitário (sem equipamentos) ..........130

FIGURA 9.2 - Custo de Implantação de Aterro Sanitário (com equipamentos) ..........130

FIGURA 9.3 - A configuração obtida para a Situação 11 ......................................... 132

FIGURA 9.4 - A configuração obtida para a Situação 12 ........................................... 133

FIGURA 9.5 - A configuração obtida para a Situação 13......................................... 134

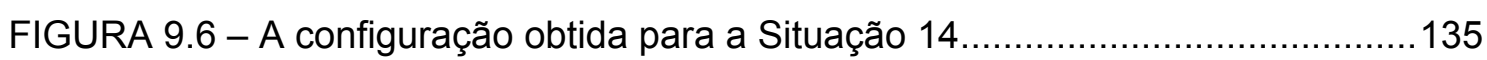

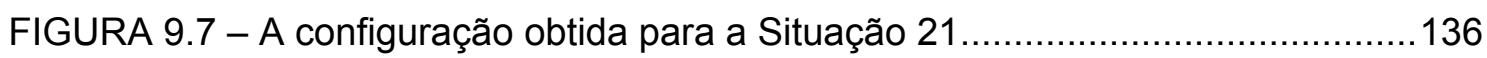

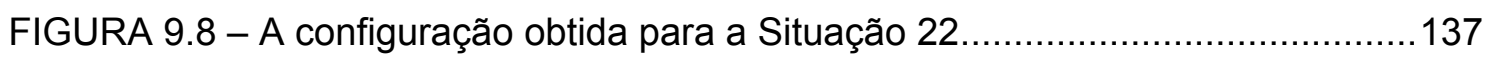

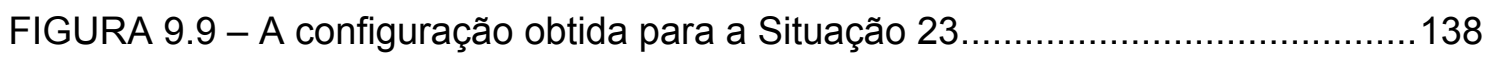

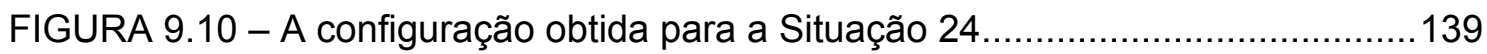

FIGURA 9.11 - Custo unitário por tonelada de RSU produzido do Sistema Consorciado segundo o número de aterros.....

FIGURA 9.12 - Custo unitário médio por tonelada de RSU produzido do Sistema Consorciado segundo a situação definida e os componentes dos custos 


\section{Lista de tabelas}

TABELA 1.1 - Enquadramento das instalações de destinação de lixo em função dos valores de IQR e IQC

TABELA 4.1 - Classificação dos resíduos sólidos quanto ao grau de biodegradabilidade

TABELA 4.2 - Classificação dos resíduos sólidos quanto à periculosidade

TABELA 4.3 - Classificação segundo a origem dos resíduos sólidos e a responsabilidade pelo seu gerenciamento

TABELA 4.4 - Modalidades de coleta seletiva .49

TABELA 5.1 - Modelos estático-determinísticos da localização de instalações ..........63

TABELA 5.2 - Características dos problemas de roteirização e programação .............65

TABELA 5.3 - Os problemas básicos de roteirização pura .........................................66

TABELA 5.4 - Característica dos problemas básicos de roteirização pura...................67

TABELA 5.5 - Os problemas básicos de programação de veículos ............................68

TABELA 5.6 - Os problemas básicos de programação de tripulação ...........................68

TABELA 5.7 - Os problemas de roteirização e programação .....................................69

TABELA 5.8 - Estratégias de solução para os problemas de roteirização e programação ................................................................................................ 70

TABELA 6.1 - Funções características de uma ferramenta SIG ...............................78

TABELA 6.2 - Critérios para seleção de ferramentas SIG .................................... 79

TABELA 6.3 - Softwares de SIG disponíveis no mercado ........................................80

TABELA 7.1 - Estimativa da População Flutuante - 2000..........................................8 88

TABELA 7.2 - Faixas mais utilizadas da geração per capita de Resíduos Sólidos .....90

TABELA 7.3 - Semanas padrões utilizadas no cálculo da geração de RSU para os dimensionamentos ao longo dos 15 anos de planejamento .................................90

TABELA 7.4 - Cálculo da quilometragem da malha viária de coleta de RSU ..............992

TABELA 7.5 - Critérios utilizados para divisão nos setores de coleta ........................93

TABELA 7.6 - Produção de RSU e o acúmulo nos dias de coleta................................95

TABELA 8.1 - A avaliação da condição de destinação final de RSU na APA de

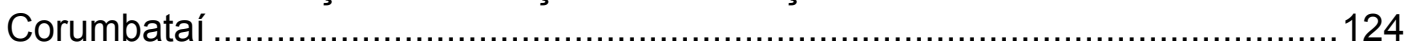

TABELA 8.2 - As ETs definidas e municípios atendidos........................................126

TABELA 9.1 - A configuração obtida para a Situação 11 ......................................132

TABELA 9.2 - A configuração obtida para a Situação 12 ...........................................133

TABELA 9.3 - A configuração obtida para a Situação 13 .........................................134

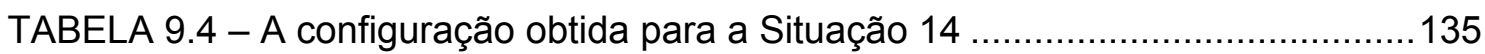


TABELA 9.5 - A configuração obtida para a Situação 21 .........................................136

TABELA 9.6 - A configuração obtida para a Situação 22 .......................................137

TABELA 9.7 - A configuração obtida para a Situação 23 .........................................138

TABELA 9.8 - A configuração obtida para a Situação 24 .........................................139

TABELA 9.9 - Veículo de transbordo: distância e tempo gastos (Situação 11) ..........140

TABELA 9.10 - Veículo de transbordo: distância e tempo gastos (Situação 12) ........141

TABELA 9.11 - Veículo de transbordo: distância e tempo gastos (Situação 13) ........141

TABELA 9.12 - Veículo de transbordo: distância e tempo gastos (Situação 14) ........142

TABELA 9.13 - Roteirização para veículo de transbordo: resultados no formato para cálculo de custos

TABELA 9.14 - Roteirização para veículo de coleta: resultados sintetizados no formato

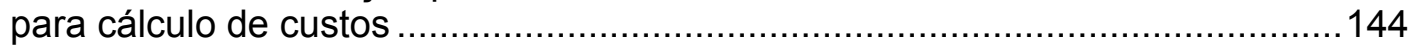

TABELA 9.15 - Roteirização para veículo de coleta: resultados sintetizados no formato

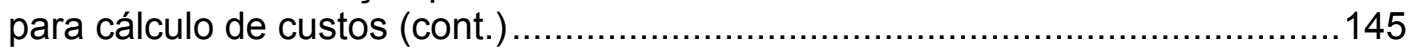

TABELA 9.16 - Entrada na planilha de custos: valores sintetizados de produção de

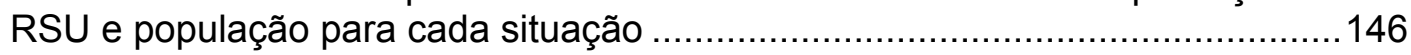

TABELA 9.17 - Entrada na planilha de custos: valores sintetizados da implantação de ETs para cada situação 146

TABELA 9.18 - Entrada na planilha de custos: valores sintetizados da implantação de Aterros para cada situação.

TABELA 9.19 - Entrada na planilha de custos: tempo de trabalho dos equipamentos nos aterros para cada situação.

TABELA 9.20 - Custos do transporte com veículo de coleta até destino.....................149

TABELA 9.21 - Custos de operação da coleta para cada situação ............................149

TABELA 9.22 - Custos do transporte com veículo de transbordo: Aterro-ET-Aterro.149

TABELA 9.23 - Custos total das componentes de operação .......................................150

TABELA 9.24 - Custos de operação dos Aterros e ETs ...........................................150

TABELA 9.25 - Custos de investimentos na implantação dos aterros e ETs .............150

TABELA 9.26 - Custos total final de todas as componentes.................................. 151 


\section{Lista de abreviaturas e siglas}

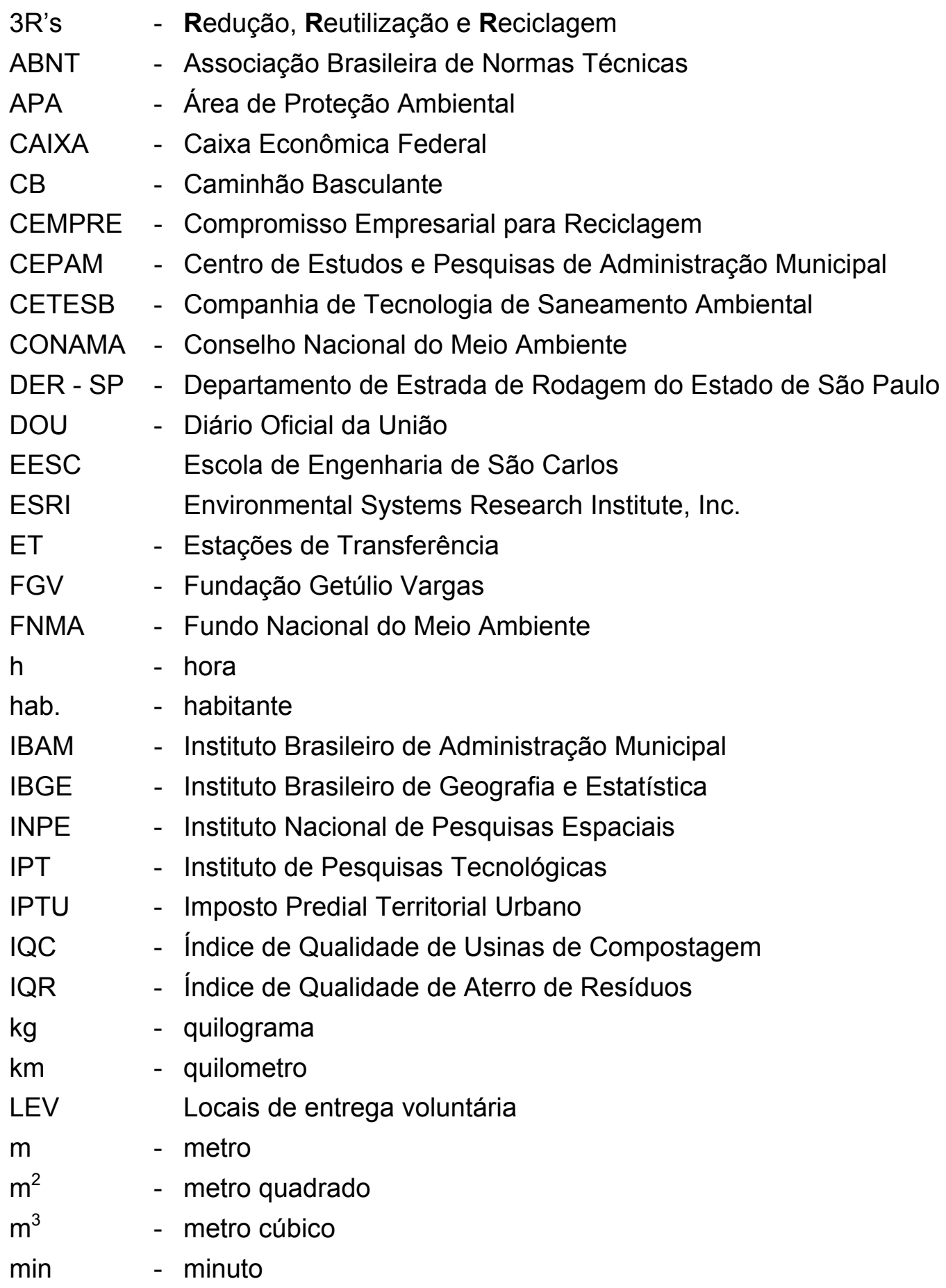




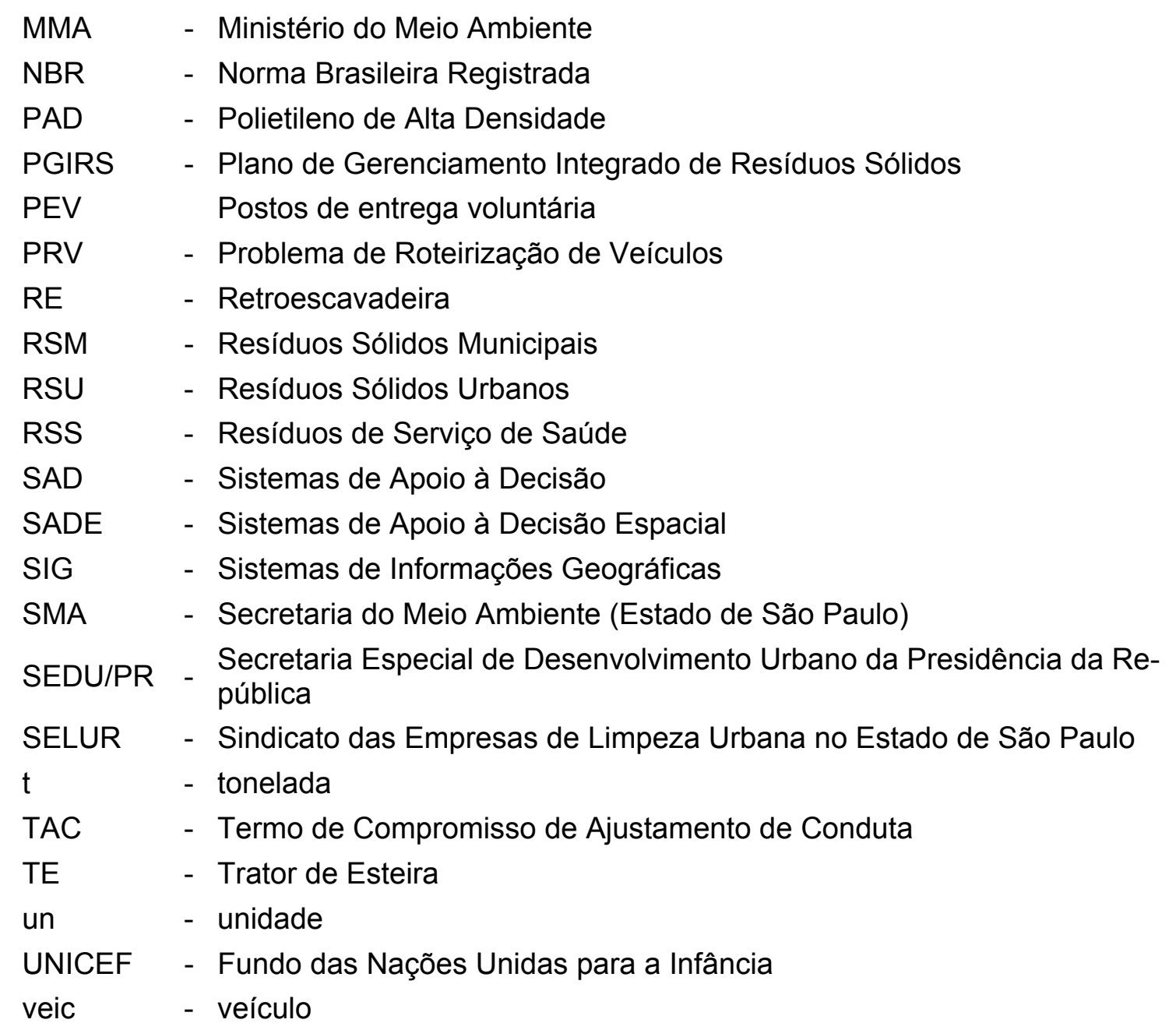




\section{RESUMO}

NARUO, M. K. (2003). O Estudo do consórcio entre municípios de pequeno porte para disposição final de Resíduos Sólidos Urbanos, utilizando Sistema de Informações Geográficas. São Carlos. 283 p. Dissertação (Mestrado) - Escola de Engenharia de São Carlos, Universidade de São Paulo.

Os consórcios são conhecidos pelo aumento da capacidade de realização que confere aos participantes, e maior eficiência no uso dos recursos disponíveis, o que auxiliaria os pequenos governos locais para solucionar a escassez de recursos. Este trabalho apresenta o estudo do sistema consorciado intermunicipal para destinação dos resíduos sólidos urbanos, para auxiliar os municípios de pequeno porte na solução da inadequada destinação do lixo, responsáveis por constantes impactos ambientais. Os estudos foram realizados através de análises de custos com enfoque logístico, no nível estratégico de localização de facilidades e roteirização e programação da frota. Os estudos foram possíveis, com o auxílio do software TransCAD, uma ferramenta de Sistema de Informações Geográficas. Através do TransCAD, foi realizado a localização dos aterros sanitários, obedecendo-se as restrições impostas, e a roteirização da frota de veículos, que levassem ao menor custo logístico. Para se chegar à situação de menor custo, diversas configurações foram consideradas, nas quais foram variados o número de aterros que atendem os municípios, e a presença ou não de estações de transferência de resíduos. O método desenvolvido promoveu a análise de custos da implantação e operação do sistema consorciado, que consiste desde a coleta de resíduos, até a disposição final em aterros sanitários. Os resultados deste trabalho comprovaram quantitativamente que o consórcio é mais eficiente do que a solução isolada para cada município.

Palavras-chave: Área de Proteção Ambiental; aterro sanitário; consórcio intermunicipal; localização de facilidades; logística; planilha de custos; Resíduo Sólido Urbano; roteirização; Sistema de Informações Geográficas. 


\section{ABSTRACT}

NARUO, M. K. (2003). The study of the consortium among small cities for the final destination of urban solid waste, using Geographical Information System. São Carlos. 283 p. Dissertação (Mestrado) - Escola de Engenharia de São Carlos, Universidade de São Paulo.

The consortium are known by the growth of the accomplishment capacity that grants to the participants, and larger efficiency in the use of the available resources, what would aid the small local governments to solve the lack of resources. This work presents the study of the intermunicipal consortium system for the destination of the urban solid waste, to aid the small cities to solve the inadequate destination of the waste, responsible for constant environmental damages. The studies were developed through the costs analysis with logistics focus, on the strategic level of facilities location and the vehicle routing. The studies were possible with the aid of the software TransCAD, a tool of Geographical Information System. Through the TransCAD, being obeyed the imposed restrictions, the location of the sanitary landfill was made, and vehicles routing, to take to the lowest logistics cost. To reach the situation of lowest cost, several configurations were considered, in which the number of sanitary landfill for the cities were varied, and the inclusion or not the solid waste transfer stations. The developed method promoted the cost analysis of the implantation and operation of the consortium system, from the waste collection, until the final disposition in sanitary landfills. The results of this work proved quantitatively that the consortium is more efficient than the isolated solution for each city.

Keywords: Environmental Protection Area; sanitary landfill; intermunicipal consortium; facility location; logistics; costing spreadsheet; Urban Solid Waste; routing; Geographical Information System. 
Este capítulo descreve a condição de inadequação na destinação de resíduos sólidos dos municípios de pequeno porte, e os problemas ocasionados pelo seu mau gerenciamento. As informações, aqui apresentadas, foram importantes para que o trabalho que levou a esta dissertação fosse proposto.

A sociedade moderna, devido ao seu crescimento populacional e a evolução dos padrões de produção e consumo, enfrenta problemas causados pelo lixo. Quando o lixo não é tratado e disposto de forma adequada, pode causar a contaminação do solo e da água, gerar odores, ou ainda, atrair e propiciar a proliferação de espécies patogênicas e vetores. Dessa forma, conforme a Secretaria do Meio Ambiente do Estado de São Paulo (SMA), (SÃO PAULO, 1998a), a questão do lixo envolve aspectos ambientais, sanitários e de saúde pública. Problemas sociais também estão associados ao lixo. Segundo o Inventário Estadual de Resíduos Sólidos Domiciliares - 1999 da SMA (SÃO PAULO, 2000a), a presença de catadores em lixões denuncia sérios problemas de ordem social e de saúde pública e vem preocupando organismos nacionais e internacionais sendo, inclusive, objeto de programas específicos como o programa Criança no lixo - Nunca mais, coordenado pelo Fundo das Nações Unidas para a Infância (UNICEF).

Desde 1997, o governo do Estado de São Paulo tem mostrado uma nova postura em relação ao lixo urbano consolidada no Programa Estadual de Resíduos Sólidos. Através da Companhia de Tecnologia de Saneamento Ambiental (CETESB), órgão da SMA, o governo instituiu dois instrumentos: o Inventário Estadual de Resíduos Sólidos Domiciliares e o Termo de Compromisso de Ajustamento de Conduta (TAC). 
Segundo a SMA (SÃO PAULO, 2001b), o TAC é "um título executivo extrajudicial estabelecido em comum acordo com as administrações municipais, definindo prazos e atividades a serem realizadas por cada município, para a regularização ambiental das instalações de destinação de lixo em operação".

O Inventário Estadual de Resíduos Sólidos Domiciliares é um instrumento de avaliação para diagnosticar a situação da destinação do lixo no Estado de São Paulo. Segundo a SMA (SÃO PAULO, 2001b), esta avaliação é realizada através de um formulário padronizado e inovador, que consiste na análise não subjetiva de 41 itens de caracteres locacional, estrutural e operacional de instalações de destino do lixo. A reunião destas análises compõe o Índice de Qualidade de Aterro de Resíduos (IQR) e o Índice de Qualidade de Usinas de Compostagem (IQC). Estes índices são utilizados para avaliar as instalação de destinação de resíduos, segundo a TABELA 1.1 .

TABELA 1.1 - Enquadramento das instalações de destinação de lixo em função dos valores de IQR e IQC

\begin{tabular}{cl}
\hline IQR ou IQC & \multicolumn{1}{c}{ Enquadramento } \\
\hline $0,0 \leq \mathrm{IQ} \leq 6,0$ & Condições Inadequadas \\
$6,0<\mathrm{IQ} \leq 8,0$ & Condições Controladas \\
$8,0<\mathrm{IQ} \leq 10,0$ & Condições Adequadas \\
\hline
\end{tabular}

Fonte: SÃO PAULO (2001b)

O Inventário é divulgado anualmente pela CETESB, conforme o estabelecido na Resolução SMA 13, de 27 de fevereiro de 1998 (SÃO PAULO, 1998b), desde 1997, sendo o último com os dados de 2000. Os resultados desta política têm sido surpreendentes, como pode ser visto através da evolução da qualidade dos aterros nos municípios, como representado no gráfico da FIGURA 1.1.

As instalações de aterros para resíduos que estavam impróprias diminuíram entre 1997 e 2000 , de $78,8 \%$ para $47,0 \%$ e as adequadas aumentaram de $3,7 \%$ para $30,4 \%$. A melhoria alcançada foi mais significativa ao avaliar as cidades com até $25.000 \mathrm{hab}$, pequeno porte, e que produzem até $10 \mathrm{t} /$ dia de lixo. De acordo com o gráfico da FIGURA 1.2, os pequenos municípios que estavam inadequados eram de $85,4 \%$ e passaram a ser em 2000 de $44,6 \%$. E os adequados que eram de apenas $1,1 \%$ passa- 
ram a ser $32,4 \%$ neste inventário. Demonstrando uma melhora significativa ao longo destes 4 anos.

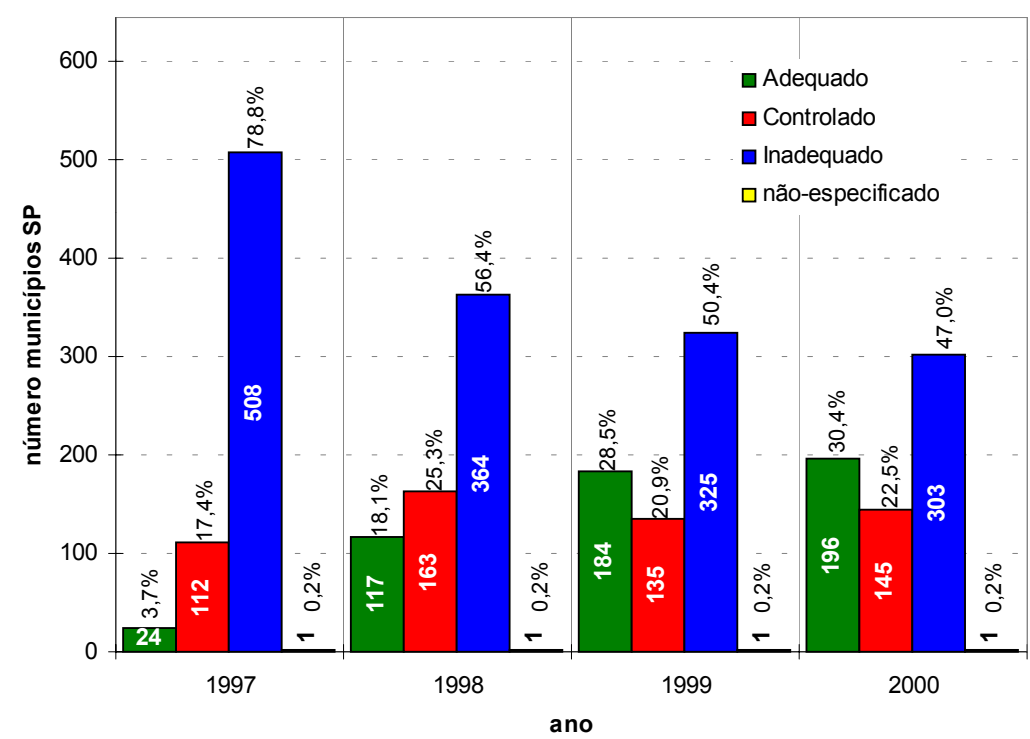

Fonte: Adaptado do Inventário Estadual de Resíduos Sólidos Domiciliares (SÃO PAULO, 2001b) Gráfico construído com dados da população de 01 de agosto de 2000 (IBGE, 2000b)

FIGURA 1.1 - Evolução da qualidade dos aterros de resíduos em todos os municípios do Estado de São Paulo

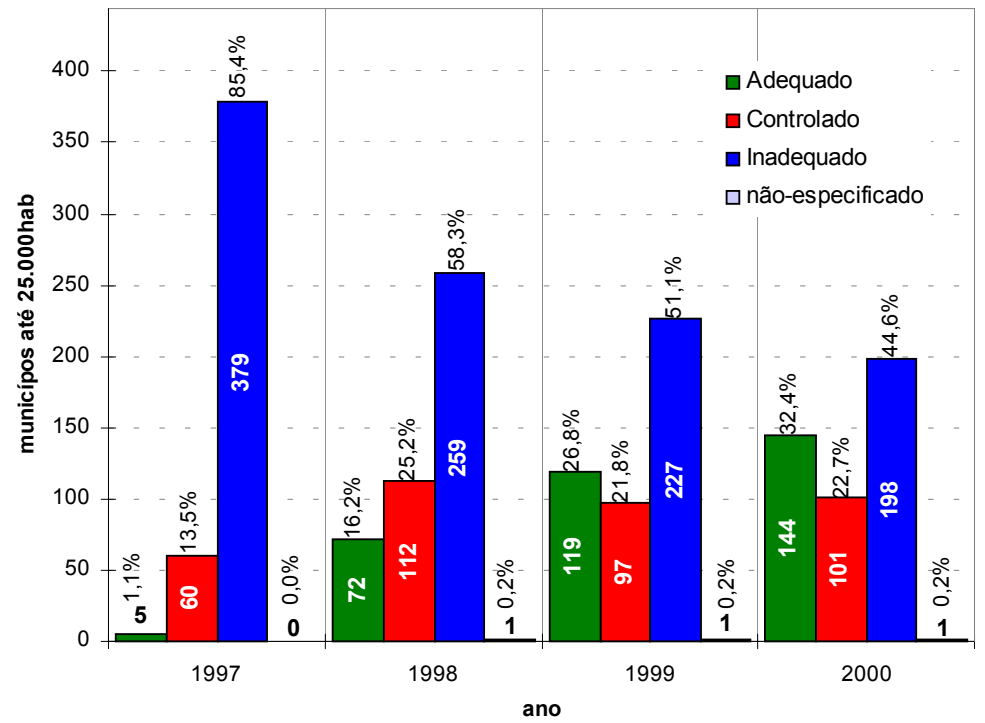

Fonte: Adaptado do Inventário Estadual de Resíduos Sólidos Domiciliares (SÃO PAULO, 2001b) Gráfico construído com dados da população de 01 de agosto de 2000 (IBGE, 2000b)

FIGURA 1.2 - Evolução da qualidade dos aterros de resíduos nos municípios de até 25.000hab do Estado de São Paulo 
Apesar da melhora percentual para os pequenos municípios, em números, eles ainda são 198 cidades em situação inadequada. E estes representam 65,3\% do total de 303 municípios do Estado de São Paulo com as instalações impróprias para a disposição de resíduos. Assim sendo, a grande maioria dos municípios com inadequação são de pequeno porte. Esta análise numérica é importante, pois cada cidade representa um potencial foco de agressão ambiental. Na FIGURA 1.3, podemos ver a distribuição dos municípios de São Paulo e do Brasil por extrato populacional. Se fosse possível estender o problema do lixo para o Brasil a situação seria mais crítica, pois a percentagem de municípios de pequeno porte é maior para todo o território nacional (79\%) se comparado com o Estado de São Paulo (69\%).

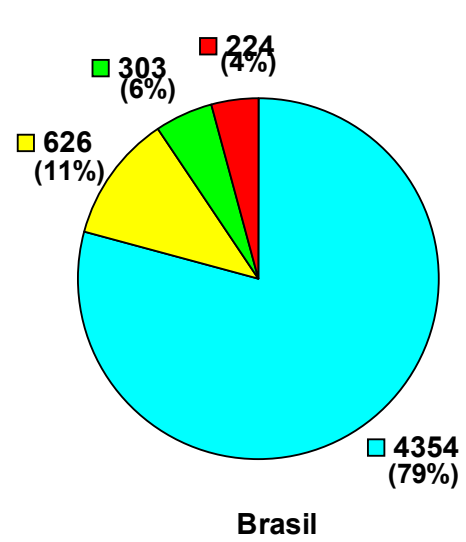

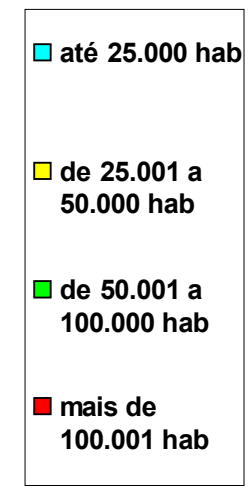

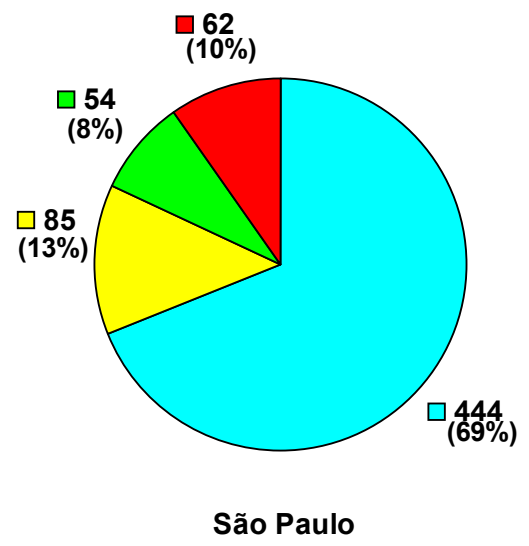

Fonte: Gráfico construído com dados da população de 01 de agosto de 2000 (IBGE, 2000b)

FIGURA 1.3 - Distribuição dos municípios por extrato populacional

Dos 5.507 municípios brasileiros, 645 pertencem ao Estado de São Paulo, que é o mais industrializado e com a maior densidade demográfica no Brasil. A dimensão dos seus problemas ambientais é inerente à sua grandeza, bem como os desafios que surgem para o seu desenvolvimento sustentável. A situação dos resíduos sólidos não difere deste panorama. De acordo com a SMA (SÃO PAULO, 1998a), para os municípios de pequeno porte com disposição inadequada de lixo, que geram quantidades inferiores ou iguais a $10 \mathrm{t} / \mathrm{dia}$ de lixo, inviabiliza-se soluções técnicas onerosas para cada um isoladamente. Um aterro sanitário, por exemplo, é uma tecnologia inviável dentro do orçamento de um município de pequeno porte, devido ao alto custo de instalação e operação, além da ociosidade de equipamentos ocasionados com sua implantação. 
Para os municípios, como os citados anteriormente, conforme a SMA (SÃO PAULO, 1998a), torna-se cada vez mais promissora a possibilidade da união de dois ou mais parceiros em busca de soluções conjuntas para a destinação dos resíduos sólidos. Dentro destas formas de soluções conjuntas está o consórcio intermunicipal. Para BORGES (2001): "o consórcio possibilita a ampliação e o fortalecimento das capacidades gerenciais dos municípios pela soma de suas capacidades administrativa, técnica e financeira, disponíveis em cada comunidade, como melhor forma de garantir solução satisfatória com integração de investimentos municipais e estaduais".

De acordo com o manual elaborado pelo Instituto de Pesquisas Tecnológicas e o Compromisso Empresarial para Reciclagem (IPT-CEMPRE), denominado Lixo municipal: Manual de Gerenciamento Integrado, coordenado por D'ALMEIDA \& VILHENA (2000), as ações regionalizadas, na forma de consórcios, parcerias ou outra solução conjunta, ampliam os benefícios e reduzem os custos. Este ponto de vista de solução em parceria também é considerado no roteiro para se elaborar o Plano de Gerenciamento Integrado de Resíduos Sólidos (PGIRS) do manual do Fundo Nacional do Meio Ambiente (FNMA), (BRASIL, 2000).

No texto da CETESB denominado PROPOSIÇÕES BÁSICAS PARA UMA POLÍTICA BRASILEIRA DE LIMPEZA PÚBLICA (1978) já se enfatizava: “... a consecução de formas sanitárias e economicamente adequadas para a disposição final do lixo pode exigir, face às peculiaridades regionais, soluções conjuntas, abrangendo mais de um município, tornando-se os serviços, matéria de interesse interlocal ou intermunicipal. No que se refere à associação de municípios para a prestação de serviços de interesse comum, deve ser considerado, como igualmente válido, a implementação de convênios que promovam a constituição de consórcio intermunicipal, instalado sob forma autárquica, ou pela constituição de empresa intermunicipal".

$\mathrm{Na}$ bibliografia pesquisada, verificou-se a existência de consórcios intermunicipais para a disposição final dos resíduos em aterros sanitários, como é o caso do Consórcio Quiriri no Estado de Santa Catarina (TEIXEIRA \& JACOBI, 2000), além de outros que estão encontrados em CRUZ (2001) e exemplificados posteriormente neste trabalho. Mas, não foram encontrados estudos com enfoque logístico para a elaboração destes sistemas consorciados na literatura consultada. Por exemplo, se estudos de planeja- 
mento fossem feitos, envolvendo o cálculo do número ideal de aterros com a sua meIhor localização, além da roteirização e programação de frotas de transporte dos resíduos, os custos poderiam ser qualificados, quantificados, analisados e minimizados.

Perante a escassez de informação e as poucas experiências no Brasil, se faz necessário desenvolver análises logísticas como descritas acima. Os ferramentais científicos utilizados neste estudo são fundamentais para auxiliar no gerenciamento dos resíduos sólidos. Principalmente para apoiar a administração de pequenas prefeituras na tomada de decisões, para a elaboração de um sistema consorciado de destinação de resíduos sólidos como potencial solução para a questão do lixo e promoção do desenvolvimento sustentável, de forma viável.

Com base no que foi discutido neste capítulo introdutório, esta pesquisa foi desenvolvida e está apresentada nos capítulos subseqüentes desta dissertação.

No Capítulo 2, desta dissertação, é apresentado em poucos parágrafos, o objetivo desta pesquisa. A revisão bibliográfica, abordando o consórcio intermunicipal, os resíduos sólidos e sua destinação, a logística e o Sistema de Informações Geográficas, está nos Capítulo 3 ao Capítulo 6. Nestes capítulos, se busca ter o entendimento dos assuntos aos quais esta pesquisa está envolvida.

Na seqüência, o Capítulo 7 descreve os materiais empregados e o método desenvolvido e aplicado nesta pesquisa. Nesta parte da dissertação, é apresentado o fluxograma geral, para que se tenha uma visão do método elaborado para o estudo do consórcio intermunicipal, como uma solução para destinação de resíduos em aterros sanitários. Além da visão geral do fluxo, cada processo é detalhado ao longo do capítulo.

No Capítulo 8, o estudo de caso, onde o método foi aplicado, é apresentado. Sendo que os resultados obtidos com a aplicação do método, e suas discussões, encontramse no Capítulo 9, anterior ao Capítulo 10, onde as conclusões desta pesquisa podem ser encontradas. 


\subsection{Objetivo Principal}

O presente trabalho tem como objetivo principal, estudar o sistema consorciado intermunicipal de destinação de resíduos sólidos urbanos (RSU), através da análise de custos com enfoque logístico, no nível estratégico de localização de aterros e de roteirização e programação de frota, com auxílio de um Sistema de Informações Geográfi$\operatorname{cas}(\mathrm{SIG})$.

\subsection{Objetivos secundários}

A pesquisa tem como objetivos secundários:

- desenvolver o método para alcançar a avaliação quantitativa do sistema consorciado intermunicipal, através de planilha de custos;

- servir de apoio à decisão na elaboração e análise de sistemas consorciados para destinação de RSU;

- avaliar a eficiência do software TransCAD, a ser utilizado como ferramenta de SIG de apoio à decisão espacial, nas análises logísticas propostas nesta pesquisa. 


\section{CONSÓRCIO INTERMUNICIPAL}

Este capítulo apresenta o estudo bibliográfico realizado sobre o consórcio intermunicipal. São descritas aqui, a conceituação de consórcio, a sua importância na solução de problemas e as formas de aplicação, dentre eles, para a destinação dos resíduos.

\subsection{Introdução}

A Constituição Federal do Brasil de 1988 (BRASIL, 2002) em seu Artigo 18, confere autonomia aos entes da organização político-administrativas da República Federativa do Brasil, que compreende a União, os Estados, o Distrito Federal e os Municípios. No Artigo 23, confere competência comum a União, Estado, Distrito Federal e Municípios: “... proteger o meio ambiente e combater a poluição em qualquer de suas formas; preservar as florestas, a fauna e a flora; ...”. E no Artigo 255, a Constituição prevê que "todos têm direito ao meio ambiente ecologicamente equilibrado, bem de uso comum do povo e essencial à sadia qualidade de vida, impondo-se ao poder público e à coletividade o dever de defendê-lo e preservá-lo para as presentes e futuras gerações".

A Constituição garante ao brasileiro o direito ao meio ambiente resguardado, e prevê a todos os entes federados, entre eles os municípios, o dever de zelar por este direito e autonomia para alcançar este objetivo. Mas, segundo CRUZ (2001), apesar da autonomia concedida aos municípios, isto não significa que estes disponham de recursos financeiros, materiais e humanos para a implementação de ações de proteção ao meio ambiente. Para esta autora, os municípios pequenos não possuem recursos suficientes para a implantação de serviços mais complexos, sendo dependentes em relação aos grandes municípios ou municípios-pólo. Assim, os governos locais devem assumir novos papéis e responsabilidades para mudar este quadro. De acordo com ZULAUF (2001), cabe ao município não só assumir claramente sua parte, mas também, estabe- 
lecer parcerias com os demais entes federados, principalmente outros municípios para conduzir ações voltadas ao fiel cumprimento dos preceitos constitucionais.

Conforme CRUZ (2001), vários municípios têm inovado e criado novas formas de prestação de serviços e de organização, assim como de articulação. Os poderes locais começaram a discutir alguns de seus problemas conjuntamente, ou seja, através do que se conhece como cooperação horizontal ou cooperação intermunicipal. Segundo esta mesma autora, este tipo de união tem se colocado como alternativa para a racionalização do modelo de gestão, sendo o consórcio intermunicipal uma destas formas.

É necessário salientar que existem inúmeras formas de "cooperação" ou "parcerias" intermunicipais: as associações, as agências, os fóruns, as empresas, as autarquias, as redes e as câmaras municipais, que são diferentes do consórcio intermunicipal (CRUZ, 2001). Como o consórcio intermunicipal tem sido o método adotado para maioria das cooperações, os conceitos dele serão discutidos neste trabalho.

\subsection{Consórcio Intermunicipal}

Segundo o dicionário HOUAISS (2001), a palavra consórcio origina-se do latim consortium e significa "associação, participação, comunidade de bens", e é definido como sendo um "grupo de empresas autônomas que têm operações comuns".

Os consórcios são definidos por MEIRELLES (199-?) apud CRUZ (2001) como "acordos firmados entre entidades estatais, autárquicas, fundacionais ou paraestatais, sempre da mesma espécie, para realizações de objetivos de interesse comum dos participantes, mediante a utilização de recursos materiais e humanos que cada um dispõe".

Assim, as parcerias entre pessoas públicas na forma de consórcio, em sua essência, apenas podem ser implantadas na mesma esfera de poder: município com município, estado com estado, autarquia com autarquia. Segundo CRUZ (2001), apesar da lei prever todas estas possibilidades, os mais comuns são firmados entre os poderes municipais: consórcio intermunicipal. Conforme a autora, os consórcios intermunicipais

\footnotetext{
${ }^{1}$ MEIRELLES, H. L. (199-?). Direito Administrativo Brasileiro. São Paulo, Malheiros.
} 
têm sido difundidos no Brasil, como parcerias entre governos locais, principalmente entre pequenas e médias cidades adjacentes, sendo que a proximidade física pode determinar a viabilidade da implantação dos consórcios.

Esta difusão da cooperação ao nível de administração local se deve à necessidade de superar os desafios ocasionados pela descentralização das políticas públicas, autonomia concebida a partir da Constituição de 1988. Para alcançar o objetivo e progredir, sem estar sujeito a uma esfera superior de governo, os municípios empenharamse em racionalizar o modelo da gestão pública através da implementação de consórcios intermunicipais.

Por diversos aspectos o consórcio intermunicipal se torna atraente, principalmente para modernizar a administração pública e torná-la capaz de cumprir com suas obriga-

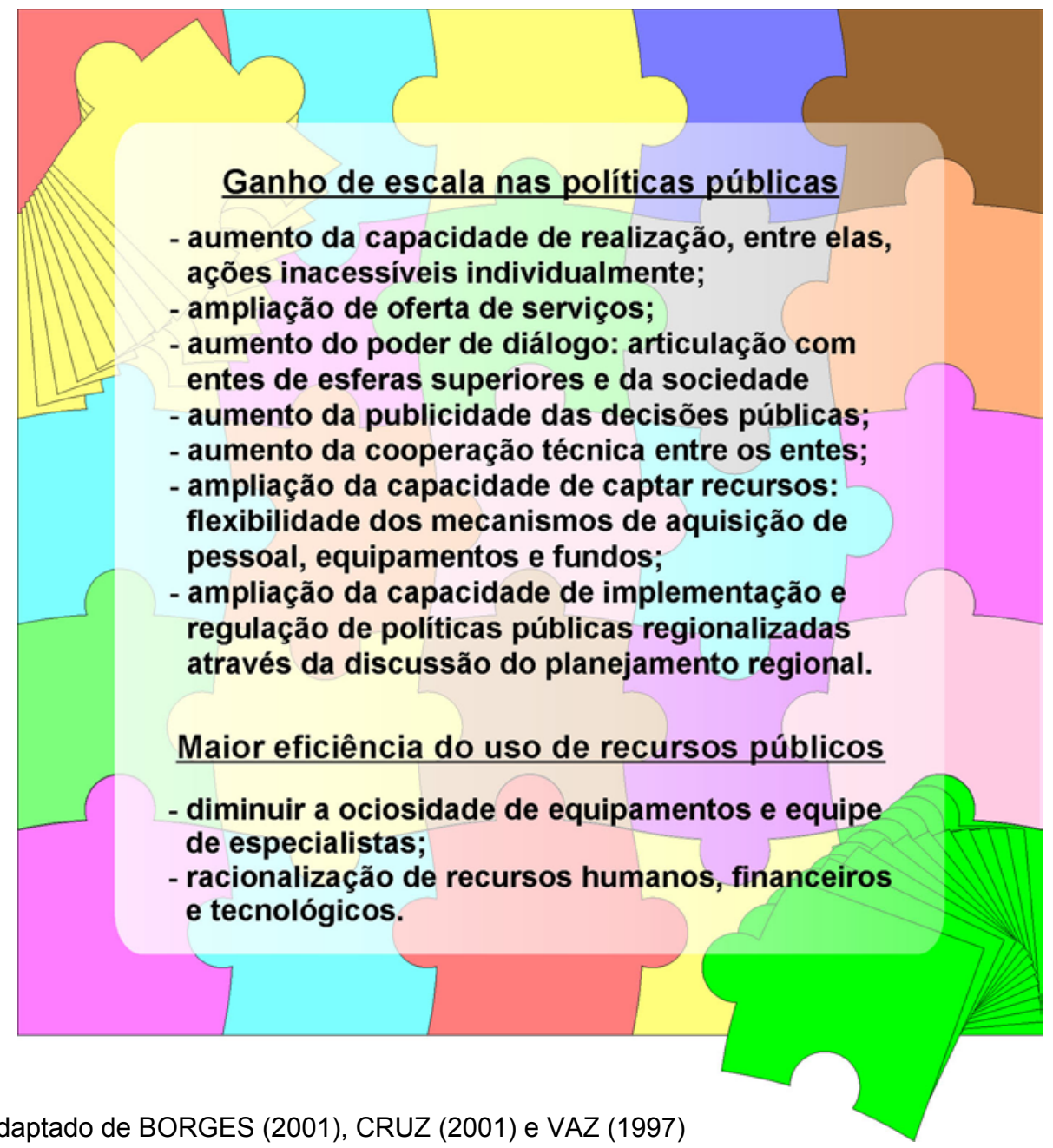

Fonte: Adaptado de BORGES (2001), CRUZ (2001) e VAZ (1997)

FIGURA 3.1 - Aspectos atrativos do consórcio intermunicipal 
ções constitucionais. Segundo BORGES (2001), CRUZ (2001) e VAZ (1997), a implantação desta forma de cooperação intermunicipal torna diversos resultados positivos possíveis para a racionalização da gestão municipal, graças a características como os descritos na FIGURA 3.1: amplificação do alcance das políticas públicas e eficiência do uso de recursos.

De acordo com BORGES (2001), todo modelo de gerenciamento municipal deve ser compatível com a realidade local. $\mathrm{E}$ também, a réplica de um método de consórcio existente depende de diversos fatores como a conjuntura política e institucional, a realidade local, o interesse dos envolvidos, a clareza dos parceiros na identificação de problemas e a consciência da impossibilidade de solucionar os problemas individualmente (CRUZ, 2001).

É necessário deixar claro, que um consórcio é apenas um acordo pactual entre os parceiros para reunir recursos financeiros, técnicos e humanos que cada um não dispõe isoladamente. Segundo LEITE $(1995)^{2}$ apud CRUZ (2001), o consórcio "não tem personalidade jurídica capaz de direitos e obrigações. Trata-se de meros ajustes. Os municípios, separadamente, é que têm personalidade jurídica, mas a união deles pelo consórcio não cria uma nova personalidade jurídica. Todas as despesas e responsabilidades são assumidas pelos municípios consorciados". De acordo com a SMA (SÃO PAULO, 1998a), o consórcio é um ajuste institucional entre os municípios que para efetivá-lo, basta uma lei autorizadora votada pela Câmara Municipal de cada município interessado, antes da sua formalização.

Quando a forma de cooperação intermunicipal exerce direitos e obrigações em seu próprio nome, neste caso, ela já assume o caráter de uma sociedade. Conforme LEITE (1995)² apud CRUZ (2001), quando a intenção não é mais apenas reunir recursos, mas a produção através da parceria, é necessário a constituição de uma pessoa jurídica, podendo ser uma sociedade civil ou comercial. Segundo o mesmo autor, esta pessoa jurídica, "cuja criação foi previamente autorizada pelas câmaras municipais dos participantes, é detentora de direito e obrigações e, portanto, pode assumir o que

\footnotetext{
${ }^{2}$ LEITE, L. G. (1995). Repasse financeiro de entidades governamentais e não-governamentais aos Consórcios intermunicipais. In: FUNADAÇÃO PREFEITO FARIA LIMA - CEPAM. Consórcio intermunicipal: estudos, pareceres e legislação básica. Informativo Jurídico n. 11. São Paulo FPFL - CEPAM, ano $\mathrm{X}$.
} 
for necessário para a execução dos seus objetivos (contratar pessoal, comprar e vender bens, contrair empréstimos), observada, evidentemente, a legislação pertinente".

Segundo CRUZ (2001), o consórcio intermunicipal tem sido utilizado como nome fantasia da sociedade civil, sendo que nestes casos, representavam pessoas jurídicas sem fins lucrativos. No texto, a autora adotou o termo consórcio para as duas formas de cooperação, o pacto e a sociedade civil, sendo flexível em relação às determinações legais e acatando a forma coloquial. Esta atitude é seguida também por VAZ (1997), que em seu artigo publicado, afirmou que "os consórcios intermunicipais possuem personalidade jurídica, estrutura de gestão autônoma e orçamento próprio". Independe de assumir ou não responsabilidades jurídicas, o consórcio tem o objetivo maior de resolver problemas, através da união de seus participantes e de maneira eficiente com o objetivo do bem comum.

Um esclarecimento mais detalhado destas duas formas de "consórcio", pacto ou sociedade civil, está apresentado no ANEXO A. Neste anexo, são discutidas três outras formas de cooperação: câmara intermunicipal, rede e agência intermunicipal. Este anexo é a transcrição da TABELA 3 encontrada em CRUZ (2001), na qual estão descritos os modos de cooperações por meio de definições das formas de parcerias, do financiamento, dos recursos humanos e materiais, das características, da estrutura organizacional básica, etc.

\subsection{Atuação do Consórcio Intermunicipal}

A cooperação intermunicipal é um poderoso ferramental para os governos locais, visto que ampliam a sua capacidade de ação e otimizam seus recursos. As áreas para implantação de consórcios são muito amplas e não se restringem apenas a união dos recursos, mas também, a variedade de objetivos que podem ser alcançados com este tipo de união. Segundo VAZ (1997), vão desde simples ações pontuais até programas de longo prazo que tem forte influência sobre o futuro dos municípios. Algumas das possibilidades de atuação do consórcio intermunicipal são exemplificados por este autor, como sendo: 
- Serviços públicos: os municípios podem oferecer serviços em conjunto nas áreas de abastecimento e nutrição (campanhas de complementos nutricionais), cultura (ônibus-biblioteca), esporte, lazer, assistência social, aparelhamento do corpo de bombeiros e saneamento. Como exemplos, existem na área de cultura (CRUZ, 2001): Consórcio Intermunicipal de Cultura da Região de Campinas-SP, Consórcio Intermunicipal de Cultura do Litoral Norte-SP, Consórcio Intermunicipal de Cultura da Região entorno de Brasília-DF, Consórcio Intermunicipal de Cultura da Região Metropolitana de Belo Horizonte-MG, Consórcio Intermunicipal de Cultura da Região Metropolitana de Curutiba-PR. Outro tipo de consórcio citado pela autora é o Consórcio Intermunicipal da Alta Mogiana-Coman (região de Franca-SP) para alimentação escolar e desenvolvimento;

- Saúde: este tipo de operação conjunta tem sido motivo de diversos consórcios. Visto que requerem grandes investimentos, podendo ser impossível a implantação para um município isoladamente ou, quando construídas, os equipamentos podem ficar ociosos, devido ao pequeno porte da cidade. Alguns exemplos: Consórcio Intermunicipal do Alto São Francisco (sede em Luz-MG, com mais 26 cidades), Consórcio Intermunicipal da Microrregião do Médio Jequitinhonha (Programa de Saúde Mental Descentralizado, sede em Araguaí-MG), Consórcio Intermunicipal de Saúde da Região Centro do Estado (sede em Santa Maria-RS, "Programa você que sabe tudo sobre sexo, vamos falar sobre Aids");

- Obras Públicas: os casos mais comuns, nesta área, ocorrem nas regiões de divisa entre municípios, principalmente em áreas conurbadas, para canalização de cursos d'água e obras viárias. O autor VAZ (1997) afirma existirem experiências com municípios do Recôncavo Baiano - BA;

- Atividades-meio: as atividades-meio (complementares) das prefeituras também podem ser realizadas através do consórcio. É o caso da informática, para compartilhar equipamentos, desenvolver sistemas informatizados entre os parceiros e treinamento de pessoal. Exemplo: Consórcio Intermunicipal de Informática da Região de São João da Boa Vista-SP (CRUZ, 2001);

- Meio Ambiente: nesta área se busca a recuperação ou preservação do meio ambiente: manejo de recursos hídricos, saneamento básico, lixo e enchentes. Alguns exemplos de CRUZ (2001): Consórcio Intermunicipal das Bacias dos Rios Piracicaba e Capivari (sede em Americana-SP), Consórcio Intermunicipal das Bacias do Alto Tamanduateí e Represa Billings (Consórcio do ABC, sede em Santo AndréSP), Consórcio Intermunicipal de Tratamento de Resíduos Sólidos Urbanos - Ci- 
tresu (sede em Três Passos - RS), Consórcio Intermunicipal da Bacia Hidrográfica do Alto Rio Negro Catarinense (Consórcio Quiriri, sede em São Bento do Sul$\mathrm{SC})$;

- Desenvolvimento Regional: existem vários propósitos aos quais podem ser implementadas ações conjuntas nesta área: incentivo a atividades econômicas (agricultura, industrialização, etc), prevenção de "guerra fiscal" entre os municípios, e no campo de turismo. A autora CRUZ (2001) apresenta alguns exemplos: Consórcio Intermunicipal de Produção e Abastecimento (CINPRA, sede em São LuísMA), Câmara do Grande ABC (sede me Santo André-SP), Associação dos Municípios da Microrregião do Vale do Aço (Programa Vale dos Peixes, sede em Ipatinga-MG).

Os casos citados anteriormente são exemplos de consórcios que podem ou não estar atuando além do contexto no qual está incluído. O importante da apresentação acima é quantificar os esforços que se tem desenvolvido através deles, para que os propósitos comuns sejam atingidos.

\subsubsection{Consórcio Intermunicipal para Resíduos Sólidos}

O manejo dos resíduos sólidos nas cidades é executado, ainda hoje, com muito empirismo e improvisações em vez de soluções planejadas. Segundo BORGES (2001), os administradores municipais vêem o problema dos resíduos sólidos como sendo apenas de coleta e transporte do lixo. Eles ignoram que é uma questão a ser tratada com visão sistêmica, na qual se deve dar a devida atenção a todas as partes constituintes, principalmente o destino final do lixo. Estes governos locais são induzidos a agir de modo simplista por falta de uma estrutura organizacional adequada, de profissionais capacitados e inaptidão para o gerenciamento.

O descaso em relação à destinação inadequada dos resíduos sólidos, em lixões a céu aberto, e os problemas conseqüentes de ordem sanitária, social, ambiental e de saúde públicas são conhecidos. De acordo com BORGES (2001), o desafio está em dar soluções técnicas e sanitárias adequadas, condizentes com a realidade financeira e recursos humanos disponíveis em cada município. 
Dentro de soluções possíveis para o gerenciamento dos resíduos sólidos, BORGES (2001) menciona o que se denomina de sistemas integrados. Conforme esta autora, para a destinação do lixo, havendo condições técnicas e financeiras favoráveis, a organização dos serviços nas microrregiões pode extrapolar a solução individual para a solução integrada, por exemplo, consórcios. Segundo a SMA (SÃO PAULO, 1998a), a adoção de soluções conjuntas para a implantação e operação de sistemas de destinação de lixo, ou apenas operação, sob a responsabilidade direta ou não de dois ou mais municípios, tem como objetivo a economia de escala.

Na destinação dos resíduos sólidos por alguma forma de cooperação intermunicipal, a obtenção do ganho de escala freqüentemente consiste em soluções que resultam em instalações centralizadas e conseqüente custos de transportes maiores. Por exemplo, se obtém economia, quando se constrói um aterro sanitário para atender várias cidades no lugar de um aterro para cada localidade. Porém, para deslocar os resíduos das cidades até o ponto de disposição, os veículos percorrerão distâncias maiores do que aquelas percorridas nos casos de aterros próprios e próximos a cada município. Desta forma, conforme a SMA (SÃO PAULO, 1998a), a cooperação intermunicipal deve ser implementada com estudo de viabilidade econômica, avaliando-se os custos das instalações de destinação, coleta e transportes dos resíduos sólidos para as soluções isolada e compartilhada.

Nesta pesquisa, busca-se dar subsídios para a quantificação dos custos de um sistema consorciado para destinação do lixo, através de análises de localização e transportes, que conduzam ao menor custo logístico dentro das diversas possibilidades para o consórcio. Estas análises são realizadas por meio da simulação em um software de SIG.

Para cada consórcio, o estudo técnico específico é necessário, se realmente se busca a economia de escala, pois cada localidade tem sua peculiaridade. E, já está implícito também que, o bem comum está acima de interesses políticos. E, neste ponto de vista, além dos estudos técnicos específicos, é importante lembrar que, para o sucesso de um sistema consorciado, é necessário que haja a criação de legislação específica pelos poderes locais envolvidos, que garanta a continuidade do projeto ao longo dos governos. Pois, sempre haverá pressão contra da população, já que os resíduos são gerados e depositados em municípios diferentes. 


\section{RESÍDUOS SÓLIDOS}

Este capítulo apresenta os conceitos básicos relacionados aos resíduos sólidos e, em seguida, é abordado o tema sobre o seu gerenciamento integrado, com indicações para a resolução das questões do lixo. No final são apresentados alguns processos convencionais de destinação dos resíduos sólidos urbanos: desde o princípio dos 3 R's até a disposição final.

\subsection{Resíduos Sólidos}

Na publicação, Lixo municipal: Manual de Gerenciamento Integrado do IPT-CEMPRE coordenada por D'ALMEIDA \& VILHENA (2000), o lixo e resíduo sólido têm o mesmo significado, adotando-se preferencialmente o termo lixo. Para GUIMARÃES (2000), quando o lixo de uma comunidade precisa ser destinado, ele passa a ser chamado de resíduo sólido. E, neste trabalho é adotado preferencialmente o termo resíduo sólido, pois a sua destinação está sendo tratada.

Para melhor compressão do tema sobre os resíduos sólidos, a seguir são apresentadas as suas definições, a classificação, o gerenciamento integrado e a destinação dos resíduos sólidos.

\subsubsection{Definições}

De acordo com o dicionário da língua portuguesa HOUAISS (2001), a palavra lixo, em português, tem origem obscura e controversa. Segundo este dicionário, não há fonte segura da origem deste vocábulo, há quem sugira o latim tardio lixa "cinza ou água misturada com cinza", ou ainda, existe a hipótese de estar relacionado com o radical lix- da família de lixa e lixívia. Na língua espanhola, a palavra equivalente é basura, e em inglês é denominado de refuse ou garbage, modernamente têm-se utilizado o ter- 
mo solid waste (OLIVEIRA (1969) ${ }^{3}$ apud SCHALCH et al. (1990). Como tradução mais próxima do termo inglês solid waste para o português, tem-se o resíduo sólido. A palavra resíduo tem origem do latim residuum, que significa o resto de determinadas substâncias, e sólido é incorporado para diferenciá-lo de líquidos e gases (BIDONE \& POVINELLI, 1999).

Entre vários conceitos encontrados na literatura, pode-se definir os RESÍDUOS SÓLIDOS (2000) como: “(1) Todos os resíduos sólidos ou semi-sólidos que não têm utilidade, nem valor funcional ou estético para o gerador e são originados em residências, indústrias, comércio, instituições, hospitais e logradouros públicos; (2) Material inútil, indesejado ou descartado, cuja composição ou quantidade de líquido não permite que se escoe livremente".

Para efeito da norma NBR 10.004 - Resíduos Sólidos, a Associação Brasileira de Normas Técnicas (ABNT, 1987a) define resíduos sólidos como sendo: "resíduos nos estados sólido e semi-sólido, que resultam de atividades da comunidade de origem: industrial, doméstica, hospitalar, comercial, agrícola, de serviços e de varrição. Ficam incluídos nesta definição os lodos provenientes de sistemas de tratamento de água, aqueles gerados em equipamentos e instalações de controle de poluição, bem como determinados líquidos cujas particularidades tornem inviável o seu lançamento na rede pública de esgotos ou corpos de água, ou exijam para isso soluções técnica e economicamente inviável em face à melhor tecnologia disponível."

Vale salientar que a definição de resíduos sólidos na NBR 10.004 não contempla o Princípio dos 3 R's: Redução, Reutilização e Reciclagem. E, o termo resíduos hospitalares, a partir de dezembro de 1987, foi substituído por resíduos de serviço de saúde (RSS) pela norma NBR 10.004 (SCHALCH, $1995^{4}$ apud SCHALCH \& LEITE, 2000). Atualmente, encontra-se entre as definições da norma NBR 12.807 - Manuseio de resíduos de serviço de saúde: procedimento (ABNT, 1993).

\footnotetext{
${ }^{3}$ OLIVEIRA, W. E. (1969). Introdução ao problema do lixo. Revista DAE, São Paulo, n. 74, p. 58 - 69.

${ }^{4} \mathrm{SCHALCH}, \mathrm{V}$. (1995). Atividades envolvidas no gerenciamento de resíduos sólidos. In: TaukTornisielo, S. M. et al. Análise ambiental: estratégias e ações. São Paulo, T. A. Queiroz, Fundação Salim Farah Maluf/Rio Claro, Centro de Estudos Ambientais, UNESP. p. 231 - 237.
} 


\subsubsection{Classificação}

De acordo com GOMES (1989), a caracterização dos resíduos sólidos é importante para qualquer projeto da área, pois através dela se faz a classificação, que é uma ferramenta para superar as dificuldades encontradas para solucionar o problema dos resíduos sólidos.

TABELA 4.1 - Classificação dos resíduos sólidos quanto ao grau de biodegradabilidade

\begin{aligned} & \hline Classificação Tipo de Resíduo Sólido \\ & \hline Facilmente degradável - F.D Matéria orgânica \\ & Moderadamente degradável - M.D Papel, papelão e outros produtos celulósicos \\ & Dificilmente degradável - D.D Trapo, couro, borracha e madeira \\ & Não-degradável - N.D Vidro, metal, plástico, pedras, terra e outros \\ & \hline\end{aligned}

Fonte: SCHALCH et al. (1990) e GOMES (1989)

Devido a sua relevância, existem na literatura vários critérios para classificar os resíduos sólidos. Estas formas de classificação podem ser encontradas em D'ALMEIDA \& VILHENA (2000), GUIMARÃES (2000), SCHALCH \& LEITE (2000), BIDONE \& POLVINELLI (1999), SCHALCH et al. (1990), GOMES (1989) e ABNT (1987a), e estão apresentadas a seguir, segundo os critérios de:

a) natureza física: seco ou molhado.

b) composição química: orgânico ou inorgânico.

c) grau de biodegradabilidade: conforme a TABELA 4.1.

TABELA 4.2 - Classificação dos resíduos sólidos quanto à periculosidade

\begin{tabular}{cl}
\hline \multicolumn{1}{c}{ Categoria } & \multicolumn{1}{c}{ Característica apresentada } \\
\hline Classe I (Perigosos) & $\begin{array}{l}\text { Apresentam risco à saúde pública ou ao meio ambiente, ca- } \\
\text { racterizando-se por possuir uma ou mais das seguintes pro- } \\
\text { priedades: inflamabilidade, corrosividade, reatividade, toxici- } \\
\text { dade e patogenicidade. }\end{array}$ \\
& $\begin{array}{l}\text { Podem ter propriedades como: combustibilidade, biodegra- } \\
\text { dabilidade ou solubilidade, porém, não se enquadram como } \\
\text { Classe II (Não-inertes) classe I ou III. }\end{array}$ \\
& $\begin{array}{l}\text { Não têm constituinte algum solubilizado em concentração } \\
\text { superior ao padrão de potabilidade das águas. }\end{array}$
\end{tabular}

Fonte: NBR 10.004 (ABNT, 1987a)

Obs.: Consultar também: NBR 10.005, NBR 10.006, NBR 10.007 (ABNT, 1987b, 1987c, 1987d) 
TABELA 4.3 - Classificação segundo a origem dos resíduos sólidos e a responsabilidade pelo seu gerenciamento

\begin{tabular}{|c|c|c|}
\hline Classificação & Origem & Responsável \\
\hline Domiciliar & Vida diária das residências & Prefeitura \\
\hline Comercial & Estabelecimentos comerciais e de serviços & Prefeitura ${ }^{(1)}$ \\
\hline Público & $\begin{array}{l}\text { Limpeza pública urbana e de áreas de feiras } \\
\text { livres }\end{array}$ & Prefeitura \\
\hline $\begin{array}{l}\text { Resíduos de serviços } \\
\text { de saúde (RSS) }\end{array}$ & Resíduos sépticos de serviços de saúde & Gerador \\
\hline $\begin{array}{l}\text { Portos, aeroportos e } \\
\text { terminais ferroviários } \\
\text { e rodoviários }\end{array}$ & $\begin{array}{l}\text { Resíduos sépticos que podem veicular doen- } \\
\text { ças provenientes de outras localidades }\end{array}$ & Gerador \\
\hline Industrial & Indústrias (maioria dos resíduos classe I) & Gerador \\
\hline Agrícola & Agricultura e pecuária & Gerador \\
\hline Entulho & Construção civil & Gerador \\
\hline
\end{tabular}

(1) A prefeitura é responsável por quantidades pequenas (menores que 50kg), de acordo com a legislação municipal específica. Quantidades maiores são de responsabilidade do gerador.

Fonte: "Lixo Municipal: Manual de Gerenciamento Integrado" (D’ALMEIDA \& VILHENA, 2000)

d) periculosidade de um resíduo: característica esta que, em função de suas propriedades físicas, químicas ou infecto-contagiosas, pode apresentar riscos potenciais à saúde pública e ao meio ambiente (ABNT, 1987a). Esta classificação está na TABELA 4.2.

e) origem: classifica-se de acordo com o gerador do resíduo, como observado na TABELA 4.3. Este critério de classificação é útil também para definir o responsável pelo seu gerenciamento.

Os resíduos que são considerados nos estudos da presente pesquisa são aqueles classificados segundo a origem, na qual as prefeituras têm a responsabilidade pelo seu gerenciamento. Este grupo de resíduos é conhecido na literatura como Resíduo Sólido Urbano (RSU), Lixo Municipal ou Resíduo Sólido Municipal (RSM). As duas últimas definições estão em D'ALMEIDA \& VILHENA (2000). Nesta pesquisa é utilizado o termo Resíduo Sólido Urbano, pois ele é o termo técnico adotado pelas normas da ABNT (ABNT, 1985, 1992).

Segundo a norma NBR 8.419 - Apresentação de projetos de aterros sanitários de resíduos sólidos urbanos (ABNT, 1992), Resíduos Sólidos Urbanos são: "resíduos sólidos gerados num aglomerado urbano, excetuados os resíduos industriais perigosos, hospitalares sépticos e de aeroportos e portos". É conveniente relembrar que os resí- 
duos hospitalares sépticos passaram a se chamar Resíduos de Serviço de Saúde, a partir da NBR 12.807 - Manuseio de resíduos de serviço de saúde: procedimento (ABNT, 1993). Os RSU são, portanto, aqueles gerados no ambiente urbano e constituídos pelos materiais de origem domiciliar, de estabelecimentos de comércio, de varrição e de feiras livres, e resíduos sólidos de outros geradores que não apresentam periculosidade efetiva ou potencial à saúde humana ou ao meio ambiente, sendo de responsabilidade exclusiva das prefeituras, desde a coleta até a destinação final.

\subsection{Gerenciamento Integrado de RSU}

No gerenciamento de RSU, para a solução do problema do lixo não existe a melhor técnica a se utilizar: recuperação de recicláveis, compostagem, incineração ou aterro sanitário. Mas sim, a necessidade de determinar em que proporção é mais apropriado conjugar estas técnicas e o melhor modo de articulá-las (RELIS \& DOMINSKI, $1990^{5}$ apud D'ALMEIDA \& VILHENA, 2000). Esta visão mais ampla é a proposta do gerenciamento integrado de RSU para superar os desafios do correto manejo dos resíduos sólidos.

\subsubsection{O conceito de Integração}

De acordo com o dicionário HOUAISS (2001), o vocábulo integrar significa "incluir(-se) um elemento num conjunto, formando um todo coerente; unir-se, formando um todo harmonioso; completar-se, complementar-se”. Deste modo, a integração ocorre quando existe uma "simbiose" entre as partes envolvidas, na qual a sobrevivência do todo depende. Assim, para uma atividade ser integrada, as ações que a envolvem devem ser articuladas e implementadas de maneira combinada para alcançar o seu sucesso.

O gerenciamento integrado de RSU é um conjunto articulado de ações normativas, operacionais, financeiras e de planejamento que uma administração municipal desenvolve - com base em critérios sanitários, ambientais, sociais e econômicos - para reduzir, coletar, segregar, reutilizar, reciclar, tratar e dispor o resíduo de uma cidade.

${ }^{5}$ RELIS, P.; DOMINSKI, A. (1990). Beyond the crisis: integrated waste management. Santa Bárbara, Gildea Resource Center / Community Environmental Council. 48 p. 
Este conceito é adaptado de D'ALMEIDA \& VILHENA (2000), acrescentando-se o aspecto social que envolve a redução e reaproveitamento de materiais.

É relevante considerar o aspecto social, porque envolve a solução de graves problemas como a dos catadores em lixões, principalmente trabalhadores infanto-juvenis, assunto tratado pelo Fórum Nacional Lixo \&Cidadania (UNICEF \& CAIXA, 2001). As palavras reduzir, reutilizar e reciclar (3 R's) também foram incluídas no conceito, pois, segundo as autoras SOARES \& GRIMBERG (1998), a gestão sustentável dos resíduos sólidos pressupõe o princípio dos 3 R's.

O gerenciamento de RSU é integrado quando segue os princípios de:

- Integração das ações: todas as ações e operações influenciam umas às outras. Uma coleta mal planejada ocasiona o aumento do custo de transporte, afetando o nível de serviço. Conseqüentemente, o cliente fica insatisfeito, diminuindo a credibilidade do modelo de gerenciamento adotado;

- Adequação à realidade: o modelo de gerenciamento e as tecnologias escolhidas precisam estar compatíveis com a realidade do município, satisfazendo os anseios da comunidade local. A geração do resíduo depende do tamanho da população, e de suas características culturais, econômicas e sociais, do grau de urbanização e dos seus hábitos de consumo;

- Proteção ambiental e à vida humana: através da garantia obtida com manejo apropriado dos resíduos sólidos, assegura-se um meio ambiente saudável e de melhor qualidade de vida aos indivíduos de hoje e às gerações futuras;

- Melhoria contínua: o processo evolutivo do gerenciamento, mantido consistentemente por vários anos seguidos através de pequenas melhorias, é mais provável de conduzir ao sucesso do que tentativas de obtê-lo em um único grande salto tecnológico (D’ALMEIDA \& VILHENA, 2000).

A administração governamental é uma peça fundamental no gerenciamento integrado do RSU. Ela tem sua responsabilidade constitucional pela destinação adequada do lixo. Ela é responsável não somente pela articulação das ações e sua implementação, mas também de fixar os parâmetros que conduzem ao correto gerenciamento. Assim sendo, compor o Modelo de Gerenciamento Integrado dos RSU é de sua competência. 


\subsubsection{Modelo de Gerenciamento Integrado de RSU}

Para auxiliar os governos locais com a gerência dos RSU, é necessário que eles trabalhem na concepção de um Modelo de Gerenciamento. Esta estruturação ajuda na compreensão da problemática do lixo através de uma retratação do processo, desde o diagnóstico da situação atual do lixo na comunidade, até a implementação de ações para solucionar os seus problemas de maneira integrada.

Existem inúmeros Modelos de Gerenciamento Integrado de RSU. LEITE (1997) apresentou em sua tese, exemplos internacionais da comunidade européia, do Japão, entre outros, e fez uma proposta de modelo para o Brasil. Porém, sem desmerecer as tentativas de estabelecer modelos genéricos, segundo D'ALMEIDA \& VILHENA (2000), nenhuma sugestão ou consultoria substitui o conhecimento que está no cidadão e em sua administração municipal. Isto se supõe ser devido às peculiaridades de cada comunidade. Assim, a elaboração do Modelo de Gerenciamento e a implementação das ações são decerto, responsabilidade do governo local amparado por parcerias com setores da sociedade civil, empresarial e tecnológica.

De acordo com D'ALMEIDA \& VILHENA (2000), o governo municipal enfrenta diversas dificuldades de âmbito administrativo na concepção de um Modelo de Gerenciamento de Resíduos Sólidos, como apresentadas a seguir:

- inexistência de uma política brasileira de limpeza pública;

- limitações de ordem financeira, como orçamentos inadequados, fluxos de caixa desequilibrados, tarifas desatualizadas, arrecadação insuficiente e inexistente de linhas de crédito específicas;

- deficiência na capacitação técnica e profissional, do gari ao engenheiro-chefe;

- descontinuidade política e administrativa;

- ausência de controle ambiental.

Para superar este problema, uma das soluções pode ser encontrada na publicação intitulada Modelo de Gestão dos Resíduos Sólidos Urbanos (BRASIL, 2001b) do Fundo Nacional do Meio Ambiente (FNMA). Neste documento, o FNMA apresenta instruções para o governo municipal trabalhar no modelo de gerenciamento dos RSU. Nele, discutem-se: o planejamento estratégico; o arcabouço legal; a estrutura operacional, 
jurídica, administrativa, financeira e técnica; a política de recursos humanos; a fiscalização; e a comunicação e mobilização comunitária.

Conforme o manual do IPT-CEMPRE (D'ALMEIDA \& VILHENA, 2000), as ações prioritárias, que podem ser combinadas, para se estabelecer um Modelo de Gerenciamento Integrado de RSU são:

- Coletar e dar destino adequado a todo RSU gerado: eliminação de lixões com construção imediata de aterro sanitário e recuperar áreas degradadas;

- Buscar formas de segregação e tratamento dos resíduos que atendem a claros requisitos ambientais e econômicos: segregação para reciclagem e reutilização, além de buscar eficientes tratamentos físicos, químicos e biológicos dos resíduos para se diminuir a toxicidade.

- Realizar campanhas de educação ambiental: sensibilização e conscientização da população sobre a questão do lixo, desde a geração até a manutenção da limpeza da cidade, dentro da escola e na comunidade.

- Incentivar a redução e a não geração dos resíduos: o primeiro passo para resolver o problema do lixo é de evitar a sua geração.

O modelo de gerenciamento Integrado de RSU pode ser planificado em um documento conhecido como Plano de Gerenciamento Integrado de Resíduos Sólidos (PGIRS). Ele é definido, segundo o FNMA, em seu manual para apresentação de propostas do Edital FNMA 02/2000 (BRASIL, 2000), como sendo: "Documento que aponta e descreve as ações relativas ao manejo de resíduos sólidos contemplando os aspectos referentes à geração, segregação, acondicionamento, coleta (convencional ou seletiva), armazenamento, transporte, tratamento e disposição final, bem como a proteção à saúde pública".

A expressão, Plano de Gerenciamento Integrado de Resíduos Sólidos, bem como a sua definição, originou-se da Resolução do CONAMA nº 005 de 5 de agosto de 1993 (BRASIL, 1993). No parágrafo II do artigo $3^{\circ}$ desta Resolução, a expressão utilizada é "Plano de Gerenciamento de Resíduos Sólidos". No contexto desta Resolução são considerados os resíduos de serviço de saúde, portos, aeroportos, terminais ferroviários e rodoviários, diferindo do manual do FNMA (BRASIL, 2000). O FNMA aproveitou 
este instrumento para auxiliar o gerenciamento do RSU e RSS na situação de responsabilidade da administração municipal. A inclusão dos resíduos de serviço de saúde no PGIRS se deve ao fato de alguns municípios realizarem a sua coleta e a disposição, mesmo o seu gerenciamento não sendo qualificado como de sua competência (D'ALMEIDA \& VILHENA, 2000).

No manual do FNMA (BRASIL, 2000), há o roteiro estruturado de como deve ser elaborado o PGIRS. O FNMA é um dos principais instrumentos de financiamento da Política Nacional do Meio Ambiente, vinculado ao Ministério do Meio Ambiente. O objetivo do roteiro para elaboração do PGIRS foi a de dar apoio financeiro na elaboração e implantação de Planos de Gerenciamento Integrado de Resíduos Sólidos, para os municípios com população urbana entre 20 e 50 mil habitantes que participaram do Edital FNMA 02/2000 (BRASIL, 2000). Apesar do roteiro ter este objetivo primário, ele tem uma serventia maior, é útil como orientação para toda proposta de elaboração e implantação de ações que visem o uso racional e sustentável dos recursos naturais, incluindo a manutenção, melhoria e recuperação da qualidade ambiental, elevando as condições de vida da população.

No próprio manual do FNMA (BRASIL, 2000), como em D'ALMEIDA \& VILHENA (2000), outras expressões são utilizadas como sinônimos do Plano de Gerenciamento Integrado de Resíduos Sólidos (PGIRS). São elas: Plano Diretor de Resíduos Sólidos, Plano de Gestão de Resíduos Sólidos, Plano de Resíduos Sólidos, ou, Plano de Gerenciamento Integrado do Lixo Municipal, Plano Diretor de Lixo Municipal e Plano de Gestão do Lixo Municipal.

Segundo o FNMA (BRASIL, 2000), o PGIRS deve ser elaborado em três fases:

- Diagnóstico da situação atual dos serviços: faz-se nesta fase a caracterização geral do município e dos resíduos sólidos. Além de levantar características sociais, administrativas, de disposições legais, de infraestrutura, da estrutura operacional, financeiras, de educação ambiental e propostas existentes na área de limpeza pública; 
- Prognóstico: baseado no diagnóstico e em propostas existentes, antecipa-se a tendência da configuração futura do gerenciamento dos resíduos sólidos no horizonte do Plano;

- Proposições: indica-se as alternativas pré-selecionadas ou já definidas das ações voltadas ao gerenciamento integrado de resíduos sólidos.

A FIGURA 4.1 representa a estrutura para elaboração do Plano de Gerenciamento Integrado de Resíduos Sólidos. De acordo com D'ALMEIDA \& VILHENA (2000), é importante compreender que as ações que se pretendem realizar, definidas dentro do PGIRS, devem ser vistas como metas a serem alcançadas a curto, médio e longo prazos, visto que a resolução do problema é um processo evolutivo de melhoria contínua e não revolucionário. Para cada ação existem várias alternativas, tanto com relação a locais das instalações, como a aspectos técnico-operacionais (roteirização, coleta,

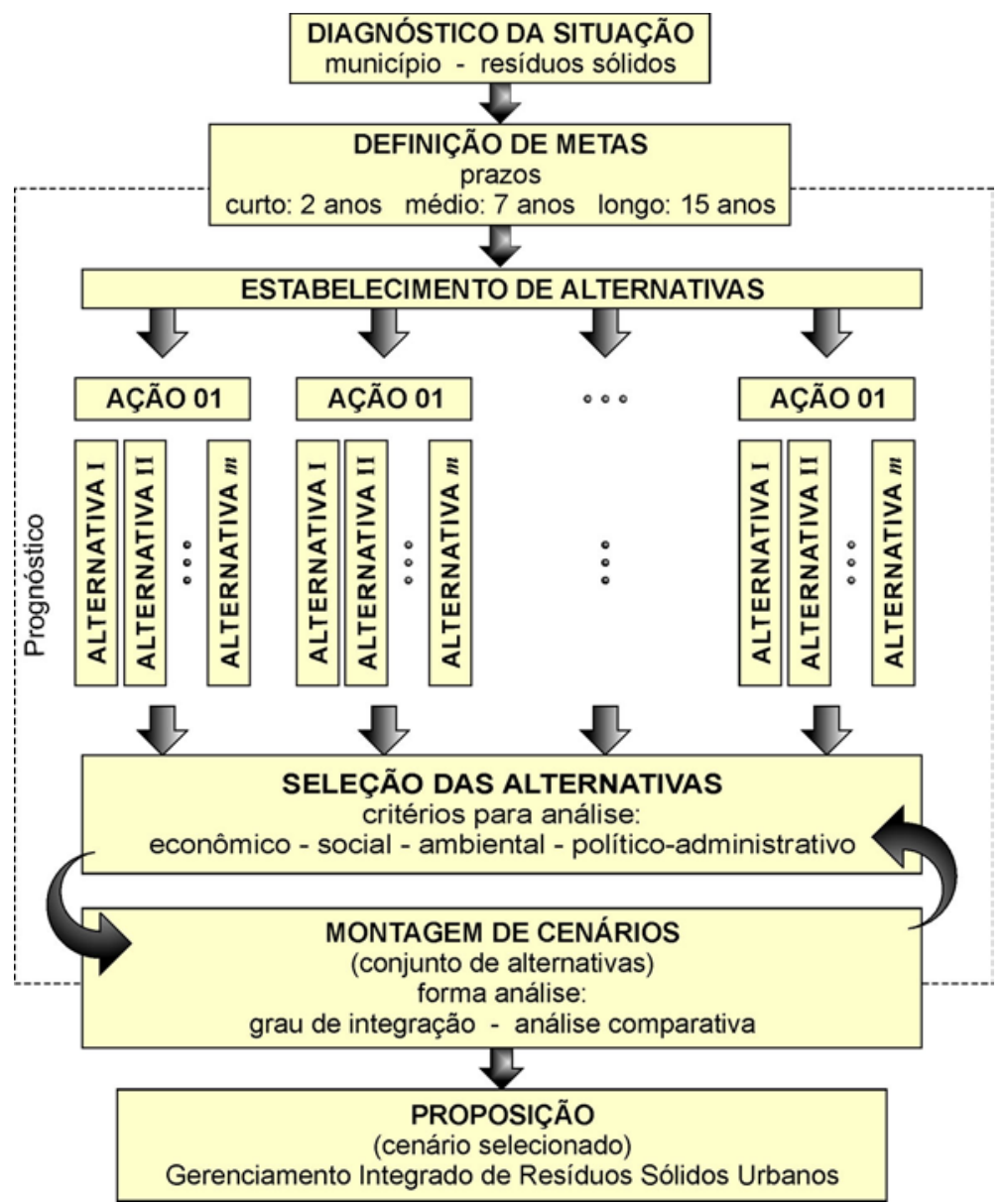

Fonte: Adaptado de D'ALMEIDA \& VILHENA (2000)

FIGURA 4.1 - Roteiro para elaboração de Plano de Gerenciamento Integrado de Resíduos Sólidos 
transporte, etc). E conforme os mesmos autores, a seleção das alternativas das ações pode ser realizada baseada em quatro critérios:

- Critério econômico-financeiro: para definir, razoavelmente, custos mínimos, taxa de retorno, custo/benefício e viabilidade financeira e tarifária do negócio (ou outro objetivo econômico-financeiro);

- Critério ambiental: para assegurar que em todas as alternativas adotadas os recursos naturais (água, ar, solo, flora e fauna) do município e da região estejam sendo preservados;

- Critério social: para estabelecer índices sobre efeitos positivos na saúde, segurança, educação, de manutenção e geração de emprego, renda, lazer, ascensão social e outros benefícios, expressos de modo eqüitativo, notadamente na população afetada pela inserção regional da alternativa;

- Critério político-gerencial: para otimizar modelos alternativos de cooperação, parcerias e acordos compensatórios, necessários à inserção regional da alternativa proposta, assegurando a receptividade, apoio e boa convivência com entidades (municipal, estadual, federativa e privada) e comunidades presentes na área geográfica influenciada.

É importante salientar que não adianta apenas selecionar a melhor alternativa para cada ação na elaboração do PGIRS, pois pode não ser o mais apropriado para a realidade do município. Portanto, se deve montar diferentes cenários com as alternativas estudadas. Este processo permite uma visão das possibilidades para gerenciar de forma integrada os RSU. Segundo D'ALMEIDA \& VILHENA (2000), estes cenários permitirão não somente visualizar o grau de integração entre as ações nas diferentes combinações, mas também selecionar a melhor alternativa, através de uma análise comparativa (custo, grau de impacto ambiental ou social, etc).

A FIGURA 4.2 representa o ciclo de melhoria contínua do Gerenciamento Integrado de RSU (e RSS, quando a competência da gerência for também da prefeitura). O ciclo ilustra desde o diagnóstico e a elaboração do PGIRS, até ações para não geração ou redução de resíduos. Ele auxilia o profissional a formular e revisar o Plano de Gerenciamento Integrado de Resíduos Sólidos, através da indicação das ações que podem ser realizadas. É importante lembrar que a implementação das ações deve ser compa- 


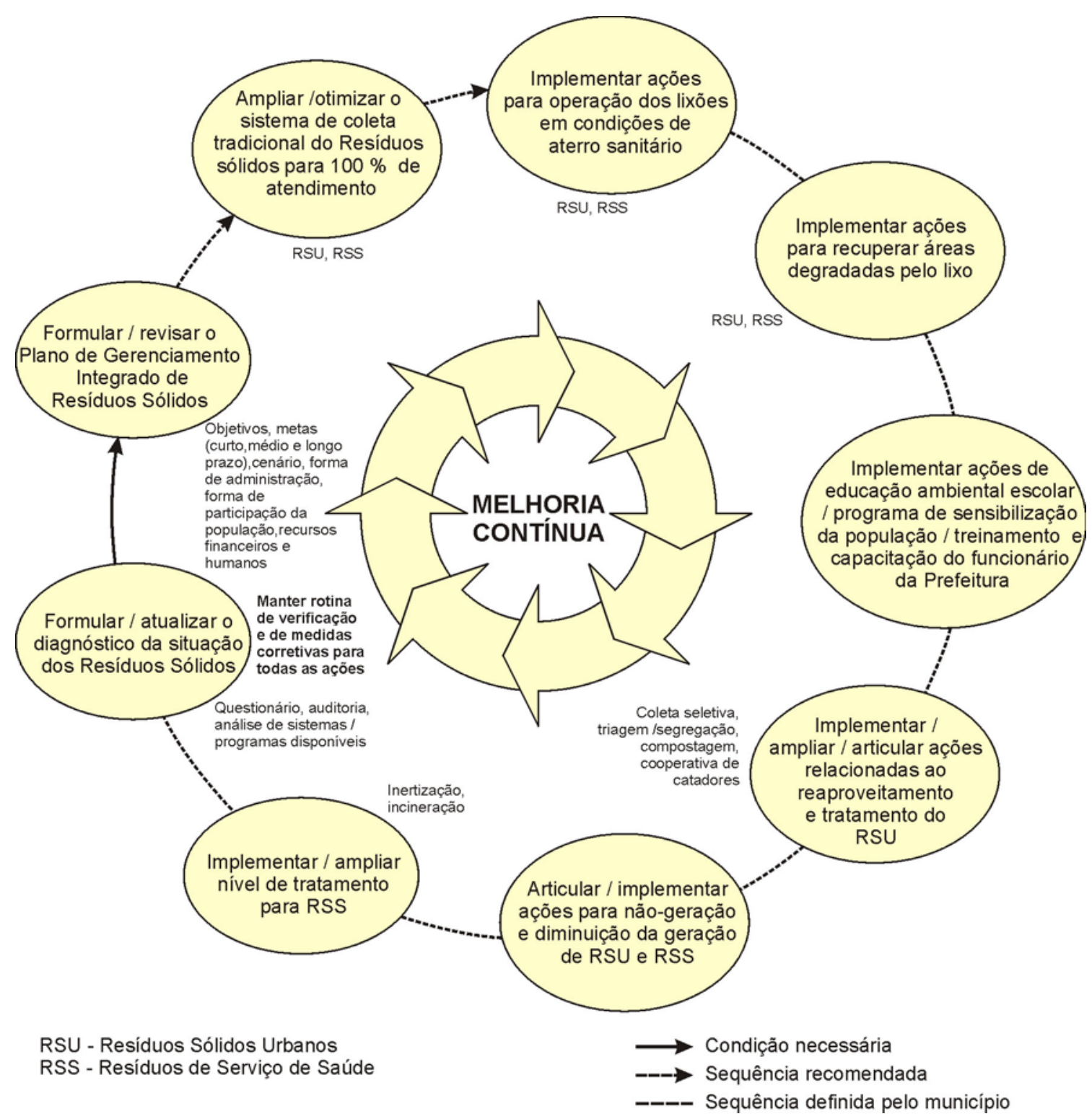

Fonte: Adaptado de D'ALMEIDA \& VILHENA (2000)

FIGURA 4.2 - O Gerenciamento Integrado de Resíduos Sólidos

tível com as necessidades e possibilidades de cada município, sobretudo a disponibilidade de recursos financeiros e humanos (D'ALMEIDA \& VILHENA, 2000). A administração municipal deve também estipular no PGIRS, os procedimentos da melhoria contínua, avaliação $\rightarrow$ redefinição $\rightarrow$ ampliação das ações, objetivando um maior compromisso e adequação ambiental, social e à saúde pública. 


\subsection{Destinação de RSU}

Para conseguir um adequado gerenciamento dos resíduos sólidos, é necessário conhecer o caminho do RSU até a sua disposição. O Instituto Brasileiro de Geografia e Estatística (IBGE, 2002) realizou o levantamento dos serviços de limpeza pública, coleta e destinação do lixo no Brasil, e disponibilizou o resultado na Pesquisa Nacional de Saneamento Básico. Esta pesquisa está baseada no censo do IBGE do ano de 2000.

Segundo D'ALMEIDA \& VILHENA (2000), em 1997, a coleta de lixo no Brasil ocorria em aproximadamente $70 \%$ dos municípios, sendo que esta porcentagem em 1990 foi de $64 \%$ e em 1981 de 49\%. Baseado na Pesquisa Nacional de Saneamento Básico do IBGE (2002), 99,3\% dos municípios realizavam a coleta do lixo em 2000. Isto representa quase que a totalidade dos municípios, demonstrando um avanço no gerenciamento do RSU, se comparado com os anos anteriores. Porém, apenas $8,2 \%$ dos municípios tem coleta seletiva e $6,4 \%$ tem reciclagem, necessitando ainda de muito trabaIho nesta área. Os dados sobre a coleta de lixo e limpeza urbana do IBGE (2002) estão ilustrados na FIGURA 4.3.

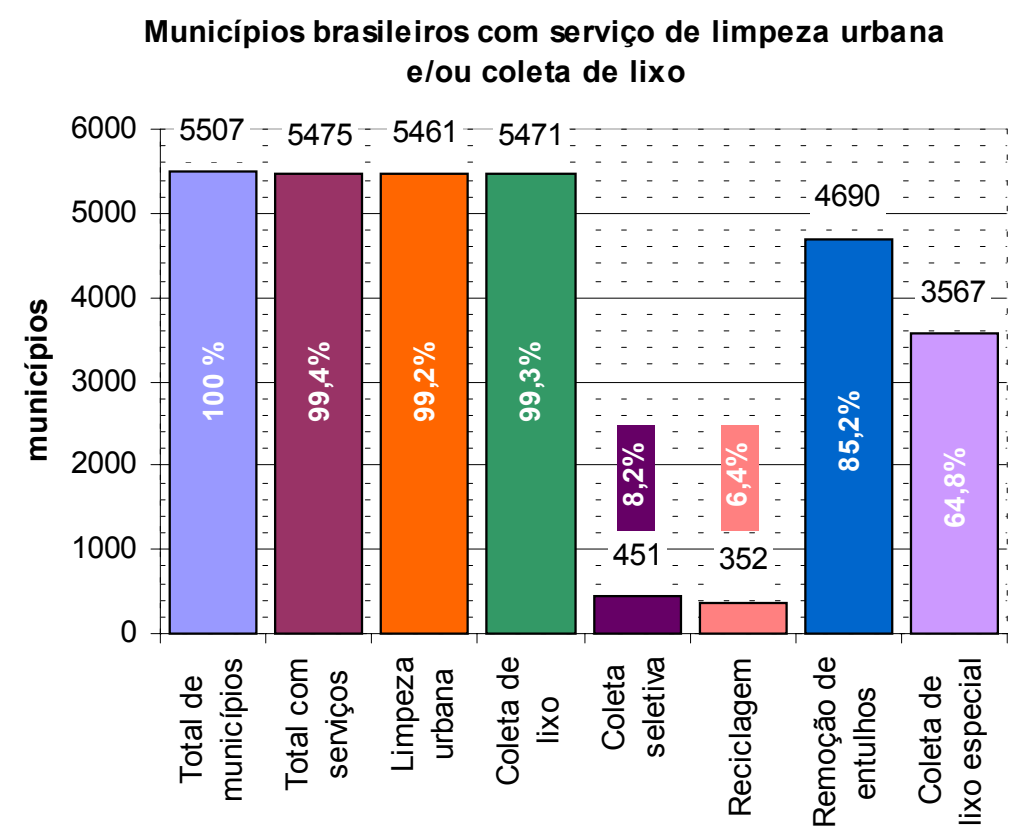

Fonte: Pesquisa Nacional de Saneamento Básico - 2000 IBGE (2002)

FIGURA 4.3 - Alcance dos serviços de limpeza urbana e/ou coleta de lixo prestados nos municípios do Brasil 


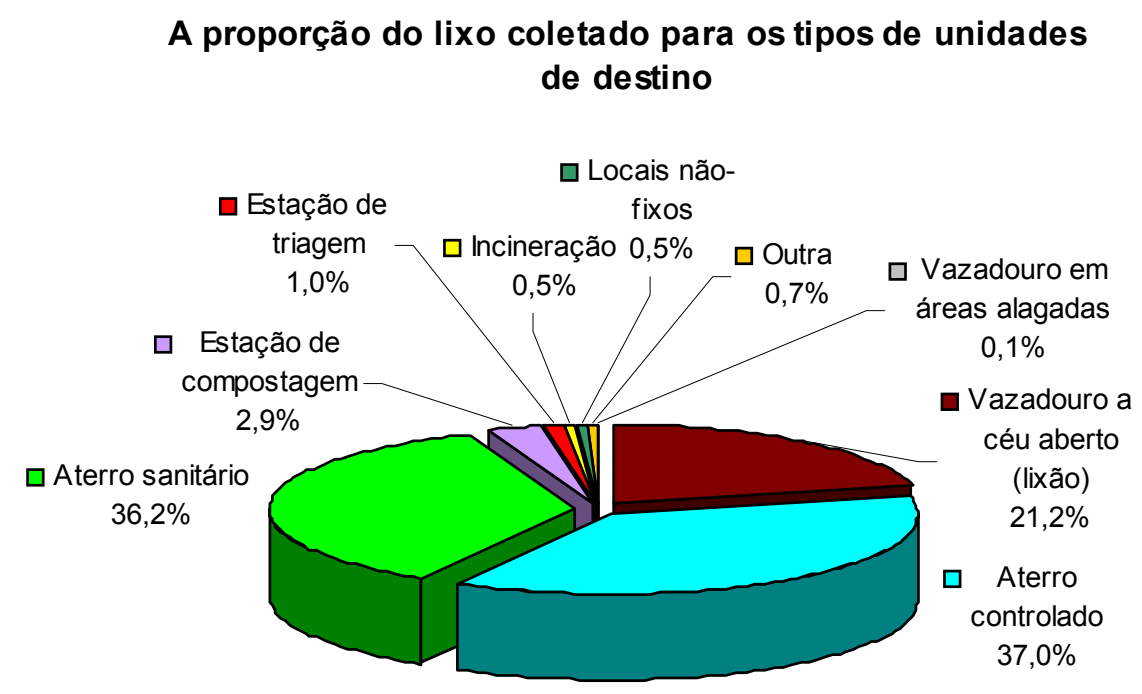

Fonte: Pesquisa Nacional de Saneamento Básico - 2000 IBGE (2002)

FIGURA 4.4 - A abrangência das formas de destinação de lixo coletado nos distritos brasileiros

De acordo com D'ALMEIDA \& VILHENA (2000), no censo de 1991 do IBGE, a disposição a céu aberto, em lixão, representava a destinação de $76 \%$ do lixo coletado; $13 \%$ para aterro controlado e $10 \%$ para aterro sanitário.

Este quadro melhorou, segundo a pesquisa do IBGE (2002), baseado no censo de 2000. A porcentagem do lixo coletado e destinado para lixões diminuiu para $21,2 \%$, e o destinado para aterro controlado aumentou para $37 \%$, bem como para aterro sanitário que subiu para $36,2 \%$. Estes dados estão ilustrados na FIGURA 4.4. Apesar da melhoria, a porcentagem destinada de $21,2 \%$ para lixões é alta, se for considerado que a opção ambientalmente correta é a inexistência desta forma de destinação. Mesmo o aterro controlado, sendo uma forma menos prejudicial do que o lixão, não garante a proteção ao meio ambiente, pois raramente existe o tratamento do percolado, que é um potencial poluidor do solo e dos mananciais de água potável.

Mesmo no quadro atual, as atividades intermediárias para reaproveitamento de materiais são muito incipientes, em termos numéricos. Segundo a pesquisa do IBGE (2002), menos de $10 \%$ dos municípios fazem coleta seletiva e/ou reciclagem e menos de $5 \%$ do lixo coletado é destinado a unidades de reaproveitamento (usinas de triagem 


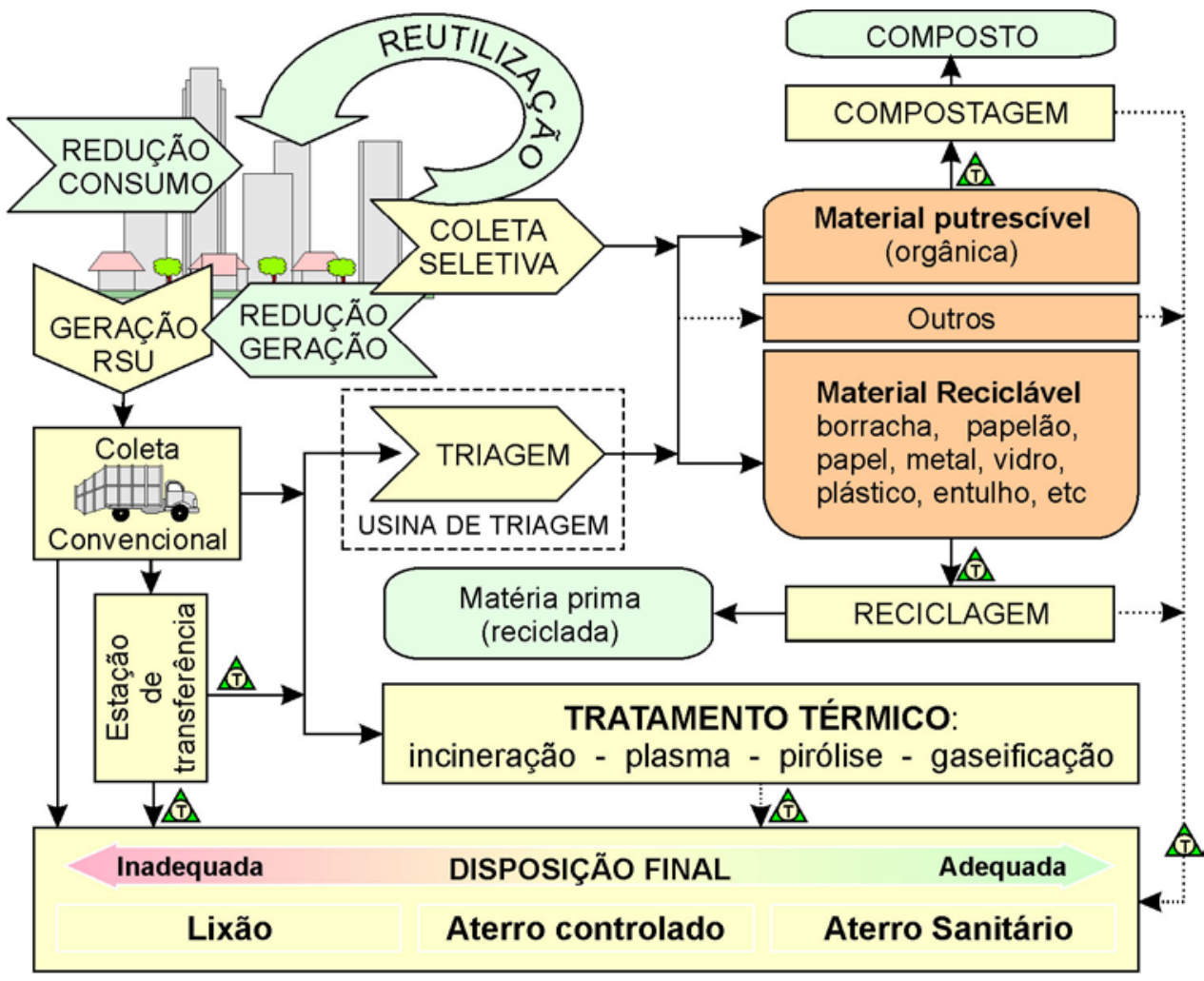

RSU Resíduos Sólidos Urbanos

Processo de destinação do RSU

…... Rejeito do processo

Produto do processo

$\longrightarrow$ Caminho do RSU

A. Transporte diferenciado

FIGURA 4.5 - O trajeto dos RSU e os processos envolvidos em seu manejo

e/ou compostagem). Vide FIGURA 4.3 e FIGURA 4.4 respectivamente. Diante destes dados, pode-se desenhar o caminho provável da destinação da maioria do RSU do Brasil como sendo: geração $\rightarrow$ coleta convencional $\rightarrow$ disposição final (lixão, aterro controlado ou aterro sanitário). Na FIGURA 4.5 foi desenhado o fluxograma do caminho do RSU e os processos técnicos que existem, ou deveriam existir, e outros que não deveriam existir para o seu manejo. Apenas para esclarecer a figura, o transporte diferenciado pode ser entendido como sendo aquele realizado em um veículo diferente, ou não, da coleta convencional, necessário para deslocar os resíduos entre dois processos consecutivos localizados em pontos geográficos diferentes.

Para melhor compreensão dos processos de destinação dos RSU, alguns dos temas relevantes presentes na FIGURA 4.5 são discutidos na seqüência deste trabalho. 


\subsubsection{Princípio dos 3 R's}

A ordem mundial é de minimizar a produção de resíduos. Esta idéia foi difundida com a Agenda 21, documento elaborado por 170 países na ECO-92, encontro realizado no Rio de Janeiro (UNICEF \& CAIXA, 2001). Segundo a AGENDA 21 (1997), em seu capítulo 21, o manejo ambientalmente saudável dos resíduos deve ir além do simples depósito ou aproveitamento por métodos seguros dos resíduos gerados. Ele deve buscar resolver a causa fundamental do problema, procurando mudar os padrões não sustentáveis de produção e consumo. Assim, foi estabelecido o princípio dos 3 R's, nesta ordem: Reduzir ao mínimo os resíduos (consumo de produtos e o desperdício de materiais); Reutilizar e Reciclar os materiais ao máximo (FIGURA 4.6).

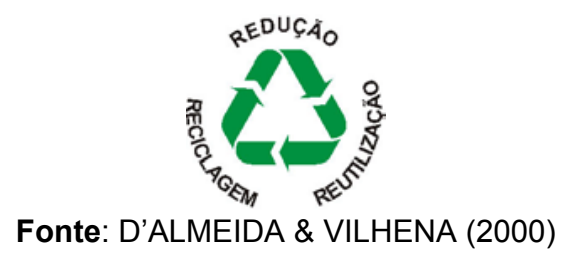

FIGURA 4.6 - Símbolo representativo do Princípio dos 3 R's

A redução dos resíduos, o primeiro do R's, consiste em atitudes como: diminuir o consumo de produtos supérfluos; consumir produtos que gerem o mínimo de resíduos; e aproveitar ao máximo o produto (evitar desperdício). Com estas atitudes se evita a geração de resíduos, além do desperdício de matéria-prima e de energia. Esta é a melhor alternativa para proteção do meio ambiente. Porém, como destacado por UNICEF \& CAIXA (2001), a implantação deste princípio tem grandes desafios, pois significa interferir na sensação de liberdade e felicidade de pessoas ou no direito de consumir.

$\mathrm{Na}$ atual sociedade, a pessoa se confunde com o consumidor que, cada vez mais cria novas necessidades de consumo. Por isso, o enfoque da redução dos resíduos deve estar em programas de caráter cultural para mudanças de hábitos da população. Para SOARES \& GRIMBERG (1998), é preciso que se estabeleça um vínculo entre as pessoas e o meio ambiente, de forma a criar novos valores e sentimentos que mudem as atitudes. Além da educação ambiental (conscientização), para UNICEF \& CAIXA (2001), os programas também devem atuar no aspecto legal, através de leis que minimizem a produção de descartáveis pela indústria. Lembrando que a indústria, é a 
que menos está interessada na redução de consumo, pois vai de encontro com os ideais consumistas das quais eles são dependentes.

A reutilização é a segunda atividade na hierarquia dos 3 R's. Antes de transformar um bem adquirido em lixo, há a possibilidade de reutilizá-la, com o objetivo de aumentar a vida útil do produto. Para a disseminação da reutilização é necessário apoiar os estabelecimentos que façam a recuperação, restauração, recondicionamento, compra e revenda de produtos usados: brechós, sebos, recuperadora de móveis, compra e venda de equipamento de informática, etc. A UNICEF \& CAIXA (2001) lembra da importância de incentivar trocas comunitárias para o reaproveitamento de objetos, em feiras específicas, estimulando "artistas" no reuso de materiais descartados.

A terceira atividade dos 3 R's é a reciclagem, que consiste na transformação de diferentes resíduos gerados e separados em matéria prima para novos produtos. Segundo UNICEF \& CAIXA (2001) foi criada uma crendice entorno da reciclagem, como sendo a panacéia para os problemas do lixo. É inegável que ela reduz o consumo de recursos naturais e energia e pode ser um processo menos poluente, mas não reduz a geração de lixo. Segundo as autoras SOARES \& GRIMBERG (1998), raramente se questiona o atual padrão de produção, não enfocando a diminuição do desperdício e nem da geração desenfreada de lixo.

Para fins de apresentação de nomenclatura, vale lembrar que, o processo de transformação do resíduo orgânico (material putrescível) existente no lixo em composto, adubo humificado, é um método de reciclagem, mas usualmente é conhecido como compostagem.

Existe a hierarquia no princípio dos 3 R's: Redução $\rightarrow$ Reutilização $\rightarrow$ Reciclagem. Porém, é importante salientar que é impossível que uma elimine a outra. $E$ também, que a aplicação do princípio resolva o problema do lixo. Isto porque, na prática, acabar com o consumo é irreal, reutilizar os produtos pra sempre é impossível e reciclar todo os resíduos é inviável. Os resíduos gerados podem ser reduzidos com a aplicação dos 3 R's, mas nunca eliminados, e sempre haverá a necessidade de encontrar um local para destiná-los. Por isso o gerenciamento integrado dos RSU se completa ao abordar desde o princípio dos 3 R's até a disposição final em aterros sanitários. 


\subsubsection{Processos intermediários para segregação}

Para possibilitar a reutilização e reciclagem do resíduo produzido, é necessário que ele seja separado, e este método é conhecido como segregação. Os processos conhecidos para segregação são a coleta seletiva e a triagem em usinas (Usinas de Triagem). A coleta seletiva é o processo pela qual há a separação dos materiais na fonte pelo gerador com posterior coleta dos materiais separados. A usina de triagem é o local de separação de materiais após a coleta convencional de RSU (D'ALMEIDA \& VILHENA, 2000).

$\mathrm{Na}$ coleta seletiva, obtêm-se materiais separados de melhor qualidade para reaproveitamento, do que aqueles obtidos na usina de triagem, visto que não há a contaminação do material inorgânico pelo orgânico, e vice-versa, contrário ao que ocorre na usina. A contaminação pode chegar a inviabilizar o reaproveitamento do produto da usina por ser de baixa qualidade (SOARES \& GRIMBERG, 1998). Segundo D'ALMEIDA \& VILHENA (2000) existem quatro modalidades de coleta seletiva, como pode ser visto na TABELA 4.4. Este processo normalmente exige a construção de um galpão de triagem para receber, separar, prensar, picar e enfardar ou embalar os recicláveis. Em alguns casos pode se fazer o pré-beneficiamento para agregar valor ao material segregado, como, por exemplo, a lavagem, a retirada de rótulos e a separação por cor.

A Resolução do CONAMA n ${ }^{\circ} 275$ de 25 de abril de 2001 (BRASIL, 2001a), a partir da publicação no Diário Oficial da União (DOU) em 19 de junho de 2001, estabeleceu o

TABELA 4.4 - Modalidades de coleta seletiva

\begin{tabular}{|c|c|}
\hline Classificação & Característica \\
\hline Porta-a-porta (ou domiciliar) & $\begin{array}{l}\text { Similar a coleta convencional, onde o morador co- } \\
\text { loca o material segregado em recipientes pré- } \\
\text { estabelecidos em frente à residência. }\end{array}$ \\
\hline $\begin{array}{l}\text { Postos de entrega voluntária (PEV) } \\
\text { Locais de entrega voluntária (LEV) }\end{array}$ & $\begin{array}{l}\text { Neste sistema, o morador se desloca até locais } \\
\text { fixos do município para depositar os recicláveis } \\
\text { em recipiente específicos com cores padrões para } \\
\text { cada material }\end{array}$ \\
\hline Postos de Troca & $\begin{array}{l}\text { Nesta modalidade o material entregue em pontos } \\
\text { fixos é trocado por algum bem ou benefício: ali- } \\
\text { mento, descontos, vales, material construção, etc. }\end{array}$ \\
\hline Catadores & $\begin{array}{l}\text { O material é coletado e/ou segregado por traba- } \\
\text { lhadores autônomos em toda cidade e revendido } \\
\text { para reciclagem. }\end{array}$ \\
\hline
\end{tabular}

Fonte: Adaptado de D'ALMEIDA \& VILHENA (2000) 
Código de cores: RESOLUÇÃO CONAMA n 275 de 25 de Abril de 2001

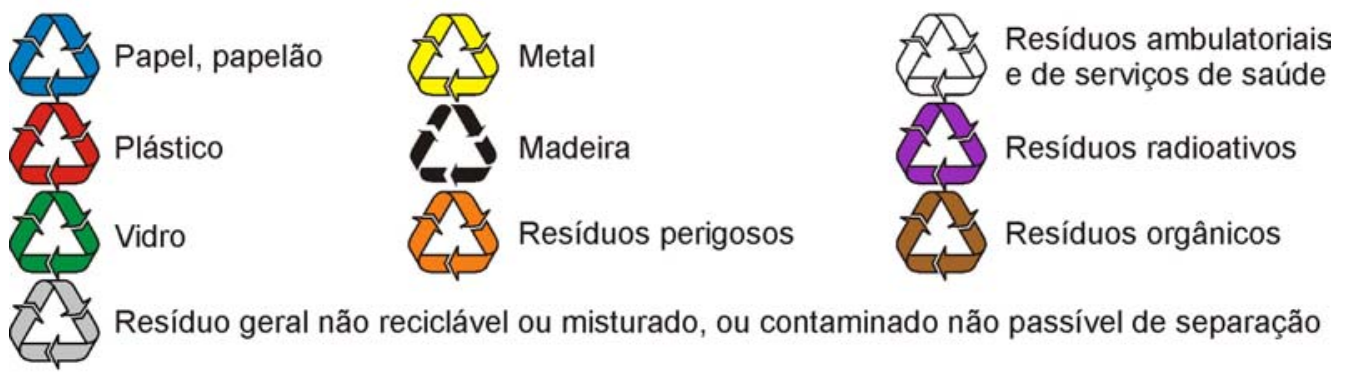

Identificação para coletores e transportadores \& programas de coleta seletiva

Fonte: Adaptado de (BRASIL, 2001a)

FIGURA 4.7 - Padrões de cores para os diferentes resíduos

novo padrão de cores para os diferentes tipos de resíduos. Este código de cores foi criado para auxiliar na coleta seletiva e na educação ambiental. Além de servir de referência para identificar coletores e transportadores dos diferentes resíduos. Como pode ser visto na FIGURA 4.7.

As Usinas de Triagem, onde ocorre o processo de segregação após a coleta convencional, quando estão conjugadas ao processo de compostagem, são chamadas de Usinas de Triagem e Compostagem (GALVÃO JÚNIOR, 1994). Apesar da coleta seletiva ser um processo melhor que a usina, pela eficiência na separação de materiais e baixa contaminação, a implantação deste sistema é demorado, pois necessita do processo de conscientização da população para que se realize a separação nos domicílios. Segundo GALVÃO JÚNIOR (1994) a usina de triagem é uma alternativa à coleta seletiva. Assim, dentro do gerenciamento integrado do RSU, pode dispor-se de usinas de triagem para que se possa diminuir os resíduos a serem aterrados, antes que se consiga implantar a coleta seletiva por completo.

\subsubsection{Processo intermediário para tratamento térmico}

De acordo com os autores D'ALMEIDA \& VILHENA (2000), diversos processos de tratamento térmico de RSU têm surgido nos últimos anos, envolvendo a aplicação de incineração, plasma, pirólise e gaseificação. A incineração é o que está disponível em 
escala comercial dentro dos processos de tratamento térmico de RSU. Os demais estão em fase experimental, e não será salientado neste trabalho.

Conforme D'ALMEIDA \& VILHENA (2000), o tratamento térmico é um processo onde pode se ter: assepsia do material, redução de volume, aproveitamento da energia contida no resíduo. Este tratamento pode ser classificado em dois tipos: o de baixa temperatura e o de alta temperatura. Os tratamentos a baixa temperatura ocorrem em uma temperatura em torno de $100^{\circ} \mathrm{C}$ e visam principalmente a assepsia do resíduo sólido, razão pela qual é utilizado normalmente para tratamento de Resíduos de Serviços de Saúde (RSS). A baixa temperatura, a massa orgânica praticamente não se altera, podendo ter uma leve redução em volume. Os tratamentos a alta temperatura normalmente ocorrem em temperaturas acima de $500^{\circ} \mathrm{C}$ onde se objetiva principalmente a redução da massa orgânica (70\%) e volume (90\%) e também a assepsia.

Além da vantagem da redução do volume para disposição final, a incineração pode ser usada na recuperação de energia contida nos resíduos, para geração de vapor d'água e energia elétrica. A grande desvantagem está no seu alto custo, mas D'ALMEIDA \& VILHENA (2000) destaca que, como os custos da disposição em aterros sanitários tendem a se elevar com o tempo nos grandes centros urbanos (uso do solo: valorização, e falta de locais adequados), a incineração com geração de energia e vapor d'água pode se tornar atraente economicamente. Porém, este não é o caso das cidades de pequeno porte. A SMA (SÃO PAULO, 1998a) destaca que a incineração de RSU, devido ao alto custo, é adotada nas cidades onde foram esgotadas todas as outras possibilidades de destinação dos resíduos.

\subsubsection{Disposição Final}

A disposição final de qualquer resíduo é o solo (GUIMARÃES, 2000). Segundo alguns autores: BIDONE \& POVINELLI (1999), D'ALMEIDA \& VILHENA (2000) e GUIMARÃES (2000), existem três tipos de disposição final: lixão (vazadouros a céu aberto), aterro controlado e aterro sanitário. Os conceitos são apresentados a seguir: 


\section{i ) Lixão}

Neste método precário de disposição final, os RSU são simplesmente descarregados sobre o solo, sem medidas de proteção ao meio ambiente ou à saúde pública (BIDONE \& POVINELLI, 1999). Essa forma de disposição promove a proliferação de vetores de doenças, geração de maus odores, poluição do solo e de mananciais superficiais e subterrâneos pelo chorume. Acrescenta-se a isso o problema social e de saúde pública referente à presença de famílias inteiras garimpando o lixo em condições insalubres. Apesar de ser o pior tipo de disposição de resíduos sólidos, cerca de $22 \%$ dos resíduos coletados no Brasil ainda são nele destinados, conforme dados da Pesquisa Nacional de Saneamento Básico - 2000 (IBGE, 2002).

\section{ii ) Aterro Controlado}

Segundo a norma NBR 8.849 - Apresentação de projetos de aterros controlados de resíduos sólidos urbanos (ABNT, 1985), o Aterro Controlado é definido como: "técnica de disposição de resíduos sólidos urbanos no solo, sem causar dados ou riscos à saúde pública e à segurança, minimizando os impactos ambientais, método este que utiliza princípios de engenharia para confinar os resíduos sólidos, cobrindo-os com uma camada de material inerte na conclusão da cada jornada de trabalho". Este método, apesar de ser melhor que o lixão, ainda está longe de ser a melhor alternativa, pois, mesmo na NBR 8.849 (ABNT, 1985), não se prevê sistemas como a de drenagem e remoção do percolado, não garantindo a proteção do solo e mananciais de água potável. Conforme os dados da Pesquisa Nacional de Saneamento Básico - 2000 (IBGE, 2002), 37\% dos resíduos coletados no país são destinados para aterros controlados.

\section{iii ) Aterro sanitário}

Segundo a NBR - 8.419 Apresentação de projetos de aterros sanitários de resíduos sólidos urbanos (ABNT, 1992), o Aterro Sanitário é definido como: "técnica de disposição de resíduos sólidos urbanos no solo, sem causar dados ou riscos à saúde pública e à segurança, minimizando os impactos ambientais, método este que utiliza princípios de engenharia para confinar os resíduos sólidos à menor área possível e reduzí-los ao 


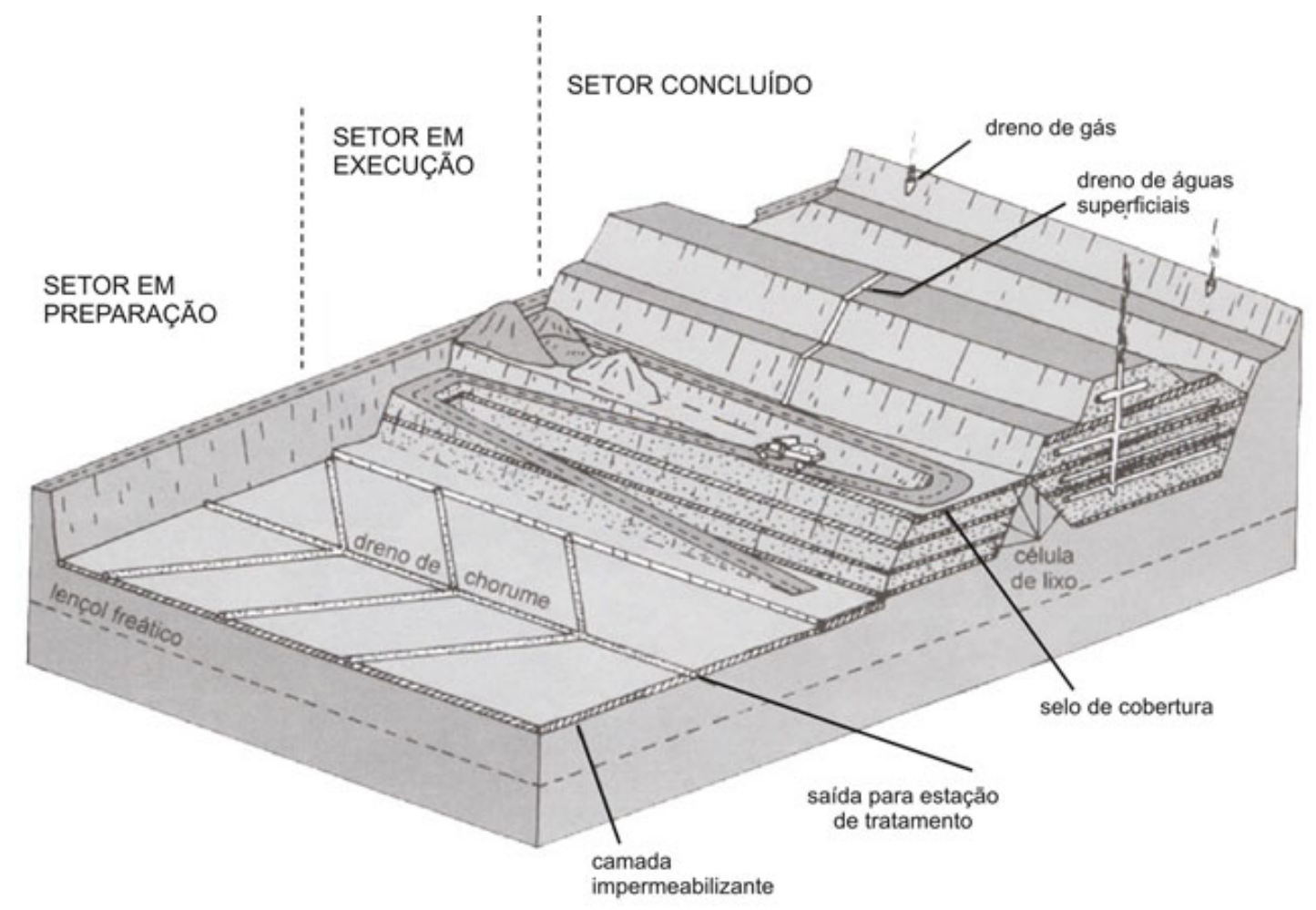

Fonte: D'ALMEIDA \& VILHENA (2000)

FIGURA 4.8 - As fases do aterro sanitário e os sistemas de proteção ambiental

menor volume permissível, cobrindo-os com uma camada de terra na conclusão da cada jornada de trabalho, ou a intervalos menores, se necessário".

Comparando a NBR 8.849 (ABNT, 1985) e a NBR 8.419 (ABNT, 1992), verifica-se que o aterro sanitário é a solução ambientalmente confiável. Além de todos os critérios de engenharia para confinar o RSU que o aterro controlado possui, um aterro sanitário exige sistema de drenagem e remoção de percolado, sistema de tratamento do percolado, impermeabilização inferior e superior do aterro e sistema de drenagem de gás. Diferença esta mencionada também em D'ALMEIDA \& VILHENA (2000). O esquema ilustrativo do aterro sanitário, nas fases de preparação, execução e conclusão com as soluções técnicas de proteção ambiental, encontra-se na FIGURA 4.8.

Como solução adequada para disposição do lixo é indicado o aterro sanitário, como acontece no manual do IPT-CEMPRE (D'ALMEIDA \& VILHENA, 2000). Apesar dos aterros sanitários sofrerem resistência no meio técnico e na própria sociedade em face dos riscos ambientais que podem apresentar, conforme ASSIS (1999), para a atual 


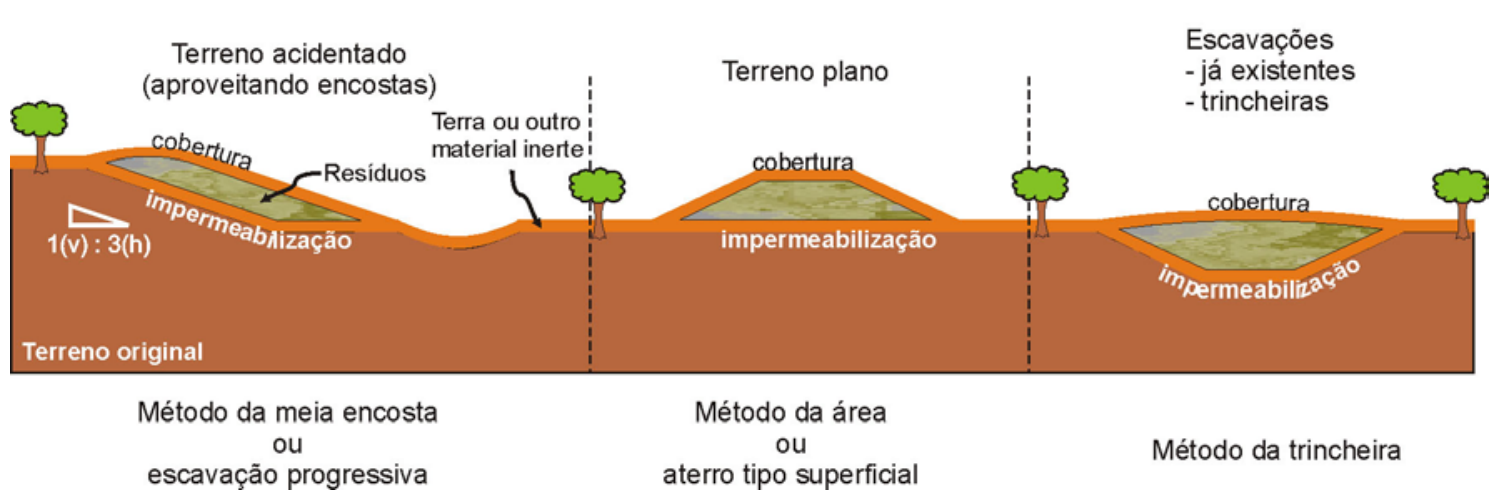

Fonte: Adaptado de BIDONE \& POVINELLI (1999) e CETESB (SÃO PAULO, 1997a)

FIGURA 4.9 - Tipos de aterros sanitários segundo o método de execução das células de lixo (executado em uma jornada de trabalho)

realidade de manejo de resíduos sólidos, os aterros sanitários ainda se apresentam como alternativa viável. Pois, com a aplicação das modernas técnicas de engenharia disponíveis para a sua implantação e operação, além da observância das leis e normas na elaboração dos projetos, pode-se garantir um alto grau de proteção ao meio, tornando essa forma de disposição de resíduo confiável e aplicável até o presente. De acordo com a SMA (SÃO PAULO, 1998a), o aterro sanitário é um método completo, pois não apresenta rejeitos ou refugos a serem tratados em outras instalações.

Os aterros sanitários podem ser classificados de acordo com o método de execução. A CETESB dentro de suas atribuições, elaborou a Apostila Ambiental de Aterro Sanitário (SÃO PAULO, 1997a), descrevendo o aterro sanitário e os sistemas de proteção ambiental, além das instalações de apoio, equipamentos e o processo de encerramento do aterro. E, a FIGURA 4.9 ilustra os tipos de aterros sanitários, segundo esta apostila, cuja classificação está baseada no método de execução das células de lixo.

\section{iv ) Aterro sanitário em valas}

O aterro sanitário convencional, descrito na seção anterior, normalmente exige a disponibilidade de equipamentos: tratores de esteiras, pás-carregadeiras, retroescavadeiras e caminhões basculantes. Isto inviabiliza este tipo de solução para muitos municípios de pequeno porte. Segundo a Apostila Ambiental de Aterro Sanitário em Valas da CETESB (SÃO PAULO, 1997b), o menor trator de esteiras disponível no mercado opera até 150 toneladas de lixo por dia. Em municípios que produzem menos de 10 toneladas por dia, o equipamento fica ocioso na maioria do tempo. 
Como solução ao problema, a CETESB (SÃO PAULO, 1997b) recomenda o aterro sanitário em valas para as cidades de pequeno porte, que são trincheiras de pequenas dimensões que podem ser executadas por equipamentos existentes no próprio município. Uma retroescavadeira de menor porte acopláveis em um trator, existentes na maioria das prefeituras, escava as trincheiras, o caminhão da própria coleta deposita o resíduo, e a cobertura pode ser realizada manualmente por alguns funcionários sem a necessidade de compactação.

De acordo com a CETESB, no aterro sanitários em valas, se forem seguidos os procedimentos para a correta operação, os volumes de percolados gerados serão pequenos e podem ser mantidos acumulados dentro da própria célula (SÃO PAULO, 1997b). $E$, os gases gerados pelo lixo se dissipam para a atmosfera sem necessidade de um sistema especial de coleta, pois a profundidade da vala é pequena. Todavia, o sistema de drenagem de águas pluviais é a medida necessária de proteção, pois a água de chuva infiltrada pode carrear o percolado para fora da célula de lixo. A cobertura dos resíduos, após a jornada de trabalho, também é necessária para evitar a infiltração de águas de chuva, a proliferação de vetores patogênicos e a presença de animais. 


\section{ABORDAGEM LOGÍSTICA}

Os estudos logísticos a serem desenvolvidos neste trabaIho englobam a localização de instalações e a roteirização e programação de frota ligados aos processos de destinação de RSU. O gerenciamento de RSU está situado dentro da logística reversa. A seguir, o presente trabalho é identificado dentro dos conceitos de logística.

\subsection{O trabalho no contexto da logística}

$\mathrm{Na}$ literatura, a logística é tratada como atividade da empresa produtora de bens e serviços. Muito dos enfoques e exemplos da bibliografia envolvem empresas de manufatura, onde a logística é estudada para auxiliá-los em sua gerência. Mas a logística não se resume a isto, e seus conceitos e aplicações podem ser utilizados na solução de problemas como o abordado neste trabalho: gerenciamento integrado de RSU. Segundo BALLOU (2001), os princípios e conceitos de logística podem ser aplicados às áreas como a prestação de serviços, militar, até mesmo, gestão ambiental. Dentro do conceito amplo de gestão ambiental, encontra-se o gerenciamento de RSU, que pode ser incluído no ramo da logística denominado na literatura como logística reversa.

De acordo com BALLOU (2001) e ROGERS \& TIBBEN-LEMBKE (1998), a logística é definida pelo US Council of Logistic Management como: "processo de planejamento e controle de fluxo eficiente e economicamente eficaz de matérias-primas, estoque em processo, produtos acabados e informações relativas desde o ponto de origem até $o$ ponto de consumo, com o propósito de atender às exigências dos clientes". E, ROGERS \& TIBBEN-LEMBKE (1998) estabelece que a logística reversa envolve todas as atividades da logística tradicional, mas elas operam de maneira reversa, e a define como: "processo de planejamento e controle de fluxo eficiente e economicamente eficaz de matérias-primas, estoque em processo, produtos acabados e informações relativas desde o ponto de consumo até o ponto de origem, com o propósito de recapturar 
valor ou dar disposição adequada". A logística tradicional e a reversa estão representadas na FIGURA 5.1 através do fluxo de produtos.

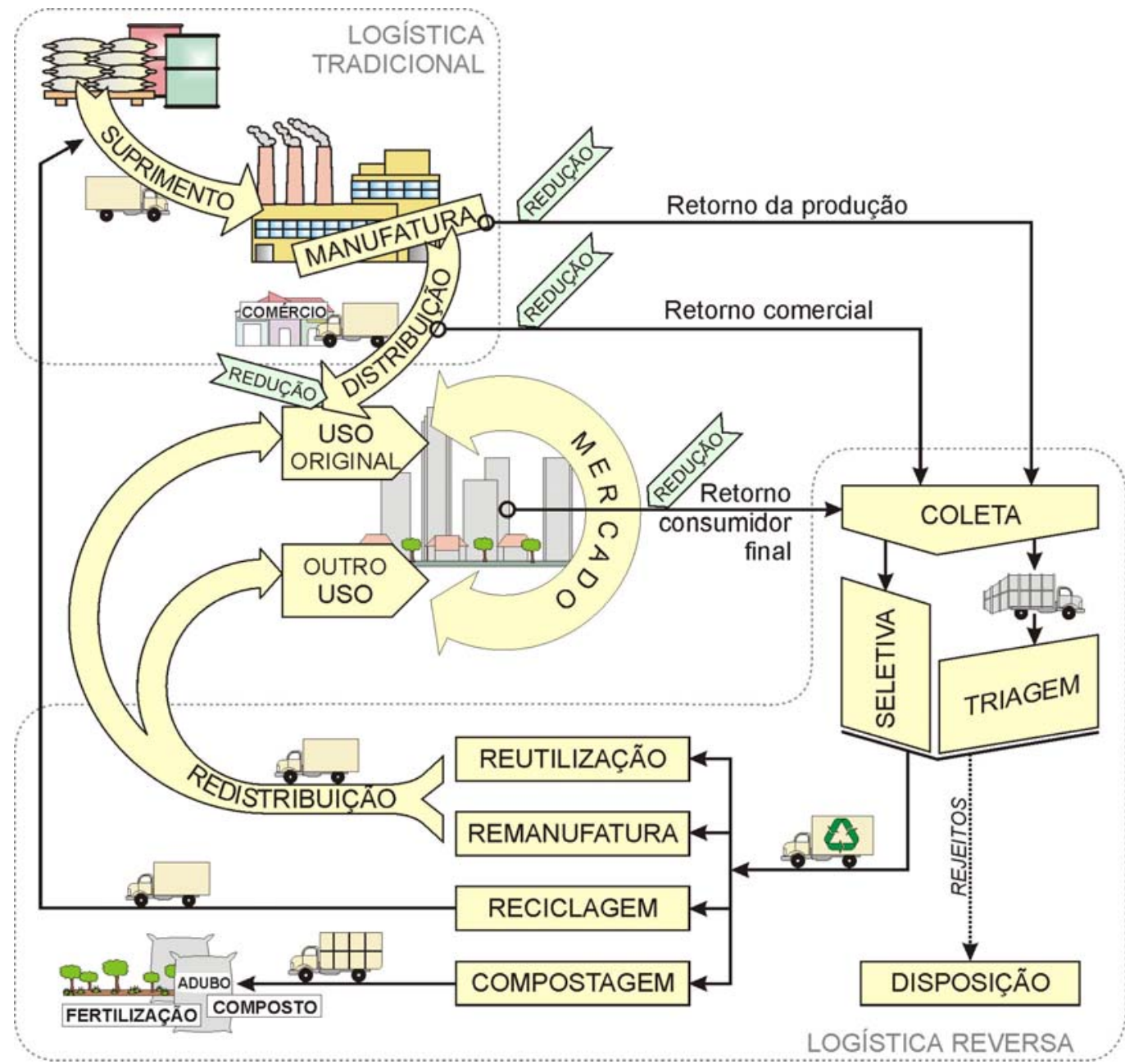

Fonte: Adaptado de KOKKINAKI et al. (2000)

FIGURA 5.1 - Fluxo de produtos na cadeia de suprimento e retorno

Após o setor industrial se ocupar durante muito tempo da obtenção de matéria-prima para produção de bens e sua distribuição, ele necessitou dar atenção ao canal reverso, caminho de volta de seu produto, pressionado pela concorrência na busca de produtos ambientalmente corretos. A logística reversa inclui processos de coleta, segregação, reutilização, remanufatura, reciclagem e compostagem, redistribuição e disposição do produto ou resíduo deste, conforme KOKKINAKI et al. (2000). O gerenciamento de RSU pode ser identificado como sendo parte da logística reversa, através de processos, desde a coleta até a disposição, além das atividades intermediárias de reaproveitamento, como pode ser visto na FIGURA 5.1. 
Para BALLOU (2001) o estudo sistemático da gestão logística conduz a dois temas. Em primeiro lugar estão as tarefas de planejamento, organização e controle para atingir os objetivos da empresa. O planejamento refere-se à decisão dos objetivos da empresa, a organização é relativo à coleta e ao posicionamento dos recursos da empresa para realizar seus objetivos, e o controle refere-se à mensuração do desempenho da empresa e à tomada de ações corretivas, quando o desempenho não estiver alinhado aos objetivos. Em segundo lugar, para se fazer um planejamento eficaz, é útil ter uma visão dos objetivos da empresa, ter conceitos e princípios para mostrar como alcançálos e ter ferramentas que ajudem a escolher cursos alternativos de ação.

Os conceitos apresentados por BALLOU (2001) servem não apenas para o setor industrial, mas são úteis também no gerenciamento do RSU pela administração pública, isto é, o RSU pode ser estudado com o enfoque da gestão logística. O governo local é uma empresa que se depara com as tarefas de planejamento, organização e controle em suas diversas áreas de atuação e, busca ser eficaz e eficiente em sua gestão, da mesma forma que diversas empresas do setor privado.

De acordo com BALLOU (2001), o núcleo da tarefa de planejamento logístico é o triângulo de tomada de decisões de transportes, estoque e localização, necessário para atender os níveis de serviços ao cliente. A atividade conhecida na literatura como localização de instalações (número, tamanho e localização) está dentro das decisões de localização. E a roteirização e programação de frota estão dentro das decisões de transporte. Segundo o mesmo autor, estas decisões podem ser tomadas em níveis estratégico, tático e operacional, diferenciados pelo horizonte de tempo para o planejamento. O planejamento no nível de decisão estratégica é considerado como sendo de longo prazo, no qual o horizonte de tempo é maior que um ano. O planejamento tático tem um alcance geralmente menor que um ano. E, o planejamento operacional é a tomada de decisões rotineira cuja freqüência é diária ou horária. O que foi discutido, está representado na FIGURA 5.2.

Através dos estudos logísticos (localização, roteirização e programação) das alternativas consorciadas para destinação de resíduos, pretende-se dar subsídios às decisões estratégicas municipais dentro do gerenciamento integrado do RSU. Assim, a presente pesquisa é desenvolvida no nível estratégico de planejamento. Recordando que, a 


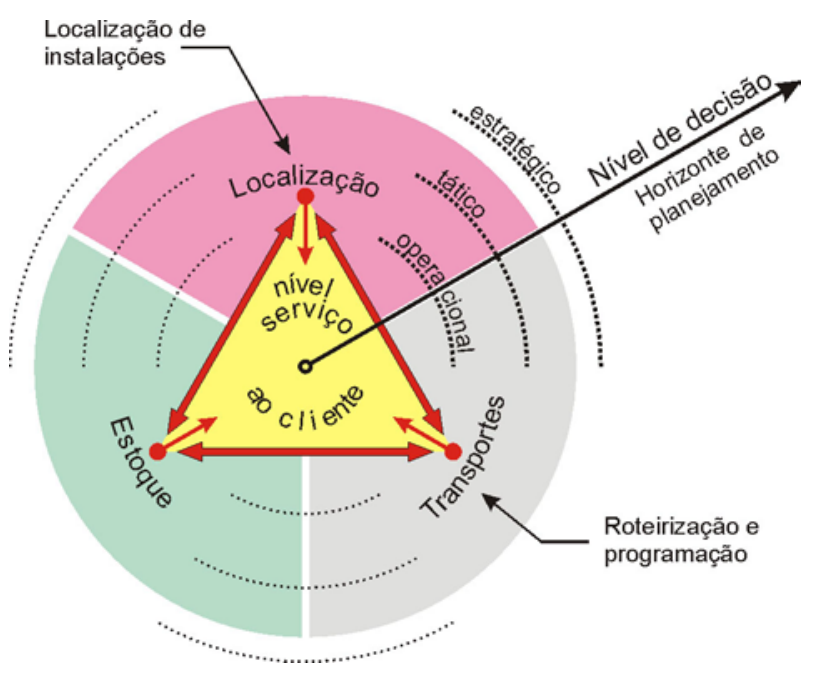

Fonte: Adaptado de BALLOU (2001)

FIGURA 5.2 - O triângulo da tomada de decisões no planejamento logístico

análise de localização de instalações está inserida nas decisões de localização e a roteirização e programação fazem parte das decisões de transporte.

\subsection{Análise de redes logísticas}

A análise espacial tem inúmeras aplicações práticas quando podem ser identificadas redes para apoiar na definição e estudo de problemas. LORENA (2001) define as redes como sendo um conjunto de pontos (nós ou vértices) e linhas (arcos ou arestas) que representam graficamente vias públicas, conexões de água, telefonia e outros. As redes para modelos de transporte descrevem em geral os diferentes tipos de vias e suas intersecções, como ilustrado na FIGURA 5.3. Os nós podem ser representações de clientes, instalações (fábricas, depósitos, etc, fornecedores do cliente) e cruzamentos de vias. E os arcos podem ser interpretados como as vias que interligam estes nós para o fluxo de algum produto e/ou pessoa.

As análises logísticas de localização de instalações, bem como de roteirização e programação, são problemas de caráter espacial. E, conforme LORENA (2001), são problemas que podem ser modelados em rede, na qual o conceito espacial de distância é usado, combinado com informações de demandas e capacidades de serviço. As medidas de distâncias envolvidas na formulação analítica dos modelos de localização, roteirização e programação são importantes e são divididas em três categorias (TOMPKINS et al., 1996): - distância retilínea: as distâncias são medidas ao longo de 


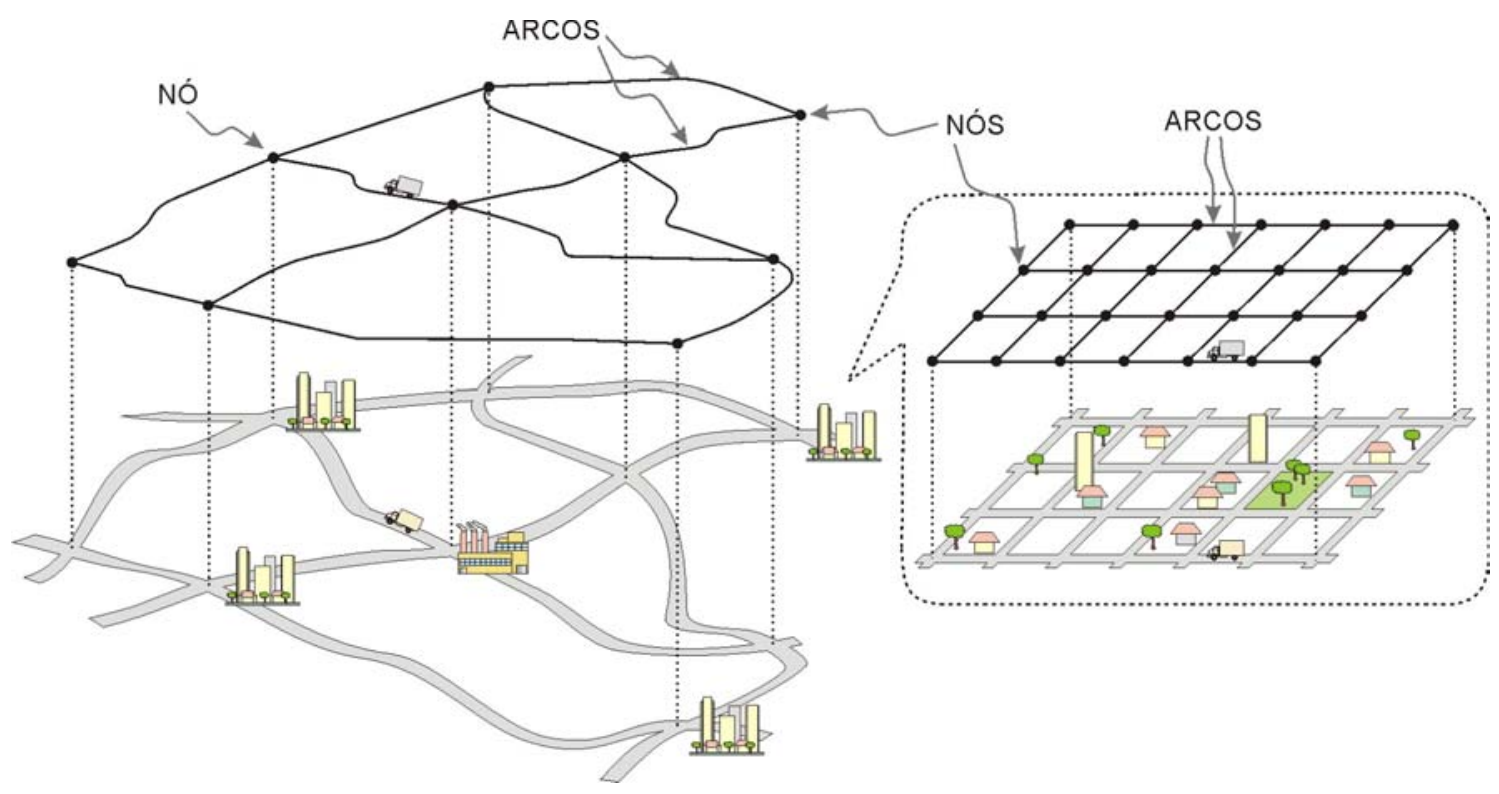

FIGURA 5.3 - Representação do espaço real na forma de rede

caminhos que são ortogonais; - distância euclidiana: as distâncias são medidas ao longo de caminhos retos entre dois pontos e; - distâncias em rede: as distâncias são medidas ao longo do atual (real) caminho entre dois pontos.

\subsubsection{Localização de instalações}

A localização de instalações, também conhecida como localização de facilidades, é a primeira atividade da análise logística deste trabalho. Através dela encontra-se o meIhor arranjo para as instalações do sistema consorciado. Este procedimento é necessário para garantir que a análise subseqüente de roteirização e programação de veículos se apóie na melhor opção de localização, o que levará ao menor custo logístico para a alternativa elaborada. Portanto, esta análise tem caráter primordial. De acordo com WANKE (2001), localizar as instalações dá forma, estrutura e conformidade ao sistema logístico.

A decisão da localização de instalações é elemento crítico no planejamento em nível estratégico para uma série de empresas públicas e privadas (OWEN \& DASKIN, 1998). Segundo LACERDA (1999), é um problema comum e dos mais importantes para os profissionais de logística. Sua importância decorre dos altos investimentos envolvidos e dos profundos impactos que as decisões de localização têm sobre os custos logísticos. Dependendo de cada caso, as instalações podem representar um 
elevado investimento em ativos fixos, de difícil reversão em curto e médio prazo, implicando em elevados custos de realocação da instalação (WANKE, 2001).

Segundo DREZNER (1995), os problemas de localização tratam de decisões sobre onde localizar uma ou mais instalações de forma a otimizar um certo critério, como o de minimizar o custo de transporte, prover todos os clientes com certo nível de serviço, capturar a maior parcela do mercado, etc. Este tipo de problema logístico está sujeito também a restrições de capacidade das instalações e demanda dos clientes.

Para auxiliar o profissional na tomada de decisões sobre o planejamento logístico, elaboraram-se estratégias para solução dos problemas de localização. BALLOU (2001) classificou e limitou as categorias destas estratégias, como é descrito a seguir:

- Por força direcionadora: a localização é determinada segundo um fator que é mais crítico que outros: econômico, de acessibilidade, etc;

- Por número de localizações: na escolha do número de instalações deve-se considerar as forças competitivas de demanda entre instalações, efeitos de consolidação de estoque e custos de instalação e transporte;

- Por escolhas discretas: através dos métodos discretos se encontra a melhor localização, a partir de uma lista de escolhas possíveis que tenham sido préselecionadas por critérios razoáveis. Já, os métodos contínuos exploram cada possibilidade de localização ao longo de um espaço contínuo de opções e selecionarão a melhor;

- Por grau de agregação de dados: os dados podem ser agregados para gerenciar e chegar a uma solução prática dos problemas de localização, que envolvem um número muito grande de configurações de projetos de rede a serem avaliados;

- Por horizonte de tempo: quando o planejamento de localização é de curto prazo, em um único período de tempo, o modelo de localização é chamado estático. No caso que se considera o planejamento para multiperíodos, os modelos são chamados de dinâmicos.

Segundo BALLOU (2001), desenvolver técnicas para locar instalações tem sido uma área comum de pesquisa. Porém, OWEN \& DASKIN (1998) entendem que encontrar um modelo de localização robusto é uma questão difícil, dada a complexidade do pro- 
blema. Para demonstrar estas limitações e/ou aptidões encontradas em diferentes métodos de solução, OWEN \& DASKIN (1998) fizeram uma revisão na literatura sobre os modelos de localização. Eles apresentaram a pesquisa classificando os problemas de localização de acordo com os seguintes modelos: estático-determinísticos, dinâmicos e estocásticos.

Nos modelos estático-determinísticos: os parâmetros de entrada são constantes e de valores conhecidos e o problema leva a uma simples solução, que é implementada para um ponto específico no tempo. Na TABELA 5.1 estão os modelos estáticodeterminísticos e seus objetivos básicos, apresentados por OWEN \& DASKIN (1998). Segundo estes autores, a maioria das publicações sobre a teoria de localização focaliza os problemas estático-determinísticos, pois são extremamente difíceis de se resolver. Assim, as formulações têm razoável caráter de pesquisa, mas não captura muitas das características dos problemas de localização do mundo real. De acordo com os mesmos autores, a natureza estratégica da localização de facilidades requer que os modelos considerem aspectos de incertezas futuras.

OWEN \& DASKIN (1998) apresentaram em seu artigo, pesquisas que lidam explicitamente com as incertezas da localização de instalações. A primeira de duas categorias, de modelos que tratam da incerteza é o modelo dinâmico, que considera o comportamento incerto do futuro no horizonte de planejamento, para solucionar problemas como a de realocação de facilidades existentes em um planejamento de longo prazo: multiperíodo.

O segundo é o modelo estocástico, que trata as incertezas de inúmeros parâmetros (variáveis) de entrada como os tempos de viagem, custos de construção, locais de demanda, quantidades demandadas. Este modelo pode ser dividido em duas outras categorias: probabilística e planejamento do cenário. Na abordagem probabilística, há a explícita consideração da distribuição de probabilidade associada às variáveis do acaso. E, a abordagem do planejamento do cenário considera um conjunto de possíveis valores futuros para os diversos parâmetros que são gerados pelos "tomadores de decisão". 
TABELA 5.1 - Modelos estático-determinísticos da localização de instalações

\begin{tabular}{|c|c|c|}
\hline & Modelo & Objetivo \\
\hline \multirow{2}{*}{ 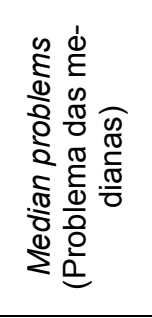 } & $\begin{array}{l}\text { P-median } \\
\text { (P-medianas) }\end{array}$ & $\begin{array}{l}\text { minimizar a distância total entre os clientes e as insta- } \\
\text { lações. A distância é ponderada pela quantidade } \\
\text { demandada pelos clientes. }\end{array}$ \\
\hline & $\begin{array}{l}\text { Maximum capture problem } \\
\text { (Problema de máxima captura - } \\
\text { p-mediana modificado) }\end{array}$ & $\begin{array}{l}\text { maximizar o número de novos clientes capturados ou } \\
\text { maximizar a quota do mercado de varejistas adicio- } \\
\text { nado, na presença de outras firmas. Obs.: Todas as } \\
\text { firmas trabalham com o mesmo produto e os clientes } \\
\text { preferenciam as firmas mais próximas }\end{array}$ \\
\hline \multirow{2}{*}{ 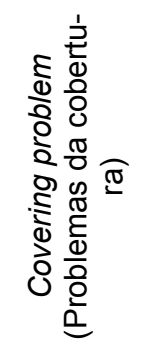 } & $\begin{array}{l}\text { Location set covering problem } \\
\text { (Problema da cobertura de um } \\
\text { conjunto de clientes) }\end{array}$ & $\begin{array}{l}\text { minimizar o custo de localização na qual um nível } \\
\text { especificado de cobertura dos clientes é obtido. Basi- } \\
\text { camente se busca minimizar o número de facilidades } \\
\text { necessárias para cobrir todos os clientes dentro de } \\
\text { uma distância especificada (limite - garantir certo } \\
\text { nível de serviço ao cliente). }\end{array}$ \\
\hline & $\begin{array}{l}\text { Maximal covering problem } \\
\text { (Problema da máxima cobertura) }\end{array}$ & $\begin{array}{l}\text { maximizar a quantidade de clientes cobertos pelo } \\
\text { serviço dentro de uma distância aceitável, localizando } \\
\text { um número fixo de instalações. }\end{array}$ \\
\hline 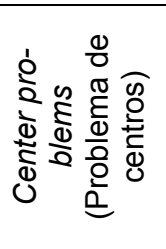 & $\begin{array}{l}\text { P-center problem (minimax) } \\
\text { (Problema de centro) } \\
\text { - vertex center problem } \\
\text { (problema de centro de vértice); } \\
\text { - absolute center problem } \\
\text { (problema de centro absoluto) }\end{array}$ & $\begin{array}{l}\text { minimizar a máxima distância entre os clientes e a } \\
\text { facilidade mais próxima. Quando a localização da } \\
\text { instalação está restrita ao nó (vértice) da rede tem-se } \\
\text { o problema de centro de vértice. Caso se permita a } \\
\text { localização em qualquer lugar da rede o problema é } \\
\text { de centro absoluto. }\end{array}$ \\
\hline \multirow{5}{*}{ 总 } & $\begin{array}{l}\text { Fixed charge facility location } \\
\text { problem } \\
\text { (Problema de localização de } \\
\text { custo fixo) }\end{array}$ & $\begin{array}{l}\text { adiciona um custo fixo (aquisição, construção) aos } \\
\text { problemas de p-mediana }\end{array}$ \\
\hline & $\begin{array}{l}\text { Location-allocation problems } \\
\text { (problema de localização- } \\
\text { alocação) }\end{array}$ & $\begin{array}{l}\text { baseados nas formulação básicas dos problemas de } \\
\text { localização, simultaneamente localiza-se as instala- } \\
\text { ções e aloca-se fluxos entre as instalações e os clien- } \\
\text { tes }\end{array}$ \\
\hline & $\begin{array}{l}\text { Antimedian problem } \\
\text { (Problema de antimediana) }\end{array}$ & $\begin{array}{l}\text { maximizar a distância média entre a instalação e o } \\
\text { cliente }\end{array}$ \\
\hline & $\begin{array}{l}\text { Anticenter problem } \\
\text { (Problema de anticentro) }\end{array}$ & $\begin{array}{l}\text { maximiza a mínima distância entre a instalação e os } \\
\text { clientes }\end{array}$ \\
\hline & $\begin{array}{l}\text { P-dispersion problem } \\
\text { (Problema da P-dispersão) }\end{array}$ & $\begin{array}{l}\text { maximiza a distância mínima entre qualquer par de } \\
\text { instalações }\end{array}$ \\
\hline
\end{tabular}

Fonte: Adaptado de OWEN \& DASKIN (1998)

Além da apresentação dos problemas de localização de facilidades, fundamentada na classificação dos modelos, como a realizada por OWEN \& DASKIN (1998), existe aquela apresentada por BALLOU (2001). Este autor classifica os problemas com base nos seguintes métodos de solução: métodos exatos, métodos de simulação e métodos heurísticos. Os métodos exatos referem-se àqueles procedimentos com capacidade de garantir uma solução matemática ótima para o problema de localização ou, pelo menos, uma solução de acurácia conhecida. Os métodos de simulação referem-se a uma representação matemática de um sistema logístico por demonstrações algébricas 
e lógicas, que podem ser manipuladas por um computador. Os métodos de simulação tentam descobrir a melhor rede, por meio de aplicações repetidas do modelo, onde a qualidade dos resultados depende da habilidade do discernimento do usuário em selecionar as localizações a serem analisadas. Os métodos heurísticos podem ser denominados como qualquer princípio ou conceito que contribui para reduzir o tempo médio de pesquisa de uma solução, também chamados de regras que guiam a solução do problema.

Os métodos exatos e heurísticos podem diferenciar no tipo de solução e na representação do problema real. Através dos métodos exatos as soluções podem ser ótimas matematicamente, mas o modelo pode estar longe de representar a situação real. As heurísticas permitem uma melhor representação dos problemas reais com menor tempo de processamento e memória computacional necessária, mas com soluções aproximadas (BALLOU, 2001). O autor LORENA (2001), apresentou em seu trabalho, sua experiência com um algoritmo baseado em método heurístico de melhora de soluções combinada com heurística Lagrangeana, para solução de problema de localizaçãoalocação. Segundo o autor, os resultados foram satisfatórios, mas considerou que sua heurística poderia ser computacionalmente excessiva para problemas grandes.

\subsubsection{Roteirização e programação}

A localização de facilidades tem caráter primordial, pois dá forma, estrutura e conformidade ao sistema logístico. Após determinar o local das instalações, a tarefa de roteirização e programação é realizada neste trabalho. Esta análise subseqüente de transportes é de grande importância nas decisões do planejamento logístico.

Para BALLOU (2001), os custos de transporte variam tipicamente entre um terço e dois terços do total dos custos logísticos, sendo assim, o transporte é geralmente o elemento mais importante dentro das atividades logísticas. Reduzir o custo dos transportes e melhorar o serviço ao cliente, através da busca dos melhores trajetos que um veículo deve fazer em uma rede viária, o qual minimizará o tempo ou distância, é um problema freqüente de decisão. Todavia, as decisões de transporte se expressam em uma variedade de formas, entre as principais estão a roteirização e a programação. 
BODIN et al. (1983) retrataram o estado-da-arte sobre a roteirização e a programação. Nesta publicação fundamental, os autores pesquisaram aproximadamente 700 trabaIhos, culminando em um estudo completo sobre os conceitos, problemas de roteirização e programação e seus métodos de solução. Todos os sistemas de roteirização e programação têm como saída básica, essencialmente o mesmo: para cada veículo ou tripulante, uma rota e um programa é providenciado. Em linhas gerais, a rota especifica a seqüência de locais a serem visitados, e o programa identifica os tempos nos quais as atividades nestes locais serão realizadas.

TABELA 5.2 - Características dos problemas de roteirização e programação

\begin{tabular}{|c|c|}
\hline Características & Possibilidades \\
\hline 1. Tamanho da frota disponível & $\begin{array}{l}\text { - um veículo } \\
\text { - vários veículos }\end{array}$ \\
\hline 2. Tipo da frota disponível & $\begin{array}{l}\text { - homogênea (somente um tipo de veículo) } \\
\text { - heterogênea (vários tipos de veículos) } \\
\text { - veículos especiais (dividido em compartimentos, etc) }\end{array}$ \\
\hline 3. Garagem dos veículos & $\begin{array}{l}\text { - um único depósito } \\
\text { - vários depósitos }\end{array}$ \\
\hline 4. Natureza da demanda & $\begin{array}{l}\text { - determinística } \\
\text { - probabilística } \\
\text { - parcialmente satisfeita }\end{array}$ \\
\hline 5. Localização da demanda & $\begin{array}{l}\text { - nos nós (não necessariamente em todos) } \\
\text { - nos arcos (não necessariamente em todos) } \\
\text { - misto }\end{array}$ \\
\hline 6. Característica da rede & $\begin{array}{l}\text { - não-orientada } \\
\text { - orientada } \\
\text { - mista } \\
\text { - euclidiana }\end{array}$ \\
\hline $\begin{array}{l}\text { 7. Restrições de capacidade do } \\
\text { veículo }\end{array}$ & $\begin{array}{l}\text { - impostas (todos os veículos com mesma capacidade) } \\
\text { - impostas (veículos com diferentes capacidades) } \\
\text { - não impostas (capacidade ilimitada) }\end{array}$ \\
\hline 8. Tempos máximos de rotas & $\begin{array}{l}\text { - impostos (todas as rotas com o mesmo tempo máximo) } \\
\text { - impostos (rotas com diferentes tempos máximos) } \\
\text { - não impostos }\end{array}$ \\
\hline 9. Operações envolvidas & $\begin{array}{l}\text { - somente coletas } \\
\text { - somente entregas } \\
\text { - mistas } \\
\text { - entregas com 'quebras' (permitidas ou proibidas) } \\
\text { - volta carregada }\end{array}$ \\
\hline 10. Custos & $\begin{array}{l}\text { - variáveis ou custos de roteirização } \\
\text { - fixos de operação ou custos de aquisição de veículos } \\
\text { - custos comuns de transporte }\end{array}$ \\
\hline 11. Objetivos & $\begin{array}{l}\text { - minimizar os custos totais de roteirização } \\
\text { - minimizar a soma dos custos fixos e variáveis } \\
\text { - minimizar o número necessário de veículos } \\
\text { - maximizar a função utilidade } \\
\text { (baseada no serviço ou na conveniência) ou, } \\
\text { (baseada nas prioridades do cliente) }\end{array}$ \\
\hline
\end{tabular}

Fonte: BODIN et al. (1983) 
As características dos problemas de roteirização e programação podem ser vistas na TABELA 5.2. Elas estão apresentadas de acordo com critérios e descrições que podem ser utilizados para modelar os problemas reais. Os diferentes problemas de roteirização e programação podem ser apresentados dentro de uma classificação. Segundo BODIN et al. (1983), os problemas podem ser divididos primeiramente em três grupos: (1) roteirização pura, (2) programação e (3) roteirização e programação; e depois subdivididos de acordo com um esquema detalhado de classificação. A classificação utilizada pelos autores nos três grupos citados é o mais clássico da literatura e estão apresentados a seguir com os diferentes tipos de problemas.

\section{i ) Roteirização pura de veículos}

A roteirização pura de veículos é um problema espacial, onde não há relações de precedência entre as atividades envolvidas nem há restrições de tempo para as ativida-

TABELA 5.3 - Os problemas básicos de roteirização pura

\begin{tabular}{|c|c|}
\hline Problema & Descrição \\
\hline Caixeiro viajante & $\begin{array}{l}\text { Consiste em determinar uma rota de mínimo custo que passe por todos os } \\
\text { nós de uma rede exatamente uma vez. É um problema de cobertura de } \\
\text { nós.Se o custo é simétrico, ou seja, se o custo de viajar entre dois nós não } \\
\text { depende da direção da viajem, é caso de problema de caixeiro viajante } \\
\text { simétrico, de outra forma é problema de caixeiro viajante assimétrico ou } \\
\text { direcionado. }\end{array}$ \\
\hline Carteiro chinês & $\begin{array}{l}\text { Este caso requer a determinação uma rota e custo mínimo que passe por } \\
\text { todos os arcos de uma rede pelo menos uma vez. É um problema de co- } \\
\text { bertura de arcos. Este problema é chamado direcionado ou não- } \\
\text { direcionado, dependendo se o arco é direcionado ou não. }\end{array}$ \\
\hline $\begin{array}{l}\text { Múltiplos caxeiros } \\
\text { viajantes }\end{array}$ & $\begin{array}{l}\text { É uma generalização do problema de caixeiro de viajante na qual é neces- } \\
\text { sário se considerar mais de um caixeiro viajante (ex.: veículos). Os } M \text { veí- } \\
\text { culos da frota originam e terminam suas rotas de um depósito comum. } \\
\text { Não há restrições sobre o número de nós que cada um pode visitar, exce- } \\
\text { to que cada veículo visite no mínimo um nó. }\end{array}$ \\
\hline $\begin{array}{l}\text { Roteirização em nós: } \\
\text { único depósito, vários } \\
\text { veículos }\end{array}$ & $\begin{array}{l}\text { É conhecido com problema clássico de roteirização de veículos (PRV). É } \\
\text { uma generalização do problema de caixeiro viajante, onde a frota de veí- } \\
\text { culos parte de um depósito central e serve todos os nós, com o objetivo de } \\
\text { minimizar a distância total percorrida pela frota. }\end{array}$ \\
\hline $\begin{array}{l}\text { Roteirização em nós: } \\
\text { vários depósitos, vários } \\
\text { veículos }\end{array}$ & $\begin{array}{l}\text { É uma generalização do problema anterior, com vários depósitos, ao invés } \\
\text { de um. Neste problema, cada veículo é alocado a um único depósito, ou } \\
\text { seja, origina e termina a viajem no mesmo depósito. }\end{array}$ \\
\hline $\begin{array}{l}\text { Roteirização em nós: } \\
\text { único depósito, vários } \\
\text { veículos, demanda } \\
\text { estocástica }\end{array}$ & $\begin{array}{l}\text { É idêntico ao PRV, exceto que a demanda não é conhecida com certeza, } \\
\text { assim ela pode originar de uma distribuição de probabilidade específica. }\end{array}$ \\
\hline $\begin{array}{l}\text { Carteiro chinês } \\
\text { capacitado }\end{array}$ & $\begin{array}{l}\text { É uma generalização do problema do carteiro chinês, onde há a restrição } \\
\text { de capacidade dos veículos. }\end{array}$ \\
\hline
\end{tabular}

Fonte: Adaptado de BODIN et al. (1983) 
des. O problema é basicamente um conjunto de nós ou arcos que devem ser atendidos por uma frota de veículos. O objetivo é construir um conjunto de rotas viáveis e de baixo custo, um para cada veículo. Os casos clássicos de problemas de roteirização pura, como o caixeiro viajante e carteiro chinês e suas variações, estão na TABELA 5.3. E, as características singulares dos problemas, segundo algumas restrições, estão na TABELA 5.4.

TABELA 5.4 - Característica dos problemas básicos de roteirização pura

\begin{tabular}{|c|c|c|c|c|c|}
\hline Problema & $\begin{array}{l}\text { Número } \\
\text { de } \\
\text { roteiros }\end{array}$ & $\begin{array}{l}\text { Localização } \\
\text { dos } \\
\text { clientes }\end{array}$ & $\begin{array}{l}\text { Limite de } \\
\text { capacidade } \\
\text { nos veículos }\end{array}$ & $\begin{array}{l}\text { Número } \\
\text { de } \\
\text { depósitos }\end{array}$ & $\begin{array}{c}\text { Tipo } \\
\text { de } \\
\text { demanda }\end{array}$ \\
\hline Caxeiro viajante & um & nós & não & um & determinística \\
\hline Carteiro chinês & um & $\operatorname{arcos}$ & não & um & determinística \\
\hline Múltiplos caxeiros viajantes & múltiplos & nós & não & um & determinística \\
\hline $\begin{array}{l}\text { Roteirização em nós: único } \\
\text { depósito, vários veículos }\end{array}$ & múltiplos & nós & $\operatorname{sim}$ & um & determinística \\
\hline $\begin{array}{l}\text { Roteirização em nós: } \\
\text { vários depósitos, vários } \\
\text { veículos }\end{array}$ & múltiplos & nós & $\operatorname{sim}$ & múltiplos & determinística \\
\hline $\begin{array}{l}\text { Roteirização em nós: único } \\
\text { depósito, vários veículos, } \\
\text { demanda estocástica }\end{array}$ & múltiplos & nós & $\operatorname{sim}$ & um & estocástica \\
\hline Carteiro chinês capacitado & múltiplos & $\operatorname{arcos}$ & $\operatorname{sim}$ & um & determinística \\
\hline
\end{tabular}

Fonte: Adaptado de BODIN et al. (1983)

\section{ii ) Programação}

O problema de programação pode ser visto como um problema de roteirização, lidando com restrições adicionais de tempo que necessitam ser consideradas, quando várias atividades precisam ser realizadas. Os problemas de programação são divididos em dois casos: programação de veículos e de tripulação. A criação da seqüência para as atividades dos veículos no espaço e no tempo é o cerne da programação de veículos. Já na programação de tripulação a preocupação primária é criar a sequência para o movimento da tripulação no espaço e no tempo, ou seja, prover de pessoal o movimento do veículo desejado (BODIN et al., 1983). 
TABELA 5.5 - Os problemas básicos de programação de veículos

\begin{tabular}{ll}
\hline \multicolumn{1}{c}{ Problema } & \multicolumn{1}{c}{ Descrição } \\
\hline Um único depósito & $\begin{array}{l}\text { Consiste no particionamento dos nós (tarefas) de uma rede acíclica em um } \\
\text { conjunto de rotas, de maneira que uma determinada função custo seja } \\
\text { minimizada. Cada rota corresponde à programação de um veículo. Uma } \\
\text { função objetivo que minimiza o número de rotas, efetivamente minimiza os } \\
\text { custos de capital desde que o número de veículos necessários seja igual } \\
\text { ao de rotas. }\end{array}$ \\
Restrições de tamanho de & $\begin{array}{l}\text { Estes problemas consistem nas considerações de restrições de tempo e } \\
\text { distância máxima de viajem, que na prática, representam a necessidade } \\
\text { deta }\end{array}$ \\
de reabastecimento e manutenção de veículos. \\
Consideram as diferentes características dos veículos para realizarem as \\
tarefas. Normalmente a característica considerada é a capacidade do veí- \\
culo. \\
Consiste em problemas com veículos que realizam tarefas a partir de dife- \\
rentes depósitos. Os veículos devem sair de e chegar ao mesmo depósito \\
e para o tamanho da frota de cada depósito deve se especificar um míni- \\
mo e o máximo.
\end{tabular}

Fonte: Adaptado de BODIN et al. (1983)

Conforme BODIN et al. (1983) as restrições que determinam a complexidade do problema de programação no mundo real são: (1) limite de tempo que um veículo pode estar em serviço antes de retornar ao depósito para reabastecimento ou manutenção; (2) certas tarefas podem ser realizadas apenas por tipos de veículos específicos; (3) a presença de diferentes depósitos dos veículos. Estes autores apresentaram, baseadas

TABELA 5.6 - Os problemas básicos de programação de tripulação

\begin{tabular}{ll}
\hline \multicolumn{1}{c}{ Problema } & \multicolumn{1}{c}{ Descrição } \\
\hline $\begin{array}{l}\text { Programação de } \\
\text { pessoal para um local } \\
\text { fixo }\end{array}$ & $\begin{array}{l}\text { uma demanda para cada trabalhador para cada período de tempo. Procu- } \\
\text { ra-se encontrar um conjunto de programas com trabalhadores para cobrir } \\
\text { todas as tarefas. É assumido que pode haver intercâmbio entre os traba- } \\
\text { lhadores, e que cada trabalhador pode ser desalocado no final de um pe- } \\
\text { ríodo de trabalho e que outro pode ser alocado ao serviço em cada come- } \\
\text { ço de um período. }\end{array}$ \\
$\begin{array}{l}\text { Programação de } \\
\text { veículos e tripulação em } \\
\text { transporte público }\end{array}$ & $\begin{array}{l}\text { viagens programadas de linhas, e determinar também as jornadas de tra- } \\
\text { balho das tripulações, considerando que as trocas de serviço e de turno só } \\
\text { podem ser realizadas em pontos específicos de trajetos das linhas. }\end{array}$ \\
$\begin{array}{l}\text { Programação de } \\
\text { tripulação no transporte } \\
\text { aéreo }\end{array}$ & $\begin{array}{l}\text { É semelhante à programação de tripulações em veículos, uma vez que as } \\
\text { tabelas de horários de partida e chegada das rotas aéreas nos diversos } \\
\text { pontos são definidas a priori e, portanto, conhecidas e determinadas. }\end{array}$ \\
$\begin{array}{l}\text { Programação de } \\
\text { pessoal em turnos de } \\
\text { revezamento }\end{array}$ & $\begin{array}{l}\text { Consiste na programação diária variando de um dia para o outro, havendo } \\
\text { um rodízio de turno de pessoal, em função de restrições trabalhistas, e } \\
\text { equilíbrio do esforço de trabalho, etc. A necessidade de revezamento no } \\
\text { cumprimento das tarefas ocorre pela necessidade de uma uniformização } \\
\text { da carga e das condições de trabalho para atividades que percebam a } \\
\text { mesma remuneração. }\end{array}$ \\
\hline
\end{tabular}

Fonte: Adaptado de BODIN et al. (1983) 
nestas restrições, alguns problemas de programação de veículos descritas na

TABELA 5.5.

Basicamente a programação de tripulação é similar a de veículos, porém envolve geralmente restrições mais complicadas, como parada para refeição de funcionários, regulamentação trabalhista, etc. Alguns exemplos destes problemas apresentados por BODIN et al. (1983) podem ser vistos na TABELA 5.6.

\section{iii ) Roteirização e programação}

Os problemas de roteirização e programação envolvem relações de precedência entre as atividades envolvidas e também restrições de janelas de tempo para as atividades (horário de atendimento, etc). O problema pode ser considerado como uma combinação dos problemas de roteirização com os de programação. Segundo DINIZ (2000),

TABELA 5.7 - Os problemas de roteirização e programação

\begin{tabular}{|c|c|}
\hline Problema & Descrição \\
\hline Ônibus escolares & $\begin{array}{l}\text { Consiste no problema de um grupo de escolas, cada qual com seu con- } \\
\text { junto de paradas de ônibus que tem vinculado, para cada ponto, um dado } \\
\text { número de estudantes e uma janela de tempo correspondente aos horá- } \\
\text { rios para pegar os alunos nas paradas e leva-los até a escola. O principal } \\
\text { objetivo é minimizar os custos de transporte para o município. }\end{array}$ \\
\hline $\begin{array}{l}\text { Caminhões: Cavalo } \\
\text { mecânico - carreta com } \\
\text { carga completa }\end{array}$ & $\begin{array}{l}\text { O termo carga completa significa que a carreta é engatada ao cavalo } \\
\text { mecânico e é transportado direto da origem ao destino. A carga na carre- } \\
\text { ta tem um único destino. A capacidade do cavalo mecânico corresponde } \\
\text { a apenas uma carreta. Este problema envolve restrições de precedência. }\end{array}$ \\
\hline $\begin{array}{l}\text { Caminhões: Cavalo } \\
\text { mecânico - carreta com } \\
\text { carga parcial }\end{array}$ & $\begin{array}{l}\text { Semelhante ao anterior, mas a carga não precisa ser completa. Assim, a } \\
\text { carga da carreta pode ser separada entre diferentes origens e destinos. }\end{array}$ \\
\hline $\begin{array}{l}\text { Serviços de coleta de } \\
\text { resíduos domiciliares e } \\
\text { de varrição de ruas }\end{array}$ & $\begin{array}{l}\text { Semelhante ao problema do carteiro chinês, porém com restrições de } \\
\text { capacidade dos veículos, de duração máxima da jornada e de janelas de } \\
\text { tempo associadas aos horários de proibição de estacionamento, de forma } \\
\text { a possibilitar a execução do serviço de varrição. Em geral, o objetivo con- } \\
\text { siste na minimização da frota ou um objetivo correlato, por exemplo, de } \\
\text { minimização do tempo morto total, para uma frota conhecida. }\end{array}$ \\
\hline $\begin{array}{l}\text { Dial-a-ride: transporte } \\
\text { especial de pessoas }\end{array}$ & $\begin{array}{l}\text { Sistema o transporte é obtido pedindo por telefone. Cada usuário tem } \\
\text { local de origem e destino diferentes e, eventualmente horários e faixas } \\
\text { horárias de saída e chegada. A precedência entre as tarefas é uma res- } \\
\text { trição decisiva para a viabilidade da solução. }\end{array}$ \\
\hline Aeronaves & $\begin{array}{l}\text { Consiste em programas simultaneamente rotas aéreas (início - escalas - } \\
\text { fim), com alocação de aeronaves e definição de tabelas de horários, le- } \\
\text { vando em consideração dados de demanda entre os pares de cidades, } \\
\text { freqüência do serviço desejado, vôos diretos vs com escalas, etc. Esse } \\
\text { problema envolve tanto o transporte de pessoas, como cargas e enco- } \\
\text { mendas. }\end{array}$ \\
\hline
\end{tabular}

Fonte: Adaptado de BODIN et al. (1983) 
estes problemas combinados freqüentemente surgem na prática e são representativos de muitas aplicações do mundo real. Os principais problemas combinados apresentados na literatura por BODIN et al. (1983) estão apresentados na TABELA 5.7.

Para a solução dos problemas de roteirização e programação, encontram-se na literatura diversas estratégias e métodos de solução. BODIN \& GOLDEN (1981) classificaram estas estratégias de solução para os problemas de roteirização e programação em sete categorias, como é descrito na TABELA 5.8 .

ASSAD (1988) identificou três direções para o desenvolvimento de método de solução para problemas com restrições mais complexas e realistas: (1) adaptar ou desenvolver alguma heurística conhecida e consagrada, (2) uso de técnicas de programação ma-

TABELA 5.8 - Estratégias de solução para os problemas de roteirização e programação

\begin{tabular}{|c|c|}
\hline Estratégia & Descrição \\
\hline $\begin{array}{l}\text { Agrupa primeiro - roteiriza } \\
\text { depois }\end{array}$ & $\begin{array}{l}\text { Procedimento este que agrupam a demanda dos nós e/ou arcos primeiro } \\
\text { e então desenvolvem rotas econômicas sobre cada agrupamento como } \\
\text { segundo passo. }\end{array}$ \\
\hline $\begin{array}{l}\text { Roteiriza primeiro - agrupa } \\
\text { depois }\end{array}$ & $\begin{array}{l}\text { Primeiro uma grande rota ou ciclo, geralmente infactível, é criada, na qual } \\
\text { incluem-se todas as entidades de demanda nos nós e/ou arcos. Depois, a } \\
\text { grande rota é particionada em rotas menores, mas factíveis.. }\end{array}$ \\
\hline Economias ou inserções & $\begin{array}{l}\text { Procedimento que constroem uma solução de tal maneira que a cada } \\
\text { passo do procedimento uma configuração corrente, que é possivelmente } \\
\text { infactível, é comparada com uma configuração alternativa que pode tam- } \\
\text { bém ser infactível.A configuração alternativa é aquela que produz a maior } \\
\text { economia termos de alguma função critério, tal como o custo total, ou que } \\
\text { insira de forma menos custosa entidades de demanda ainda não inseri- } \\
\text { das na rota(s) em construção. O processo é finalmente concluído com } \\
\text { uma configuração factível. }\end{array}$ \\
\hline Melhoria / troca & $\begin{array}{l}\text { Procedimento heurístico que, em cada etapa, uma solução factível é alte- } \\
\text { rada, resultando e outra solução factível com o custo total reduzido. Este } \\
\text { procedimento continua até que não sejam mais possíveis reduções adi- } \\
\text { cionais no custo }\end{array}$ \\
\hline Programação matemática & $\begin{array}{l}\text { Esta abordagem requer algoritmos que sejam diretamente baseadas em } \\
\text { formulação matemática do problema em questão. Esta classe de aborda- } \\
\text { gem engloba as estratégias e solução do PCV e suas variações, na maio- } \\
\text { ria programação inteira. }\end{array}$ \\
\hline Otimização interativa & $\begin{array}{l}\text { Este procedimento tem propósito geral na qual um alto grau de interação } \\
\text { humana é incorporado no processo de solução do problema. A idéia está } \\
\text { na experiência do tomador de decisões que tem a capacidade de fixar os } \\
\text { parâmetros e injetar correções subjetivas no modelo baseadas no conhe- } \\
\text { cimento e intuição. }\end{array}$ \\
\hline Métodos exatos & $\begin{array}{l}\text { Procedimentos para problemas de roteirização de veículos que incluem } \\
\text { técnicas especializadas de branch and bound, programação interia mista } \\
\text { e programação linear inteira. }\end{array}$ \\
\hline
\end{tabular}

Fonte: Adaptado de BODIN \& GOLDEN (1981) 
temática e, (3) heurísticas seqüenciais ou de decomposição. Por exemplo, o método de solução dos problemas de roterização no software TransCAD foi desenvolvido com a adaptação do método de economias de CLARKE \& WRIGHT (1964) ${ }^{6}$, incorporando novas restrições e condicionantes de YELLOW (1970) $)^{7}$ e SOLOMON (1986) ${ }^{8}$ (CALIPER, 1996a).

O método de solução é semelhante aos encontrados para problemas de localização de facilidades. A diferença está na aplicação do método para modelos específicos de cada tipo de problema, ou de localização, ou roteirização e programação. Segundo CUNHA (1997), os métodos de solução para os problemas de roteirização e programação podem ser classificados em: (1) métodos exatos, os quais possibilitam a obtenção da solução ótima; (2) métodos heurísticos, que geram soluções aproximadas, porém chegam a solução de modo mais rápido; (3) métodos emergentes, que reúnem as técnicas mais recentes e avançadas, não tradicionais, baseadas em sistemas especialistas, ou métodos de busca ou iterativos (como por exemplo algoritmos genéticos e busca tabu).

\footnotetext{
${ }^{6}$ CLARKE, G.; WRIGHT, J. W. (1964). Scheduling of vehicles from central depot to a number of delivery points. Operations Research, v.12, n.4, p.568-581.

${ }^{7}$ YELLOW, P. (1970). A computational modification to the saving method of vehicle scheduling. Op. Res. Quar., v.21, p.281-283.

${ }^{8}$ SOLOMON, M. M. (1986). On the worst-case performance of some heuristics for the vehicle routing and scheduling problem with time windows constraints. Networks, v.16, p.161-174.
} 
6. SIG

SISTEMA DE INFORMAÇÕES GEOGRÁFICAS

O Sistema de Informações Geográficas (SIG) foi utilizado na análise dos problemas logísticos deste trabalho, devido a sua facilidade para manipular informações espaciais quase que instantaneamente. A ferramenta SIG utilizada nesta pesquisa foi o software TransCAD, que possui rotinas logísticas de localização de facilidades e roteirização e programação de frota. Neste capítulo, os conceitos de SIG e as aplicações são apresentados.

\subsection{Definições}

As definições para o Sistema de Informações Geográficas (SIG) diferem entre si, na inclusão ou não de algum componente, na característica e/ou aplicação dentro de um contexto. Uma síntese das definições para os SIG, encontrada na literatura, é dada por MEULEN (1992) apud FONTES (2001), que os considera como sendo "um sistema computacional que combina o gerenciamento, a análise geográfica-estatística e a apresentação cartográfica de um banco de dados georeferenciados".

O SIG é abordado geralmente na literatura, enfocando seus conceitos no sistema computacional. Porém, partindo do princípio de que um sistema para ser implementado, não basta apenas um software que trabalhe com um banco de dados e mapas digitalizados, é importante que exista recurso humano qualificado, um objetivo no seu uso e interação com outras áreas dentro da organização. Portanto, NAZÁRIO (1998) define SIG de uma forma mais ampla, como "uma coleção de software, hardware, dados geográficos e profissionais para facilitar o processo de tomada de decisão que envolve o uso de informações georeferenciadas na organização". Isto é, o SIG para

${ }^{9}$ MEULEN, G. G. (1992). Geographical information and decision support system. Comput., Enviro. and Urban Systems, v.16, p.187-193. 
ser completo necessita pelo menos ser constituído por cinco componentes: software, hardware, dados geográficos, profissionais qualificados e o contexto organizacional.

\subsection{Dados em um SIG}

O uso de SIG no Brasil tem como limitante, de acordo com NAZÁRIO (1998), a escassez de uma base de dados confiável e atualizado, tanto em relação a dados espaciais (mapas digitalizados) quanto a dados demográficos e sócio-econômicos. Falta por parte da administração pública uma política que incentive e estabeleça regras e responsabilidades, no que diz respeito à preparação e disponibilização de um banco de dados.

A qualidade das informações de origem é extremamente importante. A confiabilidade das decisões tomadas, a partir das análises realizadas no SIG, é limitada pela acurácia do banco de dados. Assim, conforme ROMA \& SOUZA (2001), não se deve economizar esforços na fase de aquisição de dados.

Segundo ROMA \& SOUZA (2001), em um ambiente SIG, pode se identificar duas classes de dados: os espaciais e os não-especiais (atributos). Os dados espaciais são a representação de objetos em forma de pontos, linhas e áreas. Os atributos são necessários para completar com informações não-espaciais cada objeto espacial e, normalmente são armazenados na forma de tabelas com informações alfanuméricas quantitativas e qualitativas. Por exemplo, um ponto pode representar a intersecção (nó) de duas vias (arcos), e os atributos são informações como a presença ou não de uma fábrica, cliente ou depósito neste ponto. E no caso de uma fábrica, atributos como a quantidade produzida, a frota de veículos, o número de funcionários, custos, entre outros, podem ser associados.

Os dados espaciais possuem duas estruturas de representação: o raster e o vetorial; como representado na FIGURA 6.1. Segundo FONTES (2001), na representação matricial (raster), o objeto espacial se encontra em formato matricial, organizado como uma malha de células, pixels (abreviatura para elementos de imagem), que associada aos valores numéricos podem representar algum aspecto do ambiente da área em estudo. Nesta forma de representação os pontos passam a ser os pixels, as linhas são 
Forma analógica (mapa em papel)
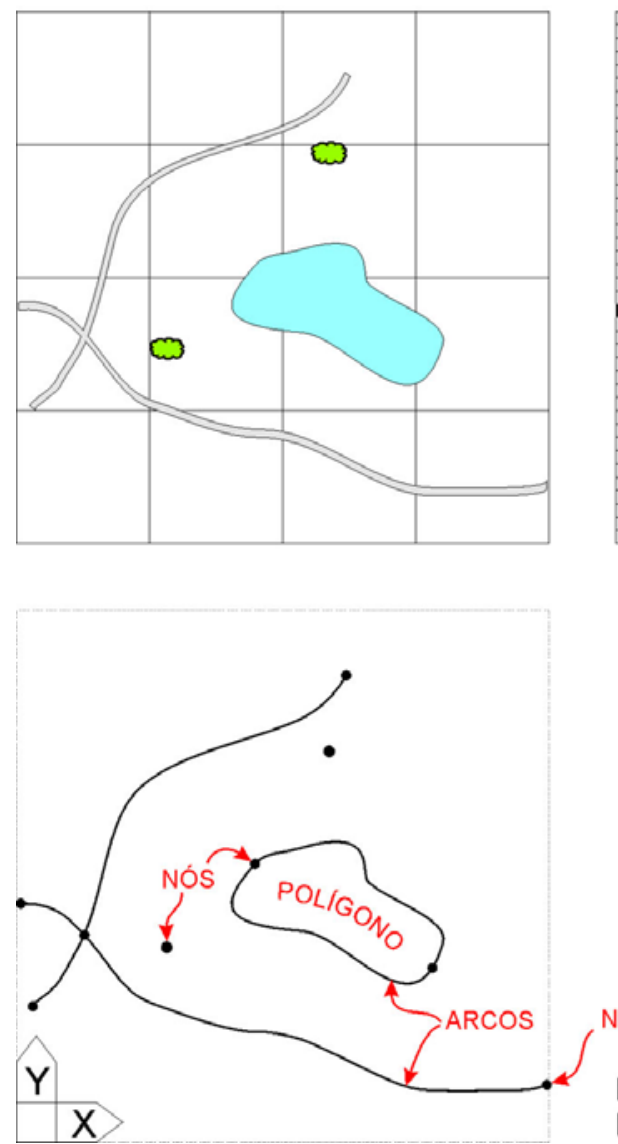

Forma digital

Representação matricial (raster)

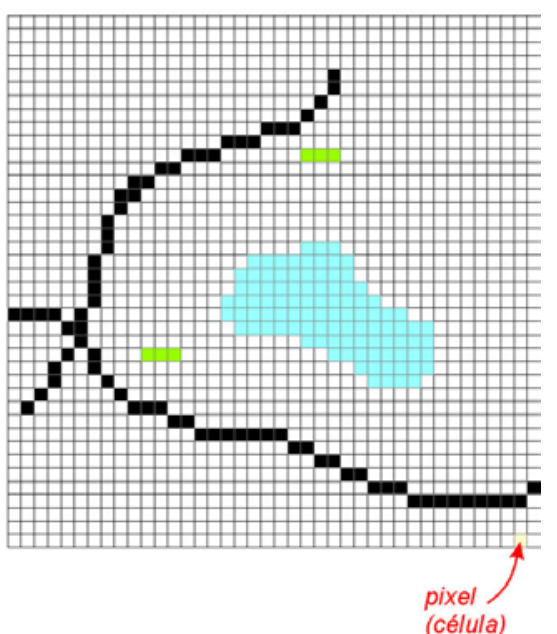

FIGURA 6.1 - Objetos espaciais em representação vetorial e matricial uma sequência de pixels adjacentes e enfileiradas, com orientação relacionada à forma, e as áreas são representadas por aglomerados de pixels adjacentes (EASTMAN, 1995). A dimensão da célula, pixel, define a precisão do processo (nível de resolução).

$\mathrm{Na}$ estrutura de representação vetorial (vector), os dados espaciais são expressos na forma vetorial, ou seja, a forma é definida graficamente através de nós (pontos), arcos (linhas definidas por segmentos de reta interligando pontos), e polígonos (áreas delimitadas por segmentos de reta). Os pontos possuem coordenadas ( $\mathrm{x}, \mathrm{y})$ correspondentes ao sistema de referência do mapa original (latitude, longitude; coordenadas UTM; etc).

O estudo das conexões entre objetos espaciais é chamado topologia. Segundo PEZZOTTI et al. (1994), toda a representação vetorial da forma dos objetos é constituída por três elementos topológicos básicos: nós, arcos e polígonos. As relações espa- 

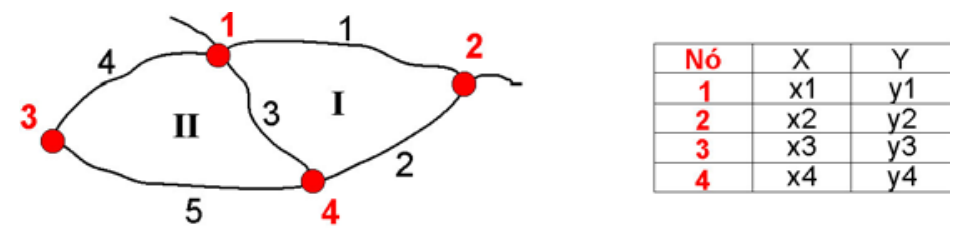

\begin{tabular}{|c|c|c|c|c}
\hline Arco & Nó inicial & Nó final & Polígono Direito & Polígono Esquerdo \\
\hline 1 & 1 & 2 & I & 0 \\
\hline 2 & 2 & 4 & I & 0 \\
\hline 3 & 1 & 4 & II & I \\
\hline 4 & 1 & 3 & 0 & II \\
\hline 5 & 3 & 4 & 0 & II \\
\hline
\end{tabular}

Fonte: Adaptado de PEZZOTTI et al. (1994)

FIGURA 6.2 - Representação topológica básica: nós, arcos e polígonos

ciais entre estes elementos são freqüentemente armazenados na forma de tabelas, como ilustrado na FIGURA 6.2.

No SIG existem certas atividades técnicas essenciais para trabalhar com os dados. ROMA \& SOUZA (2001) consideram estas atividades como sendo os elementos funcionais, e estão descritos a seguir:

- Aquisição de dados: identificação e coleta dos dados requeridos para a aplicação no sistema. Segundo SILVA (1998), quando os dados necessitam ser coletados em campo, diz-se que ele é obtido de fonte primária. No caso de os dados já existirem, eles são consideradas de fonte secundária derivada de fonte primária;

- Pré-processamento: tratamento das informações para que possam ser incorporadas ao SIG. Duas das principais tarefas incluem a conversão para o formato adequado ao SIG e identificação da locação dos objetos nos dados originais de forma sistemática;

- Gerenciamento de dados: contém as funções de gerenciamento que governam a criação e o acesso à base de dados. Estas funções fornecem métodos consistentes para entrada, atualização, descarte e recuperação das informações;

- Tratamento e análise: contém as operações analíticas que trabalham com o conteúdo da base de dados, visando derivar novas informações;

- Geração de produtos: atividade que fornece os resultados que podem ser apresentados na forma de relatórios estatísticos, mapas temáticos e gráficos de várias espécies. 


\subsection{A ferramenta computacional no SIG}

Como abordado anteriormente, o Sistema de Informações Geográficas é confundido com a ferramenta computacional. Aliás, nem mesmo se referencia ao hardware, atendo-se ao software. Quando se fala nas características de um SIG, comumente são apresentadas as funções de um software como sendo do sistema, que na definição mais ampla de NAZÁRIO (1998), a parcela computacional seria apenas um dos componentes. Como o sistema computacional é o cerne de um SIG e, de acordo com DINIZ (2000), ele nasceu e se desenvolveu com a evolução dos computadores, é compreensível que o enfoque seja dado a ele. A seguir, os conceitos encontrados na literatura como sendo de SIG, mas que na verdade se concentram na ferramenta computacional, são apresentadas. Nas seções seguintes, o termo ferramenta SIG é utilizado para referenciar o componente computacional do SIG.

\subsubsection{Características}

Segundo GIS (2001), o portal de informação da internet sobre Sistema de Informações Geográficas, criado pela ESRI (Environmental Systems Research Institute), a ferramenta computacional de SIG combina layers (camadas) de informações sobre um local para proporcionar a sua melhor compreensão (FIGURA 6.3). Como estes layers

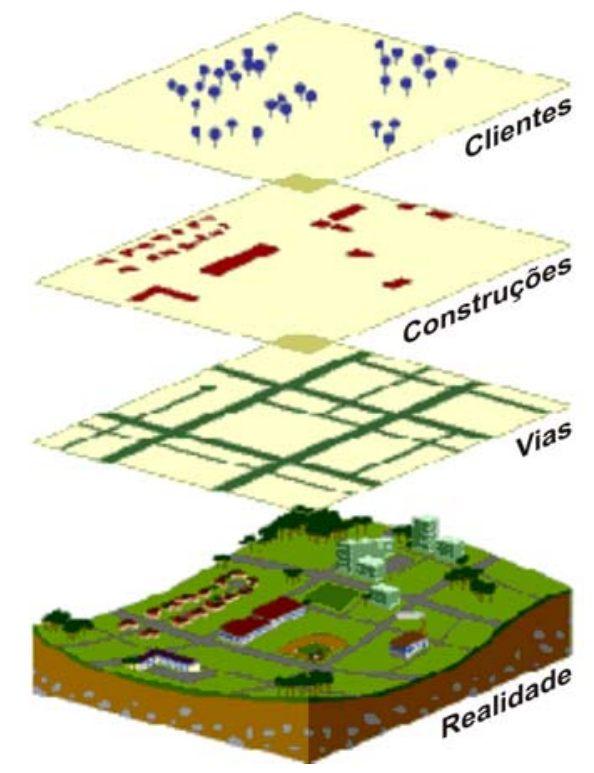

Fonte: GIS (2001)

FIGURA 6.3 - Dados armazenados em layers (camadas) no SIG 
podem ser combinados, depende do propósito: encontrar um novo local para alguma instalação, análise de danos ambientais, roteirização de veículos, entre outros.

Conforme TABACZENSKI (1995), as características encontradas em uma ferramenta SIG são: "potencial de integração com o usuário, capacidade de cruzamento de informações geográficas (entre layers), velocidade de operação, capacidade de simulações e versatilidade de apresentação de informações espaciais".

De um modo mais amplo, baseado em conceitos encontradas na literatura, DAVIS \& CÂMARA (2001) indicam as principais características como sendo:

- "inserir e integrar numa única base de dados, informações espaciais provenientes de dados cartográficos, dados censitários e cadastro urbano e rural, imagens de satélite, redes e modelos numéricos de terrenos";

- "oferecer mecanismos para combinar as várias informações, através de algoritmos de manipulação e análise, bem como para consultar, recuperar, visualizar e plotar o conteúdo da base de dados georeferenciados".

Segundo, os mesmos autores, existem funções que são características em qualquer software de SIG. E elas estão apresentadas na TABELA 6.1. De acordo com estes autores, todas estas funções podem ser agrupadas em categorias, para facilitar a comparação entre as diferentes ferramentas. As categorias básicas são: entrada de dados, gerenciamento e/ou recuperação de informação, manipulação e análise e, exibição e/ou produção de saídas. Estas classes são parte dos elementos funcionais apresentados por ROMA \& SOUZA (2001), discutido anteriormente. Estes últimos autores dividem as categorias de acordo com as atividades técnicas que envolvem o processamento dos dados, enquanto, DAVIS \& CÂMARA (2001), classificam em função da ferramenta computacional.

\subsubsection{Softwares: pacotes comerciais}

Segundo NAZÁRIO (1998), no Brasil existe uma grande variedade de softwares de SIG disponíveis. Eles vão desde os desktop mapping até softwares que possuem algoritmos que são capazes de executar tarefas, tais como: roteirização, estudo de localização, obtenção de matriz de distâncias, entre outras. 
TABELA 6.1 - Funções características de uma ferramenta SIG

\section{Funções}

1. Representar graficamente informações de natureza espacial, associando a estes gráficos informações alfanuméricas tradicionais. Representar informações gráficas sob a forma de vetores (pontos, linhas e polígonos) e/ou imagens digitais (matrizes de pixels)

2. Recuperar informações com base em critérios alfanuméricos, à semelhança de um sistema de gerenciamento de bancos de dados tradicional, e com base em relações espaciais topológicas, tais como continência, adjacência e interceptação

3. Realizar operações de aritmética de polígonos, tais como união, interseção e diferença. Gerar polígonos paralelos (buffers) ao redor de elementos ponto, linha e polígono

4. Limitar o acesso e controlar a entrada de dados através de um modelo de dados, previamente construído

5. Oferecer recursos para a visualização dos dados geográficos na tela do computador, utilizando para isto uma variedade de cores

6. Interagir com o usuário através de uma interface amigável, geralmente gráfica

7. Recuperar de forma ágil as informações geográficas, com o uso de algoritmos de indexação espacial

8. Possibilitar a importação e exportação de dados de/para outros sistemas semelhantes, ou para outros softwares gráficos

9. Oferecer recursos para a entrada e manutenção de dados, utilizando equipamentos como mouse, mesa digitalizadora e scanner

10. Oferecer recursos para a composição de saídas e geração de resultados sob a forma de mapas, gráficos e tabelas, para uma variedade de dispositivos, como impressoras e plotters

11. Oferecer recursos para o desenvolvimento de aplicativos específicos, de acordo com as necessidades do usuário, utilizando para isto alguma linguagem de programação, inclusive possibilitando a customização da interface do SIG com o usuário

Fonte: Adaptado de DAVIS \& CÂMARA (2001)

O software TransCAD da Caliper tem funções de um SIG onde estão integradas várias rotinas de análises logísticas de transportes. Segundo CALIPER (1996a), o TransCAD possui modelos que resolvem problemas de roteirização de veículos, roteirização em arcos, fluxo em redes, particionamento e agrupamento e localização de facilidades.

Segundo PELIZARO (2000), em sua pesquisa para avaliação dos softwares de roteirização, o TransCAD demonstrou ser uma ferramenta robusta, apresentando soluções cerca de $20 \%$ superior as melhores soluções encontradas na literatura revisada. Já em outro trabalho, ROSE (2001) comparou três ferramentas SIG com aplicações específicas aos transportes, conhecidos como SIG-T: UfosNet v.3.5.1, ArcView v.3.1 e TransCAD v.3.2. Segundo a autora, todos os três atenderam as funções para serem considerados um software SIG. Mas, para ser um SIG-T, o ArcView não possuía todas as ferramentas necessárias. Nestas avaliações, segundo critérios da autora, a quantidade 
TABELA 6.2 - Critérios para seleção de ferramentas SIG

\section{Recursos desejáveis dos softwares}

1. Possibilidades de customização da interface com o usuário (redefinição da estrutura de menus e diálogos; inclusão de funções desenvolvidas pelo usuário)

2. Flexibilidade da modelagem de dados

3. Existência ou não de linguagem de programação para desenvolvimento de aplicativos; complexidade e completeza da linguagem de programação

4. Existência ou não de versão em português; disponibilidade de documentação e/ou material de treinamento em português

5. Armazenamento dos dados em base de dados geográfica contínua ou necessidade de fracionamento em mapas

6. Existência ou não de restrições e controles de integridade na conexão gráfico-alfa

7. Existência ou não de sistemas de indexação espacial, para recuperação rápida de informações gráficas; tipo de sistema de indexação espacial

8. Disponibilidade de aplicações prontas, desenvolvidas por terceiros, na área de interesse do projeto

9. Capacidades de importação e exportação de dados

10. Possibilidades de operação em redes heterogêneas de equipamentos (utilização simultânea de equipamentos de diversos fabricantes diferentes)

11. Capacidades de produção de saídas: mapas, cartas, mapas temáticos, gráficos, relatórios, etc.

12. Recursos para conversão de dados

13. Capacidades de operação simultânea por diversos usuários

14. Aderência a padrões de fato ou de direito, principalmente nas áreas de bancos de dados e intercâmbio de informações

15. Recursos de gerenciamento de backups e recuperação de dados

16. Existência ou não de linguagem de consulta à base gráfica/alfanumérica

17. Recursos de processamento de polígonos (operações de união, interseção, etc.)

18. Recursos de detecção e correção de falhas nos dados gráficos (edge-matching, eliminação de undershoots e overshoots, etc.)

19. Variedade de tipos de dispositivos de saída (plotters e impressoras) e de entrada (scanners, mesas digitalizadoras, etc.)

20. Confiabilidade comercial e técnica do representante e sua equipe de suporte.

Fonte: Adaptado de DAVIS \& CÂMARA (2001)

de rotinas avançadas de SIG e específicas de transportes era superior no TransCAD se comparado aos demais programas.

Devido a grande diversidade de programas computacionais disponíveis, DAVIS \& CÂMARA (2001) recomendam analisar certas características deste pacote, conforme cada interesse, antes de alguma aquisição. Os recursos dos softwares devem ser investigados e testados para examinar a sua adequação às necessidades do projeto. Os critérios recomendados pelos autores estão descritos na TABELA 6.2. 
A TABELA 6.3 apresenta as ferramentas SIG comuns e disponíveis no mercado. Nesta tabela, DAVIS \& CÂMARA (2001) deixaram intencionalmente de fora os sistemas CAD e aqueles de sensoriamento remoto. Todos os softwares relacionados possuem condições para interligação de dados gráficos com dados alfanuméricos, armazenados em base de dados próprios ou não.

TABELA 6.3 - Softwares de SIG disponíveis no mercado

\begin{tabular}{|c|c|c|c|c|}
\hline $\begin{array}{l}\text { SIG } \\
\text { (Fabricante) }\end{array}$ & $\begin{array}{l}\text { Estrutura } \\
\text { de dados }\end{array}$ & $\begin{array}{l}\text { Banco } \\
\text { de Dados }\end{array}$ & $\begin{array}{l}\text { Sistema } \\
\text { operacional }\end{array}$ & Observações \\
\hline $\begin{array}{l}\text { APISIC } \\
\text { (APIC Systems) }\end{array}$ & $\begin{array}{l}\text { Vetorial, } \\
\text { Matricial }\end{array}$ & $\begin{array}{l}\text { Orientado a } \\
\text { objeto }\end{array}$ & $\begin{array}{l}\text { UNIX, } \\
\text { Windows }\end{array}$ & $\begin{array}{l}\text { Produzido na França, tem } \\
\text { muitas instalações na Euro- } \\
\text { pa }\end{array}$ \\
\hline $\begin{array}{l}\text { ARC/INFO } \\
(\text { ESRI) }\end{array}$ & $\begin{array}{l}\text { Vetorial } \\
\text { Topológica, } \\
\text { Matricial }\end{array}$ & Relacional & $\begin{array}{l}\text { UNIX, } \\
\text { Windows }\end{array}$ & $\begin{array}{l}\text { Produtos complementares } \\
\text { incluem o ArcCAD (apoiado } \\
\text { em AutoCAD) e o ArcView } \\
\text { (ferramenta de consulta) }\end{array}$ \\
\hline $\begin{array}{l}\text { Autodesk World } \\
\text { (AutoDesk) }\end{array}$ & Vetorial & Relacional & Windows & $\begin{array}{l}\text { Capaz de ler diretamente } \\
\text { arquivos de diversos SIG }\end{array}$ \\
\hline $\begin{array}{l}\text { DBMapa } \\
\text { (MaxiData) }\end{array}$ & Vetorial & xBASE & Windows & Apoiado no MaxiCAD \\
\hline $\begin{array}{l}\text { Genasys } \\
\text { (Genasys) }\end{array}$ & Matricial vetorial & Relacional & $\begin{array}{l}\text { UNIX, } \\
\text { Windows }\end{array}$ & - \\
\hline $\begin{array}{l}\text { GIS Plus } \\
\text { (Caliper) }\end{array}$ & Vetorial & Relacional & Windows & $\begin{array}{l}\text { O TransCAD, especializado } \\
\text { em transportes, é baseado } \\
\text { no GIS Plus }\end{array}$ \\
\hline $\begin{array}{l}\text { IDRISI } \\
\text { (Clark University) }\end{array}$ & Matricial & Proprietário & Windows & $\begin{array}{l}\text { Muito voltado para aplica- } \\
\text { ções ambientais }\end{array}$ \\
\hline $\begin{array}{l}\text { Maplnfo } \\
\text { (Maplnfo) }\end{array}$ & Vetorial & $\begin{array}{l}\text { Proprietário, } \\
\text { xBASE }\end{array}$ & Windows & $\begin{array}{l}\text { Principalmente utilizado } \\
\text { como ferramenta de Desk- } \\
\text { top Mapping }\end{array}$ \\
\hline $\begin{array}{l}\text { Maptitude } \\
\text { (Caliper) }\end{array}$ & Matricial vetorial & Relacional & Windows & $\begin{array}{l}\text { Mais usado como Desktop } \\
\text { Mapping }\end{array}$ \\
\hline $\begin{array}{l}\text { MGE } \\
\text { (Intergraph) }\end{array}$ & Vetorial matricial & Relacional & $\begin{array}{l}\text { UNIX, } \\
\text { Windows }\end{array}$ & $\begin{array}{l}\text { Baseado no sistema de } \\
\text { CAD MicroStation }\end{array}$ \\
\hline $\begin{array}{l}\text { SPRING } \\
\text { (INPE) }\end{array}$ & $\begin{array}{l}\text { Vetorial, } \\
\text { Matricial }\end{array}$ & Relacional & $\begin{array}{l}\text { UNIX, } \\
\text { Windows }\end{array}$ & $\begin{array}{l}\text { Permite uma integração en- } \\
\text { tre vetores e imagens }\end{array}$ \\
\hline $\begin{array}{l}\text { Vision*GIS } \\
\text { (System House) }\end{array}$ & Vetorial matricial & Relacional & UNIX & $\begin{array}{l}\text { Pioneiros no armazenamen- } \\
\text { to de gráficos dentro do } \\
\text { banco de dados relacional }\end{array}$ \\
\hline
\end{tabular}

Fonte: Adaptado de DAVIS \& CÂMARA (2001)

\subsection{Aplicabilidade do SIG}

Os SIG surgiram nos anos 60 , quando pesquisadores e estudantes universitários buscavam representar a geografia da Terra, utilizando uma base de dados geográfica, e 
depois exibí-la em um terminal de saída de um computador: monitor, impressora (KORTE, 1997). Segundo FONTES (2001), como evolução de sua utilização, observou-se nos anos 70 sua aplicação como instrumento de gerenciamento de informações geográficas e, na última década, devido à necessidade de manipular um maior volume de dados em uma variedade de situações, vem-se desenvolvendo como um Sistema de Apoio à Decisão (SAD).

Dentro deste contexto e da logística, o SIG tem diversas aplicações. NAZÁRIO (1998) destaca a análise de sistemas logísticos e o uso em Sistemas de Apoio à Decisão Espacial (SADE). O uso de SAD tem aumentado significativamente na logística. Estes sistemas podem ser definidos como de apoio à decisão logística, utilizando dados espaciais, e são caracterizados pela conjunção de sistemas especialistas com ferramentas SIG. Os softwares de localização e de roteirização estão dentro desta classe.

No processo de planejamento, a aplicação do SIG pode ser localizada como sendo no nível de decisão estratégica como observado em KLISKEY (1995), observe a FIGURA

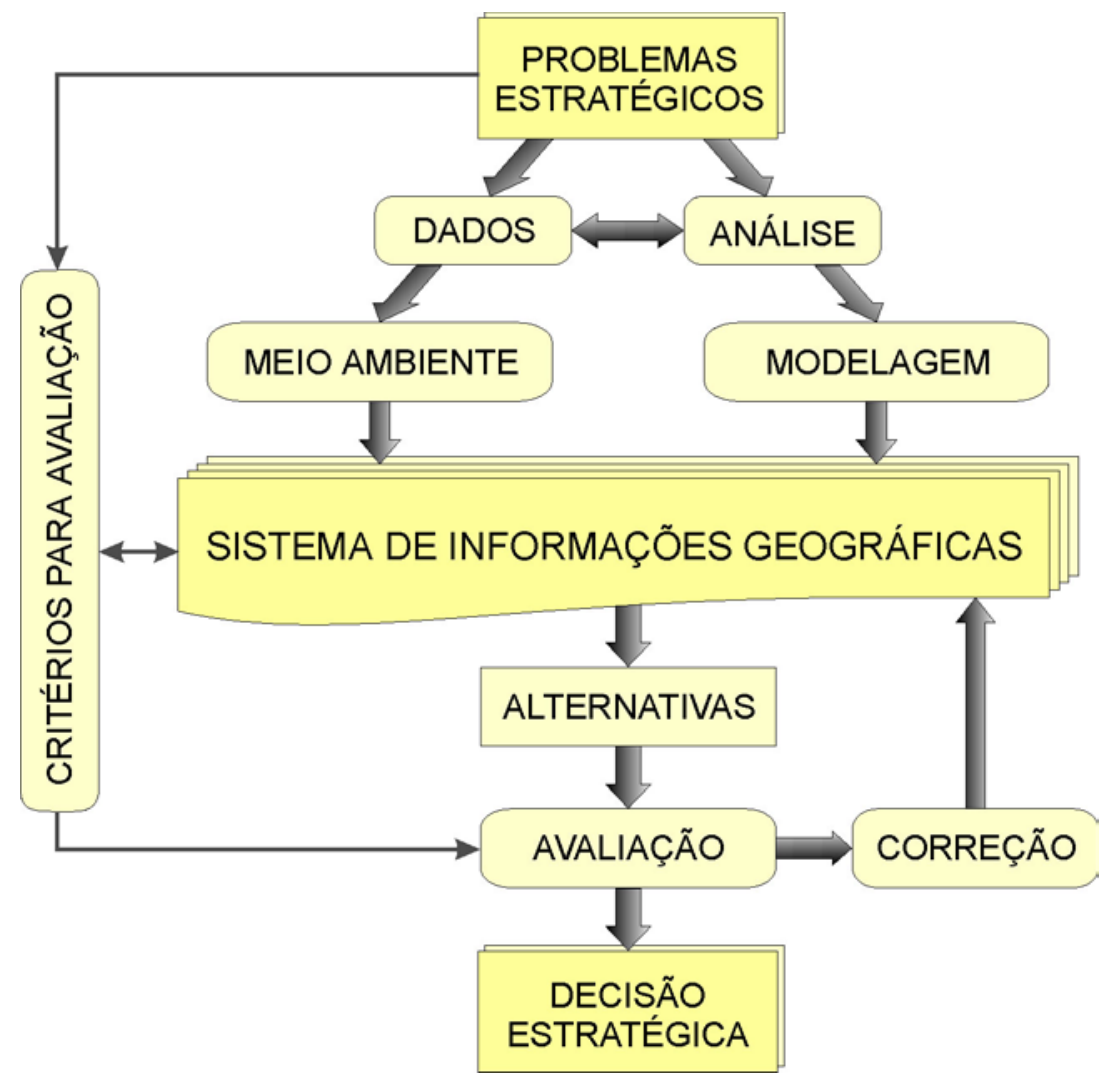

Fonte: Adaptado de KLISKEY (1995)

FIGURA 6.4 - SIG no processo de decisão no planejamento estratégico 
6.4. O autor também enfatiza que o SIG tem a capacidade de resolver questões ambientais, visto a possibilidade de projetar cenários do meio ambiente e suas mudanças, em função da facilidade do sistema de manipular dados.

Segundo SILVA (1998), o SIG é capaz de gerar informações que permitem chegar em soluções de modo rápido e preciso para vários problemas, auxiliando no processo de tomada de decisões em diversos campos de conhecimento, tais como: geologia, hidrologia, agricultura, engenharia civil, a de transportes, urbana, de minas, etc.

Logo, o SIG é um instrumento capaz de auxiliar na tomada de decisões no nível de planejamento estratégico, e dentro de um contexto da solução de problemas ambientais, através da geração de informações instantâneas, para a elaboração e escolha de alternativas. Baseado nestas possibilidades, o software TransCAD é utilizado nesta pesquisa. Pois, ele é uma poderosa ferramenta SIG voltada a transportes, um SIG-T, que possui as rotinas logísticas de localização de facilidades, roteirização e programação de veículos. 


\section{MATERIAIS E MÉTODO}

Neste capítulo é exposto o método desenvolvido para atingir o objetivo de avaliar os sistemas consorciados de destinação de RSU em aterros sanitários, através de análises logísticas com o auxílio de uma ferramenta SIG.

\subsection{Sobre o método}

O método aplicado nesta pesquisa servirá como base de apoio à decisão na análise e consolidação de sistemas consorciados para destinação de RSU. A pesquisa tem o enfoque no planejamento logístico, no nível estratégico, para auxiliar as decisões de localização de aterros e de transporte dos RSU. É importante destacar que o método empregado é apenas uma das ações necessárias, dentro de uma diversidade de atividades para alcançar o gerenciamento integrado de RSU.

Nesta pesquisa, parte do trabalho foi desenvolvida dentro de um ambiente SIG. O software que foi utilizado como ferramenta foi o SIG-T TransCAD da Caliper Corporation, versão 3.2. Este software específico para atividades de transporte possui, além das funções básicas de uma ferramenta SIG, heurísticas específicas para solucionar os problemas de roteirização e programação de frota, bem como os de localização de instalações.

A manipulação de alguns dados necessários na importação para o TransCAD, dimensionamento de fases do processo, bem como a análise de custos, foram realizados com o auxílio de planilhas do Microsoft Excel 2000.

O fluxograma do método de trabalho é representado na FIGURA 7.1. Ele foi desenvolvido dentro de conceitos apresentados na revisão bibliográfica. Nesta figura está representado desde o reconhecimento do problema, até a avaliação final do sistema 


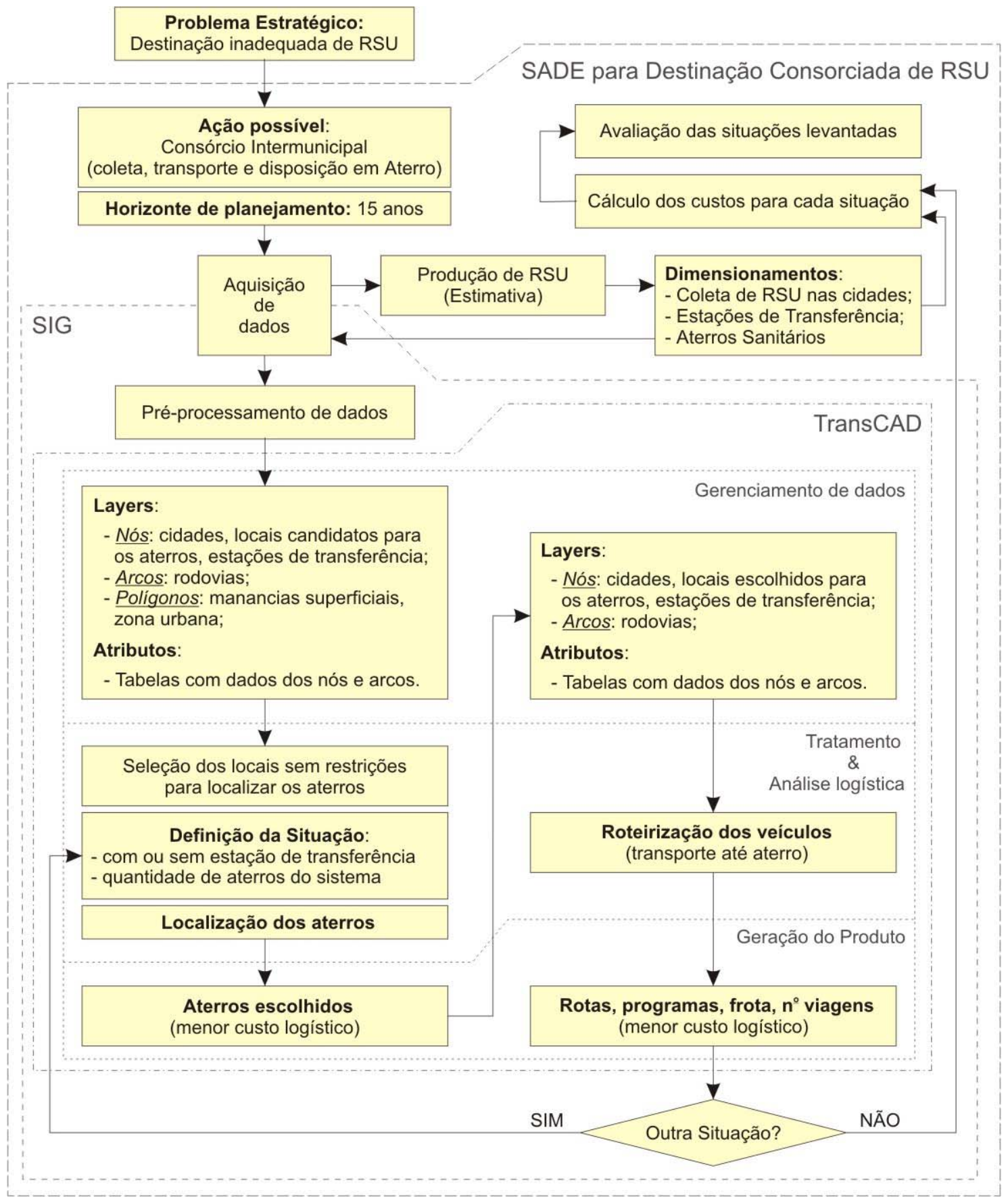

FIGURA 7.1 - Fluxograma do método

escolhido para resolvê-lo. Nas fases intermediárias, têm a aquisição de dados, os dimensionamentos dos processos de coleta, dos aterros e das estações de transferência (ETs), as análises logísticas com o TransCAD e o cálculo dos custos considerados.

Os resultados do método criado são os valores de custos de diversas configurações elaboradas do sistema consorciado intermunicipal, que são avaliados para que as de- 
vidas decisões sobre o gerenciamento dos RSU possam ser tomadas. Para se alcançar os resultados, primeiro, é necessário definir o horizonte de planejamento, para direcionar a aquisição dos dados que caracterizam a área de estudo, neste período. Conforme o método, com as informações obtidas, faz-se o dimensionamento das componentes do sistema: aterros, ETs, coleta dos RSU; além de importar os dados georeferenciados para o software TransCAD. E dentro do ambiente SIG, se definem as diversas situações para o sistema, que serão analisadas através das rotinas logísticas de localização e roteirização do TransCAD. Na sequência, através dos resultados intermediários dos dimensionamentos e das análises no TransCAD, se faz os cálculos de custos das diversas situações elaboradas, para que finalmente se possa avaliar quantitativamente os sistemas consorciados.

Nos itens subseqüentes cada atividade do método é descrita com mais detalhe.

\subsection{Definições estratégicas}

Neste método, para a solução dos problemas de destinação inadequada dos RSU, foi previsto o sistema consorciado intermunicipal para o horizonte de 15 anos, ou seja, o planejamento é de caráter estratégico. As ações previstas envolvem o dimensionamento da coleta de RSU nas cidades, o transporte pós-coleta até o destino final e a disposição em aterros sanitários.

O dimensionamento da coleta foi estimado de modo teórico, pois as cidades de pequeno porte não possuem dados confiáveis, ou simplesmente não os têm. Assim, mesmo que simplificado, elaborou-se uma estratégia para o seu dimensionamento. Dentro do horizonte de 15 anos de planejamento, o dimensionamento da coleta foi realizado para cada intervalo de 5 anos.

O transporte pós-coleta é diferenciado de acordo com cada situação, isto é, pode existir o transporte com o veículo de coleta direto até o aterro ou até uma ET, de onde um veículo de transbordo, com maior capacidade, realiza a consolidação de carga e percorre o restante do trajeto até o aterro. O dimensionamento do transporte foi realizado através de análises logísticas no TransCAD. 
Como elemento intermediário que influi no custo de transporte, foi considerada a possibilidade de se ter ETs para consolidar o RSU, antes de transportá-lo até os aterros. As estações foram dimensionadas para serem de pequeno porte, e com silos de acúmulo de material para amortizar a variação da quantidade de RSU ao longo de uma semana.

Para a destinação do RSU, o aterro sanitário foi escolhido como solução adequada. Sendo que, para a capacidade de aterro de até 10t/dia de RSU, a solução escolhida foi a de aterro em vala e acima deste valor adotou-se o aterro convencional de superfície.

Os dimensionamentos foram realizados com auxílio de planilhas do Excel.

\subsection{Aquisição de dados}

Os dados fundamentais necessários neste método são aqueles relativos aos que caracterizam a área de estudo: os dados espaciais georeferenciados e informações gerais dos municípios.

\subsubsection{Dados georeferenciados}

Para utilização da ferramenta SIG, o TransCAD, nas análises logísticas de localização de aterros e roteirização de veículos, foi necessário adquirir dados espaciais na forma de mapas digitais com georeferenciamento da área de estudo.

O mapa adquirido para a pesquisa é do Departamento de Estradas de Rodagem do Estado de São Paulo (DER-SP), (SÃO PAULO, 2000b). Este mapa está em CD ROM, na forma de arquivo digital denominado mapa_rodoviário em formato ( ${ }^{*}$.dgn), gerado através do MicroStation na versão SE. O arquivo utilizado já se encontrava convertido no formato AutoCAD 2000 ( $\left.{ }^{*} . d w g\right)$, cuja cópia estava disponível no Departamento de Transportes da Escola de Engenharia de São Carlos da Universidade de São Paulo (EESC - USP), onde se desenvolveu a presente pesquisa. Detalhes sobre o arquivo do DER-SP estão no ANEXO B. 
Este mapa contém as localizações das cidades e as rodovias que as interligam, além dos limites da zona urbana das cidades, e a representação das manaciais superficiais (rios, lagos, córregos, etc). Estes dois últimos dados foram úteis para que a localização das instalações fosse mais realista. Isto é, os locais que se encontrassem dentro destas áreas foram excluídos, de forma que não ocorresse a localização de aterros em local impróprio.

\subsubsection{Dados gerais dos municípios}

\section{i) População}

Para se conseguir os valores de RSU produzidos nas cidades, foi indispensável obter os valores de população. Inicialmente foi necessário determinar a população residente na área urbana das cidades. A população residente nas cidades, para o ano de 2000 , foi obtida através de consulta à "Tabela 202 - População residente por sexo e situação" do IBGE (2000b).

Como as cidades do estudo de caso se localizavam em uma região de grande potencial turístico, foi necessário determinar também a população flutuante. Para se obter este dado, foi necessário fazer algumas suposições, pois não foi encontrado um banco de dados com estas informações. Assim, foi realizada uma pesquisa bibliográfica para encontrar um método para estimar estes valores. Dentro da literatura pesquisada, GODINHO (1988) sugere um método de cálculo da população flutuante, que se hospeda em domicílios particulares de uso ocasional, dado este que está contemplado no censo do IBGE. O domicílio de uso ocasional é "o domicílio particular permanente que na data de referência servia ocasionalmente de moradia, ou seja, usado para descanso de fins de semana, férias ou outro fim, mesmo que, na data de referência, seus ocupantes ocasionais estivessem presentes" (IBGE, 2000e). Para o caso dos domicílios coletivos (hotéis, pousadas, etc), GODINHO (1988) diz que é de fácil estimativa, pois bastaria somente o levantamento das vagas máximas disponíveis. E a população seria determinada pelo número de vagas nas hospedagens, mais o produto do número de domicílios ocasionais pela taxa de ocupação domiciliar do IBGE para cada localidade. 
Neste trabalho, para as cidades conhecidas pela sua qualidade turística, foi determinado o número de vagas em hospedagens, através de consulta por telefone e páginas oficiais das cidades na internet. Com este valor, estimou-se parte da população flutuante, considerando que cada vaga representasse uma pessoa. $E$, além disso, com base no número de domicílios de uso ocasional nas cidades, encontrado na "Tabela 1310 - Domicílios recenseados por espécie e situação do domicílio" (IBGE, 2000a), e a ocupação média dos domicílios da "Tabela 1311 - Número de domicílios e média de moradores em domicílios particulares ocupados" (IBGE, 2000a), calculou-se o restante da população flutuante. Na TABELA 7.1 apresenta-se o esquema da estimativa da população flutuante,e os itens considerados.

Determinada a população em um ano específico, a fase seguinte foi a de determinar a população ao longo do horizonte de planejamento de 15 anos: 2003 até 2017. Para isto, calculou-se a taxa de crescimento populacional. Como não existiam valores específicos desta taxa para as cidades do estudo de caso, utilizou-se como referência a taxa de crescimento populacional para o Estado de São Paulo. O IBGE (2000c) fornece as taxas de crescimento para as unidades da federação, somente até o ano de

TABELA 7.1 - Estimativa da População Flutuante - 2000

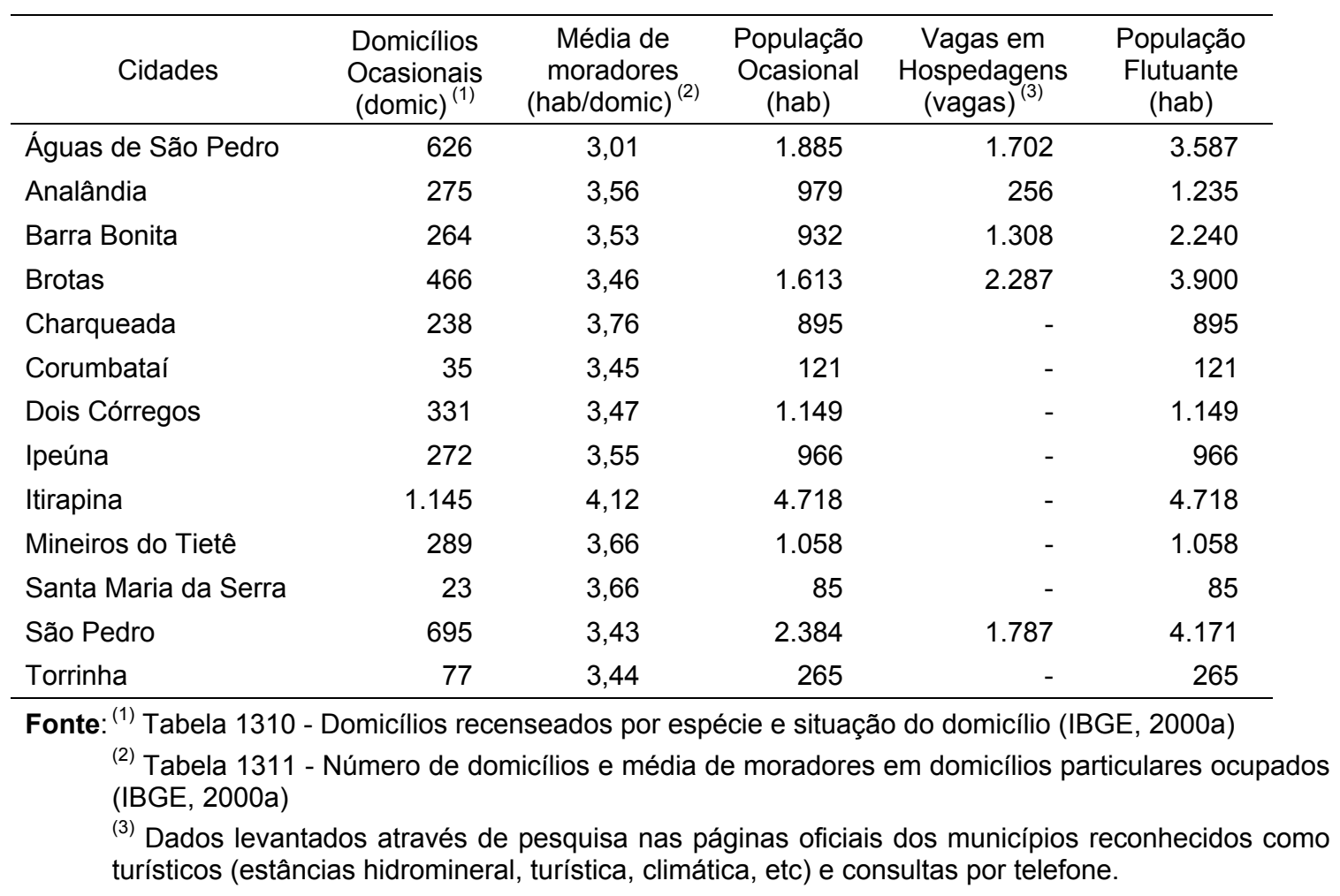


2010, sendo necessário estimar para os demais anos, para que se complete os 15 anos. Para isto, utilizou-se como referência, a taxa de crescimento do Brasil estimada pelo IBGE (2000d) até o ano de 2050. Analisando os dados do IBGE, verificou-se que a taxa para o Estado de São Paulo é sempre maior que a do Brasil, sendo que a diferença está caindo ao longo dos anos. Assim, realizou-se primeiro o estudo de tendência para a diferença entre as taxas de São Paulo e do Brasil até o ano de 2020. A partir disto, projetou-se a taxa que faltava para o Estado de São Paulo entre os anos de 2010 e 2020, somando-se na taxa existente para o Brasil, a tendência da diferença entre as taxas do Brasil e São Paulo, neste período. Este estudo está representado no gráfico da FIGURA 7.2.

\section{ii ) Produção de RSU}

Para dimensionar a coleta de RSU, os aterros e as ETs, é preciso saber as quantidades de RSU produzidas nas cidades. Para determinar estes dados, foram utilizados os valores de geração per capita indicados pelo Manual de Gerenciamento Integrado de Resíduos Sólidos elaborado pelo Instituto Brasileiro de Administração Municipal (IBAM), com o patrocínio da Secretaria Especial de Desenvolvimento Urbano da Presidência da República (SEDU/PR), (ZVEIBIL, 2001). Estes valores são apresentados

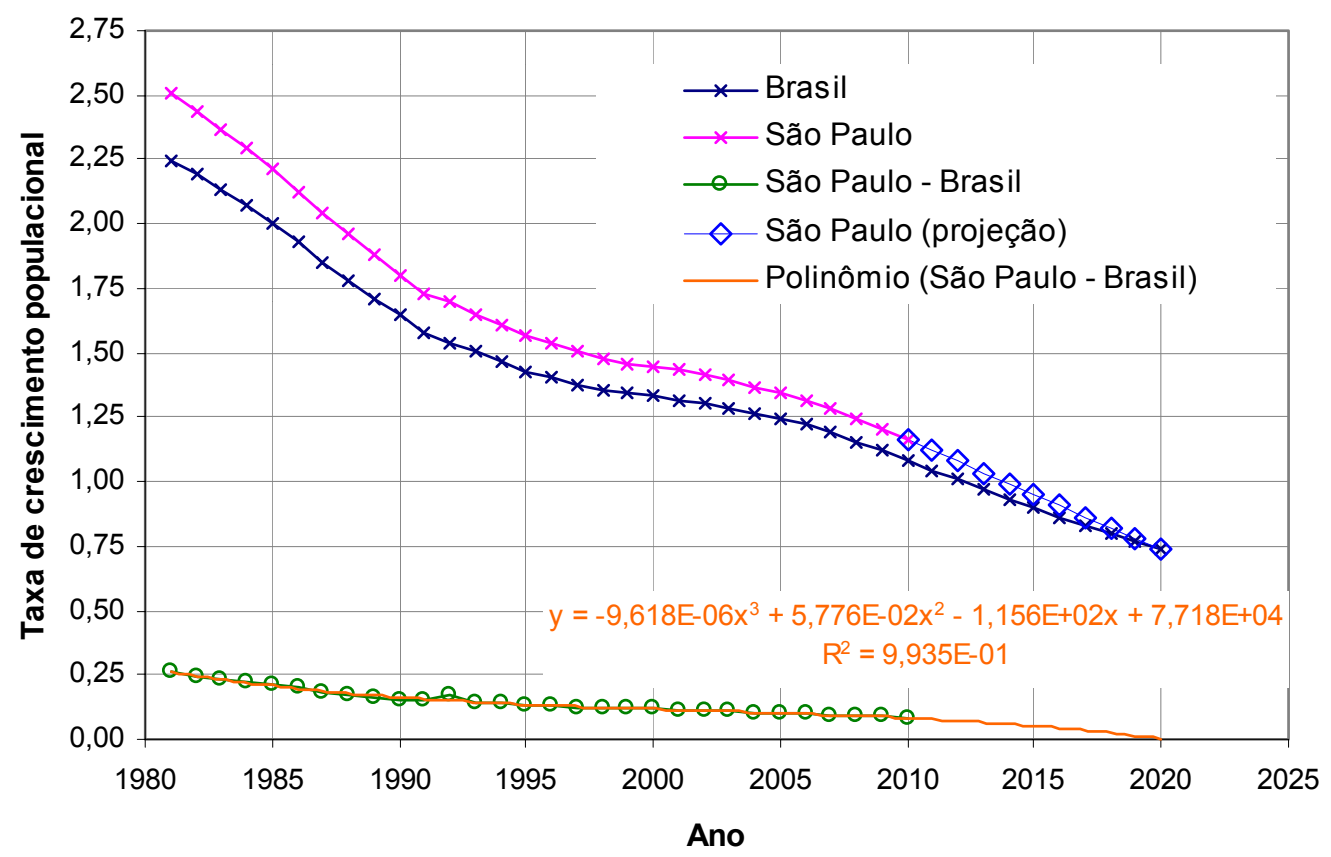

FIGURA 7.2 - Gráfico da Projeção da Taxa de Crescimento Populacional do Estado de São Paulo (2010 até 2020) 
TABELA 7.2 - Faixas mais utilizadas da geração per capita de Resíduos Sólidos

\begin{tabular}{ccc}
\hline Tamanho da Cidade & População urbana (hab) & $\begin{array}{c}\text { Geração per capita } \\
\text { (kg/hab/dia) }\end{array}$ \\
\hline Pequena & Até 30 mil & 0,50 \\
Média & De 30 mil a 500 mil & De 0,50 a 0,80 \\
Grande & De 500 mil a 5 milhões & De 0,80 a 1,00 \\
Megalópole & Acima de 5 milhões & Acima de 1,00 \\
\hline
\end{tabular}

Fonte: ZVEIBIL (2001)

na TABELA 7.2. O produto deste valor pela população determinada anteriormente, é igual a produção de RSU. No caso do cálculo do RSU produzido pela população flutuante, considerou-se um acréscimo de $70 \%$ para os dimensionamentos, como sugerido no manual do IBAM (ZVEIBIL, 2001). Segundo este manual, os turistas produzem esta porcentagem a mais de resíduos em relação aos moradores locais. Com base neste cálculo, chegou-se a capacidade produtiva diária de RSU da população residente e turística.

Como a geração de resíduos pela população flutuante ocorre em dias de feriado, finais de semana e férias, foi necessário determinar a ocorrência destes dias ao longo dos 15 anos, para calcular a produção de RSU da cidade, de forma realista. Assim, trabaIhou-se com 'semanas padrões' como são descritas na TABELA 7.3. A ocorrência destas semanas, ao longo dos anos deste estudo, pode ser observada no APÊNDICE A.

TABELA 7.3 - Semanas padrões utilizadas no cálculo da geração de RSU para os dimensionamentos ao longo dos 15 anos de planejamento

\begin{tabular}{|c|c|c|c|c|c|c|c|c|}
\hline $\begin{array}{l}\text { Semanas } \\
\text { Padrões }\end{array}$ & & & Dias c & a Sem & $a^{(1)}$ & & & Dias de feriado Oficial / férias \\
\hline A & DOM & SEG & TER & QUA & QUI & SEX & SÁB & Sem feriado ou férias \\
\hline B & DOM & SEG & TER & QUA & QUI & SEX & SÁB & Feriado Oficial na segunda \\
\hline C & DOM & SEG & TER & QUA & QUI & SEX & SÁB & Feriado Oficial na terça-feira ${ }^{(2)}$ \\
\hline D & DOM & SEG & TER & QUA & QUI & SEX & SÁB & Feriado Oficial na quarta-feira \\
\hline $\mathbf{E}$ & DOM & SEG & TER & QUA & QUI & SEX & SÁB & Feriado Oficial na quinta-feira ${ }^{(2)}$ \\
\hline $\mathbf{F}$ & DOM & SEG & TER & QUA & QUI & SEX & SÁB & Feriado Oficial na sexta-feira \\
\hline G & DOM & SEG & TER & QUA & QUI & SEX & SÁB & Semana de férias \\
\hline
\end{tabular}


Com base na informação de quanto os residentes ou turistas são capazes de produzir em um determinado dia de uma semana padrão, e tendo o conhecimento da ocorrência de cada tipo de semana padrão ao longo dos 15 anos, determinou-se a produção de RSU nas cidades. E derivado deste dado, determinou-se também, a taxa média de crescimento da produção de resíduos nas cidades ao longo dos anos, com data base de referência no primeiro ano, 2003. Este dado foi necessário para o dimensionamento dos aterros.

\section{iii ) Malha viária urbana da cidade}

Para o dimensionamento da coleta nas cidades, foram levantadas as plantas das maIhas viárias de todas as sedes urbanas. Através delas, pôde-se determinar a distância percorrida na atividade de coleta, fazendo-se a medição manualmente nas plantas. Porém, nem toda a malha é percorrida pelos veículos de coleta, pois existem muitos loteamentos inabitados, sem serviço de coleta, com caráter de especulação imobiliária. Para fazer um ajuste nos valores, tomou-se como base os dados fornecidos pelas prefeituras sobre os terrenos vazios, sem construção, existentes na cidade. Cadastro este que existe para a cobrança de IPTU nas cidades.

Como não havia dados nos municípios, sobre a quilometragem real de coleta, foi necessário adotar uma estratégia. Para a cidade que tivesse a menor porcentagem de terrenos vazios, considerou-se que não havia redução na quilometragem de coleta, ou seja, a coleta seria realizada em toda a extensão da malha viária urbana. E, para a cidade que teve a maior porcentagem de terrenos vazios, foi possível levantar, junto a prefeitura da cidade, os bairros vazios, e assim pôde-se medir, em planta, a malha real de coleta. Deste modo, havia dois pontos extremos indicando a porcentagem de redução na malha viária total. Com isto, relacionando a redução na malha viária com a porcentagem de terrenos vazios, projetou-se linearmente a redução na malha total para as demais cidades, para se obter a malha de coleta. Esta estimativa pode ser observada na TABELA 7.4.

Após determinar a malha de coleta das cidades, calculou-se o crescimento desta maIha, visto que o período de 15 anos é longo e não poderia ser considerado constante. Assim, como não se encontrou na literatura um método que determinasse esse crescimento, foi adotada uma taxa de crescimento da malha como sendo a mesma taxa de 
TABELA 7.4 - Cálculo da quilometragem da malha viária de coleta de RSU

\begin{tabular}{|c|c|c|c|c|c|c|c|}
\hline \multirow[t]{2}{*}{ Cidades } & \multicolumn{3}{|c|}{ Terrenos } & \multirow{2}{*}{$\begin{array}{c}\text { Vazios } \\
(\%)\end{array}$} & \multirow{2}{*}{$\begin{array}{l}\text { Malha } \\
\text { Total } \\
(\mathrm{km}) \\
\end{array}$} & \multirow{2}{*}{$\begin{array}{c}\text { Redução } \\
\text { na malha } \\
(\%)^{(4)}\end{array}$} & \multirow{2}{*}{$\begin{array}{c}\text { Malha } \\
\text { Coleta } \\
(\mathrm{km}) \\
\end{array}$} \\
\hline & Total & Ocupados & Vazios & & & & \\
\hline Analândia & 3.570 & 1.300 & 2.270 & $63,59 \%$ & 62,03 & $26,91 \%$ & 45,34 \\
\hline São Pedro & 21.000 & 8.286 & 12.714 & $60,54 \%$ & 154,33 & $25,18 \%$ & 115,46 \\
\hline Águas de São Pedro & 3.327 & 1.427 & 1.900 & $57,11 \%$ & 56,55 & $23,24 \%$ & 43,41 \\
\hline Brotas & 10.211 & 4.935 & 5.276 & $51,67 \%$ & 112,78 & $20,16 \%$ & 90,05 \\
\hline Ipeúna & 2.700 & 1.378 & 1.322 & $48,96 \%$ & 22,50 & $18,62 \%$ & 18,31 \\
\hline Charqueada & 5.110 & 3.006 & 2.104 & $41,17 \%$ & 44,87 & $14,21 \%$ & 38,49 \\
\hline Corumbataí & 880 & 520 & 360 & $40,91 \%$ & 11,30 & $14,06 \%$ & 9,71 \\
\hline Mineiros do Tietê & 5.920 & 3.910 & 2.010 & $33,95 \%$ & 55,19 & $10,12 \%$ & 49,61 \\
\hline Santa Maria da Serra & 1.936 & 1.285 & 651 & $33,63 \%$ & 22,46 & $9,93 \%$ & 20,23 \\
\hline Torrinha & 3.400 & 2.402 & 998 & $29,35 \%$ & 40,82 & $7,51 \%$ & 37,75 \\
\hline Dois Córregos & 9.111 & 6.854 & 2.257 & $24,77 \%$ & 121,68 & $4,92 \%$ & 115,70 \\
\hline Barra Bonita & 13.000 & 10.000 & 3.000 & $23,08 \%$ & 239,11 & $3,96 \%$ & 229,65 \\
\hline Itirapina (Broa) & 1.503 & 1.261 & 242 & $16,10 \%$ & 18,02 & $0,00 \%$ & 18,02 \\
\hline \multirow[t]{3}{*}{ Itirapina (Cidade) } & 3.529 & 2.961 & 568 & $16,10 \%$ & 42,31 & $0,00 \%$ & 42,31 \\
\hline & \multicolumn{2}{|c|}{ (2) Vazio máximo: } & Analândia & $63,59 \%$ & 62,03 & $26,91 \%$ & 45,34 \\
\hline & \multicolumn{2}{|c|}{ (3) Vazio mínimo: } & Itirapina & $16,10 \%$ & 60,33 & $0,00 \%$ & 60,33 \\
\hline
\end{tabular}

\footnotetext{
(1) Dado fornecido pelo setor de cadastro de IPTU das Prefeituras dos municípios.

(2) Para a cidade com vazio máximo, a redução na malha foi medido em planta.

(3) Para a cidade com vazio mínimo, a redução na malha foi adotado como nenhuma.

(4) Para as demais cidade, a redução na malha foi calculado através de uma relação linear entre a porcentagem de vazios e a redução, tendo os valores máximos e mínimos definidos anteriormente.
}

crescimento da população. Isto significa que a variação da densidade demográfica ao longo do período de planejamento não foi considerada.

\section{iv ) Coordenadas geográficas e distâncias entre as cidades}

Os dados georeferenciados fornecidos pelo DER-SP, mesmo corretos, poderiam ser distorcidos na fase de importação para o TransCAD. Para aferir a correta transferência destes dados para o SIG, foi necessário adquirir dois dados: as coordenadas geográficas das cidades e a distância entre elas. As coordenadas oficiais de longitude e latitude foram conseguidas através do IBGE (2001). Já, as distâncias entre alguns municípios foram obtidas com a leitura do hodômetro do veículo, aproveitando o trajeto realizado para adquirir a planta da malha viária dos municípios. Estes dados foram confrontados com os obtidos no TransCAD, após a importação do mapa da área de estudo. 


\subsection{Dimensionamento da coleta de RSU nas cidades}

Houve uma tentativa inicial de levantar os dados de coleta das cidades, porém as prefeituras não possuíam, em sua maioria, a manutenção destas informações. Isto se deve ao fato dos municípios serem de pequeno porte, e assim, não apresentarem estrutura ou mesmo a consciência da necessidade de manter estes dados. Na falta desta informação, foi elaborado um procedimento para dimensionar teoricamente a coleta nas cidades.

O dimensionamento da coleta foi realizado para três períodos diferentes: 2003 até 2007, 2008 até 2012 e 2013 até 2017. Com a coleta dimensionada foi possível derivar informações para localizar os aterros, dimensionar o transporte dos resíduos até os destinos (aterros e ETs) e compor a planilha de custos da coleta.

A primeira etapa no dimensionamento da coleta foi definir a freqüência e os setores de coleta. Para que se tivesse uma qualidade de serviço para as cidades em estudo, turísticas em sua maioria, foi levantada a necessidade de que a freqüência de coleta fosse diária nos centros das cidades, e em dias alternados nos demais setores. Para a divisão dos setores e determinação das respectivas áreas, foi adotada a condição encontrada na TABELA 7.5. Pelo critério adotado, as cidades foram divididas em 3 setores: centro, setor $A$ e setor $B$. Sendo que 1/4 (25\%) da área urbana com coleta é considerada como o centro. E o restante é dividido em duas partes, cada qual com 3/8 $(37,5 \%)$. Tanto a malha de coleta como a produção básica de RSU foi dividida proporcionalmente ao tamanho do setor, com exceção dos resíduos excedentes, característi-

TABELA 7.5 - Critérios utilizados para divisão nos setores de coleta

\begin{tabular}{|c|c|c|c|c|c|}
\hline \multirow{3}{*}{ Setores } & \multirow{3}{*}{$\begin{array}{l}\text { Divisão da } \\
\text { malha de } \\
\text { coleta }\end{array}$} & \multicolumn{3}{|c|}{ Divisão da produção de RSU } & \multirow{3}{*}{$\begin{array}{c}\text { Dias de coleta na } \\
\text { semana }\end{array}$} \\
\hline & & \multirow{2}{*}{$\begin{array}{c}\begin{array}{c}\text { População } \\
\text { residente }\end{array} \\
\text { Básica }^{(1)}\end{array}$} & \multicolumn{2}{|c|}{$\begin{array}{l}\text { População flutuante } \\
\text { (Turistas) }\end{array}$} & \\
\hline & & & Básica $^{(1)}$ & $\begin{array}{l}\text { Excedente de } \\
\qquad 70 \%\end{array}$ & \\
\hline Centro & $1 / 4$ & $1 / 4$ & $1 / 4$ & $1 / 2$ & SEG - SÁB \\
\hline A & $3 / 8$ & $3 / 8$ & $3 / 8$ & $1 / 4$ & SEG / QUA / SEX \\
\hline$B$ & $3 / 8$ & $3 / 8$ & $3 / 8$ & $1 / 4$ & TER / QUI / SAB \\
\hline
\end{tabular}


$\cos$ de atividades dos turistas. Neste caso, foi considerado que 1/2 (50\%) deste excedente gerado se concentrava no centro das cidades - em restaurantes, lanchonetes, lojas - e a outra metade seria produzido igualmente nos demais setores. A produção básica de RSU, indicada na TABELA 7.5, é aquela calculada a partir do produto da geração per capita pela população.

Depois de definida a freqüência e os setores de coleta, a quantidade diária coletada foi determinada para cada semana padrão. Para isto, foi necessário seguir a distribuição da geração dos resíduos e o acúmulo destes nos dias de coleta ao longo de cada semana padrão, como é descrito na TABELA 7.6. Para esclarecer a tabela, considere como modelo a semana padrão E. Neste tipo de semana, o feriado caiu na quintafeira, assim, é considerado que existe um feriado prolongado na sexta. No domingo e no sábado, sempre havera turistas, e com o feriado, têm-se também na quinta e na sexta. Assim, nestes quatro dias, haverá a produção de resíduos da população residente e de turistas, e esta geração foi denominada de PICO. Nos demais dias, a produção foi considerada NORMAL. Para exemplificar a quantidade coletada, na segunda-feira desta mesma semana padrão $E$, no setor $A$, terá o acúmulo dos resíduos produzidos no sábado, no domingo e na segunda, ou seja, a produção de 2 dias de PICO e 1 dia NORMAL.

Para o cálculo das horas de trabalho, dois parâmetros de cálculo foram adotados: taxa de repetição da coleta e a velocidade dos veículos. Estes dados foram adotados com base nos dados da dissertação de DELUQUI (1998), na qual se estudou a roteirização de veículos de coleta utilizando o TransCAD. Através de questionários, a autora conseguiu os valores da velocidade de coleta de aproximadamente 30 cidades de médio porte. A média destes valores foi de $11,53 \mathrm{~km} / \mathrm{h}$. Além deste dado, DELUQUI (1998) determinou, para o estudo de caso de seu trabalho, que a repetição do percurso em ruas já coletadas era na média de $35 \%$, valor este obtido utilizando-se o TransCAD. Apesar destes valores não terem sido medidos nas pequenas cidades do estudo de caso, estes foram utilizados como referência para os cálculos, por serem únicos. 
TABELA 7.6 - Produção de RSU e o acúmulo nos dias de coleta

\begin{tabular}{|c|c|c|c|c|c|c|c|c|c|c|c|c|c|c|c|c|}
\hline \multirow{3}{*}{$\begin{array}{l}\text { Semana } \\
\text { Padrão }\end{array}$} & \multirow{3}{*}{$\begin{array}{l}\text { Dias da semana: } \\
\text { Produção de RSU } \\
\text { Coleta de RSU }^{(2)}:\end{array}$} & \multirow{3}{*}{$\begin{array}{c}\mathrm{DOM} \\
\mathrm{P} \\
\end{array}$} & \multirow{2}{*}{\multicolumn{2}{|c|}{$\frac{\mathrm{SEG}}{\mathrm{N}}$}} & \multirow{2}{*}{\multicolumn{2}{|c|}{$\frac{\text { TER }}{\mathrm{N}}$}} & \multirow{2}{*}{\multicolumn{2}{|c|}{$\frac{\mathrm{QUA}}{\mathrm{N}}$}} & \multirow{2}{*}{\multicolumn{2}{|c|}{$\frac{\mathrm{QUI}}{\mathrm{N}}$}} & \multirow{2}{*}{\multicolumn{2}{|c|}{$\frac{\text { SEX }}{\mathrm{N}}$}} & \multirow{2}{*}{\multicolumn{2}{|c|}{$\frac{S A B}{P}$}} & \multirow{2}{*}{\multicolumn{2}{|c|}{ TOTAL }} \\
\hline & & & & & & & & & & & & & & & & \\
\hline & & & $P$ & $\mathrm{~N}$ & $P$ & $\mathrm{~N}$ & $P$ & $\mathrm{~N}$ & $\mathrm{P}$ & $\mathrm{N}$ & & $\mathrm{N}$ & $\mathrm{P}$ & $\mathrm{N}$ & & $\mathrm{N}$ \\
\hline \multirow{3}{*}{ A } & CENTRO & & 1 & 1 & 0 & 1 & 0 & 1 & 0 & 1 & 0 & 1 & 1 & 0 & 2 & 5 \\
\hline & Setor A & & 2 & 1 & & & 0 & 2 & & & 0 & 2 & & & 2 & 5 \\
\hline & Setor B & & & & 1 & 2 & & & 0 & 2 & & & 1 & 1 & 2 & 5 \\
\hline & Dias da semana: & DOM & \multicolumn{2}{|c|}{ SEG } & \multicolumn{2}{|c|}{ TER } & \multicolumn{2}{|c|}{ QUA } & \multicolumn{2}{|c|}{ QUI } & \multicolumn{2}{|c|}{ SEX } & \multicolumn{2}{|c|}{ SAB } & \\
\hline Semana & Produção de RSU: & $\mathrm{P}$ & \multicolumn{2}{|c|}{$\mathrm{P}$} & \multicolumn{2}{|c|}{$\mathrm{N}$} & $\mathrm{N}$ & & 1 & & $\mathrm{~N}$ & & 1 & & TO & TAL \\
\hline Padrão & Coleta de RSU: & & $\mathrm{P}$ & $\mathrm{N}$ & $\mathrm{P}$ & $\mathrm{N}$ & $\mathrm{P}$ & $\mathrm{N}$ & $\mathrm{P}$ & $\mathrm{N}$ & $\mathrm{P}$ & $\mathrm{N}$ & $\mathrm{P}$ & $\mathrm{N}$ & $\mathrm{P}$ & $\mathrm{N}$ \\
\hline & CENTRO & & 2 & 0 & 0 & 1 & 0 & 1 & 0 & 1 & 0 & 1 & 1 & 0 & 3 & 4 \\
\hline B & Setor A & & 3 & 0 & & & 0 & 2 & & & 0 & 2 & & & 3 & 4 \\
\hline & Setor B & & & & 2 & 1 & & & 0 & 2 & & & 1 & 1 & 3 & 4 \\
\hline & Dias da semana: & DOM & SE & & TE & & QL & & & & SE & & & & & \\
\hline Semana & Produção de RSU: & $\mathrm{P}$ & $\mathrm{F}$ & & $\mathrm{P}$ & & $\Lambda$ & & 1 & & $\mathrm{~N}$ & & 1 & & TO & TAL \\
\hline Padrão & Coleta de RSU: & & $P$ & $\mathrm{~N}$ & $\mathrm{P}$ & $\mathrm{N}$ & & $\mathrm{N}$ & $\mathrm{P}$ & $\mathrm{N}$ & & $\mathrm{N}$ & $P$ & $\mathrm{~N}$ & $\mathrm{P}$ & $\mathrm{N}$ \\
\hline & CENTRO & & 2 & 0 & 1 & 0 & & 1 & 0 & 1 & 0 & 1 & 1 & 0 & 4 & 3 \\
\hline C & Setor A & & 3 & 0 & & & & 1 & & & 0 & 2 & & & 4 & 3 \\
\hline & Setor B & & & & 3 & 0 & & & 0 & 2 & & & 1 & 1 & 4 & 3 \\
\hline & Dias da semana: & DOM & $\mathrm{SE}$ & & $\overline{T E}$ & & QL & JA & & & $\mathrm{SE}$ & $\mathrm{X}$ & & & & \\
\hline Semana & Produção de RSU: & $P$ & 1 & & $\Lambda$ & & $\mathrm{F}$ & & 1 & & $N$ & & r & & TO & TAL \\
\hline Padrão & Coleta de RSU: & & $\mathrm{P}$ & $\mathrm{N}$ & $\mathrm{P}$ & $\mathrm{N}$ & $\mathrm{P}$ & $\mathrm{N}$ & $\mathrm{P}$ & $\mathrm{N}$ & & $\mathrm{N}$ & $\mathrm{P}$ & $\mathrm{N}$ & $\mathrm{P}$ & $\mathrm{N}$ \\
\hline & CENTRO & & 1 & 1 & 0 & 1 & 1 & 0 & 0 & 1 & 0 & 1 & 1 & 0 & 3 & 4 \\
\hline D & Setor A & & 2 & 1 & & & 1 & 1 & & & 0 & 2 & & & 3 & 4 \\
\hline & Setor B & & & & & 2 & & & 1 & 1 & & & 1 & 1 & 3 & 4 \\
\hline & Dias da semana: & DOM & & & TE & & QL & $J A$ & & & SE & & & & & \\
\hline Semana & Produção de RSU: & $\mathrm{P}$ & $\Lambda$ & & $\Lambda$ & & $\Lambda$ & & F & & $\mathrm{P}$ & & & & TO & TAL \\
\hline Padrão & Coleta de RSU: & & $P$ & $\mathrm{~N}$ & $P$ & $\mathrm{~N}$ & $P$ & $\mathrm{~N}$ & $P$ & $\mathrm{~N}$ & & $\mathrm{~N}$ & $P$ & $\mathrm{~N}$ & $P$ & $\mathrm{~N}$ \\
\hline & CENTRO & & 1 & 1 & 0 & 1 & 0 & 1 & 1 & 0 & 1 & 0 & 1 & 0 & 4 & 3 \\
\hline$E$ & Setor A & & 2 & 1 & & & 0 & 2 & & & & 0 & & & 4 & 3 \\
\hline & Setor B & & & & 1 & 2 & & & 1 & 1 & & & 2 & 0 & 4 & 3 \\
\hline & Dias da semana: & DOM & & & $\mathrm{TE}$ & & $\mathrm{QL}$ & $J A$ & & & $\mathrm{SE}$ & $X$ & & & & \\
\hline Semana & Produção de RSU: & $P$ & & & $\Lambda$ & & $\Lambda$ & & 1 & & $\mathrm{P}$ & & & & TO & TAL \\
\hline Padrão & Coleta de RSU: & & $P$ & $\mathrm{~N}$ & $\mathrm{P}$ & $\mathrm{N}$ & $\mathrm{P}$ & $\mathrm{N}$ & $\mathrm{P}$ & $\mathrm{N}$ & & $\mathrm{N}$ & $\mathrm{P}$ & $\mathrm{N}$ & $\mathrm{P}$ & $\mathrm{N}$ \\
\hline & CENTRO & & 1 & 1 & 0 & 1 & 0 & 1 & 0 & 1 & & 0 & 1 & 0 & 3 & 4 \\
\hline $\mathrm{F}$ & Setor A & & 2 & 1 & & & 0 & 2 & & & & 1 & & & 3 & 4 \\
\hline & Setor B & & & & 1 & 2 & & & 0 & 2 & & & 2 & 0 & 3 & 4 \\
\hline & Dias da semana: & DOM & $\mathrm{SE}$ & & $\mathrm{TE}$ & & QL & $J A$ & & & SE & & & & & \\
\hline Semana & Produção de RSU: & $\mathrm{P}$ & $\mathrm{F}$ & & $\mathrm{P}$ & & $\mathrm{P}$ & & F & & $\mathrm{P}$ & & 0 & & TO & TAL \\
\hline Padrão & Coleta de RSU: & & $\mathrm{P}$ & $\mathrm{N}$ & $\mathrm{P}$ & $\mathrm{N}$ & $\mathrm{P}$ & $\mathrm{N}$ & $\mathrm{P}$ & $\mathrm{N}$ & $\mathrm{P}$ & $\mathrm{N}$ & $\mathrm{P}$ & $\mathrm{N}$ & $\mathrm{P}$ & $\mathrm{N}$ \\
\hline & CENTRO & & 2 & 0 & 1 & 0 & 1 & 0 & 1 & 0 & 1 & 0 & 1 & 0 & 7 & 0 \\
\hline G & Setor A & & 3 & 0 & & & 2 & 0 & & & 2 & 0 & & & 7 & 0 \\
\hline & Setor B & & & & 3 & 0 & & & 2 & 0 & & & 2 & 0 & 7 & 0 \\
\hline
\end{tabular}

$\mathrm{P}=$ PICO: Produção de resíduos em dias com turistas (resíduos da população residente + flutuante)

$\mathrm{N}=$ NORMAL: Produção de resíduos em dias sem turistas (resíduos da população residente)

(1) De acordo com a semana padrão, são os dias que tem produção de pico ou normal

(2) De acordo com a semana padrão, são os acúmulos das produções de pico e normal no dia de coleta

No dimensionamento da coleta, foram considerados veículos com capacidade de carga de $5 \mathrm{t}$, e em alguns casos, de $3 \mathrm{t}$. Conhecendo-se a distribuição da quantidade diária coletada de RSU para cada semana padrão e cada setor de coleta, buscou-se uma frota padrão para cada cidade, com o menor número possível de veículos e viagens 
necessárias até o destino (aterros ou ETs), para conseguir atender a demanda de RSU e realizar o serviço dentro da jornada de trabalho padrão de $7 \mathrm{~h}$ 20min (sete horas e vinte minutos). Conhecendo-se a velocidade de coleta, a quilometragem percorrida com repetição e a frota, calculou-se as horas trabalhadas por veículo.

O dimensionamento da coleta teve como objetivo, determinar os seguintes dados, que foram utilizados em outros cálculos do trabalho:

- frota de veículos de coleta;

- número de viagens da frota;

- horas de trabalho: jornada padrão diária até 7h 20min e possíveis horas extras;

- quantidade de resíduos coletados nos dias das semanas padrões, para dimensionar a capacidade de acúmulo das ETs.

\subsection{Pré-processamento de dados no SIG}

Nesta fase os dados espaciais e não-espaciais necessários para as análises de localização e roteirização no TransCAD foram organizadas de forma sistemática, para fácil gerenciamento. Nos próximos itens, estão descritos estes dados.

\subsubsection{Dados espaciais}

Para converter o mapa digital adquirido do DER-SP para arquivos geográficos do TransCAD, foram necessárias algumas manipulações no arquivo realizadas no AutoCAD 2000. Primeiro, foi necessário retirar os dados espaciais excedentes antes de isolar as informação em 3 camadas (layers): as vias com os nós, as áreas urbanas e a representação das águas superficiais (rios, lagos, represas, etc).

No primeiro layer, com os arcos que representariam as rodovias e os nós que seriam os centros geográficos das cidades, foram mantidos os elementos que somente representavam a área do estudo de caso. Para que não haja inconsistência ao importar o arquivo para o TransCAD, todas as conexões entre os arcos foram verificadas manualmente. Como o mapa rodoviário apresentava somente as rodovias e não as vias urbanas, foram criados arcos lineares entre o nó que representava o centro geográfico 
da cidade até a intersecção da rodovia mais próxima. Além disso, através do comando divide e break do AutoCAD, as vias da área de estudo foram divididas em segmentos de aproximadamente $2 \mathrm{~km}$, para se criar os pontos ao longo das rodovias, onde se poderia locar os nós candidatos para aterros e ETs.

As áreas urbanas e as representações das águas superficiais foram isoladas cada qual em um layer. Como apresentado anteriormente, através destas informações foram selecionados no TransCAD somente os nós onde não teriam restrições para localizar os aterros sanitários e ETs.

\subsubsection{Dados não-espaciais}

Os atributos, ou dados não-espaciais, são arquivos que são anexados posteriormente aos arquivos geográficos do TransCAD, para acrescentar informações necessárias utilizadas nas análises logísticas. As informações de interesse deste trabalho estavam relacionadas aos nós que representavam as cidades e aterros, e aos arcos que retratavam as rodovias.

No caso dos nós, os seguintes atributos foram organizados neste trabalho:

- Nomes das cidades da área de estudo nos nós que os representam. Este dado foi inserido, por digitação, diretamente nas tabelas do arquivo geográfico dos nós. Esta informação serviu, além de indicar visualmente os locais nas saídas gráficas, como referência para conectar outras tabelas com informações ao arquivo geográfico;

- Número total de viagens dos veículos coletores de RSU determinado com o dimensionamento da coleta para cada cidade. Para inserir esta informação no TransCAD, foi criada uma tabela no Excel e exportado na forma de arquivo com extensão *.dbf. O número de viagens foi utilizado como peso na localização de aterros na situação em que foi considerado que o transporte até os aterros, seria realizado com os próprios veículos de coleta, ou seja, sem as Ets;

- A quantidade de RSU a ser coletada nos nós que representam as ETs. Este dado também foi criado no Excel e exportado em arquivo *.dbf. Este dado foi utilizado para realizar a roteirização do veículo de transporte, que faz a coleta nas ETs. Ele limita o tamanho da rota, através da capacidade do veículo. 
No caso dos arcos, as seguintes informações foram estruturadas:

- Classificação das vias segundo o DER-SP. Este dado foi digitado diretamente na tabela do arquivo geográfico dos arcos que representavam as rodovias. A hierarquização das vias foi necessária apenas para servir de referência para escolher a velocidade de tráfego adotada para os veículos. Esta classificação já se encontrava representada no mapa rodoviário do DER-SP.

- Velocidade de tráfego de caminhão nas rodovias. Esta informação também foi digitada diretamente na tabela. A escolha das velocidades foi feita de modo subjetivo, de acordo com a hierarquia, situação das rodovias e o porte do caminhão, de modo que representasse melhor a realidade.

Além dos dados relacionados aos nós e arcos, o TransCAD tem como entrada outra tabela para que se façam as análises de roteirização. Esta tabela possui dados sobre os veículos de transporte dos resíduos das ETs, ou das cidades, até os aterros. Esta tabela pode ser criada através do TransCAD, bem como ser criada em Excel e depois importado para o TransCAD como arquivo de extensão *.dbf.

\subsection{Gerenciamento de dados: importação para o TransCAD}

Após a aquisição dos dados e o seu pré-processamento, o passo seguinte dentro do SIG foi o de importar os dados espaciais da área de estudo para o TransCAD: sedes urbanas, rodovias, áreas urbanas e águas superficiais. Para isto, inicialmente adequou-se o arquivo de saída do AutoCAD para que seja compatível com o TransCAD, exportando-o no formato *.dxf.

Na seqüência, foram definidos os parâmetros para a importação do arquivo no TransCAD. O arquivo original do DER-SP foi criado dentro do sistema de projeção policônica (SÃO PAULO, 2000b). Porém, o TransCAD utilizado nesta pesquisa não reconhece esta projeção. Assim, como alternativa, foram utilizadas 3 coordenadas geográficas conhecidas como referência para a importação do arquivo no TransCAD. Este software permite a importação arbitrária dos dados espaciais, através do relacionamento de 3 coordenadas cartesianas $X Y$ com as respectivas coordenadas globais de longitude $e$ 


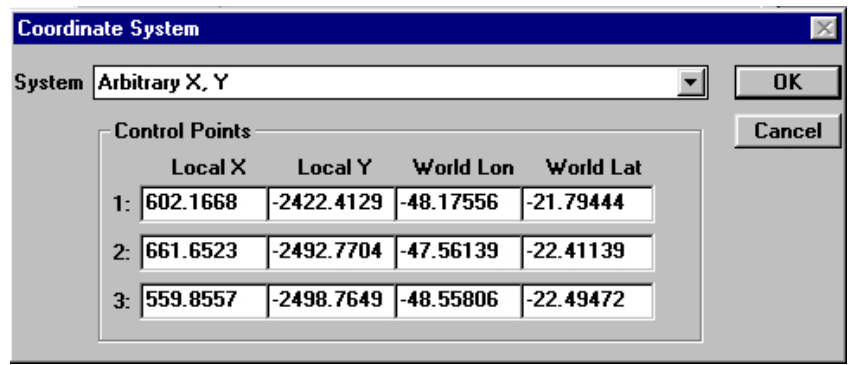

FIGURA 7.3 - Os pontos de controle escolhidos para importação dos dados espaciais para o TransCAD.

latitude das localidades (FIGURA 7.3). Para que reduzisse as distorções, foram escoIhidas 3 coordenadas formando um triângulo onde a área de interesse estivesse contida. A visualização dos pontos de controle escolhidos pode ser obtida pela FIGURA 7.4 .

Como salientado anteriormente, para avaliar a qualidade da importação, foram confrontados os valores das coordenadas globais oficiais de latitude e longitude das cida-

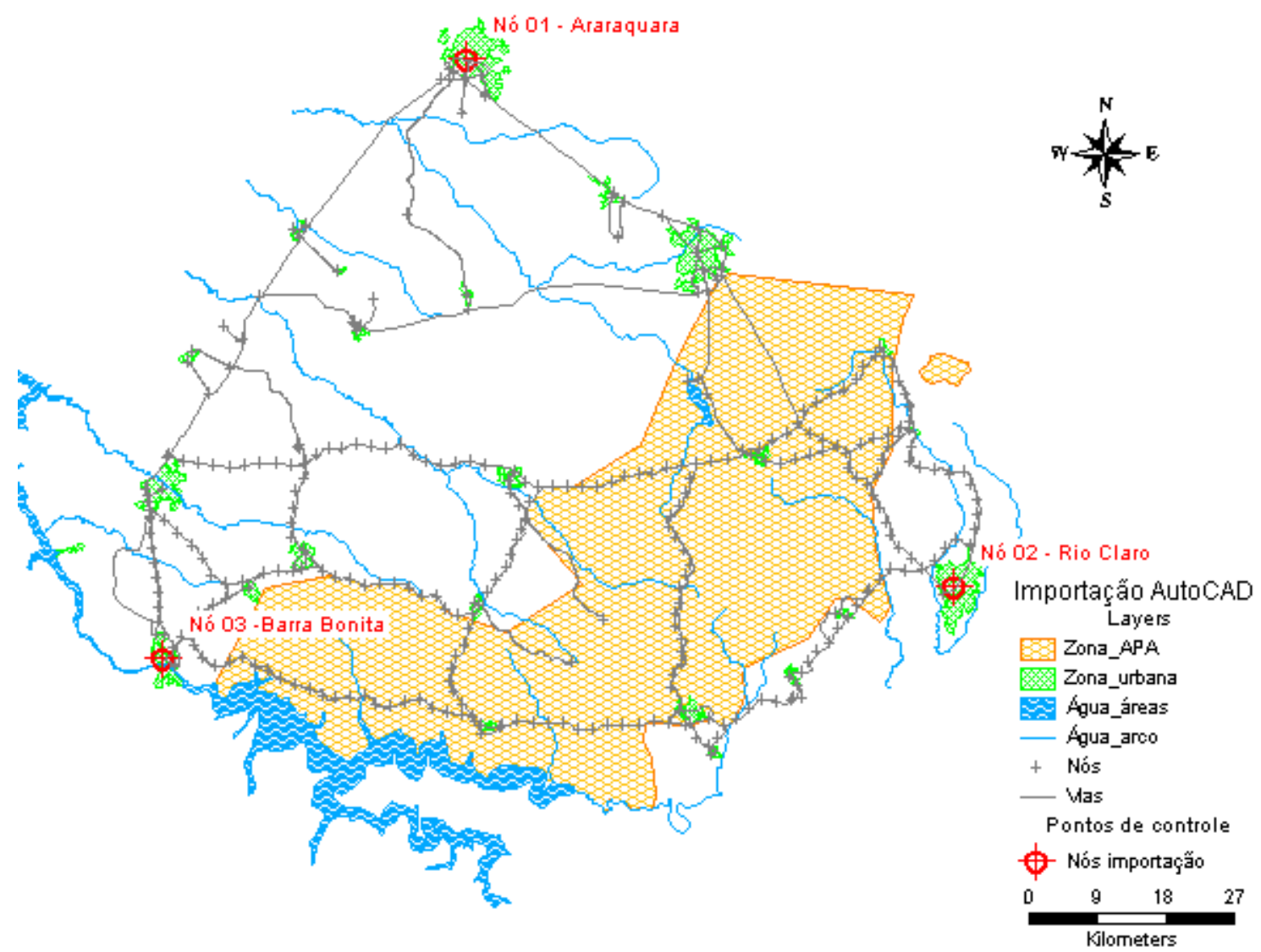

FIGURA 7.4 - Triangulação formada pelos pontos de controle escolhidos para importação do mapa rodoviário do DER-SP. 
des, encontrados no IBGE (2001), com aquelas que o TransCAD forneceu após a importação do arquivo do AutoCAD. Outro parâmetro utilizado, para fazer a mesma análise, foi a da distância entre as localidades, confrontando a leitura da distância no hodômetro do carro com as fornecidas pelo TransCAD.

\subsection{Seleções de locais sem restrições}

Na literatura, GUIMARÃES (2000), entre outros autores, utilizaram o SIG para trabaIhar com as restrições geoambientais e identificar as áreas potenciais para instalação de aterros sanitários. Para atender a estas restrições, o autor considerou aspectos geotécnicos, geológicos, hidrológicos, entre outros. Outros trabalhos específicos podem ser vistos também em RANIERI (2000), CINTRA \& BARRETO (1997), GRECCHI (1998). Porém, nesta pesquisa, todos os fatores geoambientais não puderam ser encontrados na forma de dados georeferenciados, limitando-se às restrições do zoneamento urbano e corpos d'água.

Segundo a CETESB (SÃO PAULO, 1997a), a distância mínima recomendada para instalação de aterros sanitários em relação aos corpos d'água é de $200 \mathrm{~m}$ e de $2.000 \mathrm{~m}$ no caso de áreas urbanizadas.

Para que estas restrições pudessem ser manipuladas com o auxílio do TransCAD, após a importação dos dados espaciais, foi necessário utilizar algumas ferramentas. Para fazer a seleção dos nós ao longo das rodovias sem restrições para localização dos aterros no TransCAD, utilizou-se a ferramenta Bands, com a qual foram criadas as áreas restritas, conforme critérios da CETESB (SÃO PAULO, 1997a). E com a ferramenta Selection by Location do TransCAD, os nós potenciais para localização de aterros foram escolhidos. As áreas restritas e os nós escolhidos podem ser visualizados na FIGURA 7.5. 


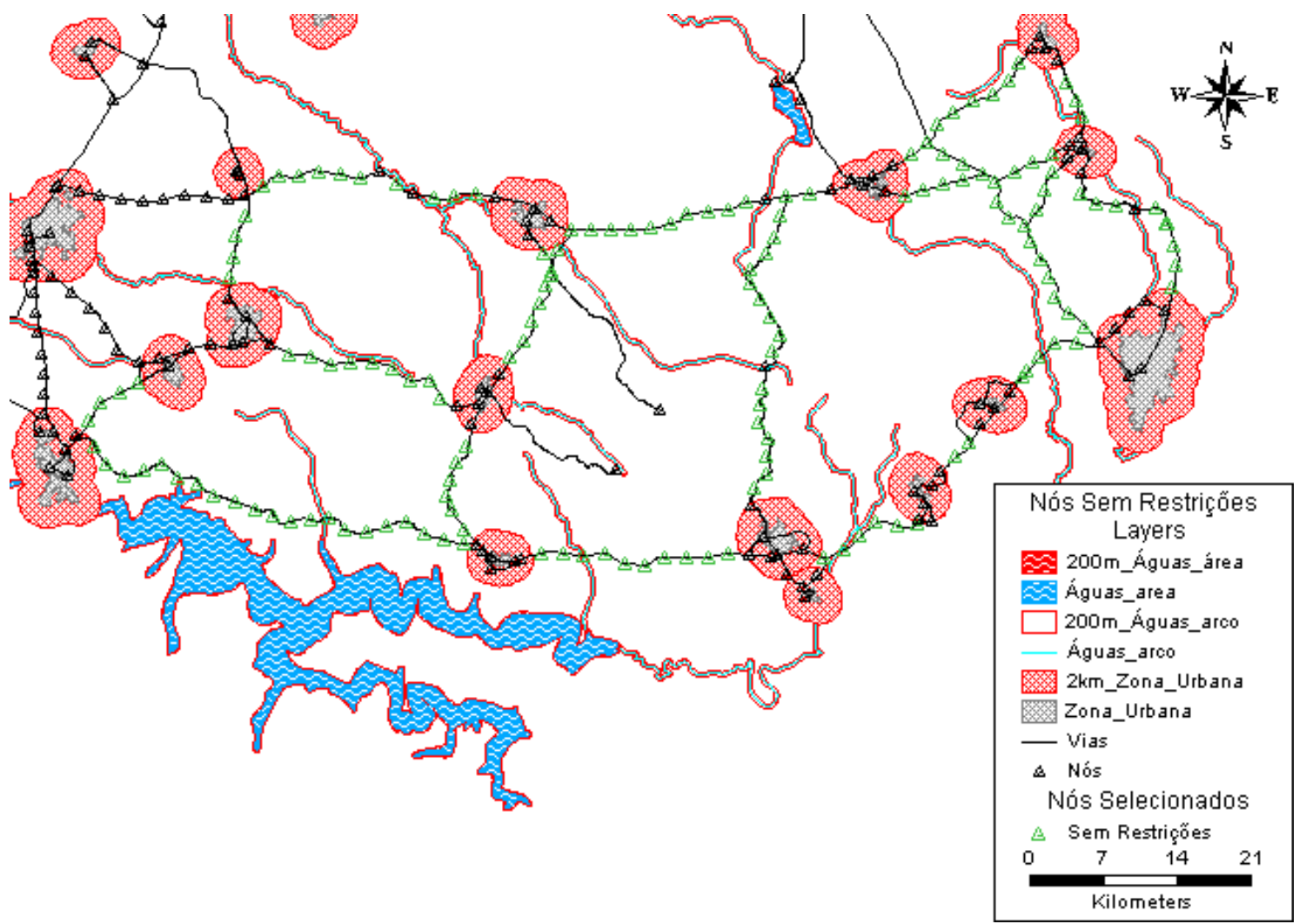

FIGURA 7.5 - Escolha de nós fora das restrições de zona urbana e águas superficiais.

\subsection{Definição das situações}

Para a localização dos aterros, foi necessário estabelecer as situações em que o sistema poderia ser configurado. Foram identificadas para este trabalho, dois parâmetros que definiram as situações possíveis. Um deles foi a consideração da existência, ou não, de Estações de Transferências no sistema, e o outro foi o número de aterros.

A ET modifica as análises de localização, pois, com a consolidação de carga de resíduos, a visita pelo caminhão de transporte é única para cada localidade, no caso deste trabalho. Isto significa que, na análise de localização dos aterros nesta situação, não se considera a adoção de nenhum peso para as localidades. Já, no caso sem as estações, onde o próprio caminhão de coleta transporta os resíduos até os aterros, o peso considerado é o número de viagens realizadas. Isto significa que a cidade com o maior número de viagens dos veículos coletores até o aterro tem peso maior, e o aterro foi localizado mais próximo desta cidade, com o objetivo de reduzir os custos logísticos. 


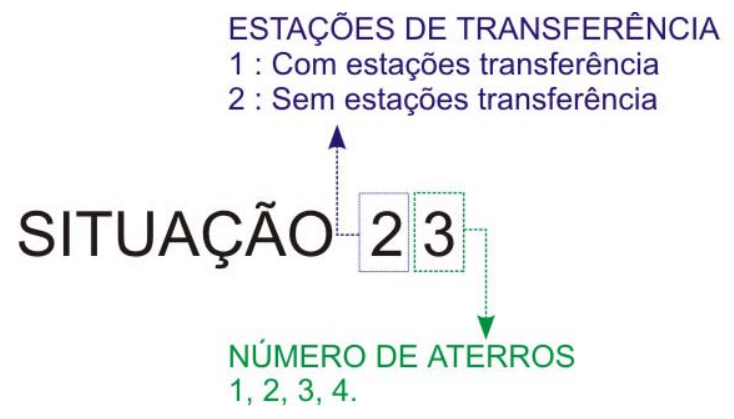

FIGURA 7.7 - Codificação utilizada para cada situação definida.

A quantidade de aterros é o parâmetro que serviu para criar as situações diversas, que levou a identificação do número ideal de aterros, com ou sem ET, para o sistema de menor custo. Para organizar e facilitar o trabalho, foi criada uma codificação utilizada para identificar cada situação criada, como pode ser visto na FIGURA 7.7.

\subsection{Localização dos aterros}

Para trabalhar com as rotinas de localização, foi necessário preparar um conjunto de dados de entrada, que são gerenciados através da janela do TransCAD que é mostrado na FIGURA 7.6. Para preparar estas informações, é necessário executar as atividades na seqüência apresentada a seguir:

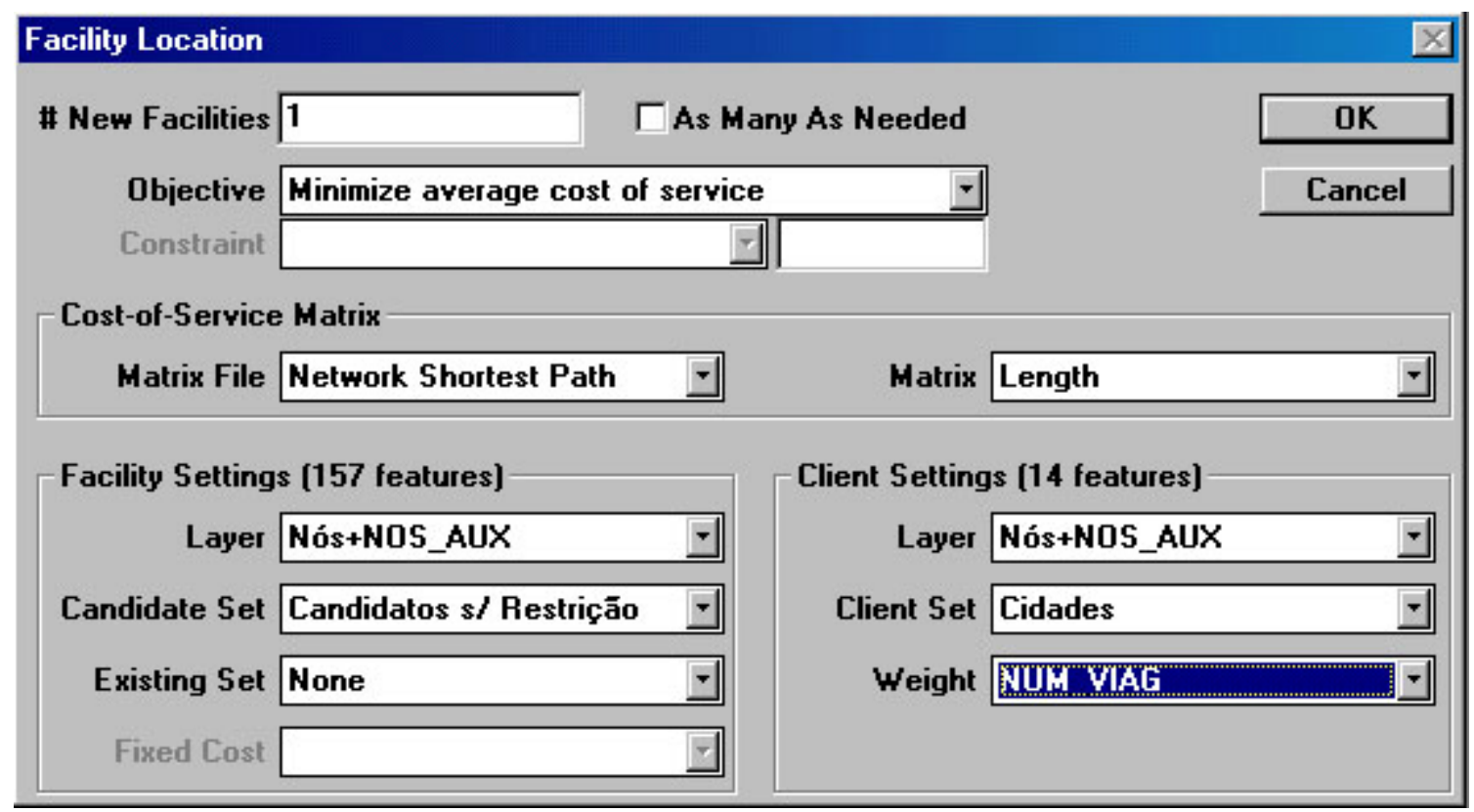

FIGURA 7.6 - Janela de entrada de dados para a rotina de localização do TransCAD. 
1) Facility Settings: selecionar os nós candidatos (sem restrições) para localizar os aterros;

2) Client Settings: selecionar os nós com os clientes servidos (cidades ou ETs);

3) Cost-of-Sevice-matrix: criar a matriz de custos de serviço (distância e tempo) entre os nós candidatos e os clientes;

4) Weight (client): criar o peso para cada cliente. Item este necessário apenas no caso onde a ET não foi considerada. E neste caso, o peso utilizado foi o número total das viagens realizadas pelos veículos de coleta das cidades até os aterro,s no intervalo de 15 anos. Este dado foi resultado do dimensionamento da coleta nas cidades.

A análise logística de localização de aterros pode ser realizada em duas frentes, na qual as situações foram divididas, conforme a consideração ou não de ETs. A diferenciação está na adoção dos pesos, e consideração de quem seria o cliente. No caso sem ET, os clientes são as próprias cidades geradoras de RSU, do contrário, são os nós onde foram locadas as estações. Para cada frente de análise, foi variado o número de aterros (New facilities), configurando uma situação diferente para cada caso.

Para as análises, a função objetivo (Objective), de minimização dos custos logísticos, adotada para a localização dos aterros, foi a de minimizar o custo médio de serviço. $E$, o custo minimizado foi o da distância percorrida, pois influi diretamente no cálculo dos custos operacionais.

Neste trabalho, as ETs não foram consideradas como existentes em todas cidades, pois elas se tornam ociosas para cidades de pequeno porte. Assim, buscou-se o menor número possível de estações. O procedimento para diminuir as estações foi o de redefinir as localizações dos aterros, após verificar que algumas cidades poderiam compartilhar as ETs, devido a sua proximidade geográfica. Na localização dos aterros, para efeito de cálculo, as ETs foram consideradas locadas nos centros geográficos das cidades. Mas, depois de locados os aterros, nós externos ao limite da zona urbana das cidades foram escolhidos para localizar as ETs, tendo como influência, a proximidade da localização do respectivo aterro que as servem. 
Como resultado das análises de localização, para cada situação definida, os locais dos aterros foram definidos, cada qual com o seu respectivo agrupamento de clientes servidos.

\subsection{Roteirização}

Depois de localizados os aterros, a análise logística do transporte destes resíduos até os aterros foi efetuada. A roteirização foi realizada para três períodos diferentes: 2003 até 2007, 2008 até 2012 e 2013 até 2017. Sendo que o último ano de cada período foi utilizado como referência para fazer as roteirizações. E, além de serem analisadas nos três períodos, as situações definidas foram estudadas também para cada semana padrão. Assim, foram obtidas as rotas e as programações da frota para todas as condições no período de estudo.

Para trabalhar com as rotinas de roteirização, foi preparado um conjunto de dados de entrada que são gerenciados através da janela mostrada na FIGURA 7.8. Estas infor-

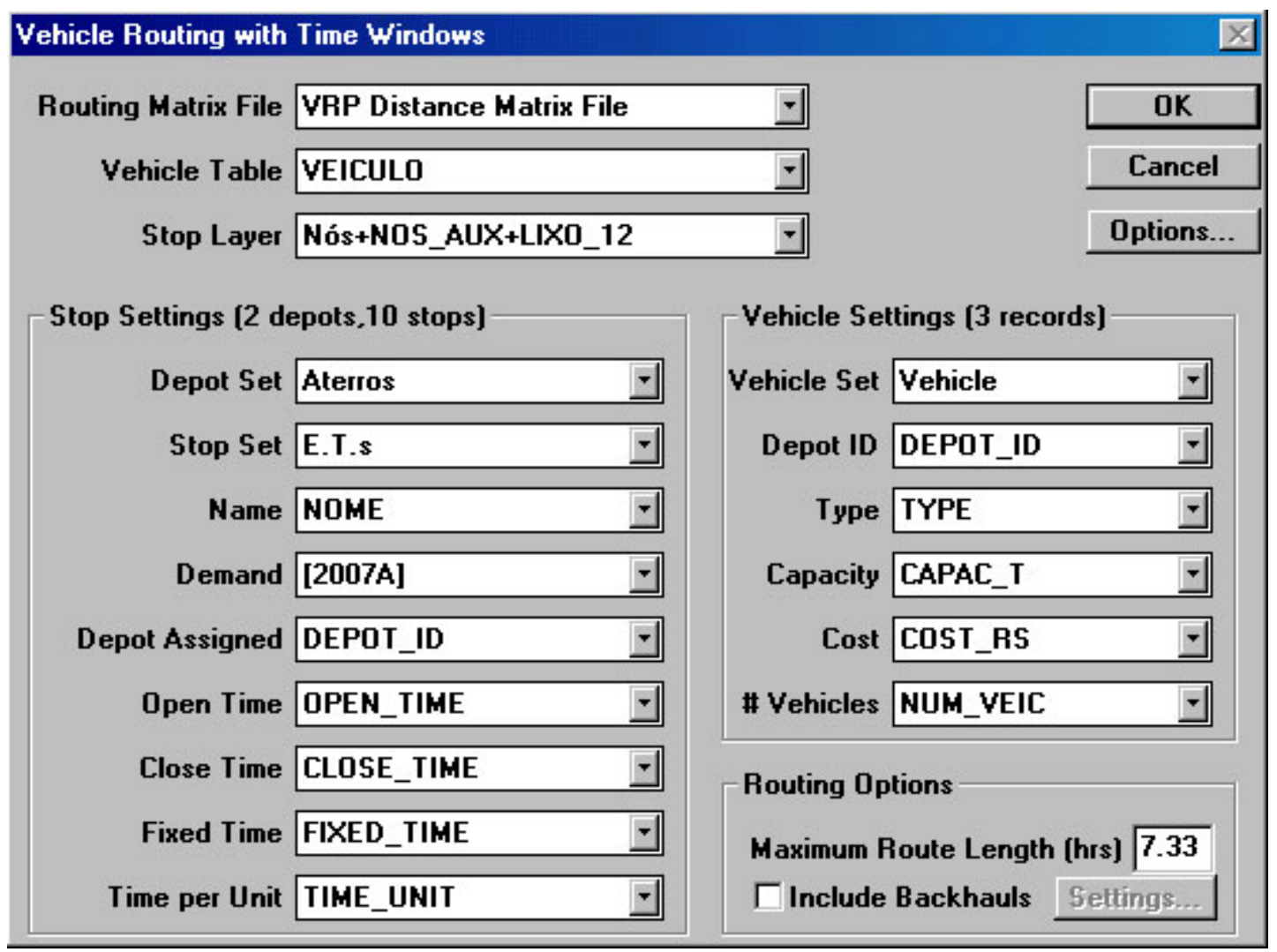

FIGURA 7.8 - Janela de entrada de dados para a rotina de roteirização do TransCAD. 
mações foram criadas, seguindo a seqüência apresentada a seguir:

1) Depot Set: selecionar os nós que representam os aterros;

2) Stop Set: selecionar os nós com os clientes servidos, cada qual identificado com o aterro que o serve;

3) Routing Matrix File: através da seleção dos aterros e clientes, criar a matriz de custos de serviço (distância e tempo);

4) Open e close time: para cada aterro e cliente foi definido o horário de início e fim de expediente. Adotou-se inicialmente como sendo das $6 \mathrm{~h}$ às $18 \mathrm{~h}$, podendo ser alterado para que permita a otimização com uma nova roteirização;

5) Fixed time: para cada aterro define-se um tempo fixo, para que se realize o serviço de descarregamento dos resíduos do veículo, e para cada cliente, um tempo fixo de carregamento. Este tempo foi adotado como sendo de $20 \mathrm{~min}$ para os dois casos;

6) Time per unit: foi definido além do tempo fixo, um tempo variável por tonelada de RSU manipulado nas instalações. O valor adotado foi de $0,5 \mathrm{~min} / \mathrm{t}$ de resíduos sólidos;

7) Demand: para cada situação definida, através da análise de roteirização, variando a demanda média de resíduos para cada cliente, conforme o período e a semana padrão, foi possível dimensionar as rotas e programações para todas as condições ao longo dos 15 anos. Os valores utilizados de demandas dos resíduos foram obtidos do dimensionamento das coletas;

8) Vehicle Settings: Para dimensionar as rotas, o TransCAD trabalha com uma tabela de veículos, onde se especifica a capacidade de carga e a quantidade de cada modelo de veículo existente em cada aterro. A tabela utilizada nesta pesquisa é apresentada na FIGURA 7.9. Os tipos existentes de veículos foram levantados, pesquisando fornecedores.

9) Maximum Route Length: o TransCAD trabalha com restrições para as rotas, que podem ser o tempo de jornada de trabalho do motorista, a autonomia do tanque de combustível, etc. Neste trabalho foi adotado que o limitante de uma frota seria a jornada diária de trabalho de $7 \mathrm{~h} 20 \mathrm{~min}$.

Como resultado das análises de roteirização, dentro de cada situação definida, as rotas e a programação dos veículos foram encontradas para cada período e semana 


\begin{tabular}{|c|c|c|c|c|c|c|}
\hline \multicolumn{4}{|c|}{ IIIIVEICULO } & & & 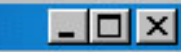 \\
\hline 口 & \multicolumn{2}{|c|}{\begin{tabular}{l|l|} 
ID & DEPOT_ID \\
\end{tabular}} & \multirow{2}{*}{$\begin{array}{l}\text { TYPE } \mid \text { MODELO } \\
11 \text { RANDON 45m3 13.5t }\end{array}$} & \multicolumn{2}{|c|}{ CAPAC_T/NUM_VEIC } & COST_RS \\
\hline \multirow{5}{*}{ - } & 1 & 101 & & 13.50 & 5 & 154000.00 \\
\hline & 2 & 101 & 28 EZC $200 / 259.60 t$ & 9.60 & $\mathbf{5}$ & 140440.00 \\
\hline & 3 & 101 & 12 GRIMALDI $12.5 t$ & 12.50 & 5 & 140000.00 \\
\hline & 4 & 101 & 13 GRIMALDI $25.0 \mathrm{t}$ & 25.00 & 2 & 173000.00 \\
\hline & 5 & 101 & 14 RANDON 55m3 16.5t & 16.90 & 5 & 175000.00 \\
\hline \multirow[t]{4}{*}{$\bullet$} & 6 & 101 & 0 Adaptado & 26.00 & 1 & 0.00 \\
\hline & 11 & 263 & 11 RANDON $45 \mathrm{~m} 313.5 \mathrm{t}$ & 13.50 & $\mathbf{5}$ & 154000.00 \\
\hline & 12 & 263 & 28 EZC $200 / 259.60 t$ & 9.60 & $\mathbf{5}$ & 140440.00 \\
\hline & 13 & 263 & 12 GRIMALDI $12.5 t$ & 12.50 & 5 & 140000.00 \\
\hline \multirow[t]{3}{*}{$\bullet$} & 14 & 263 & 13 GRIMALDI $25.0 \mathrm{t}$ & 25.00 & 2 & 173000.00 \\
\hline & 15 & 263 & 14 RANDON 55m3 16.5t & 16.90 & $\mathbf{5}$ & 175000.00 \\
\hline & 16 & 263 & 0 Adaptado & 28.00 & 1 & 0.00 \\
\hline
\end{tabular}

FIGURA 7.9 - Tabela com a frota de veículos por aterro e capacidade de carga de cada modelo.

padrão. Além disso, foi possível determinar a frota, a distância percorrida e o tempo gasto em cada rota. Estes últimos valores foram utilizados nas análises de custos.

Do mesmo modo que a localização, as roteirizações foram divididas também em duas frentes de trabalho descritas a seguir: com e sem ETs.

\subsubsection{Situações sem ET}

Para as situações definidas sem ETs, a roteirização foi mais simples, pois foi necessário analisar somente o caso do transporte de resíduos direto da cidade até os aterros com o veículo de coleta.

A roteirização consistiu apenas em determinar a rota e a programação de um veículo saindo da cidade, descarregando o veículo no respectivo aterro, e retornando à cidade. Esta análise foi apenas uma complementação do dimensionamento do serviço de coleta nas cidades. Com a roteirização, a distância percorrida e o tempo gasto por veículo na ida e volta do aterro foram obtidos. Nesta situação, não foi necessária a análise por período e semana padrão, pois já havia sido levada em consideração, quando se determinou a frota e o número de viagens através do dimensionamento da coleta. 


\subsubsection{Situações com ET}

Para cada situação definida com ETs, com os aterros já locados, foi avaliada inicialmente, a necessidade real das estações. Caso o aterro estivesse localizado muito próximo da estação, foi tomada a decisão de que o transporte seria realizado direto da cidade com os próprios veículos coletores, sem a necessidade de implantar uma estação. Esta condição fez com que se identificasse três linhas distintas de roteirização:

- o transporte direto aos aterros com o veículo de coleta;

- o transporte dos resíduos com o veículo de coleta até as ETs;

- o transporte com veículo de transbordo que sai do aterro e recolhe nas ETs.

Os dois primeiros casos caíram na situação do item anterior, sem ET. Já, o caso do transporte que recolhe os resíduos nas ETs, as análises foram realizadas para cada período e semana padrão, variando os valores de demanda de resíduos nas Ets, para cada caso. A quantidade diária a se recolher na estação é a média para cada semana padrão. Para isto ser possível, as estações foram dimensionadas considerando as sobras de resíduos na semana mais crítica no período de 15 anos.

\subsection{Dimensionamento das ETs}

Depois de definidas as configurações das ETs, compartilhadas ou não, estas foram dimensionadas. O dimensionamento constituiu em determinar a infraestrutura necessária e o respectivo custo com investimentos.

O tipo de ET escolhida para o projeto foi a com silo de acúmulo de resíduos. Para fazer a pesagem dos RSU, foi adotado que existiria um sistema com células de carga no próprio silo, de modo que houvesse o controle da quantidade recolhida diariamente em cada silo, bem como o depositado pelo veículo de coleta. O modelo de ET utilizado para os dimensionamentos bem como o silo, estão representados respectivamente nas FIGURA 7.10 e na FIGURA 7.11.

O princípio de funcionamento da ET é o mais simples possível. No carregamento do silo, o veículo coletor deposita os resíduos diretamente nos silos, e o responsável da estação marca o peso através da leitura no sistema de pesagem com células de car- 


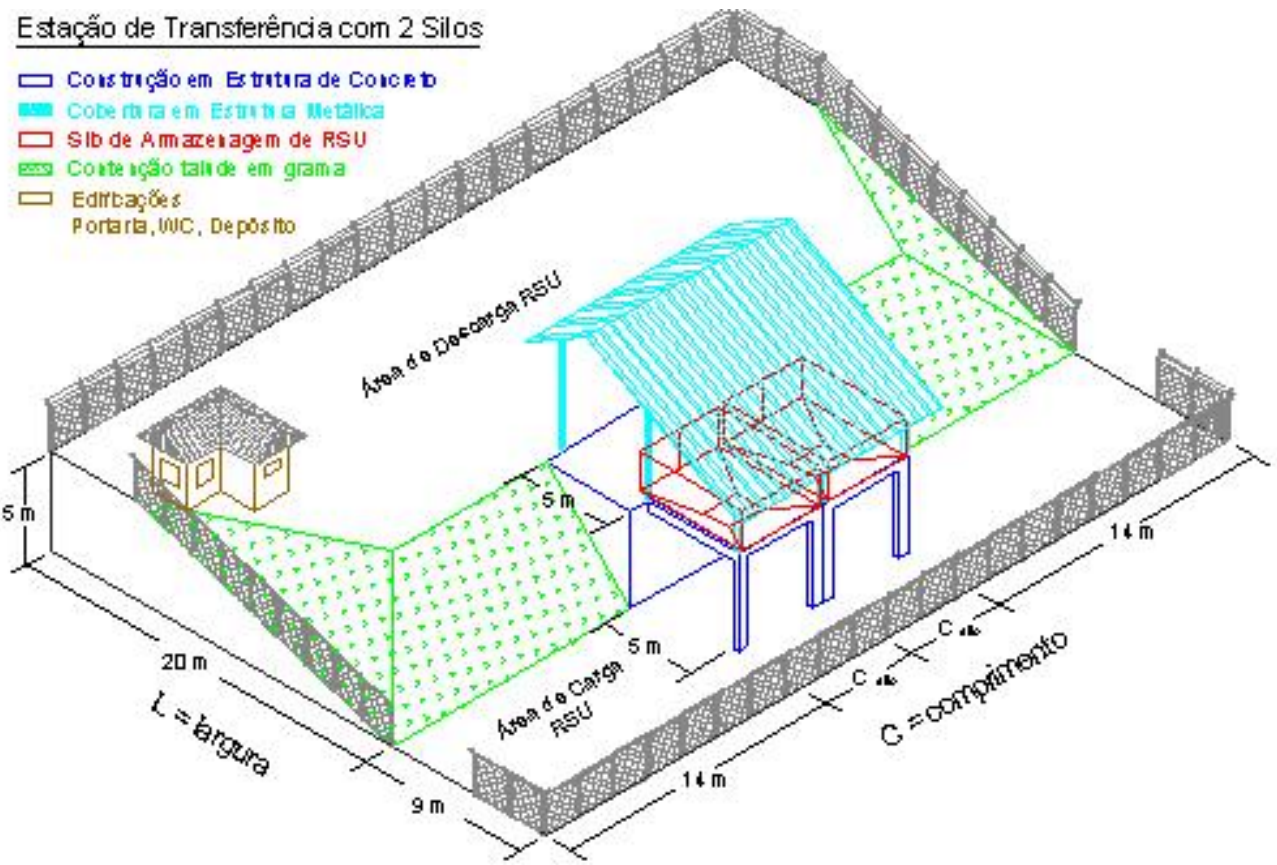

FIGURA 7.10 - Modelo criado para as ETs.

ga. E, no momento da descarga para o veículo de transbordo, o responsável controla a quantidade de resíduos transferidos verificando a leitura no sistema de pesagem. Como descrito anteriormente, a quantidade de resíduos recolhidos na estação será constante e de valor igual à média gerada na semana, o que implica em sobras nos dias de pico.

Desenho Esquemático do Silo
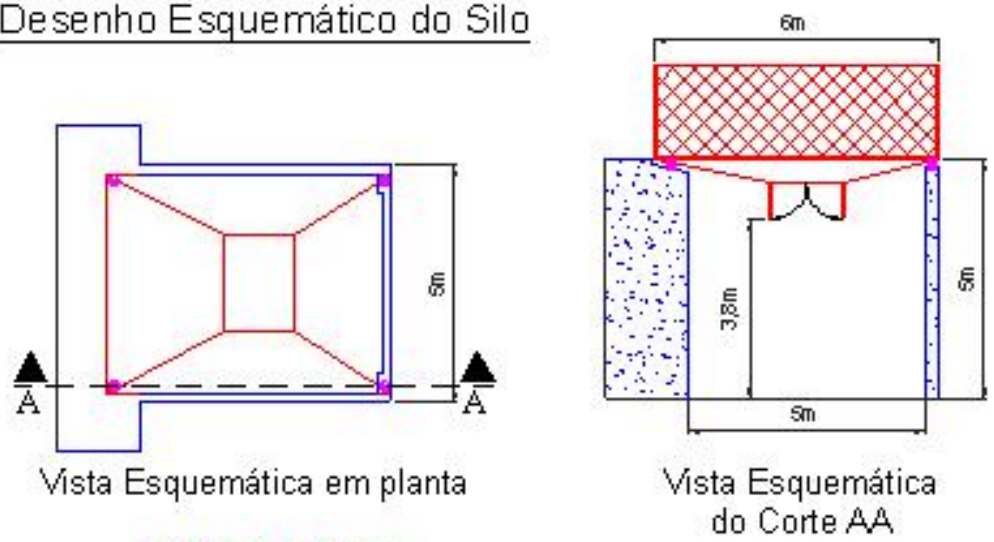

- Células de Carga

FIGURA 7.11 -Silo adotado no trabalho com sistema de pesagem acoplada. 
Para dimensionar a ET, o princípio básico está na capacidade de acúmulo dos silos para a situação crítica, dentro do planejamento de 15 anos. E, este crítico foi considerado como a produção de RSU na semana padrão $G$ do último ano, assim, a capacidade de acúmulo máximo do silo foi estimada considerando as sobras que permanecerão no dia de pico desta semana.

A principal diferença entre as ETs estava na quantidade de silos que cada uma necessitava. E o número de silos necessários para cada estação foi calculado de acordo com o volume de RSU destinado à estação, dividido pela capacidade de um silo. Os resíduos podem ter origem de uma cidade ou mais de uma, no caso da situação de estação compartilhada.

Para os cálculos, primeiro foi determinado o volume de RSU a ser acumulado na Estação, com base nos resultados do dimensionamento das coletas nas cidades. E depois, com base no modelo da FIGURA 7.10, foi calculada a necessidade de infraestrutura: áreas e construções. As componentes consideradas no dimensionamento das ETs foram desde a desapropriação do terreno até o sistema de pesagem com células de carga. A seguir as componentes adotadas estão descritas:

- Desapropriação do terreno: a área a ser desapropriada foi calculada com as medidas básicas indicadas no modelo da estação. E os valores de custos de desapropriação dos terrenos foram considerados como de lotes urbanos, pois foram locados próximos ao limite da zona urbana;

- Terraplenagem: foi considerado que existe uma inclinação natural na área de implantação da ET de aproximadamente $23 \%$ na direção da largura da estação. E, assim, foi calculado que haverá uma movimentação de terra de $27,3 \mathrm{~m}^{3}$ a cada metro linear no comprimento da estação;

- Cercamento: foi adotado o fechamento ao longo de todo o perímetro em alambrado de $2 \mathrm{~m}$ de altura, com mourões espaçados a cada $2,5 \mathrm{~m}$;

- Pavimentação: as áreas de circulação dos veículos de coleta e transbordo, carga e descarga de RSU respectivamente, foram dimensionadas com cobertura de pedregulho;

- Drenagem Superficial: canaletas de drenagem das águas pluviais foram adotadas ao longo de todo o perímetro, e para proteção dos taludes; 
- Estrutura de concreto do Silo: a estrutura do silo foi dimensionada com um muro de arrimo para contenção, e sobre ele foi colocado um piso para a descarga do RSU. E, para suportar os silos carregados, foram adotadas vigas, pilares e a fundação em bloco;

- Cobertura sobre a área do silo: foi considerada uma cobertura em estrutura de aço, com altura suficiente para o basculamento do caminhão coletor;

- Edificações: foram consideradas com áreas variáveis de acordo com o tamanho da estação. Além da portaria e sanitário, foi previsto um depósito para guardar materiais de limpeza da estação;

- Sistema de pesagem: o silo foi considerado com base em chapa maciça de aço com nervuras, e fechamento lateral com estrutura de alambrado. A altura dela foi limitada em $2 \mathrm{~m}, 50 \mathrm{~cm}$ acima da altura limite adotada para o RSU, que foi de $1,5 \mathrm{~m}$ para facilitar a movimentação do resíduo sem necessidade de equipamento pesado. E, sob cada silo, foi adotado um sistema com 4 células de carga ligadas a um visor para leitura do peso. O silo seria dotado de abertura inferior com dispositivo de fechamento mecânico que permita controlar a descarga de RSU.

Os valores adotados e os resultados destes dimensionamentos podem ser vistos nas planilhas desenvolvidas nesta pesquisa no APÊNDICE G. A maioria dos valores de custos foi tirada da revista CONSTRUÇÃO MERCADO (2002) da PINI. Alguns valores, como o custo de terrenos, foram obtidos consultando-se imobiliárias através de telefonemas, e outros custos foram obtidos junto a fornecedores. As consultas datam do $3^{\circ}$ bimestre do ano de 2002.

\subsection{Dimensionamento dos Aterros}

O método de dimensionamento utilizado para os aterros, diferiu em relação ao das ETs. No caso das estações, independente das situações definidas, as estações eram sempre as mesmas, servindo às mesmas cidades, assim o dimensionamento foi personalizado para cada estação. Já, no caso dos aterros, para cada situação nova definida, o grupo de cidades que destinavam os resíduos ao aterro variava, assim, preferiu-se fazer um dimensionamento generalizado para diversos aterros com faixas de capacidade variando em um intervalo de 0,5t/dia à 160t/dia de RSU. Isto também aju- 
daria na visualização do comportamento dos custos em relação ao tamanho dos aterros. Além disso, o trabalho de LIMA \& PIZA (1999) foi desenvolvido desta forma, tanto que foi utilizado como modelo para realizar os cálculos nesta pesquisa.

O dimensionamento desenvolvido para os aterros leva em consideração o crescimento da geração de RSU dentro dos 15 anos, utilizando-se a taxa média de crescimento da produção de resíduos (APÊNDICE E). Os cálculos deste crescimento da geração de resíduos ao longo dos anos, e o total produzido em 15 anos estão na Planilha 01a do APÊNDICE H. Como soluções, foram adotados dois tipos de aterros, primeiro, até a capacidade diária de 10t/dia, foi considerado o aterro sanitário em valas, e acima deste valor, o aterro sanitário convencional de superfície.

Para os dimensionamentos descritos na seqüência, foram adotados os parâmetros indicados pela CETESB em suas duas publicações sobre o assunto: Aterro Sanitário (SÃO PAULO, 1997a) e Aterro Sanitário em Valas (SÃO PAULO, 1997b). O trabalho de LIMA \& PIZA (1999) também serviu de guia para a adoção de métodos de cálculo deste trabalho.

\subsubsection{Aterro Sanitário em Valas}

O aterro sanitário em valas é um sistema simplificado, onde se evita altos gastos com equipamentos pesados alocados diariamente, ou sistemas de tratamento de percolados, que na maioria das vezes, para esta solução é dispensável, segundo a CETESB (SÃO PAULO, 1997b).

Para cada faixa de capacidade de recebimento diário de RSU do aterro, foi adotado uma vida útil da vala que variou de 28 dias à 3,5 dias, do menor aterro para o maior, respectivamente. Isto significa que a retroescavadeira tem um ciclo de visita ao aterro igual ao intervalo de tempo entre cada escavação de vala. No intervalo de tempo entre as escavações, o equipamento poderia ser utilizado para outras finalidades.

Basicamente, nesta solução adotada, não se considerou nenhum sistema de drenagem de gases, pois a CETESB (SÃO PAULO, 1997b) supõe que, devido à pequena profundidade das valas, o gás se dissipa naturalmente com o tempo. Baseado nesta mesma publicação da CETESB, não se adotou também nenhum sistema de drena- 
gem, impermeabilização da base do aterro e tratamento do percolado, pois, segundo esta instituição, cuidados como o correto sistema de drenagem das águas precipitadas, faz com que não haja formação suficiente do percolado para infiltrar no solo.

As valas foram consideradas com $3 \mathrm{~m}$ de profundidade e de largura, com comprimento variável segundo o ciclo de abertura de valas (vida útil), e a quantidade diária de resíduos. Para dimensionar a área útil do aterro, uma folga construtiva de $1,5 \mathrm{~m}$ foi considerada entre as valas (Planilha 02a e 02b do APÊNDICE H).

\subsubsection{Aterro Convencional}

Os cuidados tomados com o dimensionamento do aterro sanitário convencional, em relação a proteção ambiental, foram a consideração dos sistemas de drenagem de gases e percolados, a impermeabilização da base do aterro e o sistema de tratamento do percolado em lagoas de estabilização.

Para a determinação da área útil do aterro foi adotado o mesmo fator utilizado por LIMA \& PIZA (1999), o aproveitamendo do aterro $\left(A_{p}\right)$, que consiste na razão entre a quantidade de RSU depositada no aterro na vida útil de 15 anos pela área útil ocupada, ou seja: $A_{p}=C_{15} / A_{u}$. O aproveitamento adotado foi entre 3 a $8 \mathrm{t} / \mathrm{m}^{2}$, para aterros de 10t/dia a 160t/dia, respectivamente. Com a área útil e o volume total ocupado pelo RSU no formato de um cubo, calculou-se a altura do aterro, que foi utilizada para saber o comprimento dos tubos de drenagem dos gases. Mantendo-se a altura do aterro constante, o cubo foi transformado em formato de tronco de pirâmide, com talude a $45^{\circ}$, e assim, determinou-se um valor mais realista para a área útil do aterro (base). Com este novo valor de área útil, calculou-se as necessidades de impermeabilização da base do aterro, do volume de percolado a ser coletado e o seu sistema de drenagem.

\subsubsection{Componentes dos Dimensionamentos}

Além das áreas úteis ocupadas pelo aterro propriamente dito, outras áreas foram consideradas: áreas anexas e áreas entorno do aterro. As áreas anexas com as edificações, estações de tratamento do percolado e outras facilidades, foram adotadas e calculadas segundo o tamanho de cada aterro e suas necessidades, como pode ser visto 
na Planilha 01b do APÊNDICE H. E, além das áreas anexas, foi considerada uma área afastada da cerca de $10 \mathrm{~m}$ para circulação entorno do aterro.

Determinados a área total ocupada pelos aterros, foi realizado o dimensionamento das partes componentes, consideradas para os aterros: cerca, edificações, galpões, terraplenagem, acesso, drenagem superficial, drenagem de gases e percolado, impermeabilização da base do aterro, tanque de tratamento do percolado, desapropriação e equipamentos. Cada um dos itens é descrito a seguir:

- Desapropriação do terreno: a área a ser desapropriada foi calculada com relação a área total do aterro. E o custo dos terrenos foram considerados como de áreas rurais, pois estão locadas afastadas das cidades, que têm características rurais a sua volta;

- Terraplenagem: este é um item complicado de se determinar, dependendo de detalhes da topografia de cada aterro. E, como este projeto tem caráter estratégico, tal detalhamento não é necessário, mesmo porque, a avaliação real do local se faz em fases posteriores, quando se decide trabalhar no projeto, depois do estudo de viabilidade econômica. Como simplificação, adotou-se, do mesmo modo que LIMA \& PIZA (1999), um fator de volume movimentado por área. Sendo considerado, neste trabalho, o valor de $0,4 \mathrm{~m}^{3} / \mathrm{m}^{2}$;

- Cercamento: foi adotado o fechamento ao longo de todo o perímetro com 5 fios de arame farpado, com mourões espaçados a cada $2,5 \mathrm{~m}$;

- Acesso: para chegar até o aterro, foi considerada a construção de acesso com $8 \mathrm{~m}$ de largura com 100m de comprimento com cobertura de pedregulho;

- Drenagem Superficial: ao longo de todo o perímetro, para proteção dos taludes dos aterros convencionais, e para não ocorrer escoamento de água para dentro dos aterros em valas abertas, foram adotadas canaletas de drenagem das águas de chuva;

- Edificações e Galpão: foram consideradas com áreas variáveis de acordo com o tamanho e necessidade de cada aterro. Para os aterros, foram consideradas a necessidade de portaria, vestiário e sanitários, refeitórios, escritórios, depósitos fechados e galpão para veículos. Algumas destas facilidades não constaram em aterros de menor capacidade; 
- Impermeabilização da base do aterro: a solução adotada foi a de utilizar geomembrana mais simples ao longo de toda a base do aterro, com $30 \mathrm{~cm}$ de proteção mecânica em argila compactada sobre ela;

- Drenagem de gases: a forma adotada para a drenagem de gases, utilizado para o dimensionamento, foi a de tubos de concreto furado espaçados de $30 \mathrm{~m}$ e envolto por brita, ao longo de toda área útil do aterro, com uma sobra de $2 \mathrm{~m}$ em seu topo acima da altura do aterro. Os diâmetros dos tubos foram variados de $200 \mathrm{~mm}$ até $400 \mathrm{~mm}$, para os aterros de $10 \mathrm{t} / \mathrm{dia}$ até $160 \mathrm{t} / \mathrm{dia}$, respectivamente;

- Drenagem de percolado: o sistema adotado foi o de canaletas na forma de espinha de peixe, onde o dorso foi espaçado de $15 \mathrm{~m}$ entre elas, e as espinhas inclinadas de $45^{\circ}$ em relação ao dorso, também foram espaçadas de $15 \mathrm{~m}$. $O$ canal de drenagem foi considerado com seção retangular de $0,16 \mathrm{~m}^{2}$, preenchida por brita, e seu fundo e lateral protegidos com a geomembrana da impermeabilização da base do aterro;

- Sistema de Tratamento do Percolado: apesar de não ser a melhor solução, como simplificação, foram adotadas as lagoas de estabilização (anaeróbiafacultativa-estabilização), protegidas por $2 \mathrm{~mm}$ de geomembranas de Polietileno de Alta Densidade (PAD). O tamanho das lagoas foi dimensionado de acordo com o volume de percolado determinado através do Método Suíço, cuja formulação se encontra na Planilha 04 do APÊNDICE H.

Os valores adotados e os resultados destes dimensionamentos podem ser vistos nas planilhas desenvolvidas nesta pesquisa no APÊNDICE H. Os valores de custos adotados foram tirados na maioria da revista CONSTRUÇÃO MERCADO (2002) da PINI. Outros valores foram obtidos com consultas por telefone em imobiliárias e fornecedores, e datam do $3^{\circ}$ bimestre do ano de 2002.

\subsection{Cálculo dos Custos para cada Situação Definida}

Para se fazer as avaliações das situações definidas pelo método, foram analisados os custos, desde a operação de coleta nas cidades, passando pela ET, e o transporte com o caminhão de transbordo, até a operação nos aterros. Para se calcular estes custos, a planilha elaborada pela Fundação Getúlio Vargas (FGV), através de consul- 
toria para o Sindicato das Empresas de Limpeza Urbana (SELUR, 2001b), foi utilizada como referência.

A planilha da SELUR foi estudada linha a linha, e adaptada para esta pesquisa. Para o cálculo de custos, foram utilizadas as planilhas da FGV criadas para o serviço de coleta de RSU. Para calcular os gastos da operação de coleta, as planilhas foram utilizadas quase sem modificações, e nos casos das operações dos aterros, ETs e veículos de transbordo, as planilhas foram criadas como adaptações destas de coleta. A estrutura básica das planilhas da SELUR não foi alterada para nenhum dos casos, necessitando somente modificar a forma de entrada de alguns dados, como a frota, a jornada de trabalho (mão-de-obra) e equipamentos. Os resultados das planilhas foram padronizados na forma de custo unitário, para que as avaliações, por análise comparativa das situações, fossem feitas na etapa final deste método.

\subsubsection{Os custos considerados}

As planilhas foram preparadas para considerar os custos com gastos operacionais diretos e indiretos, além de despesas com gastos administrativos. Neste trabalho, foram seguidas as recomendações encontradas no trabalho da SELUR (2001a). A seguir, os tipos de gastos levados em conta estão descritos.

\section{i) Gastos operacionais diretos}

- Mão-de-obra operacional: foram incorporados gastos com salários, horas extras, encargos sociais, vale refeição, vale cesta, vale transporte, assistência médica e insalubridade, atendendo a Convenção Coletiva de Trabalho para o sindicato de Araraquara (SELUR, 2002);

- Veículos: considerou-se gastos com combustível, manutenção, pneus e câmaras, lubrificação e lavagem;

- Uniformes: para cada função foi escolhido um conjunto de vestimentas; 


\section{ii ) Gastos operacionais indiretos}

- Mão-de-obra de auxiliares, supervisores e fiscais: foram incorporados gastos com salários, horas extras, encargos sociais, vale refeição, vale cesta, vale transporte, assistência médica e insalubridade;

- Veículos: considerou-se gastos com consumo de combustível, manutenção, pneus e câmaras, lubrificação e lavagem;

\section{iii ) Depreciação e despesas de capital}

A depreciação e as despesas de capital incidem nos custos diretos e indiretos, sobre os equipamentos.

- Depreciação: a depreciação do equipamento incide sobre a parcela do investimento inicial $P$, sem o valor residual representado pelo percentual $k$ sobre $P$. A depreciação mensal foi obtida pelo método linear, de acordo com a fórmula (1-k) $\times P / n$, onde $n$ é o número de meses de vida útil do equipamento;

- Despesas de capital: isto representa o custo sobre o capital investido em equipamentos. Este gasto foi obtido através do Coeficiente de Remuneração $C$, sobre o capital investido $P$, que pode ser escrito na forma da EQUAÇÃO 7.1:

$$
C=\frac{2+(n-1) \times(k+1)}{24 \times n} \times j
$$

EQUAÇÃO 7.1

onde: $j$ é a taxa anual de juros de $12 \%$ a.a. (serviços de utilidade pública).

\section{iv ) Despesas administrativas}

- Gastos administrativos: este valor foi calculado como acréscimo percentual sobre todos os custos diretos e indiretos e demais despesas apresentadas anteriormente.

Os custos de implantação de aterros e ETs já haviam sido encontrados anteriormente nas fases de dimensionamento. Assim, os valores específicos para cada situação, foram obtidos desta análise anterior e inseridos nas planilhas de custos, para avaliação das diversas situações. 


\subsubsection{Planilhas elaboradas}

Para cada situação definida foi criado um arquivo com dez categorias de planilhas, sendo uma com o resumo dos dados de entrada para cada situação, seis comuns para todos com os dados independentes das situações, três com os cálculos para cada situação, e uma com o resumo dos custos e despesas alcançadas para cada situação.

\section{i) Planilha com resumo dos dados de entrada para caracterizar cada situação}

Esta planilha foi criada diferentemente da elaborada pela FGV (SELUR, 2001b), que não o tinha. Esta planilha teve a função de fornecer os valores específicos para cada situação na forma de dados de entrada nas planilhas de cálculo dos custos. Os dados nesta planilha foram sintetizados, dentro de cada situação, para cada "agrupamento" de municípios que destinam os RSU para um mesmo aterro. Esta planilha fornece os seguintes dados para cada aterro:

- Informações gerais: população urbana residente e quantidade mensal média de resíduos produzidos por período de dimensionamento (cada 5 anos), a produção diária média de RSU no primeiro ano, e a produção total de RSU nos 15 anos de planejamento;

- Operação com os veículos de coleta: jornadas de trabalho, horas extras, distância percorrida na coleta e até a ET (ou aterro) e frota, por período de dimensionamento (cada 5 anos);

- Operação com os veículos de transbordo: jornadas de trabalho, horas extras, distância média percorrida para percorrer as ETs e frota, por período de dimensionamento (cada 5 anos);

- Resumo do dimensionamento de cada aterro: custo unitário da implantação, quantidade de equipamentos necessários, as horas trabalhadas com os equipamentos calculadas com base na produtividade e jornada de trabalho. A produtividade foi adotada da literatura como sendo de 35 toneladas de resíduos por hora de trabalho (BRETAS, 1982), e de $25 \mathrm{~m}^{3}$ de vala escavada por hora para retroescavadeira (CARDOSO, 2002). Para os aterros em valas o único equipamento considerado foi a retroescavadeira, fazendo as valas a cada ciclo de escavação. No caso do aterro convencional, foi considerado o trator de esteira trabalhando segundo sua produtividade, além de uma retroescavadeira e 
um caminhão basculante auxiliando o trabalho em $50 \%$ das horas do trator de esteira;

- Resumo do dimensionamento para as estações: custo unitário de implantação de cada grupo de estações servindo seu respectivo aterro, custo do equipamento de pesagem para cada grupo de estações. Neste resumo não aparece a jornada de trabalho, ou seja, a mão-de-obra, pois foi considerada suficiente a presença de apenas um encarregado por estação em tempo integral.

Estes dados foram obtidos dos resultados das planilhas de dimensionamento das etapas anteriores deste método: dimensionamento da coleta, aterro e ET. Estas informações estão apresentadas da TABELA 9.13 até a TABELA 9.19 do capítulo 9.

A jornada de trabalho mencionada acima equivale a $7 \mathrm{~h}$ e $20 \mathrm{~min}$ de serviço. E ela é considerada nos cálculos, em número de jornadas necessárias para executar cada operação. Se todos os veículos de coleta dos municípios de um agrupamento, trabaIham no total 16 jornadas por dia, e a guarnição da coleta é formada de 1 motorista e 3 coletores, isto significa que haverá 16 motoristas e 48 coletores diariamente.

\section{ii ) Planilhas com dados gerais independentes das situações}

Estas planilhas são formadas por um total de seis, contendo os valores de salários, custos diversos de insumos, parâmetros, etc. Estas planilhas são as mesmas criadas pela FGV, a menos de alguns acréscimos que contemplam as operações nos aterros, nas ETs e no transbordo do RSU das estações para os aterros. As planilhas são descritas sumariamente a seguir:

- 1. Base: ela contempla os dados básicos obtidos das empresas associadas da SELUR, como consumo de combustível, vida útil de equipamentos, manutenção, etc.

- 2a. Encargos: esta planilha elaborada pela FGV, tem os valores dos encargos sociais no setor de limpeza urbana;

- 2b. Mão-de-obra: nesta planilha é determinada a composição salarial em conformidade com cada função, considerando o salário base, horas extras, insalubridade, vale cesta, vale transporte, vale refeição e convênio médico; 
- 3. Veículos e equipamentos: apresenta para cada veículo ou equipamento, o custo, a vida útil, o valor residual e a manutenção dentro da vida útil, gasto com IPVA, consumo de combustível, seguros e os valores de insumos (combustível, lubrificação, pneus e câmaras e lavagem);

- 4. Uniformes: especificação dos uniformes padrões para cada função, além do custo unitário de cada parte do uniforme;

- 5. Parâmetros: nesta planilha estão as porcentagens para absenteísmos e reserva de equipamento, além dos valores de taxas adotadas pelas empresas de limpeza urbana referentes aos impostos, remuneração de capital e administrativo (calculado à partir da planilha 1. Base).

Estas planilhas, com algumas adaptações para o estudo de caso deste trabalho, podem ser vistos no APÊNDICE K.

\section{iii ) Planilhas com os cálculos de custos para cada situação}

Estas planilhas são formadas por um total de três categorias. A primeira calcula todos os gastos referentes à operação com o veículo de coleta, a segunda com a operação de transporte por meio dos veículos de transbordo entre o aterro e as ETs. E, por último, na terceira planilha, são determinados os custos com a operação e implantação dos aterros e ETs. Neste método, utilizou-se uma planilha de cada categoria para analisar cada agrupamento (aterro e os municípios atendidos por ele), ou seja, no caso que existam 2 aterros em uma situação, serão necessários 2 planilhas de cada uma das 3 categorias para se chegar aos resultados. Na seqüência há uma breve descrição das planilhas.

- 6. Coleta: a seqüência de cálculo inicia-se com os custos diretos da operação de coleta, seguido dos custos indiretos de supervisão e fiscalização deste serviço. No final, são calculados os gastos com a operação de transporte dos resíduos após a coleta urbana, ou seja, o deslocamento do veículo carregado até uma ET ou direto para o aterro. O cálculo desta operação não foi realizado em planilha isolada da coleta propriamente dita, pois, como o veículo utilizado é o mesmo, existem despesas que não são divisíveis, como seguros, depreciação e remuneração de capital sobre este equipamento. E, a mão-de-obra também é a mesma, não tendo uma jornada de trabalho isolada para cada operação. 
Dentro desta planilha foi possível separar apenas os custos diretos, entre as operações de coleta e transporte de RSU depois da coleta, para análise comparativa entre as situações definidas na fase final deste método;

- 7. Transbordo: Aterro $\rightarrow$ ETs $\rightarrow$ Aterro: esta planilha contempla os custos com o transporte dos resíduos, com veículos de maior capacidade que recolhem os resíduos nas ETs e destinam para os aterros. Os veículos são locados nos aterros. Da mesma forma que a planilha anterior, são determinados os gastos diretos da operação e indiretos, com um fiscal desta operação para cada agrupamento de municípios;

- 8. Aterro e ET: para a operação da ET foi necessário considerar apenas o custo direto de um encarregado, a depreciação e o custo de capital do sistema de pesagem no silo. No caso da operação do aterro, além de um encarregado, foi considerada a mão-de-obra direta para operar os equipamentos (trator de esteira, retroescavadeira e caminhão basculante). Todos os equipamentos também tiveram a depreciação e remuneração de capital considerados nos custos com a operação dos aterros. No final desta planilha, são apresentados os custos de implantação de aterros e ETs para cada agrupamento, obtidos com base nos dados de entrada contidos na planilha descrita anteriormente no item 7.13.2.i ).

As planilhas, exemplificando os cálculos de custos para a Situação 11, podem ser consultados no APÊNDICE K.

\section{iv ) Planilhas com resumo dos custos e despesas alcançadas para cada situação}

Esta planilha resume todos os custos calculados, operacionais e de implantação, diretos e indiretos. Os resultados são apresentados divididos qualitativamente segundo a área dos gastos: coleta, transporte após a coleta, transporte de transbordo, operação de aterro e ET, e implantação do aterro e ET. E, quantitativamente, os custos são apresentados por mês ou por tonelada de resíduos, em cada período de 5 anos. Estes resultados também são detalhados para cada agrupamento (aterro), com o custo total além do custo unitário. A planilha resumo obtido para a Situação 11 pode ser vista no APÊNDICE K. 


\subsection{Avaliação das situações definidas}

Terminado o cálculo dos custos através das diversas planilhas, a avaliação das situações definidas foi realizada. Como cada situação é composta de um arquivo Excel, cada qual possuindo as suas planilhas, foi criado outro arquivo em Excel, juntando-se todas as planilhas de resumos dos resultados de cada situação calculada. A análise realizada constituiu-se em confrontar os custos unitários de todas as situações. A primeira avaliação que pode ser feita é verificar qual a situação de menor valor. A segunda análise, caso seja possível, é averiguar se existe uma situação intermediária que represente o mínimo, ou seja, se não existe outra situação definida, com mais ou menos aterros, cujo custo possa ser menor, dentro dos parâmetros e premissas adotadas no método.

Outras análises podem ser feitas, mas qualitativamente, como examinar o comportamento de cada componente de custo com a variação no número de aterros. Verificar o comportamento das situações definidas com e sem ET, de acordo com o número de aterros, também é possível.

O método aqui desenvolvido permite diversas análises, e mais completas do que a avaliação de um dos componentes do custo, o que normalmente se encontra na literatura. Pois, o sistema como um todo pode ser analisado, mesmo que em alguns casos, os resultados se baseiem em algumas simplificações e inferências. Porém, a incerteza será considerada igualmente entre todas as situações, podendo ser compensadas em uma análise comparativa. 


\section{ESTUDO DE CASO}

Neste capítulo, a área escolhida é exposta, além dos motivos que levaram a esta escolha. Além disso, são apresentadas algumas peculiaridades na aplicação do método desenvolvido para a área deste estudo de caso.

\subsection{A Área Escolhida como Estudo de Caso}

As Áreas de Proteção Ambiental (APAs) são instrumentos da política ambiental, estabelecidas pela Legislação Federal da Política Ambiental: Leis 6.902/81 e 6.938/81 (SÃO PAULO, 1990). As APAs têm como objetivo maior contribuir para a preservação de ecossistemas indispensáveis à sobrevivência de significativas espécies naturais. Deste modo, as ações exercidas nestes locais devem ser orientadas pela maior preo-

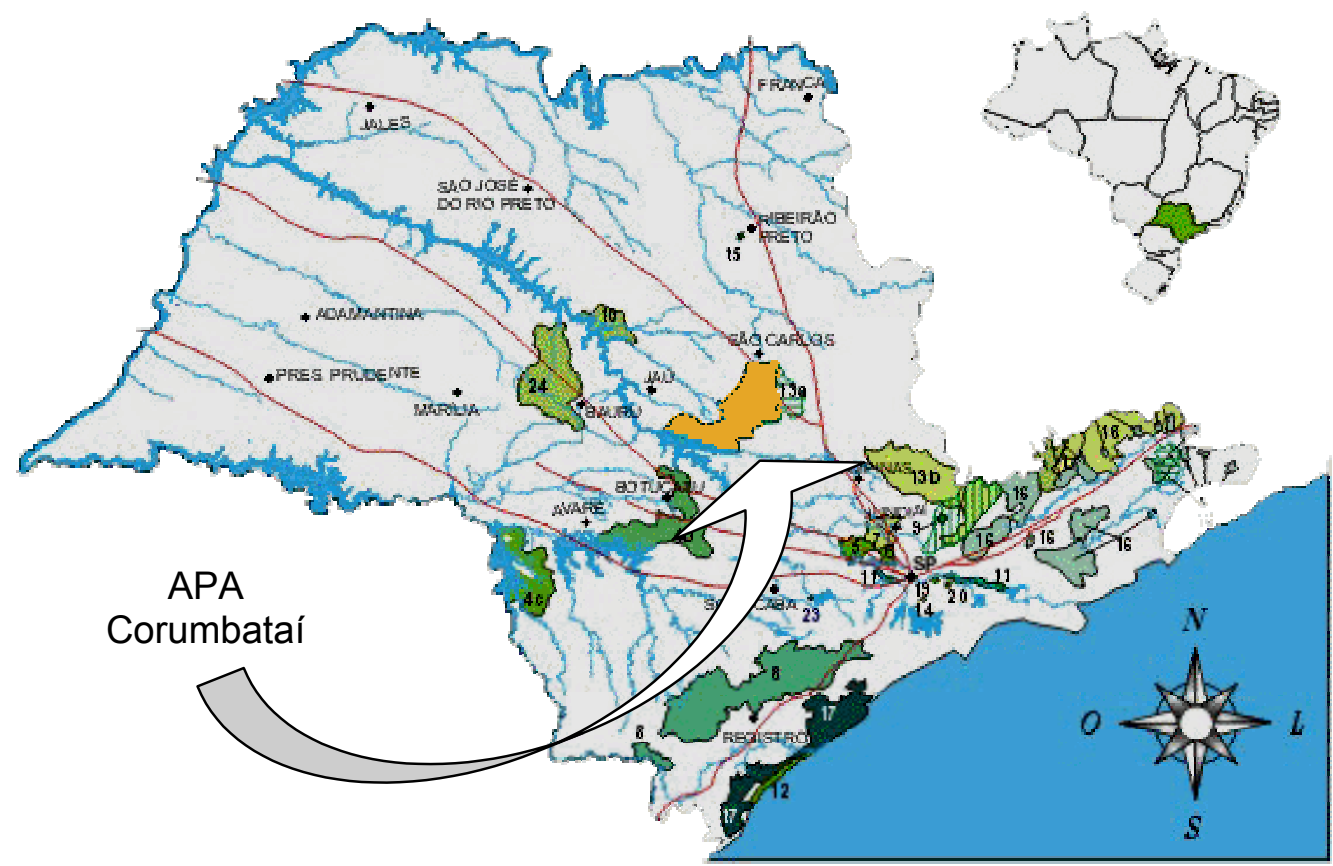

Fonte: http://www.ambiente.sp.gov.br/apas/apa.htm (SÃO PAULO, 2001a)

FIGURA 8.1 - Localização da APA de Corumbataí 
cupação com o disciplinamento do uso e ocupação do solo do que em outros locais. Dentre estas preocupações está a correta disposição e tratamento dos resíduos sólidos.

A APA de Corumbataí, criada pelo Decreto Estadual $n^{\circ}$ 20.960/83 (SÃO PAULO, 1983), localizada na região central do Estado de São Paulo (FIGURA 8.1), é formada por partes de áreas de municípios, dentre estes, 12 municípios foram considerados neste estudo de caso. Além destes municípios, o município de Águas de São Pedro foi incluído neste trabalho, que apesar de estar fora dos limites da APA, está dentro do município de São Pedro, onde destina seu RSU. Estes municípios geram, em média, menos que 10 toneladas por dia, e eles estão representados na FIGURA 8.2. Destes municípios, nenhum dispunha adequadamente seus resíduos em 1997, sendo a situação da destinação de resíduos inadequada ou controlada. Segundo a SMA (SÃO PAULO, 2001b), a condição controlada significa que o município atende às exigências mínimas em termos locacionais, mas implica em significativo potencial de poluição ambiental. Em 2000, houve uma pequena melhora, porém 10 dos 13 municípios, ou

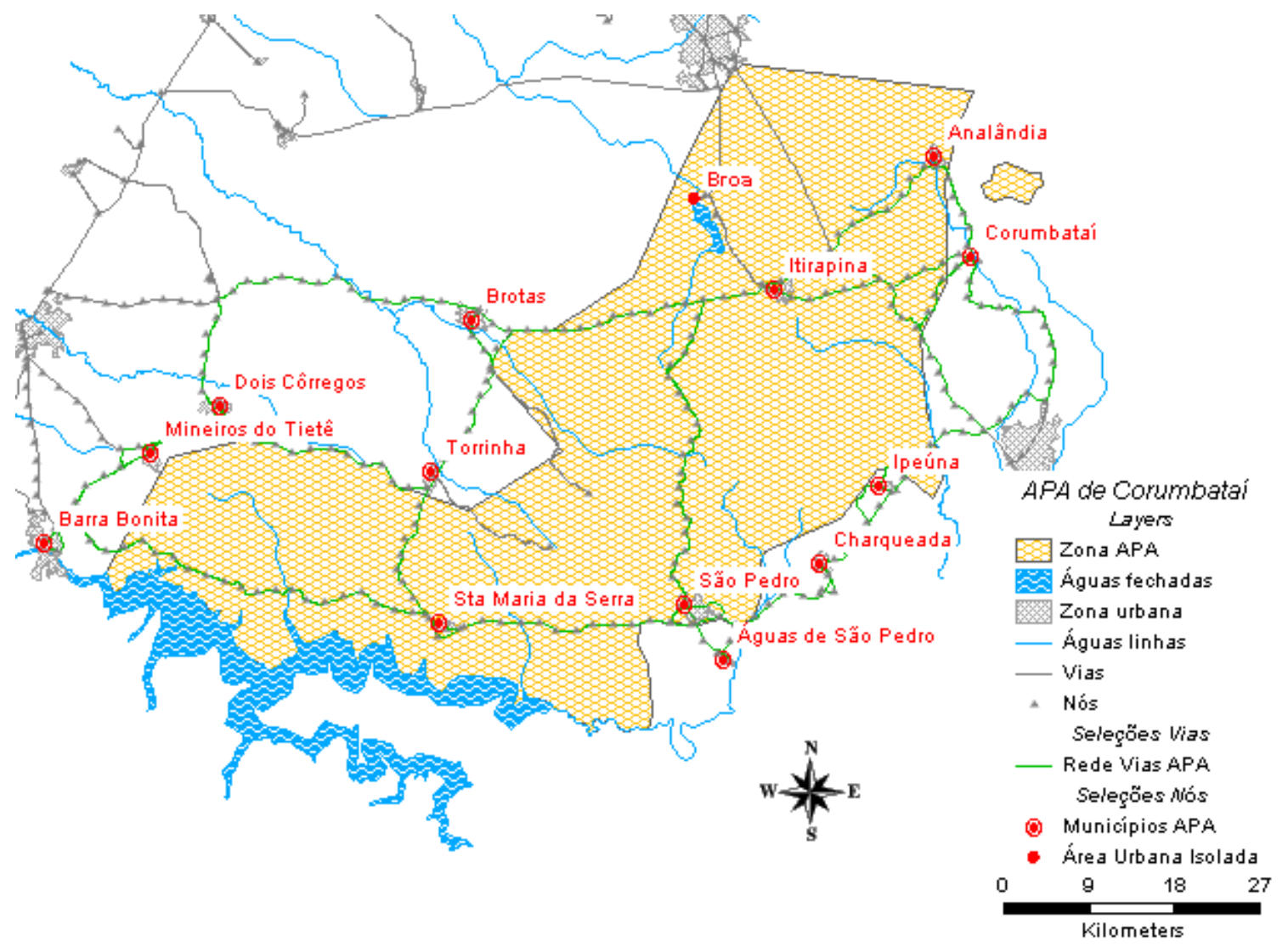

FIGURA 8.2 - APA de Corumbataí 
TABELA 8.1 - A avaliação da condição de destinação final de RSU na APA de Corumbataí

\begin{tabular}{|c|c|c|c|c|c|c|c|c|c|c|}
\hline \multirow{3}{*}{$\begin{array}{c}\text { Cidade } \\
\text { Águas de São Pedro }{ }^{(1)}\end{array}$} & \multirow{3}{*}{$\begin{array}{l}\begin{array}{l}\text { Pop. Urbana } \\
\text { Residente } 2003 \\
\text { (hab) }\end{array} \\
1.964\end{array}$} & \multirow{3}{*}{$\begin{array}{l}\begin{array}{l}\text { Produção } \\
\text { RSU 2003 } \\
\text { (t/dia) }\end{array} \\
2,42\end{array}$} & \multicolumn{8}{|c|}{$\mathrm{IQR}^{(2)}$} \\
\hline & & & \multicolumn{2}{|c|}{1997} & \multicolumn{2}{|c|}{1998} & \multicolumn{2}{|c|}{1999} & \multicolumn{2}{|c|}{2000} \\
\hline & & & 0,0 & 1 & 2,7 & 1 & 4,3 & 1 & 4,3 & 1 \\
\hline Analândia & 2.764 & 1,88 & 3,9 & I & 6,7 & C & 6,3 & C & 6,3 & C \\
\hline Barra Bonita & 36.022 & 19,05 & 3,1 & I & 3,8 & I & 3,1 & 1 & 3,2 & I \\
\hline Brotas & 16.820 & 9,98 & 4,4 & 1 & 7,3 & C & 8,3 & A & 8,8 & A \\
\hline Charqueada & 12.223 & 6,47 & 6,3 & C & 9,1 & A & 9,2 & A & 9,2 & A \\
\hline Corumbataí & 1.792 & 0,94 & 3,7 & 1 & 6,2 & C & 8,2 & A & 8,2 & A \\
\hline Dois Córregos & 21.102 & 11,01 & 4,2 & 1 & 7,3 & C & 8,9 & A & 7,7 & C \\
\hline Ipeúna & 3.594 & 2,18 & 5,5 & 1 & 6,6 & C & 7,3 & C & 7,3 & c $-1-a+a$ \\
\hline Itirapina & 11.659 & 7,72 & 2,0 & 1 & 6,2 & C & 2,2 & 1 & 2,2 & I \\
\hline Mineiros do Tietê & 11.433 & 6,14 & 5,3 & 1 & 6,7 & C & 5,8 & 1 & 5,5 & I \\
\hline Santa Maria da Serra & 4.120 & 2,09 & 6,1 & C & 8,0 & C & 7,5 & C & 7,5 & c \\
\hline São Pedro & 23.397 & 13,37 & 0,0 & 1 & 2,7 & 1 & 4,3 & 1 & 4,3 & I \\
\hline Torrinha & 7.602 & 3,91 & 2,9 & 1 & 4,5 & 1 & 6,9 & C & 6,6 & $\mathrm{C}$ \\
\hline TOTAL: & 154.491 & 87,18 & & & & & & & & \\
\hline
\end{tabular}

seja, $70 \%$ ainda continuavam em situação de não adequação. Estes municípios de pequeno porte, com os dados de população e da produção de RSU, estimadas para 2003, podem ser vistos na TABELA 8.1, assim como a avaliação da condição da disposição final dos resíduos de acordo com a SMA (SÃO PAULO, 2001b).

Como os municípios citados anteriormente, estando dentro de uma APA, apresentam problemas para destinar os resíduos de forma adequada, devido à dificuldade de solucionar os problemas isoladamente já que são de pequeno porte, estes foram escolhidos para se realizar o estudo de caso desta pesquisa.

\subsection{Considerações na aplicação do método}

Todas as considerações realizadas para desenvolver o trabalho com os municípios da APA de Corumbataí seguiram os procedimentos descritos no capítulo do método. Apenas no que consiste a base para o processo de cálculo, escolheu-se que o consórcio funcionaria de forma que cada aterro, com seu grupo de municípios, formasse um 
consórcio independente, dividindo seus custos de acordo com o que cada município produzisse de resíduos. Independente da condição, se estes formariam ou não uma sociedade civil, os consórcios foram considerados sem fins lucrativos.

Como foi destacado em capítulos anteriores, após a fase de importação do arquivo com dados espaciais da APA de Corumbataí do AutoCAD para O TransCAD, fez-se a verificação da qualidade da informação obtida, através de duas comparações.

A primeira comparação consistiu em verificar a diferença das coordenadas oficiais de longitude e latitude conhecidas das sedes dos municípios da APA com aquelas fornecidas pelo TransCAD, após a importação. Através da análise das coordenadas, chegou-se a diferença média no posicionamento das localidades de 0,70 km, e diferença máxima de 1,18 km para um dos municípios (APÊNDICE F). Ao se comparar a diferença média com a distância euclidiana mínima entre as cidades, de $27,0 \mathrm{~km}$, concluise que equivale a um percentual de apenas $2,59 \%$. Caso se compare com a distância euclidiana média de $166,8 \mathrm{~km}$, verifica-se que o percentual é de apenas $0,42 \%$.

A segunda comparação consistiu em confrontar as distâncias em rede entre cidades, obtidas do TransCAD, com os valores de quilometragem obtido através da leitura do hodômetro do carro, nas visitas realizadas em algumas das cidades para obtenção de dados. No caso das distâncias, a diferença média resultante foi de 1,33 km e máxima de 2,58 km (APÊNDICE F), ou em outros parâmetros, a diferença média em relação à distância total medida foi de $5,02 \%$ e a máxima de $12,11 \%$.

Presumindo que na análise global do sistema, estes erros são absorvidos pela inexatidão da localização das instalações e inexistência da malha urbana, a importação foi considerada satisfatória para a presente pesquisa. A diferença média de 1,33 km vem confirmar também, que a localização dos nós candidatos para os aterros na rede viária, realizada a cada $2 \mathrm{~km}$, é razoável, pois valores menores já estariam dentro das grandezas dos erros encontrados.

Na etapa subseqüente à importação dos dados no TransCAD, foram definidas 8 situações possíveis para se fazer a avaliação do sistema consorciado no estudo de caso. Este número foi definido de acordo com o método, e foi considerado adequado quando 
TABELA 8.2 - As ETs definidas e municípios atendidos

\begin{tabular}{ll}
\hline \multicolumn{1}{c}{ ETs } & \multicolumn{1}{c}{ Municípios } \\
\hline ET Barra Bonita & Barra Bonita \\
ET Brotas & Brotas \\
ET Charqueada & Charqueada \\
ET Corumbataí & Analândia, Corumbataí \\
ET Dois Córregos & Dois Córregos \\
ET Ipeúna & Ipeúna \\
ET Itirapina & Itirapina e Broa (bairro isolado) \\
ET Mineiros do Tietê & Mineiros do Tietê \\
ET Santa Maria da Serra & Santa Maria da Serra \\
ET São Pedro & Águas de São Pedro, São Pedro \\
ET Torrinha & Torrinha \\
\hline
\end{tabular}

tivesse resultados suficientes para se fazer uma avaliação consistente. As 8 situações foram divididas em 4 com e 4 sem ETs. E, estas situações foram subdividas, cada qual em casos com 1 a 4 aterros. De acordo com a codificação apresentada anteriormente, as situações definidas foram: 11, 12, 13, 14, 21, 22, 23 e 24.

Nas situações definidas com ETs, foi considerado que algumas cidades trabalhassem compartilhadas, visto que existe uma proximidade geográfica adequada e a produção de RSU era muito pequena, e não justificaria uma estação para cada uma. A TABELA 8.2 apresenta as configurações definidas para as ETs. Lembrando que, nos casos em que $o$ aterro fosse localizado próximo a alguma cidade, esta trabalharia sem uma ET e faria a destinação dos RSU diretamente ao aterro com os veículos de coleta. Para a análise de localização de aterros, foi considerado que o nó que representava cada cidade seria a referência da localização das estações. Somente após localizados os aterros, definiu-se em qual nó, fora da cidade, seria mais conveniente a instalação das estações, dada a proximidade do aterro à qual se destinaria os resíduos.

Com o mesmo intuito de evitar a ociosidade, para se definir a frota necessária para fazer a coleta nas cidades, foi estudada a possibilidade de que a frota de uma cidade trabalhasse em outra, sem prejuízo na qualidade do serviço. Analisando o tempo de coleta dentro de cada cidade e do deslocamento da frota entre cidades, foi possível verificar que as cidades de Analândia e Corumbataí, bem como São Pedro e Águas de São Pedro, puderam ter frotas em comum. 
$\mathrm{Na}$ análise de custos da coleta, foi verificado que os parâmetros de manutenção como sendo de $85 \%$ do valor dos veículos de coleta em uma vida útil de 60 meses, indicada pela SELUR (2001a), não condizia com a realidade do nosso estudo de caso. Bem como a adoção do valor residual, considerado de $22 \%$, dentro desta mesma vida útil. Esta conclusão foi tirada, sabendo-se que estes parâmetros foram estimados com base em dados de empresas que trabalham em grandes centros urbanos, ou seja, com 2 a 3 turnos de trabalho por dia. $\mathrm{E}$, as pequenas cidades deste estudo de caso podem chegar a não completar uma jornada para a coleta dos resíduos. Assim, como a manutenção e o valor residual do equipamento são função do tempo de trabalho do equipamento, para simplificação, foi adotada uma vida útil de 120 meses, o dobro do indicado pela SELUR (2001a), mantendo-se os parâmetros de manutenção e valor residual dos veículos.

\subsection{Informações da área de estudo}

As informações básicas levantadas para as cidades da APA de Corumbataí encontram-se divididas de acordo com o assunto nos apêndices localizados no final desta dissertação.

No APÊNDICE B encontra-se exemplificado, o dimensionamento da coleta com os parâmetros adotados.

No APÊNDICE C encontram-se as estimativas da população urbana residente e flutuante das cidades, para o período que inclui os 15 anos de planejamento.

No APÊNDICE D está apresentada a capacidade produtiva diária de RSU das populações residente e flutuante, estimadas para o horizonte de planejamento de 15 anos.

No APÊNDICE E pode ser vista a produção média (anual, mensal e diária) de RSU estimada para cada município, para os 15 anos de planejamento, e a respectiva taxa de crescimento médio da produção de RSU. 
No APÊNDICE F estão as coordenadas geográficas oficiais de latitude e longitude, e a distância entre as cidades da APA de Corumbataí, bem como aquelas obtidas no TransCAD após a importação do arquivo do AutoCAD.

No APÊNDICE G e APÊNDICE H, encontram-se os parâmetro adotados no dimensionamento das ETs e dos aterros, respectivamente.

No APÊNDICE K são apresentados os parâmetros adotados nas planilhas de cálculo de custos. 


\section{RESULTADOS E DISCUSSÕES}

Os resultados desta pesquisa podem ser divididos em intermediários e final. Os resultados parciais são aqueles que apóiam outras fases do método até chegar a resolução final, que são as comparações dos custos obtidos para cada situação. Neste capítulo são apresentados os resultados obtidos e a sua discussão.

\subsection{Resultados Intermediários}

As etapas intermediárias, não menos importante que os resultados finais desta pesquisa, podem ser organizado da seguinte forma: dimensionamentos, localização de aterros e roteirização dos veículos.

\subsubsection{Dimensionamentos}

Os itens dimensionados, como visto previamente, são o dimensionamento da coleta, dos aterros e das ETs. Os resultados sumarizados da coleta, em número de veículos necessários para fazer a coleta, número de viagens e tempo de coleta em horas de jornada de trabalho, estão na Planilha 04 do APÊNDICE B. E, os resultados dos dimensionamentos dos aterros e as ETs, em termos de infraestrutura necessária e custo com investimentos, estão no APÊNDICE H e APÊNDICE G, respectivamente.

A solução encontrada para o dimensionamento das estações não pode ser validada com valores reais, pois segundo a autora COSTA (1998) que fez o estudo deste tipo de instalações, as menores estações seriam de capacidade para movimentação por volta de100 t/dia de RSU. Assim não existiam referências, pois nesta pesquisa, a maior estação tem capacidade de 45 t/dia. Porém, considerando que foi utilizado o mesmo 


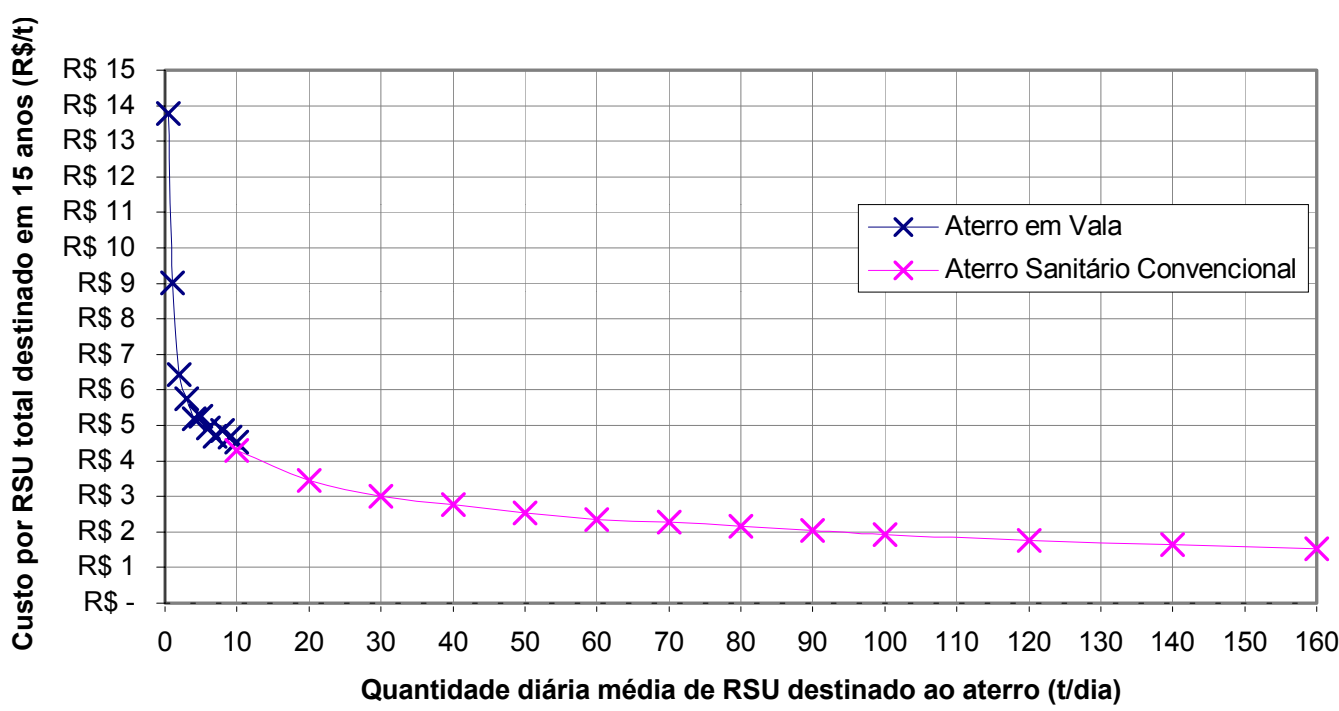

FIGURA 9.1 - Custo de Implantação de Aterro Sanitário (sem equipamentos) raciocínio do dimensionamento dos aterros, cujos resultados puderam ser avaliados, possivelmente os valores encontrados para as ETs não fogem muito da realidade.

Os resultados atingidos para os aterros puderam ser comparados com os do trabalho

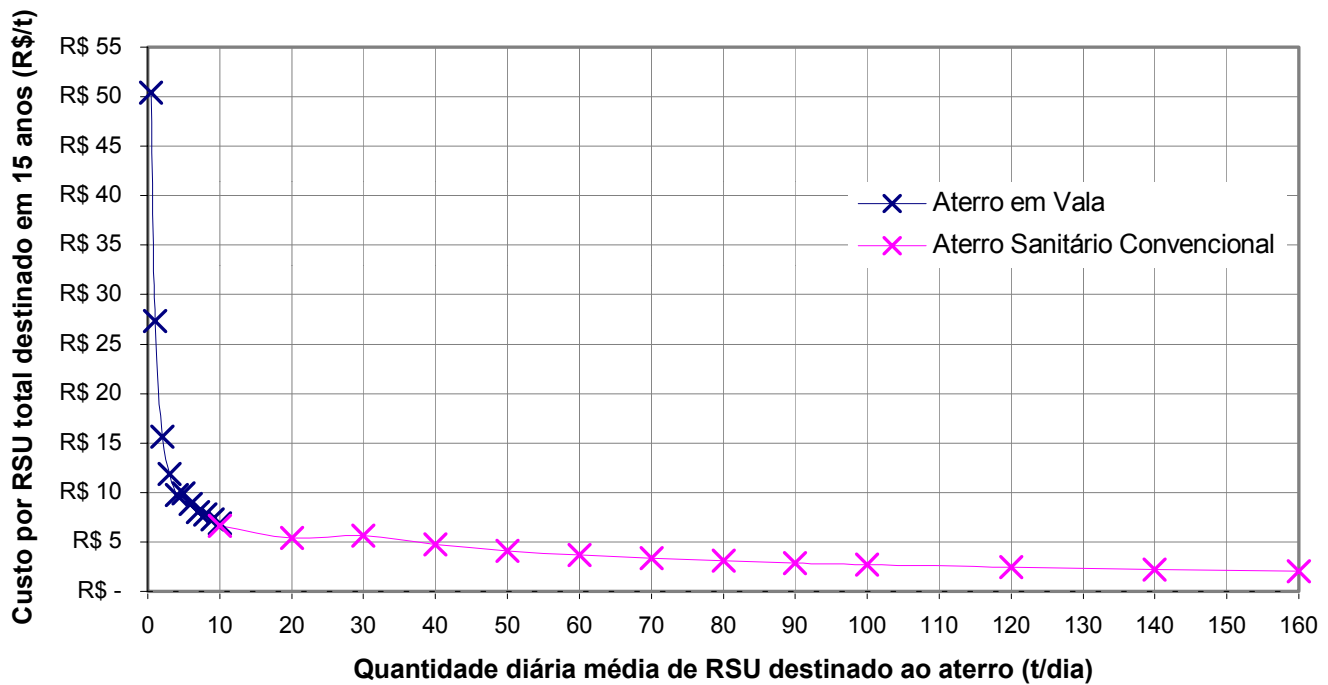

FIGURA 9.2 - Custo de Implantação de Aterro Sanitário (com equipamentos) 
de LIMA \& PIZA (1999), na qual foi baseado o dimensionamento nesta pesquisa. Os autores apresentaram um gráfico, como o representado na FIGURA 9.1, e as ordens de grandeza foram as mesmas. Por exemplo, para os aterros de 10t/dia, chegaram a um valor em torno de $\mathrm{R} \$ 4,5 / \mathrm{t}$ de RSU para o caso de aterro em vala, e $\mathrm{R} \$ 4,0 /$ t para aterro convencional. No resultado desta pesquisa, estes valores foram de $R \$ 4,53 / \mathrm{t} e$ $\mathrm{R} \$$ 4,30/t, respectivamente. A FIGURA 9.2, apresenta os custos da FIGURA 9.1 acrescido apenas dos custos de equipamentos utilizados nos aterros.

\subsubsection{Localização dos aterros}

As situações tiveram suas configurações definidas através da análise de localização dos aterros. A rotina logística de localização do TransCAD definiu para cada situação, onde estariam locados os aterros e quais clientes (estações ou cidades) seriam atendidos por eles, e com o menor custo logístico, representado pela menor distância total entre os aterros e seus respectivos clientes. As situações obtidas estão apresentadas nas TABELA 9.1 até TABELA 9.8 e FIGURA 9.3 até FIGURA 9.10, ilustrando para cada uma delas, a divisão das estações e cidades. Os relatórios fornecidos pelo TransCAD podem ser consultados no APÊNDICE I.

Para as situações com ETs, estão indicadas as sedes urbanas, para qual ET que cada uma das sedes destina os resíduos, e das ETs, para qual aterro. Quando a sede destina o RSU direto ao aterro, esta é indicada também.

Nas figuras, as ETs já estão ilustradas nos nós definidos após a análise de localização, que foi realizada considerando que ela estaria locada inicialmente, para efeito de cálculo, nos centros geográficos das sedes urbanas. 
TABELA 9.1 - A configuração obtida para a Situação 11

\begin{tabular}{llc}
\hline \multicolumn{1}{c}{ Municípios } & \multicolumn{1}{c}{ ETs } & Aterro \\
\hline Barra Bonita & ET Barra Bonita & \\
Brotas & ET Brotas & \\
Charqueada & ET Charqueada & \\
Analândia, & ET Corumbataí & Aterro 01 de 01 \\
Corumbataí & ET Dois Córregos & \\
$\begin{array}{l}\text { Dois Córregos } \\
\text { Ipeúna }\end{array}$ & ET Ipeúna & \\
Itirapina & ET Itirapina & \\
Itirapina - Broa & ET Mineiros do Tietê & \\
Mineiros do Tietê & ET Santa Maria da Serra & \\
Santa Maria da Serra & Éguas de São Pedro, & ET São Pedro \\
São Pedro & $\quad$ - direto para aterro - \\
Torrinha &
\end{tabular}

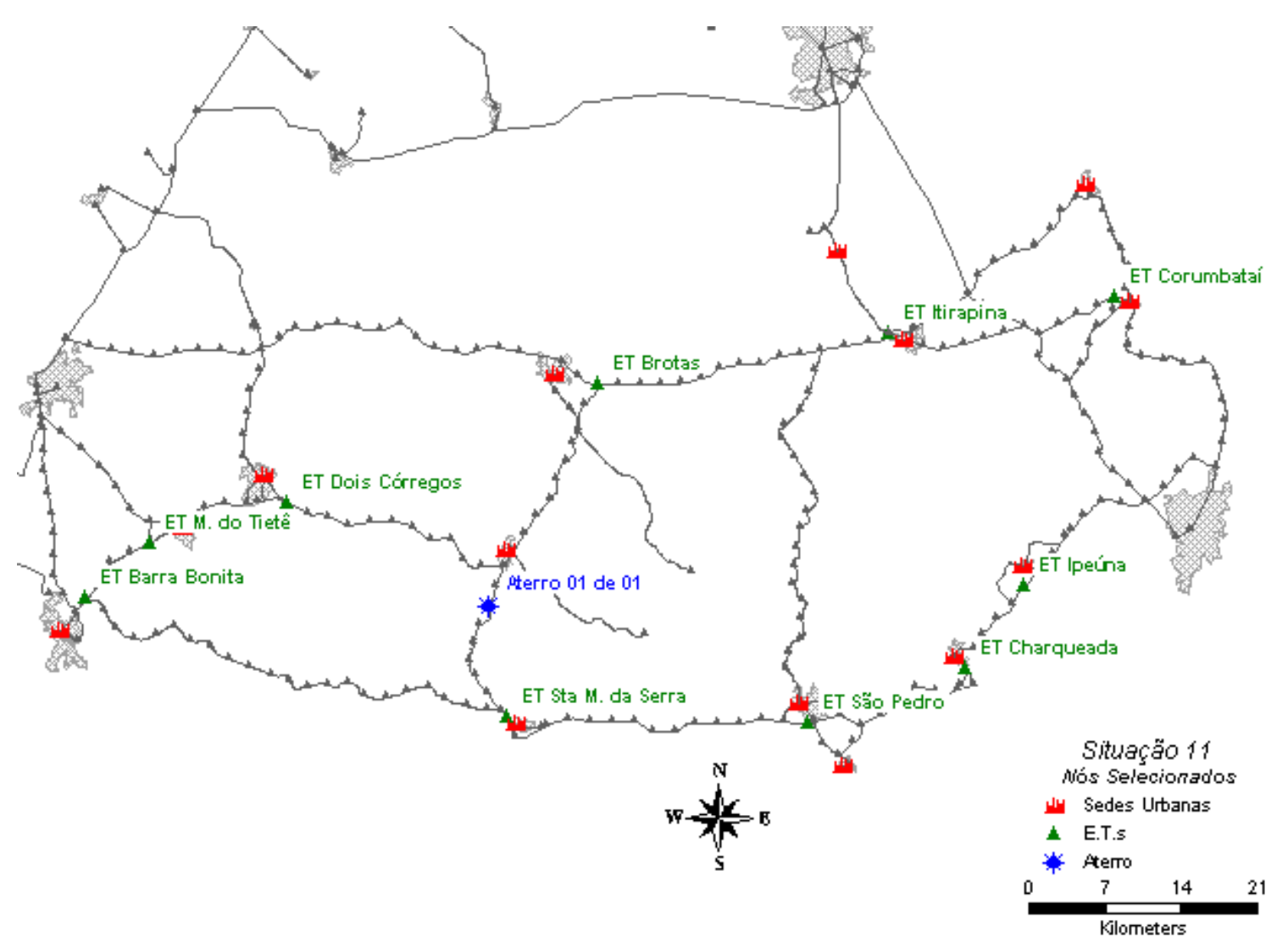

FIGURA 9.3 - A configuração obtida para a Situação 11 
TABELA 9.2 - A configuração obtida para a Situação 12

\begin{tabular}{lll}
\hline \multicolumn{1}{c}{ Municípios } & \multicolumn{1}{c}{ ETs } & Aterros \\
\hline $\begin{array}{l}\text { Barra Bonita } \\
\text { Mineiros do Tietê }\end{array}$ & ET Barra Bonita & \\
$\begin{array}{l}\text { Dois Córregos } \\
\text { Brotas }\end{array}$ & $\begin{array}{l}\text { ET Mineiros do Tietê } \\
\text { ET Dois Córregos }\end{array}$ & Aterro 01 de 02 \\
$\begin{array}{l}\text { Torrinha } \\
\text { Santa Maria da Serra }\end{array}$ & ET Torrinha & \\
\hline $\begin{array}{l}\text { Itirapina } \\
\text { Itirapina - Broa }\end{array}$ & ET Itirapina & \\
$\begin{array}{l}\text { Analândia, } \\
\text { Corumbataí } \\
\text { Ipeúna }\end{array}$ & ET Corumbataí & Aterro 02 de 02 \\
$\begin{array}{l}\text { Charqueada } \\
\text { Águas de São Pedro, } \\
\text { São Pedro }\end{array}$ & ET Charqueada & \\
\hline
\end{tabular}

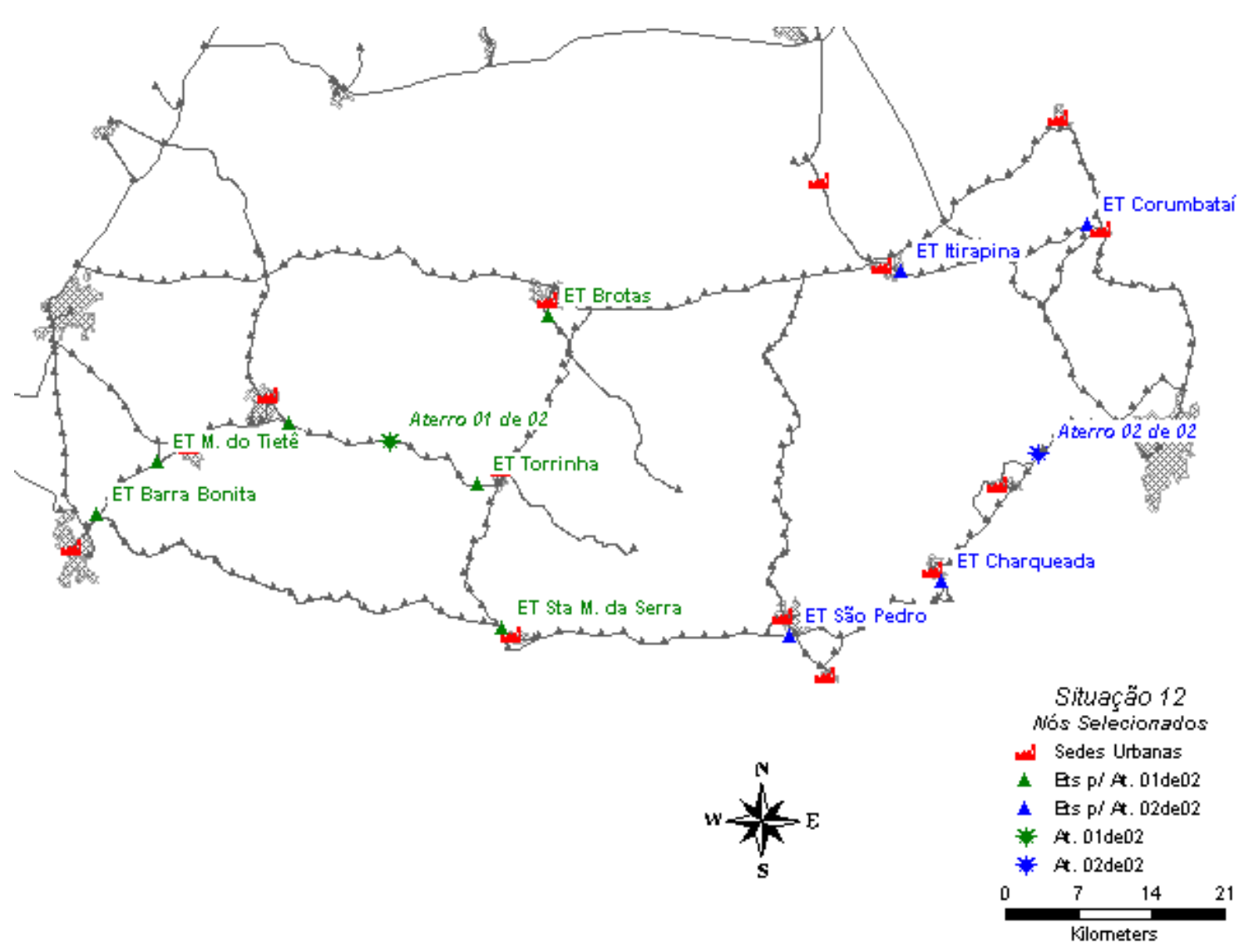

FIGURA 9.4 - A configuração obtida para a Situação 12 
TABELA 9.3 - A configuração obtida para a Situação 13

\begin{tabular}{lcc}
\hline \multicolumn{1}{c}{ Municípios } & \multicolumn{1}{c}{ ETs } & Aterros \\
\hline $\begin{array}{l}\text { Barra Bonita } \\
\text { Mineiros do Tietê }\end{array}$ & ET Barra Bonita & - direto para aterro - \\
$\begin{array}{l}\text { Torrinha } \\
\text { Dois Córregos }\end{array}$ & ET Torrinha & Aterro 01 de 03 \\
\hline $\begin{array}{l}\text { Santa Maria da Serra }{ }^{(1)} \\
\text { Águas de São Pedro, }\end{array}$ & - direto para aterro - & \\
$\begin{array}{l}\text { São Pedro } \\
\text { Charqueada }\end{array}$ & - direto para aterro - & Aterro 02 de 03 \\
Ipeúna & ET Charqueada & \\
\hline $\begin{array}{l}\text { Brotas } \\
\text { Itirapina }\end{array}$ & ET Brotas & Aterro 03 de 03 \\
Itirapina - Broa & - direto para aterro - & \\
Analândia, & & \\
Corumbataí & ET Corumbataí & \\
\hline
\end{tabular}

${ }^{(1)}$ Faz uma viagem por dia com o veículo coletor, não compensa ter ET

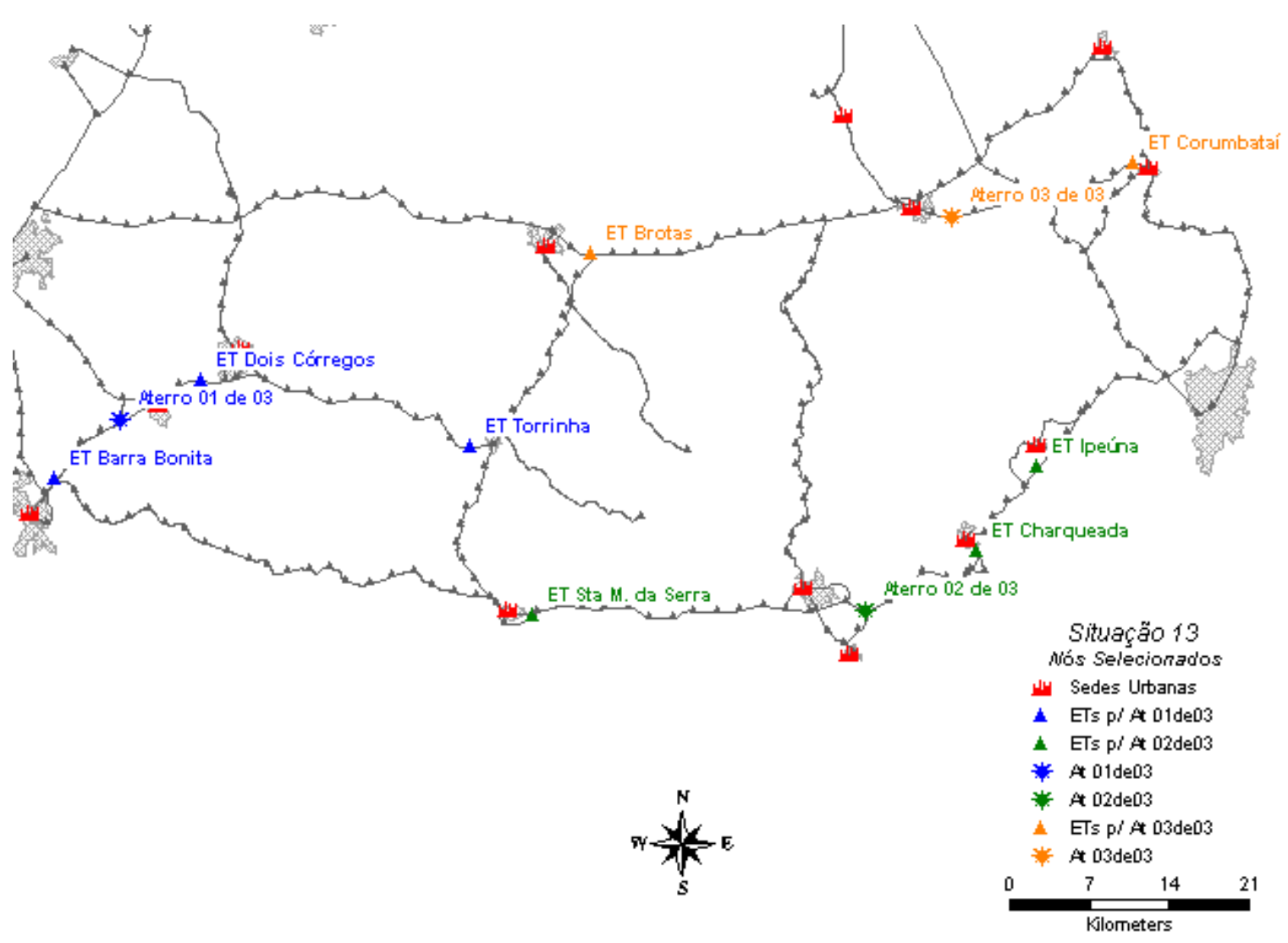

FIGURA 9.5 - A configuração obtida para a Situação 13 
TABELA 9.4 - A configuração obtida para a Situação 14

\begin{tabular}{|c|c|c|}
\hline Municípios & ETs & Aterros \\
\hline Barra Bonita & ET Barra Bonita & \multirow{3}{*}{ Aterro 01 de 04} \\
\hline Mineiros do Tietê & - direto para aterro - & \\
\hline Dois Córregos & ET Dois Córregos & \\
\hline Brotas & ET Brotas & \multirow{3}{*}{ Aterro 02 de 04} \\
\hline Torrinha & - direto para aterro - & \\
\hline Santa Maria da Serra ${ }^{(1)}$ & - direto para aterro - & \\
\hline $\begin{array}{l}\text { Águas de São Pedro, } \\
\text { São Pedro }\end{array}$ & ET São Pedro & \multirow{3}{*}{ Aterro 03 de 04} \\
\hline Charqueada & - direto para aterro - & \\
\hline Ipeúna ${ }^{(1)}$ & - direto para aterro - & \\
\hline Itirapina & ET Itirapina & \multirow[b]{2}{*}{ Aterro 04 de 04} \\
\hline Analândia, & - direto para aterro - & \\
\hline
\end{tabular}

${ }^{(1)}$ Faz uma viagem por dia com o veículo coletor, não compensa ter ET

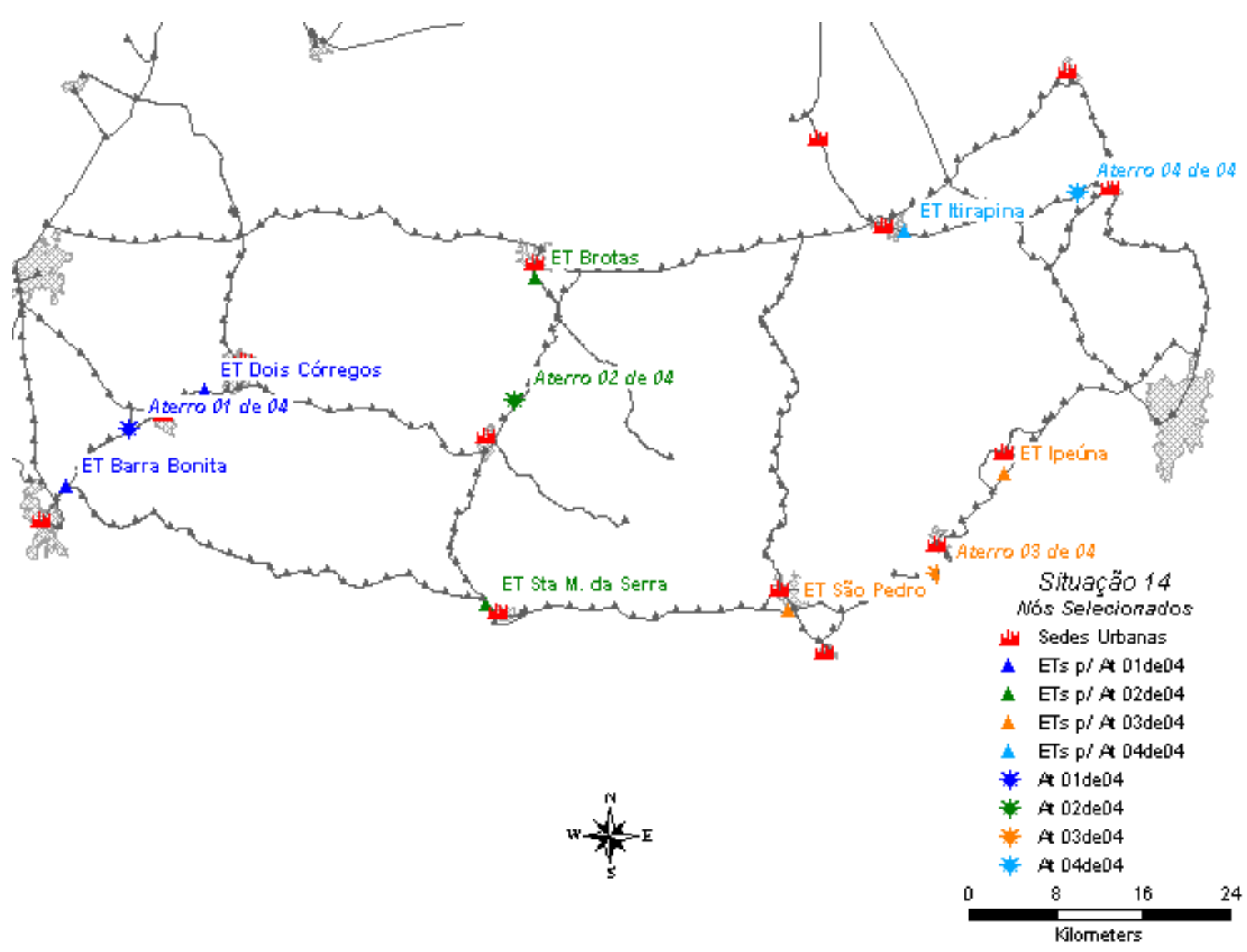

FIGURA 9.6 - A configuração obtida para a Situação 14 
TABELA 9.5 - A configuração obtida para a Situação 21

\begin{tabular}{ll}
\hline \multicolumn{1}{c}{ Municípios } & Aterros \\
\hline Barra Bonita & \\
Mineiros do Tietê & \\
Dois Córregos & \\
Brotas & \\
Torrinha & Aterro 01 de 01 \\
Santa Maria da Serra & \\
Itirapina & \\
Itirapina - Broa & \\
Analândia, & \\
Corumbataí & \\
Ipeúna & \\
Charqueada & \\
Águas de São Pedro, \\
São Pedro
\end{tabular}
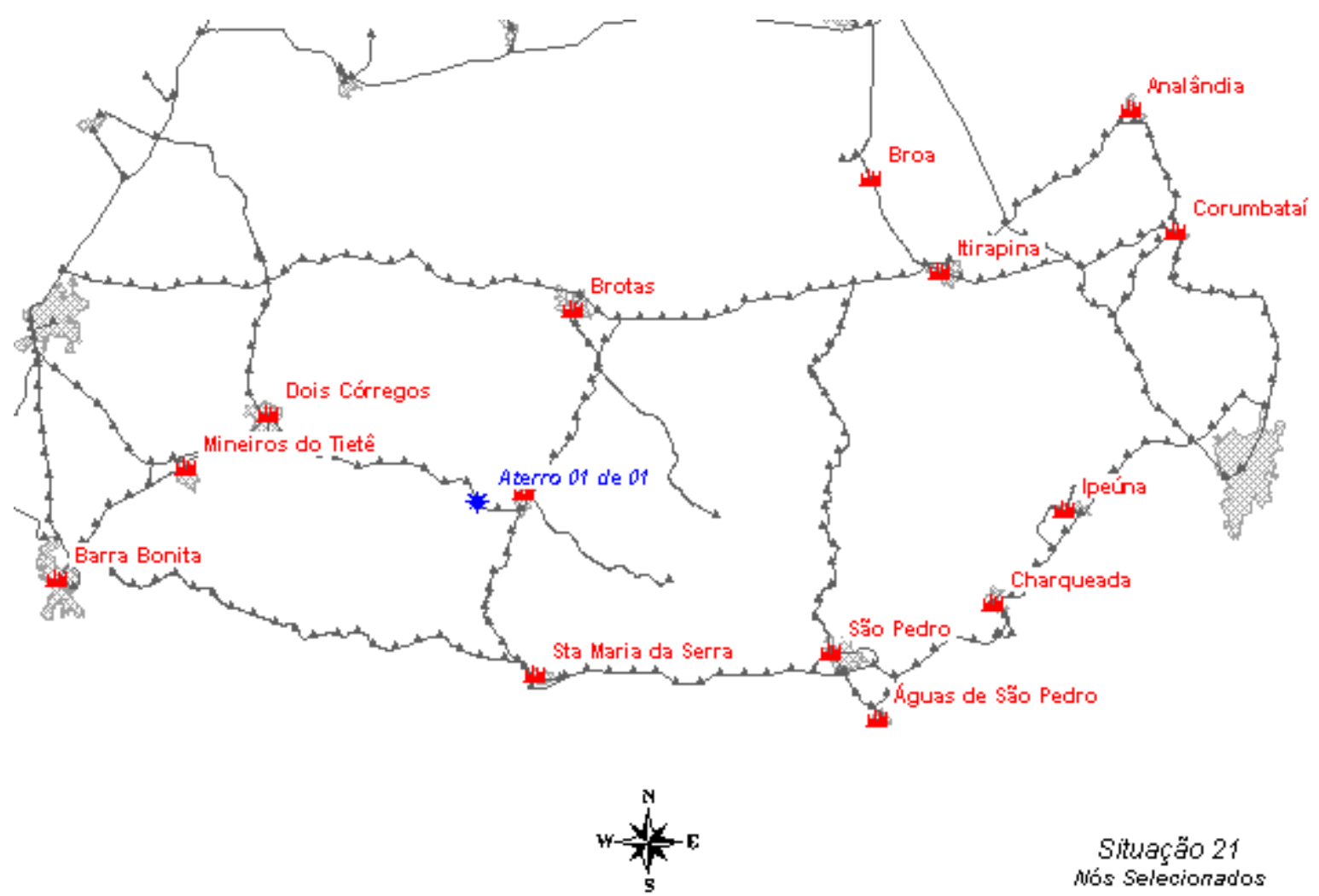

Situação 21

Nós Selecionados

Uly Sedes Uitanas

* Aterro 01 de 01

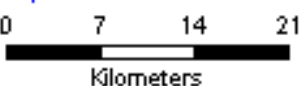

FIGURA 9.7 - A configuração obtida para a Situação 21 
TABELA 9.6 - A configuração obtida para a Situação 22

\begin{tabular}{lc}
\hline \multicolumn{1}{c}{ Municípios } & Aterros \\
\hline Barra Bonita & \\
Mineiros do Tietê & Aterro 01 de 02 \\
Dois Córregos & \\
Brotas & \\
Torrinha & \\
\hline Santa Maria da Serra & \\
Itirapina & \\
Itirapina - Broa & Aterro 02 de 02 \\
Analândia, & \\
Corumbataí & \\
Ipeúna & \\
Charqueada & \\
Águas de São Pedro, & \\
São Pedro & \\
\hline
\end{tabular}
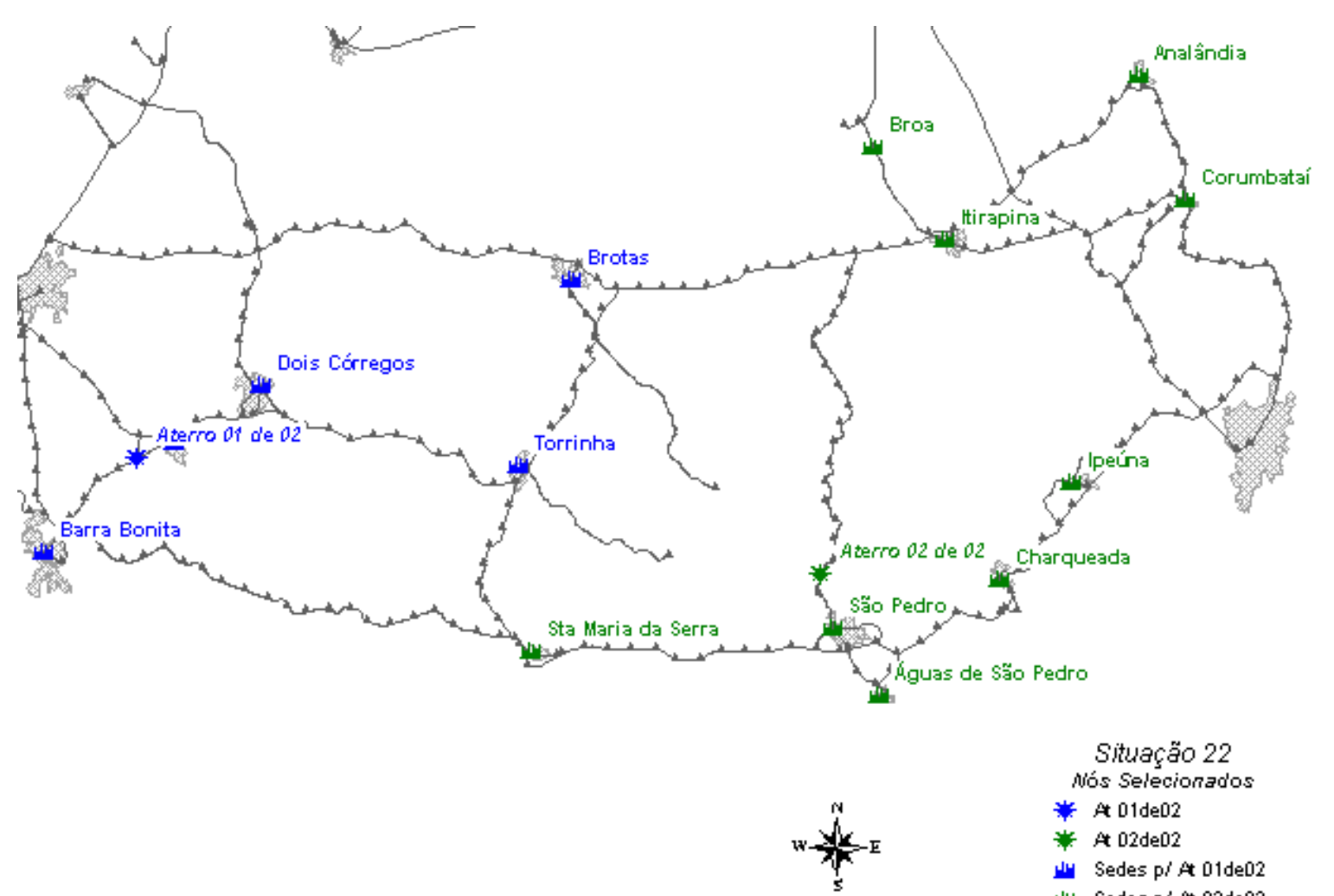

Situação 22

Mós Selecionados

$$
\text { * A } 01 \mathrm{de} 02
$$

* A $02 \mathrm{de} 02$

HU Sedes p/A 01de02

业 Sedes $p / A$ a de02

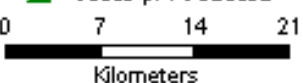

FIGURA 9.8 - A configuração obtida para a Situação 22 
TABELA 9.7 - A configuração obtida para a Situação 23

\begin{tabular}{lc}
\hline \multicolumn{1}{c}{ Municípios } & Aterros \\
\hline Barra Bonita & Aterro 01 de 03 \\
Mineiros do Tietê & \\
Dois Córregos & \\
\hline Brotas & Aterro 02 de 03 \\
Torrinha & \\
Itirapina & \\
Itirapina - Broa & \\
Analândia, & \\
Corumbataí & \\
\hline Santa Maria da Serra & \\
Ipeúna & Aterro 03 de 03 \\
Charqueada & \\
Águas de São Pedro, & \\
São Pedro & \\
\hline
\end{tabular}

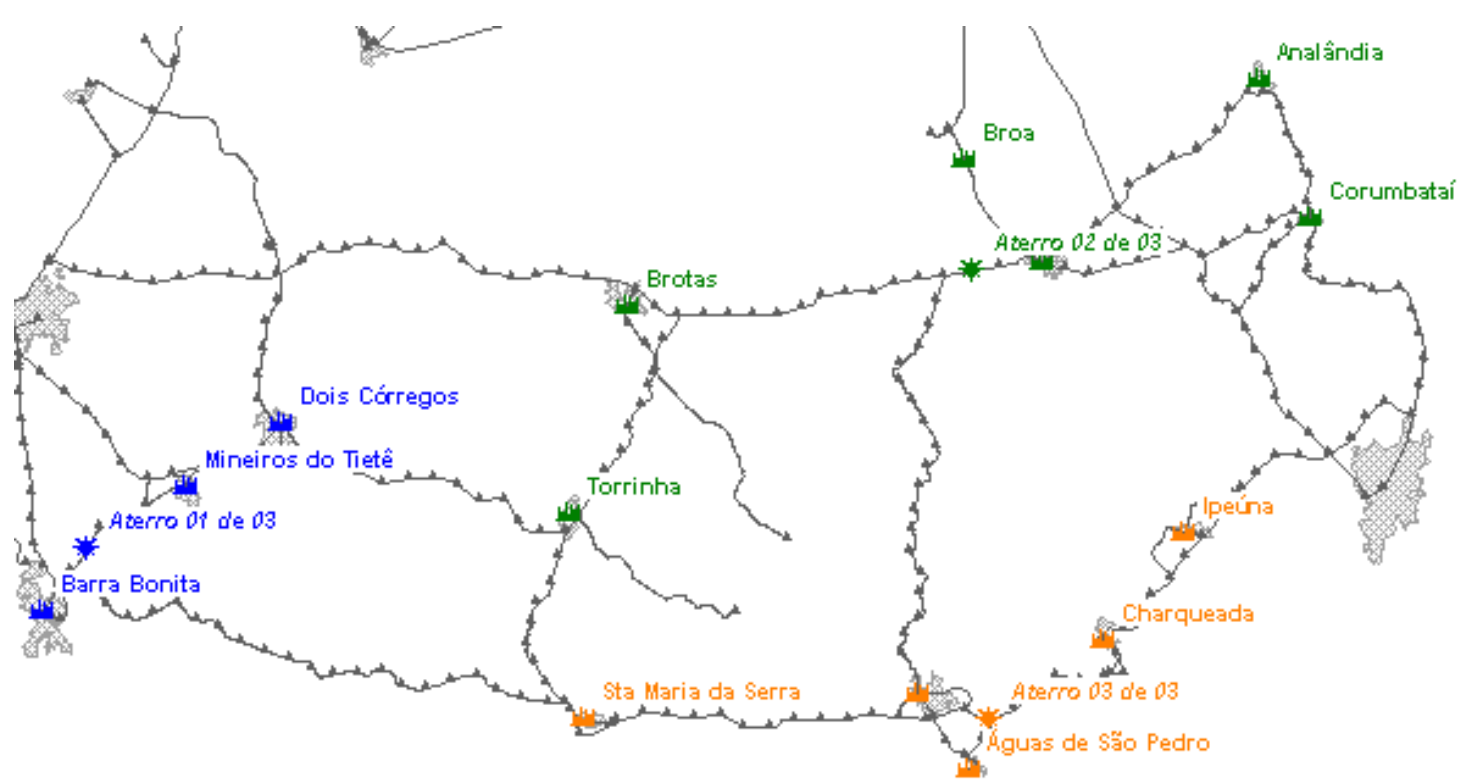

Situação 23

Nós Selecionados

* At 01de03

* At $02 \mathrm{de} 03$

* At 03 de03

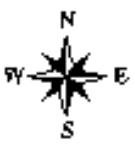

业 Sedes p/At 01de03

少 Sedes p/At 02de03

Hu Sedes p/At 03de03

$\begin{array}{llr}0 & 8 & 16\end{array}$

FIGURA 9.9 - A configuração obtida para a Situação 23 
TABELA 9.8 - A configuração obtida para a Situação 24

\begin{tabular}{lc}
\hline \multicolumn{1}{c}{ Municípios } & Aterros \\
\hline Barra Bonita & Aterro 01 de 04 \\
Mineiros do Tietê & \\
Dois Córregos & Aterro 02 de 04 \\
\hline Brotas & \\
Torrinha & \\
\hline Santa Maria da Serra & Aterro 03 de 04 \\
Águas de São Pedro, & \\
São Pedro & \\
Charqueada & \\
Ipeúna & \\
\hline Itirapina & \\
Itirapina - Broa & Aterro 04 de 04 \\
Analândia, & \\
Corumbataí & \\
\hline
\end{tabular}

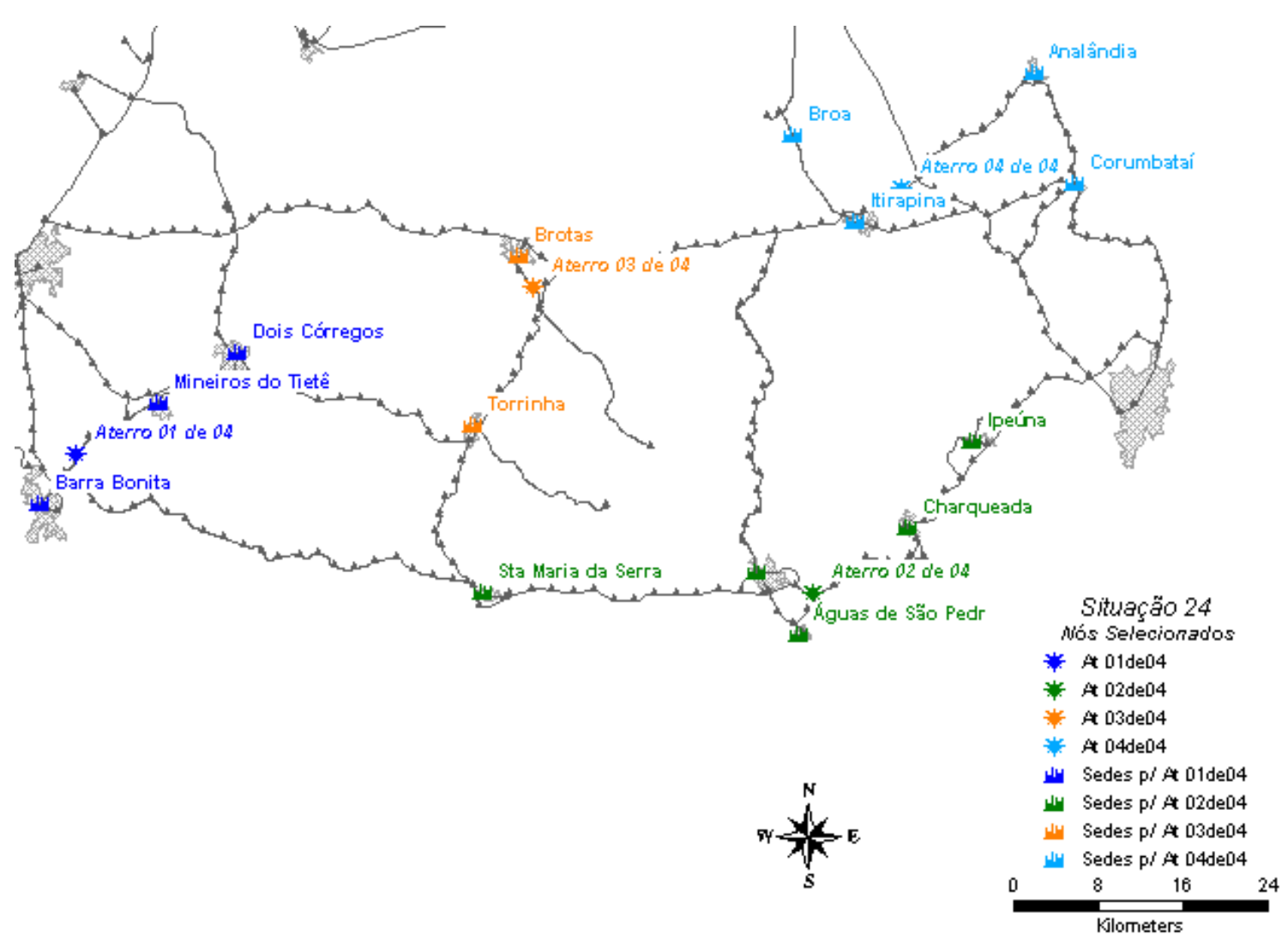

FIGURA 9.10 - A configuração obtida para a Situação 24 


\subsubsection{Roteirização dos veículos}

Os resultados esperados da roteirização são o tipo e número de veículos necessários, o número de viagens, a quilometragem e o tempo de trabalho, tudo para cada tipo de transporte: coleta $\rightarrow$ aterro; coleta $\rightarrow$ ET; ET $\rightarrow$ aterro. Estes dados foram utilizados para calcular os custos operacionais.

Para relembrar, nos casos das viagens com o veículo de coleta até o ponto de destino, a roteirização foi simples, bastando determinar a distância percorrida e o tempo necessário, pois o número de viagens e os tipos de veículos já haviam sido determinados no dimensionamento da coleta, e já considerando os tipos de semana padrão. No caso em que o veículo de transbordo sai do aterro para recolher nas ETs, foi necessário realizar a roteirização para as semanas padrões em cada situação. Os resultados obtidos estão apresentados abaixo, divididos de acordo com o tipo de transporte, com veículo de transbordo ou com o veículo de coleta.

\section{i) Veículo de transbordo}

As tabelas TABELA 9.9 à TABELA 9.12 apresentam os resultados parciais de distân-

TABELA 9.9 - Veículo de transbordo: distância e tempo gastos (Situação 11)

\begin{tabular}{|c|c|c|c|c|c|c|c|c|c|c|c|c|}
\hline \multirow{2}{*}{$\frac{\text { Situação } 11}{\text { Destino }}$} & \multicolumn{2}{|c|}{ Veículo } & \multicolumn{4}{|c|}{$\begin{array}{l}\text { Semana: } \\
2007 \text { A }\end{array}$} & \multicolumn{2}{|c|}{ Veículo } & \multicolumn{4}{|c|}{$\begin{array}{c}\text { Semana: } \\
2007 \text { B-F; } 2012 \text { ABDF; } 2017 \text { A }\end{array}$} \\
\hline & Tipo & Cap. (t) & Rota & Tour \# & $\mathrm{km}$ & $\min$ & Tipo & Cap. (t) & Rota & Tour \# & $\mathrm{km}$ & $\min$ \\
\hline At. $01 \mathrm{~d} 01$ & \multirow{3}{*}{13} & \multirow{3}{*}{25} & \multirow{3}{*}{1} & 1 & 113,80 & 300 & \multirow{3}{*}{$13^{(2)}$} & \multirow{3}{*}{25} & \multirow{3}{*}{1} & 1 & 113,80 & 300 \\
\hline At. $01 \mathrm{~d} 01$ & & & & 3 & 51,40 & 147 & & & & 5 & 29,20 & 96 \\
\hline Subtotal: & & & & & 165,20 & 447 & & & & & 143,00 & 396 \\
\hline At. $01 \mathrm{~d} 01$ & \multirow{5}{*}{$13^{(2)}$} & \multirow{4}{*}{25} & \multirow{5}{*}{2} & 2 & 59,50 & 118 & \multirow{4}{*}{13} & \multirow{4}{*}{25} & \multirow{4}{*}{2} & 2 & 59,50 & 118 \\
\hline At. $01 \mathrm{~d} 01$ & & & & 4 & 49,70 & 151 & & & & 3 & 51,40 & 169 \\
\hline At. $01 \mathrm{~d} 01$ & & & & 5 & 29,20 & 96 & & & & 4 & 49,70 & 151 \\
\hline Subtotal: & & & & & 138,40 & 365 & & & & & 160,60 & 438 \\
\hline TOTAL: & & & & & 303,60 & 812 & & & & & 303,60 & 834 \\
\hline \multirow{2}{*}{ Situação 11} & \multirow{2}{*}{\multicolumn{2}{|c|}{ Veículo }} & \multirow{2}{*}{\multicolumn{4}{|c|}{$\begin{array}{c}\text { Semana: } \\
2007 \text { G; } 2012 \text { CEG; } 2017 \text { B-G }\end{array}$}} & \multicolumn{6}{|c|}{ Valores médios diários $^{(1)}$} \\
\hline & & & & & & & 20 & 07 & 20 & 12 & 20 & \\
\hline Destino & Tipo & Cap. (t) & Rota & Tour \# & $\mathrm{km}$ & $\min$ & $\mathrm{km}$ & $\mathrm{h}$ & $\mathrm{km}$ & $\mathrm{h}$ & $\mathrm{km}$ & $\mathrm{h}$ \\
\hline At. $01 \mathrm{~d} 01$ & \multirow{3}{*}{13} & \multirow{3}{*}{25} & \multirow{3}{*}{1} & 1 & 113,80 & $\overline{278}$ & & & & & & \\
\hline At. $01 \mathrm{~d} 01$ & & & & 5 & 49,70 & 153 & & & & & & \\
\hline Subtotal: & & & & & 163,50 & 431 & 164,16 & 7,27 & 151,19 & 6,74 & 149,84 & 6,58 \\
\hline At. $01 \mathrm{~d} 01$ & \multirow{5}{*}{13} & \multirow{4}{*}{25} & \multirow{4}{*}{2} & 2 & 63,40 & 142 & & & & & & \\
\hline At. $01 \mathrm{~d} 01$ & & & & 3 & 59,50 & 150 & & & & & & \\
\hline At. 01 d 01 & & & & 4 & 51,40 & 152 & & & & & & \\
\hline Subtotal: & & & & & 174,30 & 444 & 146,91 & 6,53 & 161,65 & 7,33 & 165,17 & 7,37 \\
\hline TOTAL: & & & & & 337,80 & 875 & 311,07 & 13,80 & 312,84 & 14,07 & 315,01 & 13,95 \\
\hline
\end{tabular}


TABELA 9.10 - Veículo de transbordo: distância e tempo gastos (Situação 12)

\begin{tabular}{|c|c|c|c|c|c|c|c|c|c|c|c|c|}
\hline \multirow{2}{*}{$\begin{array}{c}\text { Situação } 12 \\
\text { Destino }\end{array}$} & \multicolumn{2}{|c|}{ Veículo } & \multicolumn{4}{|c|}{$\begin{array}{l}\text { Semana: } \\
2007 \text { A-G }\end{array}$} & \multicolumn{2}{|c|}{ Veículo } & \multicolumn{4}{|c|}{$\begin{array}{l}\text { Semana: } \\
2012 \text { A-G }\end{array}$} \\
\hline & Tipo & Cap. (t) & Rota & Tour \# & $\mathrm{km}$ & $\min$ & Tipo & Cap. (t) & Rota & Tour \# & $\mathrm{km}$ & $\min$ \\
\hline At. $02 \mathrm{~d} 02$ & \multirow{3}{*}{13} & \multirow{3}{*}{25} & \multirow{3}{*}{1} & 1 & 79,20 & 208 & \multirow{3}{*}{13} & \multirow{3}{*}{25} & \multirow{3}{*}{1} & 1 & 79,20 & 208 \\
\hline At. $02 \mathrm{~d} 02$ & & & & 2 & 43,80 & 119 & & & & 2 & 43,80 & 120 \\
\hline Subtotal: & & & & & 123,00 & 327 & & & & & 123,00 & 328 \\
\hline At. $01 \mathrm{~d} 02$ & \multirow{5}{*}{13} & \multirow{4}{*}{25} & \multirow{5}{*}{2} & 3 & 39,60 & 90 & \multirow{5}{*}{13} & \multirow{4}{*}{25} & \multirow{4}{*}{2} & 3 & 39,60 & 91 \\
\hline At. $01 \mathrm{~d} 02$ & & & & 5 & 29,70 & 123 & & & & 5 & 29,70 & 124 \\
\hline At. $01 \mathrm{~d} 02$ & & & & 4 & 59,70 & 199 & & & & 4 & 59,70 & 200 \\
\hline Subtotal: & & & & & 129,00 & 412 & & & & & 129,00 & 415 \\
\hline TOTAL: & & & & & 252,00 & 739 & & & & & 252,00 & 743 \\
\hline \multirow{2}{*}{ Situação 12} & \multirow{2}{*}{\multicolumn{2}{|c|}{ Veículo }} & \multirow{2}{*}{\multicolumn{4}{|c|}{$\begin{array}{l}\text { Semana: } \\
2017 \text { A-G }\end{array}$}} & \multicolumn{6}{|c|}{ Valores médios diários ${ }^{(1)}$} \\
\hline & & & & & & & \multicolumn{2}{|c|}{2007} & \multicolumn{2}{|c|}{2012} & \multicolumn{2}{|c|}{2017} \\
\hline Destino & Tipo & Cap. (t) & Rota & Tour \# & $\mathrm{km}$ & $\min$ & $\mathrm{km}$ & $\mathrm{h}$ & $\mathrm{km}$ & $\mathrm{h}$ & $\mathrm{km}$ & $\mathrm{h}$ \\
\hline At. $02 \mathrm{~d} 02$ & \multirow{3}{*}{13} & \multirow{3}{*}{25} & \multirow{3}{*}{1} & 1 & 79,20 & 209 & & & & & & \\
\hline At. $02 \mathrm{~d} 02$ & & & & 2 & 43,80 & 120 & & & & & & \\
\hline Subtotal: & & & & & 123,00 & 329 & 123,00 & 5,45 & 123,00 & 5,47 & 123,00 & 5,48 \\
\hline At. $01 \mathrm{~d} 02$ & \multirow{5}{*}{13} & \multirow{4}{*}{25} & \multirow{5}{*}{2} & 3 & 39,60 & 91 & & & & & & \\
\hline At. $01 \mathrm{~d} 02$ & & & & 5 & 29,70 & 124 & & & & & & \\
\hline At. $01 \mathrm{~d} 02$ & & & & 4 & 59,70 & 200 & & & & & & \\
\hline Subtotal: & & & & & 129,00 & 415 & 129,00 & 6,87 & 129,00 & 6,92 & 129,00 & 6,92 \\
\hline TOTAL: & & & & & 252,00 & 744 & 252,00 & 12,32 & 252,00 & 12,38 & 252,00 & 12,40 \\
\hline
\end{tabular}

TABELA 9.11 - Veículo de transbordo: distância e tempo gastos (Situação 13)

\begin{tabular}{|c|c|c|c|c|c|c|c|c|c|c|c|c|}
\hline \multirow{2}{*}{$\begin{array}{c}\text { Situação } 13 \\
\text { Destino }\end{array}$} & \multicolumn{2}{|c|}{ Veículo } & \multicolumn{4}{|c|}{$\begin{array}{l}\text { Semana: } \\
2007 \text { A-G }\end{array}$} & \multicolumn{2}{|c|}{ Veículo } & \multicolumn{4}{|c|}{$\begin{array}{l}\text { Semana: } \\
2012 \text { A-G }\end{array}$} \\
\hline & Tipo & Cap. (t) & Rota & Tour \# & $\mathrm{km}$ & $\min$ & Tipo & Cap. (t) & Rota & Tour \# & $\mathrm{km}$ & $\min$ \\
\hline At. $03 \mathrm{~d} 03$ & \multirow{2}{*}{14} & \multirow{2}{*}{16,9} & \multirow{2}{*}{1} & 1 & 62,00 & 177 & \multirow{2}{*}{14} & \multirow{2}{*}{16,9} & \multirow{2}{*}{1} & 1 & 62,00 & 178 \\
\hline Subtotal: & & & & & 62,00 & 177 & & & & & 62,00 & 178 \\
\hline At. $02 \mathrm{~d} 03$ & \multirow{2}{*}{12} & \multirow{2}{*}{12,5} & \multirow{2}{*}{2} & 2 & 30,00 & 111 & \multirow{2}{*}{12} & \multirow{2}{*}{12,5} & \multirow{2}{*}{2} & 2 & 30,00 & 111 \\
\hline Subtotal: & & & & & 30,00 & 111 & & & & & 30,00 & 111 \\
\hline At. $01 \mathrm{~d} 03$ & \multirow{4}{*}{13} & \multirow{3}{*}{25} & \multirow{4}{*}{3} & 4 & 9,90 & 47 & \multirow{4}{*}{13} & \multirow{3}{*}{25} & \multirow{4}{*}{3} & 4 & 9,90 & 48 \\
\hline At. $01 \mathrm{~d} 03$ & & & & 3 & 42,10 & 139 & & & & 3 & 42,10 & 139 \\
\hline Subtotal: & & & & & 52,00 & 186 & & & & & 52,00 & 187 \\
\hline TOTAL: & & & & & 144,00 & 474 & & & & & 144,00 & 476 \\
\hline \multirow{2}{*}{ Situação 13} & \multirow{2}{*}{\multicolumn{2}{|c|}{ Veículo }} & \multirow{2}{*}{\multicolumn{4}{|c|}{$\begin{array}{l}\text { Semana: } \\
2017 \text { A-G }\end{array}$}} & \multicolumn{6}{|c|}{ Valores médios diários ${ }^{(1)}$} \\
\hline & & & & & & & \multicolumn{2}{|c|}{2007} & & 12 & \multicolumn{2}{|c|}{2017} \\
\hline Destino & Tipo & Cap. (t) & Rota & Tour \# & $\mathrm{km}$ & $\min$ & $\mathrm{km}$ & $\mathrm{h}$ & $\mathrm{km}$ & $\mathrm{h}$ & $\mathrm{km}$ & $\mathrm{h}$ \\
\hline At. $03 \mathrm{~d} 03$ & 14 & 169 & 1 & 1 & 62,00 & $\overline{178}$ & & & & & & \\
\hline Subtotal: & 14 & 16,9 & 1 & & 62,00 & 178 & 62,00 & 2,95 & 62,00 & 2,97 & 62,00 & 2,97 \\
\hline At. $02 \mathrm{~d} 03$ & 12 & 125 & 2 & 2 & 30,00 & 111 & & & & & & \\
\hline Subtotal: & 12 & 12,5 & 2 & & 30,00 & 111 & 30,00 & 1,85 & 30,00 & 1,85 & 30,00 & 1,85 \\
\hline At. $01 \mathrm{~d} 03$ & & & & 4 & 9,90 & 49 & & & & & & \\
\hline At. $01 \mathrm{~d} 03$ & 13 & 25 & 3 & 3 & 42,10 & 140 & & & & & & \\
\hline Subtotal: & & & & & 52,00 & 189 & 52,00 & 3,10 & 52,00 & 3,12 & 52,00 & 3,15 \\
\hline TOTAL: & & & & & 144,00 & 478 & 144,00 & 7,90 & 144,00 & 7,93 & 144,00 & 7,97 \\
\hline
\end{tabular}

(1) Valores médios de distância percorrida e tempo gasto com veículo de transbordo 
TABELA 9.12 - Veículo de transbordo: distância e tempo gastos (Situação 14)

\begin{tabular}{|c|c|c|c|c|c|c|c|c|c|c|c|c|}
\hline \multirow{3}{*}{$\frac{\text { Situação } 14}{\text { Destino }}$} & \multirow{2}{*}{\multicolumn{2}{|c|}{ Veículo }} & \multirow{2}{*}{\multicolumn{4}{|c|}{$\begin{array}{l}\text { Semana: } \\
2017 \text { A-G }\end{array}$}} & \multicolumn{6}{|c|}{ Valores médios diários ${ }^{(1)}$} \\
\hline & & & & & & & \multicolumn{2}{|c|}{2007} & \multicolumn{2}{|c|}{2012} & \multicolumn{2}{|c|}{2017} \\
\hline & Tipo & Cap. (t) & Rota & Tour \# & $\mathrm{km}$ & $\min$ & $\mathrm{km}$ & $\mathrm{h}$ & $\mathrm{km}$ & $\mathrm{h}$ & $\mathrm{km}$ & $\mathrm{h}$ \\
\hline At. 04 d 04 & \multirow[b]{2}{*}{14} & \multirow{2}{*}{16,9} & \multirow[b]{2}{*}{1} & 1 & 21,10 & 85 & & & & & & \\
\hline Subtotal: & & & & & 21,10 & 85 & 21,10 & 1,42 & 21,10 & 1,42 & 21,10 & 1,42 \\
\hline At. 03 d 04 & \multirow{2}{*}{13} & \multirow{2}{*}{25} & \multirow{2}{*}{2} & 2 & 19,00 & 46 & & & & & & \\
\hline Subtotal: & & & & & 19,00 & 46 & 19,00 & 0,77 & 19,00 & 0,77 & 19,00 & 0,77 \\
\hline At. 02 d 04 & \multirow{2}{*}{14} & \multirow{2}{*}{16,9} & \multirow{2}{*}{3} & 3 & 16,80 & 44 & & & & & & \\
\hline Subtotal: & & & & & 16,80 & 44 & 16,80 & 0,73 & 16,80 & 0,73 & 16,80 & 0,73 \\
\hline At. $01 \mathrm{~d} 04$ & \multirow{3}{*}{14} & \multirow{3}{*}{16,9} & \multirow{3}{*}{4} & 5 & 19,80 & 72 & & & & & & \\
\hline At. 01 d 04 & & & & 4 & 10,10 & 36 & & & & & & \\
\hline Subtotal: & & & & & 29,90 & 108 & 29,90 & 1,80 & 29,90 & 1,80 & 29,90 & 1,80 \\
\hline TOTAL: & & & & & 86,80 & 283 & 86,80 & 4,72 & 86,80 & 4,72 & 86,80 & 4,72 \\
\hline
\end{tabular}

(1) Valores médios de distância percorrida e tempo gasto com veículo de transbordo

Na TABELA 9.13, os resultados foram sintetizados no formato para a fase das análises de custos.

Os primeiros resultados da roteirização dos veículos de transbordo, na maioria das vezes, necessita de retrabalho. A heurística do TransCAD é capaz de solucionar problemas com frota mista, restrição de capacidade de veículo, janela de tempo, múltiplos depósitos, tempo fixo de serviço, tempo variável de serviço e restrição do tamanho da rota (jornada, combustível, etc). Porém, possivelmente, devida a esta complexidade, as primeiras soluções, para cada roteirização realizada, não foram satisfatórias. Visualizando a rota graficamente, é possível determinar que existe uma solução lógica de

TABELA 9.13 - Roteirização para veículo de transbordo: resultados no formato para cálculo de custos

\begin{tabular}{|c|c|c|c|c|c|c|c|c|c|c|c|c|c|}
\hline \multirow[t]{2}{*}{ Situação } & \multirow[t]{2}{*}{ Destino } & \multicolumn{3}{|c|}{$\begin{array}{l}\text { N. Veiculos - } \\
\text { operação } \\
\text { (veic/dia) }\end{array}$} & \multicolumn{3}{|c|}{$\begin{array}{l}\text { N. Jornada total } \\
\text { médio }^{(1)} \\
\text { (un/dia) }\end{array}$} & \multicolumn{3}{|c|}{$\begin{array}{l}\text { Hora extra total } \\
\text { média }^{(2)} \\
(\mathrm{h} / \mathrm{dia})\end{array}$} & \multicolumn{3}{|c|}{$\begin{array}{c}\text { Quilometragem total } \\
\text { média } \\
(\mathrm{km} / \mathrm{dia})\end{array}$} \\
\hline & & 2007 & 2012 & 2017 & 2007 & 2012 & 2017 & 2007 & 2012 & 2017 & 2007 & 2012 & 2017 \\
\hline \multirow{2}{*}{11} & At. $01 \mathrm{~d} 01$ & 2 & 2 & 2 & 2 & 2 & 2 & $-0,87$ & $-0,60$ & $-0,72$ & 311,07 & 312,84 & 315,01 \\
\hline & Total: & 2 & 2 & 2 & 2 & 2 & 2 & 0,00 & 0,00 & 0,00 & 311,07 & 312,84 & 315,01 \\
\hline \multirow{3}{*}{12} & At. $02 \mathrm{~d} 02$ & 1 & 1 & 1 & 1 & 1 & 1 & $-1,88$ & $-1,87$ & $-1,85$ & 123,00 & 123,00 & 123,00 \\
\hline & At. $01 \mathrm{~d} 02$ & 1 & 1 & 1 & 1 & 1 & 1 & $-0,47$ & $-0,42$ & $-0,42$ & 129,00 & 129,00 & 129,00 \\
\hline & Total: & 2 & 2 & 2 & 2 & 2 & 2 & 0,00 & 0,00 & 0,00 & 252,00 & 252,00 & 252,00 \\
\hline \multirow{4}{*}{13} & At. 03 d 03 & 1 & 1 & 1 & 1 & 1 & 1 & $-4,38$ & $-4,37$ & $-4,37$ & 62,00 & 62,00 & 62,00 \\
\hline & At. $02 \mathrm{~d} 03$ & 1 & 1 & 1 & 1 & 1 & 1 & $-5,48$ & $-5,48$ & $-5,48$ & 30,00 & 30,00 & 30,00 \\
\hline & At. $01 \mathrm{~d} 03$ & 1 & 1 & 1 & 1 & 1 & 1 & $-4,23$ & $-4,22$ & $-4,18$ & 52,00 & 52,00 & 52,00 \\
\hline & Total: & 3 & 3 & 3 & 3 & 3 & 3 & 0,00 & 0,00 & 0,00 & 144,00 & 144,00 & 144,00 \\
\hline \multirow{5}{*}{14} & At. 04 d 04 & 1 & 1 & 1 & 1 & 1 & 1 & $-5,92$ & $-5,92$ & $-5,92$ & 21,10 & 21,10 & 21,10 \\
\hline & At. 03 d 04 & 1 & 1 & 1 & 1 & 1 & 1 & $-6,57$ & $-6,57$ & $-6,57$ & 19,00 & 19,00 & 19,00 \\
\hline & At. 02 d 04 & 1 & 1 & 1 & 1 & 1 & 1 & $-6,60$ & $-6,60$ & $-6,60$ & 16,80 & 16,80 & 16,80 \\
\hline & At. 01 d 04 & 1 & 1 & 1 & 1 & 1 & 1 & $-5,53$ & $-5,53$ & $-5,53$ & 29,90 & 29,90 & 29,90 \\
\hline & Total: & 3 & 3 & 3 & 3 & 3 & 3 & 0,00 & 0,00 & 0,00 & 86,80 & 86,80 & 86,80 \\
\hline
\end{tabular}

(1) Número de jornadas padrão de $7 \mathrm{~h}$ e $20 \mathrm{~min}$

(2) Valor negativo parcial por aterro representa a hora ociosa em relação ao tempo total de trabalho pago 
menor custo. Por outro lado, devido a mesma sofisticação proporcionada pelo TransCAD, fazendo-se alguns ajustes, ou mudando algumas opções, é possível chegar à solução otimizada. Na maioria das vezes, fazendo-se o ajuste na janela de tempo, horário de funcionamento das ETs, foi possível saltar de uma solução para outra meIhor. É necessário lembrar que se trabalhou com no máximo 15 nós neste estudo de caso, e quanto maior o número de pontos, mais estes ajustes se tornam difíceis, pois dependem de trabalho manual.

O TransCAD é um software que permite análises logísticas de transporte. No caso da distribuição de produtos manufaturados, o veículo sai carregado do depósito, descarrega quantidades pequenas nos clientes, e volta com o veículo vazio. Já no caso do veículo de transbordo de RSU, o veículo sai descarregado do aterro (depósito), coleta nas estações (clientes) e descarrega no aterro. Até este ponto, as rotinas não apresentam problemas.

Porém, há uma limitação na heurística, no caso em que o cliente tem uma quantidade maior do que a capacidade do veículo. A rotina não roteiriza fracionando a carga em dois veículos. Assim, foi necessário criar um veículo fictício, com capacidade igual à quantidade total da carga de RSU. Na prática, significa que haverá um veículo para realizar outra viagem e coletar os resíduos excedentes. No caso em que não foi possível realizar duas viagens com o mesmo veículo, adotou-se a solução de fazer a viagem com um veículo maior, carregando até a sua capacidade, e o excedente seria transportado direto pelo veículo de coleta.

\section{ii ) Veículo de Coleta}

No caso do transporte de veículos de coleta até as estações ou aterros, diferente do veículo com transbordo, a roteirização consiste em sair carregado da cidade (depósito) e descarregar no cliente (aterro ou ET). Como a origem e o destino são únicos, para todas as cidades, e tendo em vista que não se carrega lixo para dois aterros ou estações, foi roteirizada cada viagem individualmente. E para este caso, o TransCAD não apresentou nenhuma complicação nas soluções, apenas um trabalho manual maior.

Os resultados da etapa de análise de roteirização dos veículos de coleta, que realizaram o transporte de resíduos após a coleta nas cidades, é apresentada nas TABELA 
TABELA 9.14 - Roteirização para veículo de coleta: resultados sintetizados no formato para cálculo de custos

\begin{tabular}{|c|c|c|c|c|c|c|c|c|c|c|}
\hline \multirow[t]{2}{*}{ Situação } & \multirow[t]{2}{*}{ Destino } & \multicolumn{3}{|c|}{ N. Veiculos ${ }^{(1)}$} & \multicolumn{3}{|c|}{$\begin{array}{l}\text { N. Jornada total } \\
\text { médio }^{(2)} \\
\text { (un/dia) }\end{array}$} & \multicolumn{3}{|c|}{$\begin{array}{l}\text { Hora extra total média }{ }^{(3)} \\
\qquad(\mathrm{h} / \mathrm{dia})\end{array}$} \\
\hline & & 2007 & 2012 & 2017 & 2007 & 2012 & 2017 & 2007 & 2012 & 2017 \\
\hline \multirow{3}{*}{11} & At. 01d 01 & 16 & 16 & 16 & 16 & 16 & 16 & $-32,98$ & $-28,20$ & $-24,01$ \\
\hline & Total: & 16 & 16 & 16 & 16 & 16 & 16 & 0,00 & 0,00 & 0,00 \\
\hline & At. $01 \mathrm{~d} 02$ & 10 & 10 & 10 & 10 & 10 & 10 & $-22,25$ & $-19,38$ & $-17,01$ \\
\hline \multirow{2}{*}{12} & At. 02 d 02 & 6 & 6 & 6 & 6 & 6 & 6 & $-10,70$ & $-9,18$ & $-7,56$ \\
\hline & Total: & 16 & 16 & 16 & 16 & 16 & 16 & 0,00 & 0,00 & 0,00 \\
\hline \multirow{4}{*}{13} & At. $01 \mathrm{~d} 03$ & 7 & 7 & 7 & 7 & 7 & 7 & $-10,21$ & $-7,99$ & $-6,14$ \\
\hline & At. 02 d 03 & 5 & 5 & 5 & 5 & 5 & 5 & $-11,98$ & $-10,89$ & $-9,96$ \\
\hline & At. 03 d 03 & 4 & 4 & 4 & 4 & 4 & 4 & $-7,89$ & $-6,95$ & $-6,14$ \\
\hline & Total: & 16 & 16 & 16 & 16 & 16 & 16 & 0,00 & 0,00 & 0,00 \\
\hline \multirow{5}{*}{14} & At. $01 \mathrm{~d} 04$ & 6 & 6 & 6 & 6 & 6 & 6 & $-7,52$ & $-5,70$ & $-4,14$ \\
\hline & At. 02 d 04 & 4 & 4 & 4 & 4 & 4 & 4 & $-13,36$ & $-12,61$ & $-11,97$ \\
\hline & At. 03 d 04 & 4 & 4 & 4 & 4 & 4 & 4 & $-8,11$ & $-7,12$ & $-6,08$ \\
\hline & At. 04 d 04 & 2 & 2 & 2 & 2 & 2 & 2 & $-2,02$ & $-1,49$ & $-1,03$ \\
\hline & Total: & 16 & 16 & 16 & 16 & 16 & 16 & 0,00 & 0,00 & 0,00 \\
\hline \multirow{2}{*}{21} & At. $01 \mathrm{~d} 01$ & 16 & 16 & 16 & 17 & 18 & 18 & 0,57 & $-2,20$ & 2,18 \\
\hline & Total: & 16 & 16 & 16 & 17 & 18 & 18 & 0,00 & 0,00 & 0,00 \\
\hline \multirow{3}{*}{22} & At. $01 \mathrm{~d} 02$ & 9 & 9 & 9 & 9 & 9 & 9 & $-7,15$ & $-4,61$ & $-2,20$ \\
\hline & At. 02 d 02 & 7 & 7 & 7 & 7 & 7 & 7 & $-0,93$ & 1,07 & 2,68 \\
\hline & Total: & 16 & 16 & 16 & 16 & 16 & 16 & 0,00 & 1,07 & 2,68 \\
\hline \multirow{4}{*}{23} & At. $01 \mathrm{~d} 03$ & 6 & 6 & 6 & 6 & 6 & 6 & $-4,85$ & $-2,96$ & $-1,07$ \\
\hline & At. $02 \mathrm{~d} 03$ & 5 & 5 & 5 & 5 & 5 & 5 & $-5,81$ & $-4,60$ & $-3,59$ \\
\hline & At. 03 d 03 & 5 & 5 & 5 & 5 & 5 & 5 & $-10,54$ & $-9,21$ & $-8,15$ \\
\hline & Total: & 16 & 16 & 16 & 16 & 16 & 16 & 0,00 & 0,00 & 0,00 \\
\hline \multirow{5}{*}{24} & At. $01 \mathrm{~d} 04$ & 6 & 6 & 6 & 6 & 6 & 6 & $-4,85$ & $-2,96$ & $-1,07$ \\
\hline & At. 02 d 04 & 5 & 5 & 5 & 5 & 5 & 5 & $-10,54$ & $-9,21$ & $-8,15$ \\
\hline & At. 03 d 04 & 3 & 3 & 3 & 3 & 3 & 3 & $-8,49$ & $-7,84$ & $-7,27$ \\
\hline & At. 04 d 04 & 2 & 2 & 2 & 2 & 2 & 2 & $-1,76$ & $-1,21$ & $-0,76$ \\
\hline & Total: & 16 & 16 & 16 & 16 & 16 & 16 & 0,00 & 0,00 & 0,00 \\
\hline
\end{tabular}

(1) Número real de veículos, já com compartilhamento entre cidades

(2) Número de jornadas padrão de $7 \mathrm{~h}$ e $20 \mathrm{~min}$

(3) Valor negativo parcial por aterro representa a hora ociosa em relação ao tempo total de trabalho pago

9.14 e TABELA 9.15. Nelas, os valores já se encontram resumidos, considerando desde a coleta até o transporte até o destino, ET ou aterro. Como a operação do veículo de coleta é realizada continuamente pela mesma mão-de-obra, independente se é para coleta na cidade ou transporte fora dela, as jornadas e horas extras já consideram o trabalho como um todo. Apenas as distâncias estão separadas em coleta e após coleta, pois não implica na mão-de-obra, mas interfere no consumo do veículo, ou seja, nos custos operacionais do veículo. 
TABELA 9.15 - Roteirização para veículo de coleta: resultados sintetizados no formato para cálculo de custos (cont.)

\begin{tabular}{|c|c|c|c|c|c|c|c|}
\hline \multirow[t]{2}{*}{ Situação } & \multirow[t]{2}{*}{ Destino } & \multicolumn{3}{|c|}{$\begin{array}{c}\text { Quilometragem total média } \\
\text { APÓs COLETA } \\
(\mathrm{km} / \mathrm{dia})\end{array}$} & \multicolumn{3}{|c|}{$\begin{array}{c}\text { Quilometragem total média } \\
\text { NA COLETA } \\
\text { (km/dia) }\end{array}$} \\
\hline & & 2007 & 2012 & 2017 & 2007 & 2012 & 2017 \\
\hline \multirow{2}{*}{11} & At. 01d 01 & 170,56 & 191,14 & 210,05 & 777,60 & 823,85 & 863,63 \\
\hline & Total: & 170,56 & 191,14 & 210,05 & 777,60 & 823,85 & 863,63 \\
\hline \multirow{3}{*}{12} & At. $01 \mathrm{~d} 02$ & 74,29 & 83,93 & 89,14 & 482,99 & 511,72 & 536,43 \\
\hline & At. 02 d 02 & 86,55 & 86,55 & 96,76 & 294,61 & 312,13 & 327,20 \\
\hline & Total: & 160,85 & 170,49 & 185,89 & 777,60 & 823,85 & 863,63 \\
\hline \multirow{4}{*}{13} & At. $01 \mathrm{~d} 03$ & 73,75 & 76,95 & 78,68 & 384,90 & 407,79 & 427,48 \\
\hline & At. 02 d 03 & 110,50 & 110,50 & 110,50 & 209,97 & 222,46 & 233,20 \\
\hline & At. 03 d 03 & 74,18 & 74,18 & 74,18 & 182,73 & 193,60 & 202,95 \\
\hline & Total: & 258,42 & 261,63 & 263,36 & 777,60 & 823,85 & 863,63 \\
\hline \multirow{5}{*}{14} & At. $01 \mathrm{~d} 04$ & 66,95 & 66,95 & 66,95 & 351,32 & 372,21 & 390,19 \\
\hline & At. 02 d 04 & 48,95 & 48,95 & 48,95 & 131,67 & 139,50 & 146,24 \\
\hline & At. 03 d 04 & 61,92 & 61,92 & 66,68 & 191,98 & 203,39 & 213,22 \\
\hline & At. 04 d 04 & 50,78 & 50,78 & 50,78 & 102,63 & 108,74 & 113,99 \\
\hline & Total: & 228,59 & 228,59 & 233,36 & 777,60 & 823,85 & 863,63 \\
\hline \multirow{2}{*}{21} & At. $01 \mathrm{~d} 01$ & $1.782,98$ & $1.796,31$ & $1.824,04$ & 777,60 & 823,85 & 863,63 \\
\hline & Total: & $1.782,98$ & $1.796,31$ & $1.824,04$ & 777,60 & 823,85 & 863,63 \\
\hline \multirow{3}{*}{22} & At. $01 \mathrm{~d} 02$ & 469,65 & 471,36 & 477,41 & 465,00 & 492,65 & 516,44 \\
\hline & At. 02 d 02 & 569,43 & 579,76 & 585,35 & 312,60 & 331,19 & 347,19 \\
\hline & Total: & $1.039,08$ & $1.051,12$ & $1.062,76$ & 777,60 & 823,85 & 863,63 \\
\hline \multirow{4}{*}{23} & At. $01 \mathrm{~d} 03$ & 169,22 & 171,28 & 178,52 & 351,32 & 372,21 & 390,19 \\
\hline & At. $02 \mathrm{~d} 03$ & 298,16 & 298,66 & 298,59 & 216,31 & 229,17 & 240,24 \\
\hline & At. 03 d 03 & 172,90 & 180,35 & 183,65 & 209,97 & 222,46 & 233,20 \\
\hline & Total: & 640,28 & 650,29 & 660,76 & 777,60 & 823,85 & 863,63 \\
\hline \multirow{5}{*}{24} & At. $01 \mathrm{~d} 04$ & 169,22 & 171,28 & 178,52 & 351,32 & 372,21 & 390,19 \\
\hline & At. 02 d 04 & 172,90 & 180,35 & 183,65 & 209,97 & 222,46 & 233,20 \\
\hline & At. 03 d 04 & 42,07 & 42,10 & 42,09 & 113,68 & 120,44 & 126,25 \\
\hline & At. 04 d 04 & 85,57 & 85,89 & 85,83 & 102,63 & 108,74 & 113,99 \\
\hline & Total: & 469,75 & 479,62 & 490,09 & 777,60 & 823,85 & 863,63 \\
\hline
\end{tabular}

As tabelas com os resultados de todas as roteirizações apresentadas, foram obtidas do TransCAD, na forma de itinerários e rotas, que podem ser encontradas no APÊNDICE J.

\subsection{Resultado Final}

A etapa final constituiu em agrupar todas as informações das fases intermediárias, seguindo com a etapa para determinar os custos para cada situação. Finalizados os cálculos dos custos, os seus resultados foram analisados comparando-se os custos por tonelada de cada situação. 
TABELA 9.16 - Entrada na planilha de custos: valores sintetizados de produção de RSU e população para cada situação

\begin{tabular}{|c|c|c|c|c|c|c|c|c|c|}
\hline \multirow[t]{2}{*}{ Situação } & \multirow[t]{2}{*}{ Destino } & \multicolumn{3}{|c|}{ Produção média RSU } & \multirow{2}{*}{$\begin{array}{c}\text { Produção } \\
\text { total RSU } \\
(\mathrm{t}) \\
15 \text { anos }\end{array}$} & \multirow{2}{*}{$\begin{array}{c}\text { Produção } \\
\text { média RSU } \\
\text { (kg/dia) } \\
2.003\end{array}$} & \multicolumn{3}{|c|}{$\begin{array}{l}\text { População Urbana Residente } \\
\text { (hab) }\end{array}$} \\
\hline & & 2007 & 2012 & 2017 & & & 2007 & 2012 & 2017 \\
\hline 11 & At. $01 \mathrm{~d} 01$ & 2.736 .743 & 2.913 .449 & 3.065 .062 & 523.222 & $\overline{87.176}$ & 162.872 & 172.559 & 180.892 \\
\hline \multirow{2}{*}{12} & At. $01 \mathrm{~d} 02$ & 1.635 .772 & 1.742 .640 & 1.834 .051 & 313.177 & 52.179 & 102.366 & 108.454 & 113.692 \\
\hline & At. 02 d 02 & 1.100 .970 & 1.170 .808 & 1.231 .011 & 210.045 & 34.996 & 60.506 & 64.104 & 67.200 \\
\hline \multirow{3}{*}{13} & At. $01 \mathrm{~d} 03$ & 1.256 .690 & 1.339 .384 & 1.410 .046 & 240.735 & 40.110 & 80.290 & 85.065 & 89.173 \\
\hline & At. 02 d 03 & 834.117 & 887.223 & 932.865 & 159.319 & 26.545 & 47.755 & 50.595 & 53.039 \\
\hline & At. 03 d 03 & 645.936 & 686.841 & 722.152 & 123.168 & 20.521 & 34.826 & 36.898 & 38.680 \\
\hline \multirow{4}{*}{14} & At. $01 \mathrm{~d} 04$ & 1.134 .416 & 1.209 .222 & 1.273 .176 & 217.282 & 36.202 & 72.275 & 76.574 & 80.272 \\
\hline & At. 02 d 04 & 501.357 & 533.418 & 560.874 & 95.895 & 15.977 & 30.091 & 31.880 & 33.420 \\
\hline & At. 03 d 04 & 768.617 & 817.492 & 859.540 & 146.751 & 24.451 & 43.412 & 45.994 & 48.215 \\
\hline & At. 04 d 04 & 332.354 & 353.316 & 371.472 & 63.294 & 10.546 & 17.094 & 18.110 & 18.985 \\
\hline 21 & At. $01 \mathrm{~d} 01$ & 2.736 .743 & 2.913 .449 & 3.065 .062 & 523.222 & 87.176 & 162.872 & 172.559 & 180.892 \\
\hline \multirow{2}{*}{22} & At. $01 \mathrm{~d} 02$ & 1.570 .272 & 1.672 .909 & 1.760 .726 & 300.609 & 50.085 & 98.023 & 103.853 & 108.868 \\
\hline & At. 02 d 02 & 1.166 .471 & 1.240 .540 & 1.304 .336 & 222.613 & 37.090 & 64.849 & 68.706 & 72.024 \\
\hline \multirow{3}{*}{23} & At. $01 \mathrm{~d} 03$ & 1.134 .416 & 1.209 .222 & 1.273 .176 & 217.282 & 36.202 & 72.275 & 76.574 & 80.272 \\
\hline & At. 02 d 03 & 768.210 & 817.004 & 859.021 & 146.621 & 24.429 & 42.841 & 45.389 & 47.581 \\
\hline & At. 03 d 03 & 834.117 & 887.223 & 932.865 & 159.319 & 26.545 & 47.755 & 50.595 & 53.039 \\
\hline \multirow{4}{*}{24} & At. $01 \mathrm{~d} 04$ & 1.134 .416 & 1.209 .222 & 1.273 .176 & 217.282 & 36.202 & 72.275 & 76.574 & 80.272 \\
\hline & At. 02 d 04 & 834.117 & 887.223 & 932.865 & 159.319 & 26.545 & 47.755 & 50.595 & 53.039 \\
\hline & At. 03 d 04 & 435.856 & 463.687 & 487.549 & 83.327 & 13.883 & 25.747 & 27.279 & 28.596 \\
\hline & At. 04 d 04 & 332.354 & 353.316 & 371.472 & 63.294 & 10.546 & 17.094 & 18.110 & 18.985 \\
\hline
\end{tabular}

TABELA 9.17 - Entrada na planilha de custos: valores sintetizados da implantação de ETs para cada situação

\begin{tabular}{|c|c|c|c|c|c|c|c|c|}
\hline \multirow[t]{2}{*}{ Situação } & \multirow[t]{2}{*}{ Destino } & \multirow{2}{*}{$\begin{array}{l}\text { Cap. Max. } \\
\text { Total } \\
\text { Acúmulo } \\
\text { RSU nas } \\
\text { ETs } \\
\text { (t/dia) }\end{array}$} & \multicolumn{2}{|c|}{$\begin{array}{l}\text { CUSTO } \\
\text { Equipamento } \\
\text { Pesagem }\end{array}$} & \multicolumn{2}{|c|}{$\begin{array}{l}\text { CUSTO TOTAL } \\
\text { s/ equip. }\end{array}$} & \multicolumn{2}{|c|}{ CUSTO TOTAL } \\
\hline & & & & $(R \$)$ & & $(\mathrm{R} \$)$ & & $(\mathrm{R} \$)$ \\
\hline 11 & At. $01 \mathrm{~d} 01$ & 204,17 & $\mathrm{R} \$$ & 159.800 & $\mathrm{R} \$$ & 975.992 & $\mathrm{R} \$$ & 1.135 .792 \\
\hline \multirow{2}{*}{12} & At. $01 \mathrm{~d} 02$ & 121,37 & $\mathrm{R} \$$ & 94.000 & $\mathrm{R} \$$ & 579.547 & $\mathrm{R} \$$ & 673.547 \\
\hline & At. $02 \mathrm{~d} 02$ & 85,77 & $\mathrm{R} \$$ & 65.800 & $\mathrm{R} \$$ & 396.588 & $\mathrm{R} \$$ & 462.388 \\
\hline \multirow{3}{*}{13} & At. $01 \mathrm{~d} 03$ & 77,03 & $\mathrm{R} \$$ & 56.400 & $\mathrm{R} \$$ & 316.649 & $\mathrm{R} \$$ & 373.049 \\
\hline & At. $02 \mathrm{~d} 03$ & 20,52 & $\mathrm{R} \$$ & 18.800 & $\mathrm{R} \$$ & 156.128 & $\mathrm{R} \$$ & 174.928 \\
\hline & At. $03 \mathrm{~d} 03$ & 32,95 & $\mathrm{R} \$$ & 28.200 & $\mathrm{R} \$$ & 182.831 & $\mathrm{R} \$$ & 211.031 \\
\hline \multirow{4}{*}{14} & At. $01 \mathrm{~d} 04$ & 68,36 & $\mathrm{R} \$$ & 47.000 & $\mathrm{R} \$$ & 240.610 & $\mathrm{R} \$$ & 287.610 \\
\hline & At. $02 \mathrm{~d} 04$ & 25,48 & $\mathrm{R} \$$ & 18.800 & $\mathrm{R} \$$ & 106.850 & $\mathrm{R} \$$ & 125.650 \\
\hline & At. $03 \mathrm{~d} 04$ & 41,98 & $\mathrm{R} \$$ & 28.200 & $\mathrm{R} \$$ & 133.717 & $\mathrm{R} \$$ & 161.917 \\
\hline & At. 04 d 04 & 21,49 & $\mathrm{R} \$$ & 18.800 & $\mathrm{R} \$$ & 106.658 & $\mathrm{R} \$$ & 125.458 \\
\hline
\end{tabular}


TABELA 9.18 - Entrada na planilha de custos: valores sintetizados da implantação de Aterros para cada situação

\begin{tabular}{|c|c|c|c|c|c|c|c|c|c|c|c|c|}
\hline \multirow[b]{2}{*}{ Situação } & \multirow[b]{2}{*}{ Destino } & \multicolumn{7}{|c|}{ Quantidade } & \multirow{2}{*}{\multicolumn{2}{|c|}{$\begin{array}{l}\text { CUSTO TOTAL } \\
\text { s/ equip. }\end{array}$}} & \multirow{2}{*}{\multicolumn{2}{|c|}{ CUSTO TOTAL }} \\
\hline & & $\begin{array}{l}\text { Produção } \\
\text { média } \\
\text { RSU }\end{array}$ & & 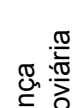 & $\begin{array}{r}\frac{\pi}{\frac{\pi}{0}} \\
\frac{\pi}{0} \\
0\end{array}$ & 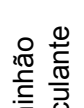 & & $\begin{array}{l}\text { USTO } \\
\text { ipamento }\end{array}$ & & & & \\
\hline 11 & At. $01 \mathrm{~d} 01$ & 87,18 & 1 & 1 & 1 & 1 & $\mathrm{R} \$$ & 467.174 & $\mathrm{R} \$$ & 1.081 .104 & $\mathrm{R} \$$ & 1.548 .279 \\
\hline \multirow{2}{*}{12} & At. $01 \mathrm{~d} 02$ & 52,18 & 1 & 1 & 1 & 1 & $\mathrm{R} \$$ & 467.174 & $\mathrm{R} \$$ & 546.690 & $\mathrm{R} \$$ & 1.013 .865 \\
\hline & At. 02 d 02 & 35,00 & 1 & 1 & 1 & 1 & $\mathrm{R} \$$ & 467.174 & $\mathrm{R} \$$ & 423.401 & $\mathrm{R} \$$ & 890.575 \\
\hline \multirow{3}{*}{13} & At. $01 \mathrm{~d} 02$ & 40,11 & 1 & 1 & 1 & 1 & $\mathrm{R} \$$ & 467.174 & $\mathrm{R} \$$ & 667.858 & $\mathrm{R} \$$ & 1.135 .033 \\
\hline & At. 02 d 02 & 26,54 & 1 & 1 & 1 & 1 & $\mathrm{R} \$$ & 386.685 & $\mathrm{R} \$$ & 498.902 & $\mathrm{R} \$$ & 885.588 \\
\hline & At. 03 d 03 & 20,52 & 0 & 1 & 1 & 1 & $\mathrm{R} \$$ & 246.374 & $\mathrm{R} \$$ & 421.935 & $\mathrm{R} \$$ & 668.309 \\
\hline \multirow{4}{*}{14} & At. $01 \mathrm{~d} 04$ & 36,20 & 1 & 1 & 1 & 1 & $\mathrm{R} \$$ & 467.174 & $\mathrm{R} \$$ & 619.804 & $\mathrm{R} \$$ & 1.086 .978 \\
\hline & At. 02 d 04 & 15,98 & 0 & 1 & 1 & 1 & $\mathrm{R} \$$ & 196.324 & $\mathrm{R} \$$ & 351.941 & $\mathrm{R} \$$ & 548.265 \\
\hline & At. 03 d 04 & 24,45 & 0 & 1 & 1 & 1 & $\mathrm{R} \$$ & 337.906 & $\mathrm{R} \$$ & 472.144 & $\mathrm{R} \$$ & 810.050 \\
\hline & At. 04 d 04 & 10,55 & 0 & 1 & 1 & 0 & $\mathrm{R} \$$ & 145.141 & $\mathrm{R} \$$ & 266.423 & $\mathrm{R} \$$ & 411.564 \\
\hline 21 & At. $01 \mathrm{~d} 01$ & 87,18 & 1 & 1 & 1 & 1 & $\mathrm{R} \$$ & 467.174 & $\mathrm{R} \$$ & 1.081 .104 & $\mathrm{R} \$$ & 1.548 .279 \\
\hline \multirow{2}{*}{22} & At. $01 \mathrm{~d} 02$ & 52,18 & 1 & 1 & 1 & 1 & $\mathrm{R} \$$ & 467.174 & $\mathrm{R} \$$ & 781.498 & $\mathrm{R} \$$ & 1.248 .673 \\
\hline & At. 02 d 02 & 35,00 & 1 & 1 & 1 & 1 & $\mathrm{R} \$$ & 467.174 & $\mathrm{R} \$$ & 604.883 & $\mathrm{R} \$$ & 1.072 .057 \\
\hline \multirow{3}{*}{23} & At. $01 \mathrm{~d} 03$ & 40,11 & 1 & 1 & 1 & 1 & $\mathrm{R} \$$ & 467.174 & $\mathrm{R} \$$ & 667.858 & $\mathrm{R} \$$ & 1.135 .033 \\
\hline & At. $02 \mathrm{~d} 03$ & 26,54 & 1 & 1 & 1 & 1 & $\mathrm{R} \$$ & 386.685 & $\mathrm{R} \$$ & 498.902 & $\mathrm{R} \$$ & 885.588 \\
\hline & At. $03 \mathrm{~d} 03$ & 20,52 & 0 & 1 & 1 & 1 & $\mathrm{R} \$$ & 246.374 & $\mathrm{R} \$$ & 421.935 & $\mathrm{R} \$$ & 668.309 \\
\hline \multirow{4}{*}{24} & At. $01 \mathrm{~d} 04$ & 30,06 & 1 & 1 & 1 & 1 & $\mathrm{R} \$$ & 467.174 & $\mathrm{R} \$$ & 543.805 & $\mathrm{R} \$$ & 1.010 .979 \\
\hline & At. 02 d 04 & 22,12 & 0 & 1 & 1 & 1 & $\mathrm{R} \$$ & 283.584 & $\mathrm{R} \$$ & 442.346 & $\mathrm{R} \$$ & 725.930 \\
\hline & At. 03 d 04 & 24,45 & 0 & 1 & 1 & 1 & $\mathrm{R} \$$ & 337.906 & $\mathrm{R} \$$ & 472.144 & $\mathrm{R} \$$ & 810.050 \\
\hline & At. 04 d 04 & 10,55 & 0 & 1 & 1 & 0 & $\mathrm{R} \$$ & 145.141 & $\mathrm{R} \$$ & 266.423 & $\mathrm{R} \$$ & 411.564 \\
\hline
\end{tabular}

\subsubsection{Resultados Obtidos de Outras Etapas}

Antes de iniciar o cálculo dos custos, além das informações contidas nas TABELA 9.13 à TABELA 9.15, foram necessárias as informações contidas nas tabelas TABELA 9.16 à TABELA 9.19, resumo dos resultados de etapas anteriores do método. Todos estes dados foram inseridos na "Planilha com resumo dos dados de entrada para caracterizar cada situação" (vide item 7.13.2.i )) de cada arquivo do Excel, de custos referentes a uma situação definida, para poder dar seqüência aos cálculos.

O exemplo de cálculo, para uma das situações de cada planilha de cálculo desenvolvida, para chegar aos valores de custos com base no método apresentado, pode ser consultado no APÊNDICE K. Além de um exemplo de planilha, com os resultados de custos de um arquivo referente a uma das situações. 
TABELA 9.19 - Entrada na planilha de custos: tempo de trabalho dos equipamentos nos aterros para cada situação

\begin{tabular}{|c|c|c|c|c|c|c|c|c|c|c|}
\hline \multirow[t]{2}{*}{ Equip. ${ }^{(1)}$} & \multirow[t]{2}{*}{ Situação } & \multirow[t]{2}{*}{ Destino } & \multicolumn{3}{|c|}{$\begin{array}{l}\text { Horas trabalhadas }{ }^{(2)} \\
\text { (h/mês) }\end{array}$} & \multirow[t]{2}{*}{ Situação } & \multirow[t]{2}{*}{ Destino } & \multicolumn{3}{|c|}{$\begin{array}{c}\text { Horas trabalhadas }{ }^{(2)} \\
\text { (h/mês) }\end{array}$} \\
\hline & & & 2007 & 2012 & 2017 & & & 2007 & 2012 & 2017 \\
\hline TE & \multirow{3}{*}{11} & \multirow{3}{*}{ At. $01 \mathrm{~d} 01$} & 78 & 83 & 88 & \multirow{3}{*}{21} & \multirow{3}{*}{ At. $01 \mathrm{~d} 01$} & 78 & 83 & 88 \\
\hline RE & & & 39 & 42 & 44 & & & 39 & 42 & 44 \\
\hline$C B$ & & & 39 & 42 & 44 & & & 39 & 42 & 44 \\
\hline TE & \multirow{6}{*}{12} & \multirow{3}{*}{ At. $01 \mathrm{~d} 02$} & 47 & 50 & 52 & \multirow{6}{*}{22} & \multirow{3}{*}{ At. $01 \mathrm{~d} 02$} & 47 & 50 & 52 \\
\hline RE & & & 23 & 25 & 26 & & & 23 & 25 & 26 \\
\hline$C B$ & & & 23 & 25 & 26 & & & 23 & 25 & 26 \\
\hline TE & & \multirow{3}{*}{ At. $02 \mathrm{~d} 02$} & 31 & 33 & 35 & & \multirow{3}{*}{ At. 02 d 02} & 31 & 33 & 35 \\
\hline RE & & & 16 & 17 & 18 & & & 16 & 17 & 18 \\
\hline$C B$ & & & 16 & 17 & 18 & & & 16 & 17 & 18 \\
\hline TE & \multirow{9}{*}{13} & \multirow{3}{*}{ At. $01 \mathrm{~d} 03$} & 36 & 38 & 40 & \multirow{9}{*}{23} & \multirow{3}{*}{ At. $01 \mathrm{~d} 03$} & 36 & 38 & 40 \\
\hline RE & & & 18 & 19 & 20 & & & 18 & 19 & 20 \\
\hline$C B$ & & & 18 & 19 & 20 & & & 18 & 19 & 20 \\
\hline TE & & \multirow{3}{*}{ At. 02 d 03} & 24 & 25 & 27 & & & 24 & 25 & 27 \\
\hline RE & & & 12 & 13 & 13 & & At. 02 d 03 & 12 & 13 & 13 \\
\hline$C B$ & & & 12 & 13 & 13 & & & 12 & 13 & 13 \\
\hline T E & & \multirow{3}{*}{ At. $03 \mathrm{~d} 03$} & 18 & 20 & 21 & & \multirow{3}{*}{ At. 03 d 03} & 18 & 20 & 21 \\
\hline RE & & & 9 & 10 & 10 & & & 9 & 10 & 10 \\
\hline$C B$ & & & 9 & 10 & 10 & & & 9 & 10 & 10 \\
\hline TE & \multirow{12}{*}{14} & \multirow{3}{*}{ At. $01 \mathrm{~d} 04$} & 33 & 35 & 36 & & \multirow{3}{*}{ At. $01 \mathrm{~d} 04$} & 27 & 29 & 30 \\
\hline RE & & & 16 & 17 & 18 & & & 13 & 14 & 15 \\
\hline$C B$ & & & 16 & 17 & 18 & & & 13 & 14 & 15 \\
\hline $\mathrm{TE}$ & & \multirow{3}{*}{ At. $02 \mathrm{~d} 04$} & 14 & 15 & 16 & & & 20 & 21 & 22 \\
\hline RE & & & 7 & 8 & 8 & & At. 02 d 04 & 10 & 11 & 11 \\
\hline$C B$ & & & 7 & 8 & 8 & 24 & & 10 & 11 & 11 \\
\hline TE & & & 22 & 23 & 25 & 24 & & 22 & 23 & 25 \\
\hline RE & & At. 03 d 04 & 11 & 12 & 12 & & At. 03 d 04 & 11 & 12 & 12 \\
\hline$C B$ & & & 11 & 12 & 12 & & & 11 & 12 & 12 \\
\hline TE & & & 0 & 0 & 0 & & & 0 & 0 & 0 \\
\hline RE & & At. 04 d 04 & 33 & 35 & 37 & & At. 04 d 04 & 33 & 35 & 37 \\
\hline $\mathrm{CB}$ & & & 0 & 0 & 0 & & & 0 & 0 & 0 \\
\hline
\end{tabular}

(1) TE: Trator de esteira; RE: Retroescavadeira; CB: Caminhão basculante

(2) Produtividade TE: 35 t/h de RSU (Aterro Convencional) Produtividade RE: $20 \mathrm{~m}^{3} / \mathrm{h}$ de escavação (Aterro em vala) Obs.: Aterro Convencional: RE e CB trabalha $50 \%$ do tempo do TE

\subsubsection{Resumo dos Resultados com os Custos}

As planilhas desenvolvidas retornaram como resposta os custos para cada componente: operação de coleta, operação dos aterros sanitários e ETs, transporte com veículo de coleta, transporte com veículo de transbordo, implantação de aterros e de estações. As formas utilizadas para apresentar os resultados foram os valores totais de cada componente, dentro do horizonte de planejamento de15 anos, e os valores unitários por tonelada de resíduos gerados no mesmo período. 
Nas tabelas a seguir, encontram-se os resultados parciais para cada componente, e o resultado final.

TABELA 9.21 - Custos de operação da coleta para cada situação

\begin{tabular}{|c|c|c|c|c|c|c|c|c|c|c|c|c|c|c|}
\hline \multirow{3}{*}{ Situação } & \multicolumn{14}{|c|}{ CUSTO Transporte Veículo de Coleta - Coleta } \\
\hline & \multirow{2}{*}{\multicolumn{2}{|c|}{2007}} & \multirow{2}{*}{\multicolumn{2}{|c|}{$\mathrm{C}_{2012}(\mathrm{ROTAL})$}} & \multirow{2}{*}{\multicolumn{2}{|c|}{2017}} & \multirow{2}{*}{\multicolumn{2}{|c|}{2007}} & \multirow{2}{*}{\multicolumn{2}{|c|}{$\begin{array}{l}\text { C UNITÁRIO } \\
2012\end{array}$}} & \multicolumn{4}{|c|}{$(\mathrm{R} \$ / \mathrm{t})$} \\
\hline & & & & & & & & & & & & & & lédio \\
\hline 11 & $\mathrm{R} \$$ & 237.894 & $\mathrm{R} \$$ & 239.234 & $\mathrm{R} \$$ & 240.386 & $\mathrm{R} \$$ & 86,93 & $\mathrm{R} \$$ & 82,11 & $\mathrm{R} \$$ & 78,43 & $\mathrm{R} \$$ & 82,49 \\
\hline 12 & $\mathrm{R} \$$ & 262.345 & $\mathrm{R} \$$ & 263.685 & $\mathrm{R} \$$ & 264.837 & $\mathrm{R} \$$ & 95,86 & $\mathrm{R} \$$ & 90,51 & $\mathrm{R} \$$ & 86,41 & $\mathrm{R} \$$ & 90,92 \\
\hline 13 & $\mathrm{R} \$$ & 275.599 & $\mathrm{R} \$$ & 276.939 & $\mathrm{R} \$$ & 278.092 & $\mathrm{R} \$$ & 100,70 & $R \$$ & 95,06 & $\mathrm{R} \$$ & 90,73 & $\mathrm{R} \$$ & 95,50 \\
\hline 14 & $\mathrm{R} \$$ & 290.375 & $\mathrm{R} \$$ & 291.715 & $\mathrm{R} \$$ & 292.867 & $\mathrm{R} \$$ & 106,10 & $\mathrm{R} \$$ & 100,13 & $\mathrm{R} \$$ & 95,55 & $\mathrm{R} \$$ & 100,59 \\
\hline 21 & $\mathrm{R} \$$ & 244.917 & $\mathrm{R} \$$ & 252.499 & $\mathrm{R} \$$ & 255.150 & $\mathrm{R} \$$ & 89,49 & $\mathrm{R} \$$ & 86,67 & $\mathrm{R} \$$ & 83,24 & $\mathrm{R} \$$ & 86,47 \\
\hline 22 & $\mathrm{R} \$$ & 252.669 & $\mathrm{R} \$$ & 254.754 & $\mathrm{R} \$$ & 257.026 & $\mathrm{R} \$$ & 92,32 & $\mathrm{R} \$$ & 87,44 & $\mathrm{R} \$$ & 83,86 & $\mathrm{R} \$$ & 87,87 \\
\hline 23 & $\mathrm{R} \$$ & 271.035 & $\mathrm{R} \$$ & 272.375 & $\mathrm{R} \$$ & 273.528 & $\mathrm{R} \$$ & 99,04 & $\mathrm{R} \$$ & 93,49 & $\mathrm{R} \$$ & 89,24 & $\mathrm{R} \$$ & 93,92 \\
\hline 24 & $\mathrm{R} \$$ & 283.742 & $\mathrm{R} \$$ & 285.082 & $\mathrm{R} \$$ & 286.235 & $\mathrm{R} \$$ & 103,68 & $\mathrm{R} \$$ & 97,85 & $\mathrm{R} \$$ & 93,39 & $\mathrm{R} \$$ & 98,31 \\
\hline
\end{tabular}

TABELA 9.20 - Custos do transporte com veículo de coleta até destino

\begin{tabular}{|c|c|c|c|c|c|c|c|c|c|c|c|c|c|c|}
\hline \multirow{3}{*}{ Situação } & \multicolumn{14}{|c|}{ CUSTO Transporte Veículo de Coleta - Após coleta } \\
\hline & \multirow{2}{*}{\multicolumn{2}{|c|}{2007}} & \multirow{2}{*}{\multicolumn{2}{|c|}{$\begin{array}{l}C_{\text {TOTAL }} \\
2012\end{array}$}} & \multirow{2}{*}{\multicolumn{2}{|c|}{2017}} & \multirow{2}{*}{\multicolumn{2}{|c|}{2007}} & \multirow{2}{*}{\multicolumn{2}{|c|}{$\begin{array}{l}\text { C UNITÁRIO } \\
2012\end{array}$}} & \multicolumn{4}{|c|}{$(R \$ / t)$} \\
\hline & & & & & & & & & & & & & & dio \\
\hline 11 & $\mathrm{R} \$$ & 4.449 & $\mathrm{R} \$$ & 4.986 & $\mathrm{R} \$$ & 5.479 & $\mathrm{R} \$$ & 1,63 & $\mathrm{R} \$$ & 1,71 & $\mathrm{R} \$$ & 1,79 & $\mathrm{R} \$$ & 1,71 \\
\hline 12 & $\mathrm{R} \$$ & 4.197 & $\mathrm{R} \$$ & 4.448 & $\mathrm{R} \$$ & 4.850 & $\mathrm{R} \$$ & 1,53 & $\mathrm{R} \$$ & 1,53 & $\mathrm{R} \$$ & 1,58 & $\mathrm{R} \$$ & 1,55 \\
\hline 13 & $\mathrm{R} \$$ & 6.743 & $\mathrm{R} \$$ & 6.826 & $\mathrm{R} \$$ & 6.871 & $\mathrm{R} \$$ & 2,46 & $\mathrm{R} \$$ & 2,34 & $\mathrm{R} \$$ & 2,24 & $\mathrm{R} \$$ & 2,35 \\
\hline 14 & $\mathrm{R} \$$ & 5.966 & $\mathrm{R} \$$ & 5.966 & $\mathrm{R} \$$ & 6.090 & $\mathrm{R} \$$ & 2,18 & $\mathrm{R} \$$ & 2,05 & $\mathrm{R} \$$ & 1,99 & $\mathrm{R} \$$ & 2,07 \\
\hline 21 & $\mathrm{R} \$$ & 46.501 & $\mathrm{R} \$$ & 46.849 & $\mathrm{R} \$$ & 47.572 & $\mathrm{R} \$$ & 16,99 & $\mathrm{R} \$$ & 16,08 & $\mathrm{R} \$$ & 15,52 & $\mathrm{R} \$$ & 16,20 \\
\hline 22 & $\mathrm{R} \$$ & 27.101 & $\mathrm{R} \$$ & 27.415 & $\mathrm{R} \$$ & 27.719 & $\mathrm{R} \$$ & 9,90 & $\mathrm{R} \$$ & 9,41 & $\mathrm{R} \$$ & 9,04 & $\mathrm{R} \$$ & 9,45 \\
\hline 23 & $\mathrm{R} \$$ & 16.701 & $\mathrm{R} \$$ & 16.962 & $\mathrm{R} \$$ & 17.236 & $\mathrm{R} \$$ & 6,10 & $\mathrm{R} \$$ & 5,82 & $\mathrm{R} \$$ & 5,62 & $\mathrm{R} \$$ & 5,85 \\
\hline 24 & $\mathrm{R} \$$ & 12.255 & $\mathrm{R} \$$ & 12.513 & $\mathrm{R} \$$ & 12.785 & $\mathrm{R} \$$ & 4,48 & $\mathrm{R} \$$ & 4,29 & $\mathrm{R} \$$ & 4,17 & $\mathrm{R} \$$ & 4,31 \\
\hline
\end{tabular}

TABELA 9.22 - Custos do transporte com veículo de transbordo: Aterro-ET-Aterro

\begin{tabular}{|c|c|c|c|c|c|c|c|c|c|c|c|c|c|c|}
\hline \multirow{3}{*}{ Situação } & \multicolumn{14}{|c|}{ CUSTO Transporte Veículo Transbordo: At-ET-At } \\
\hline & & & $\mathrm{C}_{\text {TO }}$ & $(\mathrm{R} \$)$ & & & & & & UNITÁRIO & (R\$ & & & \\
\hline & \multicolumn{2}{|c|}{2007} & \multicolumn{2}{|c|}{2012} & \multicolumn{2}{|c|}{2017} & \multicolumn{2}{|c|}{2007} & \multicolumn{2}{|c|}{2012} & \multicolumn{2}{|c|}{2017} & \multicolumn{2}{|c|}{ Médio } \\
\hline 11 & $\mathrm{R} \$$ & 38.300 & $\mathrm{R} \$$ & 38.373 & $\mathrm{R} \$$ & 38.461 & $\mathrm{R} \$$ & 13,99 & $\mathrm{R} \$$ & 13,17 & $\mathrm{R} \$$ & 12,55 & $\mathrm{R} \$$ & 13,24 \\
\hline 12 & $\mathrm{R} \$$ & 40.416 & $\mathrm{R} \$$ & 40.416 & $\mathrm{R} \$$ & 40.416 & $\mathrm{R} \$$ & 14,77 & $\mathrm{R} \$$ & 13,87 & $\mathrm{R} \$$ & 13,19 & $\mathrm{R} \$$ & 13,94 \\
\hline 13 & $\mathrm{R} \$$ & 51.012 & $\mathrm{R} \$$ & 51.012 & $\mathrm{R} \$$ & 51.012 & $\mathrm{R} \$$ & 18,64 & $\mathrm{R} \$$ & 17,51 & $\mathrm{R} \$$ & 16,64 & $\mathrm{R} \$$ & 17,60 \\
\hline 14 & $R \$$ & 63.696 & $\mathrm{R} \$$ & 63.696 & $\mathrm{R} \$$ & 63.696 & $\mathrm{R} \$$ & 23,27 & $\mathrm{R} \$$ & 21,86 & $\mathrm{R} \$$ & 20,78 & $\mathrm{R} \$$ & 21,97 \\
\hline 21 & & - & & - & & - & & & & . & & & - & \\
\hline 22 & & - & & - & & - & & & & . & & & - & \\
\hline 23 & & - & & - & & - & & & & . & & & - & \\
\hline 24 & & - & & - & & - & & & & . & & & - & \\
\hline
\end{tabular}


TABELA 9.24 - Custos de operação dos Aterros e ETs

\begin{tabular}{|c|c|c|c|c|c|c|c|c|c|c|c|c|c|c|}
\hline \multirow{3}{*}{ Situação } & \multicolumn{14}{|c|}{ CUSTO Operação Aterro e/ou E.Transferência } \\
\hline & & & $\mathbf{C}_{\text {TO }}$ & $(\mathrm{R} \$)$ & & & & & \multirow{2}{*}{\multicolumn{2}{|c|}{$\begin{array}{l}\text { C UNITÁRIO } \\
2012\end{array}$}} & \multicolumn{4}{|c|}{$(\mathrm{R} \$ / \mathrm{t})$} \\
\hline & \multicolumn{2}{|c|}{2007} & \multicolumn{2}{|c|}{2012} & \multicolumn{2}{|c|}{2017} & \multicolumn{2}{|c|}{2007} & & & & & & édio \\
\hline 11 & $\mathrm{R} \$$ & 31.879 & $\mathrm{R} \$$ & 29.041 & $\mathrm{R} \$$ & 29.666 & $\mathrm{R} \$$ & 11,65 & $\mathrm{R} \$$ & 9,97 & $\mathrm{R} \$$ & 9,68 & $\mathrm{R} \$$ & 10,43 \\
\hline 12 & $\mathrm{R} \$$ & 51.130 & $\mathrm{R} \$$ & 44.788 & $\mathrm{R} \$$ & 45.468 & $\mathrm{R} \$$ & 18,68 & $\mathrm{R} \$$ & 15,37 & $\mathrm{R} \$$ & 14,83 & $\mathrm{R} \$$ & 16,30 \\
\hline 13 & $\mathrm{R} \$$ & 68.638 & $\mathrm{R} \$$ & 58.793 & $\mathrm{R} \$$ & 59.527 & $\mathrm{R} \$$ & 25,08 & $\mathrm{R} \$$ & 20,18 & $\mathrm{R} \$$ & 19,42 & $\mathrm{R} \$$ & 21,56 \\
\hline 14 & $\mathrm{R} \$$ & 78.376 & $\mathrm{R} \$$ & 67.370 & $\mathrm{R} \$$ & 68.126 & $\mathrm{R} \$$ & 28,64 & $\mathrm{R} \$$ & 23,12 & $\mathrm{R} \$$ & 22,23 & $\mathrm{R} \$$ & 24,66 \\
\hline 21 & $\mathrm{R} \$$ & 27.507 & $\mathrm{R} \$$ & 24.669 & $\mathrm{R} \$$ & 25.294 & $\mathrm{R} \$$ & 10,05 & $\mathrm{R} \$$ & 8,47 & $\mathrm{R} \$$ & 8,25 & $\mathrm{R} \$$ & 8,92 \\
\hline 22 & $\mathrm{R} \$$ & 44.419 & $\mathrm{R} \$$ & 38.077 & $\mathrm{R} \$$ & 38.757 & $\mathrm{R} \$$ & 16,23 & $\mathrm{R} \$$ & 13,07 & $\mathrm{R} \$$ & 12,64 & $\mathrm{R} \$$ & 13,98 \\
\hline 23 & $\mathrm{R} \$$ & 61.330 & $\mathrm{R} \$$ & 51.486 & $\mathrm{R} \$$ & 52.220 & $\mathrm{R} \$$ & 22,41 & $\mathrm{R} \$$ & 17,67 & $\mathrm{R} \$$ & 17,04 & $\mathrm{R} \$$ & 19,04 \\
\hline 24 & $\mathrm{R} \$$ & 69.020 & $\mathrm{R} \$$ & 58.014 & $\mathrm{R} \$$ & 58.770 & $\mathrm{R} \$$ & 25,22 & $\mathrm{R} \$$ & 19,91 & $\mathrm{R} \$$ & 19,17 & $\mathrm{R} \$$ & 21,44 \\
\hline
\end{tabular}

TABELA 9.23 - Custos total das componentes de operação

\begin{tabular}{|c|c|c|c|c|c|c|c|c|c|c|c|c|c|c|}
\hline \multirow{4}{*}{$\begin{array}{c}\text { Situação } \\
11\end{array}$} & \multicolumn{14}{|c|}{ CUSTO OPERAÇÃO TOTAL } \\
\hline & \multirow{2}{*}{\multicolumn{2}{|c|}{2007}} & \multirow{2}{*}{\multicolumn{2}{|c|}{$\mathrm{C}_{\text {TOTAL }}(\mathrm{R} \$)$}} & \multirow{2}{*}{\multicolumn{2}{|c|}{2017}} & \multirow{2}{*}{\multicolumn{2}{|c|}{2007}} & \multirow{2}{*}{\multicolumn{2}{|c|}{$\begin{array}{l}C_{\text {UNITÁRIO }} \\
2012\end{array}$}} & \multicolumn{4}{|c|}{$(\mathrm{R} \$ / \mathrm{t})$} \\
\hline & & & & & & & & & & & & & & lédio \\
\hline & $\mathrm{R} \$$ & 312.522 & $\mathrm{R} \$$ & 311.633 & $\mathrm{R} \$$ & 313.993 & $\mathrm{R} \$$ & 114,19 & $\mathrm{R} \$$ & 106,96 & $\mathrm{R} \$$ & 102,44 & $\mathrm{R} \$$ & 107,87 \\
\hline 12 & $\mathrm{R} \$$ & 358.087 & $\mathrm{R} \$$ & 353.337 & $\mathrm{R} \$$ & 355.571 & $\mathrm{R} \$$ & 130,84 & $\mathrm{R} \$$ & & $\mathrm{R} \$$ & & $\mathrm{R} \$$ & 122,71 \\
\hline 13 & $\mathrm{R} \$$ & 401.992 & $R \$$ & 393.571 & $\mathrm{R} \$$ & 395.502 & $\mathrm{R} \$$ & 146,89 & $\mathrm{R} \$$ & 135,09 & $\mathrm{R} \$$ & 129,04 & $\mathrm{R} \$$ & 137,00 \\
\hline 14 & $\mathrm{R} \$$ & 438.412 & $\mathrm{R} \$$ & 428.746 & $\mathrm{R} \$$ & 430.779 & $\mathrm{R} \$$ & 160,19 & $\mathrm{R} \$$ & 147,16 & $\mathrm{R} \$$ & 140,55 & $\mathrm{R} \$$ & 149,30 \\
\hline 21 & $\mathrm{R} \$$ & 318.926 & $\mathrm{R} \$$ & 324.017 & $\mathrm{R} \$$ & 328.016 & $\mathrm{R} \$$ & 116,53 & $\mathrm{R} \$$ & 111,21 & $\mathrm{R} \$$ & 107,02 & $\mathrm{R} \$$ & 111,59 \\
\hline 22 & $\mathrm{R} \$$ & 324.190 & $\mathrm{R} \$$ & 320.247 & $\mathrm{R} \$$ & 323.502 & $\mathrm{R} \$$ & 118,46 & $\mathrm{R} \$$ & 109,92 & $\mathrm{R} \$$ & 105,55 & $\mathrm{R} \$$ & 111,31 \\
\hline 23 & $\mathrm{R} \$$ & 349.067 & $\mathrm{R} \$$ & 340.824 & $\mathrm{R} \$$ & 342.983 & $\mathrm{R} \$$ & 127,55 & $\mathrm{R} \$$ & 116,98 & $\mathrm{R} \$$ & 111,90 & $\mathrm{R} \$$ & 118,81 \\
\hline 24 & $\mathrm{R} \$$ & 365.017 & $\mathrm{R} \$$ & 355.608 & $\mathrm{R} \$$ & 357.790 & $\mathrm{R} \$$ & 133,38 & $\mathrm{R} \$$ & 122,06 & $\mathrm{R} \$$ & 116,73 & $\mathrm{R} \$$ & 124,06 \\
\hline
\end{tabular}

TABELA 9.25 - Custos de investimentos na implantação dos aterros e ETs

\begin{tabular}{|c|c|c|c|c|c|c|c|c|c|c|c|c|}
\hline \multirow{3}{*}{$\begin{array}{c}\text { Situação } \\
11\end{array}$} & \multicolumn{12}{|c|}{ IMPLANTAÇÃO } \\
\hline & \multicolumn{2}{|c|}{$\begin{array}{l}\text { Investimento } \\
(\mathrm{R} \$)\end{array}$} & \multicolumn{2}{|c|}{$\begin{array}{c}C_{\text {UNITÁRIO }} \\
(\mathrm{R} \$ / \mathrm{t})\end{array}$} & \multicolumn{2}{|c|}{$\begin{array}{l}\text { Investimento } \\
(\mathrm{R} \$)\end{array}$} & \multicolumn{2}{|c|}{$\begin{array}{c}C_{\text {UNITÁRIO }} \\
(\mathrm{R} \$ / \mathrm{t})\end{array}$} & \multicolumn{2}{|c|}{$\begin{array}{c}\text { Investimento } \\
(\mathrm{R} \$)\end{array}$} & \multicolumn{2}{|c|}{$\begin{array}{c}\text { C UNITÁRIO } \\
(\mathrm{R} \$ / \mathrm{t})\end{array}$} \\
\hline & $\mathrm{R} \$$ & 1.081 .104 & $\mathrm{R} \$$ & 2,07 & $\mathrm{R} \$$ & 975.992 & $\mathrm{R} \$$ & 1,87 & $\mathrm{R} \$$ & 2.057 .096 & $\mathrm{R} \$$ & 3,93 \\
\hline 12 & $\mathrm{R} \$$ & 970.091 & $\mathrm{R} \$$ & 1,85 & $\mathrm{R} \$$ & 976.135 & $\mathrm{R} \$$ & 1,87 & $\mathrm{R} \$$ & 1.946 .226 & $\mathrm{R} \$$ & 3,72 \\
\hline 13 & $\mathrm{R} \$$ & 1.588 .695 & $\mathrm{R} \$$ & 3,04 & $\mathrm{R} \$$ & 655.607 & $\mathrm{R} \$$ & 1,25 & $\mathrm{R} \$$ & 2.244 .302 & $\mathrm{R} \$$ & 4,29 \\
\hline 14 & $\mathrm{R} \$$ & 1.710 .312 & $\mathrm{R} \$$ & 3,27 & $\mathrm{R} \$$ & 587.835 & $\mathrm{R} \$$ & 1,12 & $\mathrm{R} \$$ & 2.298 .147 & $\mathrm{R} \$$ & 4,39 \\
\hline 21 & $\mathrm{R} \$$ & 1.081 .104 & $\mathrm{R} \$$ & 2,07 & & - & & & $\mathrm{R} \$$ & 1.081 .104 & $\mathrm{R} \$$ & 2,07 \\
\hline 22 & $\mathrm{R} \$$ & 1.386 .382 & $\mathrm{R} \$$ & 2,65 & & - & & & $\mathrm{R} \$$ & 1.386 .382 & $\mathrm{R} \$$ & 2,65 \\
\hline 23 & $\mathrm{R} \$$ & 1.588 .695 & $\mathrm{R} \$$ & 3,04 & & - & & & $\mathrm{R} \$$ & 1.588 .695 & $\mathrm{R} \$$ & 3,04 \\
\hline 24 & $\mathrm{R} \$$ & 1.724 .718 & $\mathrm{R} \$$ & 3,30 & & - & & & $\mathrm{R} \$$ & 1.724 .718 & $\mathrm{R} \$$ & 3,30 \\
\hline
\end{tabular}


TABELA 9.26 - Custos total final de todas as componentes

\begin{tabular}{|c|c|c|c|c|c|c|c|c|c|c|c|c|c|c|}
\hline \multirow{3}{*}{ Situação } & \multicolumn{14}{|c|}{ CUSTO TOTAL FINAL } \\
\hline & & & $\mathrm{C}_{T}$ & $(\mathrm{R} \$)$ & & & & & & S UNITÁrIo & $(\mathrm{R} \$$ & & & \\
\hline & \multicolumn{2}{|r|}{2007} & \multicolumn{2}{|r|}{2012} & \multicolumn{2}{|r|}{2017} & \multicolumn{2}{|c|}{2007} & \multicolumn{2}{|c|}{2012} & \multicolumn{2}{|c|}{2017} & \multicolumn{2}{|c|}{ Médio } \\
\hline 11 & $\mathrm{R} \$$ & 998.221 & $\mathrm{R} \$$ & 997.332 & $\mathrm{R} \$$ & 999.692 & $\mathrm{R} \$$ & 118,13 & $\mathrm{R} \$$ & 110,90 & $\mathrm{R} \$$ & 106,37 & $\mathrm{R} \$$ & 111,80 \\
\hline 12 & $\mathrm{R} \$$ & 1.006 .829 & $\mathrm{R} \$$ & 1.002 .079 & $\mathrm{R} \$$ & 1.004 .313 & $\mathrm{R} \$$ & 134,56 & $\mathrm{R} \$$ & 125,00 & $R_{s}$ & 119,73 & $\mathrm{R} \$$ & 126,43 \\
\hline 13 & $\mathrm{R} \$$ & 1.150 .092 & $\mathrm{R} \$$ & 1.141 .671 & $\mathrm{R} \$$ & 1.143 .603 & $\mathrm{R} \$$ & 151,18 & $\mathrm{R} \$$ & 139,38 & $\mathrm{R} \mathbb{\$}$ & 133,32 & $R \$$ & 141,29 \\
\hline 14 & $\mathrm{R} \$$ & 1.204 & $\mathrm{R} \$$ & 1.194 .795 & $\mathrm{R} \$$ & 1.196 .828 & $\mathrm{R} \$$ & 164 & $\mathrm{R} \$$ & 55 & $\mathrm{R} \$$ & ,94 & $R \$$ & 153,69 \\
\hline 21 & $\mathrm{R} \$$ & 679.294 & $\mathrm{R} \$$ & 684.385 & $\mathrm{R} \$$ & 688.384 & $\mathrm{R} \$$ & 118,60 & $\mathrm{R} \$$ & 28 & $\mathrm{R} \$$ & 109,08 & $R \$$ & 113,66 \\
\hline 22 & $\mathrm{R} \$$ & 786.317 & $\mathrm{R} \$$ & 782.374 & $\mathrm{R} \$$ & 785.629 & $\mathrm{R} \$$ & 121 & $\mathrm{R} \$$ & 57 & $\mathrm{R} \$$ & 108,19 & $R \$$ & 113,96 \\
\hline 23 & $\mathrm{R} \$$ & 878.632 & $\mathrm{R} \$$ & 870.389 & $\mathrm{R} \$$ & 872.548 & $\mathrm{R} \$$ & 130,58 & $\mathrm{R} \$$ & 120,02 & $\mathrm{R} \$$ & 114,94 & $R \$$ & 121,85 \\
\hline 24 & $\mathrm{R} \$$ & 939.923 & $\mathrm{R} \$$ & 930.514 & $\mathrm{R} \$$ & 932.697 & $\mathrm{R} \$$ & 136,67 & $\mathrm{R} \$$ & 125,35 & $\mathrm{R} \$$ & 120,03 & $\mathrm{R} \$$ & 127,35 \\
\hline
\end{tabular}

\subsubsection{Análise dos resultados}

Antes de iniciar a comparação dos resultados finais, a primeira observação feita é sobre a componente custo de coleta, cujo valor se apresenta fora do que comumente se vê na prática, aproximadamente a metade. Estes resultados podem ser vistos na TABELA 9.21.

No primeiro momento imaginou-se que haveria algum problema de cálculo ou de conceito. Toda a planilha de custo foi revisada, e assim, o único ponto que poderia apresentar algum problema seria a entrada de valores na planilha de custo. Assim, o problema estaria no dimensionamento da coleta. E, esta etapa foi reavaliada, através de simulações, variando-se alguns parâmetros adotados, e não foi encontrado nenhum ponto que levasse a variações muito significativas.

A compreensão, do fato do valor dos custos de coleta estar alto, foi alcançada ao se comparar a coleta de uma cidade com a mesma produção de resíduos do consórcio na situação com um aterro. Na pesquisa realizada por DELUQUI (1998), foram apresentados os valores de quantidade de resíduos, população e a frota da coleta na cidade de São Carlos-SP, para um determinado período. O tamanho da população e os valores de produção de resíduos eram próximos dos existentes nos municípios da APA de Corumbataí. Porém, a frota utilizada por São Carlos era bem menor. Enquanto a APA como um todo precisava de 16 veículos na condição otimizada, com o uso compartilhado da frota entre cidades, a frota de coleta de São Carlos era de apenas 5 veículos. 
Para se entender a diferença, primeiro substitui-se na planilha de custos, para a situação com um aterro, os valores de frota como sendo de 5 veículos, trabalhando em 2 jornadas por dia, e reduzindo a vida útil dos veículos para 60 meses (vide último parágrafo no final do item 8.2). Neste caso simplificado, o valor médio do custo unitário ficou em $R \$ 52,20$ que é um resultado mais realista.

Porém, a APA de Corumbataí não poderia trabalhar, a princípio, com 5 veículos, já que estaria assumindo 8 sedes urbanas trabalhando cada qual com sua frota, e 3 conjuntos de sedes trabalhando cada qual com uma frota compartilhada. Neste ponto de vista, se cada caso tivesse um veículo, seriam necessários no mínimo 11 veículos, o dobro da situação que ocorria em São Carlos. Assim, os valores encontrados na planiIha estão coerentes, apesar de altos. O que se pode concluir é que existe uma ociosidade imposta pela condição dos municípios serem de pequeno porte, e nem mesmo o consórcio, com as suposições desta pesquisa, conseguiu resolver.

Esclarecido este fato, pode se prosseguir com a avaliação dos custos. O sistema con-

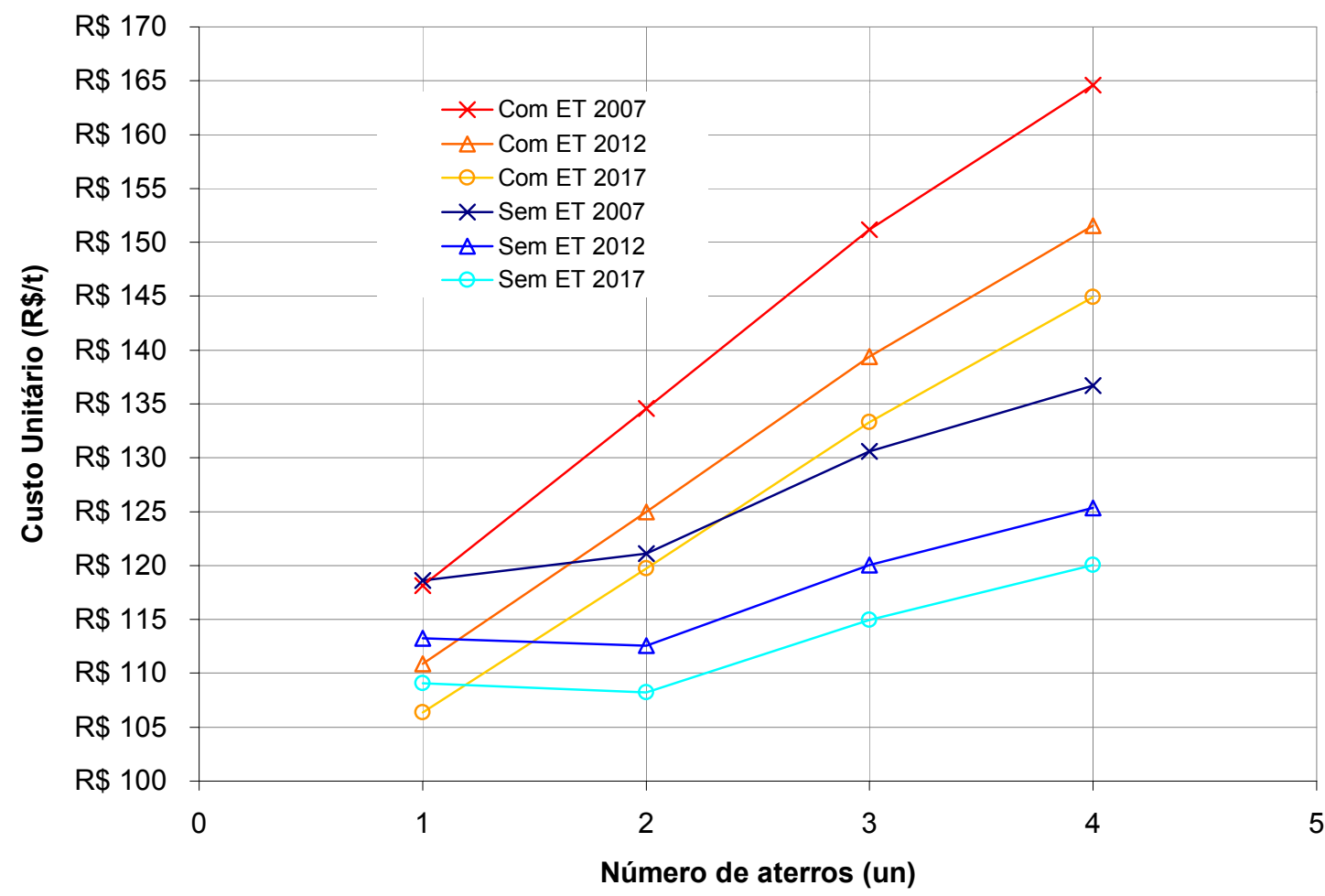

FIGURA 9.11 - Custo unitário por tonelada de RSU produzido do Sistema Consorciado segundo o número de aterros 


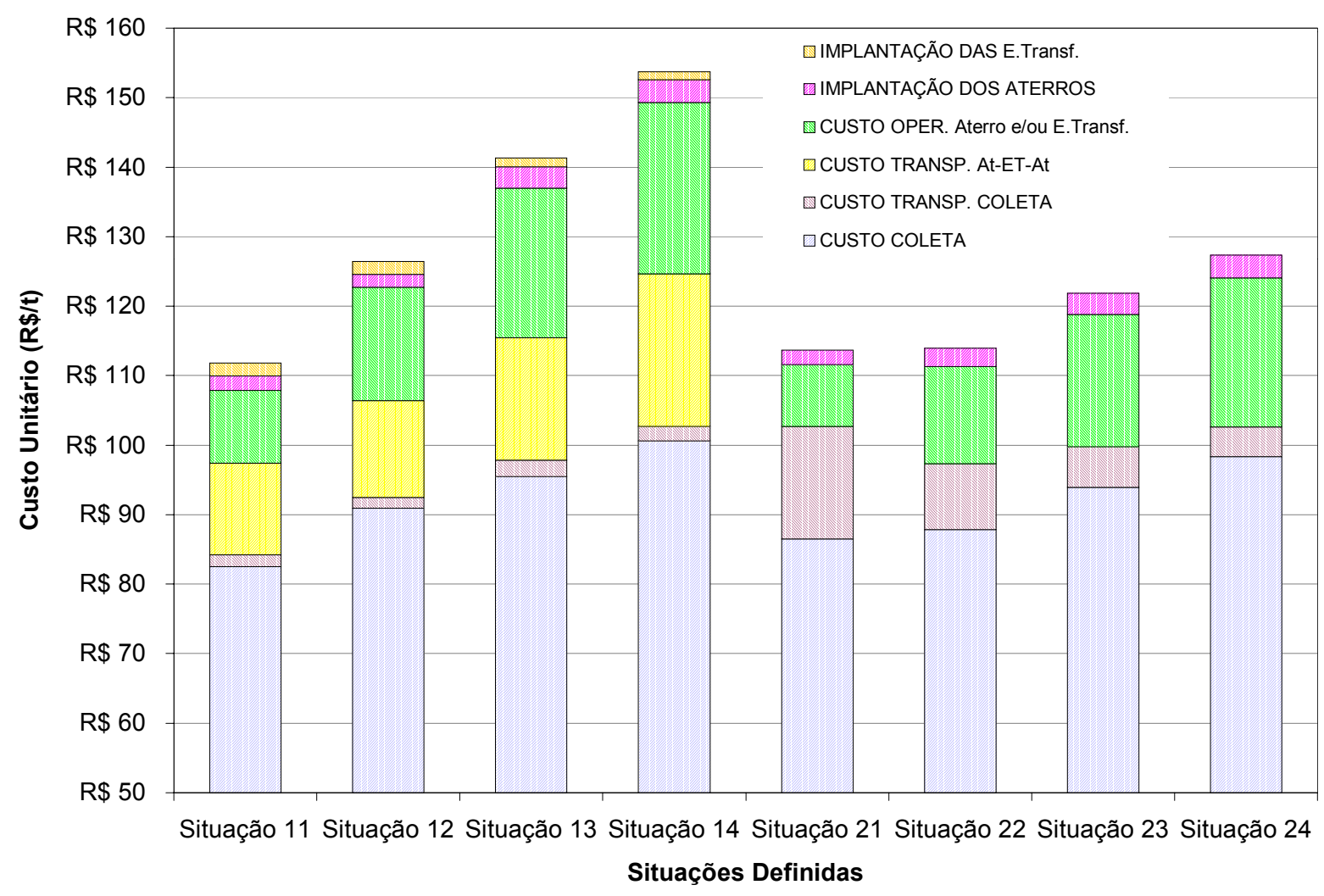

FIGURA 9.12 - Custo unitário médio por tonelada de RSU produzido do Sistema Consorciado segundo a situação definida e os componentes dos custos

sorciado foi analisado considerando-se o custo de implantação e operação do sistema. Os gastos com a fase de projeto, por exemplo, não foram computados aqui. Os gráficos da FIGURA 9.11 e FIGURA 9.12 apresentam a comparação dos resultados obtidos por tonelada de resíduos gerada para cada situação definida.

No gráfico da FIGURA 9.11, os resultados são apresentados para os períodos de dimensionamentos, de 2003 até 2007, de 2008 até 2012 e de 2013 até 2017 . O primeiro ponto que se verifica é que, com o passar do tempo, a solução se torna mais econômica. Isto pode parecer incoerente, mas não se for considerar que existe ociosidade no sistema. Isto significa que a mesma quantidade de equipamentos está fazendo o serviço, mesmo com o aumento na geração de RSU.

No mesmo gráfico, pode ser visto que a melhor solução encontrada foi a situação com 1 aterro, e com ET. Os valores exatos podem ser vistos na TABELA 9.26. Mas a situação sem ET chegou a valores bem próximos, e pode-se verificar a condição de custo mínimo, na situação com dois aterros para os dois últimos períodos. 
Continuando as análises deste mesmo gráfico, observa-se que, quanto maior é o número de aterros, ou seja, mais próximo da solução isolada (sem consórcio), há uma tendência dos custos aumentarem. Isto indica que os resultados do consórcio confirmaram, mesmo ocorrendo condições de ociosidade, uma maior eficiência com racionalização de recursos se comparada com a solução isolada.

O gráfico da FIGURA 9.12 ilustra os componentes dos custos entre as situações com ou sem ETs. Através dela pode verificar-se a composição dos componentes para cada situação e sua variação com o número de aterros. É preciso lembrar que a componente custo de transporte, com os veículos de coleta da FIGURA 9.12, está contemplado apenas o custo adicional de insumos e manutenção dos veículos de coleta. Pois os gastos individuais de mão-de-obra e os demais custos já foram incluídas no componente do custo da coleta propriamente dito. Isto explica a variação do custo total da coleta com o aumento no número de aterros.

É possível verificar também, para a situação sem $\mathrm{ET}$, a redução do custo de transporte com o veículo de coleta, com o aumento do número de aterros, ou seja, as cidades estão mais próximas dos aterros, percorrendo-se menores distâncias.

A eficiência do sistema consorciado pode ser vista também, quando se verifica que os custos unitários de operação dos aterros e estações, da operação da coleta, das implantações das instalações, são menores quando se têm menos aterros para o mesmo número de municípios. Em outras palavras, quanto maior é o número de cidades trabalhando em conjunto, para um mesmo aterro, mais eficiente se torna o sistema. 


\section{CONCLUSÕES E RECOMENDAÇÕES}

Para as cidades de pequeno porte do estudo de caso desta pesquisa, o consórcio intermunicipal não chega a resolver todos os problemas de ociosidade de instalações e equipamentos do sistema de destinação de RSU, mas confirmou ser melhor do que a situação dos municípios trabalhando de forma isolada. Os resultados confirmaram que existe uma redução significativa nos custos, quando se opta pela solução conjunta entre os municípios, para se resolver um problema em comum, no caso, a destinação dos resíduos sólidos.

Um dos problemas mais críticos do inadequado aproveitamento dos equipamentos pôde ser visto no sistema de coleta. Uma possível solução para isto, mas menos desejável, seria a diminuição na freqüência de coleta nas cidades, que foi considerada diária nos centros e alternada nos outros setores. Porém, como as cidades têm características turísticas, isto não é recomendado, pois a presença de lixo nas ruas por um tempo maior significa a probabilidade de se verificar a presença maior de roedores, baratas e moscas nas ruas, além do forte odor e prejuízo na estética da cidade.

Mas, uma alternativa que pode ser estudada, e não considerada neste trabalho para solucionar este mesmo problema, é a adoção de 3 jornadas de trabalho para os veículos de coleta. Isto é, um veículo coletaria em várias cidades em um dia, cada uma em uma jornada diferente, fazendo com que o compartilhamento da frota entre cidades aumentasse, reduzindo o número de veículos no sistema consorciado. Porém, haveria um aumento no custo da mão-de-obra com adicional noturno e horas extras, e gastos 
com a viagem do veículo entre as cidades. O limitante no compartilhamento estaria no tempo total diário de trabalho de cada veículo, que seria a soma do período de coleta nas cidades mais o tempo de viagem de uma cidade para outra. Este estudo fica como recomendação para trabalhos futuros.

O método desenvolvido nesta pesquisa não contempla os processos intermediários de reaproveitamento de materiais, através de usinas de triagem ou coleta seletiva, para que o conceito de gerenciamento integrado fosse alcançado com mais profundidade. Nada impede que o sistema consorciado contemple estas atividades. Mas, o que está considerado no método deste trabalho, é o mínimo necessário para que se inicie a correta destinação dos resíduos, começando com a coleta nas cidades e finalizando com a disposição no aterro sanitário, que é a única instalação de destino final que não apresenta refugos ou rejeitos (SÃO PAULO, 1998a). Qualquer outra atividade que fosse considerada viria apenas complementar o processo de destinação dos resíduos.

E também, não existe uma resposta pronta, ou óbvia, se os ganhos com a consideração de outros processos nas análises venham a ser vantajosas. Pode ocorrer de o custo de implantação de uma usina de triagem ou coleta seletiva seja muito alto, inviabilizando qualquer projeto. O ganho ambiental com o reaproveitamento existe, mas em qualquer administração, se há prejuízo nas contas públicas, não é justificado nenhum investimento. Nestes casos, deveria haver subsídios federais aos governos locais. E, estes gastos serão compensados ao longo dos anos, de modo global, pela diminuição dos custos ambientais, mensurados e comprovados por estudos técnicos. Em qualquer situação, considerando ou não algum processo de destinação dos resíduos, a análise técnica é necessária.

A escolha da região do estudo de caso, municípios turísticos pertencentes a APA de Corumbataí, veio enriquecer a pesquisa, pois puderam ser estudados parâmetros diversos como a população flutuante, além do consórcio servir de justificativa ambiental para que seja menor possível o número de aterros nesta região, ou seja, o mínimo de potenciais focos de agressão aos recursos naturais.

É importante que, a aplicação deste método em um caso real seja realizado com muito critério, pois nesta pesquisa muita informação foi adotada na ausência da mesma. É 
sugerido que se busque obter dados reais junto aos municípios, com a ajuda de especialistas capazes de analisar a qualidade da informação. Nada impede adotar de algum dado, porém o seu valor deve ser validado através de acompanhamento e análises estatísticas.

Sobre a inclusão da Estação de Transferência (ET) nos estudos, é de se observar que, apesar de não ter sido mencionado o aspecto de odor com a formação de percolado, dispositivos de controle devem ser criados para recolhimento dos líquidos e limpeza do local. A própria localização da ET, neste trabalho, foi realizada na periferia e fora da zona urbana, já se evitando o problema de mau cheiro na vizinhança. E, o próprio sistema de funcionamento dos silos de armazenagem, não permite o acúmulo de resíduos por um período muito longo, pois o primeiro resíduo que é depositado é sempre o primeiro que sai.

Sobre a ferramenta SIG-T TransCAD usada neste trabalho, a sua utilização foi satisfatória, com exceção da rotina de roteirização, necessitando de alguns ajustes para refazer as análises. Porém, na localização dos aterros, o resultado foi imediato. Mesmo na roteirização, apesar da resposta não ter sido obtido de forma rápida, a heurísitica da rotina de roteirização demonstrou ser flexível para realizar ajustes e análises complexas. No geral, o TransCAD demonstrou ser uma ferramenta SIG de apoio a decisão espacial útil no caso de analisar o sistema de destinação consorciada de RSU, atendendo as expectativas da presente pesquisa.

Para o caso como o da pesquisa, com poucas cidades, haveria a possibilidade de se fazer análises logísticas de forma manual, pois não seria muito trabalhoso. Esta observação é importante, pois são poucos os que poderiam adquirir um software como o TransCAD, cuja aquisição chega a ser de US\$10.000 (dez mil dólares). Caso se queira utilizar, a solução seria a de recorrer a ajuda de instituições de ensinos, ou consultorias, que possuam este tipo de ferramenta.

Nas situações de pequenas dimensões, o TransCAD tem a vantagem, sobre as análises manuais, de ter a capacidade de oferecer a visualização espacial gráfica das soluções obtidas, podendo, de forma instantânea, verificar a possibilidade de uma melhora. E, na situação de muitos municípios, como no caso de se estudar o consórcio em 
todo o Estado de São Paulo, a aplicação manual das análises já não é óbvia, sendo necessária a utilização de softwares como o TransCAD.

Como conclusão final, o método desenvolvido nesta pesquisa, as ferramentas utilizadas e a solução proposta, fizeram com que se atingisse o objetivo da pesquisa, ou seja, de analisar o sistema consorciado para destinação dos resíduos sólidos e confirmá-lo como alternativa melhor que a solução isolada.

Antes de finalizar, vale observar que o ganho com o consórcio não é apenas nos custos para os municípios, mas também, existe uma redução nos custos logísticos de instituições de fiscalização ambiental como a CETESB, pois diminuindo o número de aterros, reduz-se os locais de monitoramento e os respectivos recursos materiais e humanos necessários.

Este trabalho não pode ser considerado como o estudo completo do consórcio, muito menos como a solução para o problema do lixo, e sim, o primeiro subsídio para se desenvolver estudos mais complexos e completos que levem, em um processo de melhoria contínua, a inibição da degradação do meio ambiente e os escassos recursos.

Com estas conclusões, é desejável que esta pesquisa sirva de subsídio para que profissionais e pesquisadores da área desenvolvam estudos e até projetos, para auxiliar na implantação de soluções para destinação adequada de resíduos, principalmente para as cidades de pequeno porte, que sofrem com a falta de recursos financeiros e técnicos. 


\section{REFERÊNCIA BIBLIOGRÁFICA}

AGENDA 21 (1997). Versão eletrônica 1.1. Cópia livre. Brasília, MMA - MCT. Projeto PNUD BRA/94/016. Disponível em: <http://www.mma.gov.br/port/se/agen21/doc/ag21 .zip>. Acesso em: 15 Abr. 2002.

ASSAD, A. A. (1988). Modeling and implementation issues in vehicle routing. In: GOLDEN, B. L.; ASSAD, A. A.; ed. Vehicle routing: methods and studies. North Holland, Amsterdam. p.7-46.

ASSIS, J. F. (1999). Avaliação do uso de aterros, como alternativa para disposição de resíduos sólidos domiciliares e industriais. São Carlos. 126 p. Dissertação (Mestrado) - EESC, USP.

ASSOCIAÇÃO BRASILEIRA DE NORMAS TÉCNICAS (1985). NBR 8849 - Apresentação de projetos de aterros controlados de resíduos sólidos urbanos. Rio de Janeiro, ABNT. 9 p.

ASSOCIAÇÃO BRASILEIRA DE NORMAS TÉCNICAS (1987a). NBR 10004 - Resíduos Sólidos. Rio de Janeiro, ABNT. 63 p.

ASSOCIAÇÃO BRASILEIRA DE NORMAS TÉCNICAS (1987b). NBR 10005 - Lixiviação de Resíduos. Rio de Janeiro, ABNT. 10 p.

ASSOCIAÇÃO BRASILEIRA DE NORMAS TÉCNICAS (1987c). NBR 10006 - Solubilização de Resíduos. Rio de Janeiro, ABNT. 2 p.

ASSOCIAÇÃO BRASILEIRA DE NORMAS TÉCNICAS (1987d). NBR 10007 - Amostragem de Resíduos. Rio de Janeiro, ABNT. 25 p.

ASSOCIAÇÃO BRASILEIRA DE NORMAS TÉCNICAS (1992). NBR 8419 - Apresentação de projetos de aterros sanitários de resíduos sólidos urbanos. Rio de Janeiro, ABNT. 7 p.

ASSOCIAÇÃO BRASILEIRA DE NORMAS TÉCNICAS (1993). NBR 12807 - Manuseio de resíduos de serviço de saúde: procedimento. Rio de Janeiro, ABNT.3 p. 
BALLOU, R. H. (2001). Gerenciamento da Cadeia de Suprimentos: planejamento, organização e logística empresarial. 4. ed. Tradução: Elias Pereira. Porto Alegre, Bookman. $532 \mathrm{p}$.

BIDONE, F. R. A; POVINELLI, J. (1999). Conceitos básicos de resíduos sólidos. São Carlos, EESC. 120 p. Projeto REENGE.

BODIN, L.; GOLDEN, B. (1981). Classification in vehicle routing and scheduling. Networks, v. 11, p. 97-108.

BODIN, L.; GOLDEN, B.; ASSAD, A.; BALL, M. (1983). Routing and scheduling of vehicles: the state of the art. Pergamon Press, Great Britain, Special issue of Computers and Operations Research, v. 10, n. 2, p. 63-211.

BORGES, M. E. (2001). Dificuldades e soluções para o gerenciamento dos sistemas de limpeza urbana. In: FORATTINI, G. D. A contribuição do IBAMA para a questão ambiental municipal. Disponível em: <http://www.ecoambiental.com.br/gestaoambiental-municipio.htm>. Acesso em: 23 jun. 2001.

BRASIL. Constituição, 1988 (2002). Constituição da República Federativa do Brasil, 1998. Brasília, Senado Federal - Prodasen. Disponível em: <http://www.senado.gov. $\mathrm{br} / \mathrm{bdtextual} /$ const88/const88. htm>. Acesso em: 01 maio 2002. Última atualização: jan. 2002.

BRASIL. Ministério do Meio Ambiente. Conselho Nacional do Meio Ambiente. Leis, etc. (1993). Resolução CONAMA $n^{\circ} 005$ de 5 de ago. de 1993. Resolve sobre a definição de normas mínimas para tratamento de resíduos sólidos oriundos de serviços de saúde, portos e aeroportos, considerando a determinação contida no art. $3^{\circ}$ da Resolução CONAMA n 006 de 19 de set. de 1991, bem como a necessidade de estender tais exigências aos terminais ferroviários e rodoviários. Brasília, MMA - CONAMA. Disponível em: < http://www.mma.gov.br/port/conama/res/res93/res0593.html>. Acesso em: 8 abr. 2001.

BRASIL. Ministério do Meio Ambiente. Secretaria Executiva. Fundo Nacional do Meio Ambiente (2000). Fomento a projetos de ordenamento da coleta e disposição final adequada de resíduos sólidos: manual para apresentação de propostas. Brasília, MMA - FNMA. (Edital FNMA 02/200). Disponível em: <http://www.mma.gov.br/port/fnma led2.html\#2>. Acesso em: 8 abr. 2002.

BRASIL. Ministério do Meio Ambiente. Conselho Nacional do Meio Ambiente. Leis, etc. (2001a). Resolução CONAMA n ${ }^{\circ} 275$ de 25 de abr. de 2001. Resolve sobre o código de cores para diferentes tipos de resíduos, a ser adotado na identificação de coletores e transportadores, bem como nas campanhas informativas para a coleta seletiva. Brasília, MMA - CONAMA. Disponível em: <http://www.mma.gov.br/port/conama/res/ res01/res27501.html>. Acesso em: 15 abr. 2001.

BRASIL. Ministério do Meio Ambiente. Secretaria Executiva. Fundo Nacional do Meio Ambiente (2001b). Modelo de Gestão dos Resíduos Sólidos Urbanos. Brasília, MMA FNMA. Disponível em: <http://www.mma.gov.br/port/ fnma/doc/gestao.zip>. Acesso em: 8 abr. 2002. 
BRETAS, A. L. (1982). Equipamentos utilizados em aterros sanitários. São Paulo, CEPAM. 32 p.

CALIPER (1996a). Routing and Logistics with TransCAD 3.0 (Transportation GIS software). Version 3.0 for use with Microsoft Windows. Newton - MA, Caliper Corporation.

CARDOSO, F. F. (2002). Serviços de escavação: equipamentos e aspectos executivos. São Paulo: Escola Politécnica da USP. 25 p. Disponível em: <www.pcc.usp.br/ Graduação/PCC2435/pdf/servicos_escavacao.pdf >. Acesso em: 20 ago. 2002.

CONSTRUÇÃO MERCADO: custos, suprimentos, planejamento e controle de obras (2002). São Paulo, PINI, n. 10, maio de 2002. 328 p.

CINTRA, I. S.; BARRETO, A. A. (1997). Aplicação de SIG no gerenciamento de resíduos Sólidos: Localização de área para aterro sanitário. In: Congresso Brasileiro de Engenharia Sanitária e Ambiental, 19., Foz do Iguaçu. Rio de Janeiro, ABES. 1 CDROM.

COSTA, H. S. (1998). Aspectos operacionais das estações de transferência de resíduos sólidos domiciliares no Brasil. São Carlos. 199 p. Dissertação (Mestrado) EESC, USP.

CRUZ, M. C. M. T., org. (2001). Consórcios Intermunicipais: uma alternativa de integração regional ascendente. Programa Gestão Pública e Cidadania/EAESP/FGV. São Paulo, Pólis. 96 p. Disponível em: <http://www.polis. org.br/publicacoes/download/ arquivos/cadbid5.pdf>. Acesso em: 06 ago. 2001.

CUNHA, C.B. (1997). Uma contribuição papa o problema de roteirização de veículos com restrições operacionais. São Paulo. 222 p. Tese (Doutorado) - Escola Politécnica, USP.

D'ALMEIDA, M. L. O.; VILHENA, A., coords. (2000). Lixo municipal: manual de gerenciamento integrado. 2. ed. São Paulo, IPT - CEMPRE. 370 p.

DAVIS, C.; CÂMARA, G. (2001). Arquitetura de sistemas de informação geográfica. In: DAVIS, C.; CÂMARA, G.; MONTEIRO, A. M. V. eds. Introdução à ciência da geoinformação. Cap. 3. Primeiro de 3 livros. In: CÂMARA, G.; MONTEIRO, A. M. V. eds. Geoprocessamento: Teoria e Aplicações. Série com 3 livros. Disponível em: < http://www. dpi.inpe.br/gilberto/livro/introd/cap3-arquitetura.pdf>. Acesso em: 01 maio 2002.

DELUQUI, K. K. (1998). Roteirização para veículos de coleta de resíduos sólidos domiciliares utilizando um sistema de informação geográfica-SIG. São Carlos. 222 p. Dissertação (Mestrado) - EESC, USP.

DINIZ, U. L. (2000). Alocação e dimensionamento de frotas de veículos para apoio a maquinário agrícola de usinas sucroalcooleiras. São Carlos. 157 p. Dissertação (Mestrado) - EESC, USP.

DREZNER, Z. ed. (1995). Facility location: a survey of applications and methods. Springer Series in Operation Research. Springer - Verlag, New York. 571 p. 
EASTMAN, J. R. (1995). IDRISI for windows: User's Guide. Version 1.0. Clark University, Massachusetts.

FONTES, A. T. (2001). Sistemas de Informação Geográficas: Digitalização. v. 2. São Carlos, EESC, USP.

GALVÃO JUNIOR, A. C. (1994). Aspectos operacionais relacionados com a usina de reciclagem e compostagem de resíduos sólidos domiciliares no Brasil. São Carlos. 113 p. Dissertação (Mestrado) - EESC, USP.

GIS.com (2001). What is GIS?. USA, Environmental Systems Research Institute (ESRI). Disponível em: <http://www.gis.com/whatisgis/index.html>. Acesso em: 01 maio 2002

GODINHO, R. E. (1988). Projeção de população flutuante: uso de variáveis sintomáticas. In: ASSOCIAÇAO BRASILEIRA DE ESTUDOS POPULACIONAIS. Anais do Sexto Encontro Nacional de Estudos Populacionais, Brasília, ABEP, 1988, v. 4. p. 645659. Disponível em: <http://www.abep .org.br>. Acesso em: 30 ago. 2002.

GOMES, L. P. (1989). Estudo da caracterização física e da biodegradabilidade dos resíduos sólidos urbanos em aterros sanitários. São Carlos. 167 p. Dissertação (Mestrado) - EESC, USP.

GRECCHI, R. C. (1998). Zoneamento geoambiental da região de Piracicaba-SP, com auxílio de geoprocessamento. São Carlos. Dissertação (Mestrado) - EESC, USP.

GUIMARÃES, L.T. (2000). Utilização do sistema de informação geográfica (SIG) para identificação de áreas potenciais para a disposição de resíduos na bacia de Paquequer, muncípio de Teresópolis - RJ. Rio de Janeiro. 172 p. Dissertação (Mestrado) COPPE, Universidade Federal do Rio de Janeiro.

HOUAISS, Instituto Antônio (2001). Dicionário eletrônico Houaiss da língua portuguesa. Versão 1.0. Rio de Janeiro, Editora Objetiva.

INSTITUTO BRASILEIRO DE GEOGRAFIA E ESTATÍSTICA (2000a). Censo Demográfico 2000. Disponível em: <http://www.ibge. gov.br>. Acesso em: 4 abr. 2001.

INSTITUTO BRASILEIRO DE GEOGRAFIA E ESTATÍSTICA (2000b). Contagem da População 1996 e Censo Demográfico 2000: Tabela 3 - População residente, por sexo, situação do domicílio e taxa de crescimento anual, segundo as Grandes Regiões, Unidades da Federação e municípios - 1996/2000. Disponível em: <http://www.ibge. gov.br>. Acesso em: 4 abr. 2001.

INSTITUTO BRASILEIRO DE GEOGRAFIA E ESTATÍSTICA (2000c). Estimativas Populacionais com data de referencia em 01 de julho dos respectivos anos e Taxas Médias Geométricas de Crescimento Anual (\%). Disponível em: <http://www.ibge. gov.br>. Acesso em: 4 abr. 2001.

INSTITUTO BRASILEIRO DE GEOGRAFIA E ESTATÍSTICA (2000d). Projeção da População do Brasil por Sexo e ldade para o Período 1980-2050 - Revisão 2000. Disponível em: <http://www.ibge.gov.br>. Acesso em: 4 abr. 2001. 
INSTITUTO BRASILEIRO DE GEOGRAFIA E ESTATÍSTICA (2000e). Sinopse preliminar do censo demográfico 2000. Rio de Janeiro: IBGE. v. 7.

INSTITUTO BRASILEIRO DE GEOGRAFIA E ESTATÍSTICA (2001). Coordenadas geográficas dos municípios. Disponível em: <http://www.ibge. net>. Acesso em: 10 jan. 2001.

INSTITUTO BRASILEIRO DE GEOGRAFIA E ESTATÍSTICA (2002). Pesquisa Nacional de Saneamento Básico - 2000. Disponível em: <http://www.ibge.gov.br/home/ estatistica/populacao/condicaodevida/pnsb/ default.shtm>. Acesso em: 11 abr. 2002.

KLISKEY, A. D. (1995). The role and functionality of GIS as a planning tool in natural resource management. Comput.,Environ. and Urban Systems, v. 19, n. 1, p. 15-22.

KOKKINAKI, A. I.; DEKKER, R.; NUNEN, J.; PAPPIS, C. (2000). E-commerce for reverse logistics. First European Conference on E-Commerce / E-Business / E-Banking / Teleworking / On-Line Services and their Influences, p. 77-85, Bucharest, Romania, 45 Sep.

KORTE, G. B. (1997). The GIS book. 4. ed. Santa Fé, Onword.

LACERDA, L. (1999). Considerações sobre o estudo de localização de instalações. Artigos CEL - COPPEAD. Rio de Janeiro, UFRJ. Disponível em: <http://www. coppead.ufrj.br/pesquisa/ cel/new/fr-loc-inst>. Acesso em: 27 jun. 2001.

LEITE, W. C. A. (1997). Estudo da gestão de resíduos sólidos :uma proposta de modelo tomando a Unidade de Gerenciamento de Recursos Hídricos (UGRHI) como referência. 270 p. Tese (Doutorado) - EESC, USP.

LIMA, U. C.; PIZA, F. J. T. (1999). Comparação de viabilidade econômica entre as soluções isolada e consorciada na gestão de resíduos sólidos domésticos nos municípios do interior do Estado de São Paulo. In: CONGRESSO BRASILEIRO DE ENGENHARIA SANITÁRIA E AMBIENTAL - ABES, 20., Rio de Janeiro. Anais... Rio de Janeiro: ABES. p. 2081-2090.

LORENA, L. A. N. (2001). Análise de redes. In: CÂMARA, G.; MONTEIRO, A. M.; FUKS, S.; CAMARGO, E.; FELGUEIRAS, C. Análise Espacial de Dados Geográficos. 2 ed. (revista e ampliada). São José dos Campos, INPE. Disponível em: < http://www.lac.inpe.br/ lorena/Analise-de-redes.pdf>. Acesso em: 26 abr. 2002.

NAZÁRIO, P. R. S. (1998). GIS: Definições e aplicações na logística. Artigos CEL COPPEAD. Rio de Janeiro, UFRJ. Disponível em: <http://www.coppead.ufrj.br/ pesquisa/cel/new/fr-gis.htm>. Acesso em: 27 jun. 2001.

OWEN, S. H.; DASKIN, M. S. (1998). Strategic facility: a review. European Journal of Operational Research, n. 111, p. 423-447.

PELIZARO, C. (2000). Avaliação de desempenho do algoritmo de um programa comercial para roteirização de veículos. São Carlos. 153 p. Dissertação (Mestrado) EESC, USP. 
PEZZOTTI, A. A. et al. (1994). Proposta metodológica para a elaboração de uma base cartográfica digital para utilização em sistemas de informações geográficas. Presidente Prudente, Faculdades de Ciência e Tecnologia - UNESP.

PROPOSIÇÃO BÁSICAS PARA UMA POLÍTICA BRASILEIRA DE LIMPEZA PÚBLICA (1978). São Paulo, IPEA/CNPU/CETESB.

RANIERI, V. E. L. (2000). Discussão das potencialidades e restrições do meio como subsídio para o zoneamento ambiental: o caso do município de Descalvado (SP). São Carlos. Dissertação (Mestrado) - EESC, USP.

RESÍDUOS SÓLIDOS (2000). In: Glossário. Disponível em: <http://www. ambientebrasil.com.br/composer.php3?base=./glossario/index.html\&conteudo =/glossario/r.html>. Acesso em: 17 set. 2001.

ROGERS, D. S.; TIBBEN-LEMBKE, R. S. (1998). Going Backwards: Reverse Logistics Trends and Pratices. Reverse logistic Executive Council. Reno, Center for Logistics Management, University of Nevada. 275 p.

ROMA, W. N. L.; SOUZA, M. P. (2001). Introdução aos Sistemas de Informação Geográfica (SIG). v. 1. São Carlos, EESC, USP.

ROSE, A. (2001). Uma avaliação comparativa de alguns sistemas de informação geográfica aplicadas aos transportes. São Carlos. 135 p. Dissertação (Mestrado) - EESC, USP.

SÃO PAULO (ESTADO). Leis, etc. (1983). Decreto Estadual $n^{\circ} 20.960$ de 8 de junho de 1983. Declara área de proteção ambiental a regiões situadas em diversos municípios, dentre os quais Corumbataí, Botucatu e Tejupá. Diário Oficial, São Paulo, v. 96, n. 002,03 jan. 1983.

SÃO PAULO (ESTADO). Secretaria do Meio Ambiente (1990). Áreas de proteção estaduais - Perímetro de Corumbataí: Zoneamento ambiental. São Paulo, SMA. 41 p. (Série Documentos).

SÃO PAULO (ESTADO). Secretaria do Meio Ambiente (1997a). Aterro Sanitário. São Paulo, CETESB. 40 p. (Apostilas Ambientais).

SÃO PAULO (ESTADO). Secretaria do Meio Ambiente (1997b). Aterro Sanitário em valas. São Paulo, CETESB. 34 p. (Apostilas Ambientais).

SÃO PAULO (ESTADO). Secretaria do Meio Ambiente (1998a). A cidade e o lixo. São Paulo, CETESB. 100 p.

SÃO PAULO (ESTADO). Leis, etc. (1998b). Resolução SMA-13 de 27 de fevereiro de 1998. Resolve sobre a publicação do Inventário Estadual de Resíduos Sólidos Urbanos. Diário Oficial do Poder Executivo do Estado de São Paulo, São Paulo, SP, 6 mar., Suplemento, v.108, n.44, p1-2.

SÃO PAULO (ESTADO). Secretaria do Meio Ambiente (2000a). Inventário Estadual de Resíduos Sólidos Domiciliares-1999: relatório síntese. São Paulo, CETESB. Disponí- 
vel em: <http://www. ambiente.sp.gov.br/inventario/ introd.htm>. Acesso em: 10 nov. 2000.

SÃO PAULO (ESTADO). Secretaria de Transportes (2000b). Mapa rodoviário digital do Estado de São Paulo 2000. São Paulo, DER-SP. 1 CD ROM.

SÃO PAULO (ESTADO). Secretaria do Meio Ambiente (2001a). Ilustração com a localização da APA de Corumbataí. São Paulo, Disponível em: <http://www.ambiente.sp.gov.br/apas/apa.htm >. Acesso em: 15 jan. 2001.

SÃO PAULO (ESTADO). Secretaria do Meio Ambiente (2001b). Inventário Estadual de Resíduos Sólidos Domiciliares: relatório síntese. V. 1. São Paulo, CETESB. Disponível em: <http://www.ambiente.sp.gov.br/inventario/ introd.htm>. Acesso em: 17 set. 2001.

SCHALCH, V.; LEITE, W. C. A. (2000). Resíduos Sólidos (lixo) e meio ambiente. In: CASTELLANO, E. G.; CHAUDHRY, F. H., eds. Desenvolvimento sustentado: problemas e estratégias. São Carlos, EESC. cap. 7, p. 107 - 135. Projeto REENGE.

SCHALCH, V.; LEITE, W. C. A.; GOMES, L. P. (1990). Curso sobre gerenciamento de resíduos sólidos. Goiânia, ABES. 227 p.

SILVA, A. N. R.; (1998). Sistemas de Informações Geográficas para planejamento de transportes. São Carlos. 112 p. Tese (Livre Docência) - EESC, USP.

SINDICATO DAS EMPRESAS DE LIMPEZA URBANA NO ESTADO DE SÃO PAULO (2001a). Estudo das Planilhas de Custo dos Serviços de Limpeza Pública: relatório final. In: SINDICATO DAS EMPRESAS DE LIMPEZA URBANA NO ESTADO DE SÃO PAULO (2001). Planilhas de Custo dos Serviços de Limpeza Pública. São Paulo. 1 CD-ROM. Elaboração: FGV - SP.

SINDICATO DAS EMPRESAS DE LIMPEZA URBANA NO ESTADO DE SÃO PAULO (2001b). Planilhas de Custo dos Serviços de Limpeza Pública. São Paulo. 1 CD-ROM. Elaboração: FGV - SP.

SINDICATO DAS EMPRESAS DE LIMPEZA URBANA NO ESTADO DE SÃO PAULO (2002). Convenção Coletiva de Trabalho: Sindicato de Ararraquara - 2002. São Paulo, SELUR.

SOARES, A. P. M.; GRIMBERG, E. (1998). Coleta seletiva e princípio dos 3Rs. DICAS - Idéias para a Ação Municipal - PÓLIS-ILDESFES, Desenvolvimento Urbano, n.109. Disponível em: <http://www.polis.org.br/publicacoes/download/arquivos/Dicas109. pdf>. Acesso em: 01 nov. 2001.

TABACZENSKI, R. R. (1995). A utilização do sistema de informações geográficas para o macro-zoneamento ambiental. 140 p. Dissertação (Mestrado) - EESC, USP.

TEIXEIRA, M. A. C.; JACOBI, P. (2000). Consórcio de Tratamento de Resíduos Sólidos. DICAS/Idéias para a ação municipal/ Instituto Pólis, Desenvolvimento Urbano, n. 166. Disponível em: <http://www.polis.org.br/ publicacoes/download/arquivos /Dicas166.pdf>. Acesso em: 01 nov. 2001. 
TOMPKINS, J. A.; WHITE, J. A.; BOZER, Y. A.;FRAZELLE, E. H.; TANCHOCO, J. M. A.; TREVINO, J. (1996) Facilities Planning. 2. ed. New York, John Wiley \& Sons.

UNICEF; CAIXA Econômica Federal (2001). Do lixo à cidadania: estratégias para a ação. 1. ed. Disponível em: <http://www.unicef.org/brazil/lixoecidadania/ publicacoes/index.htm>. Acesso em: 01 nov. 2001.

VAZ, J. C. (1997). Consórcios Intermunicipais. DICAS/Idéias para a ação municipal/PÓLIS-ILDESFES, Ação Administrativa, n. 97. Disponível em: <http://www.polis. org.br/publicacoes/download/arquivos/Dicas97.pdf>. Acesso em: 01 nov. 2001.

WANKE, P. (2001). Aspectos fundamentais do problema de localização de instalações em redes logíticas. Artigos CEL - COPPEAD, UFRJ, Rio de Janeiro. Disponível em: <http://www.coppead.ufrj.br/pesquisa/cel/new/fr-loc-inst>. Acesso em: 29 nov. 2001.

ZULAUF, W. (2001). Estruturas dos municípios para a criação e implementação do Sistema de Gestão Ambiental.. In: FORATTINI, G. D. A contribuição do IBAMA para a questão ambiental municipal. Disponível em: <http://www.ecoambiental.com.br/gestaoambiental-municipio.htm>. Acesso em: 23 jun. 2001.

ZVEIBIL, V. Z., coord. (2001). Manual de Gerenciamento Inegrado de Resíduos Sólidos.. Rio de Janeiro, IBAM. 200 p. Patrocínio: Secretaria Especial de Desenvolvimento Urbano da Presidência da República - SEDU/PR. Disponível em: <http://www.resol. com.br>. Acesso em: 23 set. 2002. 


\section{ANEXOS}


ANEXO A

Cooperações Intermunicipais 
Primeira Parte: 1 de 4

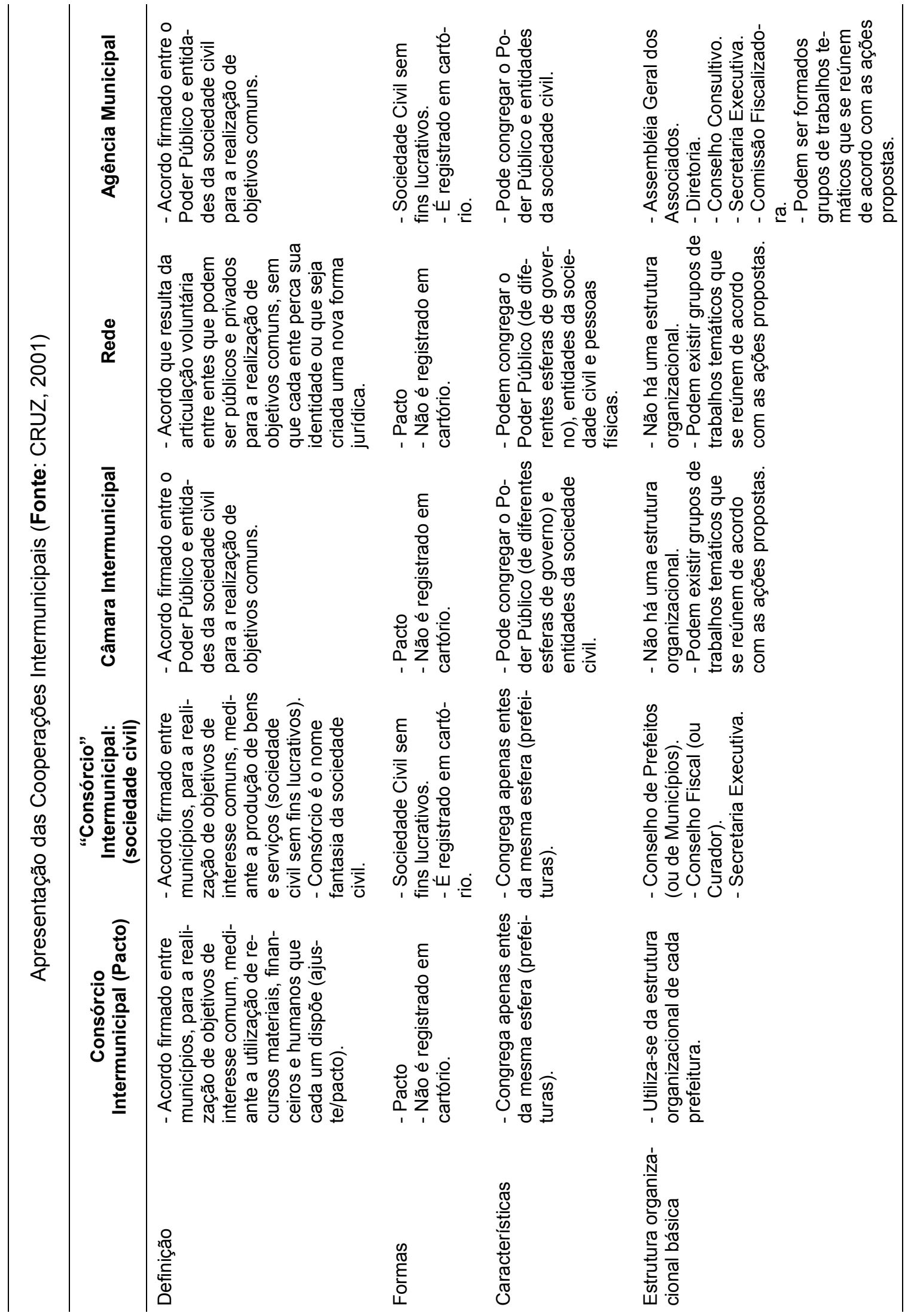




\section{Continuação (2 de 4)}

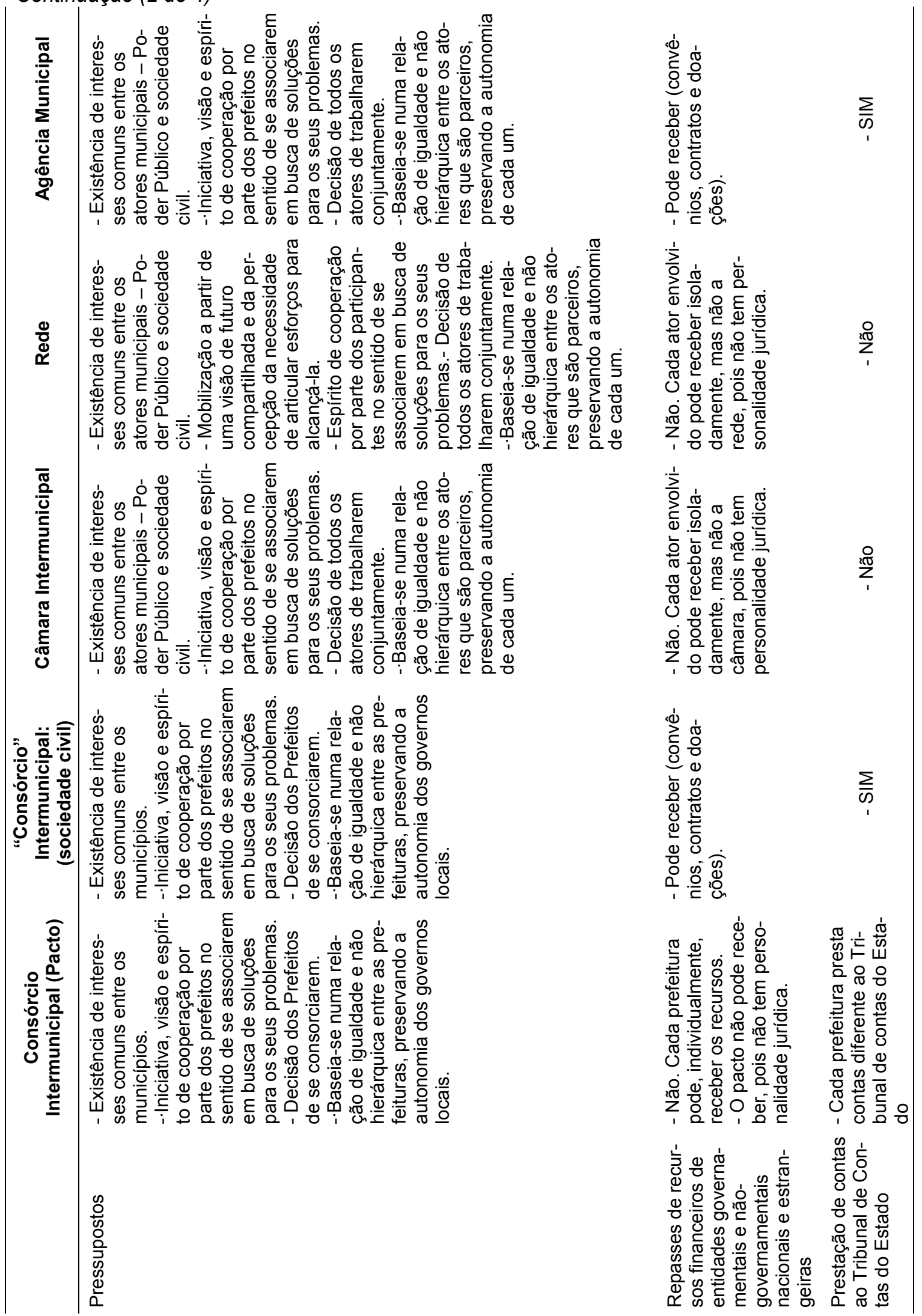




\section{Continuação (3 de 4)}

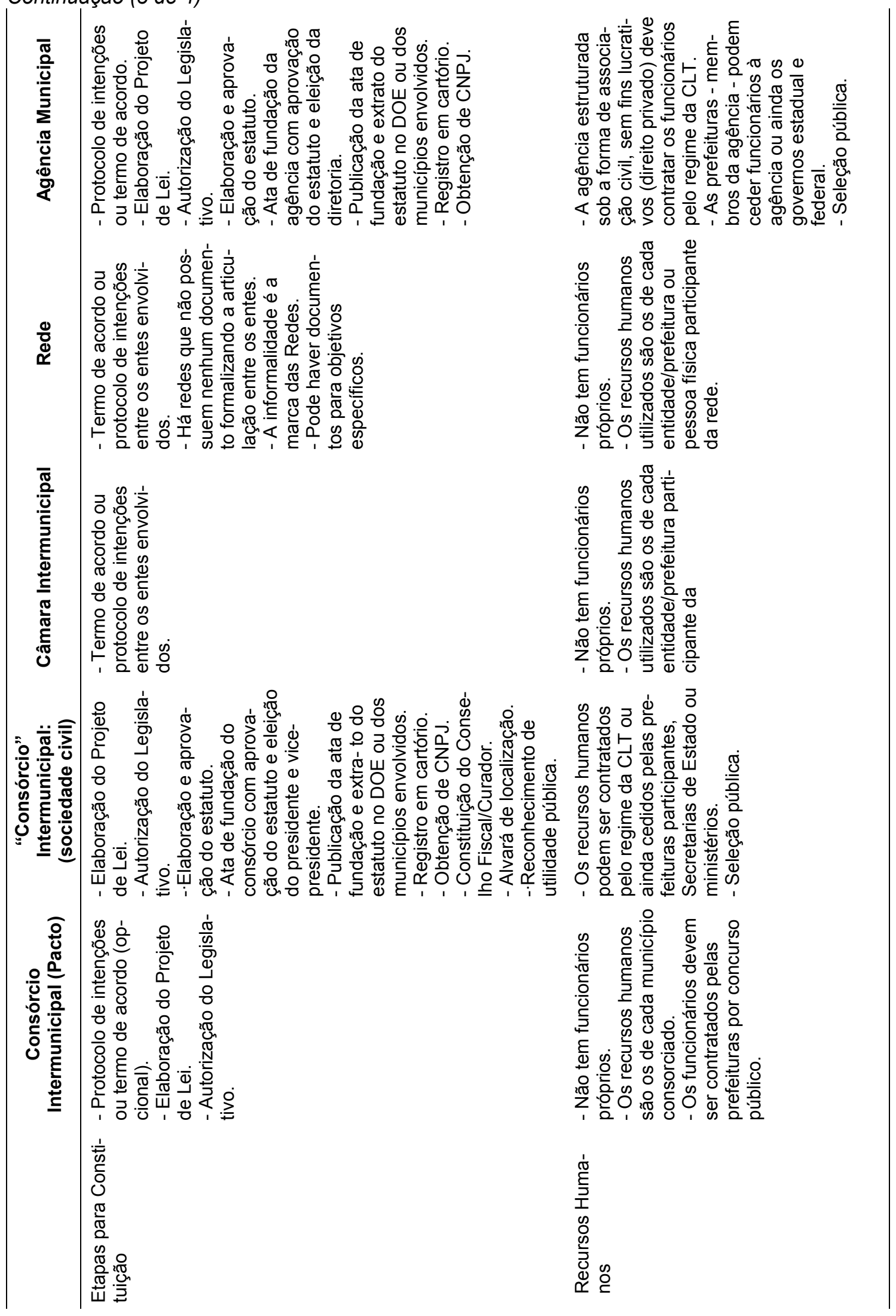




\section{Continuação (4 de 4)}

\begin{tabular}{|c|c|c|}
\hline & & \\
\hline 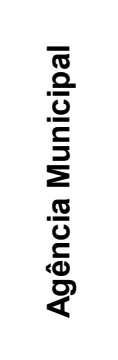 & 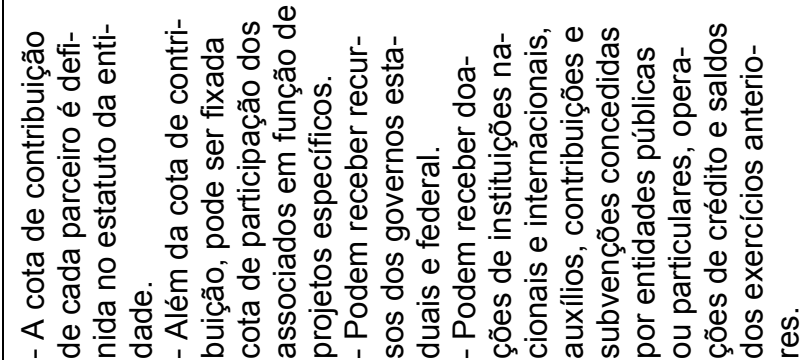 & 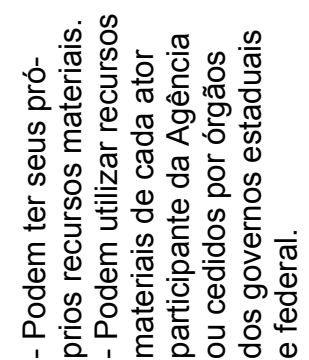 \\
\hline 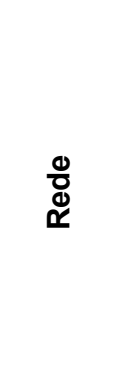 & 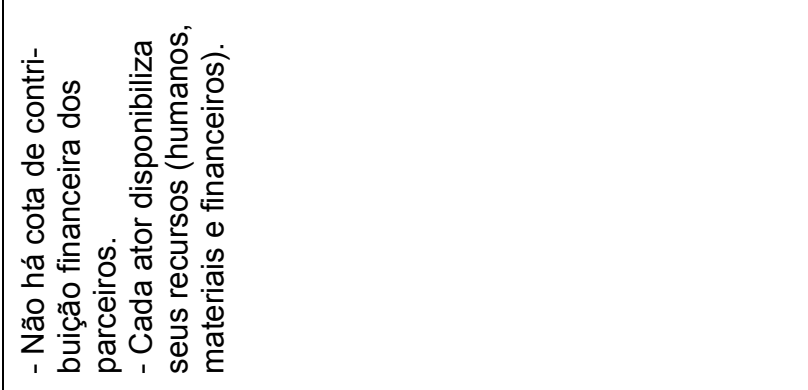 & 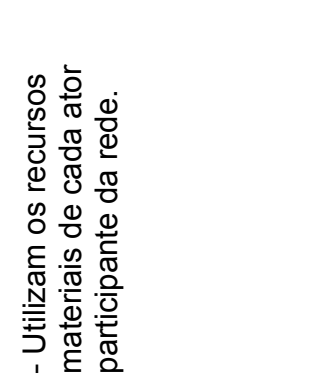 \\
\hline 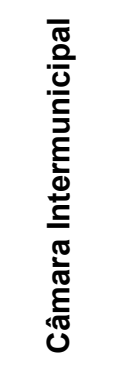 & 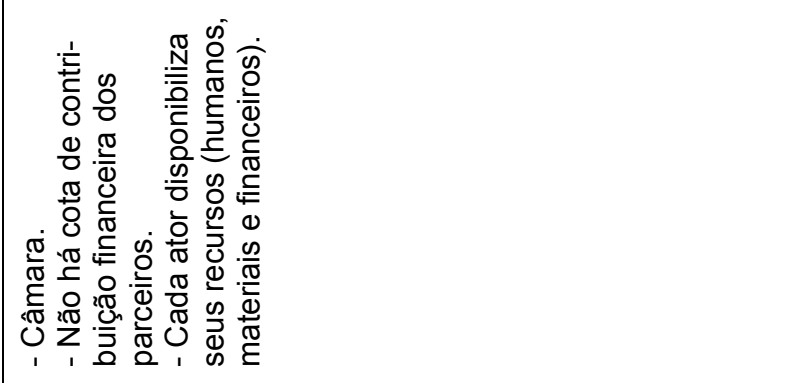 & 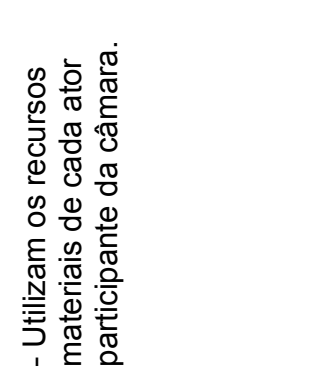 \\
\hline 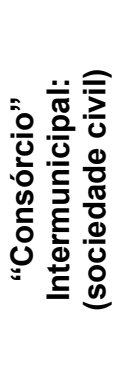 & 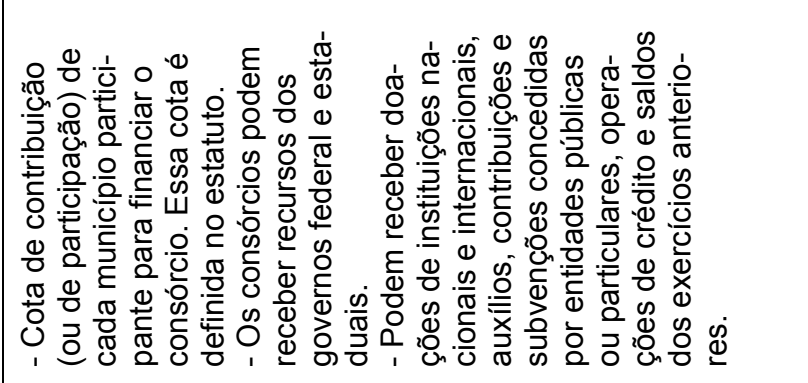 & 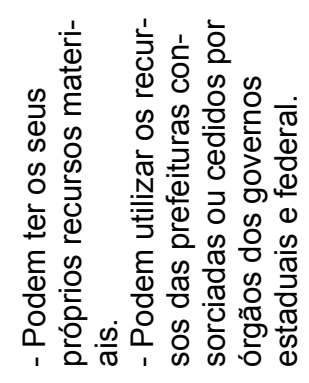 \\
\hline 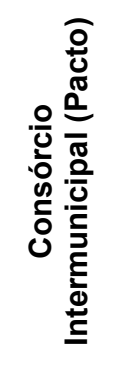 & 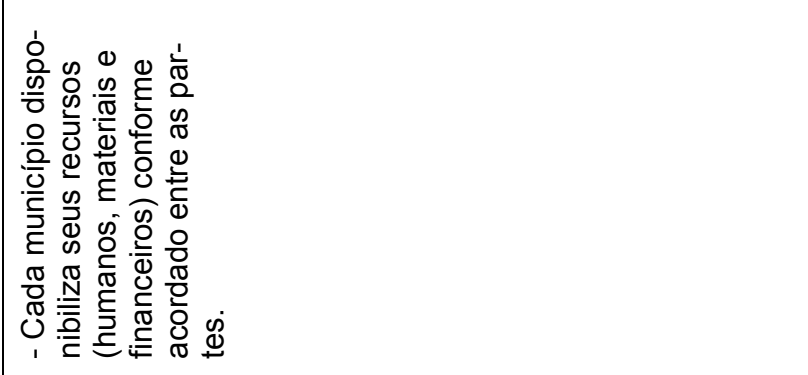 & 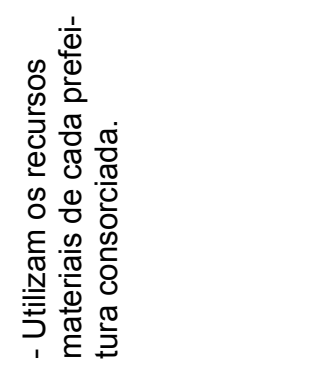 \\
\hline & 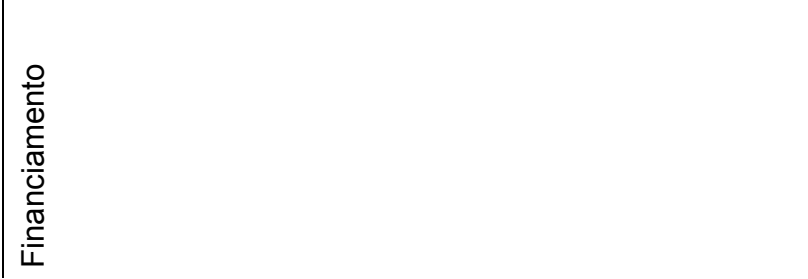 & 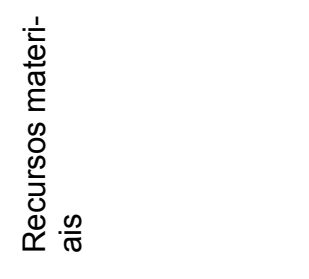 \\
\hline
\end{tabular}


ANEXO B

Sobre o arquivo do DER-SP com o mapa rodoviário do Estado de São Paulo 


\section{Secretaria dos Transportes}

\section{Departamento de Estradas de Rodagem do Estado de São Paulo}

Diretoria de Planejamento

\section{Arquivo Gráfico do Mapa Rodoviário}

O presente CD ROM contém o arquivo digital denominado mapa_rodoviário em formato MicroStation (.dgn), gerado através do MicroStation na versão SE.

Este arquivo contém dados gráficos vetoriais, incluindo anotações textuais (topônimos), símbolos (Células), linhas e áreas separados em níveis gráficos distintos.

\section{Arquivos Complementares}

Para a perfeita visualização dos textos contidos neste arquivo, o usuário deverá instalar o arquivo contendo as respectivas fontes que coexiste neste CD ROM e denominase font.rsc.

Para instalar a mesma, basta copiar o arquivo font.rsc para o diretório c:Iwin32applustationlwsmodldefaultlsymb. Recomenda-se fazer uma cópia em caráter de backup do arquivo font.rsc existente no referido diretório.

\section{Características Técnicas}

Sistema de projeção definido conforme padronização IBGE descrito em "Mapoteca Topográfica Digital - MTD" como Policônica com longitude origem -54 graus e datum South American Datum 1969 (SAD69).

Unidades de trabalho (Working units) definidas no arquivo MicroStation conforme padronização IBGE descrito em "Mapoteca Topográfica Digital - MTD" como Km:1000:M:10, ou seja, menor unidade de desenho equivalente a um decímetro.

As informações cartográficas destes arquivos gráficos seguem Padrão de Exatidão Cartográfica (PEC) conforme Decreto Lei 89817 de 20 de junho de 1984 que estabelece as "Instruções Reguladoras das Normas Técnicas da Cartografia Nacional". Precisão gráfica (PEC) e de posicionamento (Erro Padrão) do arquivo definido como Classe A para a escala gráfica 1:1.000.000.

\section{Níveis Gráficos}

\begin{tabular}{|r|r|c|c|l|}
\hline LV & \multicolumn{1}{|l|}{ Co } & LC & WT & Descrição \\
\hline 1 & 120 & - & - & Fundo Rosa Bordas \\
\hline 2 & 113 & - & - & Fundo Amarelo \\
\hline 3 & 114 & - & - & Fundo Rosa Estados \\
\hline 4 & 21 & - & - & Massa D'Água Áreas \\
\hline 5 & 113 & - & - & Fundo Amarelo Legenda \\
\hline
\end{tabular}




\begin{tabular}{|c|c|c|c|c|}
\hline 6 & 17 & $\mathrm{X}$ & - & Grid Linhas / Trópico de Capricôrnio \\
\hline 7 & 17 & - & - & Alagado \\
\hline 8 & $116 / 120$ & - & - & Mancha Urbana \\
\hline 9 & 17 & - & - & Massa D'Água Linhas \\
\hline 10 & 21 & - & - & Massa D'Água Legenda \\
\hline 11 & $119 / 37$ & - & -12 & Encarte - Áreas Verdes \\
\hline 12 & $112 / 160$ & - & - & Toponímia de Estados \\
\hline 13 & 17 & 2 & - & Represa em construção \\
\hline 14 & 17 & - & - & Hidrografia Simples \\
\hline 15 & 0 & 1 & 1 & Divisa de Regionais \\
\hline 16 & 0 & - & - & Barragem + Ponte Rodoferroviária + Detalhes \\
\hline 17 & 121 & - & 21 & Encarte - Limite de São Paulo (Roxo) \\
\hline 18 & $0 / 80$ & 1 & -13 & Encarte - Limite Municipal (Cinza / Preto) \\
\hline 19 & 37 & - & 11 & Pista não pavimentada (Verde) \\
\hline 20 & 160 & 2 & 7 & Pista não pavimentada (Branco) \\
\hline 21 & 22 & - & 4 & Rodovia municipal pavimentada \\
\hline 22 & 22 & 2 & 4 & Rodovia municipal em pavimentação \\
\hline 23 & 37 & - & 4 & Rodovia municipal não pavimentada \\
\hline 24 & 42 & 2 & 1 & Pista simples em duplicação \\
\hline 25 & 0 & - & 11 & Encarte - Principais Avenidas (Preto) \\
\hline 26 & 42 & - & 10 & Pista simples pavimentada \\
\hline 27 & 160 & - & 7 & Encarte - Principais Avenidas (Branco) \\
\hline 28 & 42 & 2 & 10 & Pista em pavimentação \\
\hline 29 & $42 / 160$ & -12 & $11 / 7$ & Rodoanel (Vermelho e Branco) \\
\hline 30 & 42 & - & 18 & Pista dupla (Vermelho) \\
\hline 31 & 27 & - & 12 & Pista dupla (Amarelo) \\
\hline 32 & 17 & - & - & Portos e Balsas \\
\hline 33 & 17 & - & - & Toponímia Hidrografia \\
\hline 34 & 17 & - & - & Toponímia Ilhas, Pontas, Portos e Barragens \\
\hline 35 & 17 & - & - & Toponímia Usinas e Barragens \\
\hline 36 & 17 & - & - & Toponímia Represas e Reservatórios \\
\hline 37 & 0 & - & - & Encarte - Toponímia de Avenidas \\
\hline 38 & 0 & - & - & Toponímia Municípios \\
\hline 39 & $\underline{0}$ & - & - & Toponímia Distrito \\
\hline 40 & 0 & - & - & Toponímia Localidade \\
\hline 41 & 0 & - & - & Coordenadas \\
\hline 42 & 0 & - & - & Toponímia Detalhes \\
\hline 43 & 0 & - & - & Quilometragem Rodovias Radiais \\
\hline 44 & 0 & - & - & Ferrovias \\
\hline 45 & 0 & - & - & Toponímia Comarca \\
\hline 46 & $112 / 128$ & - & $2 /-$ & Norte Magnético \\
\hline 47 & 22 & - & - & Distância entre locais \\
\hline 48 & $0 / 160$ & - & - & Célula Sede de Comarca (Branco/Preto) \\
\hline 49 & 0 & - & 3 & Célula Sede de Município \\
\hline 50 & $0 / 160$ & - & - & Célula Sede de Distrito (Branco/Preto) \\
\hline 51 & $0 / 160$ & - & - & Célula Bairros e Localidades (Branco/Preto) \\
\hline 53 & $0 / 160$ & - & - & Aeródromos (Preto, Branco/Preto) \\
\hline 55 & $0 / 160$ & - & - & Células Polícia Federal, Polícia Estadual (Branco/Preto) \\
\hline 57 & $0 / 160$ & - & - & Células Rodovias Federal, Estadual (Branco/Preto) \\
\hline 58 & 115 & - & - & Moldura Clara \\
\hline 59 & 117 & - & - & Moldura Escura \\
\hline 60 & $\bar{X}$ & - & $\bar{X}$ & Legenda Logo / Escala / Toponímia \\
\hline 61 & 22 & - & 1 & Toponímia Indice (Quadriculas) \\
\hline
\end{tabular}

Observações: $\mathrm{X}$ - Várias opções no mesmo layer 


\section{APÊNDICES}


APÊNDICE A

Semanas Padrão durante o prazo de 15 anos: 2003 até 2017 


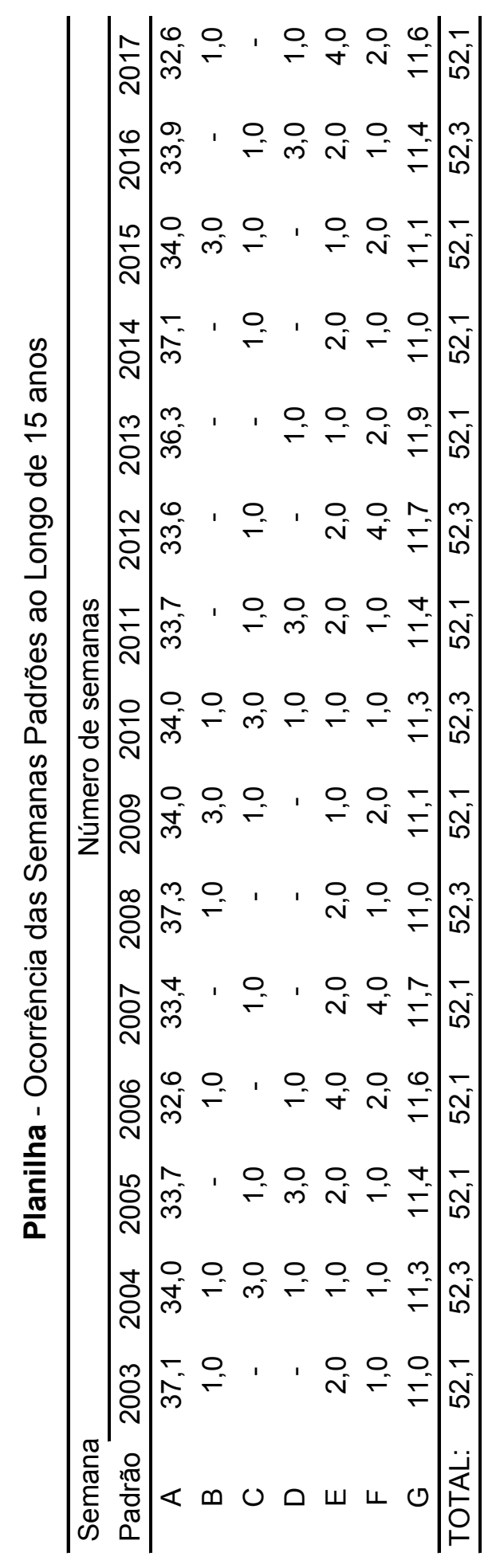


APÊNDICE B

Exemplo das planilhas do dimensionamento da coleta 


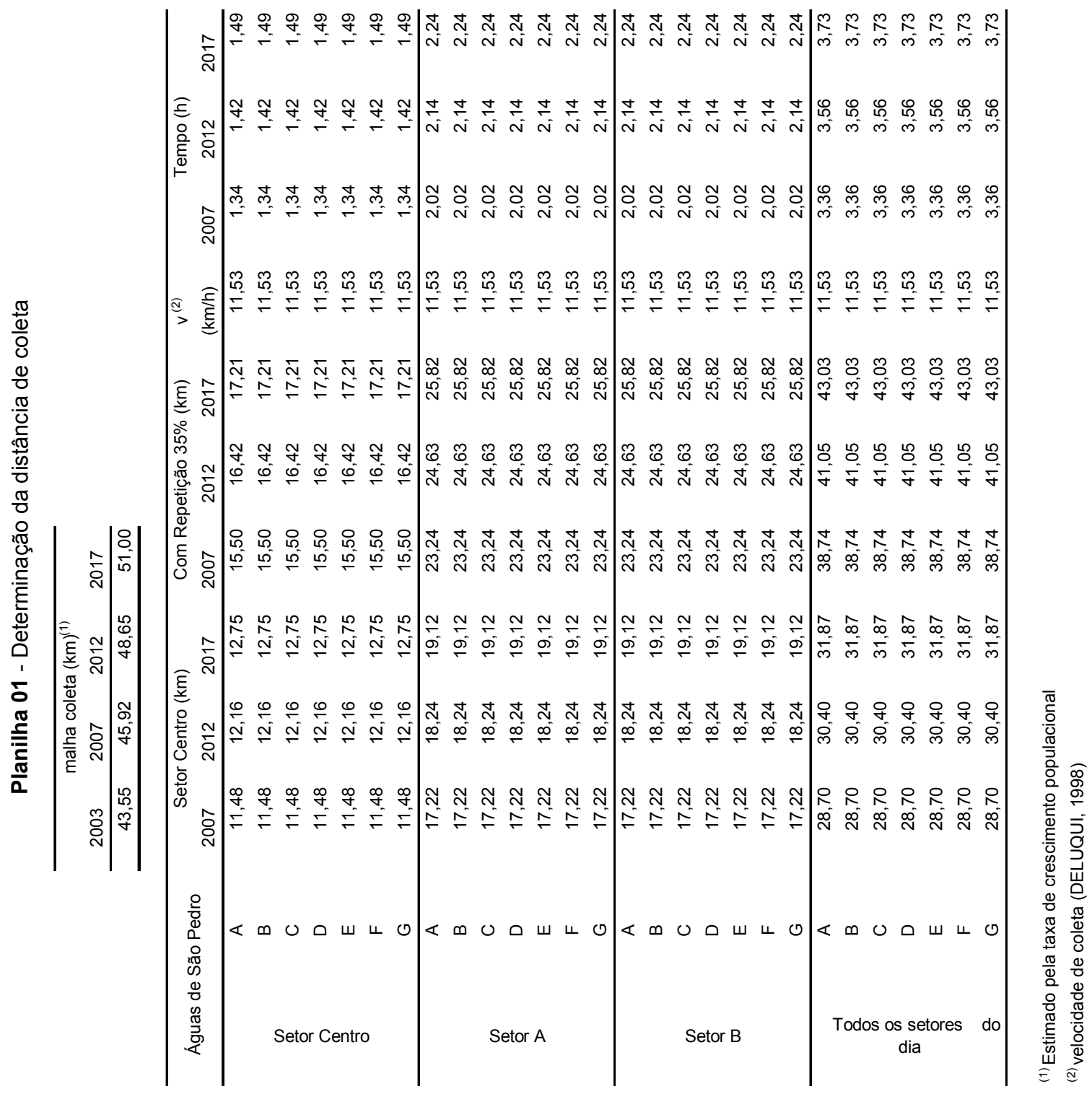




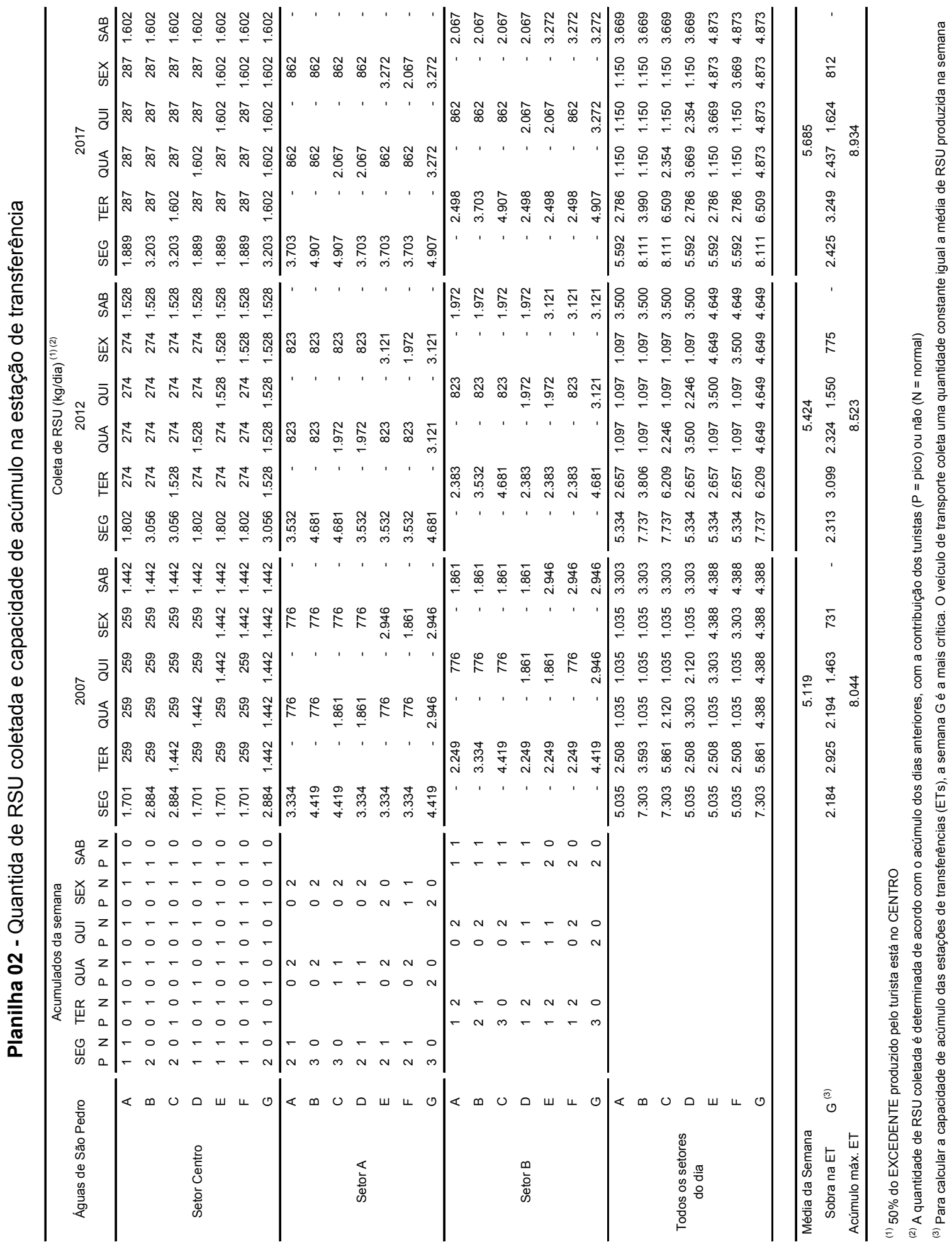




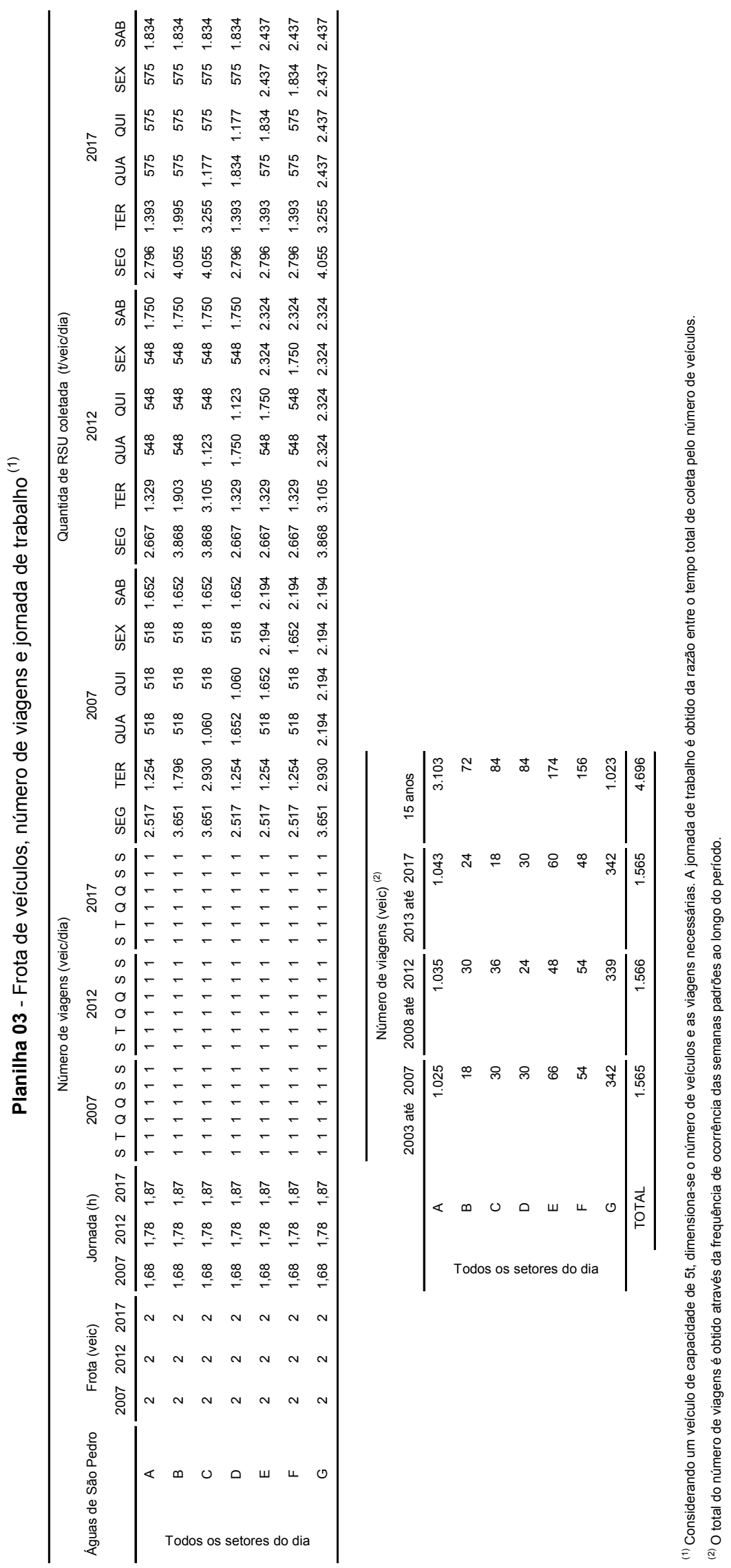




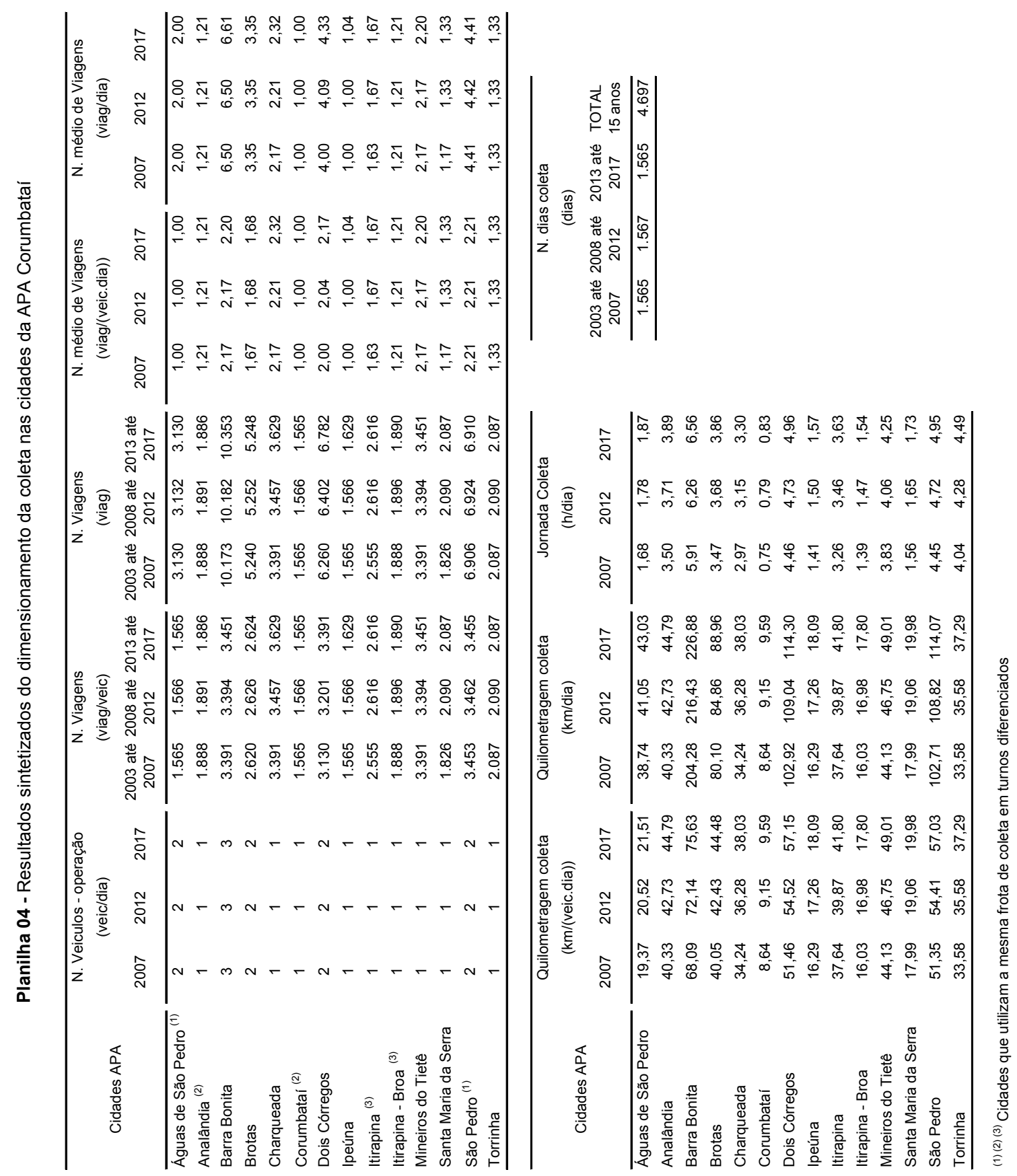


APÊNDICE C

Projeção da população residente e flutuante dos municípios da APA Corumbataí 


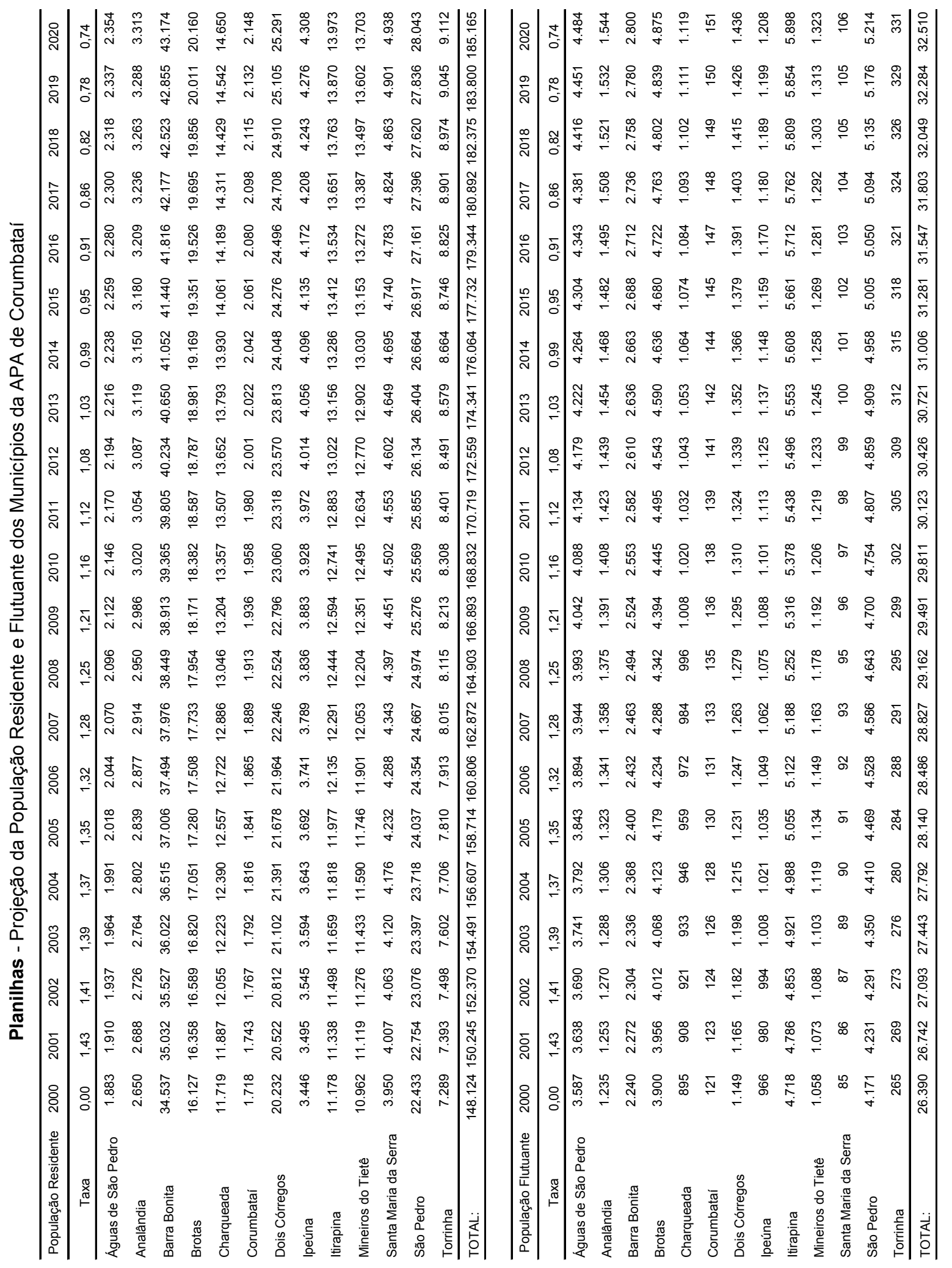


APÊNDICE D

Capacidade produtiva diária de RSU das populações residente e flutuante da APA de Corumbataí 


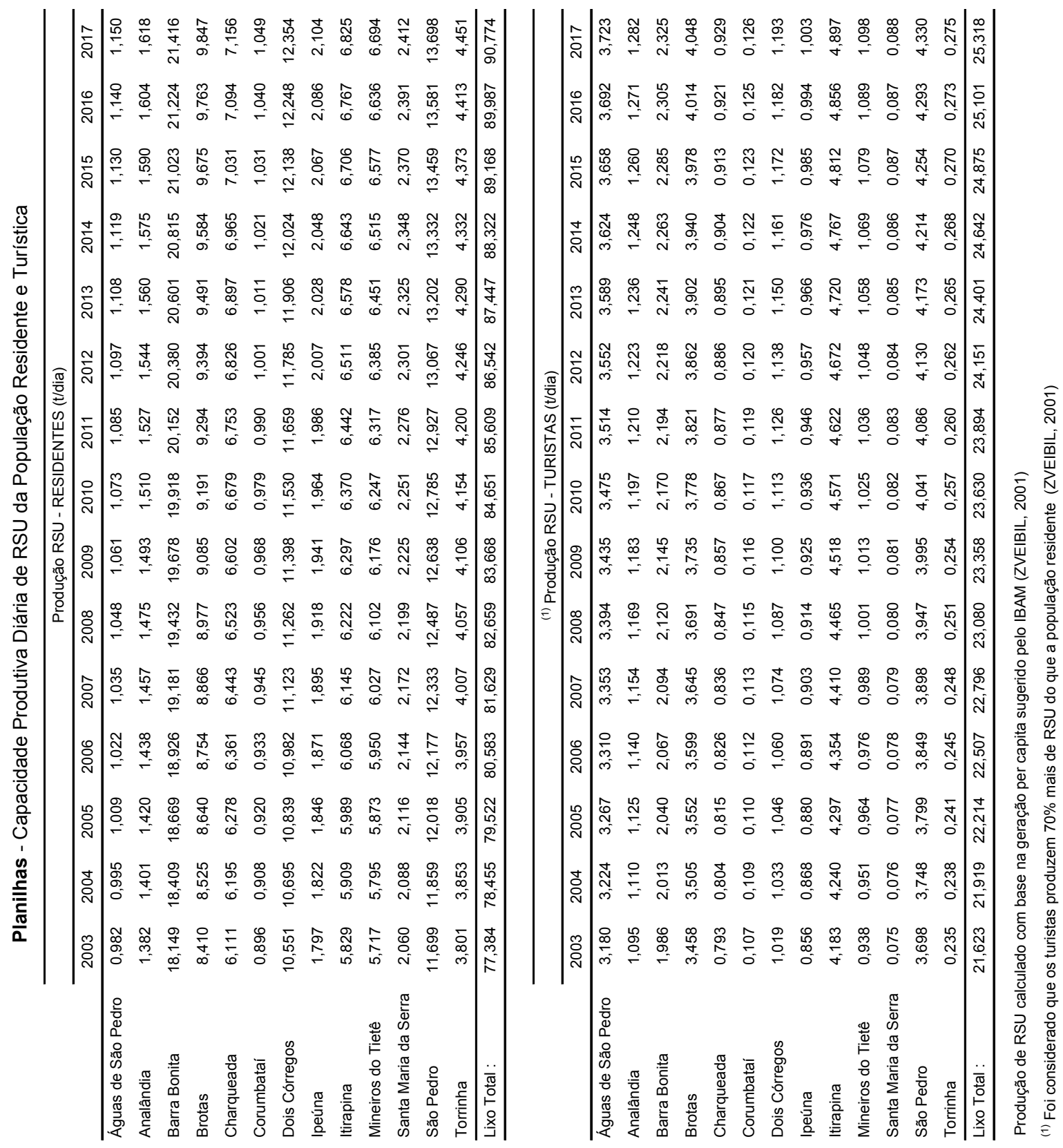


APÊNDICE E

Produção média e a taxa produtiva média de RSU da APA de Corumbataí 


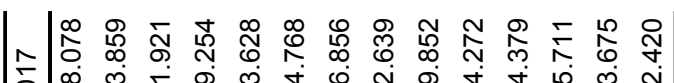

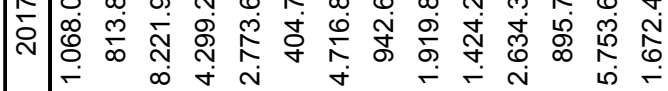

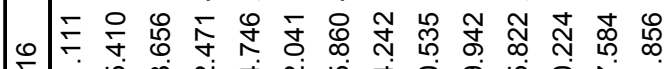

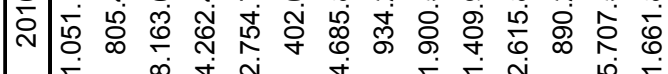

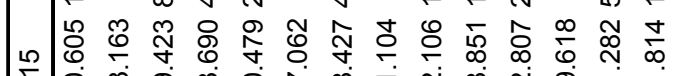

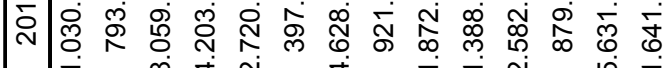

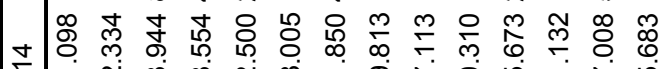

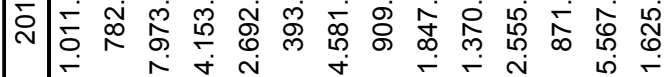

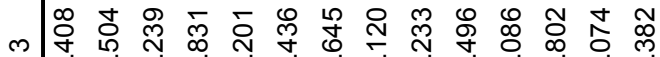

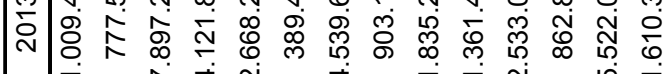

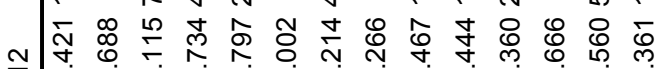

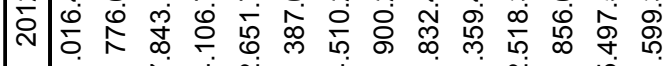

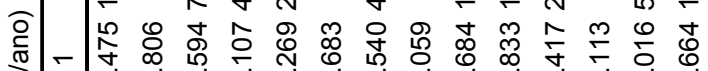

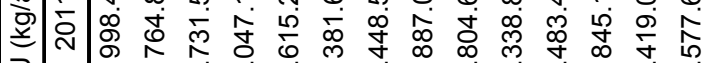

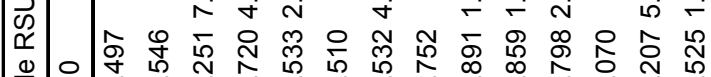

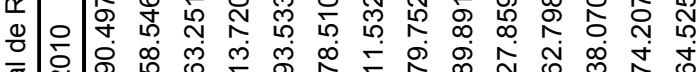

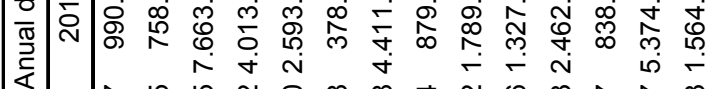

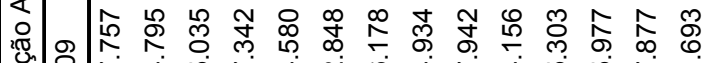

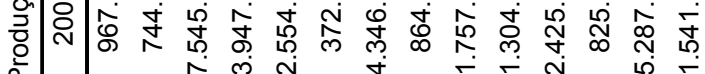

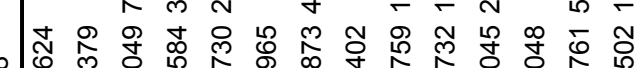

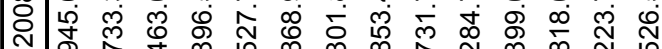
r.

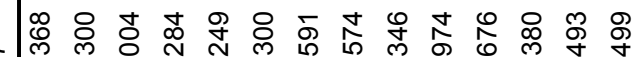

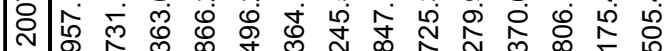

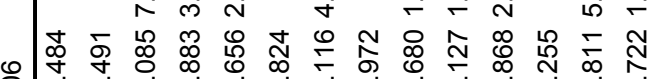

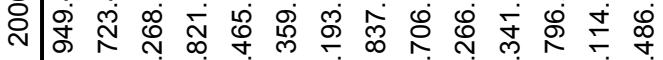

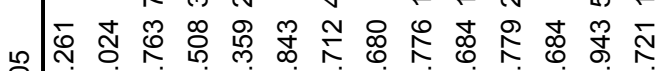

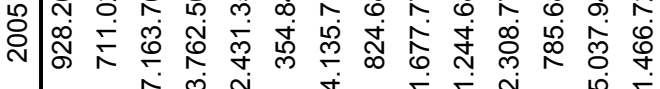

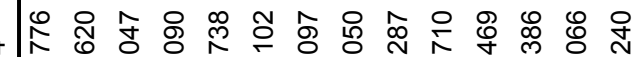

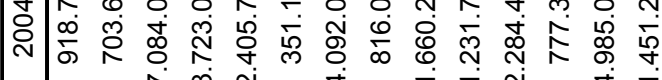

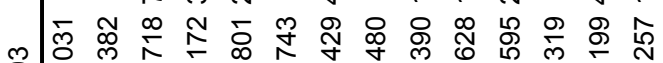

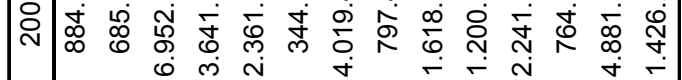

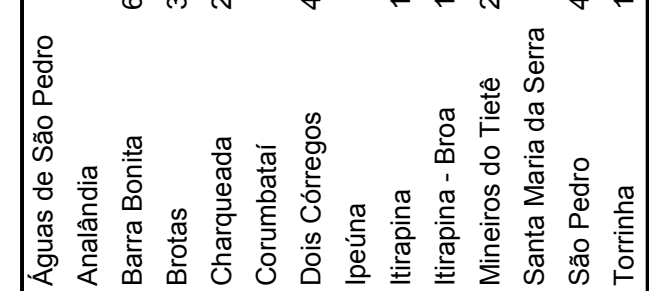

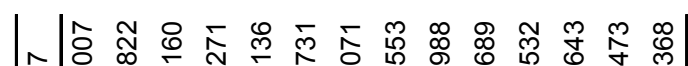

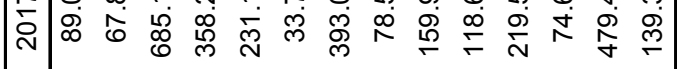

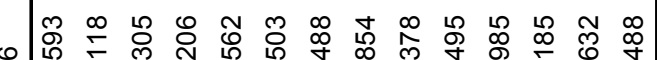

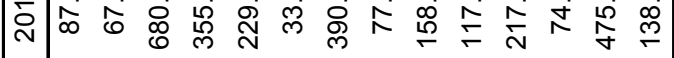

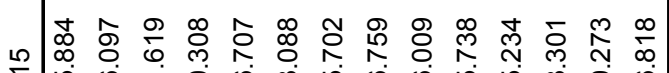

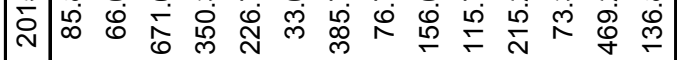

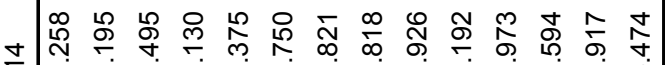

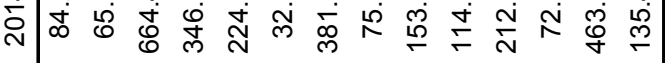

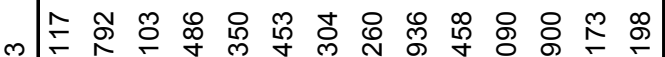

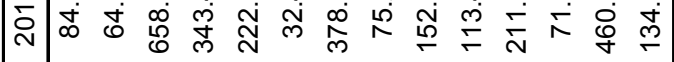
设 志总

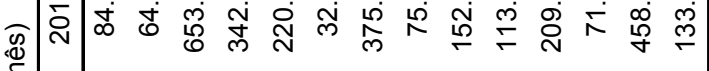

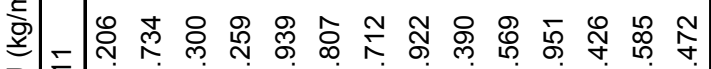

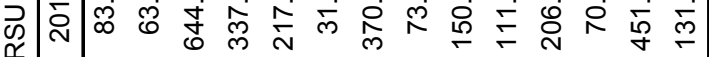

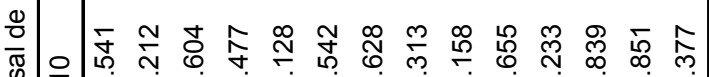

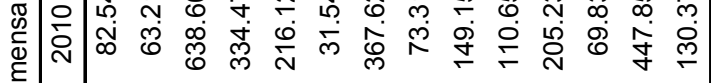

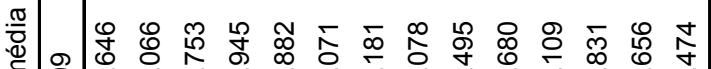

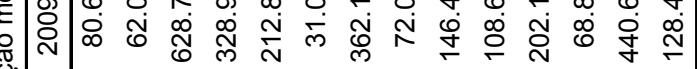

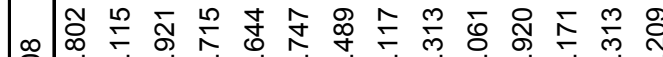

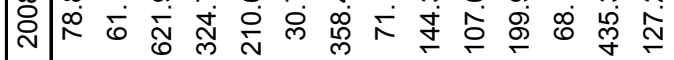

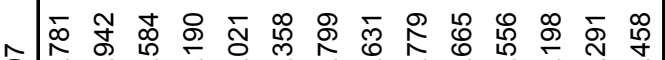

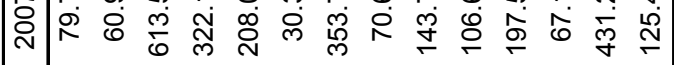

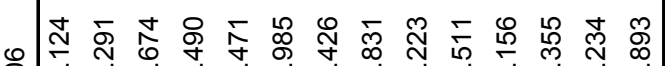

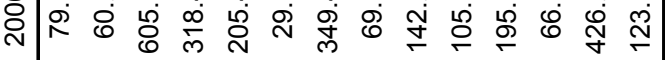

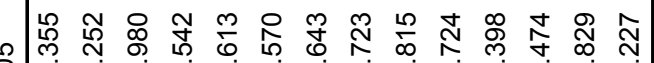

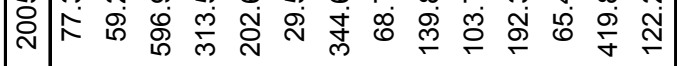

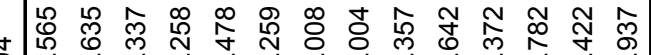

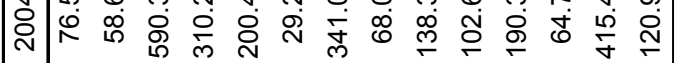

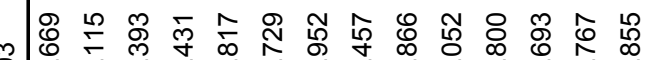

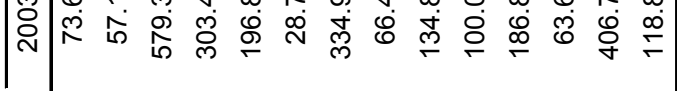

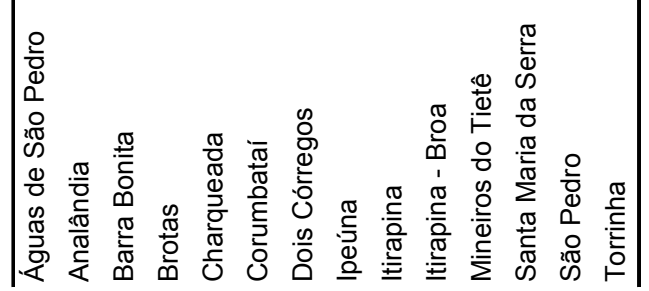




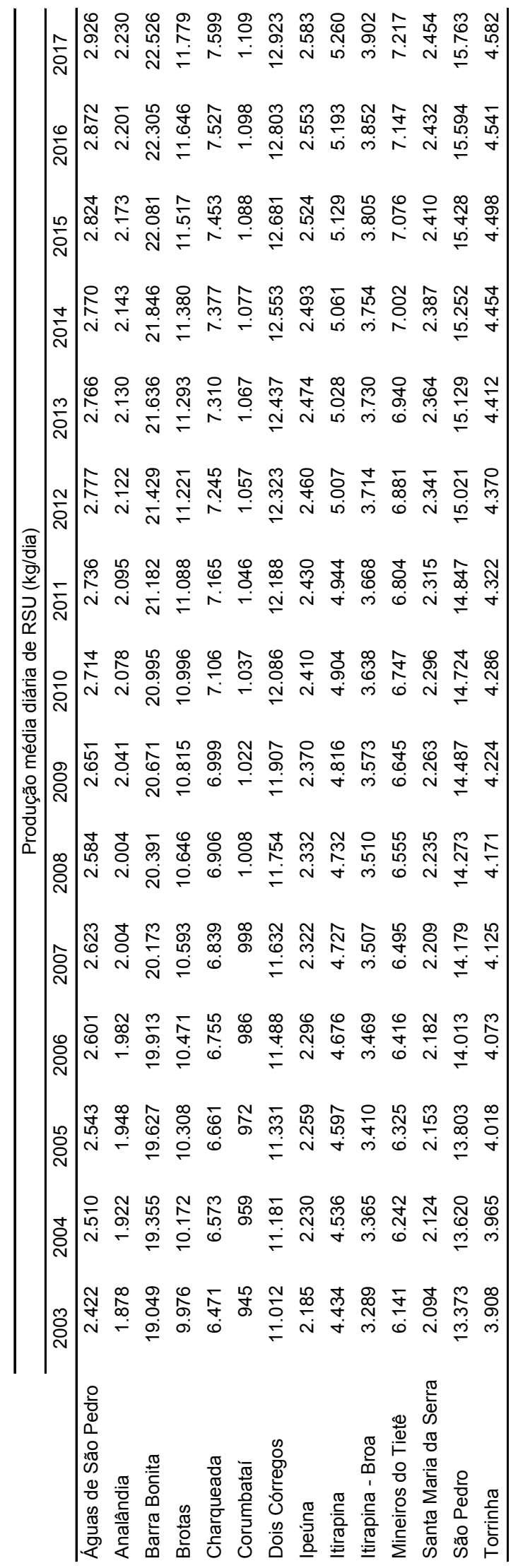

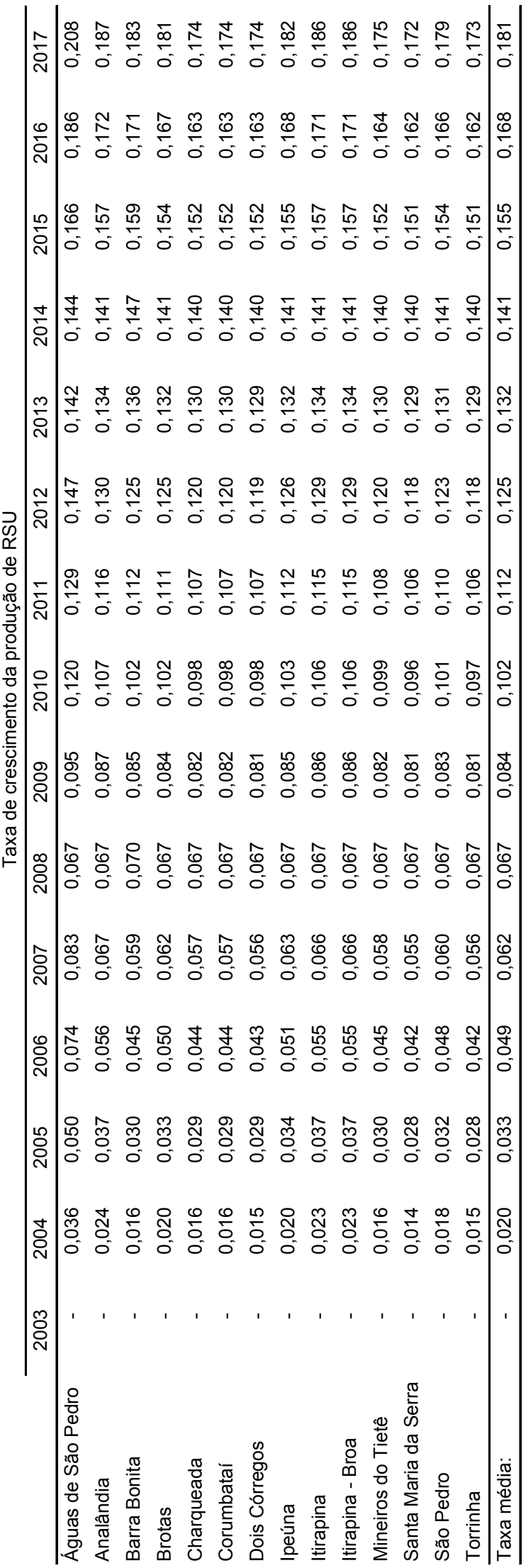


APÊNDICE F

Coordenadas e distâncias de sedes reais e obtidas do TransCAD 
Planilha 01 - Análise das Coordenadas após Importação do Arquivo do AutoCAD para o TransCAD

\begin{tabular}{|c|c|c|c|c|c|}
\hline \multirow{2}{*}{ Municípios } & \multicolumn{2}{|c|}{ Coordenadas Conhecidas ${ }^{(2)}$} & \multicolumn{2}{|c|}{ Coordenadas TransCAD ${ }^{(3)}$} & \multirow{2}{*}{$\Delta(\mathrm{km})^{(4)}$} \\
\hline & Latitude $\left({ }^{\circ}\right)$ & Longitude $\left({ }^{\circ}\right)$ & Latitude $\left({ }^{\circ}\right)$ & Longitude $\left({ }^{\circ}\right)$ & \\
\hline Analândia & $-22,126390$ & $-47,663060$ & $-22,131174$ & $-47,653925$ & 1,081 \\
\hline Barra bonita $^{(1)}$ & $-22,494720$ & $-48,558060$ & $-22,494720$ & $-48,558060$ & - \\
\hline Brotas & $-22,284170$ & $-48,126670$ & $-22,285880$ & $-48,123013$ & 0,422 \\
\hline Charqueada & $-22,509720$ & $-47,778060$ & $-22,514848$ & $-47,769408$ & 1,038 \\
\hline Corumbataí & $-22,220000$ & $-47,625830$ & $-22,225476$ & $-47,616002$ & 1,181 \\
\hline Dois Córregos & $-22,366110$ & $-48,380280$ & $-22,366599$ & $-48,379221$ & 0,122 \\
\hline Ipeúna & $-22,435830$ & $-47,718890$ & $-22,441234$ & $-47,709750$ & 1,115 \\
\hline Itirapina & $-22,252780$ & $-47,822780$ & $-22,256630$ & $-47,815404$ & 0,871 \\
\hline Mineiros do Tietê & $-22,409440$ & $-48,450560$ & $-22,409707$ & $-48,450008$ & 0,064 \\
\hline Santa Maria da Serra & $-22,567220$ & $-48,160560$ & $-22,569550$ & $-48,155792$ & 0,554 \\
\hline São Pedro & $-22,548610$ & $-47,913890$ & $-22,552705$ & $-47,906598$ & 0,876 \\
\hline Torrinha & $-22,426110$ & $-48,169170$ & $-22,427971$ & $-48,165248$ & 0,453 \\
\hline São Carlos & $-22,017500$ & $-47,890830$ & $-22,020020$ & $-47,885277$ & 0,637 \\
\hline Araraquara $^{(1)}$ & $-21,794440$ & $-48,175560$ & $-21,794440$ & $-48,175560$ & - \\
\hline \multirow[t]{2}{*}{ Rio Claro $^{(1)}$} & $-22,411390$ & $-47,561390$ & $-22,411390$ & $-47,561390$ & - \\
\hline & & & & $\begin{array}{r}\text { média: } \\
\text { máximo: }\end{array}$ & $\begin{array}{l}0,701 \\
1,181\end{array}$ \\
\hline \multicolumn{6}{|c|}{ (1) Coordenadas utilizadas para importação no TransCAD } \\
\hline \multicolumn{6}{|c|}{ (2) Coordenadas conhecidas dos municípios (IBGE, 2001) } \\
\hline \multicolumn{6}{|c|}{ (3) Coordenadas fornecidas pelo TransCAD após importar arquivo do AutoCAD } \\
\hline
\end{tabular}

Planilha 02 - Pontos de Controle Utilizados na Importação do Arquivo do AutoCAD para o TransCAD

\begin{tabular}{lcrcc}
\hline \multirow{2}{*}{ Municípios } & \multicolumn{2}{c}{ Coordenadas Conhecidas } & \multicolumn{2}{c}{ Coordenadas AutoCAD ${ }^{(1)}$} \\
& Latitude $\left({ }^{\circ}\right)$ & Longitude $\left({ }^{\circ}\right)$ & $X$ & X \\
\hline Barra bonita & $-22,494720$ & $-48,558060$ & 559,8557 & $-2498,7649$ \\
Araraquara & $-21,794440$ & $-48,175560$ & 602,1668 & $-2422,4129$ \\
Rio Claro & $-22,411390$ & $-47,561390$ & 661,6523 & $-2492,7704$ \\
\hline
\end{tabular}

(1) Coordenadas cartesianas $X Y$ do AutoCAD 
Planilha 03 - Análise das Distâncias após Importação do Arquivo do AutoCAD para o TransCAD

\begin{tabular}{|c|c|c|c|c|c|}
\hline \multicolumn{2}{|c|}{ Trajeto } & \multicolumn{2}{|c|}{ Distância (km) } & \multirow{2}{*}{$|\Delta|(\mathrm{km})^{(1)}$} & \multirow{2}{*}{$|\Delta|(\%)^{(2)}$} \\
\hline Origem & Destino & TransCAD & Hodômetro & & \\
\hline São Carlos & Itirapina & 29,73 & 31,30 & 1,57 & $5,02 \%$ \\
\hline Itirapina & Ipeúna & 48,82 & 51,40 & 2,58 & $5,02 \%$ \\
\hline Ipeúna & Charqueada & 13,90 & 13,10 & 0,80 & $6,11 \%$ \\
\hline Charqueada & São Pedro & 21,27 & 19,70 & 1,57 & $7,97 \%$ \\
\hline São Pedro & Águas de S. Pedro & 9,09 & 9,20 & 0,11 & $1,20 \%$ \\
\hline Águas de S. Pedro & Santa Maria da Serra & 33,91 & 34,50 & 0,59 & $1,71 \%$ \\
\hline Santa Maria da Serra & Entrada Torrinha & 18,20 & 19,20 & 1,00 & $5,21 \%$ \\
\hline Entrada Torrinha & Dois Córregos & 25,56 & 24,20 & 1,36 & $5,62 \%$ \\
\hline Dois Córregos & Mineiros do Tietê & 10,02 & 11,40 & 1,38 & $12,11 \%$ \\
\hline Mineiros do Tietê & Barra Bonita & 15,23 & 13,90 & 1,33 & $9,57 \%$ \\
\hline Barra Bonita & Brotas & 72,50 & 74,20 & 1,70 & $2,29 \%$ \\
\hline Brotas & Entrada Itirapina & 32,89 & 32,80 & 0,09 & $0,28 \%$ \\
\hline Entrada Itirapina & São Carlos & 28,44 & 28,10 & 0,34 & $1,20 \%$ \\
\hline São Carlos & Corumbataí & 50,03 & 51,60 & 1,57 & $3,05 \%$ \\
\hline \multirow[t]{3}{*}{ Corumbataí } & São Carlos & 50,03 & 50,70 & 0,67 & $1,33 \%$ \\
\hline & média: & 28,44 & 28,10 & 1,33 & $5,02 \%$ \\
\hline & máximo: & 72,50 & 74,20 & 2,58 & $12,11 \%$ \\
\hline
\end{tabular}

${ }^{(1)}$ Diferença entre a distância fornecida pelo TransCAD e o medido no hodômetro do automóvel

${ }^{(2)}$ Relação percentual entre a diferença das distâncias em relação ao medido no hodômetro 
APÊNDICE G

Dimensionamento das Estações de Transferência 


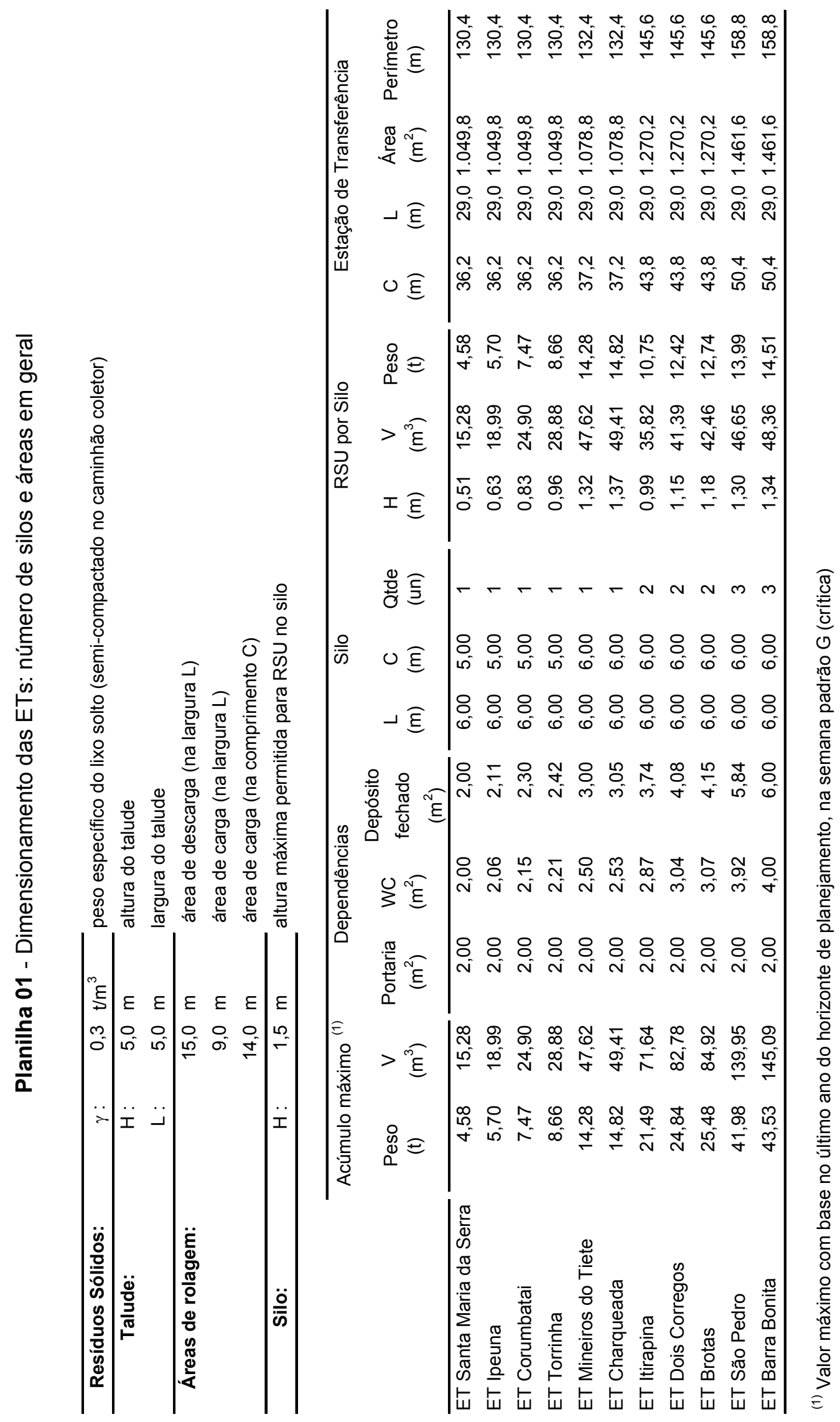




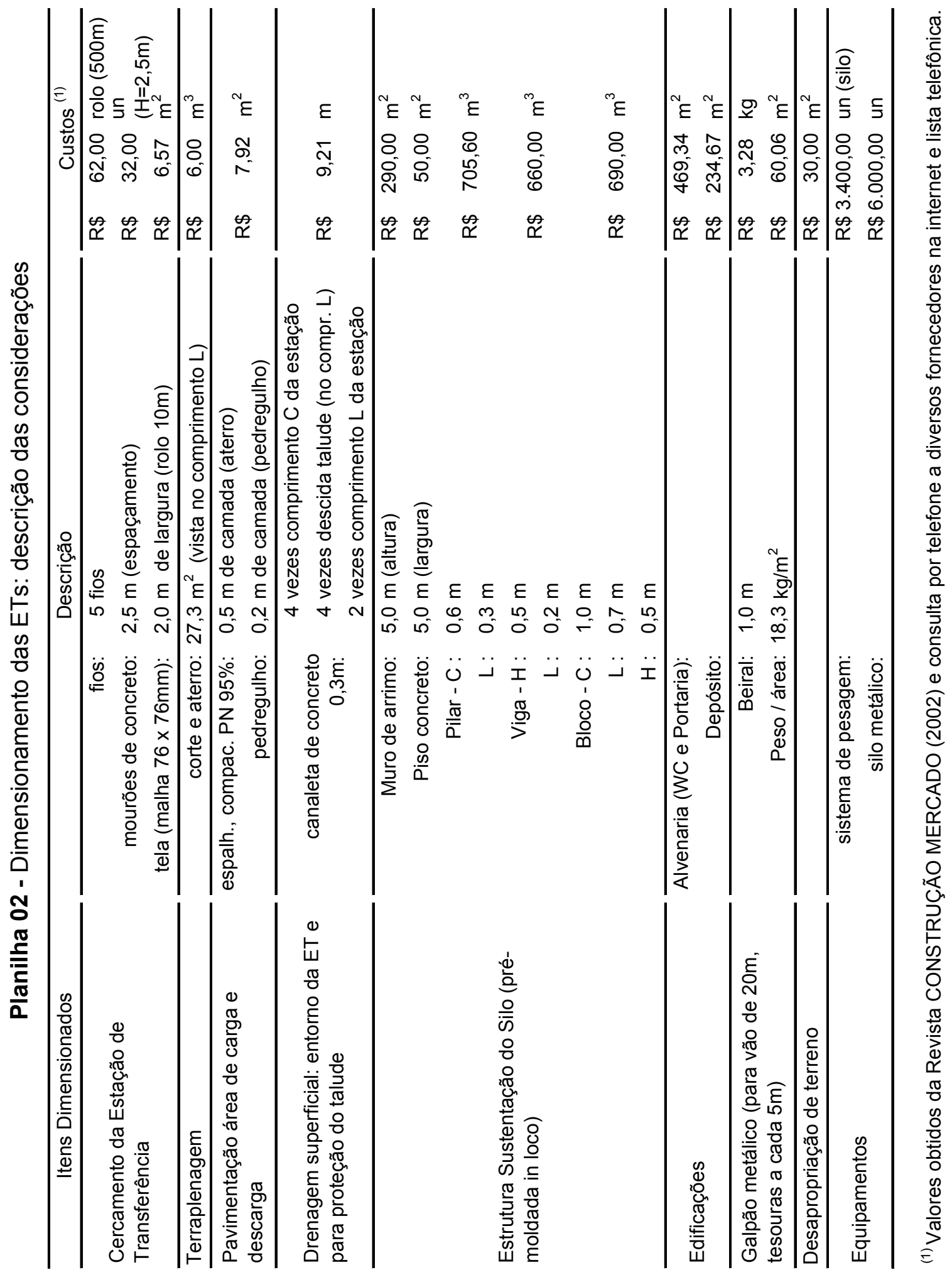




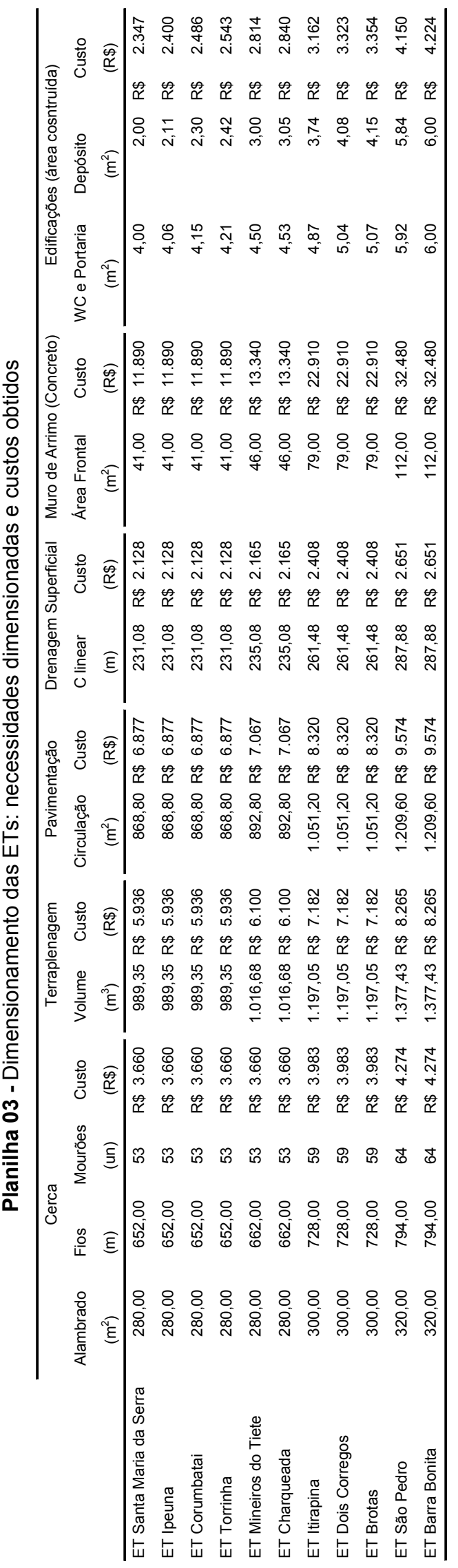

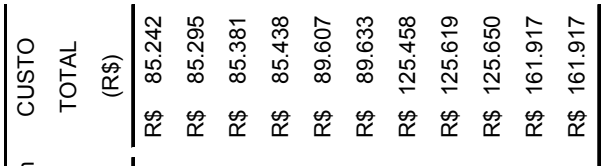

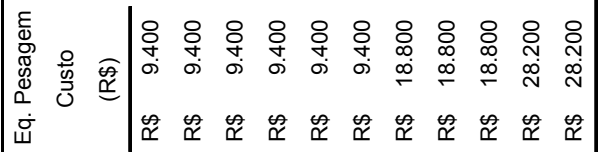

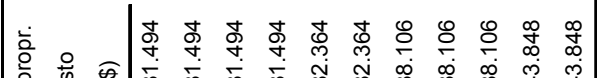

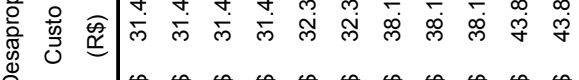

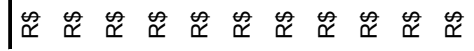

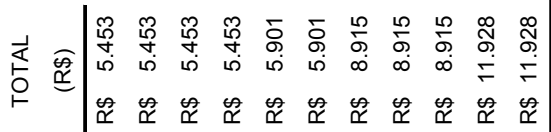
号 की 曹

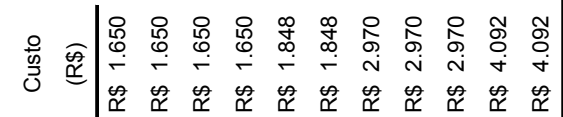
焉 u

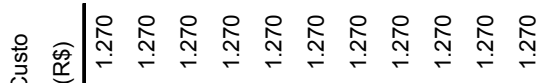

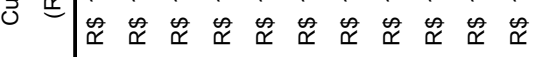
产 氖

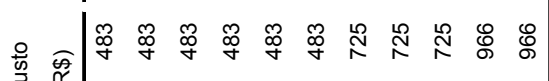

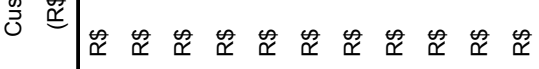
西

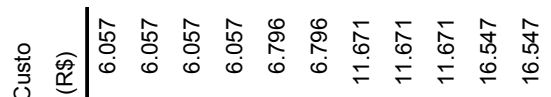
园 西

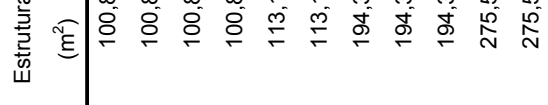

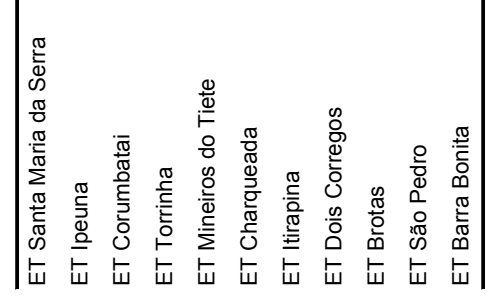


APÊNDICE H

Dimensionamento dos Aterros 


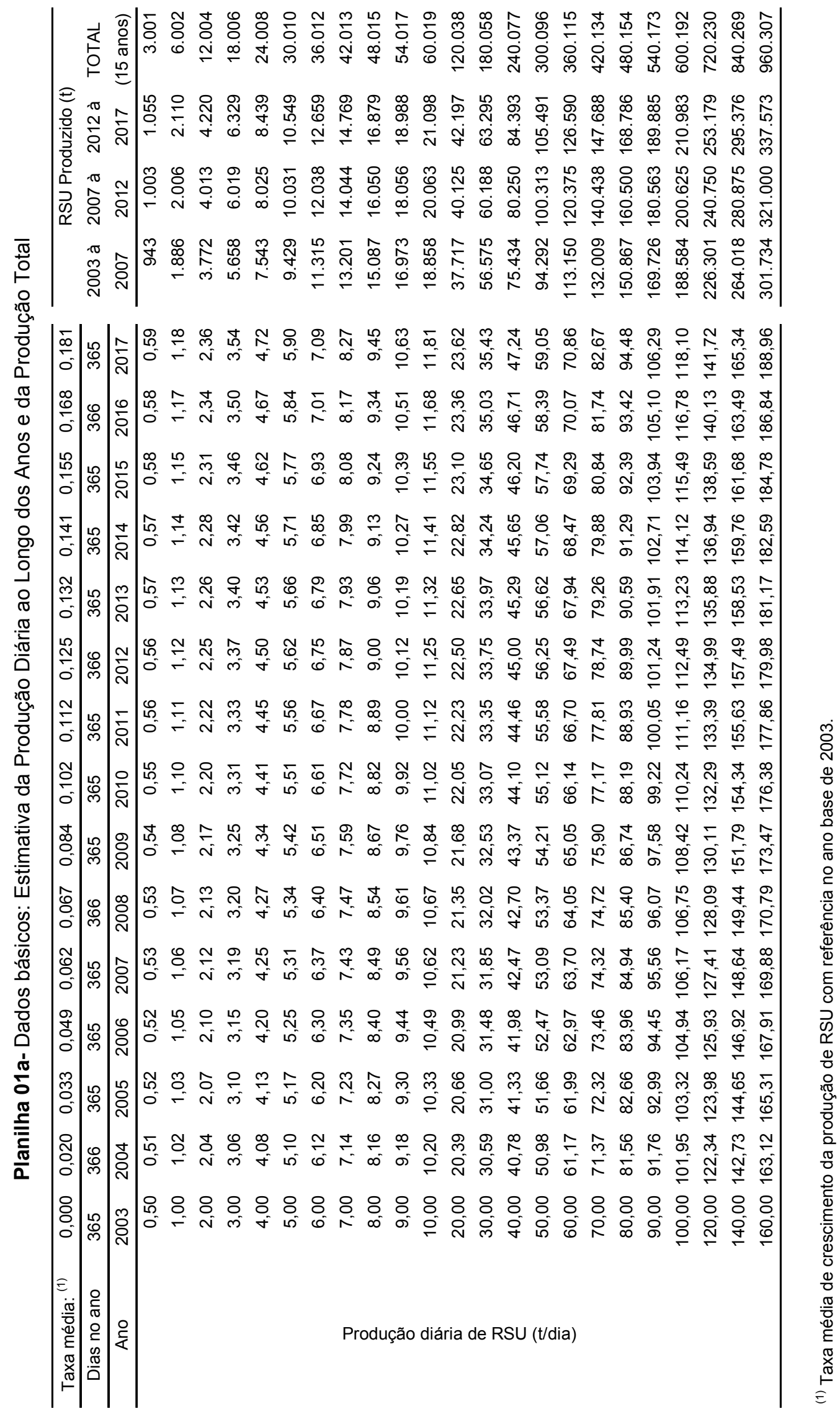



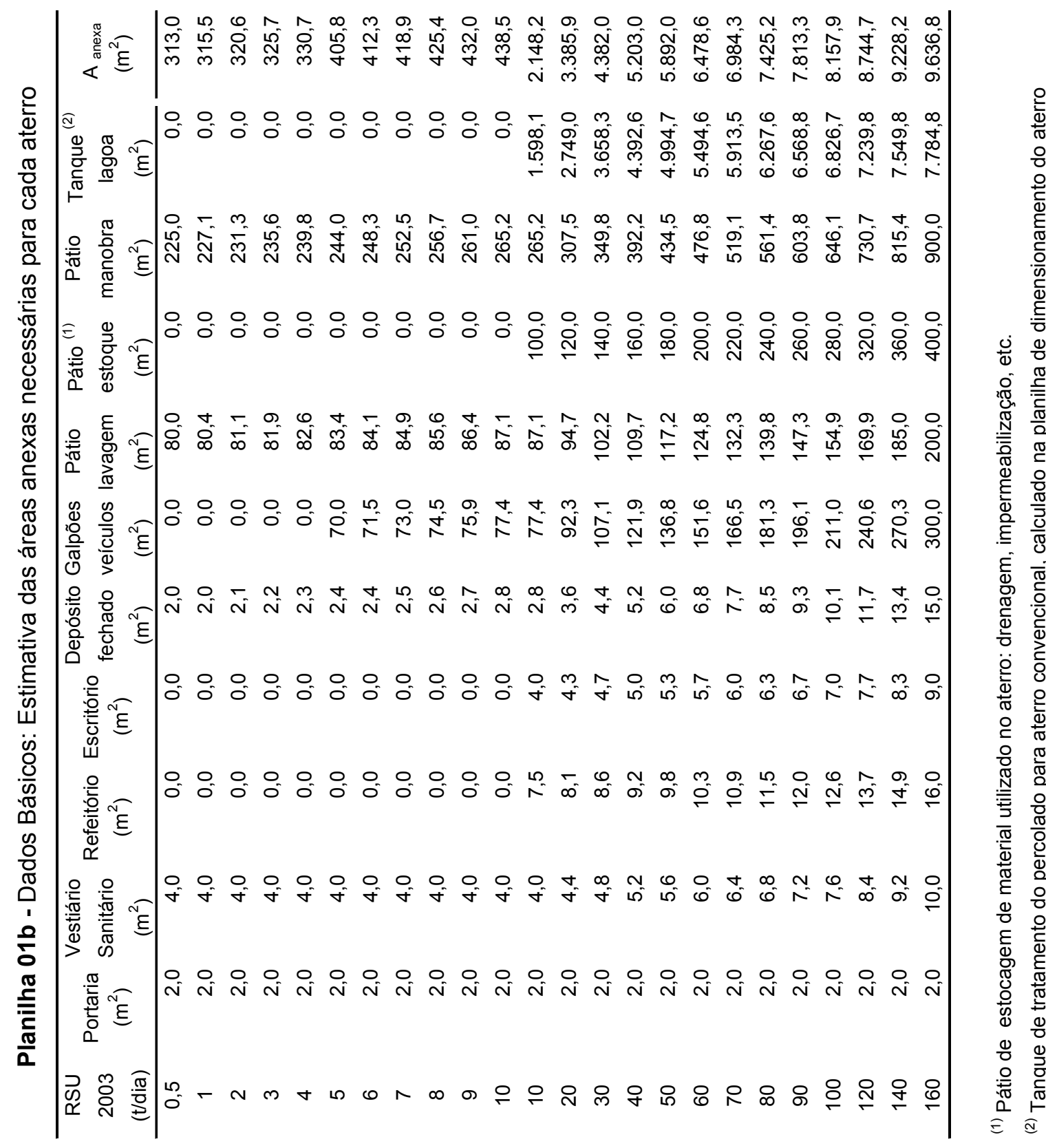


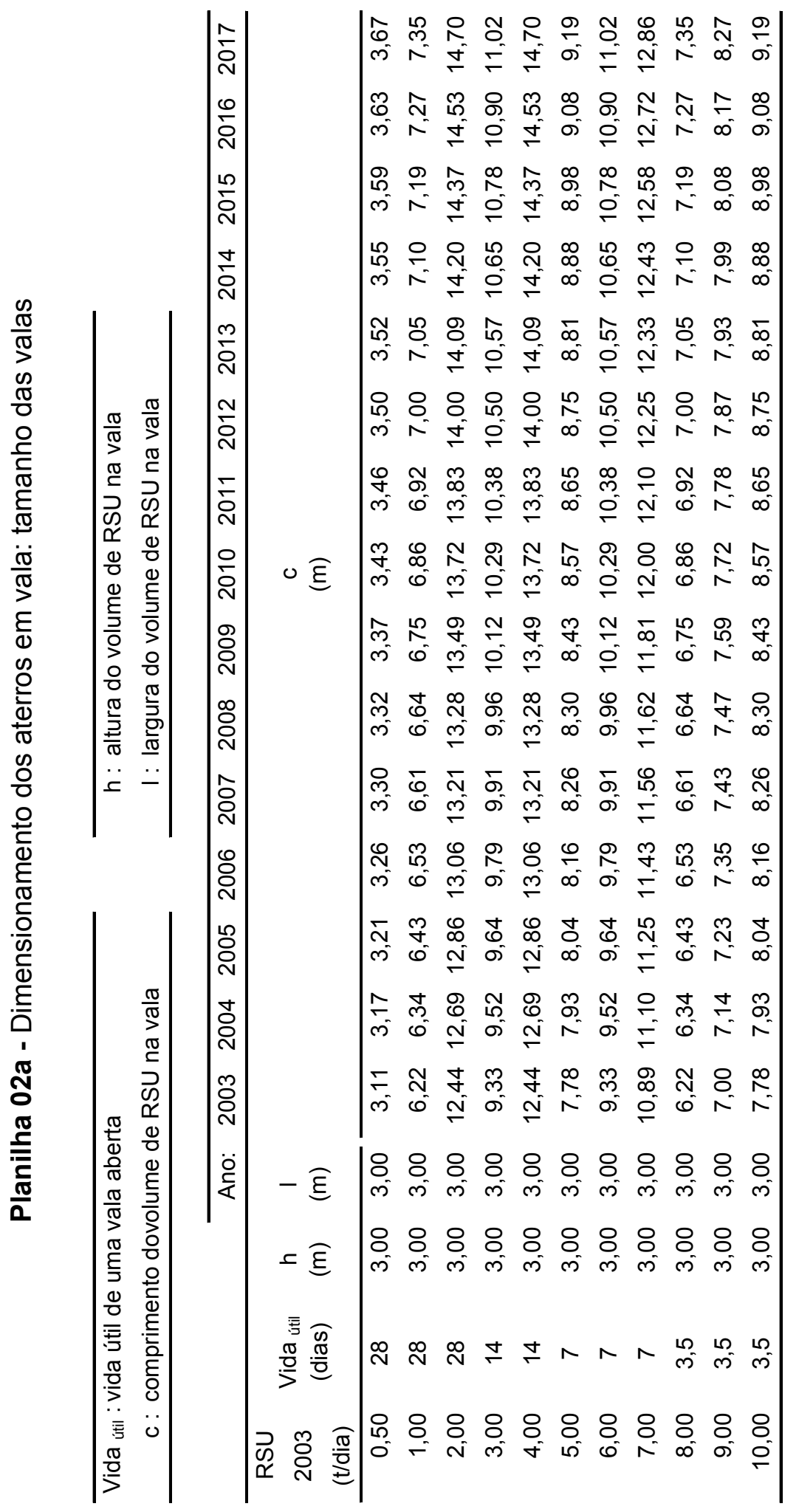




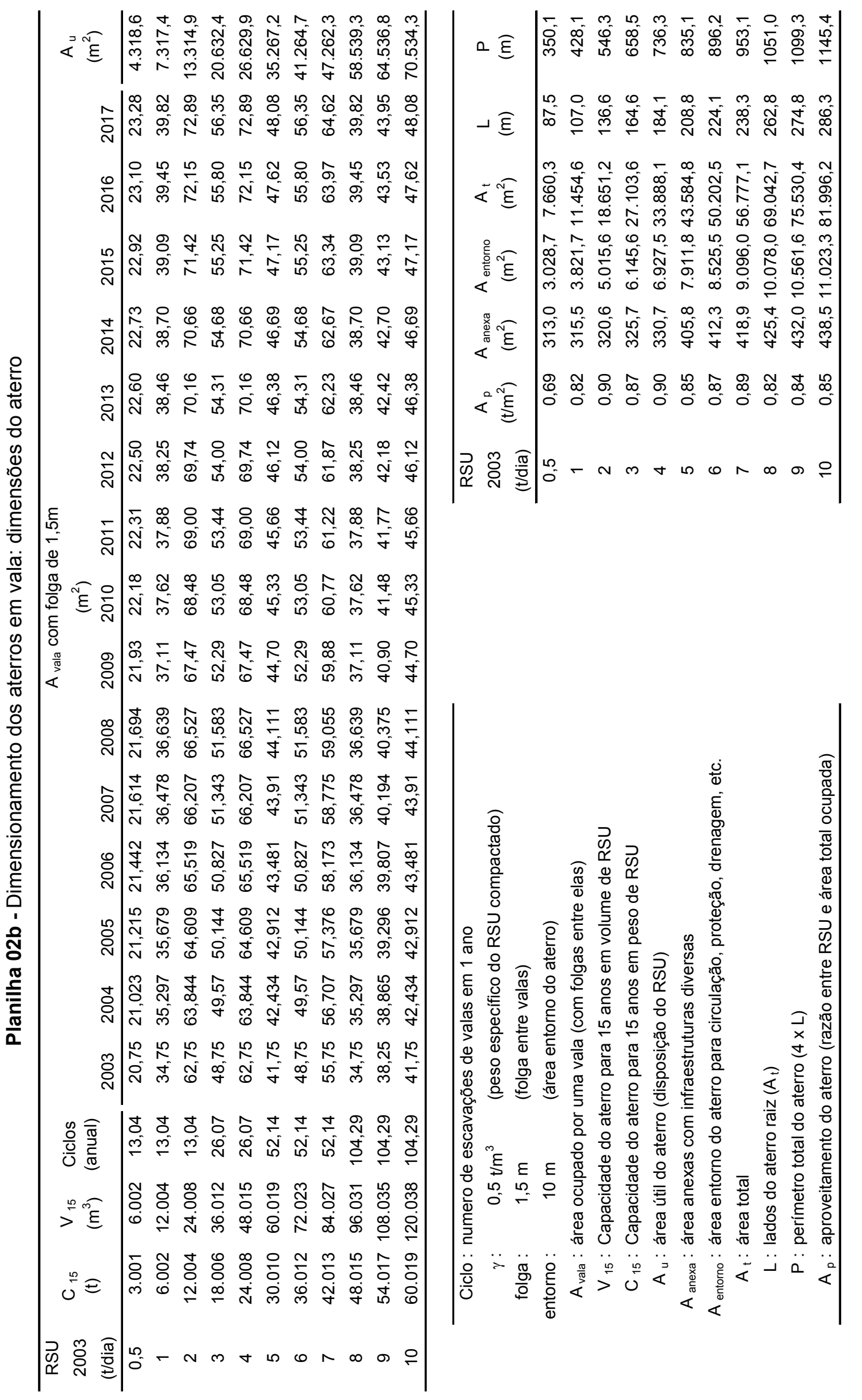




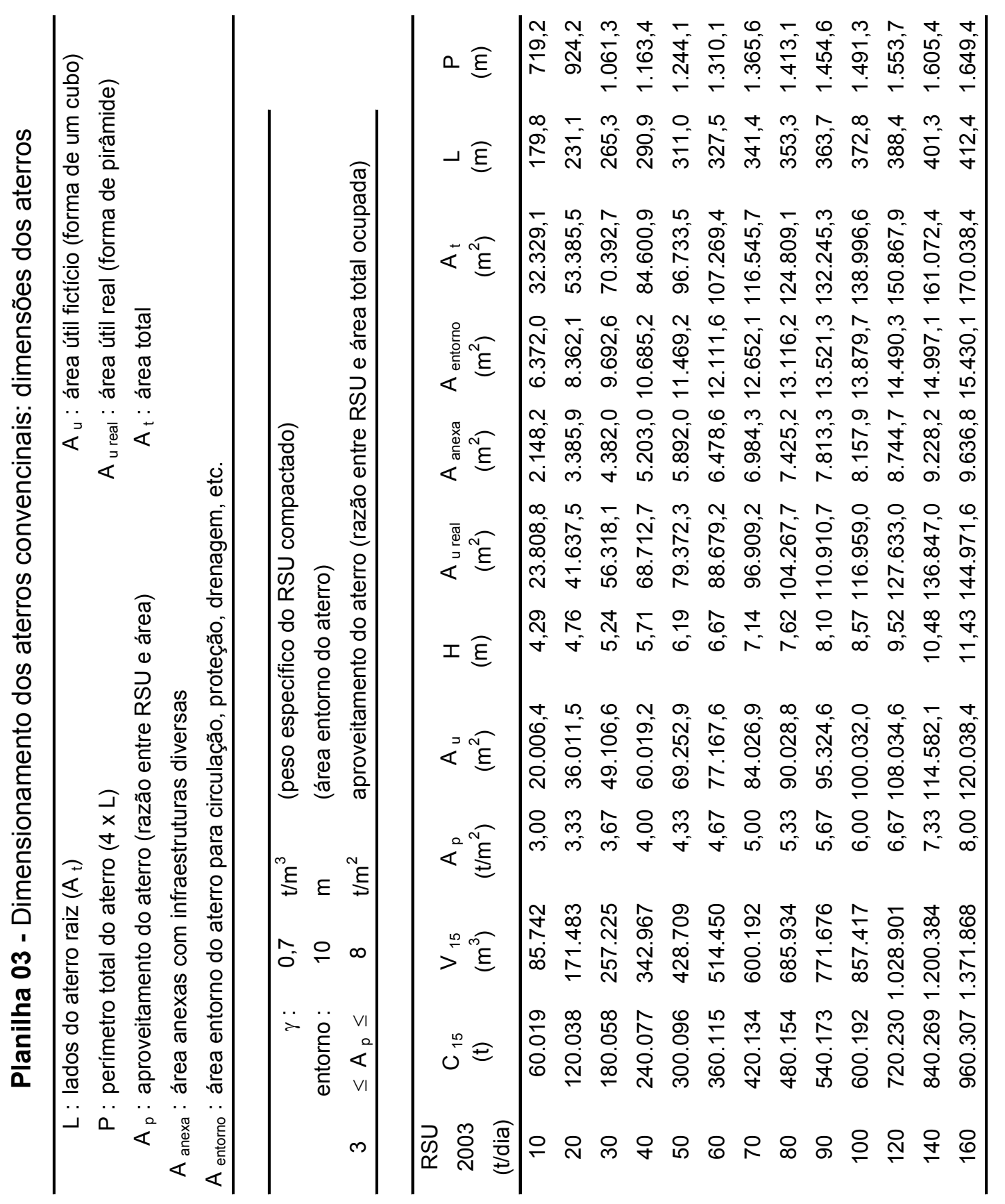




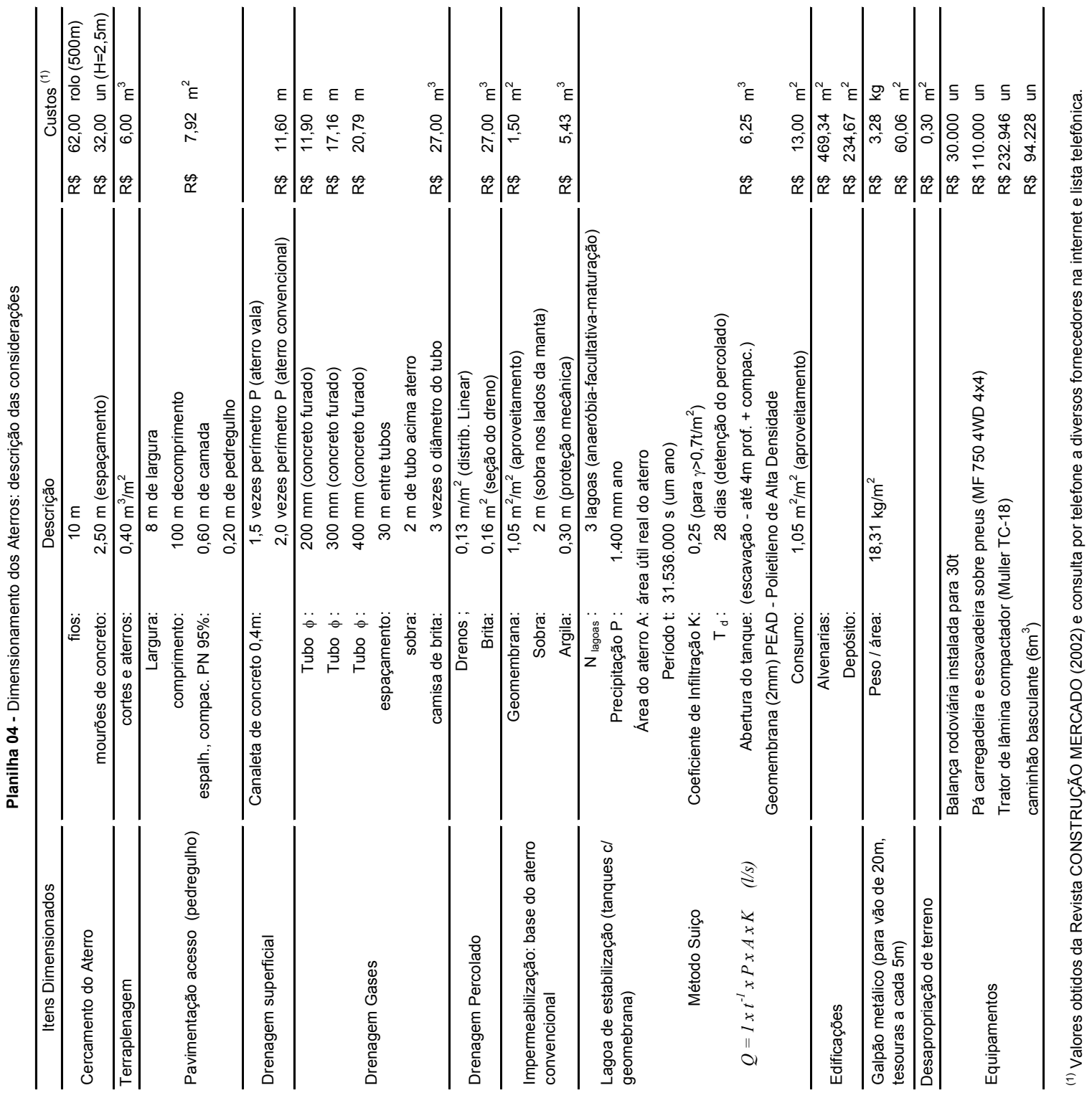




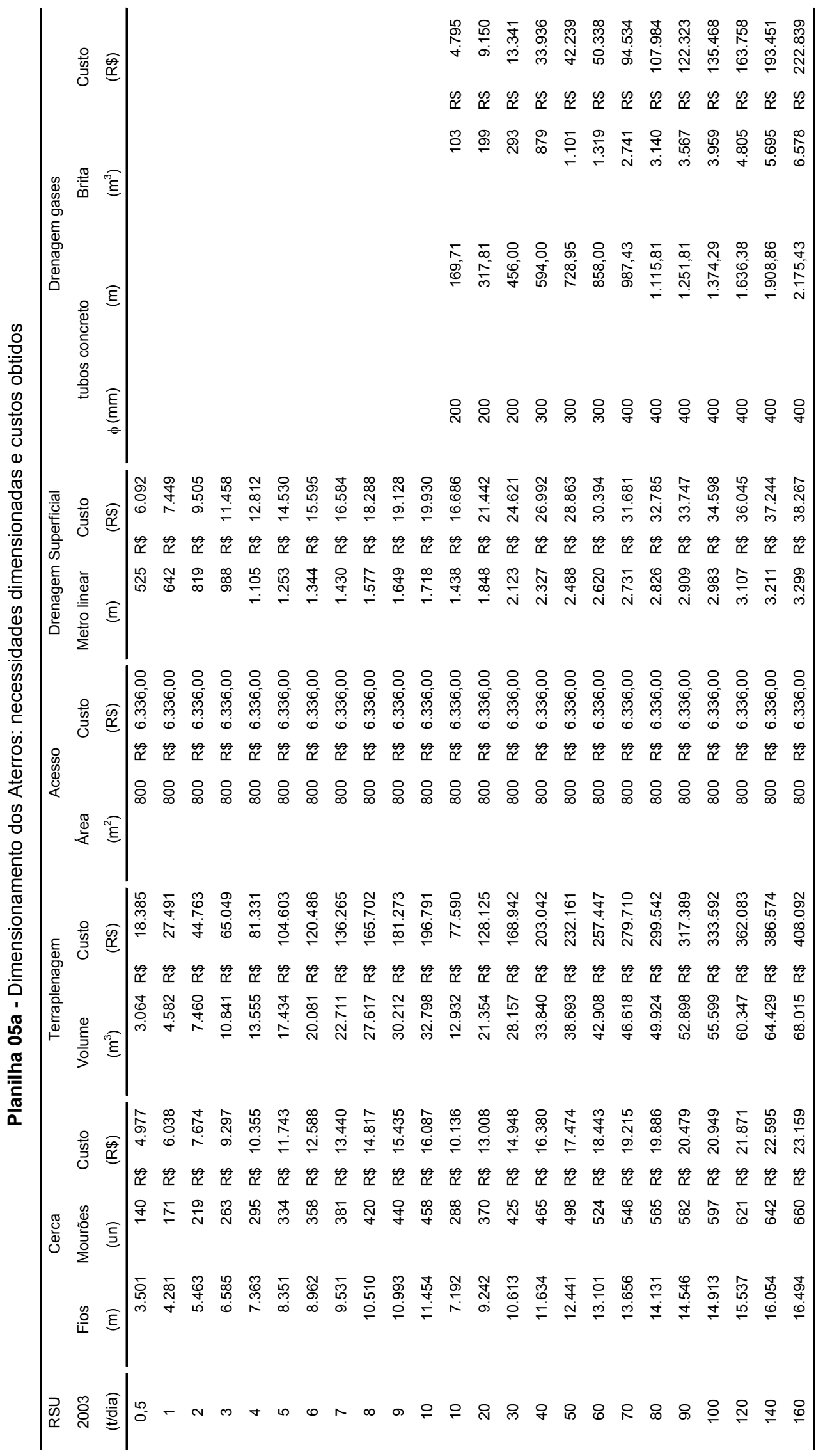




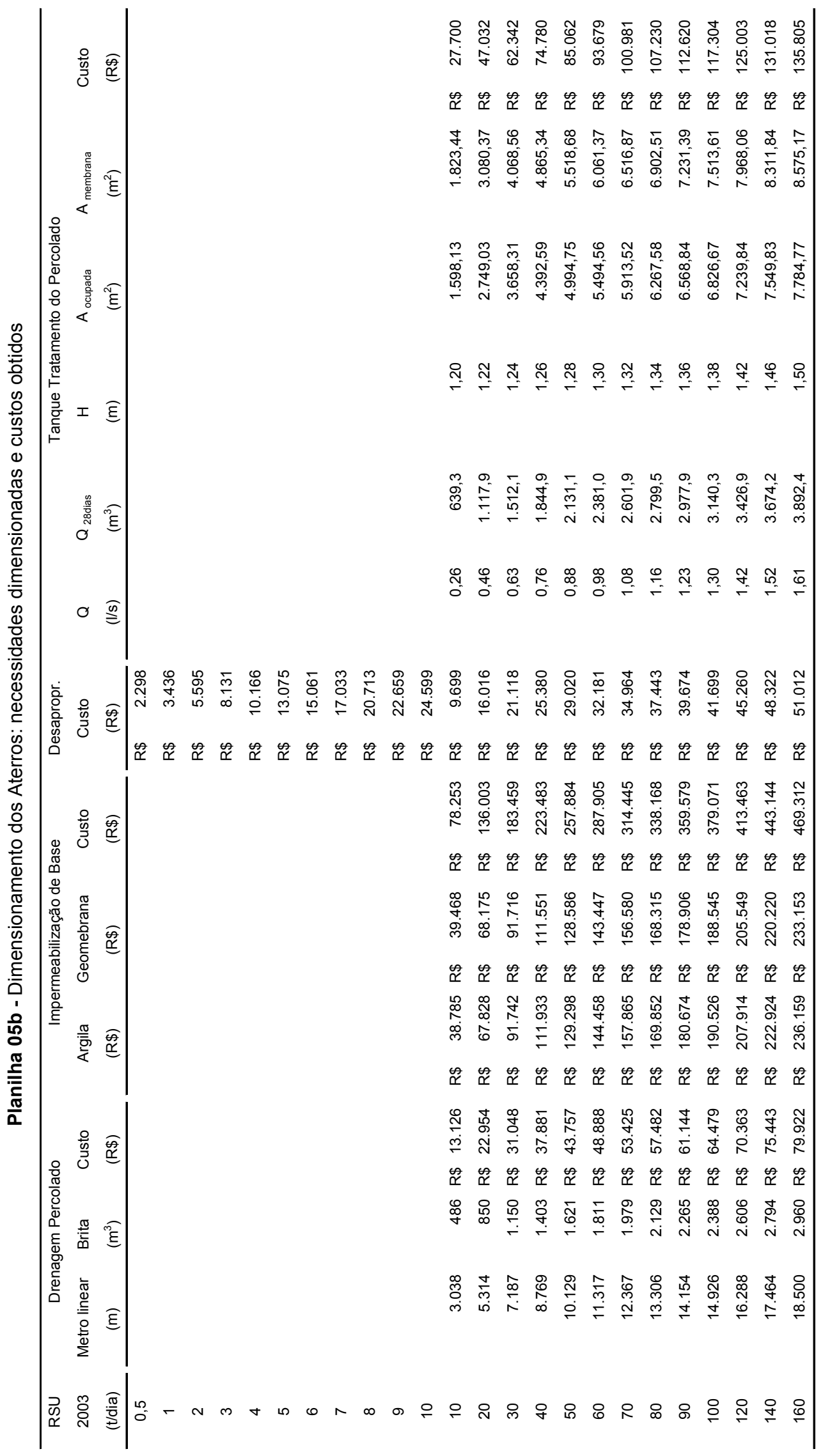




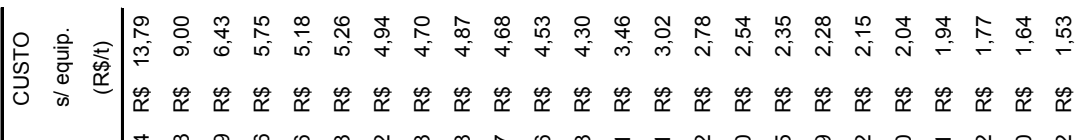

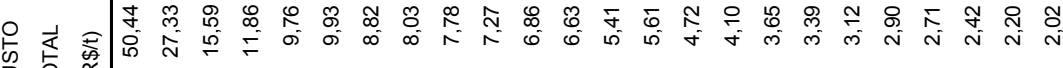

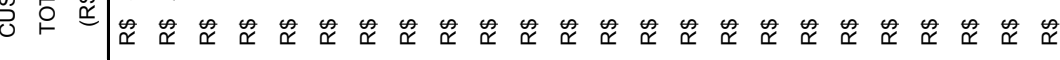

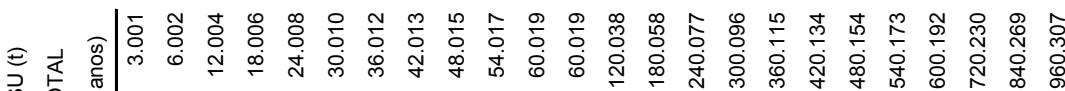

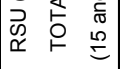

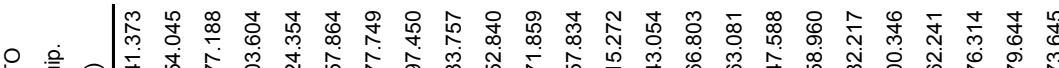

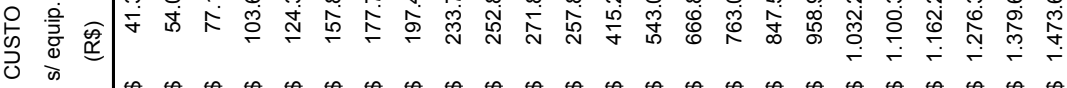

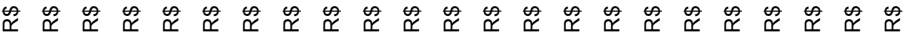

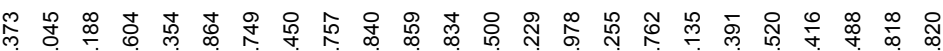

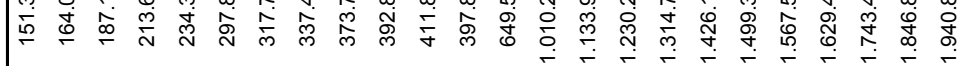

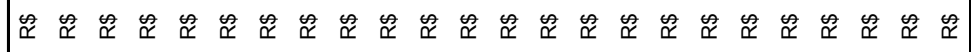

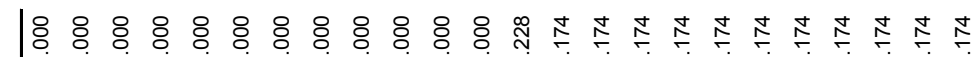

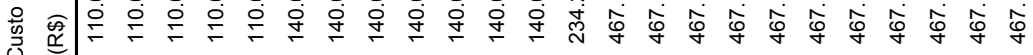

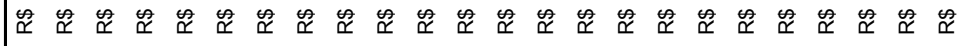
这 它

然

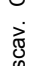
覀

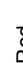
要 㠃 高畜 高 员雨 $\frac{20}{\frac{20}{20}}$ 产

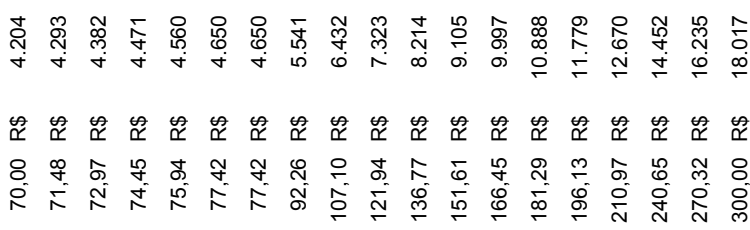

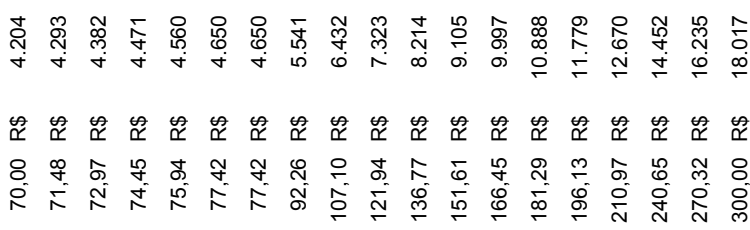

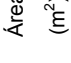

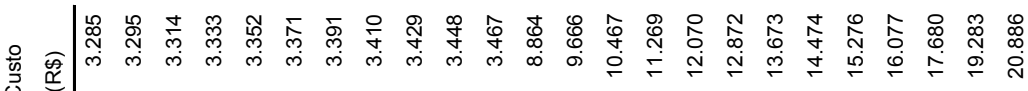

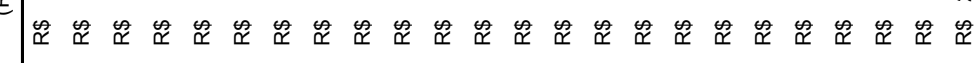

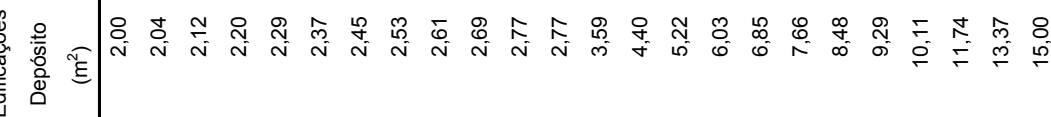
焉

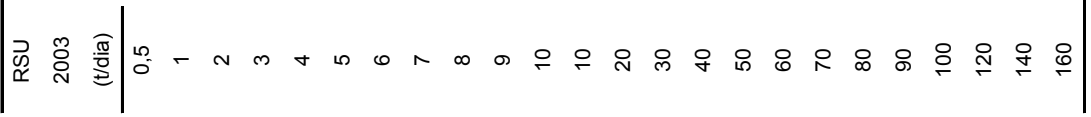


APÊNDICE I

Relatórios de saída do TransCAD obtidos com a rotina de localização aplicado para as situações definidas 


\section{Situação 11: Relatório do TransCAD}

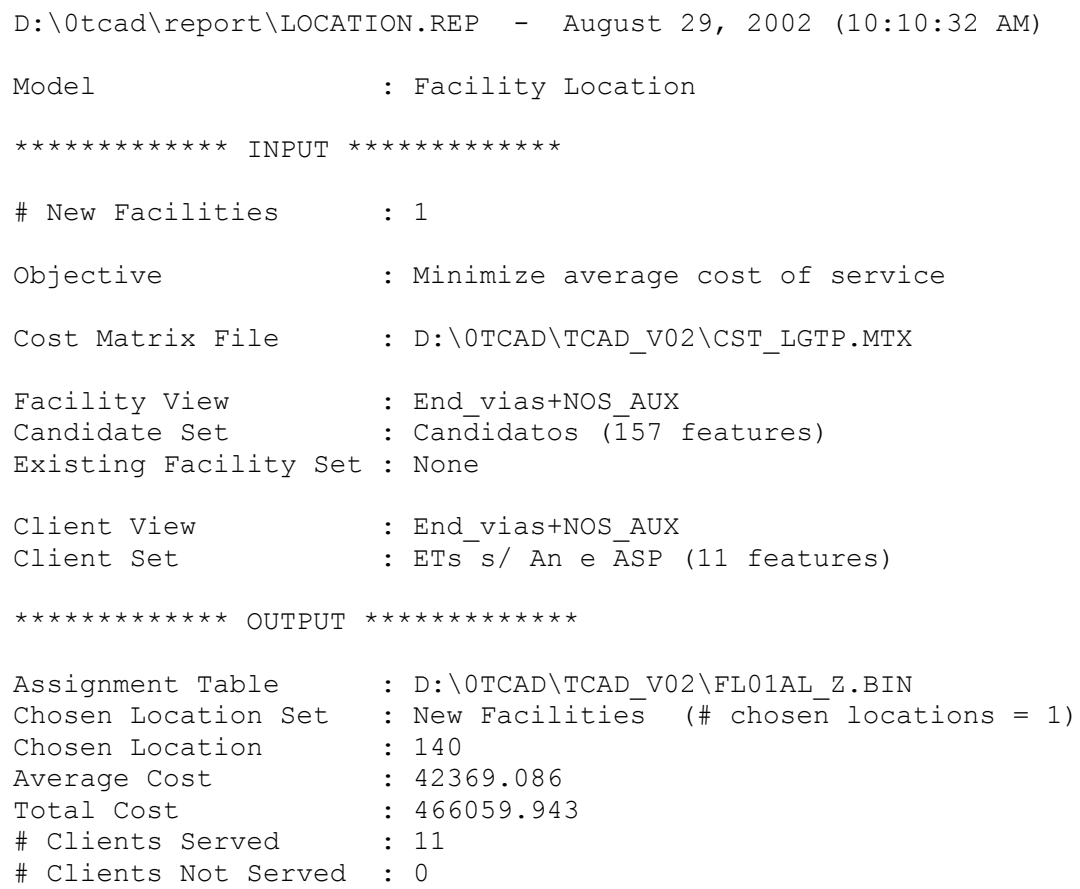

\section{Situação 12: Relatório do TransCAD}

D: \0tcad $\backslash$ report $\backslash$ LOCATION.REP - August 29, 2002 (10:22:45 AM)

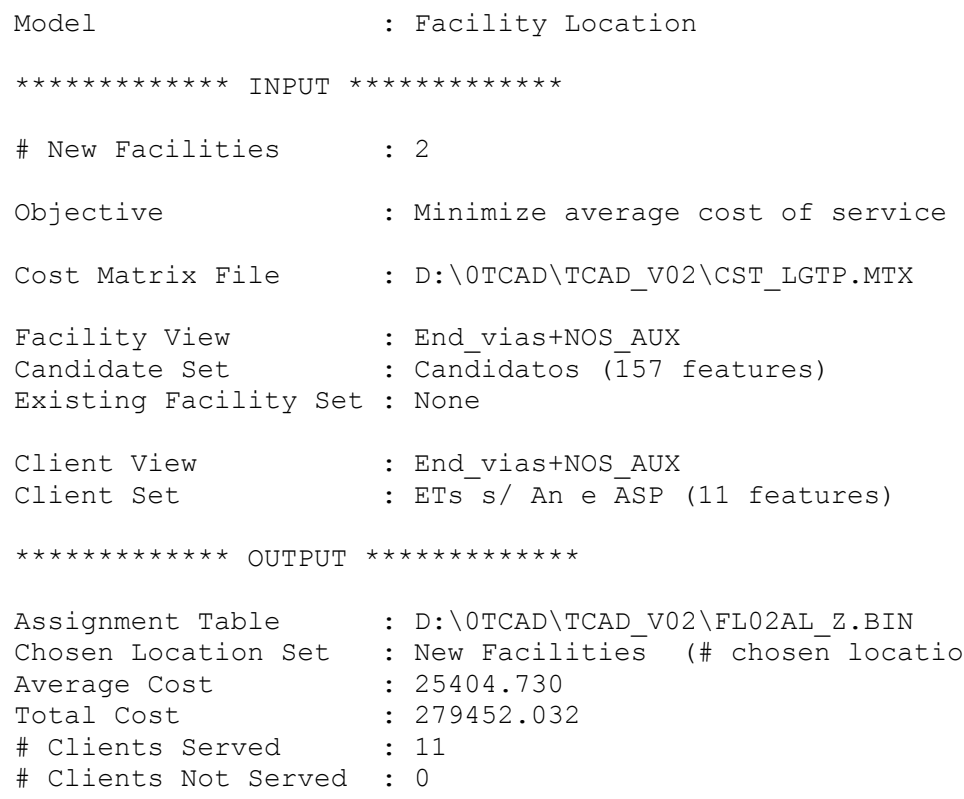




\section{Situação 13: Relatório do TransCAD}

D: \0tcad $\backslash$ report $\backslash$ LOCATION.REP - August 29, 2002 (10:33:17 AM)

Model

: Facility Location

$\star * * * * * * * * * * * *$ INPUT

\# New Facilities : 3

Objective : Minimize average cost of service

Cost Matrix File : D: \OTCAD \TCAD_V02\CST_LGTP.MTX

Facility View : End_vias+NOS_AUX

Candidate set : Candidatos ( $\overline{1} 57$ features)

Existing Facility set : None

Client View : End vias+NOS AUX

client Set : ETs ${ }^{-}$s/ An ( $1 \overline{2}$ features)

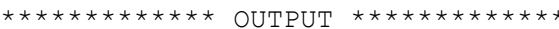

Assignment Table : D: \0TCAD \TCAD V02\FL03AL Y.BIN

Chosen Location Set : New Facilities (\# chosen locations = 3)

Average Cost : : 17803.215

Total Cost : 213638.577

\# Clients Served : 12

\# Clients Not Served : 0

\section{Situação 14: Relatório do TransCAD}

D: \0tcad \report \LOCATION.REP - August 29, 2002 (10:52:03 AM)

Model : Facility Location

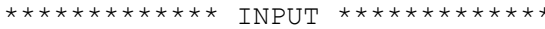

\# New Facilities : 4

Objective : Minimize average cost of service

Cost Matrix File : D: \0TCAD \TCAD_V02\CST_LGTP.MTX

Facility View : End vias+NOS AUX

Candidate set : Candidatos ( $\overline{1} 57$ features)

Existing Facility Set : None

Client View : End_vias+NOS_AUX

client set : ETs ${ }^{-}$S/ ASP ( $\overline{1} 2$ features)

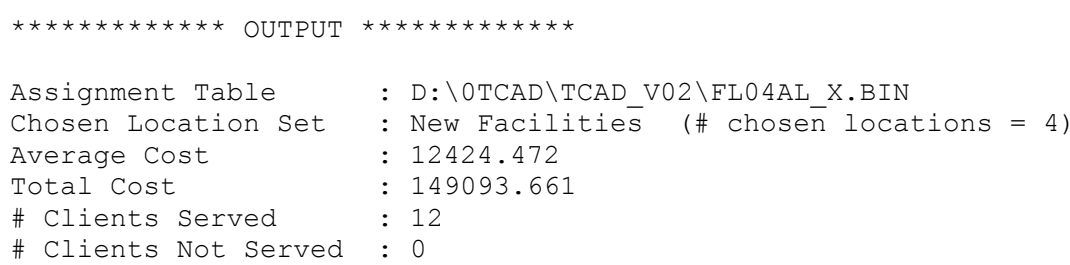




\section{Situação 21: Relatório do TransCAD}

C: $\backslash$ otcad $\backslash$ report $\backslash$ LOCATION.REP - October 20, 2002 (02:23:46 PM)

Model

: Facility Location

$\star * * * * * * * * * * * *$ INPUT

\# New Facilities : 1

Objective : Minimize average cost of service

Cost Matrix File : C: \OTCAD \TCAD_L02\CST_LGTP.MTX

Facility View : End_vias+NOS_AUX

Candidate set : Candidatos ( $\overline{1} 57$ features)

Existing Facility set : None

Client View : End vias+NOS AUX

Client set : Cidādes (14 $\overline{\text { features }}$

client Weight : NUM VIAG

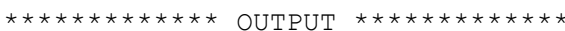

Assignment Table : C: \0TCAD TCAD L02 LSO1ALT.BIN

Chosen Location set : New Facilities (\# chosen locations = 1)

Chosen Location : 148

Average Cost : 26.751

Total Cost : 4263168.208

\# Clients Served : 14

\# Clients Not Served : 0

Situação 22: Relatório do TransCAD

C: \Otcad \report $\backslash$ LOCATION.REP - October 20, 2002 (02:51:43 PM)

Model : Facility Location

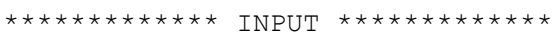

\# New Facilities : 2

objective : Minimize average cost of service

Cost Matrix File : C: \OTCAD \TCAD_L02\CST_LGTP.MTX

Facility View : End_vias+NOS_AUX

Candidate Set : Candidatos (157 features)

Existing Facility set : None

Client View : End vias+NOS AUX

Client Set : Cidādes (14 features)

client Weight : NUM VIAG

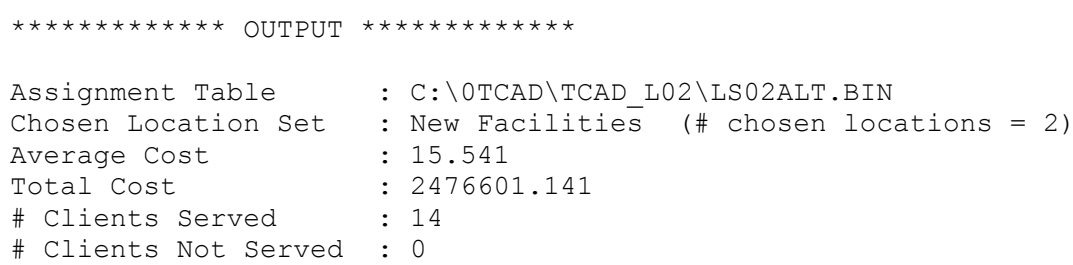




\section{Situação 23: Relatório do TransCAD}

C: $\backslash$ tcad $\backslash$ report $\backslash$ LOCATION.REP - October 20, 2002 (02:54:09 PM)

Model

: Facility Location

$\star * * * * * * * * * * * *$ INPUT

\# New Facilities : 3

Objective : Minimize average cost of service

Cost Matrix File : C: \OTCAD \TCAD_L02\CST_LGTP.MTX

Facility View : End_vias+NOS_AUX

Candidate set : Candidatos ( $\overline{1} 57$ features)

Existing Facility set : None

Client View : End vias+NOS AUX

Client set : Cidādes (14 $\overline{\text { features }}$

client Weight : NUM VIAG

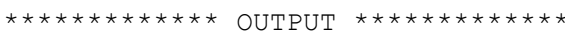

Assignment Table : C: \0TCAD TCAD L02 LLS03ALT.BIN

Chosen Location set : New Facilities (\# chosen locations = 3)

Average Cost : 9.630

Total Cost : 1534599.179

\# Clients Served : 14

\# Clients Not Served : 0

\section{Situação 24: Relatório do TransCAD}

C: \Otcad \report \LOCATION.REP - October 20, 2002 (02:56:46 PM)

Model

: Facility Location

$\star \star \star \star * \star * \star * \star \star \star \star * *$ INPUT

\# New Facilities : 4

objective : Minimize average cost of service

Cost Matrix File : C: \OTCAD \TCAD_L02\CST_LGTP.MTX

Facility View : End vias+NOS AUX

Candidate set : Candidatos (157 features)

Existing Facility Set : None

$\begin{array}{ll}\text { Client View } & \text { : End_vias+NOS_AUX } \\ \text { Client Set } & : \text { Cidades (14 features) } \\ \text { Client Weight } & : \text { NUM_VIAG }\end{array}$

Cilention

Assignment Table : C: \OTCAD TTCAD L02\LS04ALT.BIN

Chosen Location set : New Facilities (\# chosen locations = 4)

Average Cost : : 7.110

Total Cost : 1133025.949

\# Clients Served : 14

\# Clients Not Served : 0 
APÊNDICE J

Resultados da roteirização no TransCAD para as situações definidas: rotas, itinerários 


\section{Situação 11}

1. Roteirização para os Veículos de Transbordo: Aterro - ET - Aterro

1.1. Semanas: $2007 \mathrm{~A}$

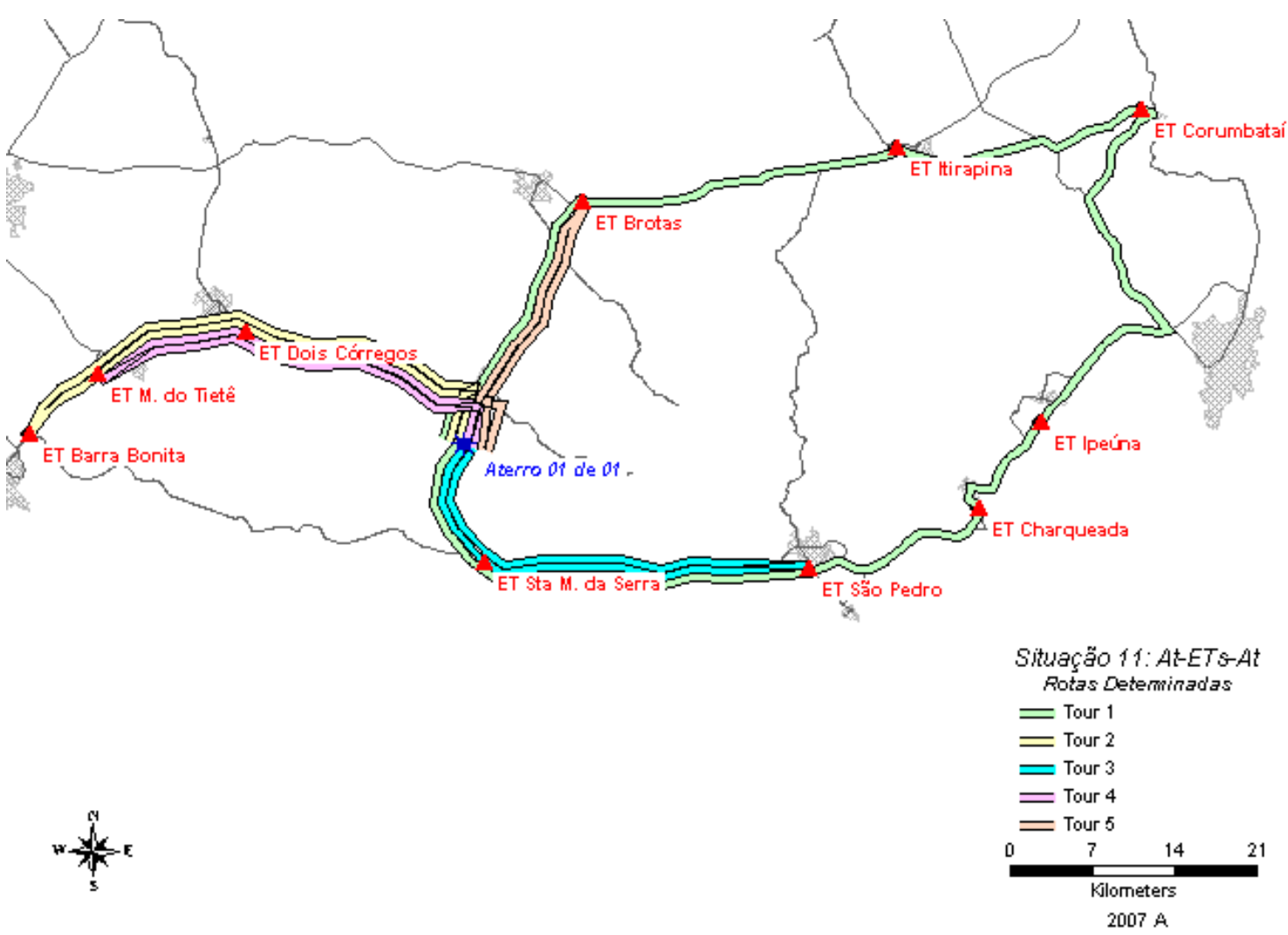

Rota 1.1 - Situação 11: 2007 A 
ITINERÁRIO 1.1 - Situação 11: 2007 A

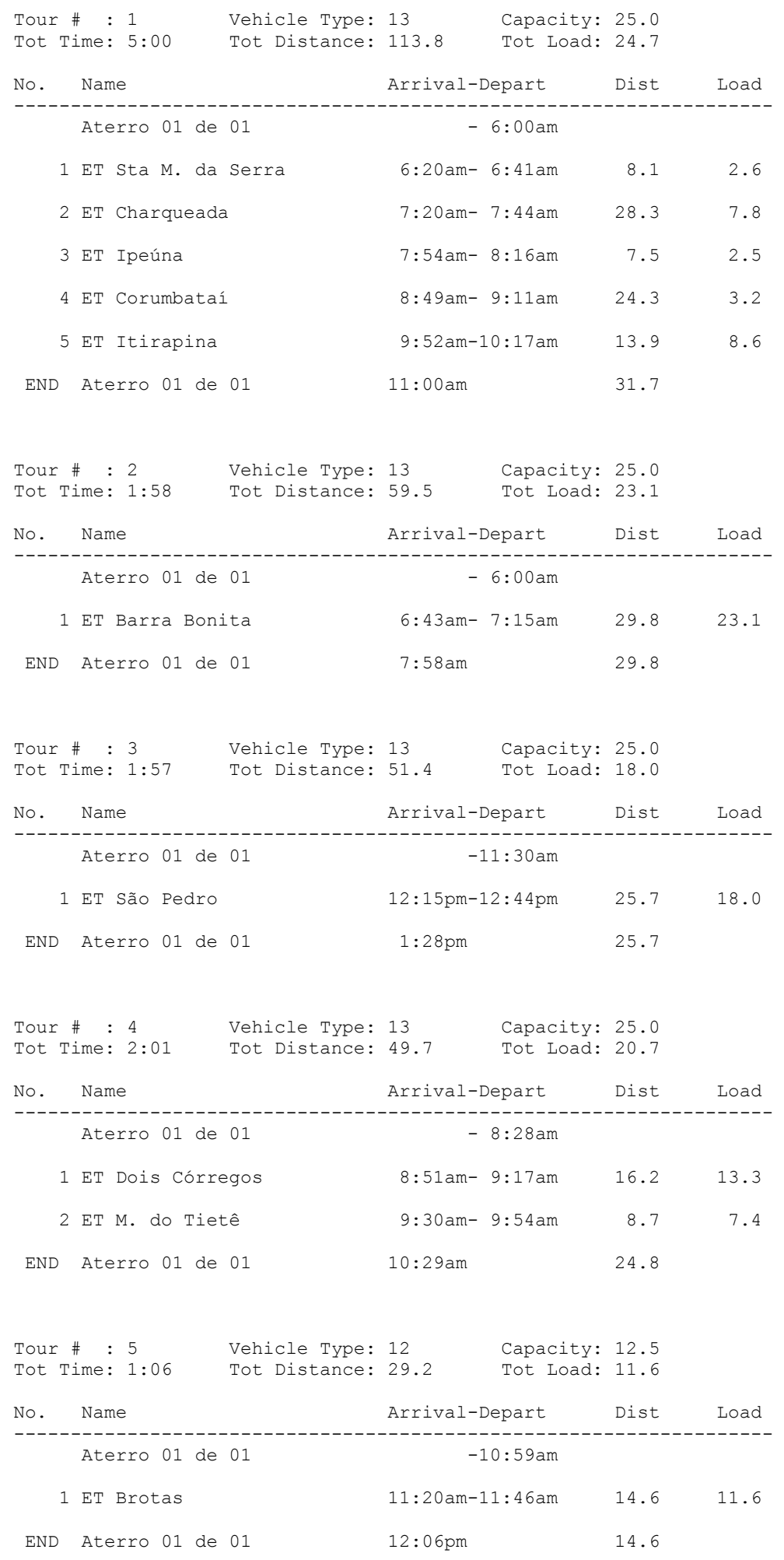


1.2. Semanas: $\quad 2007$ B-F, 2012 ABDF, 2017 A

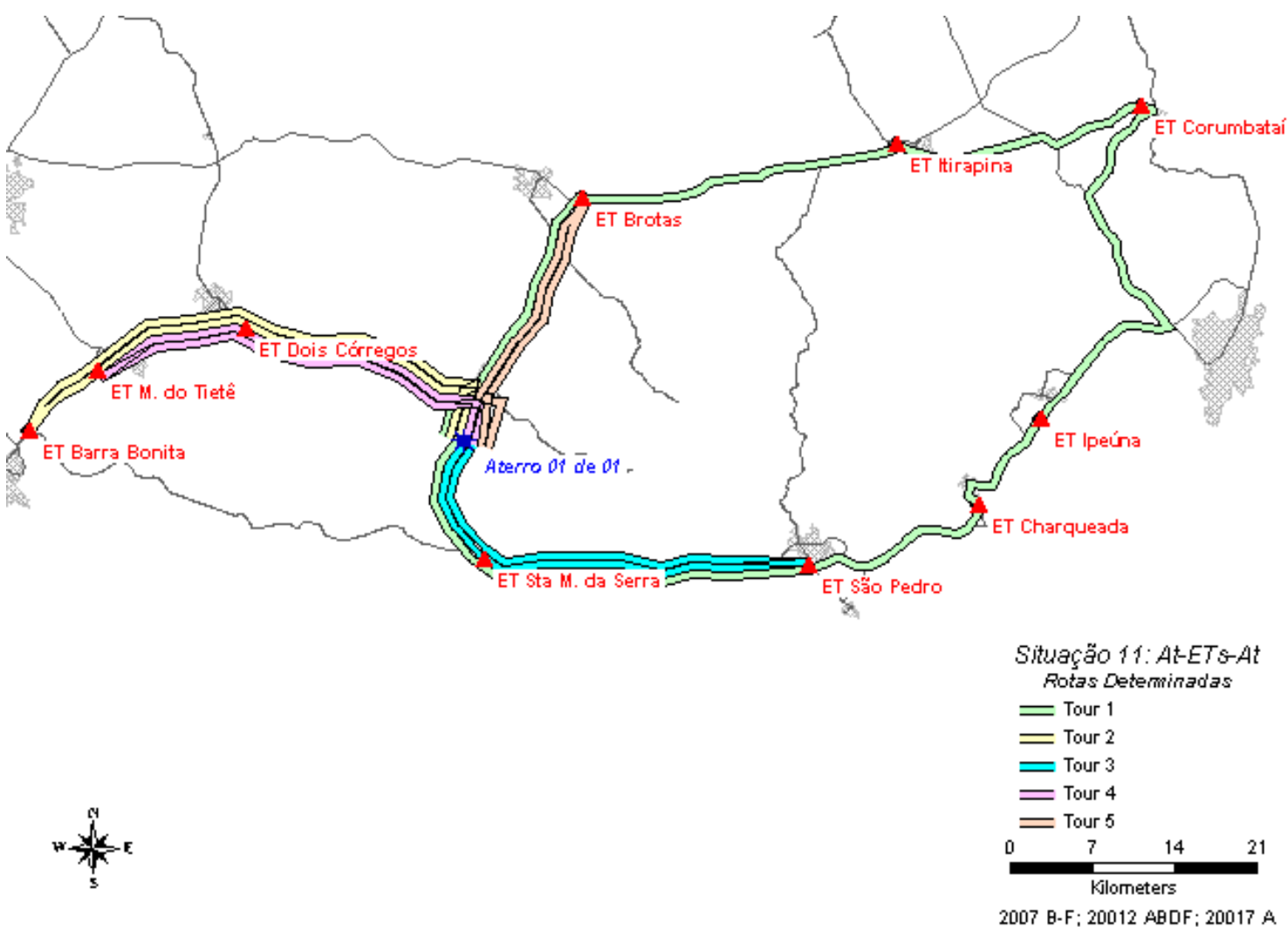

ROTA 1.2 - Situação 11: 2007 B-F, 2012 ABDF, 2017 A 
ITINERÁRIO 1.2 - Situação 11: 2007 B-F, 2012 ABDF, 2017 A

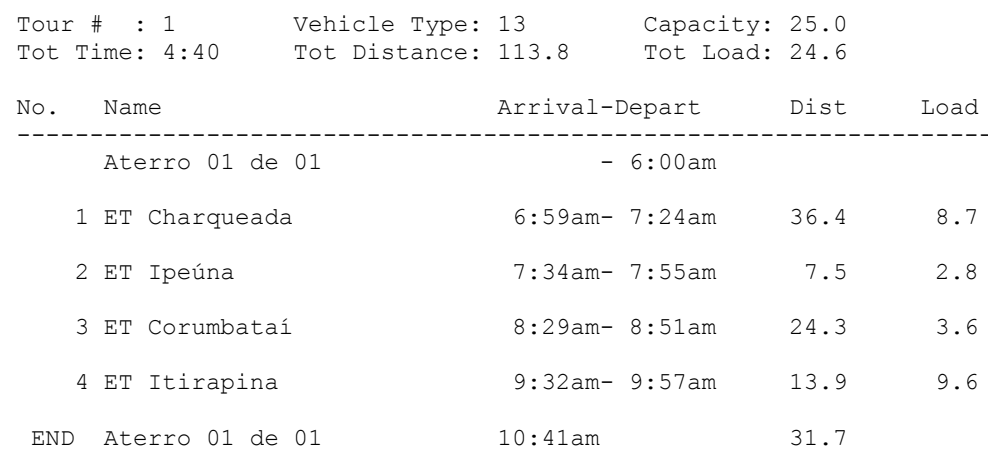

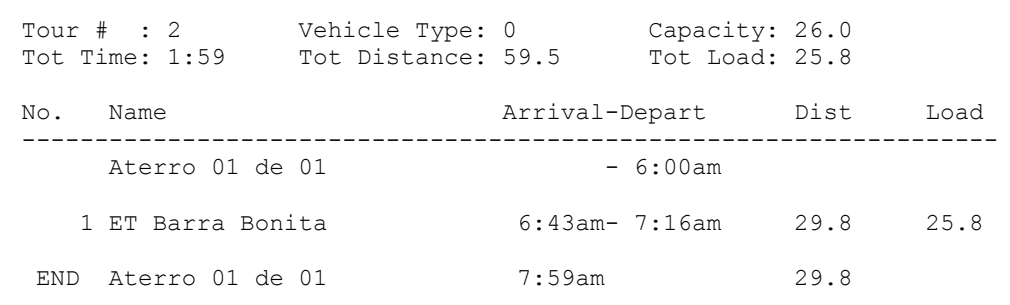

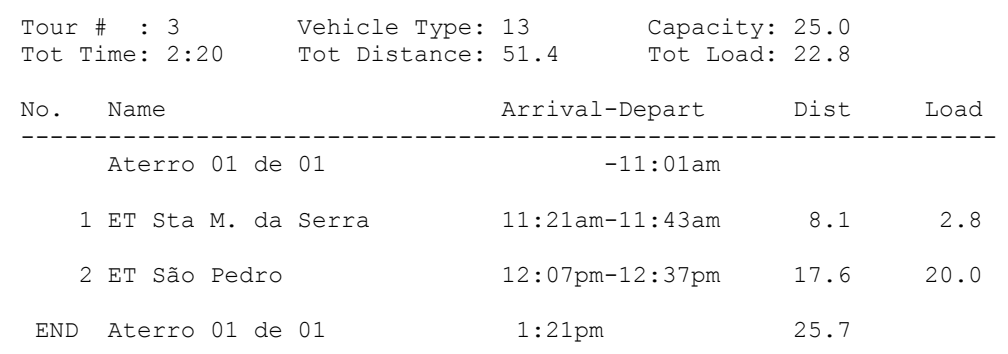

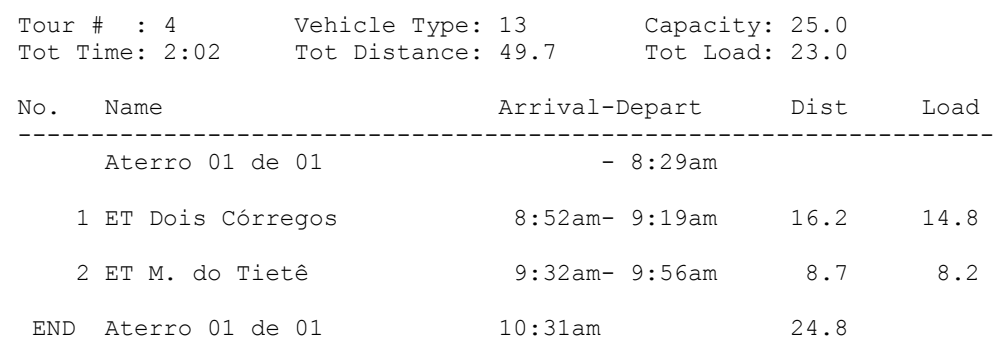

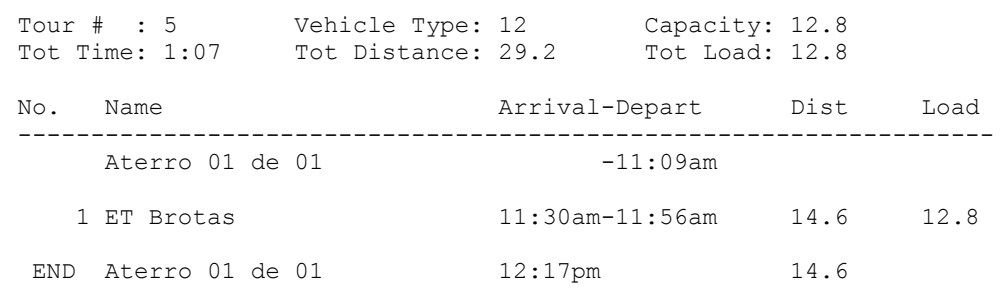


1.3. Semanas: $\quad 2007$ G, 2012 CEG, 2017 B-G

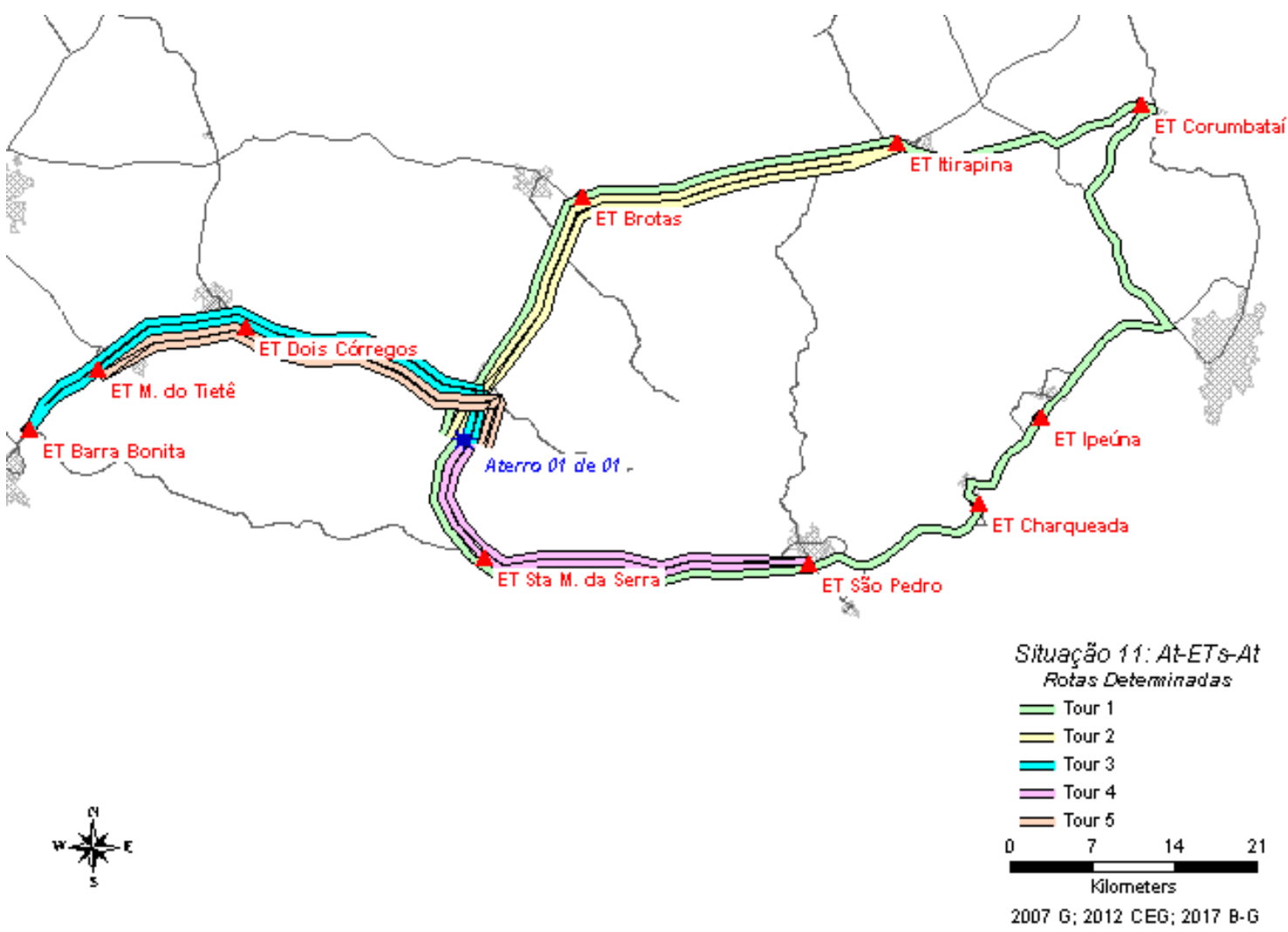

ROTA 1.3 - Situação 11: 2007 G, 2012 CEG, 2017 B-G 
ITINERÁRIO 1.3 - Situação 11: 2007 G, 2012 CEG, 2017 B-G

\begin{tabular}{|c|c|c|c|c|c|}
\hline \multicolumn{6}{|c|}{ Itinerary Report } \\
\hline $\begin{array}{l}\text { Tour \# }: 1 \\
\text { Tot Time: } 4: 38\end{array}$ & $\begin{array}{l}\text { Vehicle Type: } \\
\text { Tot Distance: }\end{array}$ & $\begin{array}{l}13 \\
113.8\end{array}$ & $\begin{array}{l}\text { Capacity: } \\
\text { Tot Load: }\end{array}$ & $\begin{array}{l}25.0 \\
20.7\end{array}$ & \\
\hline No. Name & & Arrival-I & Depart & Dist & Load \\
\hline Aterro $01 \mathrm{de}$ & 01 & & $6: 00 \mathrm{am}$ & & \\
\hline 1 ET Sta M. da & Serra & $6: 20 \mathrm{am}-$ & $6: 42 \mathrm{am}$ & 8.1 & 2.9 \\
\hline 2 ET Charquead & & $7: 21 \mathrm{am}-$ & $7: 45 \mathrm{am}$ & 28.3 & 9.4 \\
\hline 3 ET Ipeúna & & $7: 56 \mathrm{am}-$ & $8: 18 \mathrm{am}$ & 7.5 & 3.6 \\
\hline 4 ET Corumbata & & $8: 51 \mathrm{am}-$ & $9: 13 a m$ & 24.3 & 4.8 \\
\hline END Aterro 01 de & 01 & $10: 39 \mathrm{am}$ & & 45.6 & \\
\hline Tour \# : 2 & Vehicle Type: & 0 & Capacity: & 30.0 & \\
\hline Tot Time: $2: 22$ & Tot Distance: & 63.4 & Tot Load: & 29.9 & \\
\hline Name & & Arrival-I & Depart & Dist & Load \\
\hline Aterro 01 de & 01 & & $1: 08 \mathrm{am}$ & & \\
\hline 1 ET Itirapina & & $11: 52 \mathrm{am}-1$ & $2: 19 \mathrm{pm}$ & 31.7 & 13.7 \\
\hline 2 ET Brotas & & $12: 42 \mathrm{pm}-$ & $1: 11 \mathrm{pm}$ & 17.1 & 16.2 \\
\hline END Aterro 01 de & 01 & $1: 31 \mathrm{pm}$ & & 14.6 & \\
\hline
\end{tabular}

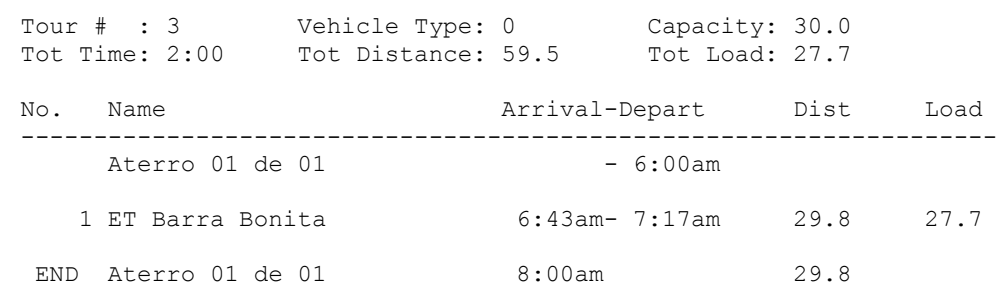

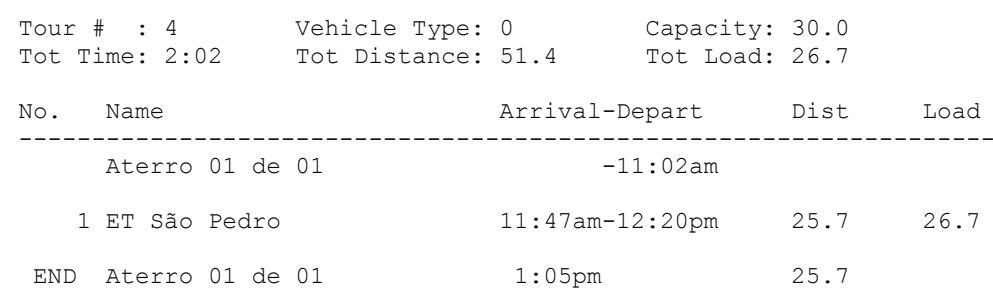

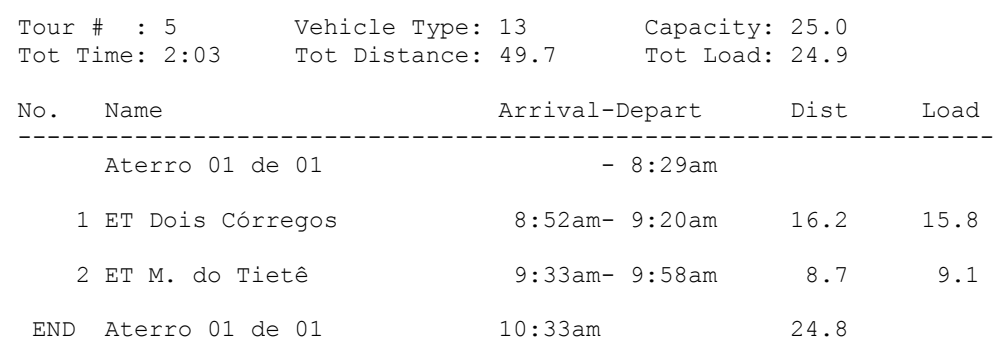


2. Roteirização com os Veículos de Coleta: até Aterro ou ET

2.1. Parte 01: destinação normal após coleta até Aterro ou ET

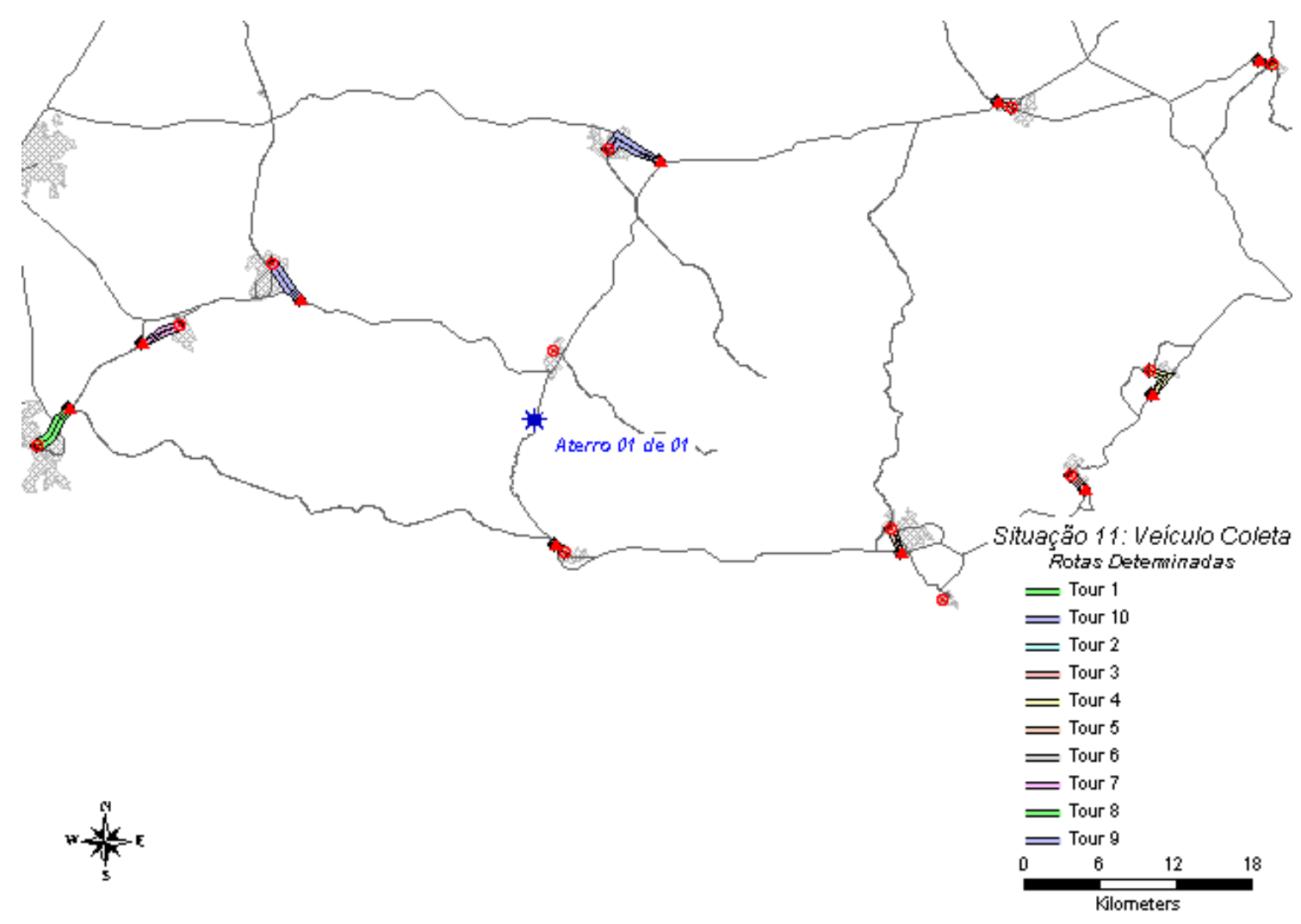

RORA 2.1 - Situação 11: Parte 01 


\section{ITINERÁRIO 2.1 - Situação 11: Parte 01}

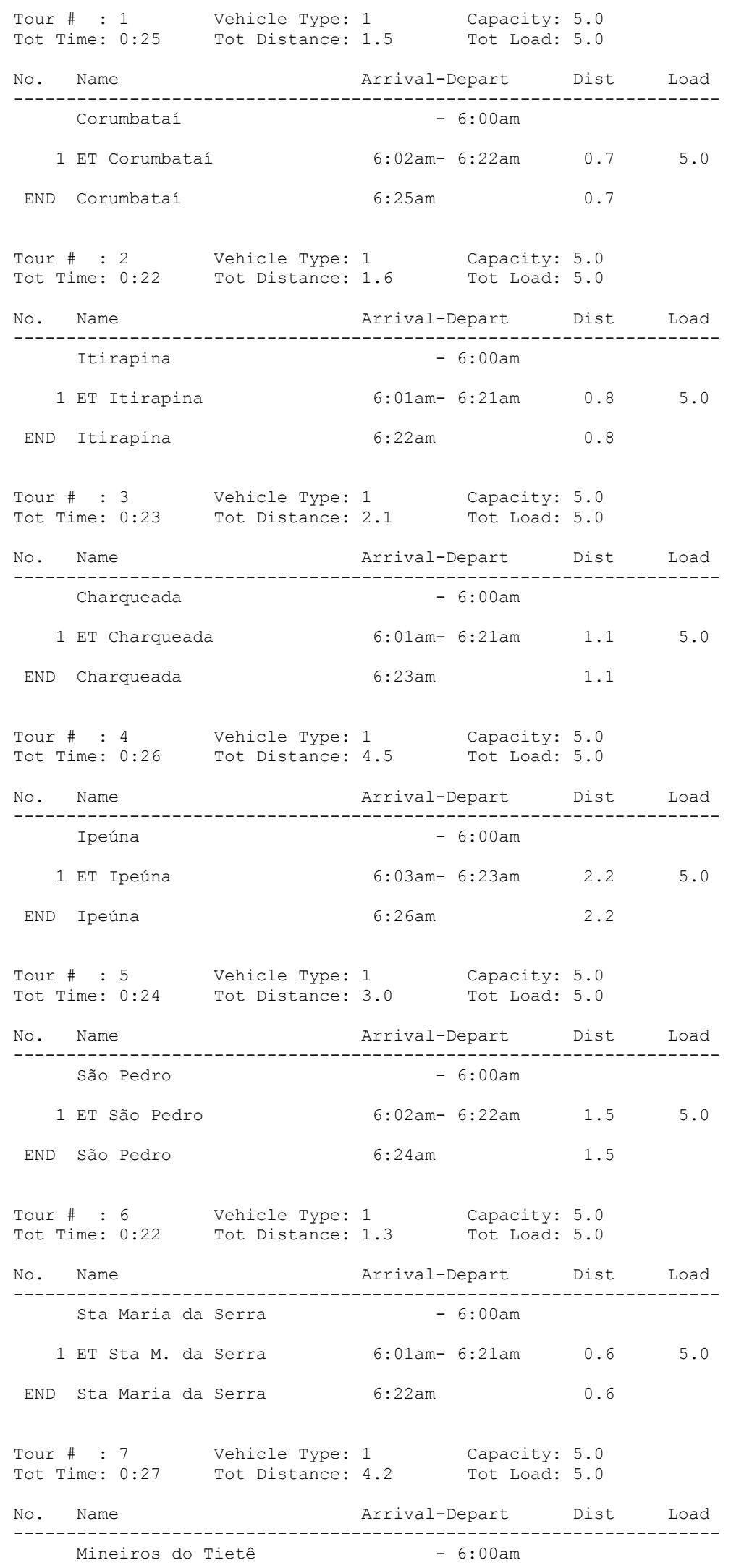




$\begin{array}{clcc}1 \text { ET M. do Tietê } & 6: 03 a m-6: 23 a m & 2.1 & 5.0 \\ \text { END Mineiros do Tietê } & 6: 27 \mathrm{am} & 2.1\end{array}$

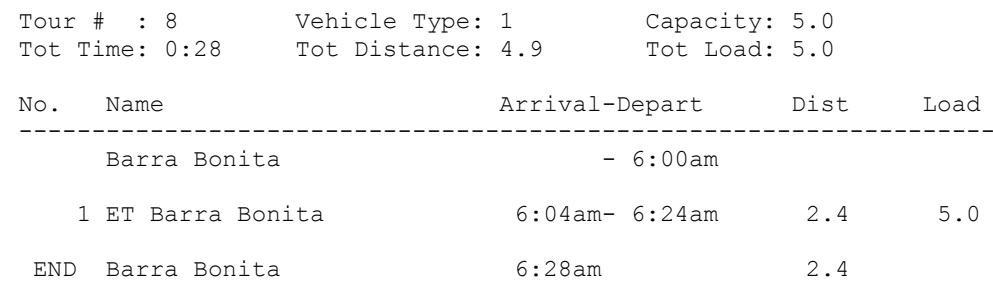

Tour \# : 9 Vehicle Type: 1 Capacity: 5.0

Tot Time: $0: 26$ Tot Distance: 4.5 Tot Load: 5.0

$\begin{array}{lrrr}\text { No. Name } & \text { Arrival-Depart } & \text { Dist Load } \\ & \text { Dois Córregos } & & \\ & & & \\ 1 \text { ET Dois Córregos } & 6: 03 \mathrm{am}-6: 23 \mathrm{am} & 2.2 & 5.0 \\ \text { END Dois Córregos } & 6: 26 \mathrm{am} & 2.2 & \end{array}$

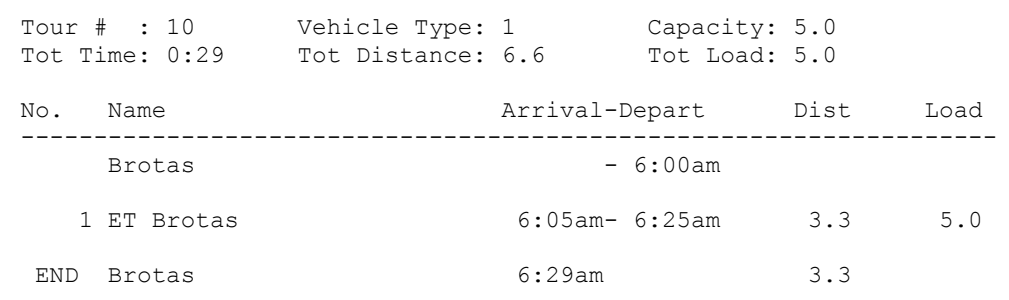


2.2. Parte 02: destinação normal após coleta até Aterro ou ET (cont.)

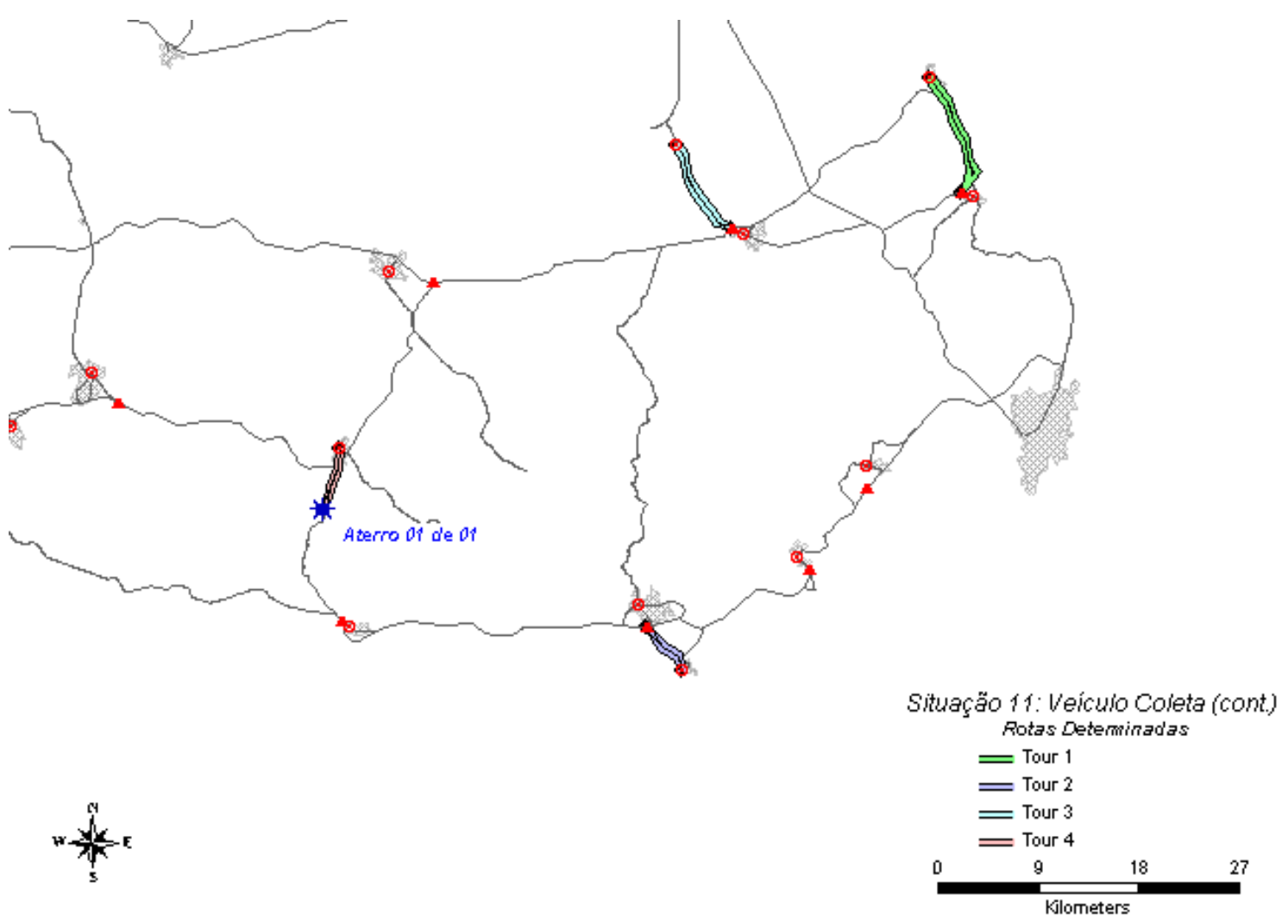

ROTA 2.2 - Situação 11: Parte 02 
ITINERÁRIO 2.2 - Situação 11: Parte 02

\begin{tabular}{|c|c|c|c|c|c|}
\hline Tour \# : 1 & Vehicle Type: & 1 & Capacity: & 5.0 & \\
\hline Tot Time: $1: 12$ & Tot Distance: & 17.4 & Tot Load: & 5.0 & \\
\hline No. Name & & Arrival-D & Depart & Dist & Load \\
\hline Analândia & & & $6: 00 \mathrm{am}$ & & \\
\hline 1 ET Corumbataí & & $6: 26 \mathrm{am}-$ & $6: 46 \mathrm{am}$ & 8.7 & 5.0 \\
\hline END Analândia & & $7: 12 \mathrm{am}$ & & 8.7 & \\
\hline Tour \# : 2 & Vehicle Type: & 1 & Capacity: & 5.0 & \\
\hline Tot Time: $0: 31$ & Tot Distance: & 8.3 & Tot Load: & 5.0 & \\
\hline No. Name & & Arrival-D & Depart & Dist & Load \\
\hline Águas de São & Pedro & - & $6: 00 \mathrm{am}$ & & \\
\hline 1 ET São Pedro & & $6: 06 \mathrm{am}-$ & $6: 26 \mathrm{am}$ & 4.1 & 5.0 \\
\hline END Águas de São & Pedro & $6: 31 \mathrm{am}$ & & 4.1 & \\
\hline Tour \# : 3 & Vehicle Type: & 1 & Capacity: & 5.0 & \\
\hline Tot Time: $0: 38$ & Tot Distance: & 11.4 & Tot Load: & 5.0 & \\
\hline No. Name & & Arrival-D & Depart & Dist & Load \\
\hline Broa & & - & $6: 00 \mathrm{am}$ & & \\
\hline 1 ET Itirapina & & $6: 09 \mathrm{am}-$ & $6: 29 \mathrm{am}$ & 5.7 & 5.0 \\
\hline END Broa & & $6: 38 \mathrm{am}$ & & 5.7 & \\
\hline Tour \# : 4 & Vehicle Type: & 1 & Capacity: & 5.0 & \\
\hline Tot Time: $0: 31$ & Tot Distance: & 7.7 & Tot Load: & 5.0 & \\
\hline No. Name & & Arrival-D & Depart & Dist & Load \\
\hline Torrinha & & - & $6: 00 \mathrm{am}$ & & \\
\hline 1 Aterro 01 de & 01 & $6: 05 \mathrm{am}-$ & $6: 25 \mathrm{am}$ & 3.8 & 5.0 \\
\hline END Torrinha & & $6: 31 \mathrm{am}$ & & 3.8 & \\
\hline
\end{tabular}


2.3. Parte 03: destinação excedente após coleta até Aterro, devido ao limite de capacidade do veículo de transbordo ter sido ultrapassado.

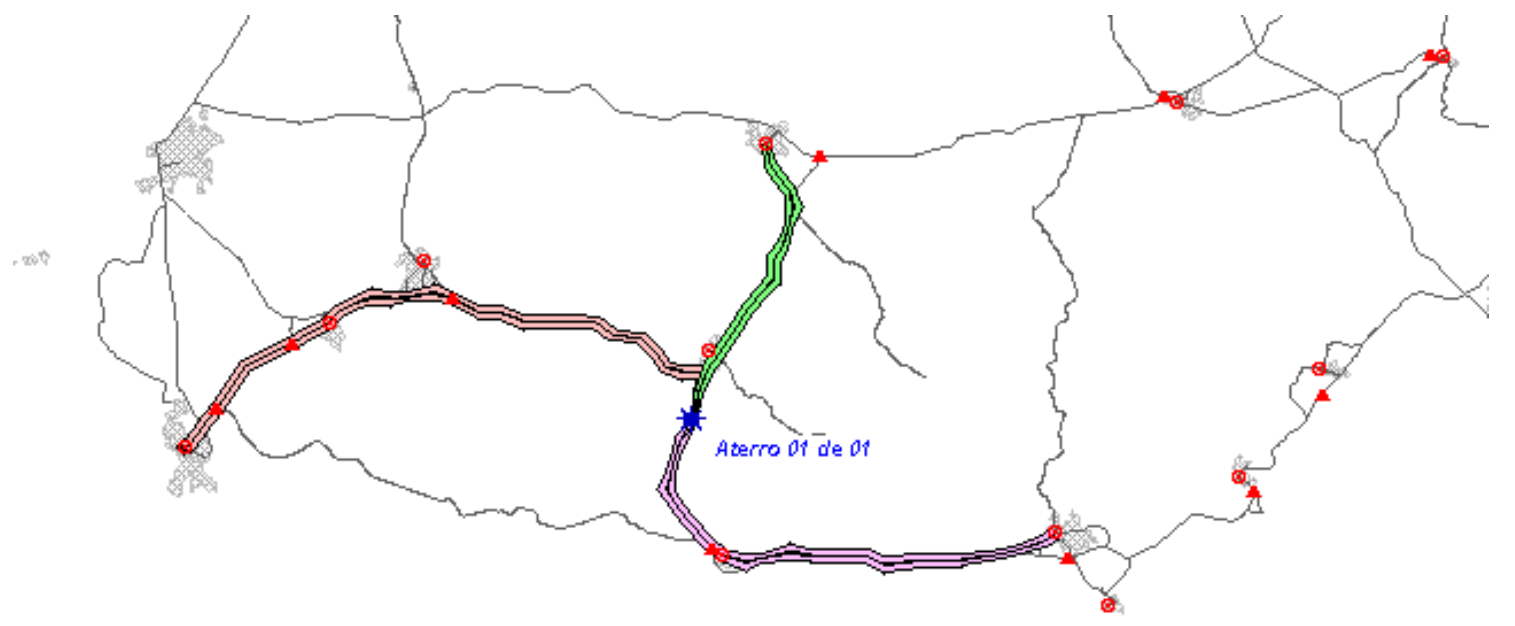

Situação 11: Veiculo Coleta Rotas Determinadas o1

= Tour 1

Rotas Determinadas 02

- Tour 1

Rotas Deteminadas 03
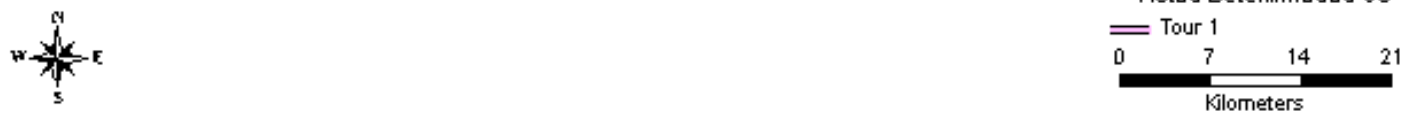

Kilometers

Excedente: At-ETs-At

ROTA 2.3 - Situação 11: Parte 03 


\section{ITINERÁRIO 2.3 - Situação 11: Parte 03}

Rotas Determinadas 01:

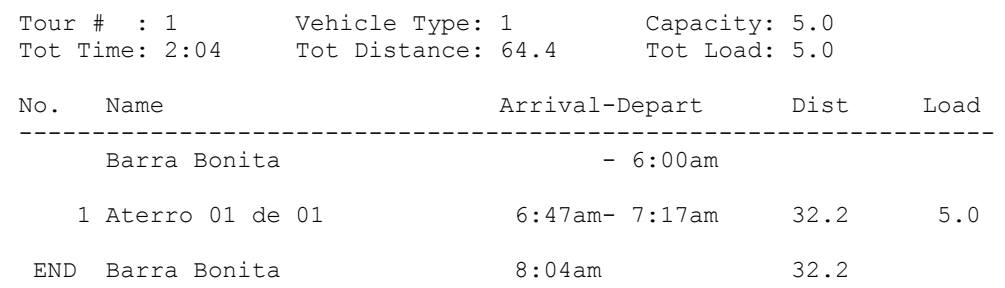

Rotas Determinadas 02:

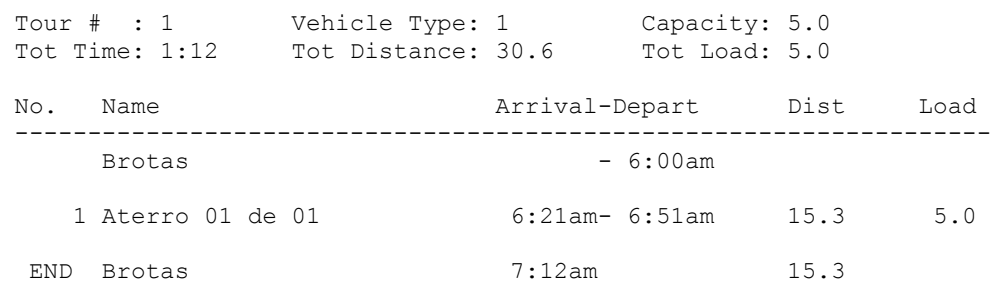

Rotas Determinadas 02:

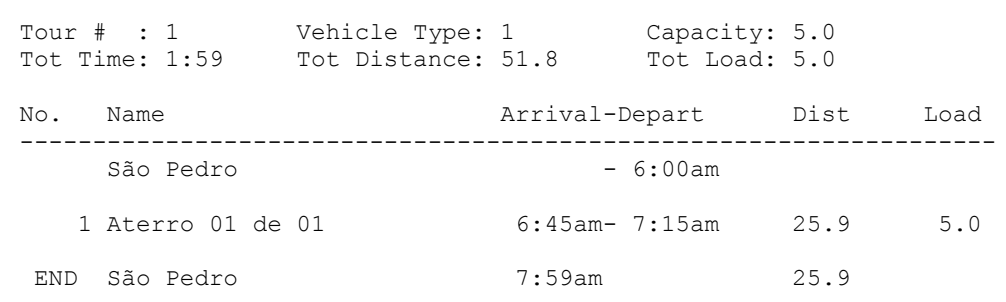




\section{Situação 12}

1. Roteirização para os Veículos de Transbordo: Aterro - ET - Aterro 1.1. Semanas: 2007 A-G, 2012 A-G, 2017 A-G

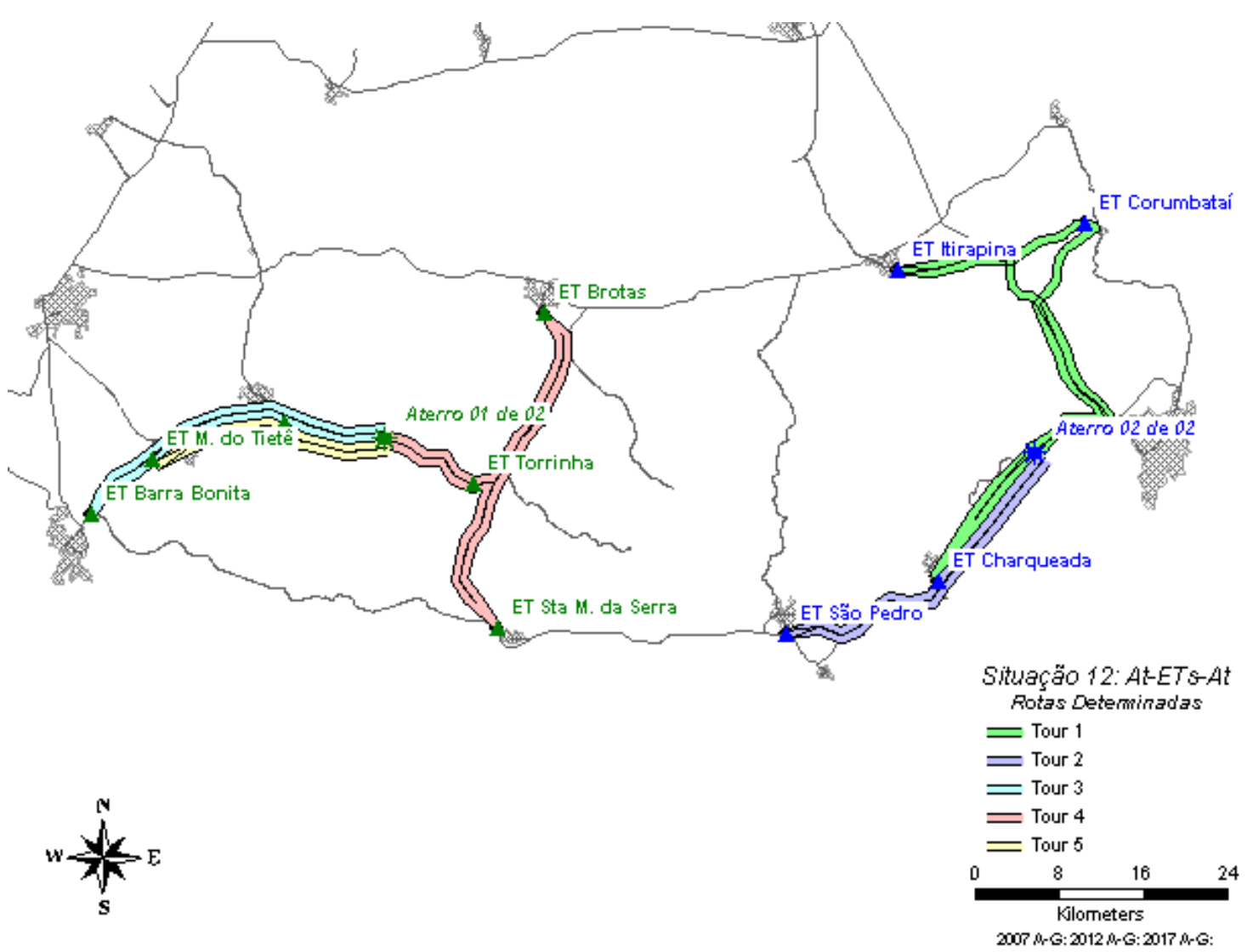

ROTA 1.1 - Situação 12: 2007 A-G, 2012 A-G, 2017 A-G 
ITINERÁRIO 1.1 - Situação 12: 2007 A-G, 2012 A-G, 2017 A-G

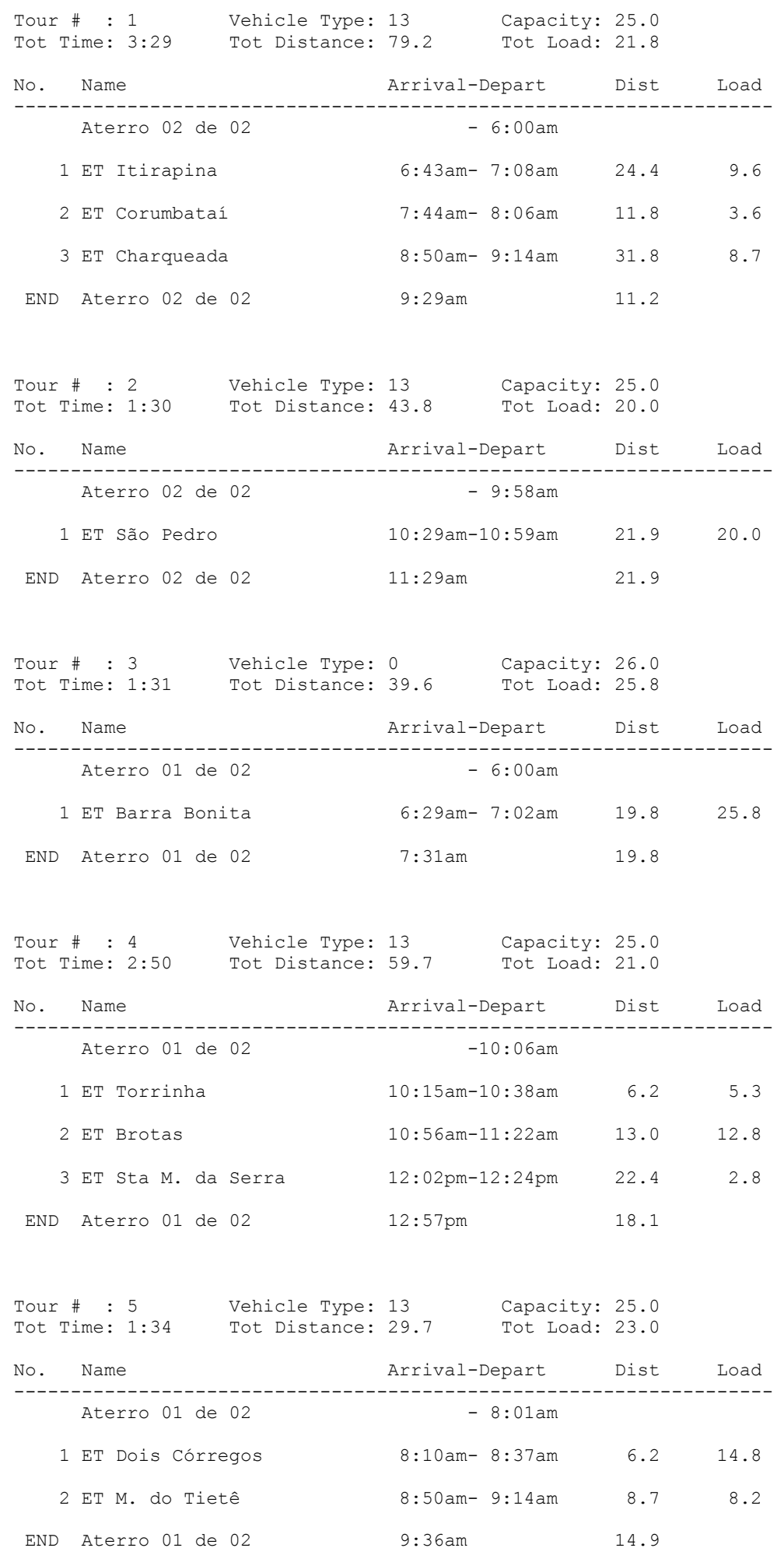




\section{Roteirização com os Veículos de Coleta: até Aterro ou ET}

2.1. Parte 01: destinação normal após coleta até Aterro ou ET

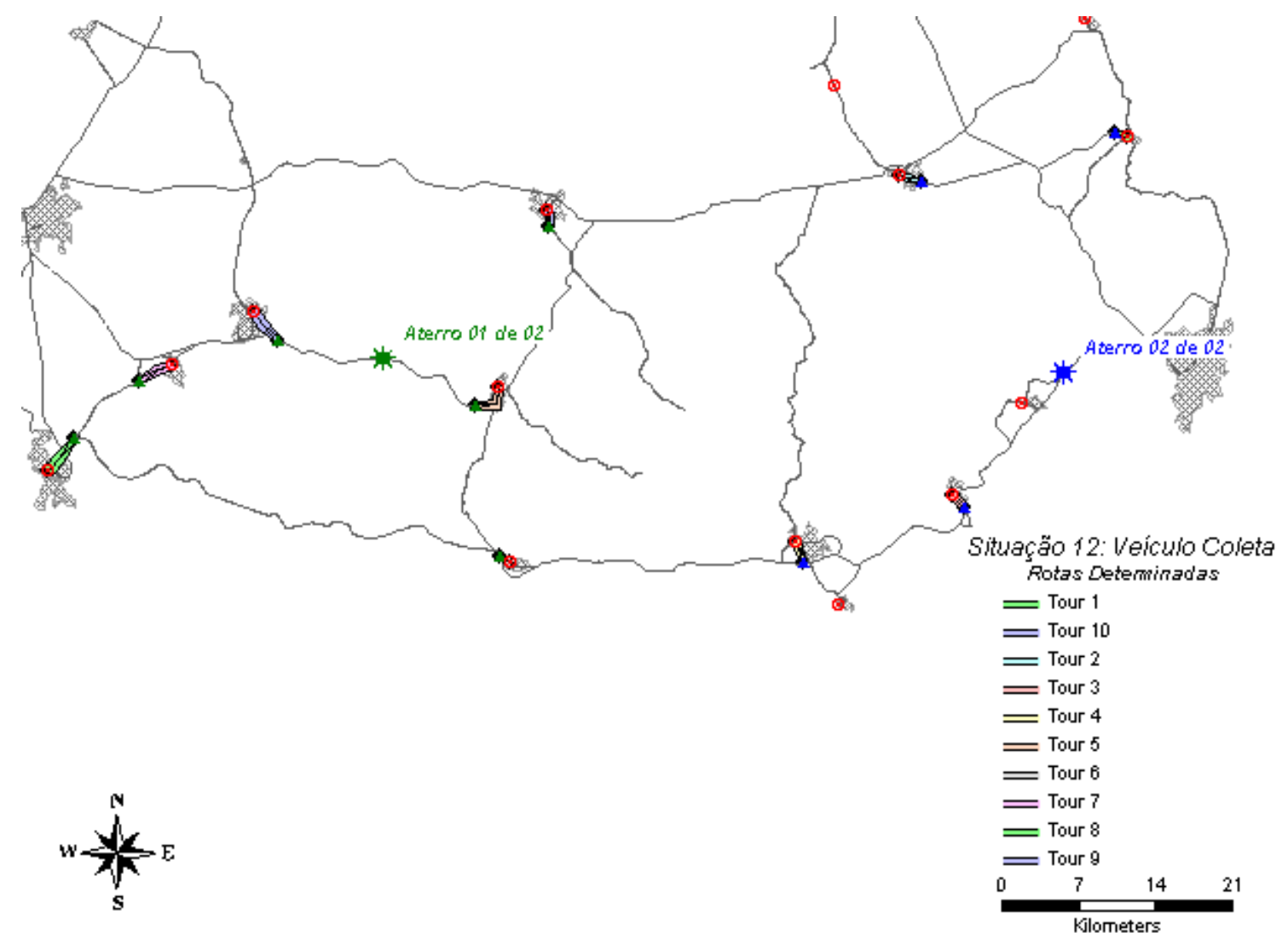

ROTA 2.1 - Situação 12: Parte 01 


\section{ITINERÁRIO 2.1 - Situação 12: Parte 01}

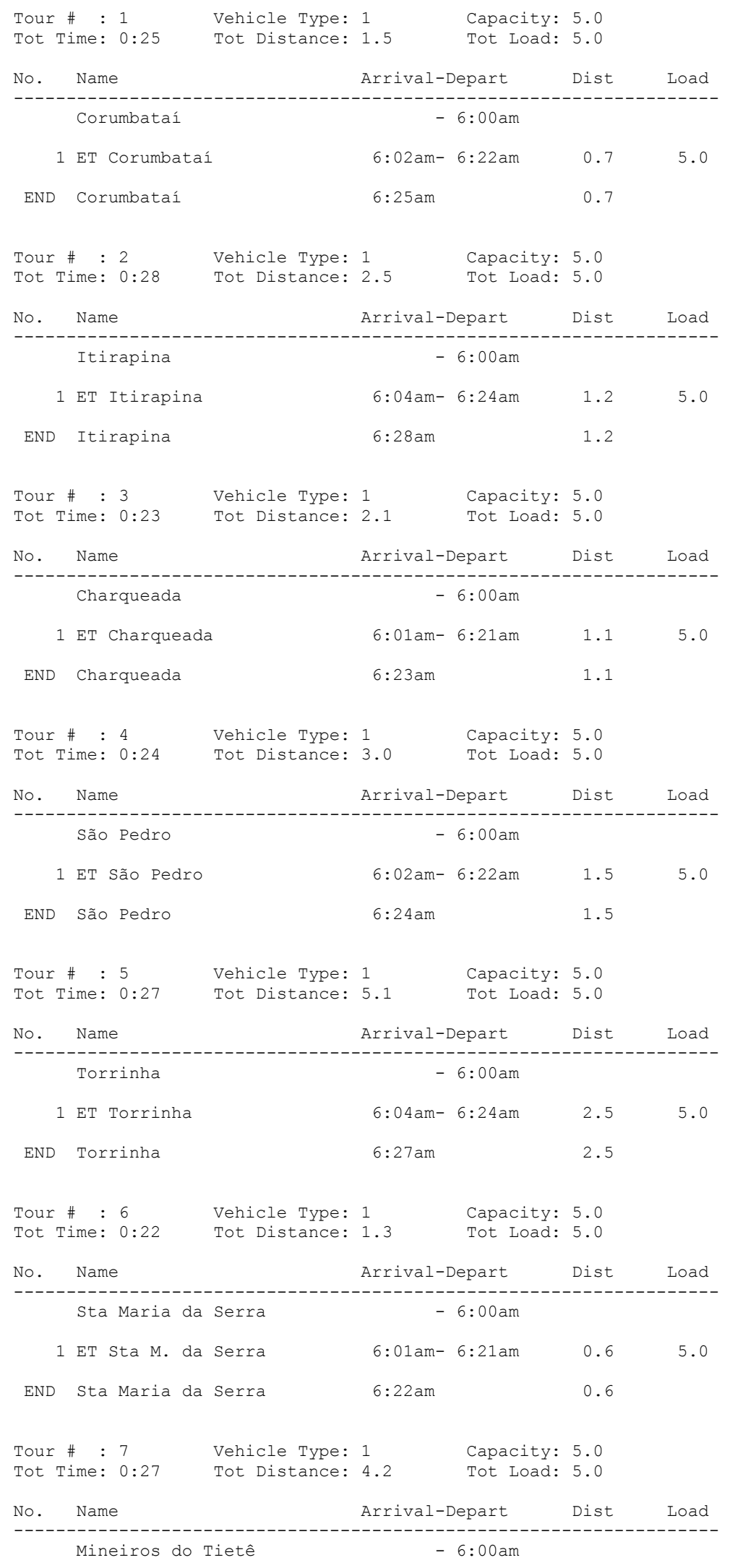




$\begin{array}{cccc}1 \text { ET M. do Tietê } & 6: 03 \mathrm{am}-6: 23 \mathrm{am} & 2.1 & 5.0 \\ \text { END Mineiros do Tietê } & 6: 27 \mathrm{am} & 2.1 & \end{array}$

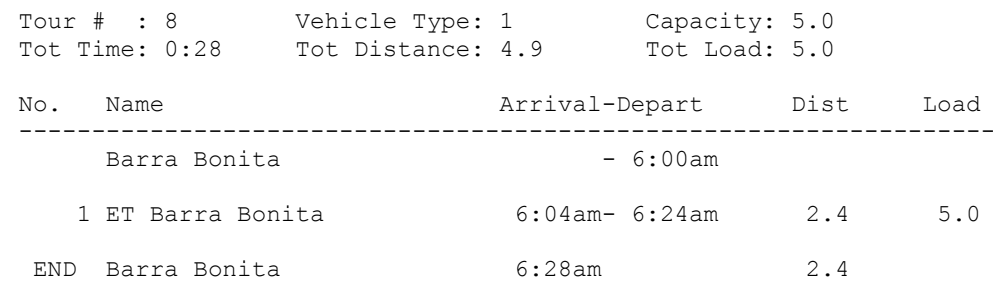

Tour \# : 9 Vehicle Type: 1 Capacity: 5.0

Tot Time: $0: 26$ Tot Distance: 4.5 Tot Load: 5.0

$\begin{array}{lrrr}\text { No. Name } & \text { Arrival-Depart } & \text { Dist Load } \\ & \text { Dois Córregos } & & \\ & & & \\ 1 \text { ET Dois Córregos } & 6: 03 \mathrm{am}-6: 23 \mathrm{am} & 2.2 & 5.0 \\ \text { END Dois Córregos } & 6: 26 \mathrm{am} & 2.2 & \end{array}$

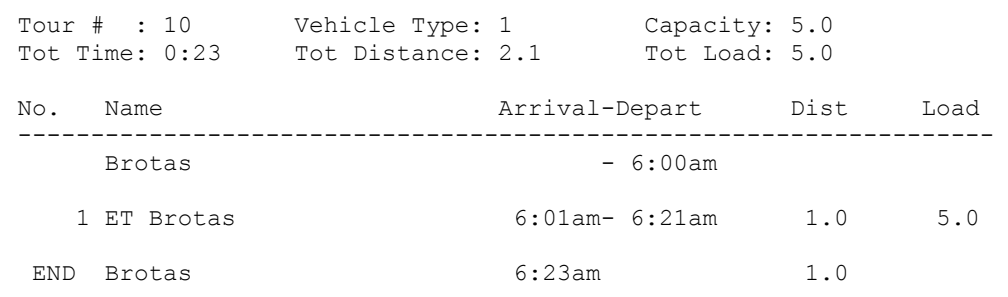


2.2. Parte 02: destinação normal após coleta até Aterro ou ET (cont.)

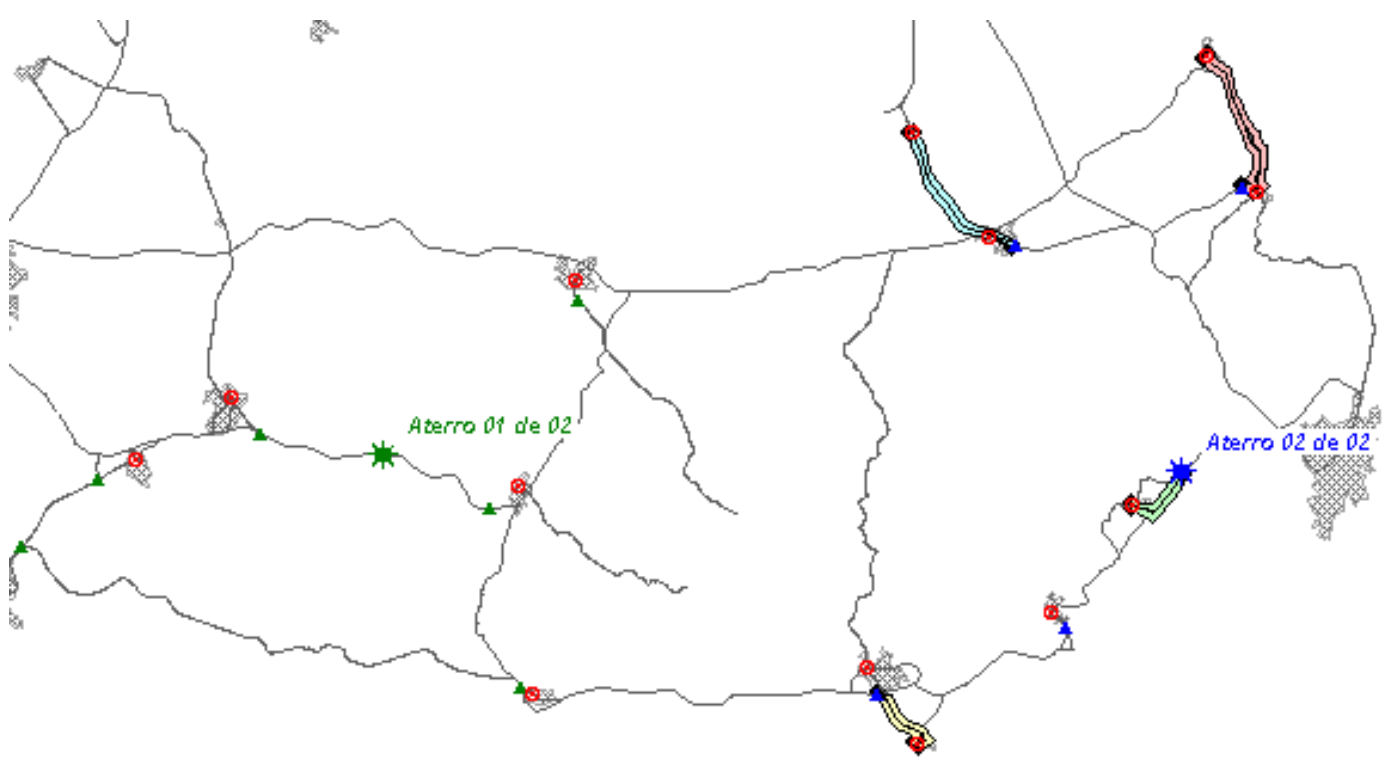

Situação 12: Veiculo Coleta (cont) Rotas Determinadas

$-\frac{2}{x}=$

$$
\begin{aligned}
& =\text { Tour } 1 \\
& =\text { Tour } 2 \\
& \overline{=} \text { Tour } 3 \\
& =\text { Tour } 4 \\
& 9
\end{aligned}
$$

ROTA 2.2 - Situação 12: Parte 02 


\section{ITINERÁRIO 2.2 - Situação 12: Parte 02}

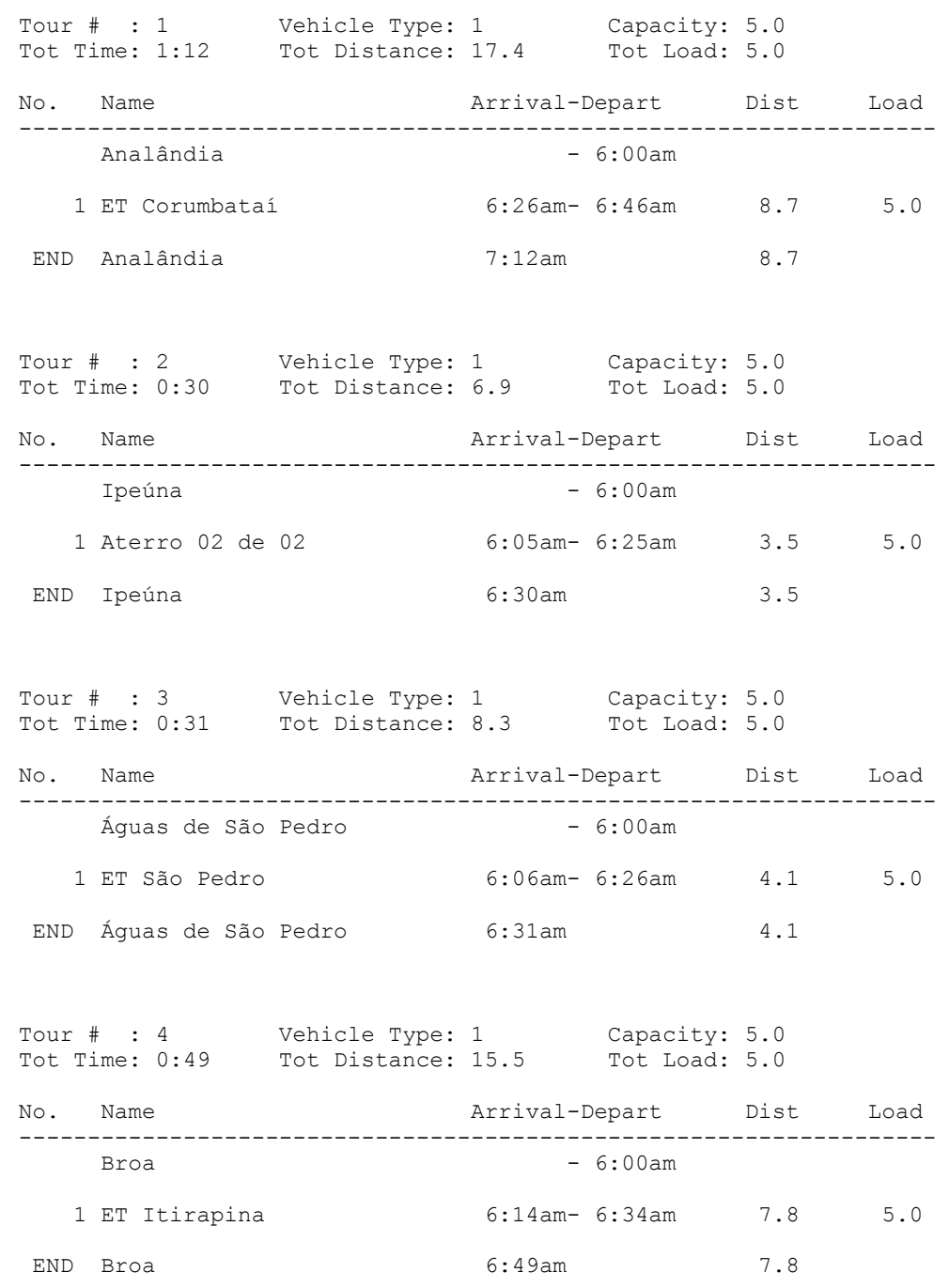


2.3. Parte 03: destinação excedente após coleta até Aterro, devido ao limite de capacidade do veículo de transbordo ter sido ultrapassado.
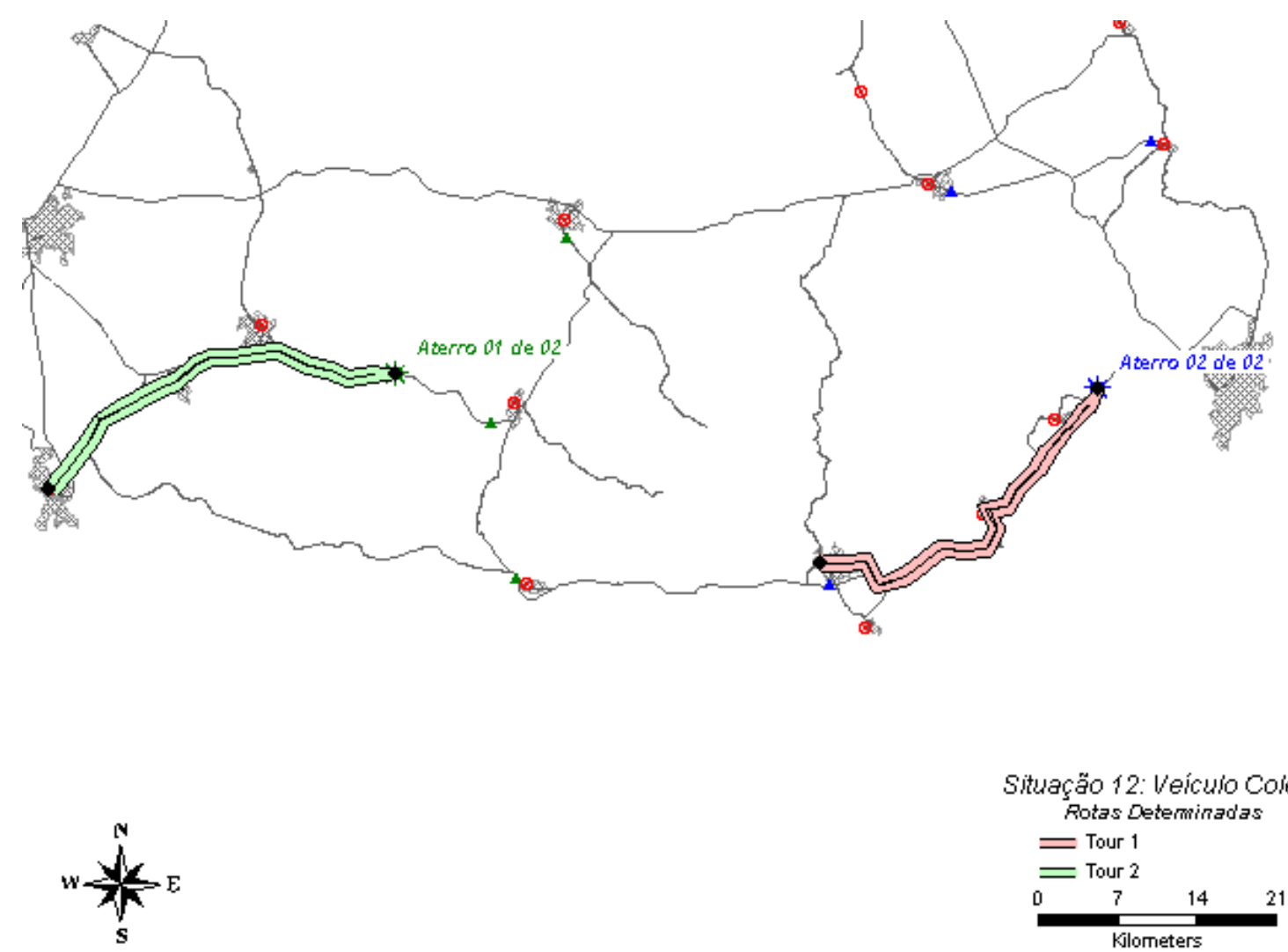

Situação 12: Veiculo Coleta

Rotas Determinadas

Tour 1

= Tour 2

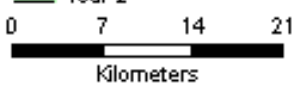

Excodencion-ETrin

ROTA 2.3 - Situação 12: Parte 03 
ITINERÁRIO 2.3 - Situação 12: Parte 03

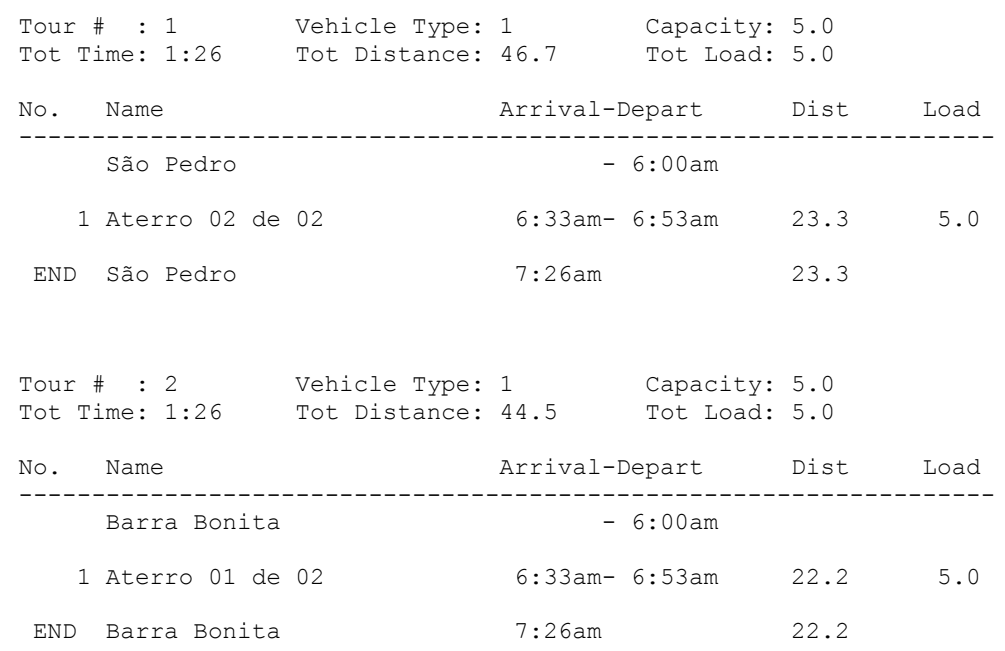




\section{Situação 13}

\section{Roteirização para os Veículos de Transbordo: Aterro - ET - Aterro}

\subsection{Semanas: $\quad 2007$ A-G, 2012 A-G, 2017 A-G}

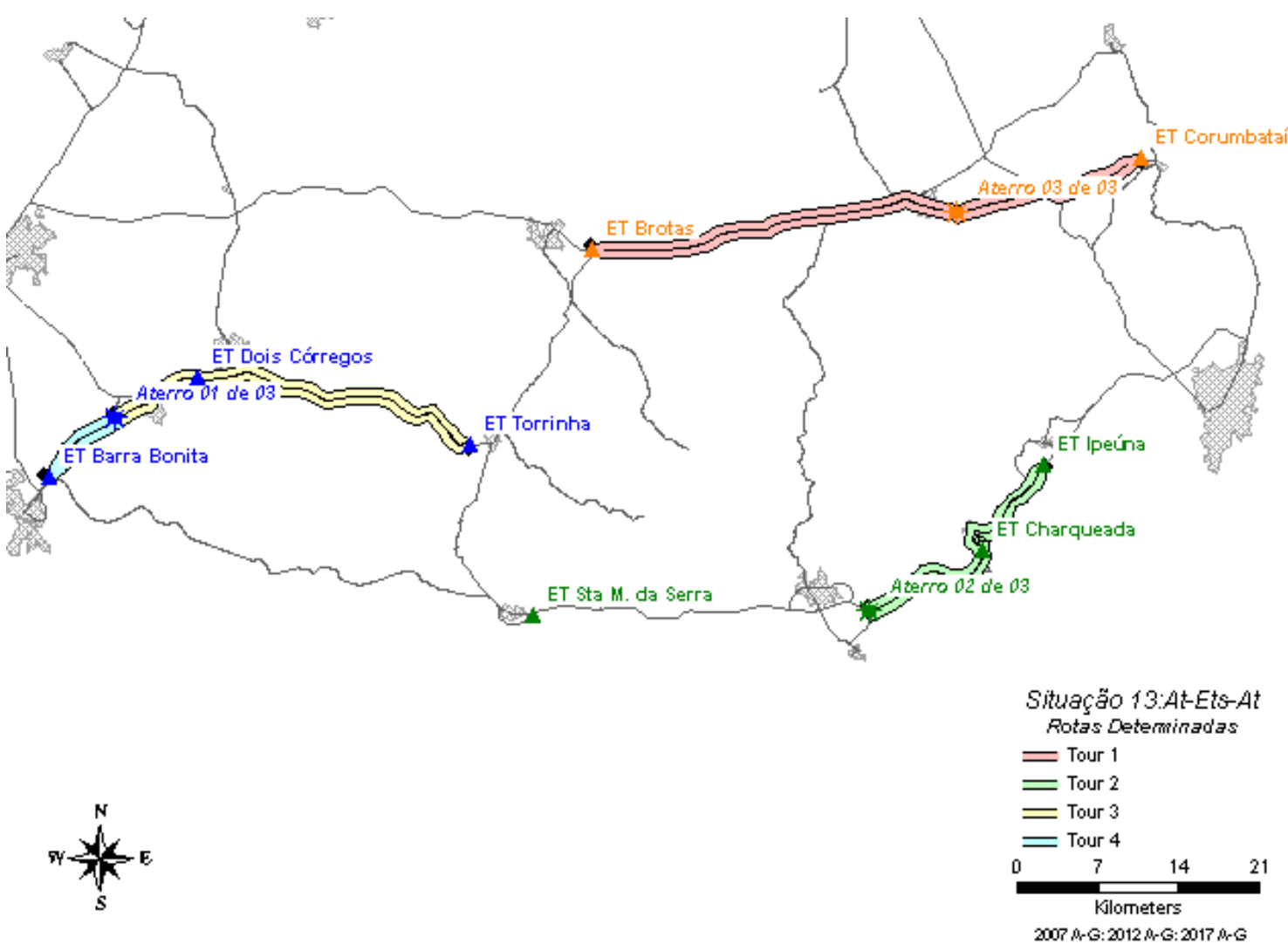

ROTA 1.1 - Situação 13: 2007 A-G, 2012 A-G, 2017 A-G

Obs.: Na rota Tour 2, da ROTA 1.1, a viagem de Santa Maria da Serra até o Aterro 02 de 03, foi substituído por viagem com do próprio veículo de coleta, sem estação de transferência, depois de verificado que haveria apenas uma viagem diária a partir desta cidade. Esta substituição está representado na ROTA 2.3. 
ITINERÁRIO 1.1 - Situação 13: 2007 A-G, 2012 A-G, 2017 A-G

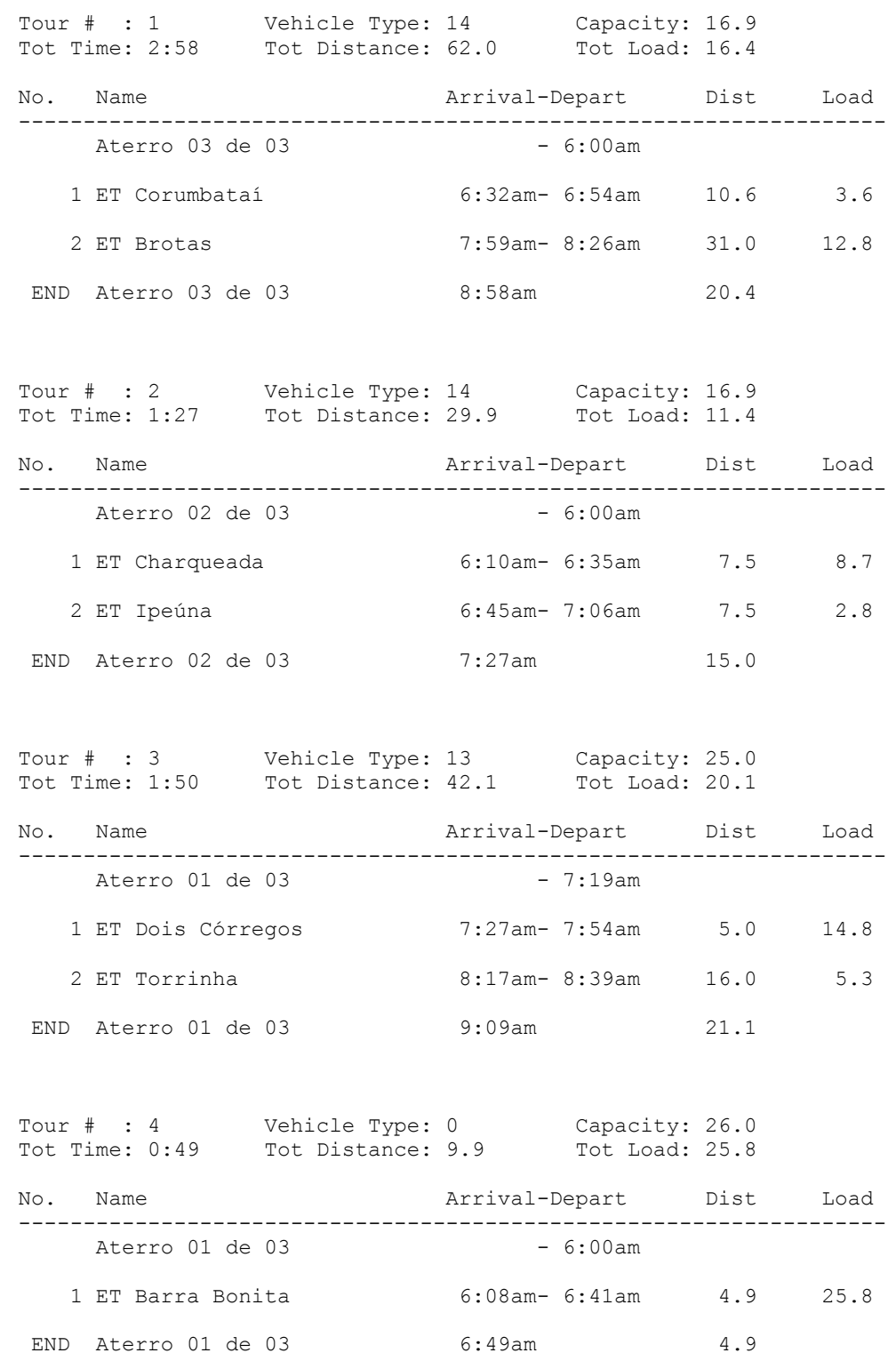




\section{Roteirização com os Veículos de Coleta: até Aterro ou ET}

\subsection{Parte 01: destinação normal após coleta até Aterro ou ET}

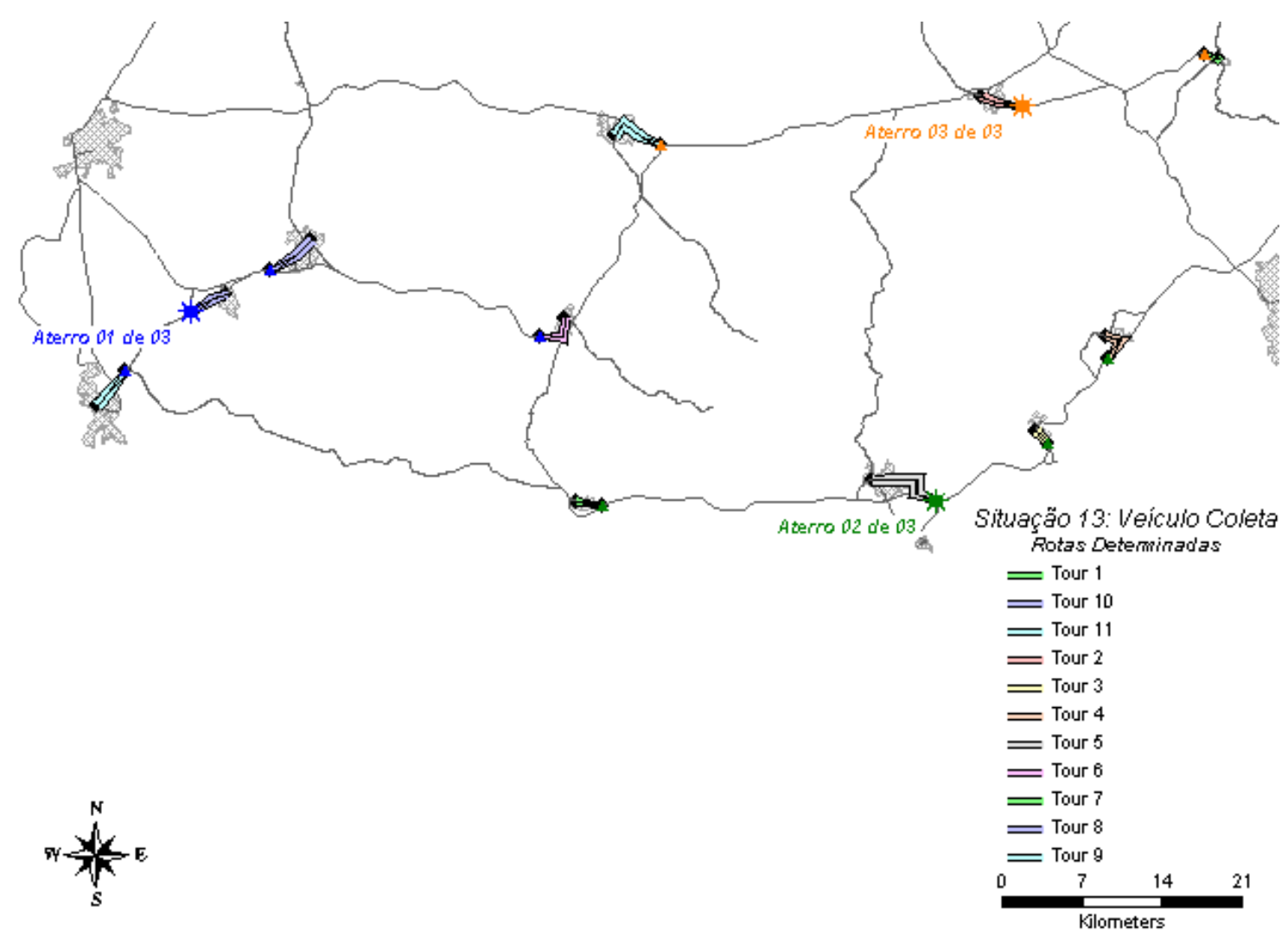

ROTA 2.1 - Situação 13: Parte 01 


\section{ITINERÁRIO 2.1 - Situação 13: Parte 01}

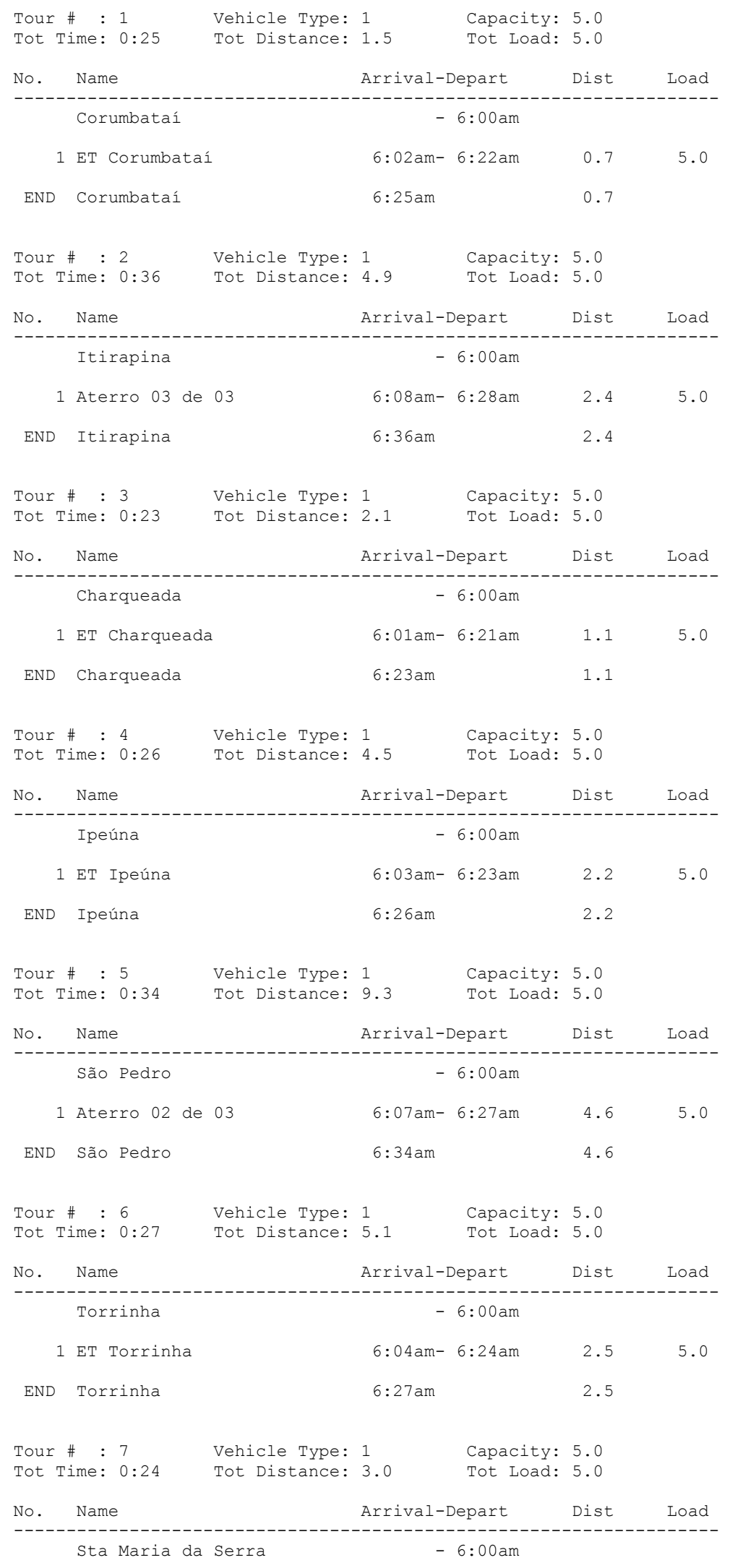




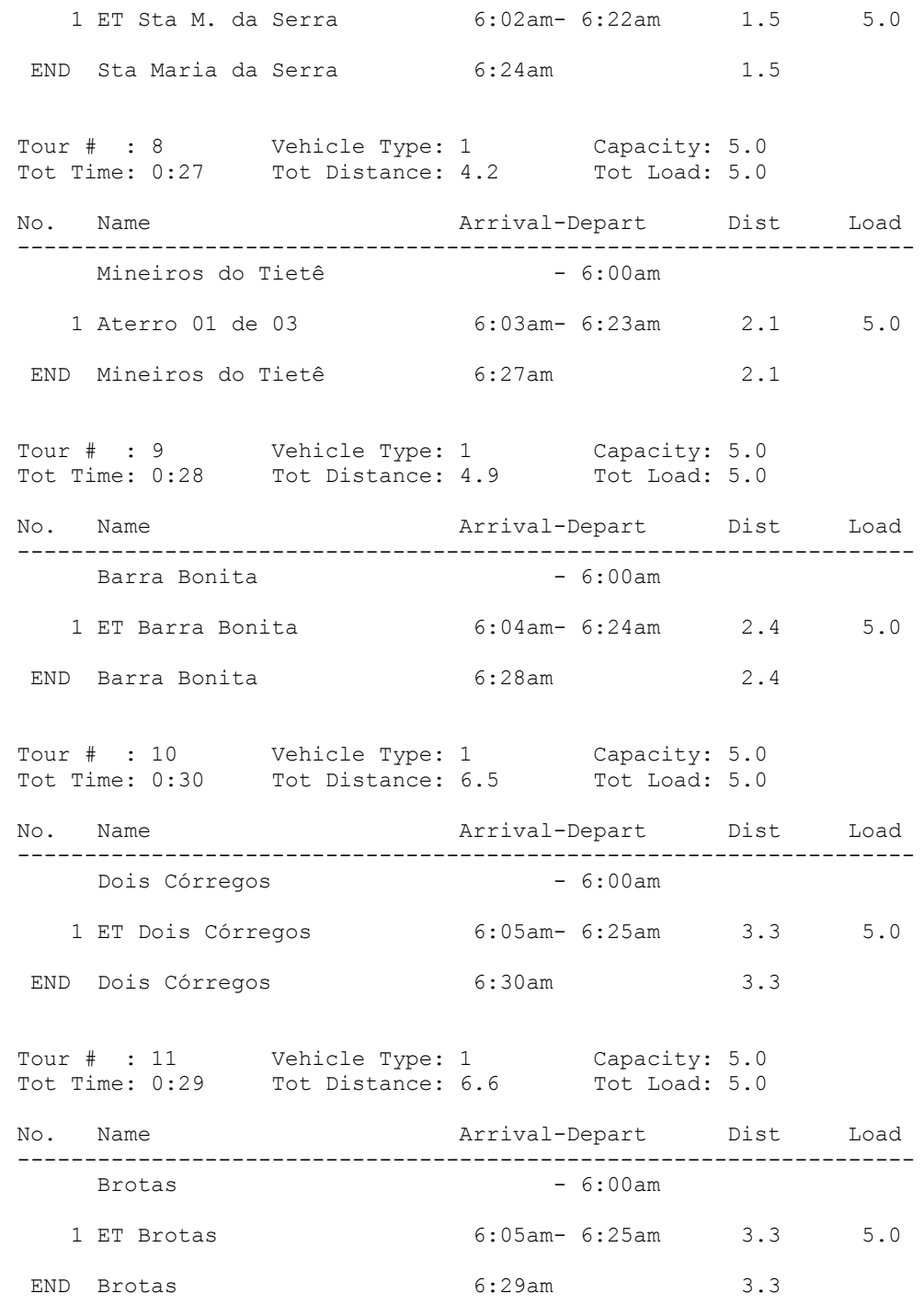


2.2 Parte 02: destinação normal após coleta até Aterro ou ET (cont.)

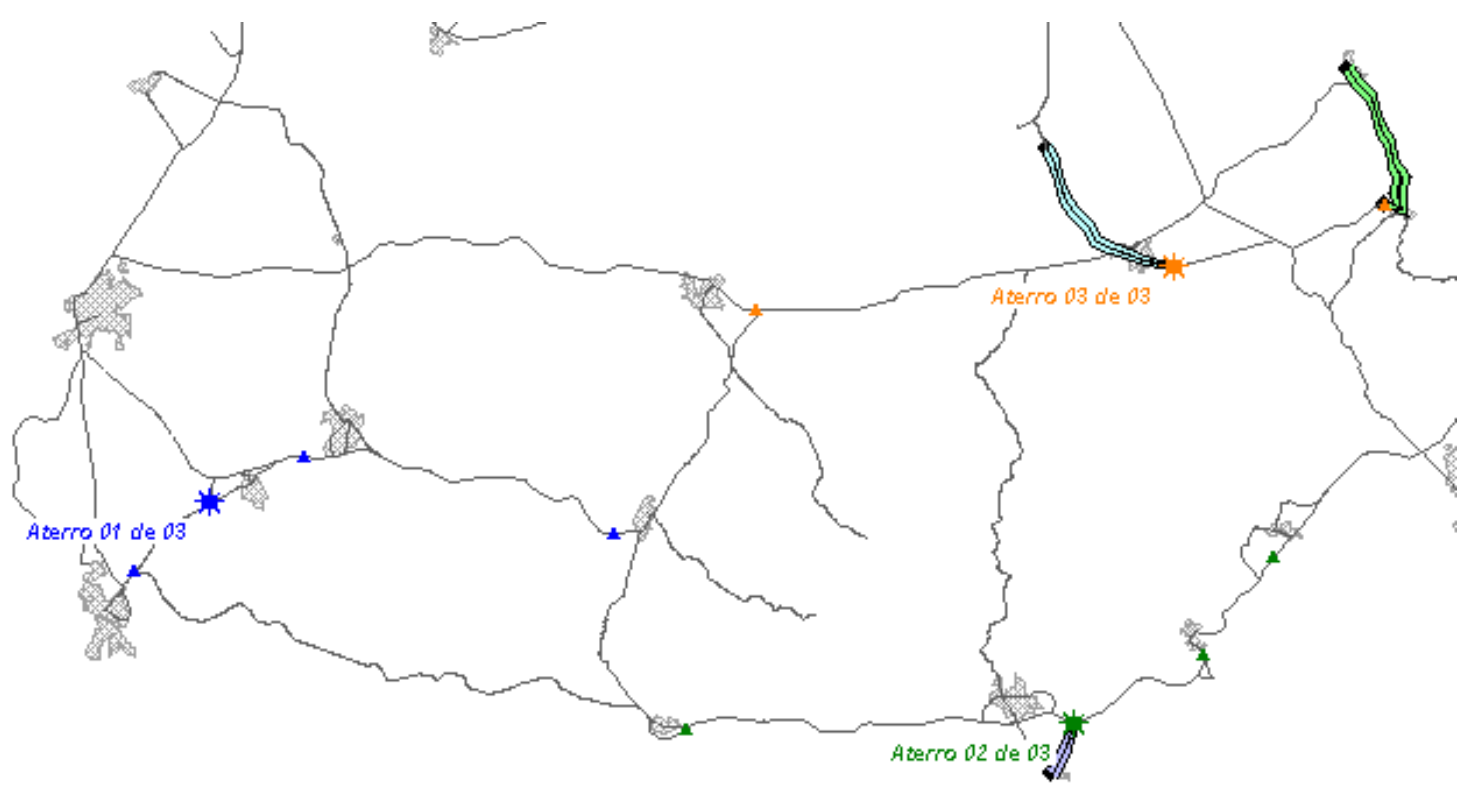

Situação 13: veicuio Coleta (cont)

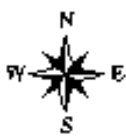
Rotas Determinadas

= Tour 1

$$
\begin{aligned}
& \overline{=} \text { Tour } 2 \\
& \overline{=} \text { Tour } 3
\end{aligned}
$$

$\begin{array}{lrr}0 & 9 & 18 \\ \text { Klometers } & 27\end{array}$

ROTA 2.2 - Situação 13: Parte 02 


\section{ITINERÁRIO 2.2 - Situação 13: Parte 02}

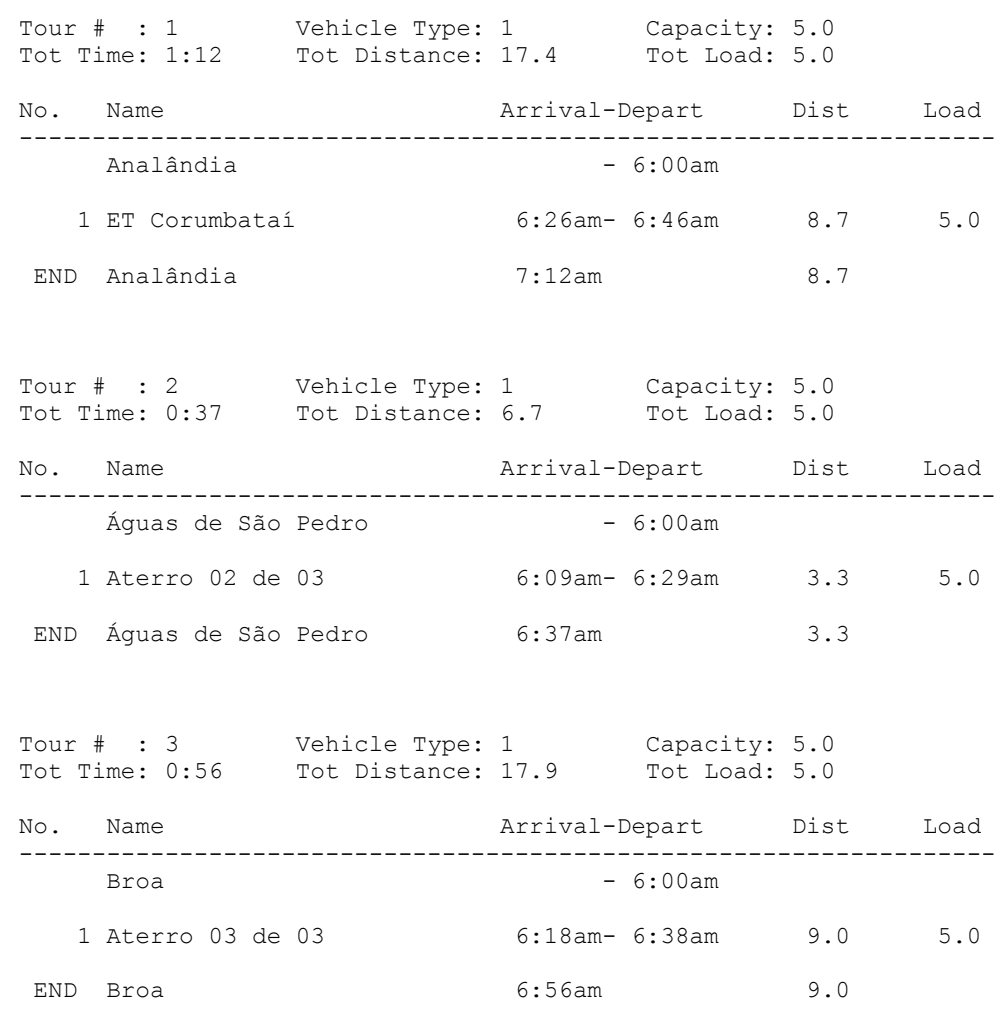


2.3 Parte 03: destinação diferenciada após coleta até o Aterro.

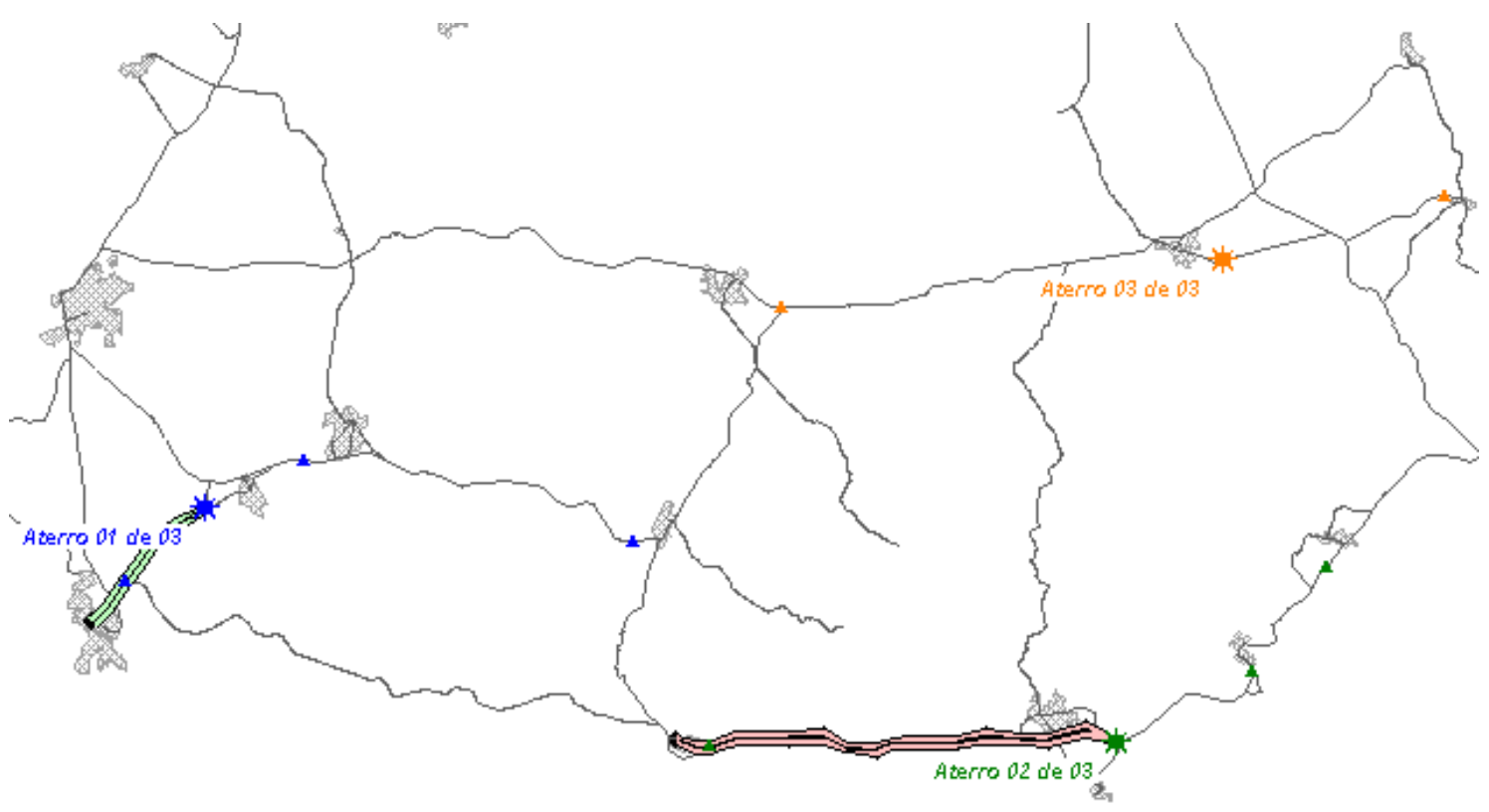

$\frac{d}{x}-E$

Situação 13: Veiculo Coleta TOUS ROUTE_MAME = Tour 1 = Tour 2

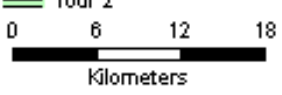

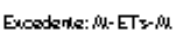

ROTA 2.3 - Situação 13: Parte 03 
ITINERÁRIO 2.3 - Situação 13: Parte 03

\begin{tabular}{|c|c|c|c|c|c|}
\hline Tour \# : 1 & Vehicle Type: & 1 & Capacity: & 5.0 & \\
\hline Tot Time: $1: 16$ & Tot Distance: & 40.3 & Tot Load: & 5.0 & \\
\hline No. Name & & Arrival-1 & Depart & Dist & Load \\
\hline Sta Maria da & Serra & & $6: 00 \mathrm{am}$ & & \\
\hline 1 Aterro 02 de & 03 & $6: 28 \mathrm{am}-$ & $6: 48 \mathrm{am}$ & 20.1 & 5.0 \\
\hline END Sta Maria da & Serra & $7: 16 \mathrm{am}$ & & 20.1 & \\
\hline Tour \# : 2 & Vehicle Type: & 1 & Capacity: & 5.0 & \\
\hline Tot Time: $0: 44$ & Tot Distance: & 14.8 & Tot Load: & 5.0 & \\
\hline Name & & Arrival-1 & Depart & Dist & Load \\
\hline Barra Bonita & & & $6: 00 \mathrm{am}$ & & \\
\hline 1 Aterro 01 de & 03 & $6: 12 \mathrm{am}-$ & $6: 32 \mathrm{am}$ & 7.4 & 5.0 \\
\hline END Barra Bonita & & $6: 44 \mathrm{am}$ & & 7.4 & \\
\hline
\end{tabular}




\section{Situação 14}

\section{Roteirização para os Veículos de Transbordo: Aterro - ET - Aterro}

\subsection{Semanas: $\quad 2007$ A-G, 2012 A-G, 2017 A-G}

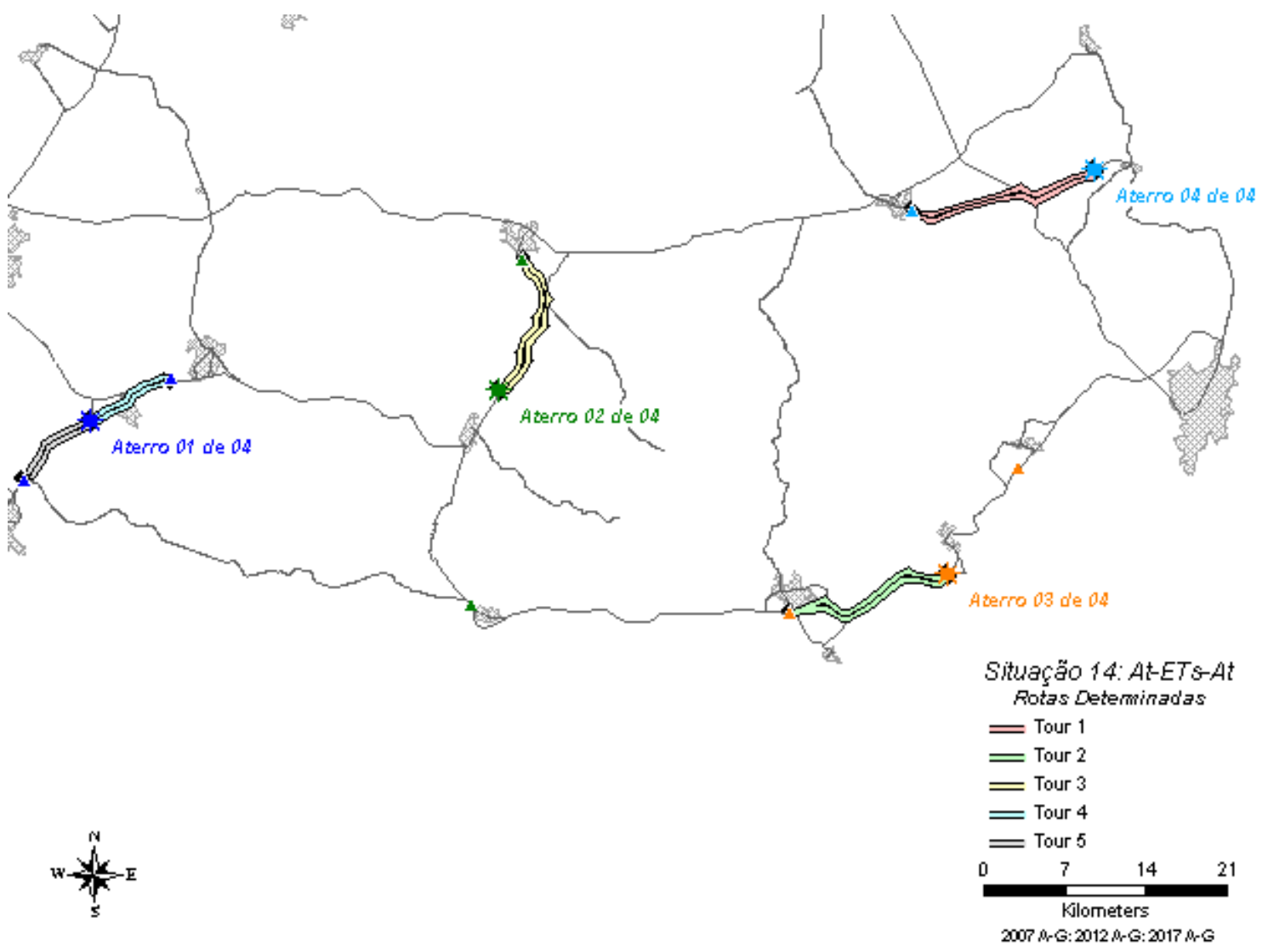

ROTA 1.1 - Situação 14: 2007 A-G, 2012 A-G, 2017 A-G

Obs.: Na rota Tour 2, da ROTA 1.1, a viagem de Ipeúna até o Aterro 03 de 04, e de Santa Maria da Serra até o Aterro 02 de 04, foram substituídos por viagens com os próprio veículo de coleta, sem estação de transferência, depois de verificado que haveria apenas uma viagem diária de cada cidade. Esta substituição está representado na ROTA 2.3. 
ITINERÁRIO 1.1 - Situação 14: 2007 A-G, 2012 A-G, 2017 A-G

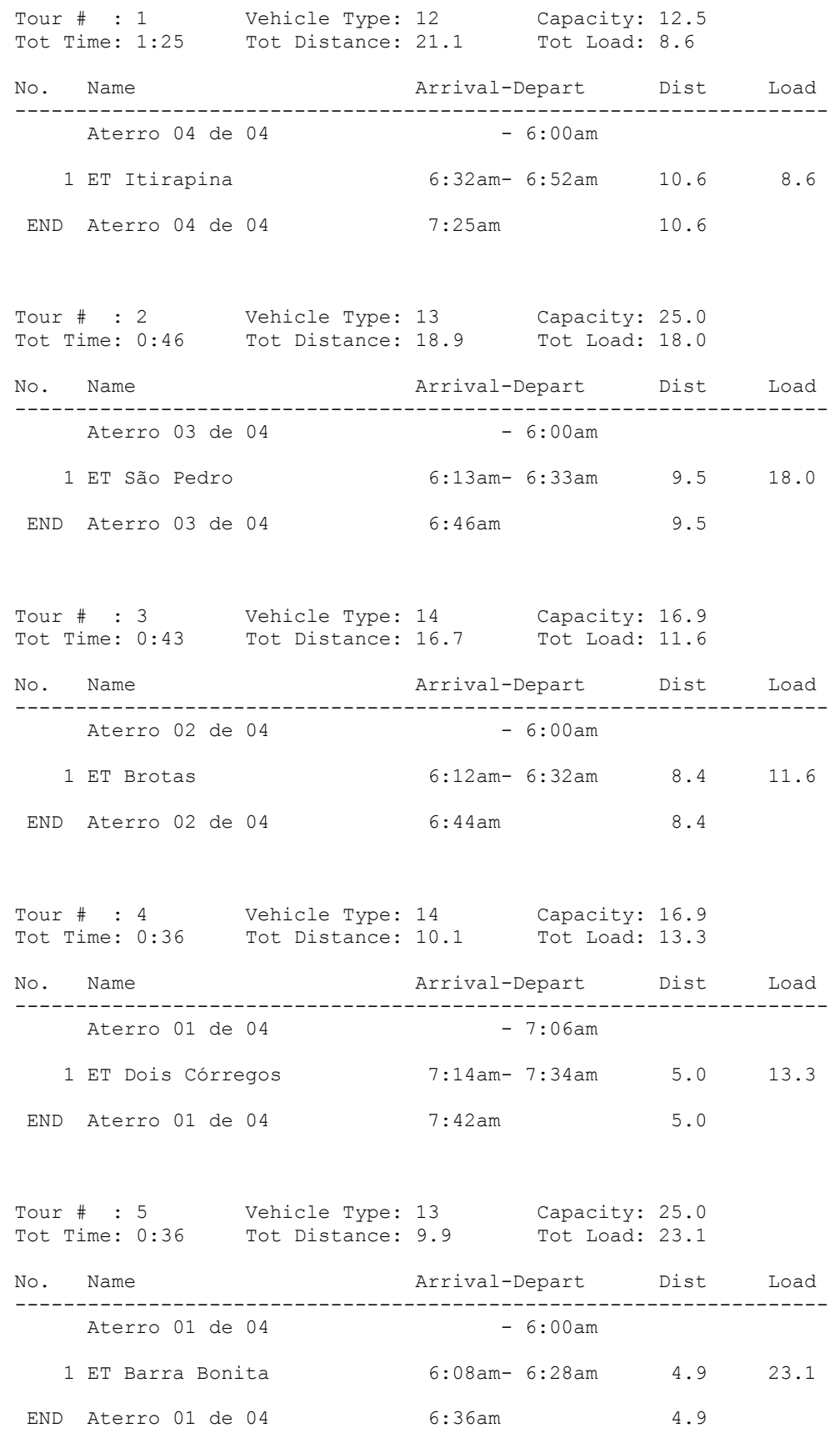




\section{Roteirização com os Veículos de Coleta: até Aterro ou ET}

2.1. Parte 01: destinação normal após coleta até Aterro ou ET

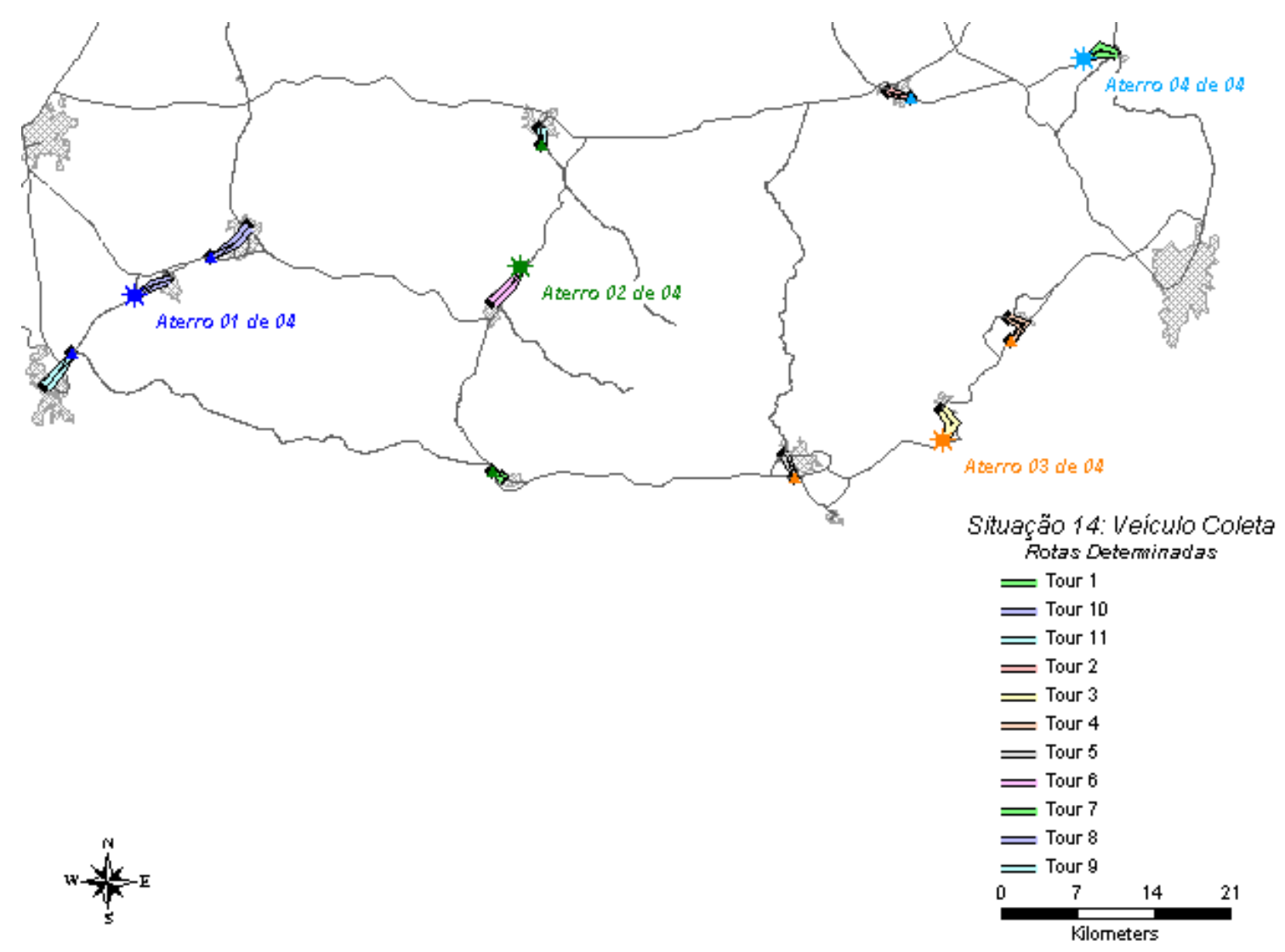

ROTA 2.1 - Situação 14: Parte 01 


\section{ITINERÁRIO 2.1 - Situação 13: Parte 01}

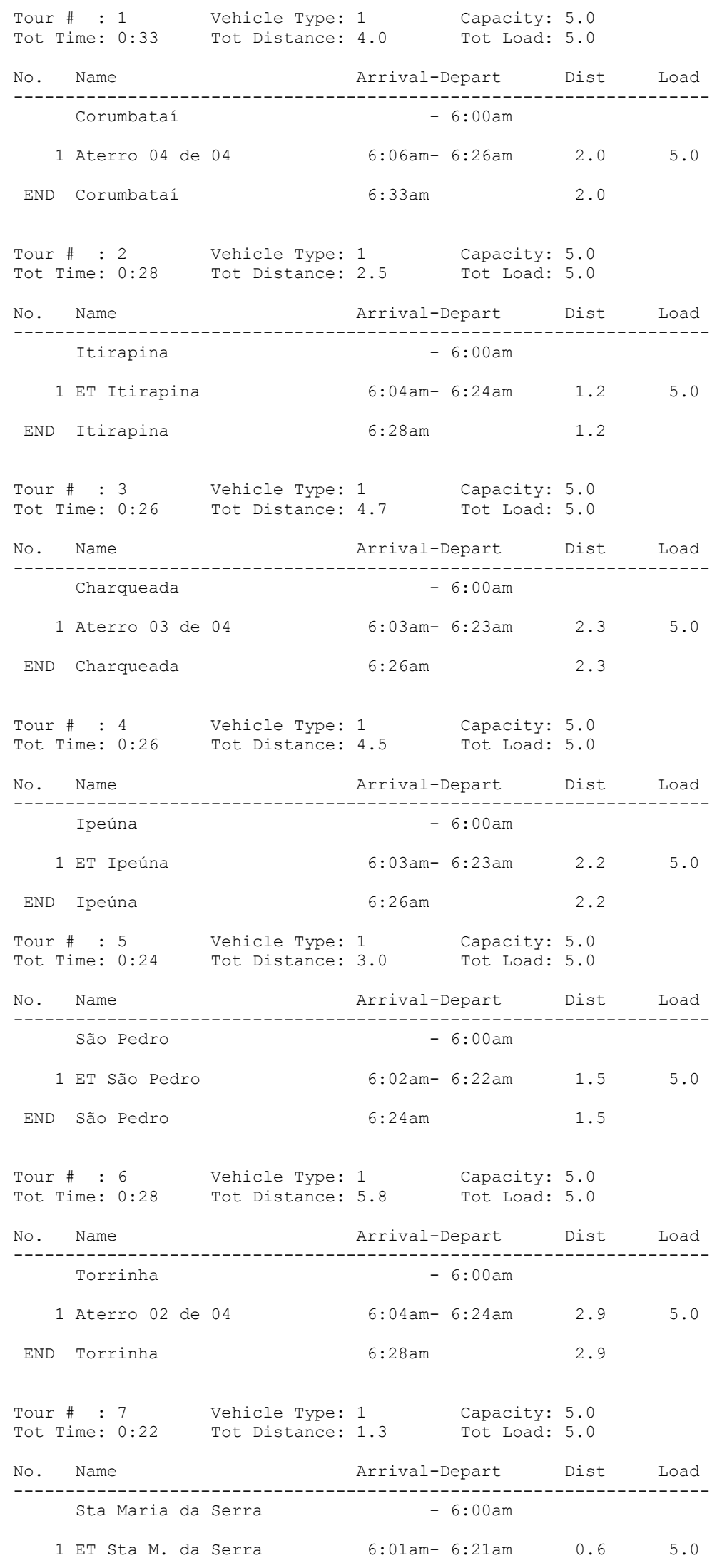




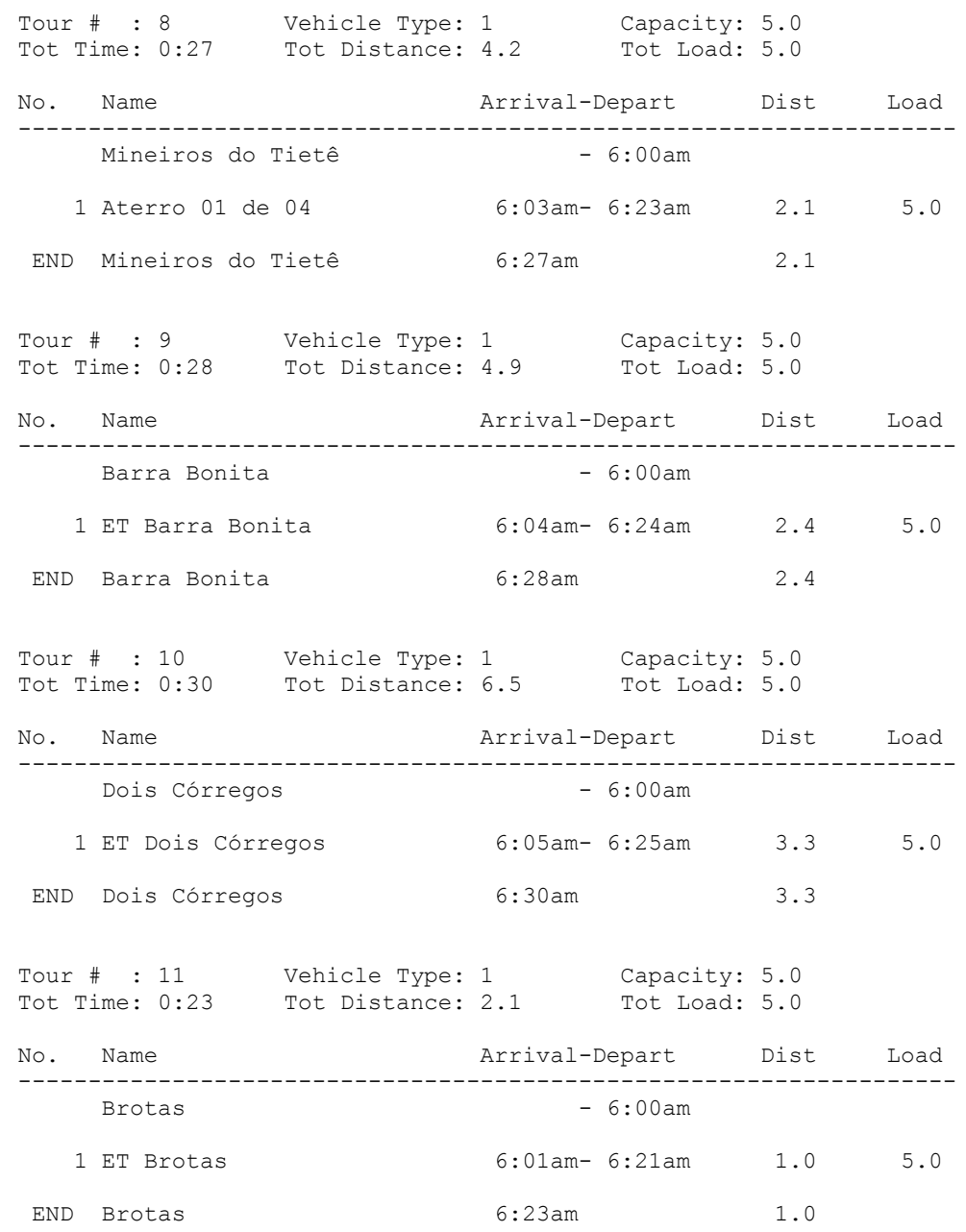


2.2. Parte 02: destinação normal após coleta até Aterro ou ET (cont.)

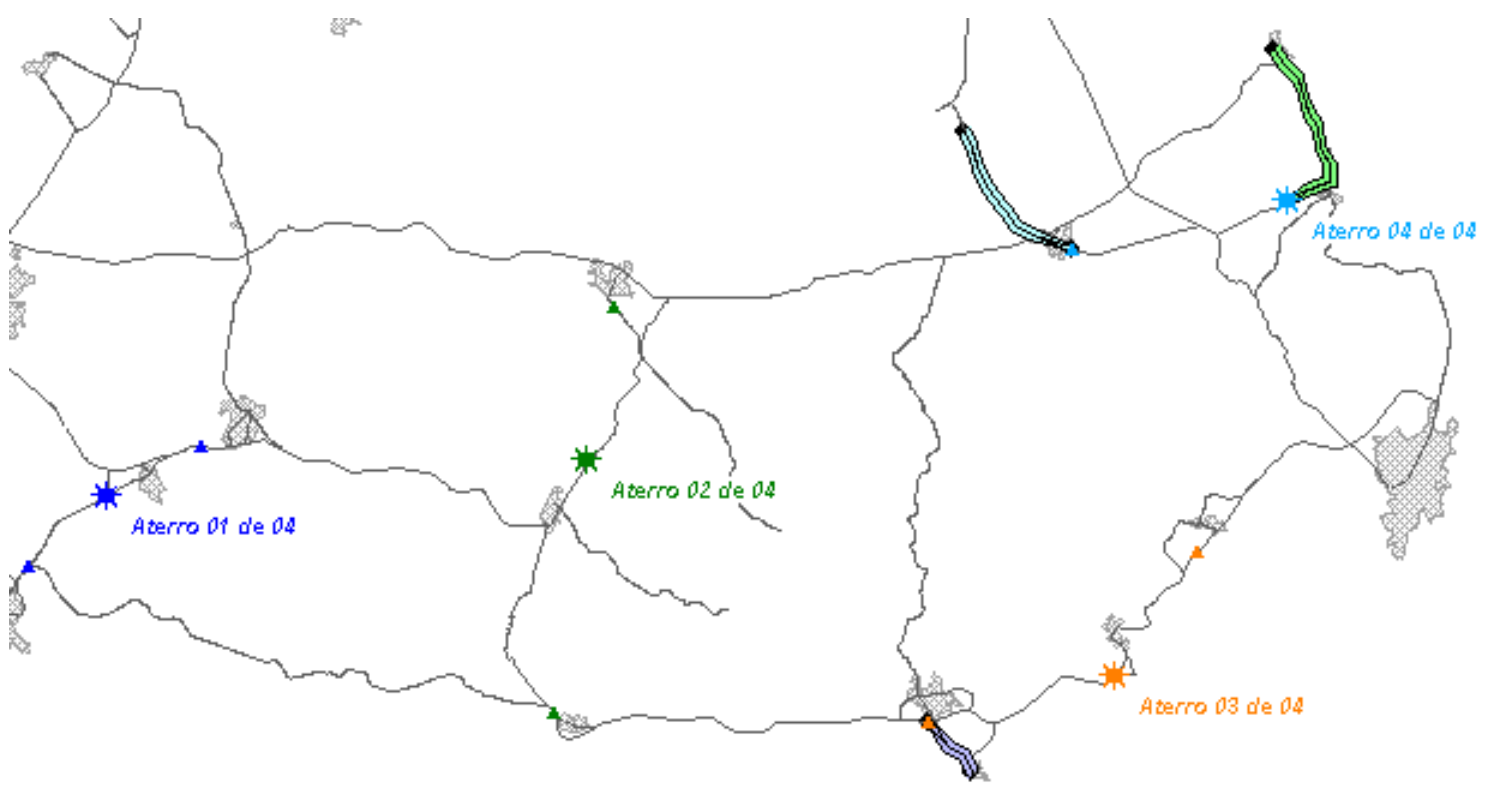

Situação 14: Veiculo coleta (cont) Rotas Determinadas

$\frac{\sqrt{x}}{x}-E$

= Tour 1

= Tour 2

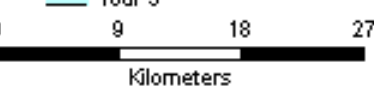

ROTA 2.2 - Situação 14: Parte 02 


\section{ITINERÁRIO 2.2 - Situação 14: Parte 02}

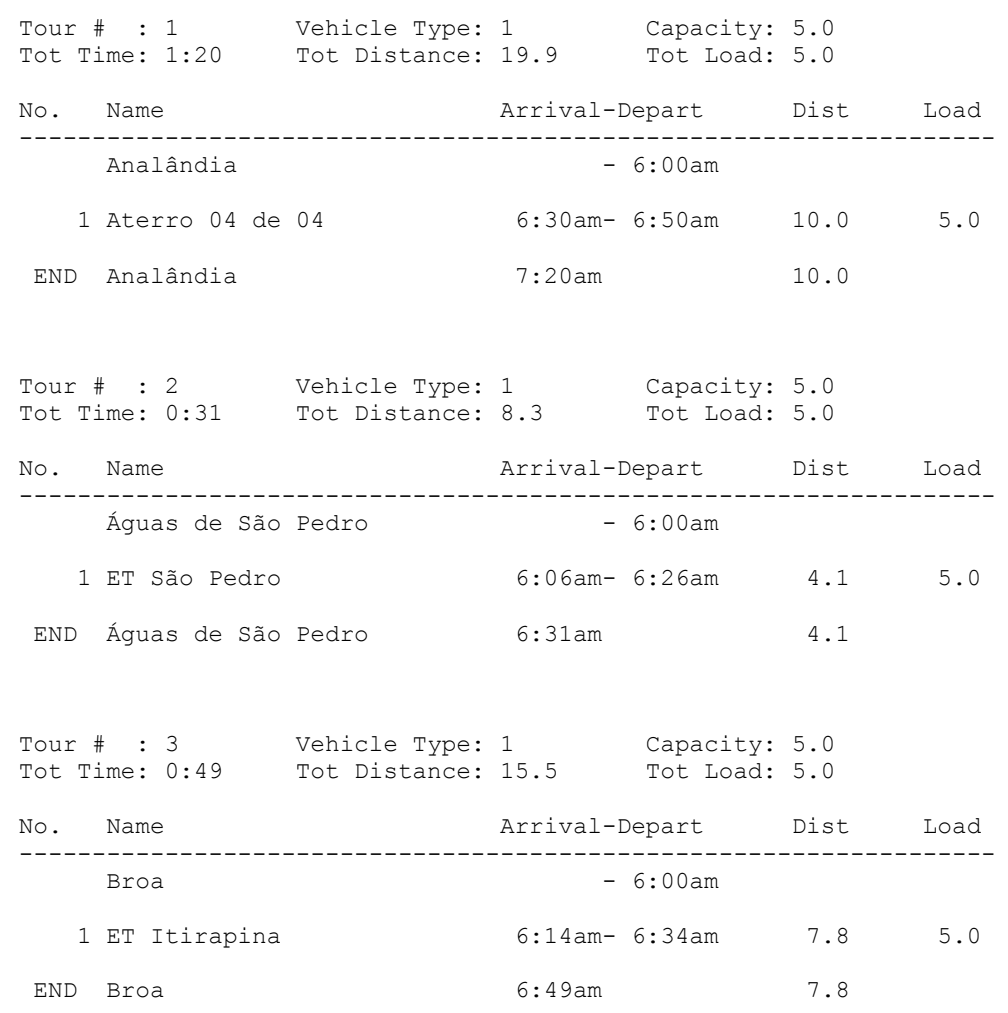


2.3. Parte 03: destinação diferenciada após coleta até o Aterro.

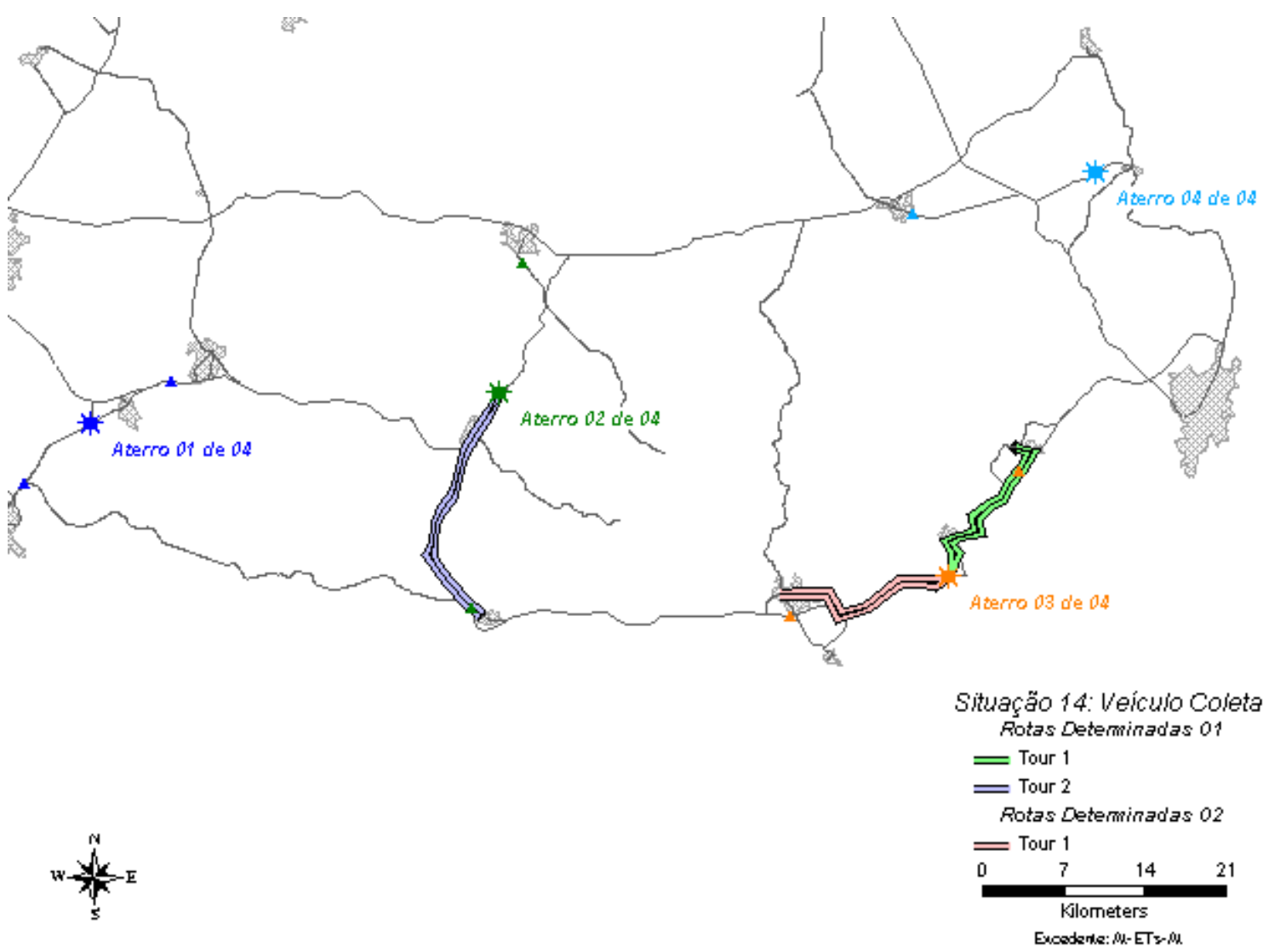

ROTA 2.3 - Situação 14: Parte 03 


\section{ITINERÁRIO 2.3 - Situação 14: Parte 03}

Rotas Determinadas 01

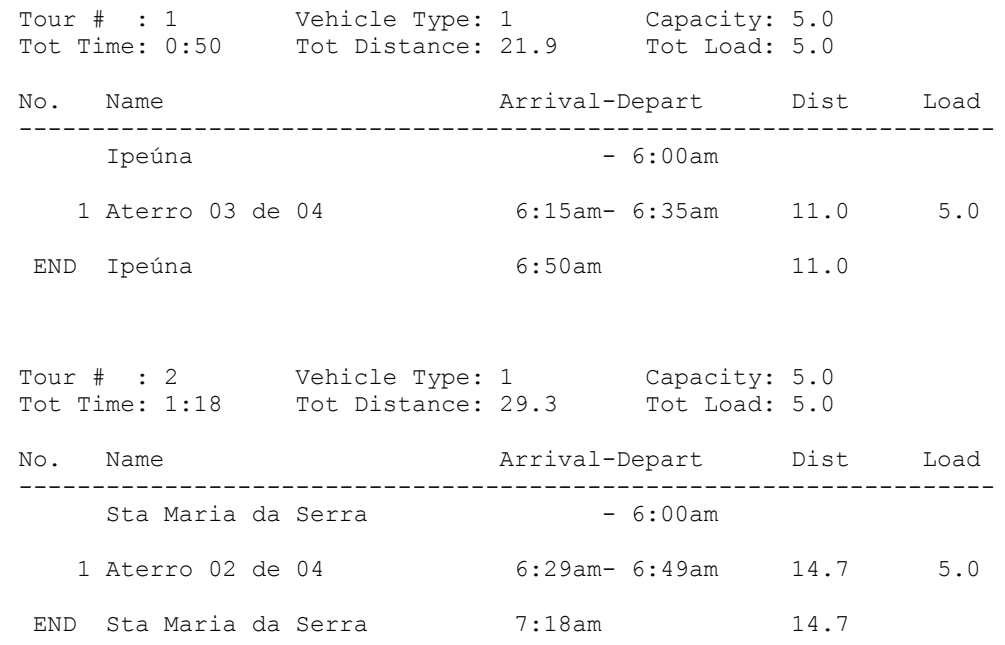

Rotas Determinadas 02

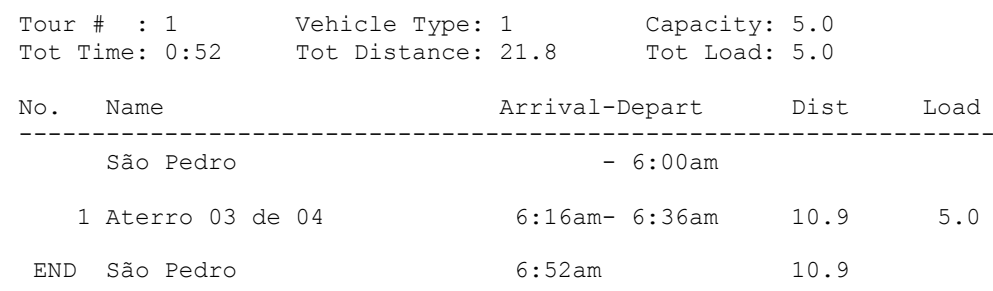


APÊNDICE K

Planilhas dos cálculos de custos 
Planilha 01 - Base

Parâmetros básicos da planilha de custos adotados pela SELUR (2001b)

\begin{tabular}{|c|c|c|c|}
\hline 1. Combustível: consumo $(\mathrm{km} / \mathrm{l})$ & & 4. Produtividade & \\
\hline Coleta & 1,60 & Trator de Esteira (t/h) & 35 \\
\hline Transporte & 1,80 & Retroescavadeira (m3/h) & 20 \\
\hline 2. Valor Residual (\% do valor) & & 5. Vida Econômica (meses) & \\
\hline Caminhão & $22,0 \%$ & Caminhão & 120 \\
\hline Caçamba & $5,0 \%$ & Caçamba & 120 \\
\hline Veículo Leve & $35,0 \%$ & Veículo Leve & 60 \\
\hline 3. Pneus: vida útil $(\mathrm{km})$ & & 6. Manutenção (\% do valor) & \\
\hline Caminhão & 36.000 & Caminhão & $85,0 \%$ \\
\hline Veículo Leve & 45.000 & Veículo Leve & $60,0 \%$ \\
\hline
\end{tabular}

\begin{tabular}{|crcccc}
\hline \multicolumn{6}{c}{ Parâmetros da planilha de custos adotados pela SELUR (2001b) de acordo com a } \\
faixa da população atendida pelo serviço \\
\hline \multicolumn{2}{c}{ Habitantes } & $\begin{array}{c}\text { Administração } \\
\text { central }\end{array}$ & $\begin{array}{c}\text { Encarregado } \\
\text { Cidade }\end{array}$ & $\begin{array}{c}\text { Fiscal } \\
\text { Cidade }\end{array}$ & $\begin{array}{c}\text { Auxiliar } \\
\text { Cidade }\end{array}$ \\
\hline 2.000 .000 & 1.999 .999 & $16 \%$ & 2 & 8 & 1 \\
1.000 .000 & 999.999 & $18 \%$ & 2 & 5 & 1 \\
700.000 & 699.999 & $18 \%$ & 1 & 2 & 1 \\
400.000 & 399.999 & $21 \%$ & 1 & 2 & 1 \\
200.000 & 0 & $28 \%$ & 1 & 1 & 1 \\
\hline
\end{tabular}


Planilha 02a - Encargos

\begin{tabular}{|c|c|c|}
\hline \multicolumn{3}{|c|}{ ENCARGOS SOCIAIS NO SETOR DE LIMPEZA } \\
\hline & DISCRIMINAÇÁO & $\begin{array}{c}\text { \% Salário } \\
\text { Mensal }\end{array}$ \\
\hline & \multicolumn{2}{|l|}{ GRUPO A } \\
\hline & \multicolumn{2}{|l|}{ Básico } \\
\hline 1 & INSS & $20,0 \%$ \\
\hline 2 & FGTS & $8,0 \%$ \\
\hline 3 & SENAI ( taxa normal 1,00 + 0,20 de adicional) & $1,2 \%$ \\
\hline 4 & SESI & $1,5 \%$ \\
\hline 5 & INCRA & $0,2 \%$ \\
\hline 6 & Salário Educação & $2,5 \%$ \\
\hline 7 & Seguro acidente do trabalho & $3,0 \%$ \\
\hline 8 & SEBRAE & $0,6 \%$ \\
\hline 9 & Taxa assistencial ( Convenção coletiva - SIEMACO) & $0,6 \%$ \\
\hline 10 & SELUR ( Sindicato das Empresas) & $0,2 \%$ \\
\hline 11 & TOTAL GRUPO A & $37,8 \%$ \\
\hline \multicolumn{3}{|c|}{ GRUPO B } \\
\hline & \multicolumn{2}{|c|}{ Encargos sociais que recebem incidências do Grupo A } \\
\hline 12 & Repouso semanal remunerado & $0,00 \%$ \\
\hline 13 & Férias & $11,11 \%$ \\
\hline 14 & Feriados & $0,00 \%$ \\
\hline 15 & $13^{\circ}$ salário ( $\left.100 \times 30 / 360\right)$ & $8,33 \%$ \\
\hline 16 & Auxílio enfermidade $(100 \times 0,35 \times 15 / 360)$ & $1,46 \%$ \\
\hline 17 & Faltas justificadas ( $100 \times 3 / 360)$ & $0,83 \%$ \\
\hline 18 & Aviso prévio idenizado & $5,53 \%$ \\
\hline 19 & TOTAL GRUPO B & $27,26 \%$ \\
\hline \multicolumn{3}{|c|}{ GRUPO C } \\
\hline & \multicolumn{2}{|c|}{ Encargos sociais que não recebem incidência do GRUPO A } \\
\hline 20 & Multa FGTS - rescisão sem justa causa & $3,26 \%$ \\
\hline 21 & $100 \times 4 \times 0,8 \times 0,1 \times(0,08 \times 0,2726+0,08)$ & \\
\hline 22 & Indenização Art. $9^{\circ}$ Lei 7.238/84 ( 100×2×0,0553/12) & $0,92 \%$ \\
\hline \multirow{3}{*}{23} & TOTAL GRUPO C & $4,18 \%$ \\
\hline & \multicolumn{2}{|l|}{ GRUPO D } \\
\hline & \multicolumn{2}{|l|}{ Taxas de reincidências } \\
\hline 24 & Grupo A x Grupo B & $10,30 \%$ \\
\hline \multirow[t]{3}{*}{25} & TOTAL GRUPO D & $10,30 \%$ \\
\hline & \multicolumn{2}{|l|}{ GRUPO E } \\
\hline & \multicolumn{2}{|c|}{ Encargos sociais que recebem incidências do Grupo A - FGTS } \\
\hline 26 & Indenização Art. $9^{\circ}$ Lei 7.238/84 & $0,27 \%$ \\
\hline 27 & $0,92 \% \times(37,8 \%-8 \%)$ & \\
\hline 28 & TOTAL GRUPO E & $0,27 \%$ \\
\hline 29 & TOTAL GERAL & $79,81 \%$ \\
\hline & & \\
\hline
\end{tabular}


Planilha 02b - Mão-de-obra

\section{DADOS}

\begin{tabular}{|rcc|}
\hline Salário Mínimo ( $\mathrm{R} \$ / \mathrm{mês}):$ & $\mathrm{R} \$$ & 200,00 \\
\hline Encargos Sociais: & $79,81 \%$ \\
\hline $\mathrm{R} \$$ / passagem ônibus: & $\mathrm{R} \$$ & 1,40 \\
\hline Num. passagem / H x dia: & 4 \\
\hline
\end{tabular}

2. MÃO-DE-OBRA DIRETA

\begin{tabular}{|c|c|c|c|c|}
\hline & \multicolumn{2}{|c|}{ MOTORISTA } & \multicolumn{2}{|c|}{ COLETOR } \\
\hline Salário Mensal (R\$) & 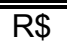 & 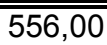 & 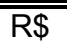 & $\overline{285,93}$ \\
\hline Salário por Hora $(\mathrm{R} \$ / \mathrm{h})$ & $\mathrm{R} \$$ & 2,52 & $\mathrm{R} \$$ & 1,29 \\
\hline Insalubridade (\%) & \multicolumn{2}{|c|}{$20,0 \%$} & \multicolumn{2}{|c|}{$40,0 \%$} \\
\hline Insalubridade (R\$/mês) & $\mathrm{R} \$$ & 40,00 & $\mathrm{R} \$$ & 80,00 \\
\hline Periculosidade ( $\mathrm{R} \$ /$ mês) & $R \$$ & 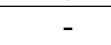 & $\mathrm{R} \$$ & - \\
\hline Vale Cesta (R\$/mês) & $\mathrm{R} \$$ & 40,61 & & 40,61 \\
\hline Vale Refeição (R\$/mês) & $\mathrm{R} \$$ & 135,00 & & 135,00 \\
\hline Vale Transporte (R\$/mês): 6\% & $\mathrm{R} \$$ & 112,69 & $\mathrm{R} \$$ & 128,89 \\
\hline Convênio Médico (R\$/mês) & $\mathrm{R} \$$ & 26,00 & $\mathrm{R} \$$ & 32,00 \\
\hline Guarnição COLETA (H x veic) & \multicolumn{2}{|c|}{1} & \multicolumn{2}{|c|}{3} \\
\hline Guarnição TRANSBORDO ET ( $\mathrm{H}$ x & \multicolumn{2}{|c|}{1} & \multicolumn{2}{|c|}{1} \\
\hline
\end{tabular}

3. MÃO-DE-OBRA DE SUPERVISÃO

\begin{tabular}{|l|rr|rr|rr|}
\hline \multicolumn{1}{|c|}{ Cargo } & \multicolumn{2}{c|}{ R\$ /H x mês } & \multicolumn{2}{c|}{ Férias } & \multicolumn{2}{c|}{$\begin{array}{c}\text { Vale } \\
\text { Cesta }\end{array}$} \\
\hline \hline Fiscal Coleta & $\mathrm{R} \$$ & $1.244,41$ & $\mathrm{R} \$$ & 103,70 & $\mathrm{R} \$$ & 40,61 \\
\hline Fiscal Pesagem & $\mathrm{R} \$$ & 583,59 & $\mathrm{R} \$$ & 48,63 & $\mathrm{R} \$$ & 40,61 \\
\hline Enc. Trafego & $\mathrm{R} \$$ & $1.993,84$ & $\mathrm{R} \$$ & 166,15 & $\mathrm{R} \$$ & 40,61 \\
\hline Aux. Trafego & $\mathrm{R} \$$ & 583,59 & $\mathrm{R} \$$ & 48,63 & $\mathrm{R} \$$ & 40,61 \\
\hline Ajudante motorista & $\mathrm{R} \$$ & 357,00 & $\mathrm{R} \$$ & 29,75 & $\mathrm{R} \$$ & 40,61 \\
\hline Operador de equipamento & $\mathrm{R} \$$ & 556,00 & $\mathrm{R} \$$ & 46,33 & $\mathrm{R} \$$ & 40,61 \\
\hline Encarregado Aterro & $\mathrm{R} \$$ & 583,59 & $\mathrm{R} \$$ & 48,63 & $\mathrm{R} \$$ & 40,61 \\
\hline Encarregado Est. de Transf. & $\mathrm{R} \$$ & 583,59 & $\mathrm{R} \$$ & 48,63 & $\mathrm{R} \$$ & 40,61 \\
\hline
\end{tabular}

\begin{tabular}{|l|rr|rr|rr|}
\hline \multicolumn{1}{|c|}{ Cargo } & \multicolumn{2}{c|}{$\begin{array}{c}\text { Vale } \\
\text { Refeição }\end{array}$} & \multicolumn{2}{c|}{$\begin{array}{c}\text { Vale } \\
\text { Transporte }\end{array}$} & Insalubridade \\
\hline \hline Fiscal Coleta & $\mathrm{R} \$$ & 135,00 & $\mathrm{R} \$$ & 71,38 & \\
\hline Fiscal Pesagem & $\mathrm{R} \$$ & 135,00 & $\mathrm{R} \$$ & 111,03 & $\mathrm{R} \$$ & 40,00 \\
\hline Enc. Trafego & $\mathrm{R} \$$ & 135,00 & $\mathrm{R} \$$ & 26,42 & & \\
\hline Aux. Trafego & $\mathrm{R} \$$ & 135,00 & $\mathrm{R} \$$ & 111,03 & & \\
\hline Ajudante motorista & $\mathrm{R} \$$ & 135,00 & $\mathrm{R} \$$ & 124,63 & $\mathrm{R} \$$ & 40,00 \\
\hline Operador de equipamento & $\mathrm{R} \$$ & 135,00 & $\mathrm{R} \$$ & 112,69 & $\mathrm{R} \$$ & 40,00 \\
\hline Encarregado Aterro & $\mathrm{R} \$$ & 135,00 & $\mathrm{R} \$$ & 111,03 & & \\
\hline Encarregado Est. de Transf. & $\mathrm{R} \$$ & 135,00 & $\mathrm{R} \$$ & 111,03 & & \\
\hline
\end{tabular}


Planilha 03 - Veículos e Equipamentos

3.1. VEICULOS E EQUIPAMENTOS

\begin{tabular}{|c|c|c|c|c|c|c|c|c|}
\hline Discriminacao & \multicolumn{2}{|c|}{$\mathrm{R} \$$ /unidade } & \multirow{2}{*}{$\begin{array}{r}\begin{array}{l}\text { Vida Util } \\
\text { (meses) }\end{array} \\
120\end{array}$} & \multirow{2}{*}{$\begin{array}{r}\text { Residual } \\
22 \%\end{array}$} & Manutenção & \multicolumn{2}{|r|}{ IPVA } & \multirow{2}{*}{$\begin{array}{r}\text { km/litro } \\
1,60\end{array}$} \\
\hline Caminhão F-14000 PBT-14.100 & $\mathrm{R} \$$ & $666.000,00$ & & & $85 \%$ & $\mathrm{R} \$$ & 990,00 & \\
\hline Caçamba compactadora para $15 \mathrm{~m}^{3}$ & $\mathrm{R} \$$ & $46.000,00$ & 120 & $5 \%$ & - & & - & - \\
\hline Caminhão VW TITAN 26310 6x4 & $\mathrm{R} \$$ & $110.000,00$ & 36.000 & $22 \%$ & $85 \%$ & $\mathrm{R} \$$ & $1.650,00$ & 1,80 \\
\hline Carrocerias (Chassis e reboque) & $\mathrm{R} \$$ & $63.000,00$ & 45.000 & $5 \%$ & - & & - & - \\
\hline Kombi VW & $\mathrm{R} \$$ & $19.850,00$ & 60 & $35 \%$ & $60 \%$ & $\mathrm{R} \$$ & 397,00 & 8,00 \\
\hline Balança Rodoviária & $\mathrm{R} \$$ & $30.000,00$ & 180 & $5 \%$ & $20 \%$ & & - & - \\
\hline Sistema de Pesagem ET & (per & ializado) & 180 & $5 \%$ & $20 \%$ & & - & - \\
\hline Pick-up Saveiro & $\mathrm{R} \$$ & $18.650,00$ & 60 & $35 \%$ & $60 \%$ & $\mathrm{R} \$$ & 373,00 & 8,00 \\
\hline
\end{tabular}

\begin{tabular}{|c|c|c|c|c|c|c|c|c|}
\hline Discriminacao & $R \$$ /unidade & $\begin{array}{c}\text { Vida Util } \\
\text { (h) } \\
\end{array}$ & Residual & $\begin{array}{c}\text { Manutenção } \\
(\mathrm{R} \$ / \mathrm{h}) \\
\end{array}$ & & IPVA & & $\begin{array}{l}\text { umos } \\
(\$ / \mathrm{h})\end{array}$ \\
\hline Trator sobre esteria com lâmina & $232.946,00$ & 10.000 & $20 \%$ & 23,58 & & 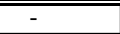 & $\mathrm{R} \$$ & 16,11 \\
\hline Retroescavadeira & $110.000,00$ & 10.000 & $20 \%$ & 6,75 & & - & $\mathrm{R} \$$ & 11,83 \\
\hline Caminhão Basculante & $94.228,37$ & 10.000 & $22 \%$ & 5,79 & $\mathrm{R} \$$ & $1.413,43$ & $\mathrm{R} \$$ & 21,31 \\
\hline
\end{tabular}

\subsection{INSUMOS}

\begin{tabular}{|c|c|c|c|}
\hline Combustível: & \multicolumn{2}{|c|}{ Custo } & \\
\hline Diesel ( $\mathrm{R} \$ /$ litro) & $\mathrm{R} \$$ & 0,90 & \\
\hline Gasolina (R\$/litro) & $\mathrm{R} \$$ & 1,80 & \\
\hline Lubrificação: & \multicolumn{2}{|c|}{ Custo } & Troca \\
\hline Motor ( $\mathrm{R} \$ /$ litro) & $\mathrm{R} \$$ & 4,22 & $5.000 \mathrm{~km} \quad$ PLANO A \\
\hline Transmissao (R\$/litro) & $\mathrm{R} \$$ & 4,52 & $20.000 \mathrm{~km} \quad$ PLANO B \\
\hline Hidraulico (R\$/litro) & $\mathrm{R} \$$ & 3,34 & $50.000 \mathrm{~km} \quad$ PLANO C \\
\hline Graxa $(R \$ / k g)$ & $\mathrm{R} \$$ & 3,46 & $300 \mathrm{~km}$ \\
\hline Pneus (R\$/unidade): & \multicolumn{2}{|c|}{ Custo } & \\
\hline $1000 \times 20 " \times 16$ & $\mathrm{R} \$$ & 384,00 & \\
\hline $1000 \times 20 " \times 16$ & $\mathrm{R} \$$ & 384,00 & \\
\hline Recauchutagem 1000x20" & $\mathrm{R} \$$ & 92,00 & \\
\hline 195/70R 14 & $\mathrm{R} \$$ & 82,95 & \\
\hline 175/70R 13 & $\mathrm{R} \$$ & 60,09 & \\
\hline Câmaras (R\$/unidade): & \multicolumn{2}{|c|}{ Custo } & \\
\hline CCR-20 (1000x20") & $\mathrm{R} \$$ & 36,24 & \\
\hline Protetor $1000 \times 20 "$ & $\mathrm{R} \$$ & 12,35 & \\
\hline $735 \times 14$ (kombi) & $\mathrm{R} \$$ & 11,00 & \\
\hline $155 \times 13$ (gol e saveiro) & $\mathrm{R} \$$ & 10,00 & \\
\hline Seguros: & \multicolumn{2}{|c|}{ Custo } & \\
\hline Obrig. Caminhao, tratores (R\$/ano) & $\mathrm{R} \$$ & 55,43 & \\
\hline Obrig. Veiculo leve (R\$/ano) & $\mathrm{R} \$$ & 32,32 & \\
\hline Caminh., trat. - Inc.e mat.c/terceiros & & $8,00 \%$ & \\
\hline Veic.Leves - Total & & $9,40 \%$ & \\
\hline Lavagem: & \multicolumn{2}{|c|}{ Custo } & \\
\hline Custo Médio Estimado por Caminhão: & $\mathrm{R} \$$ & 2,50 & \\
\hline Número de lavagens / mês / veículo & & 26,08 & \\
\hline Custo mensal com lavagens / veículo & $\mathrm{R} \$$ & 65,20 & \\
\hline Diversos: & \multicolumn{2}{|c|}{ Custo } & \\
\hline Taxa de Publicidade (R\$/ano) & $\mathrm{R} \$$ & 53,74 & \\
\hline
\end{tabular}


Planilha 04 - Uniformes

4. UNIFORMES

\begin{tabular}{|l|cc|c|c|}
\hline & \multicolumn{2}{|c|}{$\begin{array}{c}\text { Preço Unitário } \\
\text { (R\$) }\end{array}$} & $\begin{array}{c}\text { MOTORISTA } \\
\text { (AJUDANTE) }\end{array}$ & COLETOR \\
\hline \hline Calça de brim sol-a-sol & $\mathrm{R} \$$ & 10,10 & 4 & 6 \\
\hline Camisa de brim sol-a-sol & $\mathrm{R} \$$ & 9,04 & 3 & 6 \\
\hline Camiseta de malha (Hering) & $\mathrm{R} \$$ & - & 0 & 0 \\
\hline Sapato tipo Vulcabrás & $\mathrm{R} \$$ & 25,00 & 2 & 12 \\
\hline Calçado tipo "Bamba" & $\mathrm{R} \$$ & 25,00 & 0 & 2 \\
\hline Boné tipo "Jockey" & $\mathrm{R} \$$ & 2,20 & 2 & 18 \\
\hline Capa de chuva em PVC & $\mathrm{R} \$$ & 7,04 & 1 & 0 \\
\hline Luva em Raspa de Couro & $\mathrm{R} \$$ & 5,61 & 0 & 2 \\
\hline Luva de Algodão & $\mathrm{R} \$$ & 1,25 & 0 & \\
\hline Colete de Proteção & $\mathrm{R} \$$ & 5,26 & 0 & \\
\hline
\end{tabular}

Planilha 05 - Parâmetros

\subsection{COLETA DE LIXO}

\begin{tabular}{|lr|}
\hline Capital Giro (vezes) & 1 \\
\hline Absenteismo & $10,00 \%$ \\
\hline Adicional Noturno & $37,14 \%$ \\
\hline Reserva equipamento & $20,00 \%$ \\
\hline Beneficio & $0,00 \%$ \\
\hline
\end{tabular}

\subsection{TAXAS ADOTADAS}

\begin{tabular}{|lr|}
\hline Remuneração do Investimento (a.m.) & $0,9489 \%$ \\
\hline Remuneração do Investimento (a.a.) & $12,00 \%$ \\
\hline Administração (custo) & $28,00 \%$ \\
\hline ISS & $5,00 \%$ \\
\hline PIS & $0,65 \%$ \\
\hline COFINS & $3,00 \%$ \\
\hline IRRF & $1,50 \%$ \\
\hline CPMF & $0,38 \%$ \\
\hline
\end{tabular}


Planilha 06 - Coleta: At. 01 d 01 da Situação 11

COLETA E TRANSPORTE DE RESÍDUOS DOMICILIARES

CUSTO DOS SERVIÇOS

Data base:

Junho de 2002

1. DADOS BÁSICOS NECESSÁRIOS

1.1. QUANTIDADE MÉDIA DE RESÍDUOS PARA SER COLETADA

\begin{tabular}{|c|c|c|c|c|}
\hline & ATERRO & & PERÍODO & \\
\hline & At. $01 \mathrm{~d} 01$ & 2007 & 2012 & 2017 \\
\hline Resíduos Sólidos (t/mês): & & 2.737 & 2.913 & 3.065 \\
\hline
\end{tabular}

1.2. NÚMERO DE DIAS ÚTEIS POR ANO

Descontados somente domingos

Descontados domingos e feriados

\begin{tabular}{|rl||r|r|}
\hline 365 & dias/ano \\
\hline 52 & domingos/ano \\
\hline 313 & dias úteis/ano \\
\hline 26,08 & dias úteis/mes \\
\hline & & 52 & dias/ano \\
\hline & 10 & feriados/ano \\
\hline & 303 & dias uteis/ano \\
\hline 25,25 & dias úteis/mes \\
\hline
\end{tabular}

1.3. COLETA EM JORNADA NORMAL

\begin{tabular}{|c|c|c|c|c|}
\hline \multirow[b]{3}{*}{ Número de veículos (veic/dia): } & ATERRO & & PERÍODO & \\
\hline & At. $01 \mathrm{~d} 01$ & 2007 & 2012 & 2017 \\
\hline & & 16 & 16 & 16 \\
\hline \multirow[b]{3}{*}{ Número de Jornadas /dia: } & ATERRO & & PERÍODO & \\
\hline & At. $01 \mathrm{~d} 01$ & 2007 & 2012 & 2017 \\
\hline & & 16 & 16 & 16 \\
\hline \multirow[b]{3}{*}{ Horas extras totais $(h)$ : } & ATERRO & & PERÍODO & \\
\hline & At. $01 \mathrm{~d} 01$ & 2007 & 2012 & 2017 \\
\hline & & 0,00 & 0,00 & 0,00 \\
\hline
\end{tabular}

\section{DIMENSIONAMENTO DA FROTA E DO PESSOAL}

2.1. FROTA MÉDIA

\begin{tabular}{|c|c|c|c|c|}
\hline \multirow[t]{2}{*}{ Número de veículos (veic/dia) } & ATERRO & & PERÍODO & \\
\hline & At. $01 \mathrm{~d} 01$ & 2007 & 2012 & 2017 \\
\hline \multirow{3}{*}{$\begin{array}{r}\text { Operação: } \\
\text { Reserva: } \\
\text { TOTAL Necessário: }\end{array}$} & & 16 & 16 & 16 \\
\hline & $20 \%$ & 3 & 3 & 3 \\
\hline & & 19 & 19 & 19 \\
\hline
\end{tabular}

2.2. MÃO-DE-OBRA DIRETA \begin{tabular}{l|lll}
\cline { 3 - 4 } Guarnição/Veículo: & Motorista & 1 & $\mathrm{H} . \times$ veiculo coletor \\
\cline { 3 - 5 } & Coletores - diurno & &
\end{tabular}

MOTORISTA

Motorista (H/dia)

Operação:

Reserva Absenteismo: TOTAL Necessário:
ATERRO

At. $01 \mathrm{~d} 01$

$10 \%$

(2)

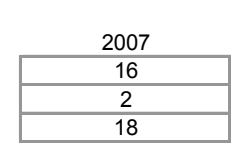

PERÍODO

\begin{tabular}{|c|}
\hline 2012 \\
\hline 16 \\
\hline 2 \\
\hline 18 \\
\hline
\end{tabular}

\begin{tabular}{|c|}
\multicolumn{1}{|c|}{2017} \\
\hline 16 \\
\hline 2 \\
\hline 18 \\
\hline
\end{tabular}


Planilha 06 - Coleta: At. 01 d 01 da Situação 11 (cont.)

COLETOR

\begin{tabular}{|c|c|c|c|c|}
\hline \multirow[t]{2}{*}{ Coletores (H/dia) } & ATERRO & & PERÍODO & \\
\hline & At. $01 \mathrm{~d} 01$ & 2007 & 2012 & 2017 \\
\hline \multirow{3}{*}{$\begin{array}{r}\text { Operação: } \\
\text { Reserva Absenteismo: } \\
\text { TOTAL Necessário: }\end{array}$} & & 48 & 48 & 48 \\
\hline & $10 \%$ & 5 & 5 & 5 \\
\hline & & 53 & 53 & 53 \\
\hline
\end{tabular}

\section{CUSTO DA MÃO-DE-OBRA DIRETA}

\begin{tabular}{|c|c|c|c|c|c|c|c|}
\hline \multirow{4}{*}{$\begin{array}{r}\text { Salário } \\
\text { Horas Mensais }\end{array}$} & \multirow{3}{*}{\begin{tabular}{|c|} 
ATERRO \\
At. 01 d 01 \\
R\$/hora
\end{tabular}} & \multicolumn{6}{|c|}{ PERÍODO } \\
\hline & & \multicolumn{2}{|c|}{2007} & \multicolumn{2}{|c|}{2012} & \multicolumn{2}{|c|}{2017} \\
\hline & & $\mathrm{R} \$$ & 2,53 & $\mathrm{R} \$$ & 2,53 & $\mathrm{R} \$$ & 2,53 \\
\hline & $\mathrm{R} \$ /$ hora & & 220 & & 220 & & 220 \\
\hline \multirow{3}{*}{ Insalubridade } & \multirow{2}{*}{ Salário Base } & $\mathrm{R} \$$ & 556,00 & $\mathrm{R} \$$ & 556,00 & $\mathrm{R} \$$ & 556,00 \\
\hline & & $\mathrm{R} \$$ & 40,00 & $\mathrm{R} \$$ & 40,00 & $\mathrm{R} \$$ & 40,00 \\
\hline & \multirow[t]{3}{*}{ Subtotal } & $\mathrm{R} \$$ & 596,00 & $\mathrm{R} \$$ & 596,00 & $\mathrm{R} \$$ & 596,00 \\
\hline \multirow{3}{*}{$\begin{array}{r}\text { Horas Extras } \\
\text { Feriado Diurno }\end{array}$} & & $\mathrm{R} \$$ & - & $\mathrm{R} \$$ & - & $\mathrm{R} \$$ & - \\
\hline & & $\mathrm{R} \$$ & 30,92 & $\mathrm{R} \$$ & 30,92 & $\mathrm{R} \$$ & 30,92 \\
\hline & Salário Mensal & $\mathrm{R} \$$ & 626,92 & $\mathrm{R} \$$ & 626,92 & $\mathrm{R} \$$ & 626,92 \\
\hline Salário Mensal com Encargos & & $\mathrm{R} \$$ & $1.127,26$ & $\mathrm{R} \$$ & $1.127,26$ & $\mathrm{R} \$$ & $1.127,26$ \\
\hline \multirow{5}{*}{$\begin{array}{r}\text { Vale Refeição } \\
\text { Vale Cesta } \\
\text { Convênio Médico } \\
\text { Vale Transporte } \\
\text { Custo Mensal Unitário }\end{array}$} & & $\mathrm{R} \$$ & 135,00 & $\mathrm{R} \$$ & 135,00 & $\mathrm{R} \$$ & 135,00 \\
\hline & & $\mathrm{R} \$$ & 40,61 & $\mathrm{R} \$$ & 40,61 & $\mathrm{R} \$$ & 40,61 \\
\hline & & $\mathrm{R} \$$ & 26,00 & $\mathrm{R} \$$ & 26,00 & $\mathrm{R} \$$ & 26,00 \\
\hline & & $\mathrm{R} \$$ & 112,69 & $\mathrm{R} \$$ & 112,69 & $\mathrm{R} \$$ & 112,69 \\
\hline & $\mathrm{R} \$ / \mathrm{mês}$ & $\mathrm{R} \$$ & $1.441,56$ & $\mathrm{R} \$$ & $1.441,56$ & $\mathrm{R} \$$ & $1.441,56$ \\
\hline
\end{tabular}

\begin{tabular}{|c|c|c|c|c|c|c|c|}
\hline \multirow{16}{*}{$\begin{array}{r}\text { Salário Mensal com Encargos } \\
\text { Vale Refeição } \\
\text { Vale Cesta } \\
\text { Convênio Médico } \\
\text { Vale Transporte } \\
\text { Custo Mensal Unitário }\end{array}$} & \multirow{2}{*}{$\begin{array}{l}\text { ATERRO } \\
\text { At. } 01 \mathrm{~d} 01\end{array}$} & \multicolumn{6}{|c|}{ PERÍODO } \\
\hline & & \multicolumn{2}{|c|}{2007} & \multicolumn{2}{|c|}{2012} & \multicolumn{2}{|c|}{2017} \\
\hline & \multirow[t]{2}{*}{$\mathrm{R} \$$ /hora } & $\mathrm{R} \$$ & 1,30 & $\mathrm{R} \$$ & 1,30 & $\mathrm{R} \$$ & 1,30 \\
\hline & & & 220 & & 220 & & 220 \\
\hline & \multirow[t]{2}{*}{ Salário Base } & $\mathrm{R} \$$ & 285,93 & $\mathrm{R} \$$ & 285,93 & $\mathrm{R} \$$ & 285,93 \\
\hline & & $\mathrm{R} \$$ & 80,00 & $\mathrm{R} \$$ & 80,00 & $\mathrm{R} \$$ & 80,00 \\
\hline & \multirow[t]{3}{*}{ Subtotal } & $\mathrm{R} \$$ & 365,93 & $\mathrm{R} \$$ & 365,93 & $\mathrm{R} \$$ & 365,93 \\
\hline & & $\mathrm{R} \$$ & - & $\mathrm{R} \$$ & - & $\mathrm{R} \$$ & - \\
\hline & & $\mathrm{R} \$$ & 15,89 & $\mathrm{R} \$$ & 15,89 & $\mathrm{R} \$$ & 15,89 \\
\hline & \multirow[t]{6}{*}{ Salário Mensal } & $\mathrm{R} \$$ & 381,82 & $\mathrm{R} \$$ & 381,82 & $\mathrm{R} \$$ & 381,82 \\
\hline & & $\mathrm{R} \$$ & 686,55 & $\mathrm{R} \$$ & 686,55 & $\mathrm{R} \$$ & 686,55 \\
\hline & & $\mathrm{R} \$$ & 135,00 & $\mathrm{R} \$$ & 135,00 & $\mathrm{R} \$$ & 135,00 \\
\hline & & $\mathrm{R} \$$ & 40,61 & $\mathrm{R} \$$ & 40,61 & $\mathrm{R} \$$ & 40,61 \\
\hline & & $\mathrm{R} \$$ & 32,00 & $\mathrm{R} \$$ & 32,00 & $\mathrm{R} \$$ & 32,00 \\
\hline & & $\mathrm{R} \$$ & 128,89 & $\mathrm{R} \$$ & 128,89 & $\mathrm{R} \$$ & 128,89 \\
\hline & $\mathrm{R} \$ /$ mês & $\mathrm{R} \$$ & $1.023,05$ & $\mathrm{R} \$$ & $1.023,05$ & $\mathrm{R} \$$ & $1.023,05$ \\
\hline & \multicolumn{2}{|l|}{ Feriados e domingos } & $100 \%$ & \multicolumn{4}{|c|}{ VALE TRANSPORTE: } \\
\hline & \multirow{2}{*}{\multicolumn{2}{|c|}{$\begin{array}{r}\text { Horas Extras } \\
\text { Adic.Not. }(22 \mathrm{~h} \text { as } 5 \mathrm{~h})\end{array}$}} & $50 \%$ & \multicolumn{3}{|c|}{$\mathrm{R} \$$ / pasagem ônibus } & 1,40 \\
\hline & & & $20,00 \%$ & \multicolumn{3}{|c|}{ passagem/dia (media) } & 4 \\
\hline & \multicolumn{2}{|l|}{ Adic.Not.(22h as $5 \mathrm{~h})$} & $79,81 \%$ & & A deduzir & & $6,00 \%$ \\
\hline
\end{tabular}

3.1. CUSTO MENSAL

\begin{tabular}{|c|c|c|c|c|c|c|c|}
\hline \multirow[t]{2}{*}{ Despesa: mão-de-obra } & \multirow{2}{*}{$\begin{array}{c}\text { ATERRO } \\
\text { At. } 01 \mathrm{~d} 01\end{array}$} & \multicolumn{6}{|c|}{ PERIOODO } \\
\hline & & \multicolumn{2}{|c|}{2007} & \multicolumn{2}{|c|}{2012} & \multicolumn{2}{|c|}{2017} \\
\hline \multirow[t]{2}{*}{ Motorista } & H/ mês & \multicolumn{2}{|r|}{18} & \multicolumn{2}{|c|}{18} & \multicolumn{2}{|r|}{18} \\
\hline & $\mathrm{R} \$ / \mathrm{H}$ & $\mathrm{R} \$$ & $1.441,56$ & $\mathrm{R} \$$ & $1.441,56$ & $\mathrm{R} \$$ & $1.441,56$ \\
\hline \multirow{4}{*}{ Coletor } & $\mathrm{R} \$$ /mês & $\mathrm{R} \$$ & $25.948,08$ & $\mathrm{R} \$$ & $25.948,08$ & $\mathrm{R} \$$ & $25.948,08$ \\
\hline & $\mathrm{H} /$ mês & \multicolumn{2}{|r|}{53} & \multicolumn{2}{|c|}{53} & \multicolumn{2}{|r|}{53} \\
\hline & $\mathrm{R} \$ / \mathrm{H}$ & $\mathrm{R} \$$ & $1.023,05$ & $\mathrm{R} \$$ & $1.023,05$ & $\mathrm{R} \$$ & $1.023,05$ \\
\hline & $\mathrm{R} \$ / \mathrm{mês}$ & $\mathrm{R} \$$ & $54.221,65$ & $\mathrm{R} \$$ & $54.221,65$ & $\mathrm{R} \$$ & $54.221,65$ \\
\hline TOTAL mão-de-obra & $\mathrm{R} \$ / \mathrm{mês}$ & $\mathrm{R} \$$ & $80.169,73$ & $\mathrm{R} \$$ & $80.169,73$ & $\mathrm{R} \$$ & $80.169,73$ \\
\hline
\end{tabular}


Planilha 06 - Coleta: At. 01 d 01 da Situação 11 (cont.)

4. VEÍCULOS COLETORES/COMPACTADORES

4.1. QUILOMETRAGEM PERCORRIDA

dias /mês

26,08

\begin{tabular}{|c|c|c|c|c|}
\hline \multirow[t]{3}{*}{$\mathrm{Km}$ percorrido na coleta } & ATERRO & & PERÍODO & \\
\hline & At. $01 \mathrm{~d} 01$ & 2007 & 2012 & 2017 \\
\hline & $\mathrm{km} / \mathrm{dia}$ & 778 & 824 & 864 \\
\hline SUBTOTAL & $\mathrm{km} /$ mês & 20.280 & 21.486 & 22.524 \\
\hline
\end{tabular}

4.2. CONSUMO COMBUSTÍVEL

\begin{tabular}{|c|c|c|c|c|}
\hline $\begin{array}{r}\text { Diesel (R\$ / litro) } \\
\text { Consumo (km/litro) }\end{array}$ & \begin{tabular}{|c|}
0,90 \\
1,60
\end{tabular} & & & \\
\hline \multirow{3}{*}{ Despesa: combustível } & ATERRO & & PERÍODO & \\
\hline & At. $01 \mathrm{~d} 01$ & 2007 & 2012 & 2017 \\
\hline & $\mathrm{km} /$ mês & 20.280 & 21.486 & 22.524 \\
\hline SUBTOTAL & $\mathrm{R} \$$ / mês & $11.407,36$ & $12.085,83$ & $12.669,47$ \\
\hline
\end{tabular}

4.3. MANUTENÇÃO

Veiculo Coletor-Compactador

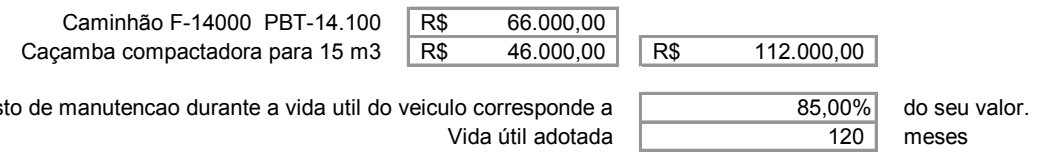

Despesa: manutenção

\begin{tabular}{|c|c|}
\hline ATERRO & \\
\hline At. $01 \mathrm{~d} 01$ & 2007 \\
\hline Número de veículos & 19 \\
\hline $\mathrm{R} \$ / \mathrm{mês}$ & $15.073,33$ \\
\hline
\end{tabular}

\begin{tabular}{|c|c|}
\multicolumn{1}{c|}{} & PERIOODO \\
2012 \\
\hline \multicolumn{1}{c|}{19} \\
\hline $\mathrm{R} \$$ & $19.073,33$ \\
\hline
\end{tabular}

\begin{tabular}{|c|c|}
\multicolumn{1}{c}{2017} \\
\hline \multicolumn{2}{|c|}{19} \\
\hline $\mathrm{R} \$$ & $15.073,33$ \\
\hline
\end{tabular}

4.4. PNEUS E CÂMARAS

\begin{tabular}{|c|c|c|c|c|c|c|c|}
\hline \multicolumn{4}{|c|}{ Admite-se uma troca de pneus e duas recapagens a cada ciclo de } & \multicolumn{2}{|r|}{36.000} & \multicolumn{2}{|c|}{ quilômetros } \\
\hline \multirow{6}{*}{$\begin{array}{r}1000 \text { x 20" x } 16 \\
1000 \text { x 20" x } 16 \\
\text { Câmaras } \\
\text { Recapagens } \\
\text { Protetores }\end{array}$} & & & & & & & \\
\hline & $2 x$ & $\mathrm{R} \$$ & $384,00=$ & $=\mathrm{R} \$$ & 768,00 & & \\
\hline & $4 x$ & $\mathrm{R} \$$ & $384,00=$ & $=\mathrm{R} \$$ & $1.536,00$ & & \\
\hline & $18 x$ & $\mathrm{R} \$$ & $36,24=$ & $=\mathrm{R} \$$ & 652,32 & & \\
\hline & $18 x$ & $\mathrm{R} \$$ & $92,00=$ & $=R \$$ & $1.656,00$ & & \\
\hline & $18 x$ & $\mathrm{R} \$$ & $12,35=$ & $=\mathrm{R} \$$ & 222,30 & $\mathrm{R} \$$ & $4.834,62$ \\
\hline \multirow[t]{3}{*}{ Despesa: pneus e câmaras } & ATERRO & & & \multicolumn{2}{|c|}{ PERÍODO } & & \\
\hline & At. $01 \mathrm{~d} 01$ & \multicolumn{2}{|c|}{2007} & \multicolumn{2}{|c|}{2012} & \multicolumn{2}{|c|}{2017} \\
\hline & $\mathrm{km} /$ mês & & 280 & & & & 524 \\
\hline SUBTOTAL & $\mathrm{R} \$$ / mês & $\mathrm{R} \$$ & $2.723,47$ & $\mathrm{R} \$$ & $2.885,45$ & $\mathrm{R} \$$ & $3.024,79$ \\
\hline
\end{tabular}

4.5. LUBRIFICAÇÃO E LAVAGEM

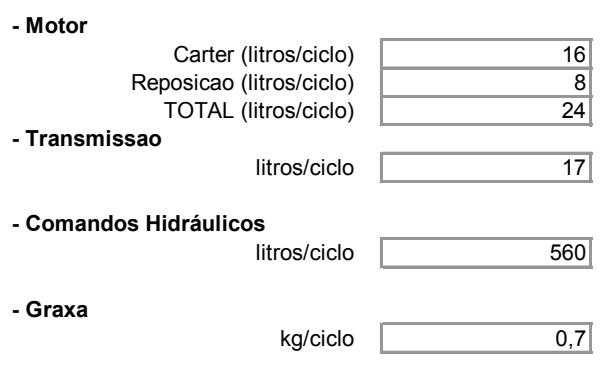

\begin{tabular}{|c|c|c|c|c|}
\hline \multirow{2}{*}{$\begin{array}{r}\mathrm{R} \$ \text { /litro } \\
\mathrm{km} / \text { ciclo }\end{array}$} & $\mathrm{R} \$$ & 4,22 & \multirow[b]{2}{*}{$\mathrm{R} \$$} & \multirow[b]{2}{*}{0,020} \\
\hline & & 5.000 & & \\
\hline \multirow{2}{*}{$\begin{array}{r}\mathrm{R} \$ / \text { litro } \\
\mathrm{km} / \text { ciclo }\end{array}$} & $\mathrm{R} \$$ & 4,52 & & \\
\hline & & 20.000 & $\mathrm{R} \$$ & 0,004 \\
\hline \multirow{2}{*}{$\begin{array}{r}\mathrm{R} \$ / \text { litro } \\
\mathrm{km} / \text { ciclo }\end{array}$} & $\mathrm{R} \$$ & 3,34 & & \\
\hline & & 50.000 & $\mathrm{R} \$$ & 0,037 \\
\hline \multirow{3}{*}{$\begin{array}{r}\mathrm{R} \$ / \mathrm{kg} \\
\mathrm{km} / \text { ciclo }\end{array}$} & $\mathrm{R} \$$ & 3,46 & & \\
\hline & & 300 & $\mathrm{R} \$$ & 0,008 \\
\hline & & TOTAL: & $\mathrm{R} \$$ & 0,069 \\
\hline
\end{tabular}


Planilha 06 - Coleta: At. 01 d 01 da Situação 11 (cont.)

- Filtros

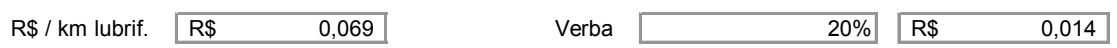

TOTAL: $\mathrm{R} \$ \quad 0,083 \quad \mathrm{~km}$

4.5.1. Consumo

Despesa: lubrificação

\begin{tabular}{|c|c|}
\hline ATERRO & \\
\hline At. $01 \mathrm{~d} 01$ & 2007 \\
\hline $\mathrm{km} /$ mês & 20.280 \\
\hline $\mathrm{R} \$$ / mês & $1.683,22$ \\
\hline
\end{tabular}

\begin{tabular}{|c|c|}
\hline \multicolumn{2}{|c|}{ PERÍODO } \\
\hline & \\
\hline $\mathrm{R} \$$ & $1.783,33$ \\
\hline
\end{tabular}

\begin{tabular}{|l|l|}
\hline \multicolumn{1}{|c|}{2017} \\
\hline $\mathrm{R} \$$ & 22.524 \\
\hline
\end{tabular}

4.5.2. LAVAGEM (água, Luz, Xampu, Desinfetante e Mão-de-obra)

$\begin{array}{lllll}\text { Custo mensal para lavagem de um veículo } & \mathrm{R} \$ & 65,20 & \text { /veic.mês } \\ & & \end{array}$

\begin{tabular}{|c|c|c|c|c|c|c|c|}
\hline \multirow{3}{*}{ Despesa: lavagem } & ATERRO & \multicolumn{6}{|c|}{ PERÍODO } \\
\hline & At. $01 \mathrm{~d} 01$ & \multirow{2}{*}{\multicolumn{2}{|c|}{$\begin{array}{c}2007 \\
19\end{array}$}} & & & \multirow{2}{*}{\multicolumn{2}{|c|}{$\begin{array}{c}2017 \\
19\end{array}$}} \\
\hline & Número de veículos & & & & & & \\
\hline PARCIAL & $\mathrm{R} \$$ / mês & $\mathrm{R} \$$ & $1.238,80$ & $\mathrm{R} \$$ & $1.238,80$ & $\mathrm{R} \$$ & $1.238,80$ \\
\hline
\end{tabular}

4.5.3. LUBRIFICAÇÃO E LAVAGEM

\begin{tabular}{|c|c|c|c|c|c|c|c|}
\hline \multirow[t]{3}{*}{ Despesa: lubrif. e lavagem } & ATERRO & \multicolumn{6}{|c|}{ PERÍODO } \\
\hline & At. $01 \mathrm{~d} 01$ & & 07 & & & & 17 \\
\hline & $\mathrm{R} \$$ / mês & $\mathrm{R} \$$ & $2.922,02$ & $\mathrm{R} \$$ & $3.022,13$ & $\mathrm{R} \$$ & $3.108,25$ \\
\hline
\end{tabular}

4.6. LICENCIAMENTO E SEGUROS

Custo Veículo/ano

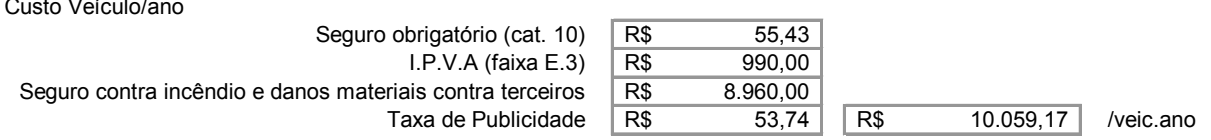

Custo Mensal

\begin{tabular}{|c|c|c|c|c|c|c|c|}
\hline \multirow[t]{3}{*}{ Despesa: licenc. e seguros } & ATERRO & \multicolumn{6}{|c|}{ PERÍODO } \\
\hline & At. $01 \mathrm{~d} 01$ & & 2007 & & 12 & & 2017 \\
\hline & Número de veículos & & 19 & & 9 & & 19 \\
\hline SUBTOTAL & $\mathrm{R} \$$ / mês & $\mathrm{R} \$$ & $15.927,02$ & $\mathrm{R} \$$ & $15.927,02$ & $\mathrm{R} \$$ & $15.927,02$ \\
\hline
\end{tabular}

4.7. DEPRECIAÇÃO

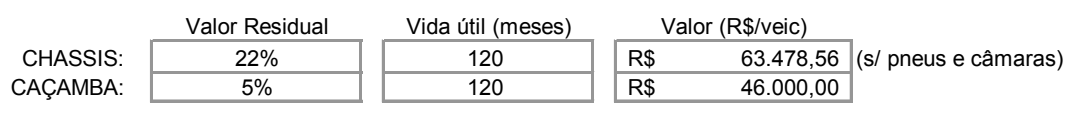

Despesa: depreciação

\begin{tabular}{|c|c|c|}
\hline ATERRO & \multirow{2}{*}{\multicolumn{2}{|c|}{2007}} \\
\hline At. $01 \mathrm{~d} 01$ & & \\
\hline \multirow{2}{*}{$\begin{array}{r}\text { Número de veículos } \\
\mathrm{R} \$ \text { / mês }\end{array}$} & \multicolumn{2}{|r|}{19} \\
\hline & $\mathrm{R} \$$ & $7.839,60$ \\
\hline $\mathrm{R} \$$ / mês & $\mathrm{R} \$$ & $6.919,17$ \\
\hline $\mathrm{R}$ \$ / mês & $\mathrm{R} \$$ & $14.758,77$ \\
\hline
\end{tabular}

\begin{tabular}{|c|c|}
\hline \multicolumn{2}{|c|}{$\begin{array}{c}\text { PERÍODO } \\
2012\end{array}$} \\
\hline & \\
\hline $\mathrm{R} \$$ & $7.839,60$ \\
\hline $\mathrm{R} \$$ & $6.919,17$ \\
\hline $\mathrm{R} \$$ & $14.758,77$ \\
\hline
\end{tabular}

\begin{tabular}{|lr|}
\multicolumn{2}{c|}{2017} \\
\hline \multicolumn{1}{|c|}{19} \\
\hline $\mathrm{R} \$$ & $7.839,60$ \\
\hline $\mathrm{R} \$$ & $6.919,17$ \\
\hline $\mathrm{R} \$$ & $14.758,77$ \\
\hline
\end{tabular}

4.8. CUSTO DE CAPITAL (remuneração)

\begin{tabular}{|c|c|c|c|c|c|c|}
\hline \multirow{3}{*}{ Coef. Remun.(/mês) } & \multirow{2}{*}{$\begin{array}{l}C= \\
C=\end{array}$} & \multicolumn{2}{|c|}{$[(2+(n-1)(k+1)) / 24 n] j$, ou } & \multicolumn{2}{|c|}{$\mathrm{j}=$ Juros } & \multirow[b]{3}{*}{ Coef. Remun. (/mês) } \\
\hline & & {$[(n+1)+r .(n-1)]$.} & 2. 12. n), onde: & & & \\
\hline & & $\mathrm{k}=$ Valor Residual & $\mathrm{n}=$ Vida útil (anos) & & २\$/veic) & \\
\hline \multirow{2}{*}{\multicolumn{2}{|c|}{$\begin{array}{l}\text { CHASSIS: } \\
\text { CACAMBA: }\end{array}$}} & $22 \%$ & 10 & $\mathrm{R} \$$ & $66.000,00$ & 0,006490 \\
\hline & & $5 \%$ & 10 & $\mathrm{R} \$$ & $46.000,00$ & 0,005725 \\
\hline
\end{tabular}


Planilha 06 - Coleta: At. 01 d 01 da Situação 11 (cont.)

\begin{tabular}{|c|c|c|c|c|c|c|c|}
\hline \multirow[t]{2}{*}{ Despesa: custo capital } & ATERRO & \multicolumn{6}{|c|}{ PERÍODO } \\
\hline & At. $01 \mathrm{~d} 01$ & \multicolumn{2}{|c|}{2007} & \multicolumn{2}{|c|}{2012} & \multicolumn{2}{|c|}{2017} \\
\hline Operação & Número de veículos & & 16 & & 6 & & 16 \\
\hline CHASSIS & $\mathrm{R} \$$ / mês & $\mathrm{R} \$$ & $6.853,44$ & $\mathrm{R} \$$ & $6.853,44$ & $\mathrm{R} \$$ & $6.853,44$ \\
\hline CAÇAMBA & $\mathrm{R} \$$ / mês & $\mathrm{R} \$$ & $4.213,60$ & $\mathrm{R} \$$ & $4.213,60$ & $\mathrm{R} \$$ & $4.213,60$ \\
\hline SUBTOTAL & $\mathrm{R} \$$ / mês & $\mathrm{R} \$$ & $11.067,04$ & $\mathrm{R} \$$ & $11.067,04$ & $\mathrm{R} \$$ & $11.067,04$ \\
\hline
\end{tabular}

4.9. RESUMO VEÍCULOS COLETORES/COMPACTADORES

\begin{tabular}{|c|c|c|c|c|c|c|c|}
\hline \multirow{10}{*}{$\begin{array}{l}\text { Despesas: veículos } \\
\text { CONSUMO COMBUSTÍVEL } \\
\text { MANUTENÇÃO } \\
\text { PNEUS E CÂMARAS } \\
\text { LUBRIFICAÇÃO E LAVAGEM } \\
\text { LICENCIAMENTO E SEGUROS } \\
\text { DEPRECIAÇÃO } \\
\text { CUSTO DE CAPITAL (remuneração) } \\
\text { TOTAL Veículos }\end{array}$} & \multirow{2}{*}{$\begin{array}{c}\text { ATERRO } \\
\text { At. } 01 \mathrm{~d} 01\end{array}$} & \multicolumn{6}{|c|}{ PERÍODO } \\
\hline & & \multicolumn{2}{|c|}{2007} & \multicolumn{2}{|c|}{2012} & \multicolumn{2}{|c|}{2017} \\
\hline & & $\mathrm{R} \$$ & $11.407,36$ & $\mathrm{R} \$$ & $12.085,83$ & $\mathrm{R} \$$ & $12.669,47$ \\
\hline & & $\mathrm{R} \$$ & $15.073,33$ & $\mathrm{R} \$$ & $15.073,33$ & $\mathrm{R} \$$ & $15.073,33$ \\
\hline & & $\mathrm{R} \$$ & $2.723,47$ & $\mathrm{R} \$$ & $2.885,45$ & $\mathrm{R} \$$ & $3.024,79$ \\
\hline & & $\mathrm{R} \$$ & $2.922,02$ & $\mathrm{R} \$$ & $3.022,13$ & $\mathrm{R} \$$ & $3.108,25$ \\
\hline & & $\mathrm{R} \$$ & $15.927,02$ & $\mathrm{R} \$$ & $15.927,02$ & $\mathrm{R} \$$ & $15.927,02$ \\
\hline & & $\mathrm{R} \$$ & $14.758,77$ & $\mathrm{R} \$$ & $14.758,77$ & $\mathrm{R} \$$ & $14.758,77$ \\
\hline & & $\mathrm{R} \$$ & $11.067,04$ & $\mathrm{R} \$$ & $11.067,04$ & $\mathrm{R} \$$ & $11.067,04$ \\
\hline & $\mathrm{R} \$$ / mês & $\mathrm{R} \$$ & $73.879,01$ & $\mathrm{R} \$$ & $74.819,57$ & $\mathrm{R} \$$ & $75.628,67$ \\
\hline
\end{tabular}

5. UNIFORMES

MOTORISTAS

CALÇA DE BRIM

CAMISA DE BRIM

CALÇADO TIPO VULCABRÁS

BONÉ TIPO JOCKEY

CAPA DE CHUVA

UNIFORME COMPLETO:

COLETORES

CALÇA DE BRIM

CAMISA DE BRIM

CALCADO TIPO BAMBA

BONÉ TIPO JOCKEY

LUVAS EM RASPA DE COURO

COLETE DE PROTEÇÃO

CAPA DE CHUVA

UNIFORME COMPLETO:

CONSUMO MENSAL

\begin{tabular}{|c|c|c|c|c|c|}
\hline \multirow{3}{*}{$\begin{array}{l}\text { un / ano } \\
\text { un / ano }\end{array}$} & \multicolumn{2}{|c|}{ Quantidade } & \multicolumn{3}{|c|}{ Preço Unitário } \\
\hline & 4 & $x \mathrm{R} \$$ & 10,10 & $=\mathrm{R} \$$ & 3,37 \\
\hline & 3 & $x \quad R \$$ & 9,04 & $=\mathrm{R} \$$ & 2,26 \\
\hline ares / ano & 2 & $\times \mathrm{R} \$$ & 25,00 & $=\mathrm{R} \$$ & 4,17 \\
\hline un / ano & 2 & $x \mathrm{R} \$$ & 2,20 & $=\mathrm{R} \$$ & 0,37 \\
\hline un / ano & 1 & $x \mathrm{R} \$$ & 7,04 & $=R \$$ & 0,59 \\
\hline
\end{tabular}

/ H. mês

un / ano

un / ano

Pares / ano

un / ano

Pares / ano

un/ano

un / ano

\begin{tabular}{|c|c|c|c|c|}
\hline Quantidade & & & & \\
\hline 6 & $\begin{array}{ll}x & R \$\end{array}$ & $10,10=$ & $=\mathrm{R} \$$ & 5,05 \\
\hline 6 & $x \quad R \$$ & $9,04=$ & $=\mathrm{R} \$$ & 4,52 \\
\hline 12 & $\begin{array}{ll}x & R \$\end{array}$ & $25,00=$ & $=\mathrm{R} \$$ & 25,00 \\
\hline 2 & $x \quad R \$$ & $2,20=$ & $=\mathrm{R} \$$ & 0,37 \\
\hline 18 & $x \quad R \$$ & $5,61=$ & $=\mathrm{R} \$$ & 8,42 \\
\hline 2 & $\begin{array}{ll}x & R \$\end{array}$ & $5,26=$ & $=\mathrm{R} \$$ & 0,88 \\
\hline 1 & $x \quad R \$$ & $7,04=$ & $=\mathrm{R} \$$ & 0,59 \\
\hline & & & $\mathrm{R} \$$ & 44,83 \\
\hline
\end{tabular}

/ H. mês

\begin{tabular}{|c|c|c|c|c|c|c|c|}
\hline \multirow[t]{2}{*}{ Despesa: uniformes } & ATERRO & & & \multicolumn{2}{|c|}{ PERÍODO } & \\
\hline & At. $01 \mathrm{~d} 01$ & & & & & & \\
\hline \multirow[t]{2}{*}{ MOTORISTA } & $\mathrm{H}$ & \multicolumn{2}{|c|}{18} & \multicolumn{2}{|c|}{18} & \multicolumn{2}{|c|}{18} \\
\hline & $\mathrm{R} \$$ / mês & $\mathrm{R} \$$ & 193,68 & $\mathrm{R} \$$ & 193,68 & $\mathrm{R} \$$ & 193,68 \\
\hline \multirow[t]{2}{*}{ COLETOR } & $\mathrm{H}$ & \multicolumn{2}{|c|}{53} & \multicolumn{2}{|c|}{53} & \multicolumn{2}{|c|}{53} \\
\hline & $\mathrm{R} \$$ / mês & $\mathrm{R} \$$ & $2.375,99$ & $\mathrm{R} \$$ & $2.375,99$ & $\mathrm{R} \$$ & $2.375,99$ \\
\hline SUBTOTAL & $\mathrm{R} \$$ / mês & $\mathrm{R} \$$ & $2.569,67$ & $\mathrm{R} \$$ & $2.569,67$ & $\mathrm{R} \$$ & $2.569,67$ \\
\hline
\end{tabular}

6. RESUMO DOS CUSTOS OPERACIONAIS

\begin{tabular}{|c|c|c|c|c|c|c|c|c|}
\hline \multirow[t]{3}{*}{ Despesas operacionais } & \multicolumn{2}{|c|}{ ATERRO } & \multirow{2}{*}{\multicolumn{2}{|c|}{2007}} & \multicolumn{2}{|c|}{ PERÍODO } & & \\
\hline & At. & d 01 & & & \multicolumn{2}{|c|}{2012} & \multicolumn{2}{|r|}{2017} \\
\hline \multirow{3}{*}{\multicolumn{3}{|c|}{$\begin{array}{l}\text { MÃO-DE-OBRA DIRETA } \\
\text { VEÍCULOS COLETORES/COMPACTADORES } \\
\text { UNIFORMES }\end{array}$}} & $\mathrm{R} \$$ & $80.169,73$ & $\mathrm{R} \$$ & $80.169,73$ & $\mathrm{R} \$$ & $80.169,73$ \\
\hline & & & $\mathrm{R} \$$ & $73.879,01$ & $\mathrm{R} \$$ & $74.819,57$ & $\mathrm{R} \$$ & $75.628,67$ \\
\hline & & & $\mathrm{R} \$$ & $2.569,67$ & $\mathrm{R} \$$ & $2.569,67$ & $\mathrm{R} \$$ & $2.569,67$ \\
\hline TOTAL Operacional & & $\mathrm{R}$ \$ / mês & $\mathrm{R} \$$ & $156.618,41$ & $\mathrm{R} \$$ & $157.558,97$ & $\mathrm{R} \$$ & $158.368,07$ \\
\hline
\end{tabular}


Planilha 06 - Coleta: At. 01 d 01 da Situação 11 (cont.)

7. MÃO-DE-OBRA DE SUPERVISÃO

\begin{tabular}{|c|c|c|c|c|c|c|c|}
\hline & $\begin{array}{c}\text { ATERRO } \\
\text { At. } 01 \mathrm{~d} 01\end{array}$ & \multicolumn{2}{|c|}{ Fiscal Coleta } & & Enc.Tráfego & \multicolumn{2}{|r|}{ Aux.Tráfego } \\
\hline \multirow{3}{*}{$\begin{array}{l}\text { Salário Base } \\
\text { Encargos Sociais }\end{array}$} & & $\mathrm{R} \$$ & $1.244,41$ & $\mathrm{R} \$$ & $1.993,84$ & $\mathrm{R} \$$ & 583,59 \\
\hline & $79,81 \%$ & $\mathrm{R} \$$ & 993,16 & $\mathrm{R} \$$ & $1.591,28$ & $\mathrm{R} \$$ & 465,76 \\
\hline & & $\mathrm{R} \$$ & $2.237,57$ & $\mathrm{R} \$$ & $3.585,12$ & $\mathrm{R} \$$ & $1.049,35$ \\
\hline \multirow{4}{*}{$\begin{array}{r}\text { Vale Cesta } \\
\text { Vale Refeição } \\
\text { Vale Transporte } \\
\text { Custo Mensal Unitário }\end{array}$} & & $\mathrm{R} \$$ & 40,61 & $\mathrm{R} \$$ & 40,61 & $\mathrm{R} \$$ & 40,61 \\
\hline & & $\mathrm{R} \$$ & 135,00 & $\mathrm{R} \$$ & 135,00 & $\mathrm{R} \$$ & 135,00 \\
\hline & & $\mathrm{R} \$$ & 71,38 & $\mathrm{R} \$$ & 26,42 & $\mathrm{R} \$$ & 111,03 \\
\hline & $\mathrm{R} \$$ / mês & $\mathrm{R} \$$ & $2.484,56$ & $\mathrm{R} \$$ & $3.787,15$ & $\mathrm{R} \$$ & $1.335,99$ \\
\hline
\end{tabular}

\begin{tabular}{|c|c|c|c|c|c|c|c|}
\hline \multirow[t]{2}{*}{ Despesa: mão-de-obra } & ATERRO & \multicolumn{6}{|c|}{ PERÍODO } \\
\hline & At. $01 \mathrm{~d} 01$ & \multicolumn{2}{|c|}{2007} & \multicolumn{2}{|c|}{2012} & \multicolumn{2}{|c|}{2017} \\
\hline \multirow{2}{*}{ Fiscal Coleta } & $\mathrm{H} /$ mês & \multicolumn{2}{|c|}{$\frac{200 t}{1}$} & \multicolumn{2}{|c|}{1} & \multicolumn{2}{|c|}{1} \\
\hline & $\mathrm{R} \$ / \mathrm{H}$ & $\mathrm{R} \$$ & $2.484,56$ & $\mathrm{R} \$$ & $2.484,56$ & $\mathrm{R} \$$ & $2.484,56$ \\
\hline \multirow{4}{*}{ Enc.Tráfego } & $\mathrm{R} \$$ / mês & $\mathrm{R} \$$ & $2.484,56$ & $\mathrm{R} \$$ & $2.484,56$ & $\mathrm{R} \$$ & $2.484,56$ \\
\hline & $\mathrm{H} /$ mês & \multicolumn{2}{|r|}{1} & \multicolumn{2}{|c|}{1} & \multicolumn{2}{|r|}{1} \\
\hline & $\mathrm{R} \$ / \mathrm{H}$ & $\mathrm{R} \$$ & $3.787,15$ & $\mathrm{R} \$$ & $3.787,15$ & $\mathrm{R} \$$ & $3.787,15$ \\
\hline & $\mathrm{R} \$ /$ mês & $\mathrm{R} \$$ & $3.787,15$ & $\mathrm{R} \$$ & $3.787,15$ & $\mathrm{R} \$$ & $3.787,15$ \\
\hline \multirow{3}{*}{ Aux.Tráfego } & H/ mês & \multicolumn{2}{|r|}{1} & \multicolumn{2}{|c|}{1} & \multicolumn{2}{|r|}{1} \\
\hline & $\mathrm{R} \$ / \mathrm{H}$ & $\mathrm{R} \$$ & $1.335,99$ & $\mathrm{R} \$$ & $1.335,99$ & $\mathrm{R} \$$ & $1.335,99$ \\
\hline & $\mathrm{R} \$$ / mês & $\mathrm{R} \$$ & $1.335,99$ & $\mathrm{R} \$$ & $1.335,99$ & $\mathrm{R} \$$ & $1.335,99$ \\
\hline TOTAL mão-de-obra & $\mathrm{R} \$$ / mês & $\mathrm{R} \$$ & $7.607,70$ & $\mathrm{R} \$$ & $7.607,70$ & $\mathrm{R} \$$ & $7.607,70$ \\
\hline
\end{tabular}

8. VEÍCULO PARA SUPERVISÃO DOS SERVIÇOS
Pick-up Saveiro ou similar:
$\mathrm{R} \$ \quad 18.650,00$
Distância:
$100 \mathrm{~km} / \mathrm{dia}$
26,08 dias/mês

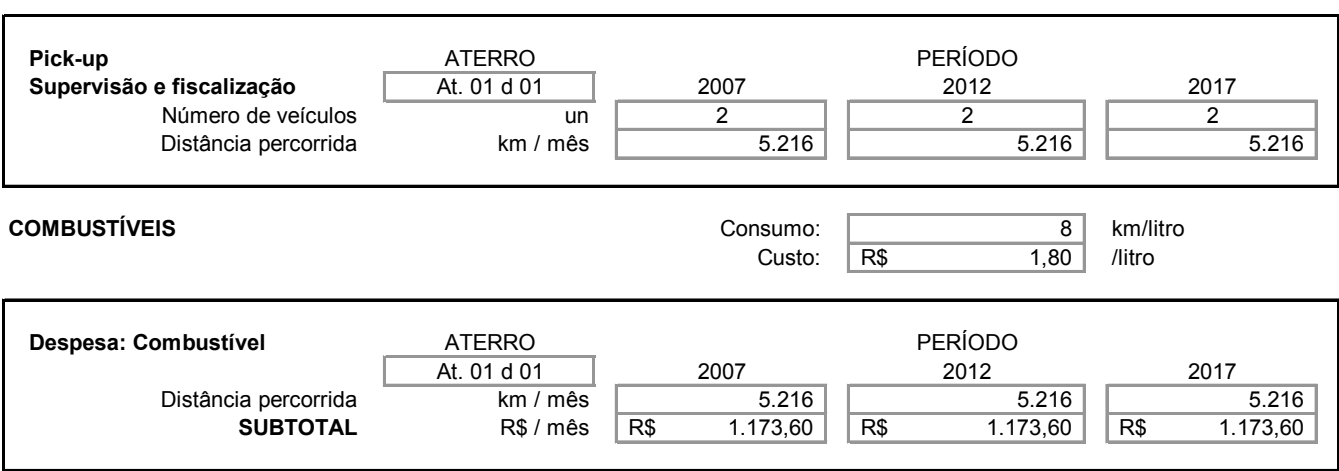

8.2. MANUTENÇÃO

\begin{tabular}{|c|c|c|c|c|}
\hline \multirow[b]{2}{*}{ Pick-up Saveiro ou similar: } & & \multirow{2}{*}{$\begin{array}{r}\text { Fator: } \\
\text { Vida útil: }\end{array}$} & $60 \%$ & \multirow[b]{2}{*}{ meses } \\
\hline & $18.650,00$ & & 60 & \\
\hline \multirow[t]{4}{*}{ Despesa: manutenção } & ATERRO & \multirow[b]{2}{*}{2007} & PERÍODO & \multirow[b]{2}{*}{2017} \\
\hline & At. $01 \mathrm{~d} 01$ & & 2012 & \\
\hline & Número de veículos & 2 & 2 & 2 \\
\hline & $\mathrm{R} \$$ /mês & 373,00 & 373,00 & 373,00 \\
\hline
\end{tabular}

8.3. PNEUS E CÂMARAS

\begin{tabular}{|c|c|c|c|c|}
\hline \multirow{3}{*}{$\begin{array}{r}\mathrm{km} / \text { ciclo } \\
\text { pneus e câmaras }\end{array}$} & 45.000 & \multirow{3}{*}{$\begin{array}{l}\text { Pneu } \\
\text { Câmara } \\
\text { R\$/conj. }\end{array}$} & $\mathrm{R} \$$ & 60,09 \\
\hline & \multirow[t]{2}{*}{4} & & $\mathrm{R} \$$ & 10,00 \\
\hline & & & $\mathrm{R} \$$ & 70,09 \\
\hline
\end{tabular}

\begin{tabular}{|c|c|c|c|c|c|c|c|}
\hline \multirow[t]{2}{*}{ Despesa: pneus e câmaras } & ATERRO & \multicolumn{6}{|c|}{ PERÍODO } \\
\hline & At. $01 \mathrm{~d} 01$ & \multicolumn{2}{|c|}{2007} & & & \multicolumn{2}{|c|}{2017} \\
\hline & $\mathrm{km} / \mathrm{mês}$ & & 5.216 & & 5.216 & & 5.216 \\
\hline SUBTOTAL & $\mathrm{R} \$$ / mês & $\mathrm{R} \$$ & 32,50 & $\mathrm{R} \$$ & 32,50 & $\mathrm{R} \$$ & 32,50 \\
\hline
\end{tabular}


Planilha 06 - Coleta: At. 01 d 01 da Situação 11 (cont.)

8.4. LUBRIFICAÇÃO E LAVAGEM
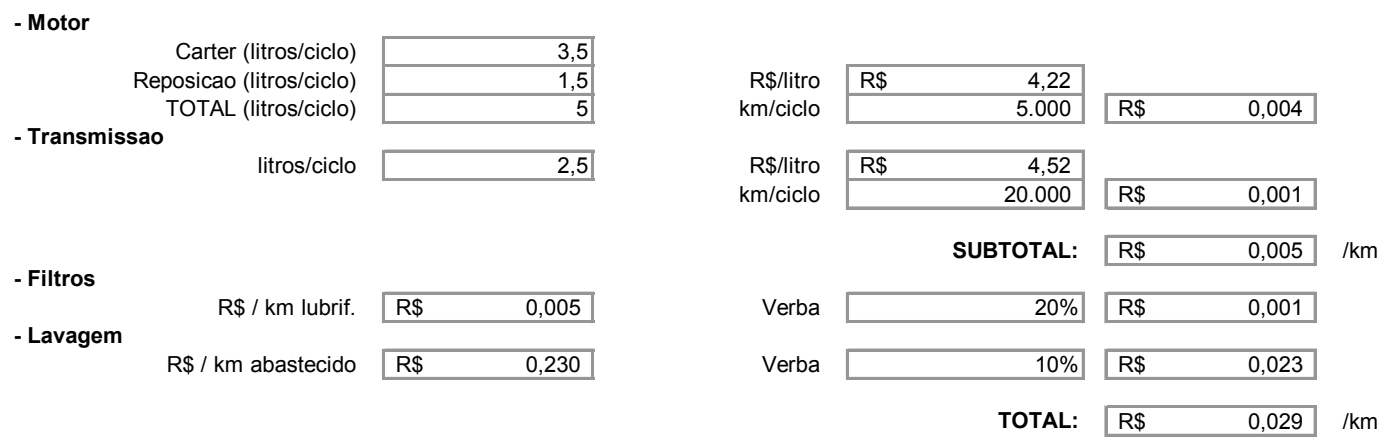

\begin{tabular}{|c|c|c|c|c|c|c|c|}
\hline \multirow{3}{*}{ Despesa: lubrif. e lavagem } & ATERRO & \multicolumn{6}{|c|}{ PERÍODO } \\
\hline & At. $01 \mathrm{~d} 01$ & & & & & & \\
\hline & $\mathrm{km} / \mathrm{mês}$ & & 5.216 & & 5.216 & & 5.216 \\
\hline SUBTOTAL & $\mathrm{R} \$$ / mês & $\mathrm{R} \$$ & 151,26 & $\mathrm{R} \$$ & 151,26 & $\mathrm{R} \$$ & 151,26 \\
\hline
\end{tabular}

8.5. LICENCIAMENTO E SEGUROS

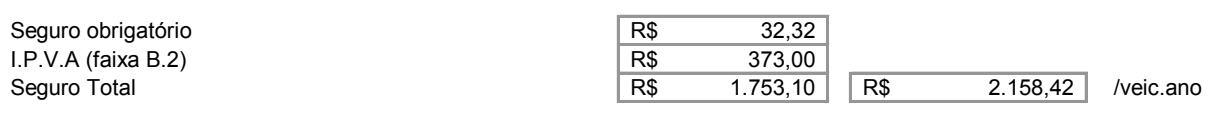

\begin{tabular}{|c|c|c|c|c|c|c|c|}
\hline \multirow[t]{3}{*}{ Despesa: licenc. e seguros } & ATERRO & \multicolumn{6}{|c|}{ PERÍODO } \\
\hline & At. $01 \mathrm{~d} 01$ & \multicolumn{2}{|c|}{2007} & \multirow{2}{*}{\multicolumn{2}{|c|}{2012}} & \multicolumn{2}{|c|}{2017} \\
\hline & Número de veículos & \multicolumn{2}{|c|}{2} & & & \multicolumn{2}{|c|}{2} \\
\hline SUBTOTAL & $\mathrm{R} \$ /$ mês & $\mathrm{R} \$$ & 359,74 & $\mathrm{R} \$$ & 359,74 & $\mathrm{R} \$$ & 359,74 \\
\hline
\end{tabular}

8.6. DEPRECIACAO

\begin{tabular}{|c|c|c|c|c|c|}
\hline & Valor Residual & Vida útil (meses) & \multicolumn{2}{|c|}{ Valor ( $R \$ /$ veic) } & \multirow[b]{2}{*}{ (s/ pneus e câmaras) } \\
\hline Pick-up Saveiro ou similar: & $35 \%$ & 60 & $\mathrm{R} \$$ & $18.369,64$ & \\
\hline \multirow{4}{*}{ Despesa: depreciação } & ATERRO & \multirow[b]{2}{*}{2007} & \multicolumn{2}{|c|}{ PERÍODO } & \multirow[b]{2}{*}{2017} \\
\hline & At. $01 \mathrm{~d} 01$ & & \multicolumn{2}{|c|}{2012} & \\
\hline & Número de veículos & 2 & & 2 & 2 \\
\hline & $\mathrm{R} \$$ / mês & 398,01 & $\mathrm{R} \$$ & 398,01 & 398,01 \\
\hline
\end{tabular}

8.7. CUSTO DE CAPITAL (remuneração)

\begin{tabular}{|c|c|c|c|c|c|c|}
\hline $\begin{array}{ll} & C= \\
\text { Coef. Remun.(/mês) } & C=\end{array}$ & {$[(2+(n-1)(k+1))$} & $4 \mathrm{n}] \mathrm{j}$, ou & & $\frac{\text { Juros }}{2 \%}$ & \multirow{2}{*}{\multicolumn{2}{|c|}{ Coef. Remun. (/mês }} \\
\hline \multirow[b]{2}{*}{ Pick-up Saveiro ou similar: } & $\mathrm{k}=$ Valor Residual & $\mathrm{n}=$ Vida útil (anos) & \multicolumn{2}{|c|}{ Valor (R\$/veic) } & & \\
\hline & $35 \%$ & 5 & $\mathrm{R} \$$ & $18.650,00$ & & 007400 \\
\hline \multirow[t]{2}{*}{ Despesa: custo capital } & ATERRO & \multirow{3}{*}{$\frac{2007}{2}$} & \multicolumn{2}{|c|}{ PERÍODO } & & \\
\hline & At. $01 \mathrm{~d} 01$ & & \multirow{2}{*}{\multicolumn{2}{|c|}{2}} & \multicolumn{2}{|c|}{2017} \\
\hline \multirow{2}{*}{$\begin{array}{r}\text { Operação } \\
\text { SUBTOTAL }\end{array}$} & Número de veículos & & & & \multicolumn{2}{|c|}{2} \\
\hline & $\mathrm{R} \$ /$ mês & 276,02 & $\mathrm{R} \$$ & 276,02 & $\mathrm{R} \$$ & 276,02 \\
\hline
\end{tabular}

8.8. RESUMO - VEÍCULO PARA SUPERVISÃO DOS SERVIÇOS

\begin{tabular}{|c|c|c|c|c|c|c|c|}
\hline Despesas: veículos & $\begin{array}{c}\text { ATERRO } \\
\text { At. } 01 \text { d } 01\end{array}$ & \multicolumn{2}{|c|}{2007} & & $\begin{array}{l}\text { DO } \\
2\end{array}$ & \multicolumn{2}{|c|}{2017} \\
\hline \multirow{8}{*}{$\begin{array}{l}\text { CONSUMO COMBUSTIVEL } \\
\text { MANUTENÇÃO } \\
\text { PNEUS E CÂMARAS } \\
\text { LUBRIFICAÇÃO E LAVAGEM } \\
\text { LICENCIAMENTO E SEGUROS } \\
\text { DEPRECIAÇÃO } \\
\text { CUSTO DE CAPITAL (remuneração) } \\
\text { TOTAL Veículos }\end{array}$} & & $\mathrm{R} \$$ & $1.173,60$ & $\mathrm{R} \$$ & $1.173,60$ & $\mathrm{R} \$$ & $1.173,60$ \\
\hline & & $\mathrm{R} \$$ & 373,00 & $\mathrm{R} \$$ & 373,00 & $\mathrm{R} \$$ & 373,00 \\
\hline & & $\mathrm{R} \$$ & 32,50 & $\mathrm{R} \$$ & 32,50 & $\mathrm{R} \$$ & 32,50 \\
\hline & & $\mathrm{R} \$$ & 151,26 & $\mathrm{R} \$$ & 151,26 & $\mathrm{R} \$$ & 151,26 \\
\hline & & $\mathrm{R} \$$ & 359,74 & $\mathrm{R} \$$ & 359,74 & $\mathrm{R} \$$ & 359,74 \\
\hline & & $\mathrm{R} \$$ & 398,01 & $\mathrm{R} \$$ & 398,01 & $\mathrm{R} \$$ & 398,01 \\
\hline & & $\mathrm{R} \$$ & 276,02 & $\mathrm{R} \$$ & 276,02 & $\mathrm{R} \$$ & 276,02 \\
\hline & $\mathrm{R} \$$ / mês & $\mathrm{R} \$$ & $2.764,13$ & $\mathrm{R} \$$ & $2.764,13$ & $\mathrm{R} \$$ & $2.764,13$ \\
\hline
\end{tabular}


Planilha 06 - Coleta: At. 01 d 01 da Situação 11 (cont.)

9. RESUMO DOS CUSTOS DE SUPERVISÃO

\begin{tabular}{|c|c|c|c|c|c|c|c|}
\hline \multirow{4}{*}{\begin{tabular}{|c} 
Despesas de supervisão \\
MÃO-DE-OBRA DE SUPERVISÃO \\
VEÍCULO PARA SUPERVISÃO DOS S \\
TOTAL Supervisáo
\end{tabular}} & $\begin{array}{c}\text { ATERRO } \\
\text { At. } 01 \mathrm{~d} 01\end{array}$ & \multicolumn{6}{|c|}{ PERÍODO } \\
\hline & & $\mathrm{R} \$$ & $7.607,70$ & $\mathrm{R} \$$ & $7.607,70$ & $\mathrm{R} \$$ & $7.607,70$ \\
\hline & SERVIÇOS & $\mathrm{R} \$$ & $2.764,13$ & $\mathrm{R} \$$ & $2.764,13$ & $\mathrm{R} \$$ & $2.764,13$ \\
\hline & $\mathrm{R} \$$ / mês & $\mathrm{R} \$$ & $10.371,83$ & $\mathrm{R} \$$ & $10.371,83$ & $\mathrm{R} \$$ & $10.371,83$ \\
\hline
\end{tabular}

10. DESPESAS DE ADMINISTRACAO

$28 \%$ sobre parte do custo direto e indireto para cobrir despesas com honorários, salários e ordenados, taxas, despesas gerais como água,

Taxa de Administração: $28 \%$ luz, telefones, impressos e outras.

\begin{tabular}{|c|c|c|c|c|c|c|c|}
\hline \multirow{2}{*}{ Despesas de administração } & ATERRO & \multicolumn{6}{|c|}{ PERÍODO } \\
\hline & At. $01 \mathrm{~d} 01$ & \multicolumn{2}{|r|}{2007} & \multicolumn{2}{|c|}{2012} & \multicolumn{2}{|r|}{2017} \\
\hline DESPESAS DE OPERAÇÃO & \multirow{4}{*}{$\mathrm{R} \$$ / mês } & $\mathrm{R} \$$ & $156.618,41$ & $\mathrm{R} \$$ & $157.558,97$ & $\mathrm{R} \$$ & $158.368,07$ \\
\hline DESPESAS DE SUPERVISÃO & & $\mathrm{R} \$$ & $10.371,83$ & $\mathrm{R} \$$ & $10.371,83$ & $\mathrm{R} \$$ & $10.371,83$ \\
\hline TOTAL (Oper.+Superv.) & & $\mathrm{R} \$$ & $166.990,24$ & $\mathrm{R} \$$ & $167.930,80$ & $\mathrm{R} \$$ & $168.739,90$ \\
\hline DESPESAS DE ADMINISTRAÇÃO & & $\mathrm{R} \$$ & $46.757,27$ & $\mathrm{R} \$$ & $47.020,62$ & $\mathrm{R} \$$ & $47.247,17$ \\
\hline
\end{tabular}

11. BENEFICIO

Benefício $\quad 0,00 \%$ sobre o total dos custos

\begin{tabular}{|c|c|c|c|c|c|c|c|}
\hline \multirow[t]{2}{*}{ Benefício } & ATERRO & \multicolumn{6}{|c|}{ PERÍODO } \\
\hline & At. $01 \mathrm{~d} 01$ & \multicolumn{2}{|r|}{2007} & \multicolumn{2}{|c|}{2012} & \multicolumn{2}{|r|}{2017} \\
\hline DESPESAS DE OPER.+SUPERV. & \multirow{4}{*}{$\mathrm{R} \$$ / mês } & $\mathrm{R} \$$ & $166.990,24$ & $\mathrm{R} \$$ & $167.930,80$ & $\mathrm{R} \$$ & $168.739,90$ \\
\hline DESPESAS DE ADMINISTRAÇÃO & & $\mathrm{R} \$$ & $46.757,27$ & $\mathrm{R} \$$ & $47.020,62$ & $\mathrm{R} \$$ & $47.247,17$ \\
\hline TOTAL (Oper.+Superv.+Admin.) & & $\mathrm{R} \$$ & $213.747,51$ & $\mathrm{R} \$$ & $214.951,42$ & $\mathrm{R} \$$ & $215.987,07$ \\
\hline BENEFÍCIO & & $\mathrm{R} \$$ & - & $\mathrm{R} \$$ & - & $\mathrm{R} \$$ & - \\
\hline
\end{tabular}

12. FATURAMENTO MENSAL (f)

\begin{tabular}{|c|c|c|c|c|c|c|c|}
\hline \multirow{7}{*}{\begin{tabular}{l}
\multicolumn{1}{c}{ Faturamento } \\
DESPESAS DE OPERAÇÃO \\
DESPESAS DE SUPERVISÃO \\
DESPESAS DE ADMINISTRAÇÃO \\
BENEFÍCIO \\
FATURAMENTO
\end{tabular}} & \multirow{2}{*}{$\begin{array}{c}\text { ATERRO } \\
\text { At. } 01 \mathrm{~d} 01\end{array}$} & \multicolumn{6}{|c|}{ PERÍODO } \\
\hline & & \multicolumn{2}{|r|}{2007} & \multicolumn{2}{|c|}{2012} & \multicolumn{2}{|r|}{2017} \\
\hline & & $\mathrm{R} \$$ & $156.618,41$ & $\mathrm{R} \$$ & $157.558,97$ & $\mathrm{R} \$$ & $158.368,07$ \\
\hline & & $\mathrm{R} \$$ & $10.371,83$ & $\mathrm{R} \$$ & $10.371,83$ & $\mathrm{R} \$$ & $10.371,83$ \\
\hline & & $\mathrm{R} \$$ & $46.757,27$ & $\mathrm{R} \$$ & $47.020,62$ & $\mathrm{R} \$$ & $47.247,17$ \\
\hline & & $\mathrm{R} \$$ & - & $\mathrm{R} \$$ & - & $\mathrm{R} \$$ & - \\
\hline & $\mathrm{R} \$$ / mês & $\mathrm{R} \$$ & $213.747,51$ & $\mathrm{R} \$$ & $214.951,42$ & $\mathrm{R} \$$ & $215.987,07$ \\
\hline
\end{tabular}

13. ISS, PIS, COFINS e CPMF

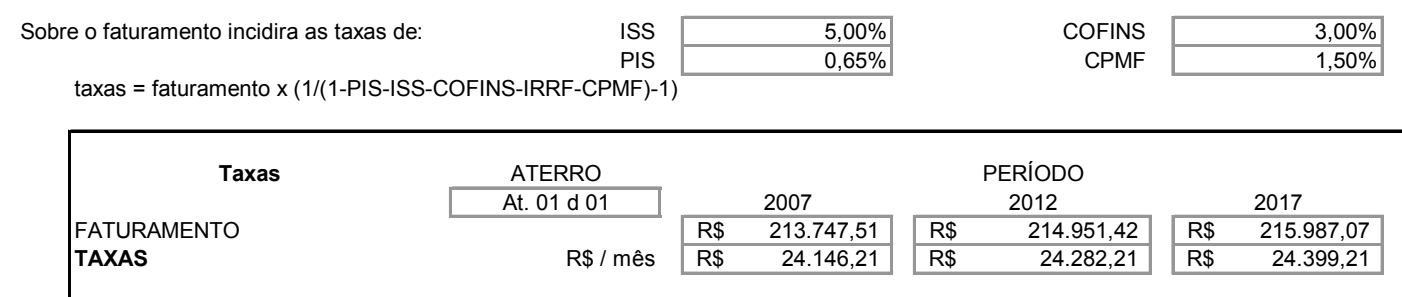

\section{CUSTO MENSAL}

\begin{tabular}{|c|c|c|c|c|c|c|c|}
\hline \multirow[t]{2}{*}{ Custo mensal } & ATERRO & \multicolumn{6}{|c|}{ PERÍODO } \\
\hline & At. $01 \mathrm{~d} 01$ & & 2007 & & 012 & & 2017 \\
\hline \multirow{3}{*}{$\begin{array}{l}\text { FATURAMENTO } \\
\text { TAXAS } \\
\text { TOTAL CUSTO }\left(\mathbf{C}_{\mathrm{t}}\right)\end{array}$} & \multirow[b]{3}{*}{$\mathrm{R} \$$ / mês } & $\mathrm{R} \$$ & $213.747,51$ & $\mathrm{R} \$$ & $214.951,42$ & $\mathrm{R} \$$ & $215.987,07$ \\
\hline & & $\mathrm{R} \$$ & $24.146,21$ & $\mathrm{R} \$$ & $24.282,21$ & $\mathrm{R} \$$ & $24.399,21$ \\
\hline & & $\mathrm{R} \$$ & $237.893,72$ & $\mathrm{R} \$$ & $239.233,63$ & $\mathrm{R} \$$ & $240.386,28$ \\
\hline
\end{tabular}


Planilha 06 - Coleta: At. 01 d 01 da Situação 11 (cont.)

15. CUSTO POR TONELADA DE LIXO COLETADO

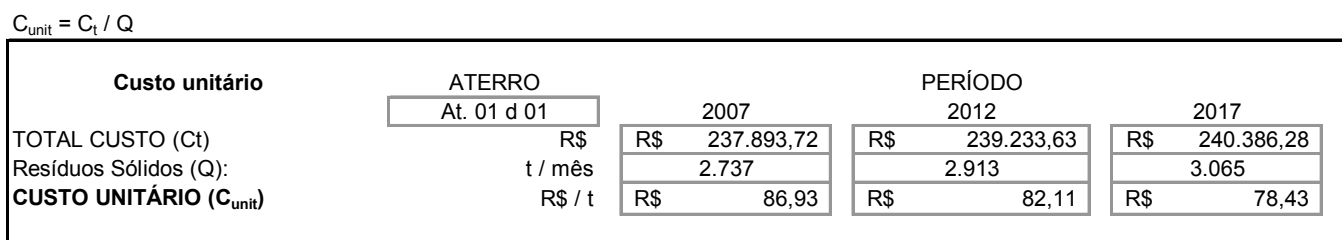

NOTA: ESTE PREÇO FOI CALCULADO COM BASE NOS VALORES VIGENTES EM

\section{TRANSPORTE FORA DOS LIMITES DA CIDADE}

Cálculo do custo da tonelada por quilômetro para transporte de lixo para o ponto de destinação indicado, fora do perímetro da Cidade (Aterro ou Estação de transferência - com o veículo coletor)

Para efeito de cálculo serao consideradas somente os gastos reais incidentes sobre o transporte propriamente dito, ou seja,

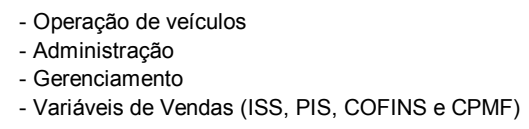

uma vez que os gastos relativos à mão de obra direta e indireta, uniformes, fiscalização, etc... já estão incluídas no custo da coleta.

16.1. QUILOMETRAGEM TRANSPORTE

dias /mês 26,08

\begin{tabular}{|c|c|c|c|c|}
\hline \multirow{2}{*}{$\mathrm{Km}$ percorrido transporte } & ATERRO & & PERÍODO & \\
\hline & At. $01 \mathrm{~d} 01$ & 2007 & 2012 & 2017 \\
\hline \multirow[b]{2}{*}{ SUBTOTAL } & $\mathrm{km} / \mathrm{dia}$ & 171 & 191 & 210 \\
\hline & $\mathrm{km} /$ mês & 4.448 & 4.985 & 5.478 \\
\hline
\end{tabular}

16.2. OPERAÇÃo DE VÉ́CULO

- Combustível

- Manutenção

Despesas consideradas anteriormente.

$\mathrm{R} \$$ /litro $\mathrm{R} \$ \quad 0,90$

\begin{tabular}{|c|c|}
\hline 180 & 0,500 \\
\hline
\end{tabular}

- Pneus e Câmaras

- Lubrificação

$\mathrm{R} \$$ /conjunto $\mathrm{km} / \mathrm{ciclo}$

\begin{tabular}{|c|c|c|c|}
\hline & \multirow[t]{2}{*}{$\mathrm{R} \$$} & \multirow[t]{2}{*}{ - } \\
\hline $\mathrm{R} \$$ & $4.834,62$ & & \\
\hline & 36.000 & $\mathrm{R} \$$ & 0,130 \\
\hline $\mathrm{R} \$$ & 0,083 & $\mathrm{R} \$$ & 0,083 \\
\hline
\end{tabular}

- Licenciamento e Seguros

Despesas consideradas anteriormente.

$\mathrm{R} \$$

- Depreciação

Despesas consideradas anteriormente.

$\mathrm{R} \$$

- Despesas de Capital

Despesas consideradas anteriormente.

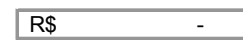

\begin{tabular}{lll}
\hline $\mathrm{R} \$$ & $0,713 \quad \mathrm{~km}$
\end{tabular}

16.3. ADMINISTRACAO

\begin{tabular}{|c|c|}
\hline \multirow{2}{*}{ Taxa de Administração: } & 28,0 \\
\hline & 0,713 \\
\hline
\end{tabular}

$\mathrm{R} \$ \quad 0,200 \quad / \mathrm{km}$

16.4. BENEFíCIO

Benefício sobre o total dos custos excluindo depreciações

Custos diretos e indiretos (excluindo depreciações)

Operação da Frota

$\mathrm{R} \$ \quad 0,713$

Despesas de Administração

$\mathrm{R} \$ \quad 0,200$

$\mathrm{R} \$$ $/ \mathrm{km}$ 
Planilha 06 - Coleta: At. 01 d 01 da Situação 11 (cont.)

16.5. FATURAMENTO MENSAL (f)

Operação da Frota

Despesas de Administração

Benefício

\begin{tabular}{|lc|}
\hline $\mathrm{R} \$$ & 0,713 \\
\hline $\mathrm{R} \$$ & 0,200 \\
\hline $\mathrm{R} \$$ & - \\
\hline
\end{tabular}

$\mathrm{R} \$ \quad 0,913 \quad / \mathrm{km}$

16.6. VARIÁVEIS DE VENDAS

Sobre o faturamento incidira as taxas de:

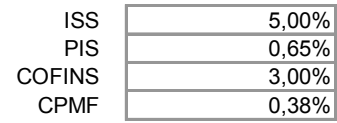

16.7, CUSTO MENSAL (Ct)

$\mathrm{C}_{\mathrm{t}}=$ faturamento + taxas

$C t=f /(1-$ PIS - ISS - COFINS - CPMF- IRPJ. $)=$

$\mathrm{R} \$$

$1,000 \quad / \mathrm{km}$

\begin{tabular}{|c|c|c|c|c|c|c|c|}
\hline \multirow[t]{2}{*}{ Custo mensal } & ATERRO & \multicolumn{6}{|c|}{ PERÍODO } \\
\hline & At. 01 d 01 & \multicolumn{2}{|c|}{2007} & \multicolumn{2}{|c|}{2012} & \multicolumn{2}{|c|}{2017} \\
\hline \multirow{3}{*}{$\begin{array}{l}\text { QUILOMETRAGEM TRANSPORTE } \\
\text { CUSTO MENSAL }(\mathrm{Ct}) \\
\text { TOTAL CUSTO }\left(\mathbf{C}_{\mathrm{t}}\right)\end{array}$} & $\mathrm{km} /$ mês & \multicolumn{2}{|c|}{4.448} & \multicolumn{2}{|c|}{4.985} & & \\
\hline & $\mathrm{R} \$ / \mathrm{km}$ & $\mathrm{R} \$$ & 1,000 & $\mathrm{R} \$$ & 1,000 & $\mathrm{R} \$$ & 1,000 \\
\hline & $\mathrm{R} \$$ / mês & $\mathrm{R} \$$ & $4.449,33$ & $\mathrm{R} \$$ & $4.986,05$ & $\mathrm{R} \$$ & $5.479,06$ \\
\hline
\end{tabular}

16.8. CUSTO POR TONELADA DE LIXO COLETADO

\begin{tabular}{|c|c|c|c|c|c|c|c|}
\hline \multirow[t]{2}{*}{ Custo unitário } & \multirow{2}{*}{$\begin{array}{c}\text { ATERRO } \\
\text { At. } 01 \mathrm{~d} 01\end{array}$} & \multirow{2}{*}{\multicolumn{2}{|c|}{2007}} & \multicolumn{2}{|c|}{ PERÍODO } & \multirow{2}{*}{\multicolumn{2}{|c|}{2017}} \\
\hline & & & & & & & \\
\hline \multirow{3}{*}{$\begin{array}{l}\text { TOTAL CUSTO (Ct) } \\
\text { Resíduos Sólidos (Q): } \\
\left.\text { CUSTO UNITÁRIO ( } \mathbf{C}_{\text {unit }}\right)\end{array}$} & $\mathrm{R} \$$ / mês & $\mathrm{R} \$$ & $4.449,33$ & $\mathrm{R} \$$ & $4.986,05$ & $\mathrm{R} \$$ & 79,06 \\
\hline & $t /$ mês & \multicolumn{2}{|c|}{2.737} & \multicolumn{2}{|c|}{2.913} & \multicolumn{2}{|c|}{3.065} \\
\hline & $\mathrm{R} \$ / \mathrm{t}$ & $\mathrm{R} \$$ & 1,63 & $\mathrm{R} \$$ & 1,71 & $\mathrm{R} \$$ & 1,79 \\
\hline
\end{tabular}

NOTA: ESTE PREÇO FOI CALCULADO COM BASE NOS VALORES VIGENTES EM 
Planilha 07 - Transporte At $\rightarrow$ ETs $\rightarrow$ At: At. 01 d 01 da Situação 11

TRANSPORTE DE RESÍDUOS DOMICILIARES DA ESTAÇÃO DE TRANSFERÊNCIA ATÉ O ATERRO

CUSTO DOS SERVIÇOS

\begin{tabular}{l} 
Data base: \\
\hline Junho de 2002
\end{tabular}

1. DADOS BÁSICOS NECESSÁRIOS

1.1. QUANTIDADE MÉdIA DE RESíduOS PARA SER COLETADA

\begin{tabular}{|c|c|c|c|c|}
\hline & ATERRO & & PERÍODO & \\
\hline & At. $01 \mathrm{~d} 01$ & 2007 & 2012 & 2017 \\
\hline Resíduos Sólidos (t/mês): & & 2.737 & 2.913 & 3.065 \\
\hline
\end{tabular}

1.2. NÚMERO DE DIAS ÚTEIS POR ANO

Descontados somente domingos

Descontados domingos e feriados

$\begin{aligned} 365 & \text { dias/ano } \\ 52 & \text { domingos/ano } \\ 313 & \text { dias úteis/ano } \\ 26,08 & \text { dias úteis/mes }\end{aligned}$

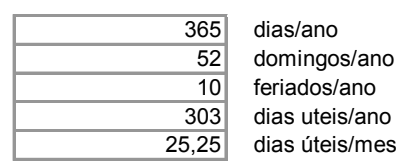

1.3. COLETA EM JORNADA NORMAL
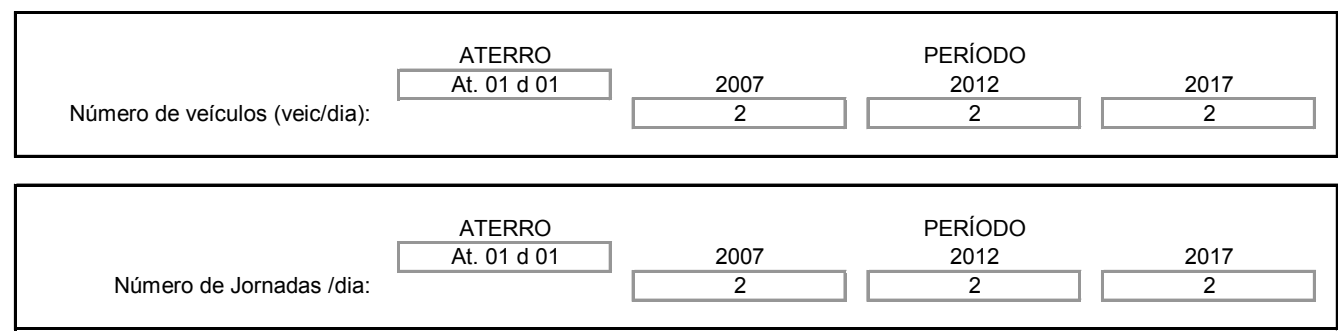

\begin{tabular}{|c|c|c|c|c|}
\hline & ATERRO & & PERÍODO & \\
\hline & At. $01 \mathrm{~d} 01$ & 2007 & 2012 & 2017 \\
\hline Horas extras totais $(\mathrm{h})$ : & & 0,00 & 0,00 & 0,00 \\
\hline
\end{tabular}

2. DIMENSIONAMENTO DA FROTA E DO PESSOAL

\subsection{FROTA MÉDIA}

Número de veículos (veic/dia)

$$
\begin{array}{r}
\text { Operação: } \\
\text { Reserva: }
\end{array}
$$

TOTAL Necessário:
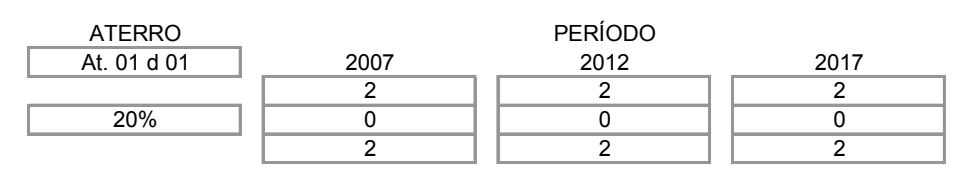

2.2. MÃO-DE-OBRA DIRETA

Guarnição/Veículo:

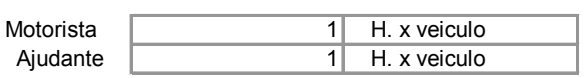

MOTORISTA

\begin{tabular}{|c|c|c|c|c|}
\hline \multirow{2}{*}{ Motorista (H/dia) } & ATERRO & & PERÍODO & \\
\hline & At. $01 \mathrm{~d} 01$ & 2007 & 2012 & 2017 \\
\hline \multirow{3}{*}{$\begin{array}{r}\text { Operaç̧ão: } \\
\text { Reserva Absenteismo: } \\
\text { TOTAL Necessário: }\end{array}$} & & 2 & 2 & 2 \\
\hline & $10 \%$ & 0 & 0 & 0 \\
\hline & & 2 & 2 & 2 \\
\hline
\end{tabular}


Planilha 07 - Transporte At $\rightarrow$ ETs $\rightarrow$ At: At. 01 d 01 da Situação 11 (cont.)

\begin{tabular}{|c|c|c|c|c|}
\hline \multirow[t]{2}{*}{ Coletores (H/dia) } & ATERRO & & PERÍODO & \\
\hline & At. $01 \mathrm{~d} 01$ & 2007 & 2012 & 2017 \\
\hline \multirow{2}{*}{$\begin{array}{r}\text { Operação: } \\
\text { Reserva Absenteismo: }\end{array}$} & & 2 & 2 & 2 \\
\hline & $10 \%$ & 0 & 0 & 0 \\
\hline \multicolumn{2}{|l|}{ TOTAL Necessário: } & 2 & 2 & 2 \\
\hline
\end{tabular}

3. CUSTO DA MÃO-DE-OBRA DIRETA

MOTORISTA

\begin{tabular}{|c|c|c|c|c|c|c|c|}
\hline \multirow{4}{*}{$\begin{array}{r}\text { Salário } \\
\text { Horas Mensais }\end{array}$} & \multirow{2}{*}{$\begin{array}{c}\text { ATERRO } \\
\text { At. } 01 \text { d } 01 \\
\end{array}$} & \multicolumn{6}{|c|}{ PERÍODO } \\
\hline & & \multicolumn{2}{|c|}{2007} & \multicolumn{2}{|c|}{2012} & \multicolumn{2}{|c|}{2017} \\
\hline & \multirow[t]{2}{*}{$\mathrm{R} \$ /$ hora } & $\mathrm{R} \$$ & 2,53 & $\mathrm{R} \$$ & 2,53 & $\mathrm{R} \$$ & 2,53 \\
\hline & & & 220 & & 220 & & 220 \\
\hline \multirow[b]{2}{*}{ Insalubridade } & \multirow[t]{2}{*}{ Salário Base } & $\mathrm{R} \$$ & 556,00 & $\mathrm{R} \$$ & 556,00 & $\mathrm{R} \$$ & 556,00 \\
\hline & & $\mathrm{R} \$$ & 40,00 & $\mathrm{R} \$$ & 40,00 & $\mathrm{R} \$$ & 40,00 \\
\hline \multirow{4}{*}{$\begin{array}{l}\text { Horas Extras } \\
\text { Feriado Diurno }\end{array}$} & \multirow[t]{3}{*}{ Subtotal } & $\mathrm{R} \$$ & 596,00 & $\mathrm{R} \$$ & 596,00 & $\mathrm{R} \$$ & 596,00 \\
\hline & & $\mathrm{R} \$$ & - & $\mathrm{R} \$$ & - & $\mathrm{R} \$$ & - \\
\hline & & $\mathrm{R} \$$ & 30,92 & $\mathrm{R} \$$ & 30,92 & $\mathrm{R} \$$ & 30,92 \\
\hline & \multirow[t]{6}{*}{ Salário Mensal } & $\mathrm{R} \$$ & 626,92 & $\mathrm{R} \$$ & 626,92 & $\mathrm{R} \$$ & 626,92 \\
\hline Salário Mensal com Encargos & & $\mathrm{R} \$$ & $1.127,26$ & $\mathrm{R} \$$ & $1.127,26$ & $\mathrm{R} \$$ & $1.127,26$ \\
\hline Vale Refeição & & $\mathrm{R} \$$ & 135,00 & $\mathrm{R} \$$ & 135,00 & $\mathrm{R} \$$ & 135,00 \\
\hline Vale Cesta & & $\mathrm{R} \$$ & 40,61 & $\mathrm{R} \$$ & 40,61 & $\mathrm{R} \$$ & 40,61 \\
\hline Convênio Médico & & $\mathrm{R} \$$ & 26,00 & $\mathrm{R} \$$ & 26,00 & $\mathrm{R} \$$ & 26,00 \\
\hline Vale Transporte & & $\mathrm{R} \$$ & 112,69 & $\mathrm{R} \$$ & 112,69 & $\mathrm{R} \$$ & 112,69 \\
\hline Custo Mensal Unitário & $\mathrm{R} \$ /$ mês & $\mathrm{R} \$$ & $1.441,56$ & $\mathrm{R} \$$ & $1.441,56$ & $\mathrm{R} \$$ & $1.441,56$ \\
\hline
\end{tabular}

\begin{tabular}{|c|c|c|c|c|c|c|c|}
\hline & ATERRO & \multicolumn{6}{|c|}{ PERÍODO } \\
\hline & At. $01 \mathrm{~d} 01$ & \multicolumn{2}{|c|}{2007} & \multicolumn{2}{|c|}{2012} & \multicolumn{2}{|c|}{2017} \\
\hline \multirow{2}{*}{$\begin{array}{r}\text { Salário } \\
\text { Horas Mensais }\end{array}$} & \multirow[t]{2}{*}{$\mathrm{R} \$$ /hora } & $\mathrm{R} \$$ & 1,62 & $\mathrm{R} \$$ & 1,62 & $\mathrm{R} \$$ & 1,62 \\
\hline & & & 220 & & 220 & & 220 \\
\hline \multirow{3}{*}{ Insalubridade } & \multirow[t]{2}{*}{ Salário Base } & $\mathrm{R} \$$ & 357,00 & $\mathrm{R} \$$ & 357,00 & $\mathrm{R} \$$ & 357,00 \\
\hline & & $\mathrm{R} \$$ & 40,00 & $\mathrm{R} \$$ & 40,00 & $\mathrm{R} \$$ & 40,00 \\
\hline & \multirow[t]{3}{*}{ Subtotal } & $\mathrm{R} \$$ & 397,00 & $\mathrm{R} \$$ & 397,00 & $\mathrm{R} \$$ & 397,00 \\
\hline \multirow{2}{*}{$\begin{array}{r}\text { Horas Extras } \\
\text { Feriado Diurno }\end{array}$} & & $\mathrm{R} \$$ & - & $\mathrm{R} \$$ & - & $\mathrm{R} \$$ & - \\
\hline & & $\mathrm{R} \$$ & 19,80 & $\mathrm{R} \$$ & 19,80 & $\mathrm{R} \$$ & 19,80 \\
\hline & \multirow[t]{6}{*}{ Salário Mensal } & $\mathrm{R} \$$ & 416,80 & $\mathrm{R} \$$ & 416,80 & $\mathrm{R} \$$ & 416,80 \\
\hline \multirow{6}{*}{$\begin{array}{r}\text { Salário Mensal com Encargos } \\
\text { Vale Refeição } \\
\text { Vale Cesta } \\
\text { Convênio Médico } \\
\text { Vale Transporte } \\
\text { Custo Mensal Unitário }\end{array}$} & & $\mathrm{R} \$$ & 749,45 & $\mathrm{R} \$$ & 749,45 & $\mathrm{R} \$$ & 749,45 \\
\hline & & $\mathrm{R} \$$ & 135,00 & $\mathrm{R} \$$ & 135,00 & $\mathrm{R} \$$ & 135,00 \\
\hline & & $\mathrm{R} \$$ & 40,61 & $\mathrm{R} \$$ & 40,61 & $\mathrm{R} \$$ & 40,61 \\
\hline & & $\mathrm{R} \$$ & 26,00 & $\mathrm{R} \$$ & 26,00 & $\mathrm{R} \$$ & 26,00 \\
\hline & & $\mathrm{R} \$$ & 124,63 & $\mathrm{R} \$$ & 124,63 & $\mathrm{R} \$$ & 124,63 \\
\hline & $\mathrm{R} \$ /$ mês & $\mathrm{R} \$$ & $1.075,69$ & $\mathrm{R} \$$ & $1.075,69$ & $\mathrm{R} \$$ & $1.075,69$ \\
\hline & \multicolumn{2}{|l|}{ Feriados e domingos } & $100 \%$ & \multicolumn{4}{|c|}{ VALE TRANSPORTE: } \\
\hline & \multirow{2}{*}{\multicolumn{2}{|c|}{$\begin{array}{r}\text { Horas Extras } \\
\text { Adic. Not. }(22 \mathrm{~h} \text { as } 5 \mathrm{~h})\end{array}$}} & $50 \%$ & \multicolumn{2}{|c|}{$\mathrm{R} \$$ / pasagem ônibus } & & 1,40 \\
\hline & & Adic.Not.(22h as $5 \mathrm{~h})$ & $20,00 \%$ & \multicolumn{2}{|c|}{ passagem/dia (media) } & & \multirow{2}{*}{$6.00 \%$} \\
\hline & \multicolumn{2}{|l|}{ Encargos Sociais } & $79,81 \%$ & \multicolumn{3}{|c|}{ A deduzir } & \\
\hline
\end{tabular}

3.1. CUSTO MENSAL

Despesa: mão-de-obra

MOTORISTA

TOTAL mão-de-obra
ATERRO At. $01 \mathrm{~d} 01$ $\mathrm{H} \$ / \mathrm{H}$ $\mathrm{R} \$ / \mathrm{mês}$

$\mathrm{H} /$ mês

$\mathrm{R} \$ / \mathrm{H}$

$\mathrm{R} \$ / \mathrm{mês}$ $\mathrm{R} \$ /$ mês

\begin{tabular}{|c|c|}
\hline \multicolumn{2}{|c|}{2007} \\
\hline \multicolumn{2}{|r|}{2} \\
\hline $\mathrm{R} \$$ & $1.441,56$ \\
\hline $\mathrm{R} \$$ & $2.883,12$ \\
\hline \multicolumn{2}{|r|}{2} \\
\hline $\mathrm{R} \$$ & $1.075,69$ \\
\hline $\mathrm{R} \$$ & $2.151,38$ \\
\hline $\mathrm{R} \$$ & $5.034,50$ \\
\hline
\end{tabular}

PERÍODO

\begin{tabular}{|cc|}
\multicolumn{2}{c}{2012} \\
\hline & 2 \\
\hline$R \$$ & $1.441,56$ \\
\hline$R \$$ & $2.883,12$ \\
\hline & 2 \\
\hline$R \$$ & $1.075,69$ \\
\hline$R \$$ & $2.151,38$ \\
\hline$R \$$ & $5.034,50$ \\
\hline
\end{tabular}

4. VEÍCULOS TRANSPORTE E.TRANSF.-ATERRO

4.1. QUILOMETRAGEM PERCORRIDA

dias /mês 26,08 
Planilha 07 - Transporte At $\rightarrow$ ETs $\rightarrow$ At: At. 01 d 01 da Situação 11 (cont.)

\begin{tabular}{|c|c|c|c|c|}
\hline \multirow[t]{2}{*}{ Km percorrido na coleta } & ATERRO & & PERÍODO & \\
\hline & At. $01 \mathrm{~d} 01$ & 2007 & 2012 & 2017 \\
\hline \multirow[b]{2}{*}{ SUBTOTAL } & $\mathrm{km} / \mathrm{dia}$ & 311 & 313 & 315 \\
\hline & $\mathrm{km} /$ mês & 8.113 & 8.159 & 8.215 \\
\hline
\end{tabular}

4.2. CONSUMO COMBUSTÍVEL

\begin{tabular}{|c|c|}
\hline ( & 0,90 \\
\hline
\end{tabular}

\begin{tabular}{|c|c|c|c|c|c|c|c|}
\hline \multirow{3}{*}{ Despesa: combustível } & ATERRO & \multicolumn{6}{|c|}{ PERÍODO } \\
\hline & At. $01 \mathrm{~d} 01$ & & & & 12 & & 17 \\
\hline & $\mathrm{km} /$ mês & & & & 59 & & 215 \\
\hline SUBTOTAL & $\mathrm{R} \$$ / mês & $\mathrm{R} \$$ & $4.056,39$ & $\mathrm{R} \$$ & $4.079,46$ & $\mathrm{R} \$$ & $4.107,68$ \\
\hline
\end{tabular}

4.3. MANUTENÇÃO

Veiculo Coletor-Compactador

\begin{tabular}{|c|c|c|c|c|c|}
\hline \multirow{2}{*}{$\begin{array}{r}\text { Caminhão VW TITAN } 263106 \times 4 \\
\text { Carrocerias (Chassis e reboque) }\end{array}$} & $\mathrm{R} \$$ & $110.000,00$ & & & \multirow{4}{*}{$\begin{array}{l}\text { do seu valor } \\
\text { meses }\end{array}$} \\
\hline & $\mathrm{R} \$$ & $63.000,00$ & $\mathrm{R} \$$ & $173.000,00$ & \\
\hline \multirow{2}{*}{\multicolumn{3}{|c|}{$\begin{array}{r}\text { e manutencao durante a vida util do veiculo corresponde a } \\
\text { Vida útil adotada }\end{array}$}} & & $85,00 \%$ & \\
\hline & & & & 120 & \\
\hline
\end{tabular}

\begin{tabular}{r|rr} 
O custo de manutencao durante a vida util do veiculo corresponde a & Vida útil adotada & $85,00 \%$ \\
& do seu valor. & 120 \\
& meses
\end{tabular}

\begin{tabular}{|c|c|c|c|c|c|c|c|}
\hline \multirow[t]{3}{*}{ Despesa: manutenção } & ATERRO & \multicolumn{6}{|c|}{ PERÍODO } \\
\hline & At. $01 \mathrm{~d} 01$ & \multirow{2}{*}{\multicolumn{2}{|c|}{$\begin{array}{c}2007 \\
2\end{array}$}} & & 12 & \multirow{2}{*}{\multicolumn{2}{|c|}{$\frac{2017}{2}$}} \\
\hline & Número de veículos & & & & 2 & & \\
\hline SUBTOTAL & $\mathrm{R} \$ /$ mês & $\mathrm{R} \$$ & $2.450,83$ & $\mathrm{R} \$$ & $2.450,83$ & $\mathrm{R} \$$ & $2.450,83$ \\
\hline
\end{tabular}

4.4. PNEUS E CÂMARAS

\begin{tabular}{|c|c|c|c|c|c|c|c|}
\hline \multicolumn{4}{|c|}{ Admite-se uma troca de pneus e duas recapagens a cada ciclo de } & & 36.000 & \multicolumn{2}{|c|}{ quilômetros } \\
\hline \multirow{6}{*}{$\begin{array}{r}1000 \times 20 " \times 16 \\
1000 \times 20 " \times 16 \\
\text { Câmaras } \\
\text { Recapagens } \\
\text { Protetores }\end{array}$} & & & & & & & \\
\hline & $10 x$ & $\mathrm{R} \$$ & $384,00=$ & $=\mathrm{R} \$$ & $3.840,00$ & & \\
\hline & $8 x$ & $\mathrm{R} \$$ & $384,00=$ & $=\mathrm{R} \$$ & $3.072,00$ & & \\
\hline & $18 x$ & $\mathrm{R} \$$ & $36,24=$ & $=\mathrm{R} \$$ & 652,32 & & \\
\hline & $18 x$ & $\mathrm{R} \$$ & $92,00=$ & $=\mathrm{R} \$$ & $1.656,00$ & & \\
\hline & $18 x$ & $\mathrm{R} \$$ & $12,35=$ & $=\mathrm{R} \$$ & 222,30 & $\mathrm{R} \$$ & $9.442,62$ \\
\hline \multirow[t]{3}{*}{ Despesa: pneus e câmaras } & ATERRO & & \multicolumn{2}{|c|}{ PERÍODO } & \multirow{2}{*}{\multicolumn{2}{|c|}{2017}} \\
\hline & At. $01 \mathrm{~d} 01$ & \multicolumn{2}{|c|}{2007} & \multicolumn{2}{|c|}{2012} & & \\
\hline & $\mathrm{km} / \mathrm{mês}$ & \multicolumn{2}{|c|}{8113} & \multicolumn{2}{|c|}{8159} & \multicolumn{2}{|c|}{8215} \\
\hline SUBTOTAL & $\mathrm{R} \$$ / mês & $\mathrm{R} \$$ & $2.127,94$ & $\mathrm{R} \$$ & $2.140,05$ & $\mathrm{R} \$$ & $2.154,85$ \\
\hline
\end{tabular}

4.5. LUBRIFICAÇÃO E LAVAGEM

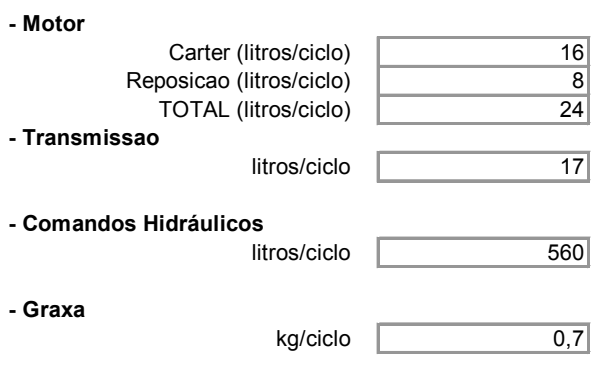

- Filtros

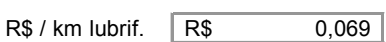

\begin{tabular}{|c|c|c|c|c|}
\hline \multirow{2}{*}{$\begin{array}{r}\mathrm{R} \$ / \text { litro } \\
\mathrm{km} / \mathrm{ciclo}\end{array}$} & $\mathrm{R} \$$ & 4,22 & & \\
\hline & & 5.000 & $\mathrm{R} \$$ & 0,020 \\
\hline \multirow{2}{*}{$\begin{array}{r}\mathrm{R} \$ / \text { litro } \\
\mathrm{km} / \text { ciclo }\end{array}$} & $\mathrm{R} \$$ & 4,52 & & \\
\hline & & 20.000 & $\mathrm{R} \$$ & 0,004 \\
\hline \multirow{2}{*}{$\begin{array}{r}\mathrm{R} \$ / \text { litro } \\
\mathrm{km} / \mathrm{ciclo}\end{array}$} & $\mathrm{R} \$$ & 3,34 & & \\
\hline & & 50.000 & $\mathrm{R} \$$ & 0,037 \\
\hline \multirow{3}{*}{$\begin{array}{r}\mathrm{R} \$ / \mathrm{kg} \\
\mathrm{km} / \text { ciclo }\end{array}$} & $\mathrm{R} \$$ & 3,46 & & \\
\hline & & 300 & $\mathrm{R} \$$ & 0,008 \\
\hline & & SUBTOTAL: & $\mathrm{R} \$$ & 0,069 \\
\hline \multirow[t]{2}{*}{ Verba } & & $20 \%$ & $\mathrm{R} \$$ & 0,014 \\
\hline & & TOTAL: & $\mathrm{R} \$$ & 0,083 \\
\hline
\end{tabular}


Planilha 07 - Transporte At $\rightarrow$ ETs $\rightarrow$ At: At. 01 d 01 da Situação 11 (cont.)

\subsection{RESUMO VEÍCULOS TRANSPORTE E.TRANSF.-ATERRO}

\begin{tabular}{|c|c|c|c|c|c|c|c|}
\hline \multirow{10}{*}{\begin{tabular}{l}
\multicolumn{1}{c}{ Despesas: veículos } \\
CONSUMO COMBUSTÍVEL \\
MANUTENÇÃO \\
PNEUS E CÂMARAS \\
LUBRIFICAÇÃO E LAVAGEM \\
LICENCIAMENTO E SEGUROS \\
DEPRECIAÇÃO \\
CUSTO DE CAPITAL (remuneração) \\
\multicolumn{2}{c}{ TOTAL Veículos }
\end{tabular}} & \multirow{2}{*}{$\begin{array}{c}\text { ATERRO } \\
\text { At. } 01 \mathrm{~d} 01\end{array}$} & \multicolumn{6}{|c|}{ PERÍODO } \\
\hline & & \multicolumn{2}{|c|}{2007} & \multicolumn{2}{|c|}{2012} & \multicolumn{2}{|c|}{2017} \\
\hline & & $\mathrm{R} \$$ & $4.056,39$ & $\mathrm{R} \$$ & $4.079,46$ & $\mathrm{R} \$$ & $4.107,68$ \\
\hline & & $\mathrm{R} \$$ & $2.450,83$ & $\mathrm{R} \$$ & $2.450,83$ & $\mathrm{R} \$$ & $2.450,83$ \\
\hline & & $\mathrm{R} \$$ & $2.127,94$ & $\mathrm{R} \$$ & $2.140,05$ & $\mathrm{R} \$$ & $2.154,85$ \\
\hline & & $\mathrm{R} \$$ & 803,76 & $\mathrm{R} \$$ & 807,59 & $\mathrm{R} \$$ & 812,28 \\
\hline & & $\mathrm{R} \$$ & $2.599,86$ & $\mathrm{R} \$$ & $2.599,86$ & $\mathrm{R} \$$ & $2.599,86$ \\
\hline & & $\mathrm{R} \$$ & $2.319,64$ & $\mathrm{R} \$$ & $2.319,64$ & $\mathrm{R} \$$ & $2.319,64$ \\
\hline & & $\mathrm{R} \$$ & $2.149,15$ & $\mathrm{R} \$$ & $2.149,15$ & $\mathrm{R} \$$ & $2.149,15$ \\
\hline & $\mathrm{R} \$$ / mês & $\mathrm{R} \$$ & $16.507,57$ & $\mathrm{R} \$$ & $16.546,58$ & $\mathrm{R} \$$ & $16.594,29$ \\
\hline
\end{tabular}

5. UNIFORMES

MOTORISTA \& AJUDANTE

CALÇA DE BRIM

CAMISA DE BRIM

CALCADO TIPO VULCABRÁS

BONÉ TIPO JOCKEY

CAPA DE CHUVA

UNIFORME COMPLETO:

\begin{tabular}{|c|c|c|c|c|c|}
\hline \multirow{3}{*}{$\begin{array}{l}\text { un / ano } \\
\text { un / ano }\end{array}$} & Quantidade & \multicolumn{2}{|c|}{ Preço Unitário } & & \\
\hline & 4 & $x \quad R \$$ & $10,10=$ & $=\mathrm{R} \$$ & 3,37 \\
\hline & 3 & $\begin{array}{ll}x & R \$\end{array}$ & $9,04=$ & $=\mathrm{R} \$$ & 2,26 \\
\hline Pares / ano & 2 & $x \quad R \$$ & $25,00=$ & $=\mathrm{R} \$$ & 4,17 \\
\hline un / ano & 2 & $\begin{array}{ll}x & R \$\end{array}$ & $2,20=$ & $=\mathrm{R} \$$ & 0,37 \\
\hline un / ano & 1 & $x \mathrm{R} \$$ & $7,04=$ & $=\mathrm{R} \$$ & 0,59 \\
\hline
\end{tabular}

CONSUMO MENSAL

\begin{tabular}{|c|c|c|c|c|c|c|c|}
\hline \multirow[t]{2}{*}{ Despesa: uniformes } & ATERRO & \multicolumn{6}{|c|}{ PERÍODO } \\
\hline & At. $01 \mathrm{~d} 01$ & & & & & & \\
\hline \multirow{2}{*}{ 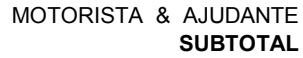 } & $\mathrm{H}$ & \multicolumn{2}{|c|}{4} & \multicolumn{2}{|c|}{4} & \multicolumn{2}{|c|}{4} \\
\hline & $\mathrm{R} \$$ / mês & $\mathrm{R} \$$ & 43,04 & $\mathrm{R} \$$ & 43,04 & $\mathrm{R} \$$ & 43,04 \\
\hline
\end{tabular}

6. RESUMO DOS CUSTOS OPERACIONAIS

\begin{tabular}{|c|c|c|c|c|c|c|c|}
\hline \multirow[t]{3}{*}{ Despesas operacionais } & ATERRO & & & \multicolumn{2}{|c|}{ PERÍODO } & & \\
\hline & At. $01 \mathrm{~d} 01$ & \multicolumn{2}{|c|}{2007} & \multicolumn{2}{|c|}{2012} & \multicolumn{2}{|c|}{2017} \\
\hline \multirow{3}{*}{\multicolumn{2}{|c|}{$\begin{array}{l}\text { MÃO-DE-OBRA DIRETA } \\
\text { VEÍCULOS TRANSPORTE E.TRANSF.-ATERRO } \\
\text { UNIFORMES }\end{array}$}} & $\mathrm{R} \$$ & $5.034,50$ & $\mathrm{R} \$$ & $5.034,50$ & $\mathrm{R} \$$ & $5.034,50$ \\
\hline & & $\mathrm{R} \$$ & $16.507,57$ & $\mathrm{R} \$$ & $16.546,58$ & $\mathrm{R} \$$ & $16.594,29$ \\
\hline & & $\mathrm{R} \$$ & 43,04 & $\mathrm{R} \$$ & 43,04 & $\mathrm{R} \$$ & 43,04 \\
\hline TOTAL Operacional & $\mathrm{R} \$$ / mês & $\mathrm{R} \$$ & $21.585,11$ & $\mathrm{R} \$$ & $21.624,12$ & $\mathrm{R} \$$ & $21.671,83$ \\
\hline
\end{tabular}

7. MÃO-DE-OBRA DE SUPERVISÃO

\begin{tabular}{|c|c|c|c|}
\hline & $\begin{array}{l}\text { ATERRO } \\
\text { At. } 01 \mathrm{~d} 01\end{array}$ & \multicolumn{2}{|c|}{ Fiscal } \\
\hline \multirow{2}{*}{$\begin{array}{l}\text { Salário Base } \\
\text { Encargos Sociais }\end{array}$} & & $\mathrm{R} \$$ & $1.244,41$ \\
\hline & $79,81 \%$ & $\mathrm{R} \$$ & 993,16 \\
\hline \multirow{5}{*}{$\begin{array}{r}\text { Vale Cesta } \\
\text { Vale Refeição } \\
\text { Vale Transporte } \\
\text { Custo Mensal Unitário }\end{array}$} & \multirow[b]{5}{*}{$\mathrm{R} \$$ / mês } & $\mathrm{R} \$$ & $2.237,57$ \\
\hline & & $\mathrm{R} \$$ & 40,61 \\
\hline & & $\mathrm{R} \$$ & 135,00 \\
\hline & & $\mathrm{R} \$$ & 71,38 \\
\hline & & $\mathrm{R} \$$ & $2.484,56$ \\
\hline
\end{tabular}

\begin{tabular}{|c|c|c|c|c|c|c|c|}
\hline \multirow[t]{2}{*}{ Despesa: mão-de-obra } & ATERRO & \multicolumn{6}{|c|}{ PERÍODO } \\
\hline & At. $01 \mathrm{~d} 01$ & & 007 & & 12 & \multirow{2}{*}{\multicolumn{2}{|c|}{$\frac{2017}{1}$}} \\
\hline \multirow[b]{4}{*}{ TOTAL mão-de-obra } & $\mathrm{H} /$ mês & \multicolumn{2}{|c|}{$\frac{2007}{1}$} & \multicolumn{2}{|c|}{$\frac{2012}{1}$} & & \\
\hline & $\mathrm{R} \$ / \mathrm{H}$ & $\mathrm{R} \$$ & $2.484,56$ & $\mathrm{R} \$$ & $2.484,56$ & $\mathrm{R} \$$ & $2.484,56$ \\
\hline & $\mathrm{R} \$$ / mês & $\mathrm{R} \$$ & $2.484,56$ & $\mathrm{R} \$$ & $2.484,56$ & $\mathrm{R} \$$ & $2.484,56$ \\
\hline & $\mathrm{R} \$$ / mês & $\mathrm{R} \$$ & $2.484,56$ & $\mathrm{R} \$$ & $2.484,56$ & $\mathrm{R} \$$ & $2.484,56$ \\
\hline
\end{tabular}

8. VEÍCULO PARA SUPERVISÃO DOS SERVIÇOS

\begin{tabular}{l|ll|} 
Pick-up Saveiro ou similar: & $\mathrm{R} \$$ & $18.650,00$ \\
\hline
\end{tabular} 
Planilha 07 - Transporte At $\rightarrow$ ETs $\rightarrow$ At: At. 01 d 01 da Situação 11 (cont.)

\begin{tabular}{|c|c|c|c|c|c|c|c|}
\hline \multirow{3}{*}{$\begin{array}{l}\text { Pick-up } \\
\text { Supervisão e fiscalização } \\
\qquad \text { Número de veículos }\end{array}$} & \multirow{2}{*}{$\begin{array}{l}\text { ATERRO } \\
\text { At. } 01 \mathrm{~d} 01\end{array}$} & \multicolumn{6}{|c|}{ PERÍODO } \\
\hline & & \multicolumn{2}{|c|}{2007} & \multicolumn{2}{|c|}{2012} & \multicolumn{2}{|c|}{2017} \\
\hline & \multirow{3}{*}{$\begin{array}{l}\text { un } \\
\mathrm{km} / \text { mês } \\
\mathrm{km} / \text { mês }\end{array}$} & & 1 & \multicolumn{2}{|c|}{1} & \multicolumn{2}{|r|}{1} \\
\hline \multirow[b]{2}{*}{ Distância percorrida } & & \multicolumn{2}{|r|}{311} & \multicolumn{2}{|r|}{313} & \multirow{2}{*}{\multicolumn{2}{|c|}{$\begin{array}{r}315 \\
8.215\end{array}$}} \\
\hline & & & 8.113 & & 8.159 & & \\
\hline \multirow[t]{2}{*}{ COMBUSTÍVEIS } & & \multirow{2}{*}{\multicolumn{2}{|c|}{$\begin{array}{r}\text { Consumo: } \\
\text { Custo: }\end{array}$}} & & 8 & \multirow{2}{*}{\multicolumn{2}{|c|}{$\begin{array}{l}\mathrm{km} / \mathrm{litro} \\
\text { /litro }\end{array}$}} \\
\hline & & & & $\mathrm{R} \$$ & 1,80 & & \\
\hline \multirow[t]{2}{*}{ Despesa: Combustível } & ATERRO & & & \multicolumn{2}{|c|}{ PERÍODO } & \multirow{2}{*}{\multicolumn{2}{|c|}{2017}} \\
\hline & At. $01 \mathrm{~d} 01$ & & 007 & \multirow{2}{*}{\multicolumn{2}{|c|}{2012}} & & \\
\hline \multirow{2}{*}{$\begin{array}{r}\text { Distância percorrida } \\
\text { SUBTOTAL }\end{array}$} & $\mathrm{km} / \mathrm{mês}$ & & 8.113 & & & \multicolumn{2}{|r|}{8.215} \\
\hline & $\mathrm{R} \$$ / mês & $\mathrm{R} \$$ & $1.825,43$ & $\mathrm{R} \$$ & $1.835,78$ & $\mathrm{R} \$$ & $1.848,38$ \\
\hline
\end{tabular}

8.2. MANUTENÇÃO

\begin{tabular}{|c|c|c|c|c|}
\hline Pick-up Saveiro ou similar: & $18.650,00$ & $\begin{array}{r}\text { Fator: } \\
\text { Vida útil: }\end{array}$ & \begin{tabular}{c|}
$60 \%$ \\
60
\end{tabular} & meses \\
\hline \multirow[t]{4}{*}{ Despesa: manutenção } & ATERRO & \multicolumn{2}{|r|}{ PERÍODO } & \\
\hline & & 2007 & 2012 & 2017 \\
\hline & Número de veículos & 1 & 1 & 1 \\
\hline & $\mathrm{R} \$ / \mathrm{mês}$ & 187,00 & 187,00 & 187,00 \\
\hline
\end{tabular}

8.3. PNEUS E CÂMARAS

\begin{tabular}{|c|c|c|c|c|}
\hline \multirow{3}{*}{$\begin{array}{r}\mathrm{km} / \text { ciclo } \\
\text { pneus e câmaras }\end{array}$} & 45.000 & \multirow{3}{*}{$\begin{array}{r}\text { Pneu } \\
\text { Câmara } \\
\mathrm{R} \$ / \text { conj. }\end{array}$} & $\mathrm{R} \$$ & 60,09 \\
\hline & \multirow[t]{2}{*}{4} & & $\mathrm{R} \$$ & 10,00 \\
\hline & & & $\mathrm{R} \$$ & 70,09 \\
\hline
\end{tabular}

\begin{tabular}{|c|c|c|c|c|c|c|c|}
\hline \multirow{3}{*}{ Despesa: pneus e câmaras } & ATERRO & \multicolumn{6}{|c|}{ PERÍODO } \\
\hline & At. $01 \mathrm{~d} 01$ & \multicolumn{2}{|c|}{2007} & & & \multicolumn{2}{|c|}{2017} \\
\hline & $\mathrm{km} /$ mês & & 8.113 & & 8.159 & & 8.215 \\
\hline SUBTOTAL & $\mathrm{R} \$$ / mês & $R \$$ & 50,55 & $\mathrm{R} \$$ & 50,83 & $\mathrm{R} \$$ & 51,18 \\
\hline
\end{tabular}

8.4. LUBRIFICAÇÃO E LAVAGEM

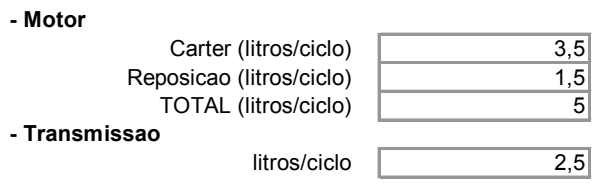

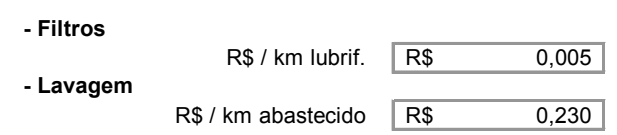

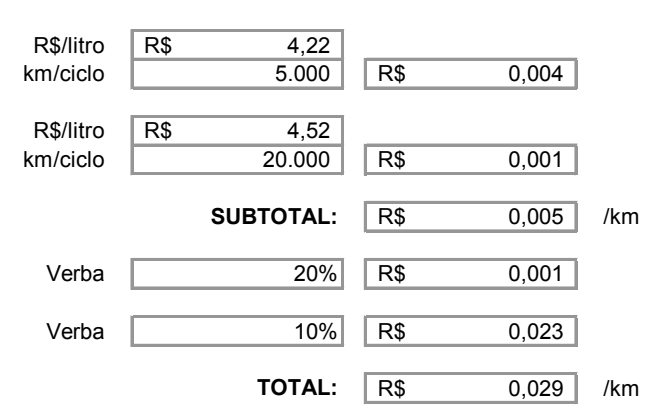

\begin{tabular}{|c|c|c|c|c|c|c|c|}
\hline \multirow[t]{3}{*}{ Despesa: lubrif. e lavagem } & ATERRO & \multicolumn{6}{|c|}{ PERÍODO } \\
\hline & At. $01 \mathrm{~d} 01$ & \multicolumn{2}{|c|}{2007} & & & \multicolumn{2}{|c|}{2017} \\
\hline & $\mathrm{km} / \mathrm{mês}$ & & 8.113 & & 8.159 & & 8.215 \\
\hline SUBTOTAL & $\mathrm{R} \$$ / mês & $\mathrm{R} \$$ & 235,28 & $\mathrm{R} \$$ & 236,61 & $\mathrm{R} \$$ & 238,24 \\
\hline
\end{tabular}

8.5. LICENCIAMENTO E SEGUROS

Seguro obrigatório

Seguro Total

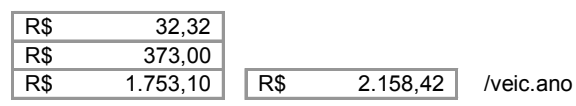


Planilha 07 - Transporte At $\rightarrow$ ETs $\rightarrow$ At: At. 01 d 01 da Situação 11 (cont.)

Custo Mensal

\begin{tabular}{|c|c|c|c|c|c|c|c|}
\hline \multirow[t]{3}{*}{ Despesa: licenc. e seguros } & ATERRO & \multicolumn{6}{|c|}{ PERÍODO } \\
\hline & At. $01 \mathrm{~d} 01$ & \multirow{2}{*}{\multicolumn{2}{|c|}{2007}} & & & \multirow{2}{*}{\multicolumn{2}{|c|}{$\begin{array}{c}2017 \\
1\end{array}$}} \\
\hline & Número de veículos & & & & & & \\
\hline SUBTOTAL & $\mathrm{R}$ \& / mês & $\mathrm{R} \$$ & 179,87 & $\mathrm{R} \$$ & 179,87 & $\mathrm{R} \$$ & 179,87 \\
\hline
\end{tabular}

8.6. DEPRECIACAO

\begin{tabular}{|c|c|c|c|c|c|}
\hline \multirow[b]{2}{*}{ Pick-up Saveiro ou similar: } & \multirow{2}{*}{$\begin{array}{c}\text { Valor Residual } \\
35 \%\end{array}$} & \multirow{2}{*}{$\begin{array}{c}\text { Vida útil (meses) } \\
60\end{array}$} & \multicolumn{2}{|c|}{ Valor (R\$/veic) } & \multirow[b]{2}{*}{ (s/ pneus e câmaras) } \\
\hline & & & $\mathrm{R} \$$ & $18.369,64$ & \\
\hline \multirow[t]{3}{*}{ Despesa: depreciação } & ATERRO & & \multicolumn{2}{|c|}{ PERÍODO } & \\
\hline & At. $01 \mathrm{~d} 01$ & 2007 & \multicolumn{2}{|c|}{2012} & 2017 \\
\hline & Número de veículos & 1 & \multicolumn{2}{|r|}{1} & 1 \\
\hline SUBTOTAL & $\mathrm{R} \$$ / mês & 199,00 & $\mathrm{R} \$$ & 199,00 & 199,00 \\
\hline
\end{tabular}

8.7. CUSTO DE CAPITAL (remuneração)

\begin{tabular}{|c|c|c|c|c|c|c|}
\hline \multirow[t]{2}{*}{$\begin{array}{ll} & \text { C } \\
\text { Coef. Remun.(/mês) } & \text { C }\end{array}$} & \multirow[t]{2}{*}{$\begin{array}{l}\mathrm{C}= \\
\mathrm{C}=\end{array}$} & \multicolumn{2}{|c|}{$[(2+(n-1)(k+1)) / 24 n] j$, ou } & \multicolumn{2}{|c|}{$\begin{array}{c}\mathrm{j}=\text { Juros } \\
12 \%\end{array}$} & \multirow[b]{2}{*}{ Coef. Remun. (/mês) } \\
\hline & & $\mathrm{k}=$ Valor Residual & $\mathrm{n}=$ Vida útil (anos) & & (R\$/veic) & \\
\hline \multicolumn{2}{|l|}{ Pick-up Saveiro ou similar: } & $35 \%$ & 5 & $\mathrm{R} \$$ & $18.650,00$ & 0,007400 \\
\hline \multirow{2}{*}{\multicolumn{2}{|c|}{ Despesa: custo capital }} & ATERRO & \multicolumn{4}{|c|}{ PERÍODO } \\
\hline & & At. $01 \mathrm{~d} 01$ & 2007 & & 012 & 2017 \\
\hline \multirow{2}{*}{\multicolumn{2}{|c|}{$\begin{array}{r}\text { Operação } \\
\text { SUBTOTAL }\end{array}$}} & Número de veículos & 1 & & 1 & 1 \\
\hline & & $\mathrm{R} \$$ / mês & 138,01 & $\mathrm{R} \$$ & 138,01 & 138,01 \\
\hline
\end{tabular}

8.8. RESUMO - VEÍCULO PARA SUPERVISÃO DOS SERVIÇOS

\begin{tabular}{|c|c|c|c|c|c|c|c|}
\hline \multirow{10}{*}{\begin{tabular}{l}
\multicolumn{2}{c}{ Despesas: veículos } \\
CONSUMO COMBUSTÍVEL \\
MANUTENÇÃO \\
PNEUS E CÂMARAS \\
LUBRIFICAÇÃO E LAVAGEM \\
LICENCIAMENTO E SEGUROS \\
DEPRECIAÇÃO \\
CUSTO DE CAPITAL (remuneração) \\
TOTAL Veículos
\end{tabular}} & \multirow{2}{*}{$\begin{array}{c}\text { ATERRO } \\
\text { At. } 01 \mathrm{~d} 01\end{array}$} & \multicolumn{6}{|c|}{ PERÍODO } \\
\hline & & \multicolumn{2}{|c|}{2007} & \multicolumn{2}{|c|}{2012} & \multicolumn{2}{|c|}{2017} \\
\hline & & $\mathrm{R} \$$ & $1.825,43$ & $\mathrm{R} \$$ & $1.835,78$ & $\mathrm{R} \$$ & $1.848,38$ \\
\hline & & $\mathrm{R} \$$ & 187,00 & $\mathrm{R} \$$ & 187,00 & $\mathrm{R} \$$ & 187,00 \\
\hline & & $\mathrm{R} \$$ & 50,55 & $\mathrm{R} \$$ & 50,83 & $\mathrm{R} \$$ & 51,18 \\
\hline & & $\mathrm{R} \$$ & 235,28 & $\mathrm{R} \$$ & 236,61 & $\mathrm{R} \$$ & 238,24 \\
\hline & & $\mathrm{R} \$$ & 179,87 & $\mathrm{R} \$$ & 179,87 & $\mathrm{R} \$$ & 179,87 \\
\hline & & $\mathrm{R} \$$ & 199,00 & $\mathrm{R} \$$ & 199,00 & $\mathrm{R} \$$ & 199,00 \\
\hline & & $\mathrm{R} \$$ & 138,01 & $\mathrm{R} \$$ & 138,01 & $\mathrm{R} \$$ & 138,01 \\
\hline & $\mathrm{R}$ / mês & $\mathrm{R} \$$ & $2.815,14$ & $\mathrm{R} \$$ & $2.827,10$ & $\mathrm{R} \$$ & $2.841,68$ \\
\hline
\end{tabular}

9. RESUMO DOS CUSTOS DE SUPERVISÃO

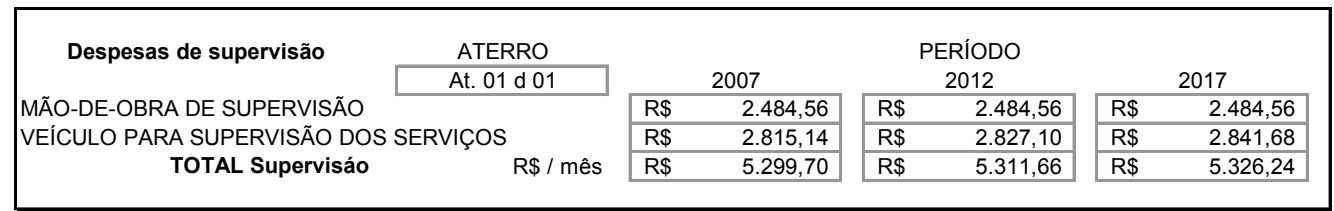

10.

DESPESAS DE ADMINISTRACAO

$28 \%$ sobre parte do custo direto e indireto para cobrir despesas com honorários, salários e ordenados, taxas,despesas gerais como água,

Taxa de Administração:

$28 \%$ luz, telefones, impressos e outras.

\begin{tabular}{|c|c|c|c|c|c|c|c|}
\hline \multirow[t]{2}{*}{ Despesas de administração } & ATERRO & \multicolumn{6}{|c|}{ PERÍODO } \\
\hline & At. $01 \mathrm{~d} 01$ & \multicolumn{2}{|c|}{2007} & & 012 & \multicolumn{2}{|c|}{2017} \\
\hline DESPESAS DE OPERAÇÃO & \multirow{4}{*}{$\mathrm{R} \$$ / mês } & $\mathrm{R} \$$ & $21.585,11$ & $\mathrm{R} \$$ & $21.624,12$ & $\mathrm{R} \$$ & $21.671,83$ \\
\hline DESPESAS DE SUPERVISÃO & & $\mathrm{R} \$$ & $5.299,70$ & $\mathrm{R} \$$ & $5.311,66$ & $\mathrm{R} \$$ & $5.326,24$ \\
\hline TOTAL (Oper.+Superv.) & & $\mathrm{R} \$$ & $26.884,81$ & $\mathrm{R} \$$ & $26.935,78$ & $\mathrm{R} \$$ & $26.998,07$ \\
\hline DESPESAS DE ADMINISTRAÇÃO & & $\mathrm{R} \$$ & $7.527,75$ & $\mathrm{R} \$$ & $7.542,02$ & $\mathrm{R} \$$ & $7.559,46$ \\
\hline
\end{tabular}




\section{Planilha 07 - Transporte At $\rightarrow$ ETs $\rightarrow$ At: At. 01 d 01 da Situação 11 (cont.)}

11. BENEFICIO

Benefício sobre o total dos custos

\begin{tabular}{|c|c|c|c|c|c|c|c|}
\hline Benefício & ATERRO & \multicolumn{6}{|c|}{ PERÍODO } \\
\hline & At. $01 \mathrm{~d} 01$ & & 2007 & & 012 & & 2017 \\
\hline \multirow{4}{*}{$\begin{array}{l}\text { DESPESAS DE OPER.+SUPERV. } \\
\text { DESPESAS DE ADMINISTRAÇÃO } \\
\text { TOTAL (Oper.+Superv.+Admin.) } \\
\text { BENEFÍCIO }\end{array}$} & \multirow{4}{*}{$\mathrm{R} \$$ / mês } & $\mathrm{R} \$$ & $26.884,81$ & $\mathrm{R} \$$ & $26.935,78$ & $\mathrm{R} \$$ & $26.998,07$ \\
\hline & & $\mathrm{R} \$$ & $7.527,75$ & $\mathrm{R} \$$ & $7.542,02$ & $\mathrm{R} \$$ & $7.559,46$ \\
\hline & & $\mathrm{R} \$$ & $34.412,56$ & $\mathrm{R} \$$ & $34.477,80$ & $\mathrm{R} \$$ & $34.557,53$ \\
\hline & & $\mathrm{R} \$$ & - & $\mathrm{R} \$$ & - & $\mathrm{R} \$$ & - \\
\hline
\end{tabular}

12. FATURAMENTO MENSAL (f)

\begin{tabular}{|c|c|c|c|c|c|c|c|}
\hline Faturamento & ATERRO & \multicolumn{6}{|c|}{ PERÍODO } \\
\hline DESPESAS DE OPERAÇÃO & & $\mathrm{R} \$$ & $21.585,11$ & $\mathrm{R} \$$ & $21.624,12$ & $\mathrm{R} \$$ & $21.671,83$ \\
\hline DESPESAS DE SUPERVISÃO & & $\mathrm{R} \$$ & $5.299,70$ & $\mathrm{R} \$$ & $5.311,66$ & $\mathrm{R} \$$ & $5.326,24$ \\
\hline DESPESAS DE ADMINISTRAÇÃO & & $\mathrm{R} \$$ & $7.527,75$ & $\mathrm{R} \$$ & $7.542,02$ & $\mathrm{R} \$$ & $7.559,46$ \\
\hline BENEFÍCIO & & $\mathrm{R} \$$ & - & $\mathrm{R} \$$ & - & $\mathrm{R} \$$ & - \\
\hline FATURAMENTO & $\mathrm{R}$ / mês & $\mathrm{R} \$$ & $34.412,56$ & $\mathrm{R} \$$ & $34.477,80$ & $\mathrm{R} \$$ & $34.557,53$ \\
\hline
\end{tabular}

13. ISS, PIS, COFINS e CPMF

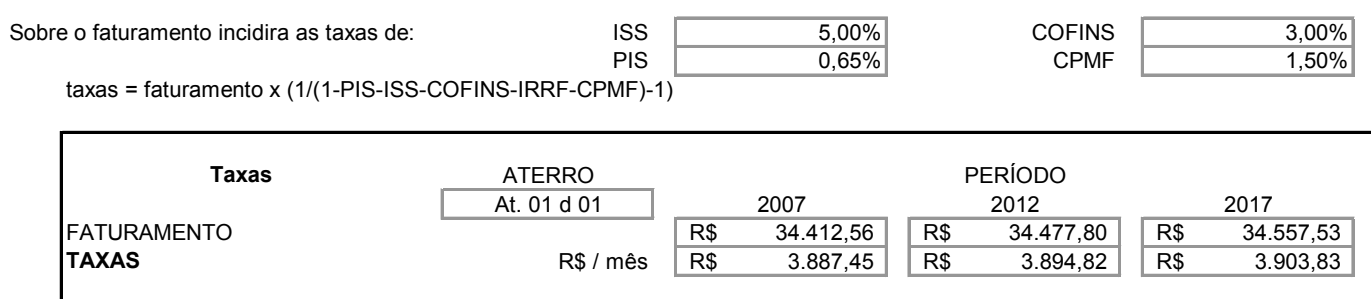

14. CUSTO MENSAL

$\mathrm{C}_{\mathrm{t}}=$ faturamento + taxas

\begin{tabular}{|c|c|c|c|c|c|c|c|}
\hline \multirow{2}{*}{ Custo mensal } & ATERRO & \multicolumn{6}{|c|}{ PERÍODO } \\
\hline & At. $01 \mathrm{~d} 01$ & & 007 & & 012 & & 017 \\
\hline \multirow{3}{*}{$\begin{array}{l}\text { FATURAMENTO } \\
\text { TAXAS } \\
\text { TOTAL CUSTO }\left(\mathbf{c}_{\mathrm{t}}\right)\end{array}$} & \multirow[b]{3}{*}{$\mathrm{R} \$$ / mês } & $\mathrm{R} \$$ & $34.412,56$ & $\mathrm{R} \$$ & $34.477,80$ & $\mathrm{R} \$$ & $34.557,53$ \\
\hline & & $\mathrm{R} \$$ & $3.887,45$ & $\mathrm{R} \$$ & $3.894,82$ & $\mathrm{R} \$$ & $3.903,83$ \\
\hline & & $\mathrm{R} \$$ & $38.300,01$ & $\mathrm{R} \$$ & $38.372,62$ & $\mathrm{R} \$$ & $38.461,36$ \\
\hline
\end{tabular}

15. CUSTO POR TONELADA DE LIXO COLETADO

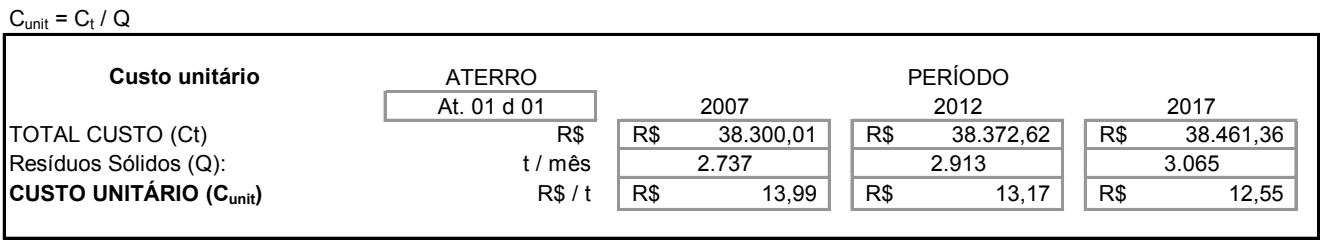


Planilha 08 - Aterro e ETs: At. 01 d 01 da Situação 11

OPERAÇÃO: ESTAÇÃO DE TRANSFERÊNCIA E ATERRO

CUSTO DOS SERVIÇOS

Data base:

Junho de 2002

1. DADOS BÁSICOS NECESSÁRIOS

1.1. QUANTIDADE MÉDIA DE RESÍDUOS

\begin{tabular}{|c|c|c|c|c|}
\hline & ATERRO & & PERÍODO & \\
\hline & At. $01 \mathrm{~d} 01$ & 2007 & 2012 & 2017 \\
\hline Resíduos Sólidos (t/mês): & & 2.737 & 2.913 & 3.065 \\
\hline
\end{tabular}

1.2. NÚMERO DE DIAS ÚTEIS POR ANO

Descontados somente domingos

\begin{tabular}{|rl|}
\hline 365 & dias/ano \\
\hline 52 & domingos/ano \\
\hline 313 & dias úteis/ano \\
\hline 26,08 & dias úteis/mes \\
\hline
\end{tabular}

1.3. SERVIÇO EM JORNADA NORMAL

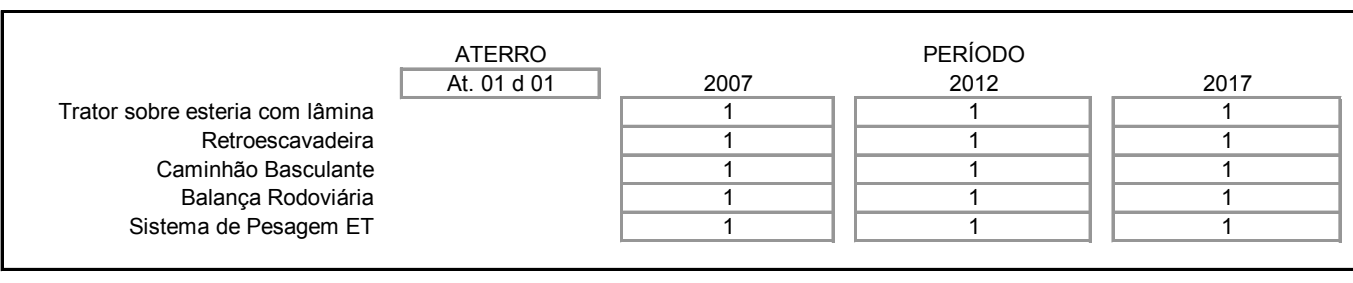

\begin{tabular}{|c|c|c|c|c|}
\hline & ATERRO & & PERÍODO & \\
\hline & At. $01 \mathrm{~d} 01$ & 2007 & 2012 & 2017 \\
\hline Número de Jornadas /dia: & & 1 & 1 & 1 \\
\hline
\end{tabular}

\begin{tabular}{|c|c|c|c|c|}
\hline & ATERRO & & PERÍODO & \\
\hline & At. $01 \mathrm{~d} 01$ & 2007 & 2012 & 2017 \\
\hline Horas extras totais $(\mathrm{h})$ : & & 0,00 & 0,00 & 0,00 \\
\hline
\end{tabular}

2. DIMENSIONAMENTO DA FROTA E DO PESSOAL

2.1. MÃO-DE-OBRA DIRETA

Trator sobre esteria com lâmina

Retroescavadeira

Caminhão Basculante

Guarnição:

Motorista

Motorista

Motorista

Descontados domingos e feriados

\begin{tabular}{|rl|}
\hline 365 & dias/ano \\
\hline 52 & domingos/ano \\
\hline 10 & feriados/ano \\
\hline 303 & dias uteis/ano \\
\hline 25,25 & dias úteis/mes \\
\hline
\end{tabular}

25,25 dias úteis/mes

MOTORISTAS

\begin{tabular}{|c|c|c|c|c|}
\hline \multirow[t]{2}{*}{ Motorista (H/dia) } & ATERRO & & PERÍODO & \\
\hline & At. $01 \mathrm{~d} 01$ & 2007 & 2012 & 2017 \\
\hline \multirow{3}{*}{$\begin{array}{r}\text { Operação: } \\
\text { Reserva Absenteismo: } \\
\text { TOTAL Necessário: }\end{array}$} & & 2 & 2 & 2 \\
\hline & $10 \%$ & 0 & 0 & 0 \\
\hline & & 2 & 2 & 2 \\
\hline
\end{tabular}


Planilha 08 - Aterro e ETs: At. 01 d 01 da Situação 11 (cont.)

3. CUSTO DA MÃO-DE-OBRA DIRETA

MOTORISTAS

\begin{tabular}{|c|c|c|c|c|c|c|c|}
\hline & ATERRO & \multicolumn{6}{|c|}{ PERÍODO } \\
\hline & At. $01 \mathrm{~d} 01$ & \multicolumn{2}{|c|}{2007} & \multicolumn{2}{|c|}{2012} & \multicolumn{2}{|c|}{2017} \\
\hline \multirow{2}{*}{$\begin{array}{r}\text { Salário } \\
\text { Horas Mensais }\end{array}$} & \multirow[t]{2}{*}{$\mathrm{R} \$$ /hora } & $\mathrm{R} \$$ & 2,53 & $\mathrm{R} \$$ & 2,53 & $\mathrm{R} \$$ & 2,53 \\
\hline & & & 220 & & 220 & & 220 \\
\hline \multirow{3}{*}{ Insalubridade } & \multirow[t]{2}{*}{ Salário Base } & $\mathrm{R} \$$ & 556,00 & $\mathrm{R} \$$ & 556,00 & $\mathrm{R} \$$ & 556,00 \\
\hline & & $\mathrm{R} \$$ & 40,00 & $\mathrm{R} \$$ & 40,00 & $\mathrm{R} \$$ & 40,00 \\
\hline & \multirow[t]{3}{*}{ Subtotal } & $\mathrm{R} \$$ & 596,00 & $\mathrm{R} \$$ & 596,00 & $\mathrm{R} \$$ & 596,00 \\
\hline \multirow{2}{*}{$\begin{array}{l}\text { Horas Extras } \\
\text { Feriado Diurno }\end{array}$} & & $\mathrm{R} \$$ & - & $\mathrm{R} \$$ & - & $\mathrm{R} \$$ & - \\
\hline & & $\mathrm{R} \$$ & 30,92 & $\mathrm{R} \$$ & 30,92 & $\mathrm{R} \$$ & 30,92 \\
\hline \multirow{7}{*}{$\begin{array}{r}\text { Salário Mensal com Encargos } \\
\text { Vale Refeição } \\
\text { Vale Cesta } \\
\text { Convênio Médico } \\
\text { Vale Transporte } \\
\text { Custo Mensal Unitário }\end{array}$} & \multirow[t]{6}{*}{ Salário Mensal } & $\mathrm{R} \$$ & 626,92 & $\mathrm{R} \$$ & 626,92 & $\mathrm{R} \$$ & 626,92 \\
\hline & & $\mathrm{R} \$$ & $1.127,26$ & $\mathrm{R} \$$ & $1.127,26$ & $\mathrm{R} \$$ & $1.127,26$ \\
\hline & & $\mathrm{R} \$$ & 135,00 & $\mathrm{R} \$$ & 135,00 & $\mathrm{R} \$$ & 135,00 \\
\hline & & $\mathrm{R} \$$ & 40,61 & $\mathrm{R} \$$ & 40,61 & $\mathrm{R} \$$ & 40,61 \\
\hline & & $\mathrm{R} \$$ & 26,00 & $\mathrm{R} \$$ & 26,00 & $\mathrm{R} \$$ & 26,00 \\
\hline & & $\mathrm{R} \$$ & 112,69 & $\mathrm{R} \$$ & 112,69 & $\mathrm{R} \$$ & 112,69 \\
\hline & $\mathrm{R} \$ /$ mês & $\mathrm{R} \$$ & $1.441,56$ & $\mathrm{R} \$$ & $1.441,56$ & $\mathrm{R} \$$ & $1.441,56$ \\
\hline & \multicolumn{2}{|l|}{ Eeriados e domingos } & $100 \%$ & \multicolumn{4}{|c|}{ VALE TRANSPORTE: } \\
\hline & \multirow{2}{*}{\multicolumn{2}{|c|}{$\begin{array}{r}\text { Horas Extras } \\
\text { Adic.Not. } 22 \mathrm{~h} \text { as } 5 \mathrm{~h})\end{array}$}} & $50 \%$ & \multicolumn{3}{|c|}{$\mathrm{R} \$$ / pasagem ônibus } & 1,40 \\
\hline & & & $20,00 \%$ & \multicolumn{3}{|c|}{ passagem/dia (media) } & 4 \\
\hline & \multicolumn{2}{|l|}{ Encargos Sociais } & $79,81 \%$ & & A deduzir & & $6,00 \%$ \\
\hline
\end{tabular}

3.1. CUSTO MENSAL

\begin{tabular}{|c|c|c|c|c|c|c|c|}
\hline \multirow[t]{2}{*}{ Despesa: mão-de-obra } & ATERRO & \multicolumn{6}{|c|}{ PERÍODO } \\
\hline & At. $01 \mathrm{~d} 01$ & \multirow{2}{*}{\multicolumn{2}{|c|}{$\begin{array}{c}2007 \\
2\end{array}$}} & & & \multirow{2}{*}{\multicolumn{2}{|c|}{$\begin{array}{c}2017 \\
2\end{array}$}} \\
\hline \multirow[t]{3}{*}{ MOTORISTAS } & H/ mês & & & \multicolumn{2}{|c|}{$\begin{array}{c}2012 \\
2\end{array}$} & & \\
\hline & $\mathrm{R} \$ / \mathrm{H}$ & $\mathrm{R} \$$ & $1.441,56$ & $\mathrm{R} \$$ & $1.441,56$ & $\mathrm{R} \$$ & $1.441,56$ \\
\hline & $\mathrm{R} \$$ /mês & $\mathrm{R} \$$ & $2.883,12$ & $\mathrm{R} \$$ & $2.883,12$ & $\mathrm{R} \$$ & $2.883,12$ \\
\hline TOTAL mão-de-obra & $\mathrm{R} \$$ /mês & $\mathrm{R} \$$ & $2.883,12$ & $\mathrm{R} \$$ & $2.883,12$ & $\mathrm{R} \$$ & $2.883,12$ \\
\hline
\end{tabular}

\section{EQUIPAMENTOS}

4.1. Horas trabalhadas

\begin{tabular}{|c|c|c|c|c|}
\hline \multirow[t]{2}{*}{ Horas trabalhadas } & ATERRO & & PERÍODO & \\
\hline & At. $01 \mathrm{~d} 01$ & 2007 & 2012 & 2017 \\
\hline \multirow{3}{*}{$\begin{array}{l}\text { Trator sobre esteria com lâmina } \\
\text { Retroescavadeira } \\
\text { Caminhão Basculante }\end{array}$} & h/ mês & 78 & 83 & 88 \\
\hline & h / mês & 39 & 42 & 44 \\
\hline & $\mathrm{h} /$ mês & 39 & 42 & 44 \\
\hline
\end{tabular}

4.2. INSUMOS, MANUTENÇÃO, ETC

\begin{tabular}{|c|c|c|c|c|c|c|}
\hline \multirow{4}{*}{$\begin{array}{l}\text { Custos unitários } \\
\text { Trator sobre esteria com lâmina } \\
\text { Retroescavadeira } \\
\text { Caminhão Basculante }\end{array}$} & $\begin{array}{c}\text { ATERRO } \\
\text { At. } 01 \mathrm{~d} 01\end{array}$ & \multicolumn{2}{|c|}{$\begin{array}{c}\text { Insumos } \\
(\mathrm{R} \$ / \mathrm{h})\end{array}$} & \multicolumn{2}{|c|}{$\begin{array}{c}\text { Manutenção } \\
(R \$ / h)\end{array}$} & Outros \\
\hline & & $\mathrm{R} \$$ & 16,11 & $\mathrm{R} \$$ & 23,58 & $6,50 \%$ \\
\hline & & $\mathrm{R} \$$ & 11,83 & $\mathrm{R} \$$ & 6,75 & \\
\hline & & $\mathrm{R} \$$ & 21,31 & $\mathrm{R} \$$ & 5,79 & \\
\hline
\end{tabular}

\begin{tabular}{|c|c|c|c|c|c|c|c|}
\hline \multirow[t]{2}{*}{ Insumos } & ATERRO & \multicolumn{6}{|c|}{ PERÍODO } \\
\hline & At. $01 \mathrm{~d} 01$ & \multicolumn{2}{|c|}{2007} & \multicolumn{2}{|c|}{2012} & \multicolumn{2}{|c|}{2017} \\
\hline Trator sobre esteria com lâmina & $\mathrm{R} \$ / \mathrm{mês}$ & $\mathrm{R} \$$ & $1.261,18$ & $\mathrm{R} \$$ & $1.341,71$ & $\mathrm{R} \$$ & $1.410,97$ \\
\hline Retroescavadeira & $\mathrm{R} \$ /$ mês & $\mathrm{R} \$$ & 463,06 & $\mathrm{R} \$$ & 492,63 & $\mathrm{R} \$$ & 518,06 \\
\hline Caminhão Basculante & $\mathrm{R} \$ /$ mês & $\mathrm{R} \$$ & 834,13 & $\mathrm{R} \$$ & 887,39 & $\mathrm{R} \$$ & 933,20 \\
\hline
\end{tabular}

\begin{tabular}{|c|c|c|c|c|c|c|c|}
\hline \multirow[t]{2}{*}{ Manutenção } & ATERRO & \multicolumn{6}{|c|}{ PERÍODO } \\
\hline & At. $01 \mathrm{~d} 01$ & \multicolumn{2}{|c|}{2007} & \multicolumn{2}{|c|}{2012} & \multicolumn{2}{|c|}{2017} \\
\hline Trator sobre esteria com lâmina & $\mathrm{R} \$ / \mathrm{mês}$ & $\mathrm{R} \$$ & $1.845,97$ & $\mathrm{R} \$$ & $1.963,84$ & $\mathrm{R} \$$ & $2.065,22$ \\
\hline Retroescavadeira & $\mathrm{R} \$$ /mês & $\mathrm{R} \$$ & 264,21 & $\mathrm{R} \$$ & 281,08 & $\mathrm{R} \$$ & 295,60 \\
\hline Caminhão Basculante & $\mathrm{R} \$$ /mês & $\mathrm{R} \$$ & 226,64 & $\mathrm{R} \$$ & 241,11 & $\mathrm{R} \$$ & 253,55 \\
\hline
\end{tabular}


Planilha 08 - Aterro e ETs: At. 01 d 01 da Situação 11 (cont.)

\begin{tabular}{|c|c|c|c|c|c|c|c|}
\hline \multirow{2}{*}{ Insumos, Manutenção, etc } & \multirow{2}{*}{$\begin{array}{c}\text { ATERRO } \\
\text { At. } 01 \mathrm{~d} 01\end{array}$} & \multicolumn{6}{|c|}{ PERÍODO } \\
\hline & & \multicolumn{2}{|c|}{2007} & \multicolumn{2}{|c|}{2012} & \multicolumn{2}{|c|}{2017} \\
\hline \multirow{6}{*}{$\begin{array}{l}\text { Trator sobre esteria com lâmina } \\
\text { Retroescavadeira } \\
\text { Caminhão Basculante } \\
\text { Insumos \& Manutenção } \\
\text { Outros (lavagem, lubrif.) } \\
\text { SUBTOTAL }\end{array}$} & $\mathrm{R} \$$ /mês & $\mathrm{R} \$$ & $3.107,15$ & $\mathrm{R} \$$ & $3.305,54$ & $\mathrm{R} \$$ & $3.476,20$ \\
\hline & $\mathrm{R} \$$ /mês & $\mathrm{R} \$$ & 727,27 & $\mathrm{R} \$$ & 773,71 & $\mathrm{R} \$$ & 813,65 \\
\hline & $\mathrm{R} \$$ /mês & $\mathrm{R} \$$ & $1.060,77$ & $\mathrm{R} \$$ & $1.128,50$ & $\mathrm{R} \$$ & $1.186,76$ \\
\hline & $\mathrm{R} \$$ /mês & $\mathrm{R} \$$ & $4.895,19$ & $\mathrm{R} \$$ & $5.207,75$ & $\mathrm{R} \$$ & $5.476,61$ \\
\hline & $\mathrm{R} \$$ /mês & $\mathrm{R} \$$ & 318,19 & $\mathrm{R} \$$ & 338,50 & $\mathrm{R} \$$ & 355,98 \\
\hline & & $\mathrm{R} \$$ & $5.213,38$ & $\mathrm{R} \$$ & $5.546,25$ & $\mathrm{R} \$$ & $5.832,59$ \\
\hline
\end{tabular}

4.3. LICENCIAMENTO E SEGUROS

\begin{tabular}{|c|c|c|c|c|c|c|}
\hline & rator & eria com lâmi & & scavadeira & Can & Basculante \\
\hline Preço do equipamento & $\mathrm{R} \$$ & $232.946,00$ & $\mathrm{R} \$$ & $110.000,00$ & $\mathrm{R} \$$ & $94.228,37$ \\
\hline Seguro obrigatório (cat. 10) & $\mathrm{R} \$$ & 55,43 & $\mathrm{R} \$$ & 55,43 & $\mathrm{R} \$$ & 55,43 \\
\hline I.P.V.A (faixa E.3) & $\mathrm{R} \$$ & - & $\mathrm{R} \$$ & - & $\mathrm{R} \$$ & $1.413,43$ \\
\hline eguro contra incêndio e danos materiais contra terceiros & $\mathrm{R} \$$ & $18.635,68$ & $\mathrm{R} \$$ & $8.800,00$ & $\mathrm{R} \$$ & $7.538,27$ \\
\hline Custo anual (/equip.ano) & $\mathrm{R} \$$ & $18.691,11$ & $\mathrm{R} \$$ & $8.855,43$ & $\mathrm{R} \$$ & $9.007,13$ \\
\hline
\end{tabular}

\begin{tabular}{|c|c|c|c|c|c|c|c|}
\hline \multirow[t]{2}{*}{ Despesa: licenc. e seguros } & ATERRO & \multicolumn{6}{|c|}{ PERÍODO } \\
\hline & At. $01 \mathrm{~d} 01$ & & 07 & & & & \\
\hline \multirow{2}{*}{$\begin{array}{l}\text { Trator sobre esteria com lâmina } \\
\text { Retroescavadeira }\end{array}$} & $\mathrm{R} \$$ / mês & $\mathrm{R} \$$ & $1.557,59$ & $\mathrm{R} \$$ & 737,95 & $\mathrm{R} \$$ & 750,59 \\
\hline & $\mathrm{R} \$$ / mês & $\mathrm{R} \$$ & $1.557,59$ & $\mathrm{R} \$$ & 737,95 & $\mathrm{R} \$$ & 750,59 \\
\hline \multirow[t]{2}{*}{ Caminhão Basculante } & $\mathrm{R} \$$ / mês & $\mathrm{R} \$$ & $1.557,59$ & $\mathrm{R} \$$ & 737,95 & $\mathrm{R} \$$ & 750,59 \\
\hline & $\mathrm{R} \$$ / mês & $\mathrm{R} \$$ & $4.672,77$ & $\mathrm{R} \$$ & $2.213,85$ & $\mathrm{R} \$$ & $2.251,77$ \\
\hline
\end{tabular}

4.4. DEPRECIAÇÃO

Trator sobre esteria com lâmina

Retroescavadeira

Caminhão Basculante

Balança Rodoviária

Sistema de Pesagem ET

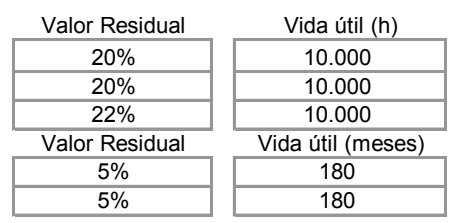

Valor (R\$/veic)

\begin{tabular}{|cc|}
\hline $\mathrm{R} \$$ & $232.946,00$ \\
\hline $\mathrm{R} \$$ & $110.000,00$ \\
\hline $\mathrm{R} \$$ & $94.228,37$ \\
\hline \multicolumn{2}{|c|}{ Valor (R\$) } \\
\hline $\mathrm{R} \$$ & $30.000,00$ \\
\hline $\mathrm{R} \$$ & $159.800,00$ \\
\hline
\end{tabular}

\begin{tabular}{|c|c|c|c|c|c|c|c|}
\hline \multirow[t]{2}{*}{ Despesa: depreciação } & ATERRO & \multicolumn{6}{|c|}{ PERÍODO } \\
\hline & At. $01 \mathrm{~d} 01$ & & 07 & & & & \\
\hline \multirow{5}{*}{$\begin{array}{l}\text { Trator sobre esteria com lâmina } \\
\text { Retroescavadeira } \\
\text { Caminhão Basculante } \\
\text { Balança Rodoviária } \\
\text { Sistema de Pesagem ET }\end{array}$} & $\mathrm{R} \$$ / mês & $\mathrm{R} \$$ & $1.458,90$ & $\mathrm{R} \$$ & $1.552,05$ & $\mathrm{R} \$$ & $1.632,18$ \\
\hline & $\mathrm{R} \$$ / mês & $\mathrm{R} \$$ & 344,46 & $\mathrm{R} \$$ & 366,45 & $\mathrm{R} \$$ & 385,37 \\
\hline & $\mathrm{R} \$$ / mês & $\mathrm{R} \$$ & 287,69 & $\mathrm{R} \$$ & 306,06 & $\mathrm{R} \$$ & 321,86 \\
\hline & $\mathrm{R} \$$ / mês & $\mathrm{R} \$$ & 158,33 & $\mathrm{R} \$$ & 158,33 & $\mathrm{R} \$$ & 158,33 \\
\hline & $\mathrm{R} \$$ / mês & $\mathrm{R} \$$ & 843,39 & $\mathrm{R} \$$ & 843,39 & $\mathrm{R} \$$ & 843,39 \\
\hline SUBTOTAL & $\mathrm{R} \$$ / mês & $\mathrm{R} \$$ & $3.092,77$ & $\mathrm{R} \$$ & $3.226,29$ & $\mathrm{R} \$$ & $3.341,14$ \\
\hline
\end{tabular}

4.5. CUSTO DE CAPITAL (remuneração)

$$
C=[(2+(n-1)(k+1)) / 24 n] j, \text { ou }
$$

Coef. Remun.(/mês) $\quad C=[(n+1)+r \cdot(n-1)] \cdot j /(2 \cdot 12 \cdot n)$, onde:
$\mathrm{j}=\mathrm{Juros}$

$12 \%$

\footnotetext{
Trator sobre esteria com lâmina Retroescavadeira

Caminhão Basculante

Balança Rodoviária

Sistema de Pesagem ET
}
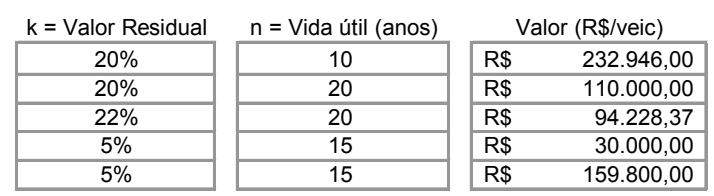

Coef. Remun. (/mês)

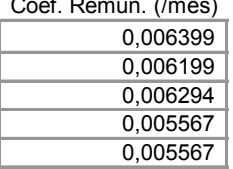

Despesa: custo capital

Trator sobre esteria com lâmina

Retroescavadeira

Caminhão Basculante

Balança Rodoviária

Sistema de Pesagem ET

SUBTOTAL

ATERRO

At. $01 \mathrm{~d} 01$

$\mathrm{R} \$$ / mês

$\mathrm{R} \$$ / mês

$\mathrm{R}$ / mês

$\mathrm{R}$ / mês

$\mathrm{R} \$$ / mês

$\mathrm{R} \$ /$ mês

\begin{tabular}{|rr|}
\multicolumn{1}{c}{2007} \\
\hline$R \$$ & $1.490,62$ \\
\hline$R \$$ & 681,89 \\
\hline$R \$$ & 593,07 \\
\hline$R \$$ & 167,01 \\
\hline$R \$$ & 889,61 \\
\hline$R \$$ & $3.822,20$ \\
\hline
\end{tabular}

PERÍODO

\begin{tabular}{|lr|}
\multicolumn{2}{c}{2012} \\
\hline$R \$$ & $1.490,62$ \\
\hline$R \$$ & 681,89 \\
\hline$R \$$ & 593,07 \\
\hline$R \$$ & 167,01 \\
\hline$R \$$ & 889,61 \\
\hline$R \$$ & $3.822,20$ \\
\hline
\end{tabular}

2017

\begin{tabular}{|lr|}
\multicolumn{2}{c}{2017} \\
\hline $\mathrm{R} \$$ & $1.490,62$ \\
\hline $\mathrm{R} \$$ & 681,89 \\
\hline $\mathrm{R} \$$ & 593,07 \\
\hline $\mathrm{R} \$$ & 167,01 \\
\hline $\mathrm{R} \$$ & 889,61 \\
\hline $\mathrm{R} \$$ & $3.822,20$ \\
\hline
\end{tabular}


Planilha 08 - Aterro e ETs: At. 01 d 01 da Situação 11 (cont.)

4.6. RESUMO EQUIPAMENTOS

\begin{tabular}{|c|c|c|c|c|c|c|c|}
\hline \multirow{6}{*}{$\begin{array}{l}\text { Despesas: veículos } \\
\text { INSUMOS, MANUTENÇÃO, ETC } \\
\text { LICENCIAMENTO E SEGUROS } \\
\text { DEPRECIAÇÃO } \\
\text { CUSTO DE CAPITAL (remuneração) } \\
\text { TOTAL Equipamentos }\end{array}$} & $\begin{array}{l}\text { ATERRO } \\
\text { At. } 01 \mathrm{~d} 01\end{array}$ & \multicolumn{6}{|c|}{ PERÍODO } \\
\hline & & $\mathrm{R} \$$ & $5.213,38$ & $\mathrm{R} \$$ & $5.546,25$ & $\mathrm{R} \$$ & $5.832,59$ \\
\hline & & $\mathrm{R} \$$ & $4.672,77$ & $\mathrm{R} \$$ & $2.213,85$ & $\mathrm{R} \$$ & $2.251,77$ \\
\hline & & $\mathrm{R} \$$ & $3.092,77$ & $\mathrm{R} \$$ & $3.226,29$ & $\mathrm{R} \$$ & $3.341,14$ \\
\hline & & $\mathrm{R} \$$ & $3.822,20$ & $\mathrm{R} \$$ & $3.822,20$ & $\mathrm{R} \$$ & $3.822,20$ \\
\hline & $\mathrm{R} \$$ / mês & $\mathrm{R} \$$ & $16.801,12$ & $\mathrm{R} \$$ & $14.808,59$ & $\mathrm{R} \$$ & $15.247,70$ \\
\hline
\end{tabular}

5. UNIFORMES

MOTORISTAS

CALÇA DE BRIM

CAMISA DE BRIM

CALÇADO TIPO VULCABRÁS

BONÉ TIPO JOCKEY

CAPA DE CHUVA

$$
\text { UNIFORME COMPLETO: }
$$

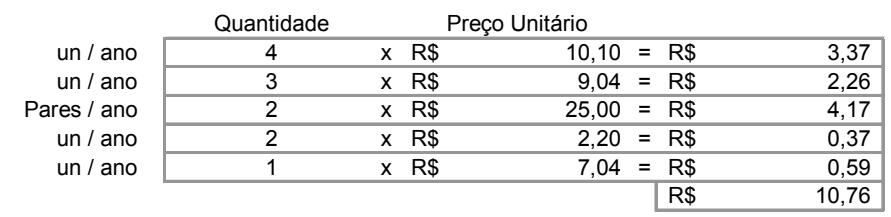

\begin{tabular}{|c|c|c|c|c|c|c|c|}
\hline \multirow{2}{*}{ Despesa: uniformes } & ATERRO & \multicolumn{6}{|c|}{ PERÍODO } \\
\hline & At. $01 \mathrm{~d} 01$ & \multirow{2}{*}{\multicolumn{2}{|c|}{$\frac{2007}{2}$}} & & & & \\
\hline \multirow{2}{*}{$\begin{array}{r}\text { MOTORISTAS } \\
\text { SUBTOTAL }\end{array}$} & & & & & & \multicolumn{2}{|c|}{2} \\
\hline & $\mathrm{R} \$$ / mês & $\mathrm{R} \$$ & 21,52 & $\mathrm{R} \$$ & 21,52 & $\mathrm{R} \$$ & 21,52 \\
\hline
\end{tabular}

6. RESUMO DOS CUSTOS OPERACIONAIS

\begin{tabular}{|c|c|c|c|c|c|c|c|}
\hline \multirow{4}{*}{$\begin{array}{l}\text { EQUIPAMENTOS } \\
\text { UNIFORMES }\end{array}$} & ATERRO & \multicolumn{6}{|c|}{ PERÍODO } \\
\hline & & $\mathrm{R} \$$ & $2.883,12$ & $\mathrm{R} \$$ & $2.883,12$ & $\mathrm{R} \$$ & $2.883,12$ \\
\hline & & $\mathrm{R} \$$ & $16.801,12$ & $\mathrm{R} \$$ & $14.808,59$ & $\mathrm{R} \$$ & $15.247,70$ \\
\hline & & $\mathrm{R} \$$ & 21,52 & $\mathrm{R} \$$ & 21,52 & $\mathrm{R} \$$ & 21,52 \\
\hline TOTAL Operacional & $\mathrm{R} \$$ / mês & $\mathrm{R} \$$ & $19.705,76$ & $\mathrm{R} \$$ & $17.713,23$ & $\mathrm{R} \$$ & $18.152,34$ \\
\hline
\end{tabular}

7. MÃO-DE-OBRA: ENCARREGADOS

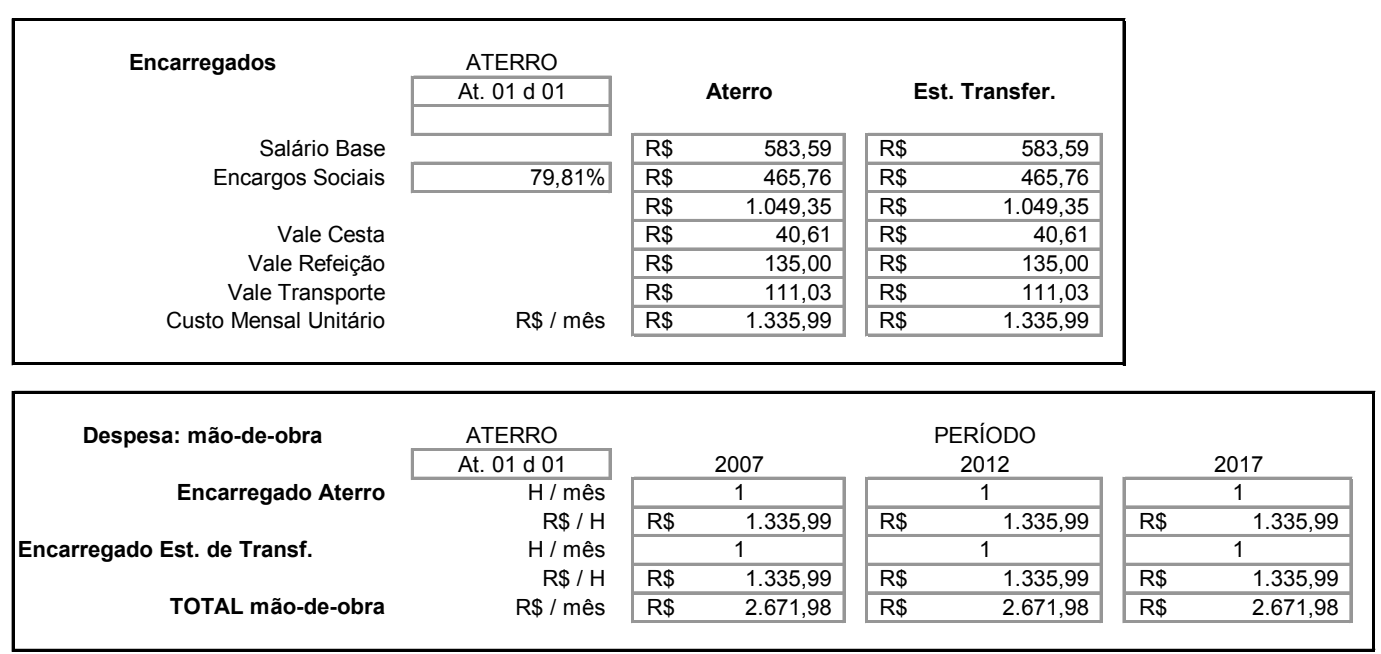

8. RESUMO DOS CUSTOS COM ENCARREGADOS

\begin{tabular}{|c|c|c|c|c|c|c|c|}
\hline \multirow{4}{*}{$\begin{array}{l}\text { Despesas com encarregados } \\
\text { MÃO-DE-OBRA: ENCARREGADOS } \\
\text { TOTAL Encarregados }\end{array}$} & ATERRO & \multicolumn{6}{|c|}{ PERÍODO } \\
\hline & At. $01 \mathrm{~d} 01$ & \multicolumn{2}{|c|}{2007} & & & \multicolumn{2}{|c|}{2017} \\
\hline & & $\mathrm{R} \$$ & $2.671,98$ & $\mathrm{R} \$$ & $2.671,98$ & $\mathrm{R} \$$ & $2.671,98$ \\
\hline & $\mathrm{R} \$$ / mês & $\mathrm{R} \$$ & $2.671,98$ & $\mathrm{R} \$$ & $2.671,98$ & $\mathrm{R} \$$ & $2.671,98$ \\
\hline
\end{tabular}


Planilha 08 - Aterro e ETs: At. 01 d 01 da Situação 11 (cont.) DESPESAS DE ADMINISTRACAO

$28 \%$ sobre parte do custo direto e indireto para cobrir despesas com honorários, salários e ordenados, taxas,despesas gerais como água,

Taxa de Administração:

$28 \%$ luz, telefones, impressos e outras.

\begin{tabular}{|c|c|c|c|c|c|c|c|}
\hline \multirow{2}{*}{ Despesas de administração } & ATERRO & \multicolumn{6}{|c|}{ PERÍODO } \\
\hline & At. $01 \mathrm{~d} 01$ & \multicolumn{2}{|c|}{2007} & \multicolumn{2}{|c|}{2012} & \multicolumn{2}{|c|}{2017} \\
\hline DESPESAS DE OPERAÇÃO & \multirow{4}{*}{$\mathrm{R} \$$ / mês } & $\mathrm{R} \$$ & $19.705,76$ & $\mathrm{R} \$$ & $17.713,23$ & $\mathrm{R} \$$ & $18.152,34$ \\
\hline DESPESAS ENCARREGADOS & & $\mathrm{R} \$$ & $2.671,98$ & $\mathrm{R} \$$ & $2.671,98$ & $\mathrm{R} \$$ & $2.671,98$ \\
\hline TOTAL (Oper.+Superv.) & & $\mathrm{R} \$$ & $22.377,74$ & $\mathrm{R} \$$ & $20.385,21$ & $\mathrm{R} \$$ & $20.824,32$ \\
\hline DESPESAS DE ADMINISTRAÇÃO & & $\mathrm{R} \$$ & $6.265,77$ & $\mathrm{R} \$$ & $5.707,86$ & $\mathrm{R} \$$ & $5.830,81$ \\
\hline
\end{tabular}

10. BENEFICIO

Benefício $\quad 0,00 \%$ sobre o total dos custos

\begin{tabular}{|c|c|c|c|c|c|c|c|}
\hline \multirow[t]{2}{*}{ Benefício } & ATERRO & \multicolumn{6}{|c|}{ PERÍODO } \\
\hline & At. $01 \mathrm{~d} 01$ & & 007 & & 12 & & 017 \\
\hline \multirow{4}{*}{$\begin{array}{l}\text { DESPESAS DE OPER.+ENCARREG. } \\
\text { DESPESAS DE ADMINISTRAÇÃO } \\
\text { TOTAL (Oper.+Enc.+Admin.) } \\
\text { BENEFÍCIO }\end{array}$} & \multirow{4}{*}{$\mathrm{R} \$$ / mês } & $\mathrm{R} \$$ & $22.377,74$ & $\mathrm{R} \$$ & $20.385,21$ & $\mathrm{R} \$$ & $20.824,32$ \\
\hline & & $\mathrm{R} \$$ & $6.265,77$ & $\mathrm{R} \$$ & $5.707,86$ & $\mathrm{R} \$$ & $5.830,81$ \\
\hline & & $\mathrm{R} \$$ & $28.643,51$ & $\mathrm{R} \$$ & $26.093,07$ & $\mathrm{R} \$$ & $26.655,13$ \\
\hline & & $\mathrm{R} \$$ & - & $\mathrm{R} \$$ & - & $\mathrm{R} \$$ & - \\
\hline
\end{tabular}

11. FATURAMENTO MENSAL (f)

\begin{tabular}{|c|c|c|c|c|c|c|c|}
\hline \multirow[t]{2}{*}{ Faturamento } & ATERRO & \multicolumn{6}{|c|}{ PERÍODO } \\
\hline & At. $01 \mathrm{~d} 01$ & \multicolumn{2}{|c|}{2007} & \multicolumn{2}{|c|}{2012} & \multicolumn{2}{|c|}{2017} \\
\hline DESPESAS DE OPERAÇÃO & & $\mathrm{R} \$$ & $19.705,76$ & $\mathrm{R} \$$ & $17.713,23$ & $\mathrm{R} \$$ & $18.152,34$ \\
\hline DESPESAS ENCARREGADOS & & $\mathrm{R} \$$ & $2.671,98$ & $\mathrm{R} \$$ & $2.671,98$ & $\mathrm{R} \$$ & $2.671,98$ \\
\hline DESPESAS DE ADMINISTRAÇÃO & & $\mathrm{R} \$$ & $6.265,77$ & $\mathrm{R} \$$ & $5.707,86$ & $\mathrm{R} \$$ & $5.830,81$ \\
\hline BENEFÍCIO & & $\mathrm{R} \$$ & - & $\mathrm{R} \$$ & - & $\mathrm{R} \$$ & - \\
\hline FATURAMENTO & $\mathrm{R} \$$ / mês & $\mathrm{R} \$$ & $28.643,51$ & $\mathrm{R} \$$ & $26.093,07$ & $\mathrm{R} \$$ & $26.655,13$ \\
\hline
\end{tabular}

12. ISS, PIS, COFINS e CPMF

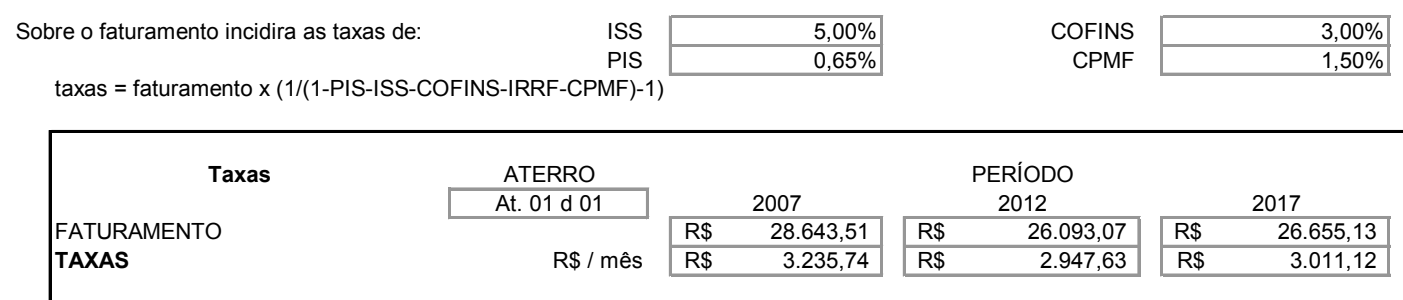

13. CUSTO MENSAL

\begin{tabular}{|c|c|c|c|c|c|c|c|}
\hline \multirow[t]{2}{*}{ Custo mensal } & ATERRO & \multicolumn{6}{|c|}{ PERÍODO } \\
\hline & At. $01 \mathrm{~d} 01$ & & 2007 & & 12 & & 017 \\
\hline \multirow{3}{*}{$\begin{array}{l}\text { FATURAMENTO } \\
\text { TAXAS } \\
\text { TOTAL CUSTO }\left(\mathbf{C}_{\mathrm{t}}\right)\end{array}$} & \multirow[b]{3}{*}{$\mathrm{R} \$ /$ mês } & $\mathrm{R} \$$ & $28.643,51$ & $\mathrm{R} \$$ & $26.093,07$ & $\mathrm{R} \$$ & $26.655,13$ \\
\hline & & $\mathrm{R} \$$ & $3.235,74$ & $\mathrm{R} \$$ & $2.947,63$ & $\mathrm{R} \$$ & $3.011,12$ \\
\hline & & $\mathrm{R} \$$ & $31.879,25$ & $\mathrm{R} \$$ & $29.040,70$ & $\mathrm{R} \$$ & $29.666,25$ \\
\hline
\end{tabular}

14. CUSTO POR TONELADA DE LIXO COLETADO

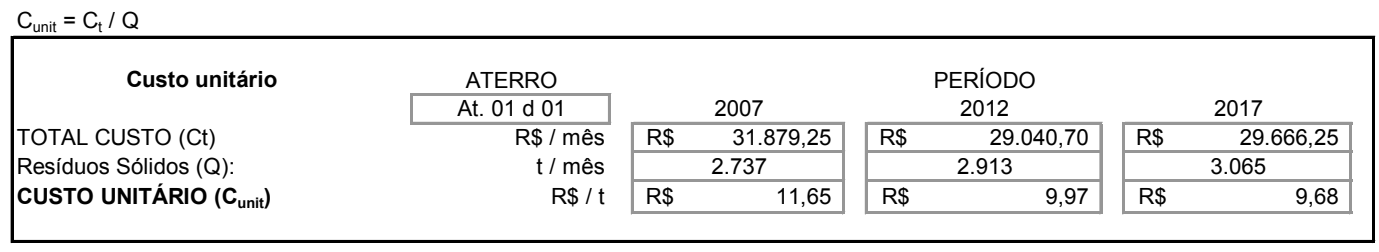


Planilha 08 - Aterro e ETs: At. 01 d 01 da Situação 11 (cont.)

IMPLANTAÇÃO: ESTAÇÃO DE TRANSFERÊNCIA E ATERRO

INVESTIMENTOS

14. CUSTO POR TONELADA DE LIXO COLETADO

14.1. IMPLANTAÇÃO DOS ATERROS

\begin{tabular}{|c|c|c|c|c|}
\hline \multirow{4}{*}{$\begin{array}{l}\text { Investimento (I): } \\
\text { Resíduos Sólidos (Q): } \\
\left.\text { CUSTO UNITÁRIO ( } \text { ( }_{\text {unit }}\right)\end{array}$} & ATERRO & Vida útil aterro de & \multicolumn{2}{|c|}{15 anos } \\
\hline & At. $01 \mathrm{~d} 01$ & $\mathrm{R} \$$ & $\mathrm{R} \$$ & 4,35 \\
\hline & & $\mathrm{t}$ & \multicolumn{2}{|c|}{523.222} \\
\hline & & $\mathrm{R} \$ / \mathrm{t}$ & $\mathrm{R} \$$ & 2,07 \\
\hline
\end{tabular}

14.2. IMPLANTAÇÃO DAS Ets

\begin{tabular}{|c|c|c|c|c|}
\hline Custo unitário & ATERRO & Vida útil aterro de & \multicolumn{2}{|c|}{15 anos } \\
\hline Investimento (I): & At $01 \mathrm{~d} 01$ & \multirow{2}{*}{$\begin{array}{r}\mathrm{R} \$ \\
\mathrm{t}\end{array}$} & $\mathrm{R} \$$ & 975.991 .81 \\
\hline Resíduos Sólidos (Q): & & & \multicolumn{2}{|c|}{523.222} \\
\hline CUSTO UNITÁRIO ( $\mathrm{C}_{\text {unit }}$ ) & & $\mathrm{R} \$ / \mathrm{t}$ & $\mathrm{R} \$$ & 1,87 \\
\hline
\end{tabular}

14.3. TOTAL IMPLANTAÇÃO

\begin{tabular}{|c|c|c|c|c|}
\hline \multirow{4}{*}{$\begin{array}{l}\text { Investimento (I): } \\
\text { Resíduos Sólidos (Q): } \\
\left.\text { CUSTO UNITÁRIO ( } \text { ( }_{\text {unit }}\right)\end{array}$} & ATERRO & \multirow{4}{*}{$\begin{array}{r}\text { Vida útil aterro de } \\
\qquad \begin{array}{r}\mathrm{R} \$ \\
\mathrm{t} \\
\mathrm{R} \$ / \mathrm{t}\end{array}\end{array}$} & \multicolumn{2}{|c|}{15 anos } \\
\hline & At. $01 \mathrm{~d} 01$ & & $\mathrm{R} \$$ & 96,16 \\
\hline & & & \multicolumn{2}{|c|}{523.222} \\
\hline & & & $\mathrm{R} \$$ & 3,93 \\
\hline
\end{tabular}


Planilha 09 - Resumo dos Custos: At. 01 d 01 da Situação 11

SISTEMA CONSORCIADO INTERMUNICIPAL PARA DESTINAÇÃO DOS RSU

APA de Corumbataí - SP

Data base:

Junho de 2002

1. RESUMO CUSTO SERVIÇOS

1.1. CUSTO COLETA

\begin{tabular}{|c|c|c|c|c|c|c|c|}
\hline \multirow{7}{*}{$\begin{array}{l}\text { DESPESAS DE OPERAÇÃO } \\
\text { DESPESAS DE SUPERVISÃO } \\
\text { DESPESAS DE ADMINISTRAÇÃO } \\
\text { BENEFÍCIO } \\
\text { TAXAS }\end{array}$} & \multirow{3}{*}{$\begin{array}{c}\text { ATERRO } \\
\text { At. } 01 \mathrm{~d} 01\end{array}$} & \multicolumn{6}{|c|}{ PERÍODO } \\
\hline & & \multicolumn{2}{|r|}{2007} & \multicolumn{2}{|r|}{2012} & \multicolumn{2}{|r|}{2017} \\
\hline & & $\mathrm{R} \$$ & $156.618,41$ & $\mathrm{R} \$$ & $157.558,97$ & $\mathrm{R} \$$ & $158.368,07$ \\
\hline & & $\mathrm{R} \$$ & $10.371,83$ & $\mathrm{R} \$$ & $10.371,83$ & $\mathrm{R} \$$ & $10.371,83$ \\
\hline & & $\mathrm{R} \$$ & $46.757,27$ & $\mathrm{R} \$$ & $47.020,62$ & $\mathrm{R} \$$ & $47.247,17$ \\
\hline & & $\mathrm{R} \$$ & - & $\mathrm{R} \$$ & - & $\mathrm{R} \$$ & - \\
\hline & & $\mathrm{R} \$$ & $24.146,21$ & $\mathrm{R} \$$ & $24.282,21$ & $\mathrm{R} \$$ & $24.399,21$ \\
\hline TOTAL CUSTO (Ct) & $\mathrm{R} \$$ / mês & $\mathrm{R} \$$ & $237.893,72$ & $\mathrm{R} \$$ & $239.233,63$ & $\mathrm{R} \$$ & $240.386,28$ \\
\hline CUSTO UNITÁRIO (Cunit) & $\mathrm{R} \$ / \mathrm{t}$ & $\mathrm{R} \$$ & 86,93 & $\mathrm{R} \$$ & 82,11 & $\mathrm{R} \$$ & 78,43 \\
\hline DESPESAS DE OPERAÇÃO & 1 Aterro & $\mathrm{R} \$$ & $156.618,41$ & $\mathrm{R} \$$ & $157.558,97$ & $\mathrm{R} \$$ & $158.368,07$ \\
\hline DESPESAS DE SUPERVISÃO & & $\mathrm{R} \$$ & $10.371,83$ & $\mathrm{R} \$$ & $10.371,83$ & $\mathrm{R} \$$ & $10.371,83$ \\
\hline DESPESAS DE ADMINISTRAÇÃO & & $\mathrm{R} \$$ & $46.757,27$ & $\mathrm{R} \$$ & $47.020,62$ & $\mathrm{R} \$$ & $47.247,17$ \\
\hline BENEFÍCIO & & $\mathrm{R} \$$ & - & $\mathrm{R} \$$ & - & $\mathrm{R} \$$ & - \\
\hline TAXAS & & $\mathrm{R} \$$ & $24.146,21$ & $\mathrm{R} \$$ & $24.282,21$ & $\mathrm{R} \$$ & $24.399,21$ \\
\hline TOTAL CUSTO (Ct) & $\mathrm{R} \$ /$ mês & $\mathrm{R} \$$ & $237.893,72$ & $\mathrm{R} \$$ & $239.233,63$ & $\mathrm{R} \$$ & $240.386,28$ \\
\hline CUSTO UNITÁRIO (Cunit) & $\mathrm{R} \$ / \mathrm{t}$ & $\mathrm{R} \$$ & 86,93 & $\mathrm{R} \$$ & 82,11 & $\mathrm{R} \$$ & 78,43 \\
\hline
\end{tabular}

1.2. CUSTO TRANSPORTE COLETA

\begin{tabular}{|c|c|c|c|c|c|c|c|}
\hline \multirow{5}{*}{$\begin{array}{l}\text { TOTAL CUSTO (Ct) } \\
\text { CUSTO UNITÁRIO (Cunit) }\end{array}$} & ATERRO & \multicolumn{6}{|c|}{ PERÍODO } \\
\hline & At. $01 \mathrm{~d} 01$ & \multicolumn{2}{|c|}{2007} & \multicolumn{2}{|c|}{2012} & \multicolumn{2}{|c|}{2017} \\
\hline & $\mathrm{R}$ \$ / mês & $\mathrm{R} \$$ & $4.449,33$ & $\mathrm{R} \$$ & $4.986,05$ & $\mathrm{R} \$$ & $5.479,06$ \\
\hline & $R \$ / t$ & $\mathrm{R} \$$ & 1,63 & $\mathrm{R} \$$ & 1,71 & $\mathrm{R} \$$ & 1,79 \\
\hline & 1 Aterro & & & & & & \\
\hline TOTAL CUSTO (Ct) & $\mathrm{R} \$$ / mês & $\mathrm{R} \$$ & $4.449,33$ & $\mathrm{R} \$$ & $4.986,05$ & $\mathrm{R} \$$ & $5.479,06$ \\
\hline CUSTO UNITÁRIO (Cunit) & $\mathrm{R} \$ / \mathrm{t}$ & $\mathrm{R} \$$ & 1,63 & $\mathrm{R} \$$ & 1,71 & $\mathrm{R} \$$ & 1,79 \\
\hline
\end{tabular}

1.3. CUSTO TRANSPORTE At-ET-At

\begin{tabular}{|c|c|c|c|c|c|c|c|}
\hline \multirow{7}{*}{$\begin{array}{l}\text { DESPESAS DE OPERAÇÃO } \\
\text { DESPESAS DE SUPERVISÃO } \\
\text { DESPESAS DE ADMINISTRAÇÃO } \\
\text { BENEFÍCIO } \\
\text { TAXAS }\end{array}$} & \multirow[t]{2}{*}{ ATERRO } & \multicolumn{6}{|c|}{ PERÍODO } \\
\hline & & \multicolumn{2}{|c|}{2007} & \multicolumn{2}{|c|}{2012} & \multicolumn{2}{|c|}{2017} \\
\hline & \begin{tabular}{|l|} 
At. $01 \mathrm{~d} 01$ \\
\end{tabular} & $\mathrm{R} \$$ & $21.585,11$ & $\mathrm{R} \$$ & $21.624,12$ & $\mathrm{R} \$$ & $21.671,83$ \\
\hline & & $\mathrm{R} \$$ & $5.299,70$ & $\mathrm{R} \$$ & $5.311,66$ & $\mathrm{R} \$$ & $5.326,24$ \\
\hline & & $\mathrm{R} \$$ & $7.527,75$ & $\mathrm{R} \$$ & $7.542,02$ & $\mathrm{R} \$$ & $7.559,46$ \\
\hline & & $\mathrm{R} \$$ & - & $\mathrm{R} \$$ & - & $\mathrm{R} \$$ & - \\
\hline & & $\mathrm{R} \$$ & $3.887,45$ & $\mathrm{R} \$$ & $3.894,82$ & $\mathrm{R} \$$ & $3.903,83$ \\
\hline TOTAL CUSTO (Ct) & $\mathrm{R} \$ /$ mês & $\mathrm{R} \$$ & $38.300,01$ & $\mathrm{R} \$$ & $38.372,62$ & $\mathrm{R} \$$ & $38.461,36$ \\
\hline CUSTO UNITÁRIO (Cunit) & $\mathrm{R} \$ / \mathrm{t}$ & $\mathrm{R} \$$ & 13,99 & $\mathrm{R} \$$ & 13,17 & $\mathrm{R} \$$ & 12,55 \\
\hline DESPESAS DE OPERAÇÃO & 1 Aterro & $\mathrm{R} \$$ & $21.585,11$ & $\mathrm{R} \$$ & $21.624,12$ & $\mathrm{R} \$$ & $21.671,83$ \\
\hline DESPESAS DE SUPERVISÃO & & $\mathrm{R} \$$ & $5.299,70$ & $\mathrm{R} \$$ & $5.311,66$ & $\mathrm{R} \$$ & $5.326,24$ \\
\hline DESPESAS DE ADMINISTRAÇÃO & & $\mathrm{R} \$$ & $7.527,75$ & $\mathrm{R} \$$ & $7.542,02$ & $\mathrm{R} \$$ & $7.559,46$ \\
\hline BENEFÍCIO & & $\mathrm{R} \$$ & - & $\mathrm{R} \$$ & - & $\mathrm{R} \$$ & - \\
\hline TAXAS & & $\mathrm{R} \$$ & $3.887,45$ & $\mathrm{R} \$$ & $3.894,82$ & $\mathrm{R} \$$ & $3.903,83$ \\
\hline TOTAL CUSTO $(\mathrm{Ct})$ & $\mathrm{R} \$$ / mês & $\mathrm{R} \$$ & $38.300,01$ & $\mathrm{R} \$$ & $38.372,62$ & $\mathrm{R} \$$ & $38.461,36$ \\
\hline CUSTO UNITÁRIO (Cunit) & $\mathrm{R} \$ / \mathrm{t}$ & $\mathrm{R} \$$ & 13,99 & $\mathrm{R} \$$ & 13,17 & $\mathrm{R} \$$ & 12,55 \\
\hline
\end{tabular}


Planilha 09 - Resumo dos Custos: At. 01 d 01 da Situação 11 (cont.)

1.4. CUSTO OPERAÇÃO Aterro - E.transf.

\begin{tabular}{|c|c|c|c|c|c|c|c|}
\hline \multirow{6}{*}{$\begin{array}{l}\text { DESPESAS DE OPERAÇÃO } \\
\text { DESPESAS ENCARREGADOS } \\
\text { DESPESAS DE ADMINISTRAÇÃO } \\
\text { BENEFÍCIO } \\
\text { TAXAS }\end{array}$} & ATERRO & \multicolumn{6}{|c|}{ PERÍODO } \\
\hline & At. $01 \mathrm{~d} 01$ & $\mathrm{R} \$$ & $19.705,76$ & $\mathrm{R} \$$ & $17.713,23$ & $\mathrm{R} \$$ & $18.152,34$ \\
\hline & & $\mathrm{R} \$$ & $2.671,98$ & $\mathrm{R} \$$ & $2.671,98$ & $\mathrm{R} \$$ & $2.671,98$ \\
\hline & & $\mathrm{R} \$$ & $6.265,77$ & $\mathrm{R} \$$ & $5.707,86$ & $\mathrm{R} \$$ & $5.830,81$ \\
\hline & & $\mathrm{R} \$$ & & $\mathrm{R} \$$ & & $\mathrm{R} \$$ & \\
\hline & & $\mathrm{R} \$$ & $3.235,74$ & $\mathrm{R} \$$ & $2.947,63$ & $\mathrm{R} \$$ & $3.011,12$ \\
\hline TOTAL CUSTO (Ct) & $\mathrm{R} \$ /$ mês & $\mathrm{R} \$$ & $31.879,25$ & $\mathrm{R} \$$ & $29.040,70$ & $\mathrm{R} \$$ & $29.666,25$ \\
\hline CUSTO UNITÁRIO (Cunit) & $\mathrm{R} \$ / \mathrm{t}$ & $\mathrm{R} \$$ & 11,65 & $\mathrm{R} \$$ & 9,97 & $\mathrm{R} \$$ & 9,68 \\
\hline DESPESAS DE OPERAÇÃO & 1 Aterro & $\mathrm{R} \$$ & $19.705,76$ & $\mathrm{R} \$$ & $17.713,23$ & $\mathrm{R} \$$ & $18.152,34$ \\
\hline DESPESAS ENCARREGADOS & & $\mathrm{R} \$$ & $2.671,98$ & $\mathrm{R} \$$ & $2.671,98$ & $\mathrm{R} \$$ & $2.671,98$ \\
\hline DESPESAS DE ADMINISTRAÇÃO & & $\mathrm{R} \$$ & $6.265,77$ & $\mathrm{R} \$$ & $5.707,86$ & $\mathrm{R} \$$ & $5.830,81$ \\
\hline BENEFÍCIO & & $\mathrm{R} \$$ & & $\mathrm{R} \$$ & & $\mathrm{R} \$$ & \\
\hline TAXAS & & $\mathrm{R} \$$ & $3.235,74$ & $\mathrm{R} \$$ & $2.947,63$ & $\mathrm{R} \$$ & $3.011,12$ \\
\hline TOTAL CUSTO $(\mathrm{Ct})$ & $\mathrm{R} \$ /$ mês & $\mathrm{R} \$$ & $31.879,25$ & $\mathrm{R} \$$ & $29.040,70$ & $\mathrm{R} \$$ & $29.666,25$ \\
\hline CUSTO UNITÁRIO (Cunit) & $R \$ / t$ & $\mathrm{R} \$$ & 11,65 & $\mathrm{R} \$$ & 9,97 & $\mathrm{R} \$$ & 9,68 \\
\hline
\end{tabular}

1.5. CUSTO TOTAL

\begin{tabular}{|c|c|c|c|c|c|c|c|}
\hline \multirow[b]{2}{*}{ CUSTO COLETA } & \multirow[t]{2}{*}{1 Aterro } & \multicolumn{6}{|c|}{ PERIODO } \\
\hline & & & 2007 & & 2012 & & 2017 \\
\hline TOTAL CUSTO (Ct) & $\mathrm{R} \$$ / mês & $\mathrm{R} \$$ & $237.893,72$ & $\mathrm{R} \$$ & $239.233,63$ & $\mathrm{R} \$$ & $240.386,28$ \\
\hline CUSTO UNITÁRIO (Cunit) & $R \$ / t$ & $\mathrm{R} \$$ & 86,93 & $\mathrm{R} \$$ & 82,11 & $\mathrm{R} \$$ & 78,43 \\
\hline CUSTO TRANSPORTE COLETA & & & & & & & \\
\hline TOTAL CUSTO (Ct) & $\mathrm{R} \$$ / mês & $\mathrm{R} \$$ & $4.449,33$ & $\mathrm{R} \$$ & $4.986,05$ & $\mathrm{R} \$$ & $5.479,06$ \\
\hline CUSTO UNITÁRIO (Cunit) & $R \$ / t$ & $\mathrm{R} \$$ & 1,63 & $\mathrm{R} \$$ & 1,71 & $\mathrm{R} \$$ & 1,79 \\
\hline CUSTO TRANSPORTE At-ET-At & & & & & & & \\
\hline TOTAL CUSTO (Ct) & $\mathrm{R} \$$ / mês & $\mathrm{RS}$ & $38.300,01$ & $\mathrm{R} \$$ & $38.372,62$ & $\mathrm{R} \$$ & $38.461,36$ \\
\hline CUSTO UNITÁRIO (Cunit) & $R \$ / t$ & $\mathrm{R} \$$ & 13,99 & $\mathrm{R} \$$ & 13,17 & $\mathrm{R} \$$ & 12,55 \\
\hline CUSTO OPERAÇÃO Aterro - E.transf. & & & & & & & \\
\hline TOTAL CUSTO (Ct) & $\mathrm{R} \$$ / mês & $\mathrm{R} \$$ & $31.879,25$ & $\mathrm{R} \$$ & $29.040,70$ & $\mathrm{R} \$$ & $29.666,25$ \\
\hline CUSTO UNITÁRIO (Cunit) & $R \$ / t$ & $\mathrm{R} \$$ & 11,65 & $\mathrm{R} \$$ & 9,97 & $\mathrm{R} \$$ & 9,68 \\
\hline TOTAL CUSTO (Ct) & $\mathrm{R} \$ /$ mês & $\mathrm{R} \$$ & $312.522,31$ & $\mathrm{R} \$$ & $311.633,00$ & $\mathrm{R} \$$ & $313.992,95$ \\
\hline CUSTO UNITÁRIO (Cunit) & $R \$ / t$ & $\mathrm{R} \$$ & 114,19 & $\mathrm{R} \$$ & 106,96 & $\mathrm{R} \$$ & 102,44 \\
\hline
\end{tabular}

NOTA: ESTE PREÇO FOI CALCULADO COM BASE NOS VALORES VIGENTES EM Junho de 2002 
Planilha 09 - Resumo dos Custos: At. 01 d 01 da Situação 11 (cont.)

2. RESUMO CUSTO IMPLANTAÇÃO

2.1. IMPLANTAÇÃO DOS ATERROS

\begin{tabular}{|c|c|c|c|c|}
\hline & ATERRO & & & \\
\hline Investimento (I): & At. $01 \mathrm{~d} 01$ & $\begin{array}{r}\text { Vida útil aterro de } \\
R \$\end{array}$ & $\mathrm{R} \$$ & $\frac{15 \text { anos }}{1.081 .104 .35}$ \\
\hline CUSTO UNITÁRIO ( $\left.\mathrm{C}_{\text {unit }}\right)$ & & $R \$ / t$ & $\mathrm{R} \$$ & 2,07 \\
\hline Investimento (I): & 1 Aterro & $\mathrm{R} \$$ & $\mathrm{R} \$$ & $1.081 .104,35$ \\
\hline CUSTO UNITÁRIO ( $\left.\mathrm{C}_{\text {unit }}\right)$ & & $R \$ / t$ & $\mathrm{R} \$$ & 2,07 \\
\hline
\end{tabular}

2.2. IMPLANTAÇÃO DAS Ets

\begin{tabular}{|c|c|c|c|c|}
\hline \multirow{3}{*}{$\begin{array}{l}\text { Investimento (I): } \\
\left.\text { CUSTO UNITÁRIO ( } \mathrm{C}_{\text {unit }}\right)\end{array}$} & ATERRO & Vida útil aterro de & \multicolumn{2}{|r|}{15 anos } \\
\hline & At. $01 \mathrm{~d} 01$ & $\mathrm{R} \$$ & $\mathrm{R} \$$ & $975.991,81$ \\
\hline & & $\mathrm{R} \$ / \mathrm{t}$ & $\mathrm{R} \$$ & 1,87 \\
\hline Investimento (I): & 1 Aterro & $\mathrm{R} \$$ & $\mathrm{R} \$$ & $975.991,81$ \\
\hline CUSTO UNITÁRIO ( $\left.\mathrm{C}_{\text {unit }}\right)$ & & $R \$ / t$ & $\mathrm{R} \$$ & 1,87 \\
\hline
\end{tabular}

2.3. TOTAL IMPLANTAÇÃO

\begin{tabular}{|c|c|c|c|c|}
\hline \multirow[b]{2}{*}{ IMPLANTAÇÃO DOS ATERROS } & 1 Aterro & Vida útil aterro de & & 15 anos \\
\hline & & & & \\
\hline Investimento (I): & & $\mathrm{R} \$$ & $\begin{array}{ll}\mathrm{R} \$ \\
\mathrm{DS}\end{array}$ & $1.081 .104,35$ \\
\hline CUSTO UNITÁRIO (C $\left.\mathrm{C}_{\text {unit }}\right)$ & & $R \$ / t$ & $\mathrm{R} \$$ & 2,07 \\
\hline IMPLANTAÇÃO DAS Ets & & & & \\
\hline Investimento (I): & & $\mathrm{R} \$$ & $\mathrm{R} \$$ & $975.991,81$ \\
\hline CUSTO UNITÁRIO ( $\left.\mathrm{C}_{\text {unit }}\right)$ & & $R \$ / t$ & $\mathrm{R} \$$ & 1,87 \\
\hline Investimento (I): & & $\mathrm{R} \$$ & $\mathrm{R} \$$ & $2.057 .096,16$ \\
\hline CUSTO UNITÁRIO ( $\left.\mathrm{C}_{\text {unit }}\right)$ & & $\mathrm{R} \$ / \mathrm{t}$ & $R \$$ & 3,93 \\
\hline
\end{tabular}

NOTA: ESTE PREÇO FOI CALCULADO COM BASE NOS VALORES VIGENTES EM 